Geologic and Hydrologic Records of

Observation Wells, Test Holes, Test Wells,

Supply Wells, Springs, and Surface Water

Stations in the Los Alamos Area

W. D. Purtymun 


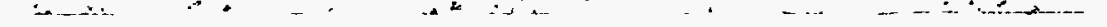

, 


\section{DISCLAIMER}

This report was prepared as an account of work sponsored by an agency of the United States Government. Neither the United States Government nor any agency thereof, nor any of their employees, make any warranty, express or implied, or assumes any legal liability or responsibility for the accuracy, completeness, or usefulness of any information, apparatus, product, or process disclosed, or represents that its use would not infringe privately owned rights. Reference herein to any specific commercial product, process, or service by trade name, trademark, manufacturer, or otherwise does not necessarily constitute or imply its endorsement, recommendation, or favoring by the United States Government or any agency thereof. The views and opinions of authors expressed herein do not necessarily state or reflect those of the United States Government or any agency thereof. 


\section{DISCLAIMER}

Portions of this document may be illegible in electronic image products. Images are produced from the best available original document. 


\section{CONTENTS}

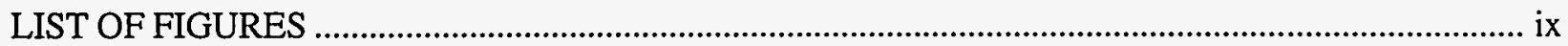

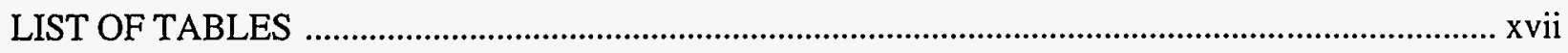

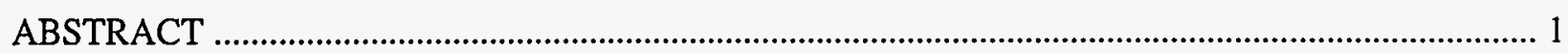

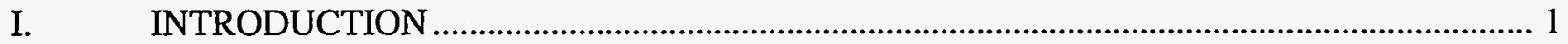

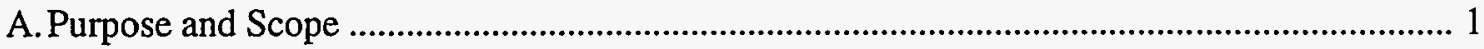

B. Locations of Test Holes, Wells, and Monitoring Stations ................................................ 2

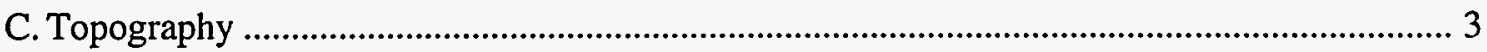

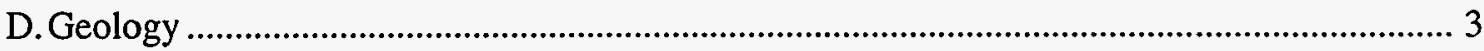

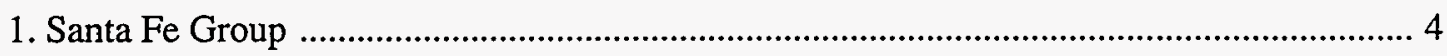

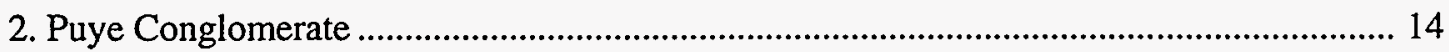

3. Basaltic Rocks of Chino Mesa .............................................................................................. 14

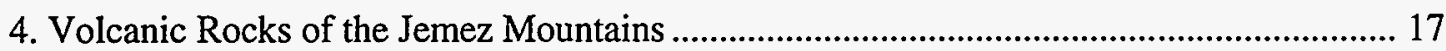

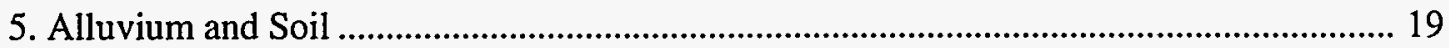

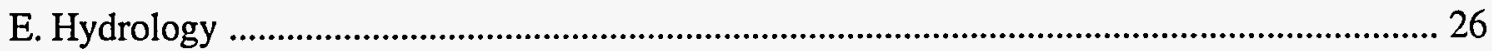

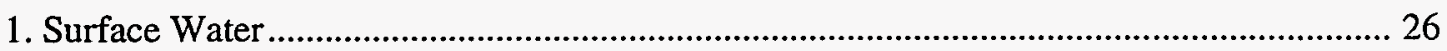

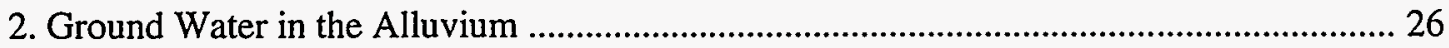

3. Perched Water in Volcanic Sediments and Basalts ............................................................. 28

4. Main Aquifer of the Los Alamos Area ............................................................................. 29

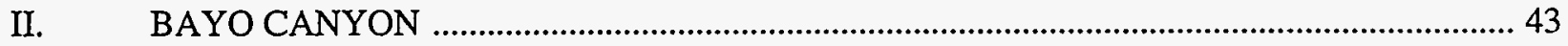

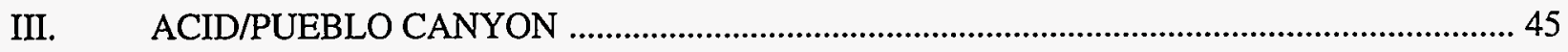

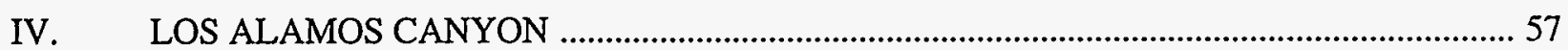

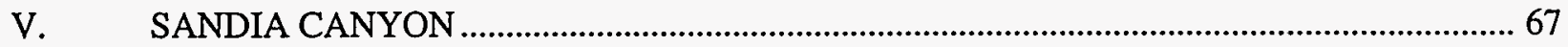

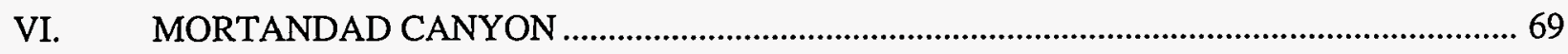

VII. CAÑADA DEL BUEY AND PAJARITO CANYON ….................................................. 113

VIII. OBSERVATION WELLS TO MEET SPECIAL PERMIT CONDITIONS ........................... 137

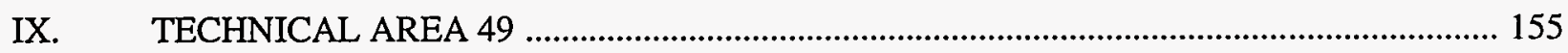

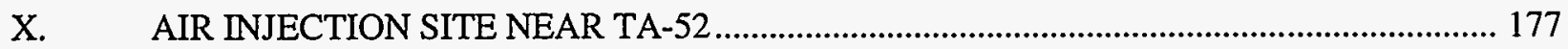

XI. AIR AND WATER INJECTION SITES NEAR TA-50 …................................................... 179

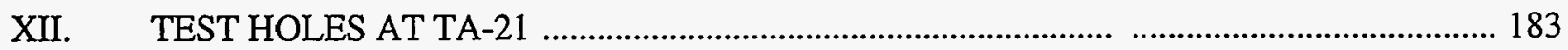

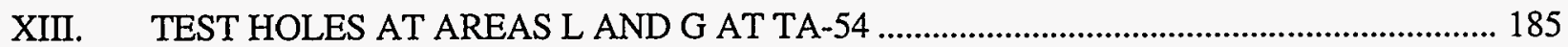

XIV. TEST HOLES AT AREA P AT TA-16 ….......................................................................... 193

XV. U.S. GEOLOGICAL SURVEY TEST HOLE NEAR TA-52 …........................................ 207

XVI. CARBON ISOTOPE PRODUCTION HOLES AT TA-21 AND TA-46 .............................. 209

XVII. TEST WELLS AND TEST HOLES ON THE PAJARITO PLATEAU ................................. 211

XVIII. TEST HOLES IN THE VALLE TOLEDO AND VALLE GRANDE (1948) ........................ 229

XIX. TEST HOLES IN THE VALLE TOLEDO, VALLE GRANDE, AND VALLE DE LOS POSOS (1949) 
XX. TEST HOLES ALONG THE RIO GRANDE AND LOWER LOS ALAMOS CANYON ..... 245

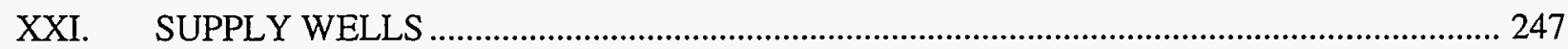

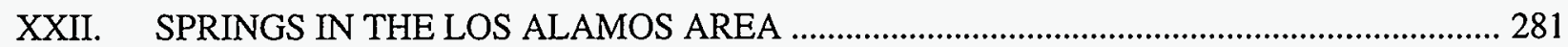

XXIII. DOCUMENTED STUDIES RELATED TO GEOLOGY, HYDROLOGY,

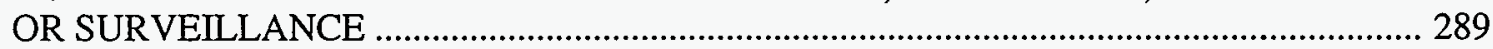

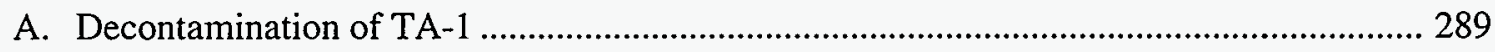

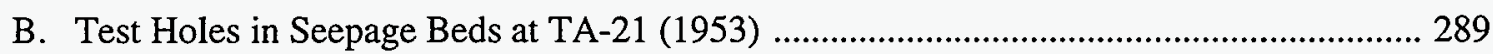

C. Test Holes in Seepage Beds at TA-21 (1985) ............................................................... 289

D. Movement of Plutonium through Tuff at TA-21 ........................................................... 289

E. Movement of Fluids and Plutonium from Shafts at TA-21 ......................................... 289

F. Exploratory and Foundation Test Holes at TA-3 ....................................................... 290

G. Exploratory and Foundation Test Holes at TA-53 .................................................. 290 =

H. Preliminary Site Investigation of the Plutonium Processing Facility at TA-55 ............... 290

I. Movement of Tritium through Tuff at TA-54, Area G ..................................................... 291

J. Containment of Tritium in Buried Wastes at TA-54, Area G ........................................ 291

K. Horizontal Core Holes at TA-54, Area G, and Other Studies at TA-54, Areas G and L ... 291

L. Test Holes at TA-33 (1989) .......................................................................................... 291

M. Near-Surface Land Disposal Facilities for Radioactive Wastes

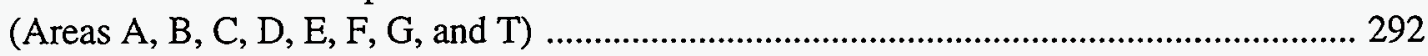

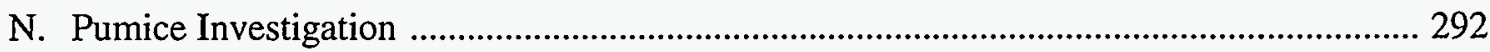

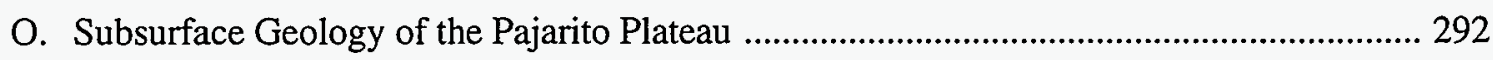

P. Proposed Borrow Pit in Mortandad Canyon .................................................................. 292

Q. Construction of Sediment Retention Ponds in Mortandad Canyon ................................... 292

R. Long-Range Plan for Water Supply (1986) .................................................................... 293

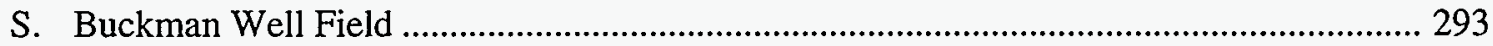

T. Ground Water Model of the Buckman Well Field ................................................................. 293

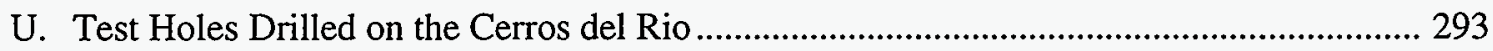

V. Environmental Study of the Pueblo of San Ildefonso ...................................................... 293

W. Seismic Hazards Program Core Holes ............................................................................. 293

X. Earthquake and Rockfall Potential at Omega Site ............................................................ 294

XXIV. RACK ASSEMBLY ALIGNMENT FACILITIES .......................................................... 297

XXV. TEST HOLES IN UPPER GUAJE CANYON ................................................................ 299

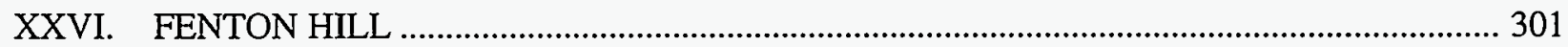

XXVII. GUAJE AND LOS ALAMOS RESERVOIRS ........................................................... 313

XXVIII. LOW-FLOW INVESTIGATIONS IN SANTA CLARA, GUAJE, LOS ALAMOS, AND

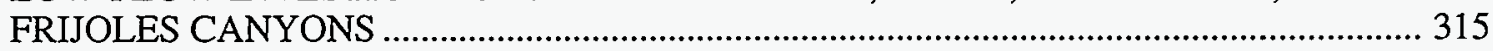

XXIX. SURFACE WATER GAGING STATIONS ON THE RIO CHAMA, RIO GRANDE, JEMEZ RIVER, RIO GUADALUPE, SANTA CLARA CREEK, AND RITO DE LOS FRIJOLES

XXX. STUDY OF SURFACE IMPOUNDMENT AT TA-53 …............................................... 327 
XXXI. TRANSPORT STUDIES OF URANIUM IN POTRILLO CANYON TA-36.....

XXXII. SPECIAL TEST HOLES AT TA-49 TO MEASURE BAROMETRIC EFFECTS AND DEFORMATION OF THE TUFF 335

ACKNOWLEDGMENTS 339 


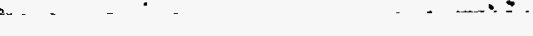




\section{FIGURES}

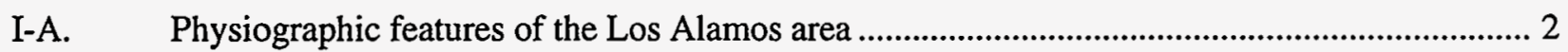

I-B. Topographic features in the Los Alamos area and their relation to the volcanic rocks of the Jemez Mountains .................................................................................................................... 3

I-C. Diagram of stratigraphic units used in this report ............................................................ 4

I-D. Geologic sections showing the stratigraphy and structure from the Sierra de los Valles across

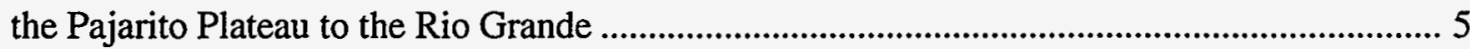

I-E. Stratigraphic nomenclature of the pre-Bandelier sediments ............................................ 6

I-F. Diagrammatic section showing stratigraphy beneath the Pajarito Plateau .............................. 7

I-G. Diagrammatic section showing the distribution of the Chaquehui Formation of the Santa Fe Group and interbedded basalts beneath the Pajarito Plateau ......................................................... 9

I-H. Type section of the maar sediments on the south wall of Chaquehui Canyon at the Rio Grande

I-I. Generalized geologic section on the south wall of Chaquehui Canyon at the Rio Grande showing the maar sediments and basalts overlain by the Basaltic Rocks of Chino Mesa and Bandelier Tuff

I-J. Generalized section showing the thickness of Old Alluvium in road cut near Totavi ............. 13

I-K. Stratigraphic nomenclature of the Cerros del Rio Basalts ................................................... 13

I-L. Stratigraphic nomenclature of the Bandelier Tuff ......................................................... 15

I-M. Type section showing the thickness of members of the Bandelier Tuff near the junction of

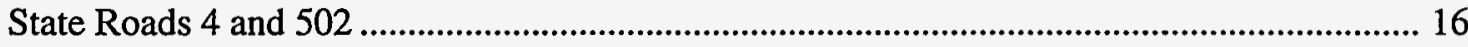

I-N. Geologic section of the Tsankawi Pumice Bed near the junction of State Roads 4 and $502 \ldots 16$

I-O. Type section of units in the Tshirege Member of the Bandelier Tuff in Mortandad Canyon... 20

I-P. Locations of diagrammatic sections of alluvium in major canyons ...................................... 20

I-Q. Diagrammatic section showing rocks underlying alluvium in lower Pueblo Canyon .............. 21

I-R. Diagrammatic section showing rocks underlying alluvium in Los Alamos Canyon ................ 21

I-S. Diagrammatic section showing rocks underlying alluvium in lower Sandia Canyon .............. 22

I-T. Diagrammatic section showing rocks underlying alluvium in Mortandad Canyon .................. 22,

I-U. Diagrammatic section showing rocks underlying alluvium in lower Cañada del Buey ........... 23

I-V. Diagrammatic section showing rocks underlying alluvium in lower Pajarito Canyon ............. 23

I-W. Diagrammatic section showing rocks underlying alluvium in lower Potrillo Canyon ............. 24

I-X. Diagrammatic section showing rocks underlying alluvium in lower Fence Canyon ............... 24

I-Y. Diagrammatic section showing rocks underlying alluvium in Water Canyon ........................ 25 
I-Z. Diagrammatic section showing rocks underlying alluvium in part of Ancho Canyon .............25

I-AA. Map showing shallow ground water in alluvium of Los Alamos and DP Canyons ............... 27

I-AB. Map showing shallow ground water in alluvium of Mortandad Canyon .............................. 27

I-AC. Map with cross section along Pueblo Canyon showing perched water in volcanic sediments in the middle and lower reaches of Pueblo Canyon.

I-AD. Water level contours of the top of the perched aquifer in volcanic sediments and basalts in lower Pueblo canyon and the midreach of Los Alamos Canyon .......................................... 29

I-AE. Generalized water-level contours of the top of the main aquifer ........................................... 30

I-AF. Rate of movement of water in the main aquifer ................................................................. 32

I-AG. Proposed locations for additional supply wells and area for the development of high-yield, low-drawdown wells 35

I-AH. Partial geologic logs of supply wells Otowi 1 and 4 showing equivalent saturated sections (main aquifer) in the Puye Conglomerate and Santa Fe Group and a comparison of their hydrologic characteristics

I-AI. Graphic comparison of average chemical constituents in water in supply wells from the main aquifer

I-AJ. Graphic comparison of average chemical constituents in water in test wells from the main aquifer

I-AK. Graphic comparison of average chemical constituents in water from the main aquifer in springs, in and adjacent to White Rock Canyon ................................................................... 38

II-A. Generalized location of test holes in Bayo Canyon .................................................................4 43

III-A. Generalized location of surface water sampling stations, shallow wells, and the spring sampling stations in Acid and Pueblo Canyons

III-B. Location of observation wells and test holes in the vicinity of Hamilton Bend Spring and Otowi Seep in Pueblo Canyon

III-C. Pueblo Canyon observation well PO-3B ............................................................................ 48

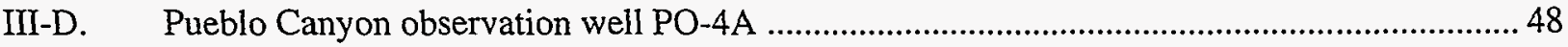

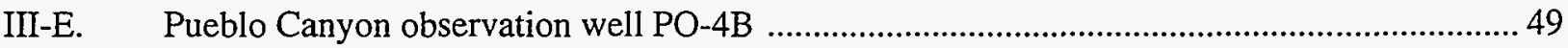

IV-A. Location of observation wells, test wells, and a supply well in Los Alamos Canyon .............. 58

IV-B. Los Alamos Canyon observation well LAO-C ................................................................... 58

IV-C. Los Alamos Canyon observation well LAO-1 ......................................................................5 59

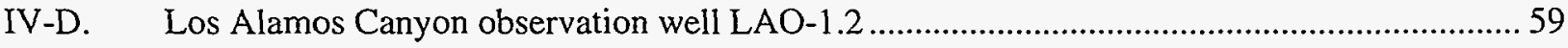

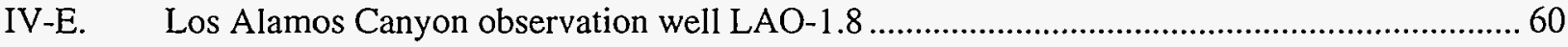

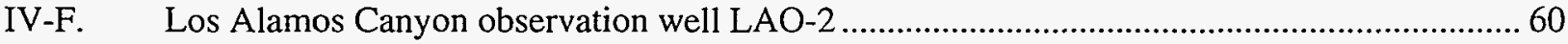

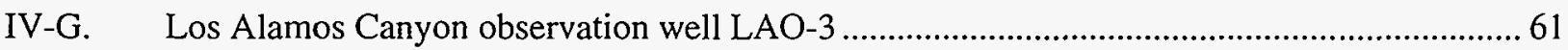




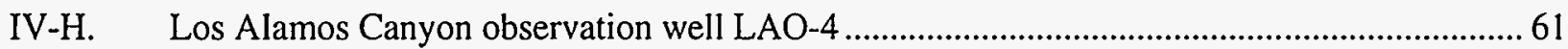

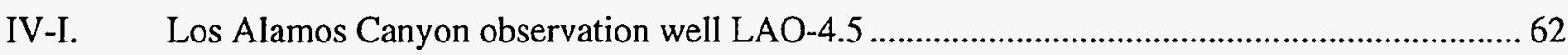

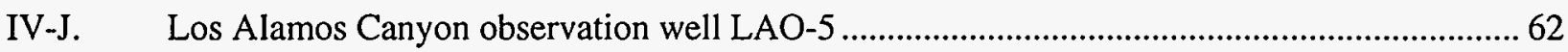

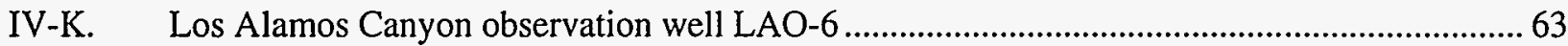

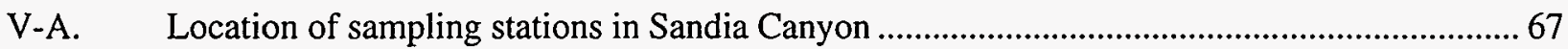

VI-A. Location of observation wells in Mortandad Canyon ........................................................ 71

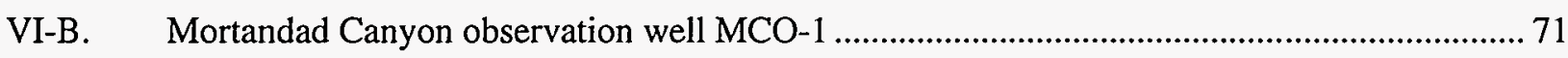

VI-C. Mortandad Canyon observation well MCO-2 …............................................................................ 72

VI-D. Mortandad Canyon observation well MCO-3 …................................................................... 72

VI-E. Mortandad Canyon observation well MCO-4 …............................................................... $73^{\text {* }}$

VI-F. Mortandad Canyon observation well MCO-4.9 .............................................................. 73

VI-G. Mortandad Canyon observation well MCO-5 .......................................................................... 74

VI-H. Mortandad Canyon observation well MCO-6 ..................................................................... 74

VI-I. Mortandad Canyon observation well MCO-6.5A ......................................................... 75

VI-J. Mortandad Canyon observation well MCO-6.5B .................................................................. 75

VI-K. Mortandad Canyon observation well MCO-7 ..................................................................... 76

VI-L. Mortandad Canyon observation well MCO-7.5A and adjacent well MCO-7.5B ................... 76

VI-M. Mortandad Canyon observation well MCO-8 …................................................................ 77

VI-N. Mortandad Canyon observation well MCO-8A ................................................................... 77

VI-O. Mortandad Canyon observation well MCO-8.2 ........................................................... 78

VI-P. Mortandad Canyon observation well MCO-9 ..................................................................... 78

VI-Q. Mortandad Canyon observation well MCO-9.5 …..................................................................... 79

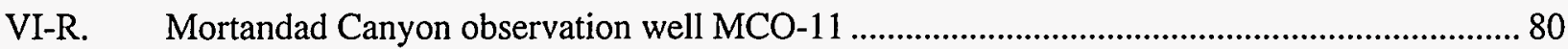

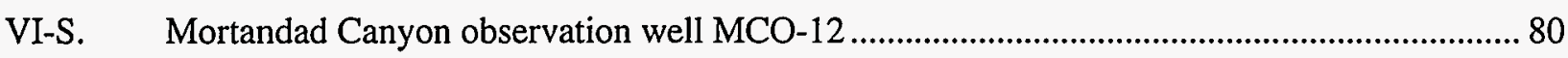

VI-T. Mortandad Canyon observation well MCO-12 …............................................................... 81

VI-U. Mortandad Canyon observation well MCO-13 …................................................................. 81

VI-V. Ten Site Canyon observation well TSCO-1 .......................................................................... 82

VI-W. Location of test holes and special moisture-access holes in Mortandad Canyon ..................... 82

VI-X. Cross section across stream channel showing Mortandad test hole MCM-2.2 …................... 83

VI-Y. Cross section across stream channel showing Mortandad test hole MCM-2.8 ...................... 83

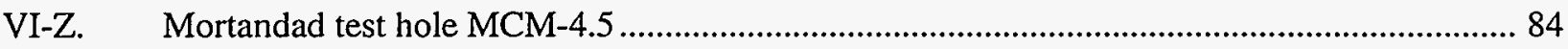

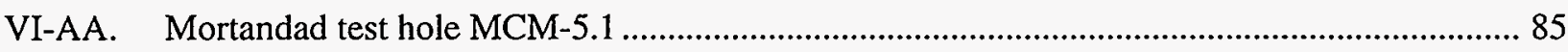

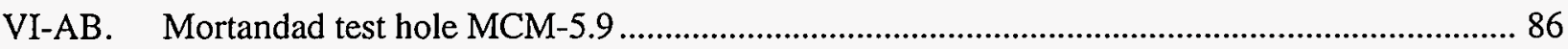


VI-AC. Mortandad test hole MCM-5.9A

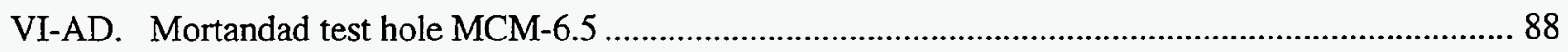

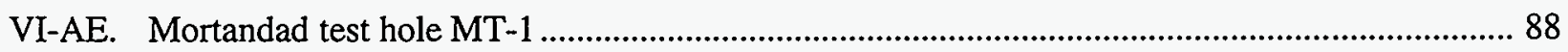

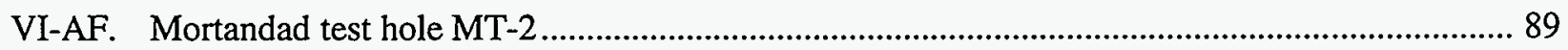

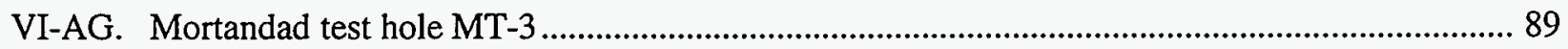

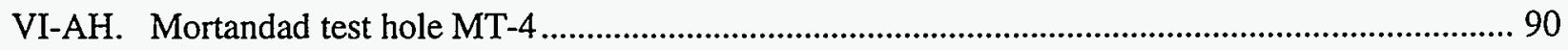

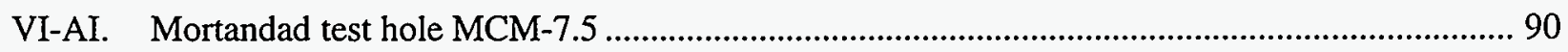

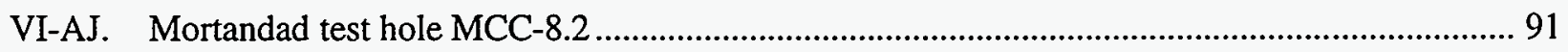

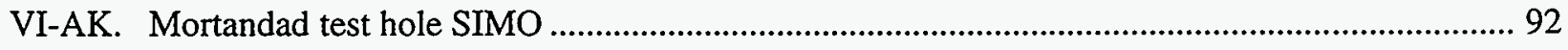

VI-AL. Mortandad test holes MCM-10-1, MCM-10-2, and MCM-3A-B .......................................... 93

VI-AM. Locations of moisture-access holes in Mortandad Canyon ....................................................... 93

VI-AN. Geologic section showing alluvium, unweathered tuff, and the saturated zone in lower

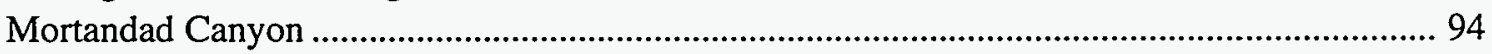

VI-AO. Geologic section showing alluvium, unweathered tuff, and the saturated zone across lower

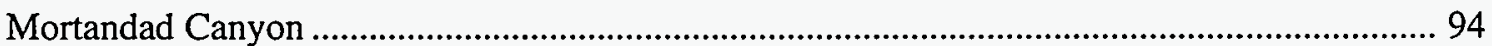

VII-A. Location of observation wells in Cañada del Buey (CDBO-series) and Pajarito Canyon (PCO-series) and moisture-access holes in Pajarito Canyon (PCM-series) .............................. 115

VII-B. Typical observation well construction in Cañada del Buey and Pajarito Canyon .................... 115

VII-C. Location of observation wells and moisture-access holes in Cañada del Buey ........................ 116

VII-D. Geologic log and casing schedule of observation well CDBO-1 .................................... 116

VII-E. Geologic log and casing schedule of observation well CDBO-2 ….................................... 117

VII-F. Geologic log and casing schedule of observation well CDBO-3 ......................................... 117

VII-G. Geologic log and casing schedule of observation well CDBO-4 ...................................... 118

VII-H. Geologic log and casing schedule of observation well PCO-1 ............................................... 118

VII-I. Geologic log and casing schedule of observation well PCO-2 .............................................. 119

VII-J. Geologic $\log$ and casing schedule of observation well PCO-3 ............................................ 119

VII-K. Geologic log and casing schedule of test hole PCM-1 ................................................... 120

VII-L. Geologic log and casing schedule of test hole PCM-2 ...................................................... 120

VII-M. Geologic log and casing schedule of test hole PCM-3 ...................................................... 121

VII-N. Geologic log and casing schedule of test hole PCM-4 ................................................... 121

VII-O. Geologic log and casing schedule of observation well CDBO-5 ........................................ 122

VII-P. Geologic log and casing schedule of observation well CDBO-6 ........................................ 122

VII-Q. Geologic log and casing schedule of observation well CDBO-7 ....................................... 123 
VII-R. Geologic log and casing schedule of observation well CDBO-8 ….................................... 123

VII-S. Geologic log and casing schedule of observation well CDBO-9 ......................................... 124

VII-T. Geologic log and casing schedule of moisture-access hole CDBM-1 ................................... 125

VII-U. Geologic log and casing schedule of moisture-access hole CDBM-2 _................................. 126

VIII-A. Locations of observation wells to meet special permit conditions ......................................... 137

VIII-B. Type of wellhead security used on observation wells ........................................................ 138

VIII-C. Pueblo Canyon observation well APCO-1 ....................................................................... 138

VIII-D. Los Alamos Canyon observation well LAO-3A ............................................................. 139

VIII-E. Los Alamos Canyon observation well LAO-4.5A …................................................................ 139

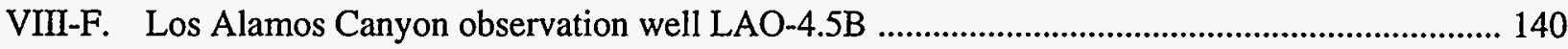

VIII-G. Los Alamos Canyon observation well LAO-4.5C ............................................................. 141

VIII-H. Los Alamos Canyon observation well LAO-6A .................................................................... 141

VIII-I. Sandia Canyon observation well SCO-1 ................................................................................. 142

VIII-J. Sandia Canyon observation well SCO-2 ….............................................................................. 143

VIII-K. Mortandad Canyon observation well MCO-4A .................................................................. 144

VIII-L. Mortandad Canyon observation well MCO-4B .................................................................... 145

VIII-M. Mortandad Canyon observation well MCO-6A …................................................................ 146

VIII-N. Mortandad Canyon observation well MCO-6B …...................................................................... 147

VIII-O. Mortandad Canyon observation well MCO-7A ..................................................................... 148

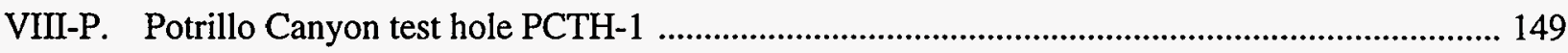

VIII-Q. Fence Canyon observation well FCO-1 _..................................................................... 150

VIII-R. Water Canyon observation well WCO-1 ............................................................................ 151

VIII-S. Water Canyon observation well WCO-2 …................................................................................ 152

VIII-T. Water Canyon observation well WCO-3 ......................................................................... 152

IX-A. Type section of the Tshirege Member of the Bandelier Tuff in Water Canyon north of TA-49 . 156

IX-B. Correlation of units of the Tshirege Member of the Bandelier Tuff at TA-49 with the type section in Mortandad Canyon ........................................................................................... 157

IX-C. Location of deep test wells (DT-series), core holes (CH-series), and test holes (TH-series) .......... 157

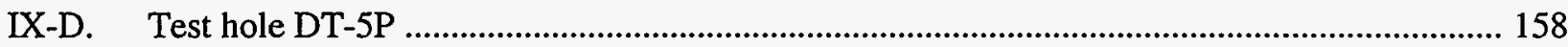

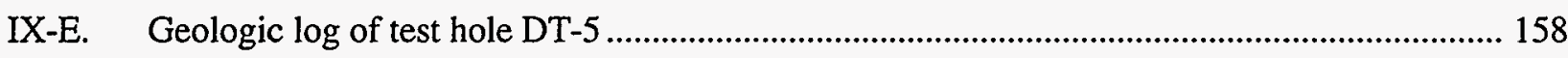

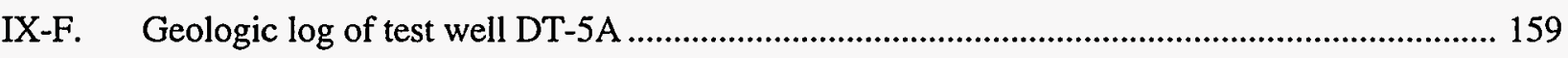

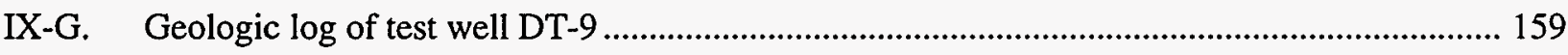

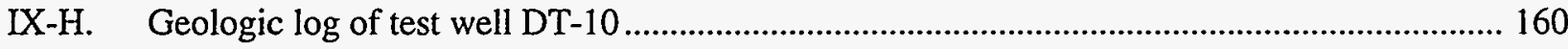




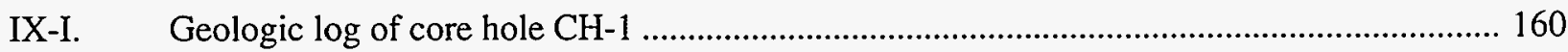

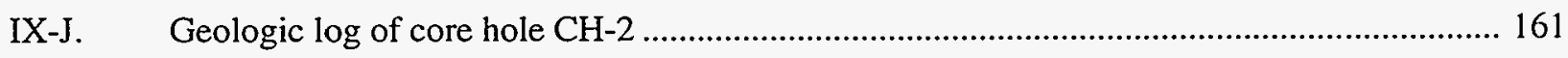

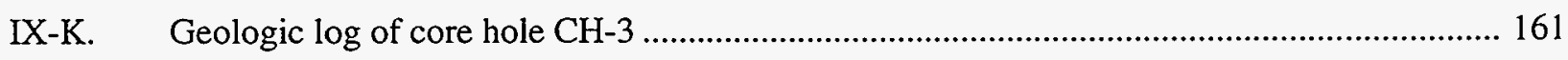

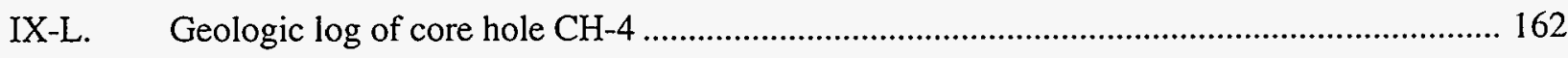

IX-M. Geologic log of Alpha Hole ......................................................................................... 162

IX-N. Geologic log of Beta Hole ......................................................................................... 163

IX-O. Geologic log of Gamma Hole …………………………............................................ 163

IX-P. Geologic $\log$ of Area 2 Test Hole 1 ............................................................................. 164

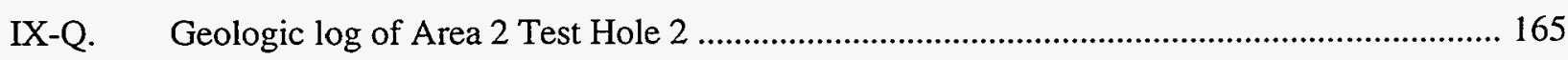

IX-R. Geologic log of Area 2 Test Hole 3 ………………................................................ 165

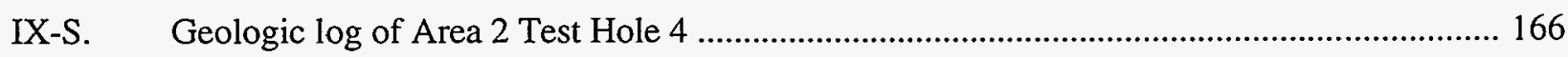

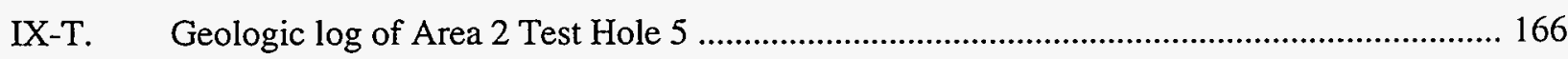

IX-U. Locations of wells, holes, and a surface water sampling station in Water Canyon

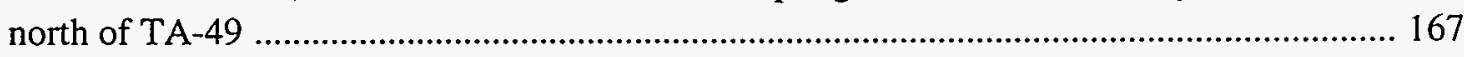

IX-V. Locations of moisture-access holes at TA-49 ................................................................. 167

X-A. Locations of test holes at air injection site near TA-52 ………………………………......... 177

XI-A. Locations of test holes at Site 1 and Site 2 near TA-50 …………………………................ 179

XII-A. Locations of test holes at solid waste Area B near TA-21 ................................................ 183

XIII-A. Locations of 18 test holes at Areas G and L on Mesita del Buey ......................................... 187

XIII-B. Locations of seven test holes on Mesita del Buey ............................................................ 187

XIII-C. Correlation differences in the thicknesses of units of the Tshirege Member at Area $\mathrm{L}$ between

Bendix test holes (1985-1986) and LANL test holes (1988-1990) ....................................... 188

XIII-D. Locations of the 10 test holes at Areas L and G on Mesita del Buey .................................... 188

XIV-A. Locations of exploratory test holes at Area P, TA-16 ......................................................... 194

XIV-B. Locations of four sets of cluster holes at Area P, TA-16 .................................................... 194

XIV-C. Locations of ground water observation wells at Area P, TA-16 ............................................ 195

XIV-D. Locations of test holes completed as moisture-access holes at Area P, TA-16 ...................... 195

XV-A. Location of U.S. Geological Survey test hole east of Waste Disposal Area C ........................ 207

XVI-A. Distillation holes at TA-21 and TA-46 ……………………………………………........ 209

XVII-A. Test wells and test holes on the Pajarito Plateau ............................................................. 212

XVII-B. Geologic logs of test well TW-1 and offset test well TW-1A ............................................ 213

XVII-C. Geologic logs of test well TW-2 and offset test well TW-2A ............................................. 214

XVII-D. Geologic log of test well TW-3 ..................................................................................... 214 


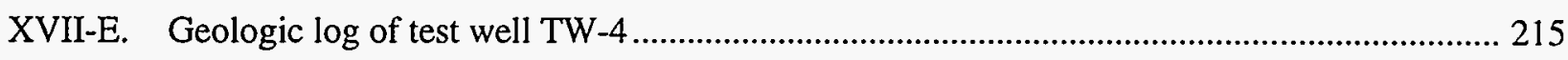

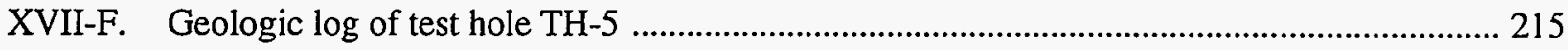

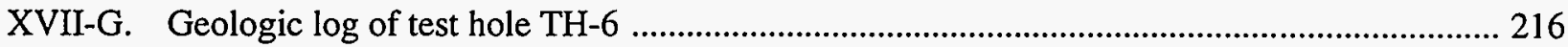

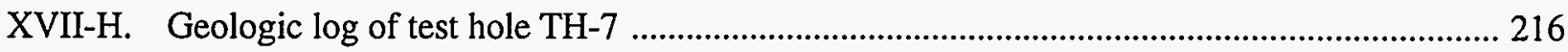

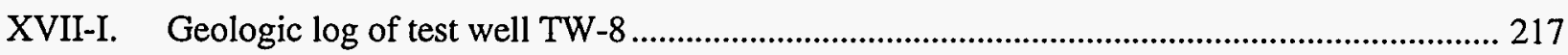

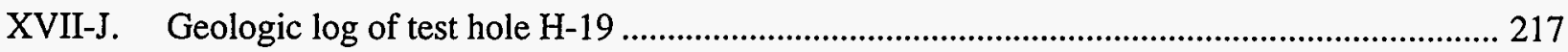

XVII-K Geologic log of test hole Sigma Mesa ........................................................................... 218

XVIII-A Test wells and springs in the Valle Toledo and Valle Grande ........................................... 229

XIX-A. Locations of test holes in the Valle Toledo ................................................................... 235

XIX-B. Generalized location of test holes in the Valle Grande ...................................................... 236 =

XIX-C. Locations of test holes in the Valle de los Posos and on the drainage divide ........................ 236

XIX-D. Locations of test holes used in the aquifer test in Valle Toledo .......................................... 237

XIX-E. Locations of test holes used in the aquifer test in the Valle Grande ...................................... 237

XX-A. Locations of Rio Grande and Guaje test holes .................................................................. 245

XXI-A. Locations of supply wells in the Los Alamos, Guaje, Pajarito, and Otowi well fields .......... 249

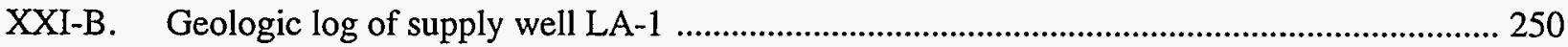

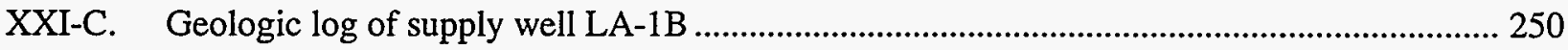

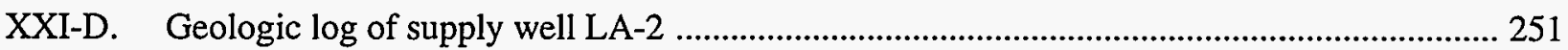

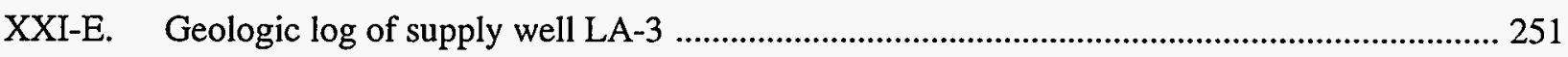

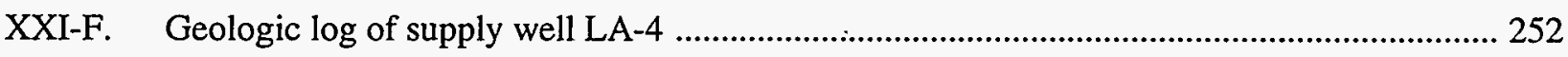

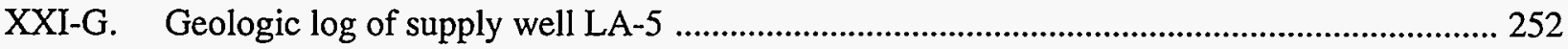

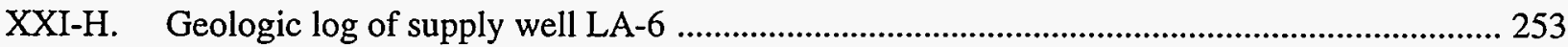

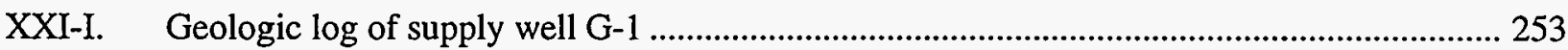

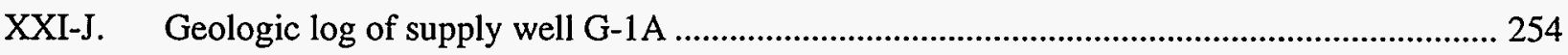

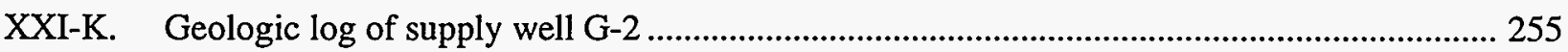

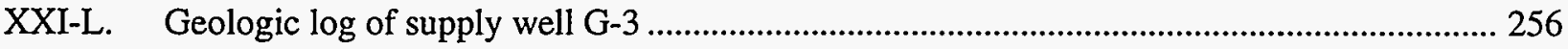

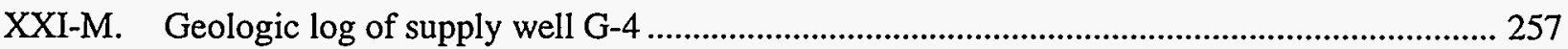

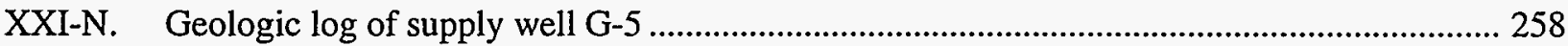

XXI-O. Geologic log of supply well G-6

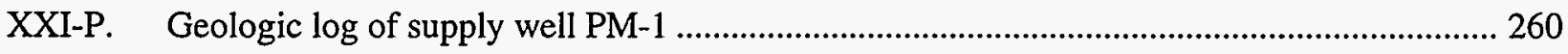

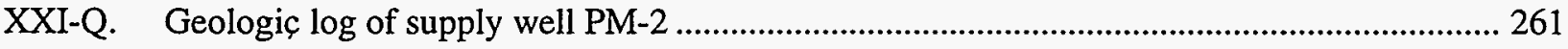

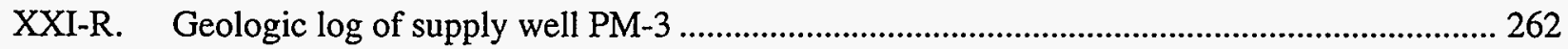

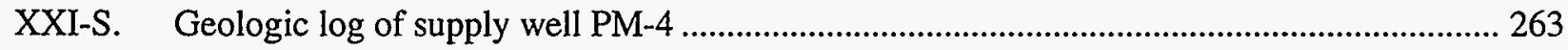




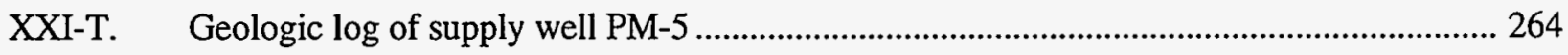

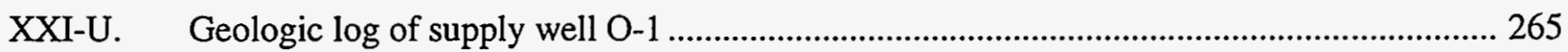

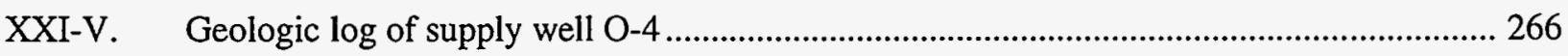

XXII-A. Locations of springs on the east flank of the Sierra de los Valles ..................................... 282

XXII-B. Locations of springs in lower Los Alamos Canyon and in White Rock Canyon along

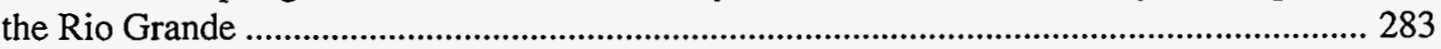

XXIII-A. Locations of geologic, hydrologic, engineering, and environmental investigations ........... 294

XXIII-B. Locations of test holes for seismic investigation ............................................................ 295

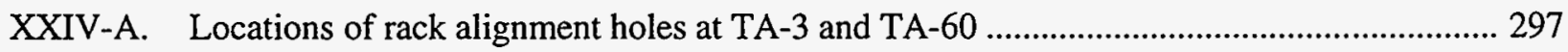

XXV-A. Locations of test holes in upper Guaje Canyon ............................................................ 299

XXVI-A. Heat flow sites, December 1971 and February 1972 ..................................................... 302

XXVI-B. Location of test holes, (TH-series, PC-series, and GT-1) west of the Valles Caldera.......... 303

XXVI-C. Site map of Fenton Hill showing location of observation, supply, exploratory, and

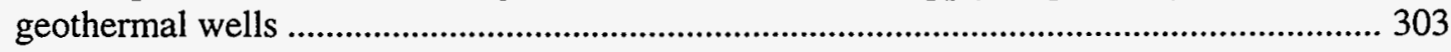

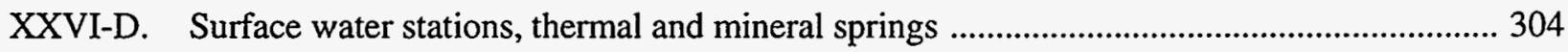

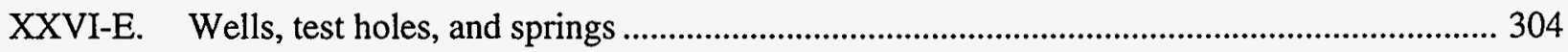

XXVI-F. Locations of surface-water stations and wells used in monitoring quality of water after 1974

XXVII-A. Locations of Guaje and Los Alamos reservoirs ............................................................ 313

XXVIII-A. Locations of low-flow investigations in Santa Clara, Guaje, Los Alamos, and Frijoles Canyons

XXVIII-B. Geologic section of Santa Clara Canyon showing locations of low-flow measurements .... 316

XXVIII-C. Geologic section of Guaje Canyon showing locations of low-flow measurements ............. 317

XXVIII-D. Geologic section of Los Alamos Canyon showing locations of low-flow measurements ... 317

XXVIII-E. Geologic section of Frijoles Canyon showing locations of low-flow measurements ........... 318

XXIX-A. Locations of gaging stations on the Rio Chama, Rio Grande, Jemez River, Rio Guadalupe, Santa Clara Creek, and Rito de los Frijoles ...................................................................... 325

XXX-A. Locations of test holes near the TA-53 surface impoundment ........................................ 327

XXXI-A. Locations of moisture-access holes and observation wells in Potrillo Canyon ................... 331

XXXI-B. Construction and geologic logs of observation wells POTO-4A, POTO-4B, and

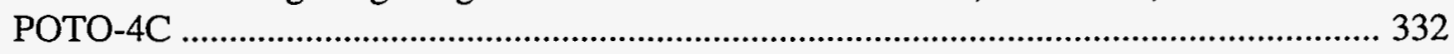

XXXI-C. Construction and geologic logs of observation wells POTO-5A and POTO-5B ............... 333

XXXII-A. Locations of test holes TBM-1 and TBM-2 at TA-49 ........................................................ 335

XXXII-B. Geologic logs of test holes TBM-1 and TBM-2 at TA-49 .......................................... 336

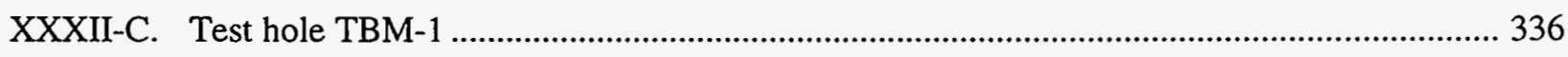

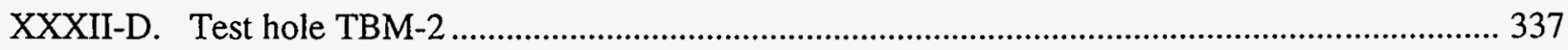




\section{TABLES}

I-A. Hydrologic Characteristics of Supply and Test Wells Completed in Main Aquifer ............... 31

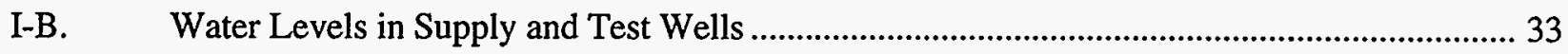

II-A. Records of Test Holes at Bayo Canyon Site, 1961 and 1973 .............................................. 44

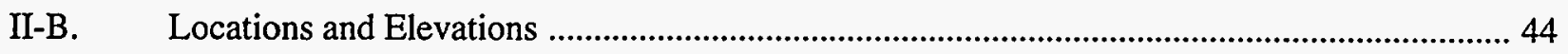

III-A. Surface Water Stations and Shallow Wells in Acid/Pueblo Canyon ...................................... 50

III-B. Records of Observation Wells and Test Holes in the Vicinity of Hamilton Bend Spring in

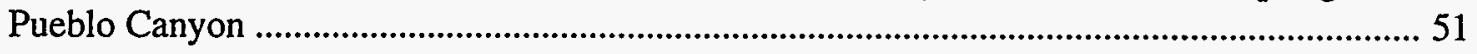

III-C. Geologic Logs and Construction Data of Observation Wells and Test Holes in the Vicinity of Hamilton Bend Spring in Pueblo Canyon ............................................................................. 52

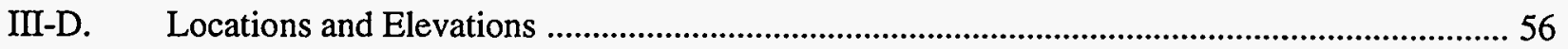

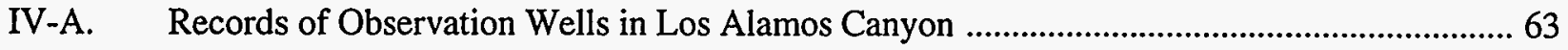

IV-B. Geologic Logs and Construction Data of Observation Wells in Los Alamos Canyon ............. 64

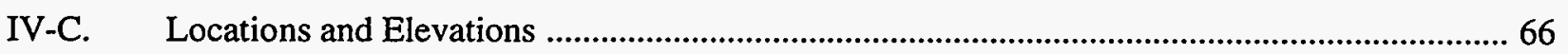

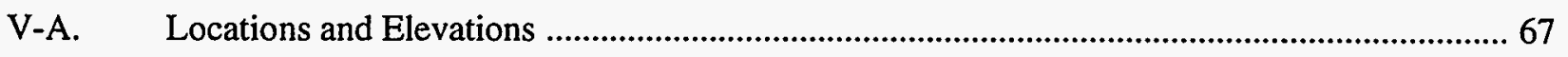

VI-A. Hydrologic Data for Observation Wells in Mortandad Canyon ...........................................95

VI-B. Geologic Logs and Construction Data for Observation Wells in Mortandad Canyon ............. 96

VI-C. Hydrologic Data for Test Wells in Mortandad Canyon ...................................................... 101

VI-D. Geologic Logs and Construction Data for Test Holes in Mortandad Canyon ........................... 102

VI-E. Geologic Logs and Construction Data for Moisture-Access Holes in Mortandad Canyon .... 109

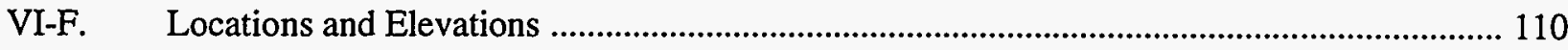

VII-A. Geologic Logs and Construction Data for Observation Wells in Cañada del Buey ............... 127

VII-B. Geologic Logs and Construction Data for Observation Wells in Pajarito Canyon ................ 129

VII-C. Geologic Logs and Construction Data for Moisture-Access Holes in Pajarito Canyon .......... 130

VII-D. Geologic Logs and Construction Data for Observation Wells in Cañada del Buey (1992) ... 131

VII-E. Geologic Logs and Construction Data for Moisture-Access Holes in Cañada del Buey ........ 133

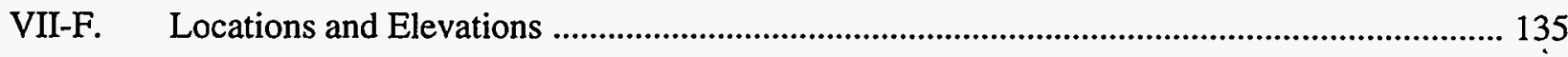

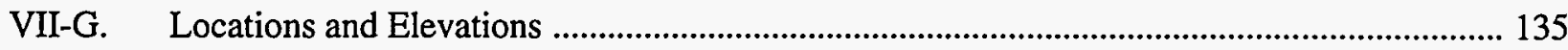

VIII-A. Locations, Elevations, and Measuring Points ......................................................................... 153

VIII-B. Characteristics and Water Levels of Observation Wells .................................................. 154

IX-A. Construction and Hydrologic Data for Test Holes, Test Wells, and Core Holes at TA-49 .... 168

IX-B. Geologic Logs and Construction Data for Test Holes and Test Wells ................................ 168

IX-C. Geologic Logs and Construction Data for Core and Shallow Test Holes ............................ 171 
IX-D. Geologic Logs of 23 Moisture-Access Holes and 2 Observation Wells at TA-49 ............... 175

IX-E. Locations and Elevations ...................................................................................... 176

X-A. Construction Data for Test Holes at Air-Tuff Transfer Site Near TA-52 ........................... 178

X-B. Locations and Elevations .................................................................................... 178

XI-A. Construction Data for Test Holes at Air-Tuff Transfer Site 1 Near TA-50 ......................... 180

XI-B. Construction Data for Test Holes at Liquid Injection Site 2 Near TA-50 ........................... 180

XI-C. Locations and Elevations .......................................................................................... 181

XII-A. Geologic Logs of Test Holes Near Solid Waste Disposal Area B at TA-21 ...................... 183

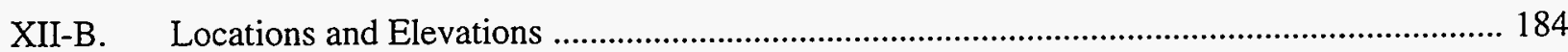

XIII-A. Geologic Logs of Test Holes at Areas G and L, TA-54, Mesita del Buey (1985) ................ 189

XIII-B. Geologic Logs of Test Holes at Area L, TA-54, Mesita del Buey (1986) ........................... 190

XIII-C. Geologic Logs of Test Holes at Areas G and L, TA-54, Mesita del Buey (1990) ................. 190

XIII-D. Locations and Elevations .......................................................................................... 191

XIV-A. Geologic Logs of Exploratory Holes at TA-16 ............................................................... 196

XIV-B. Geologic Logs and Construction Data for Vadose Monitoring Holes at TA-16 .................. 198

XIV-C. Geologic Logs and Construction Data for Observation Wells at TA-16 ............................ 201

XIV-D. Geologic Logs and Construction Data for Moisture-Access Holes at TA-16 ..................... 203

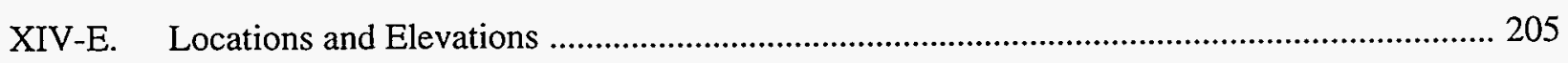

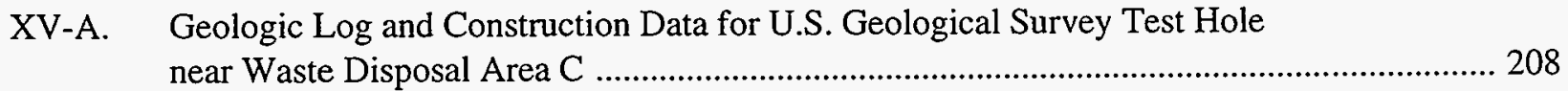

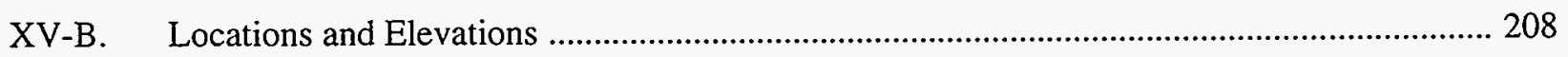

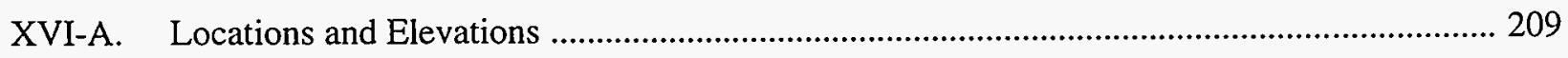

XVII-A. Construction and Hydrologic Data for Test Wells and Test Holes on the Pajarito Plateau ....... 219

XVII-B. Geologic Logs and Construction Data for Test Wells and Test Holes on the Pajarito Plateau .. 220

XVII-C. Drilling Progress Report for Sigma Mesa EGH-LA-1 ….................................................... 227

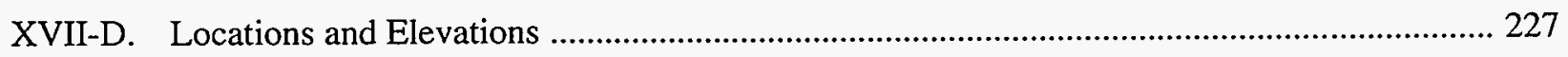

XVIII-A. Records of the Test Holes in the Valle Toledo and Valle Grande ......................................... 230

XVIII-B. Geologic Logs of Test Holes in the Valle Toledo and Valle Grande ................................... 231

XVIII-C. Records of Springs in the Valle Toledo and Valle Grande .................................................. 232

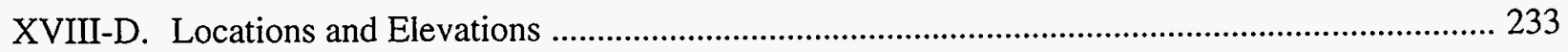

XIX-A. Records of Test Holes in the Valle Toledo, Valle Grande, and Adjacent Areas .................... 238

XIX-B. Geologic Logs and Casing Schedules of Test Holes in the Valle Toledo, Valle Grande, and Adjacent Areas 
XIX-C. Locations and Elevations

XX-A. Geologic Logs and Construction Data of Rio Grande and Guaje Test Holes ................... 246

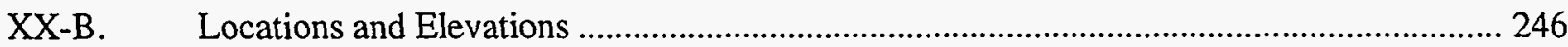

XXI-A. Construction Data and Hydrologic Characteristics of Supply Wells in the Los Alamos, Guaje, Pajarito, and Otowi Well Fields .................................................................................. 267

XXI-B. Geologic Logs and Casing Schedules for Supply Wells in the Los Alamos Well Field ..... 268

XXI-C. Geologic Logs and Casing Schedules for Supply Wells in the Guaje Well Field ............... 271

XXI-D. Geologic Logs and Casing Schedules for Supply Wells in the Pajarito Well Field ............ 275

XXI-E. Geologic Logs and Casing Schedules for Supply Wells in the Otowi Well Field .............. 278

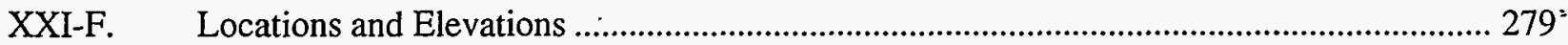

XXII-A. Records of Springs in the Los Alamos Area ........................................................................ 284

XXII-B. Major Canyons and Streams Entering the Rio Grande in White Rock Canyon .................. 286

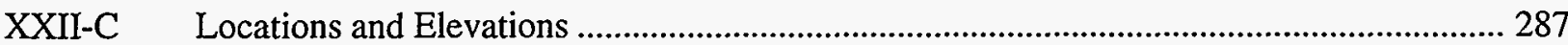

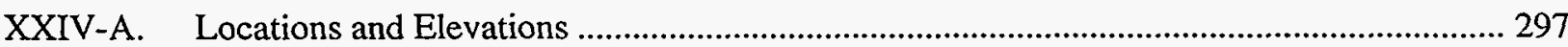

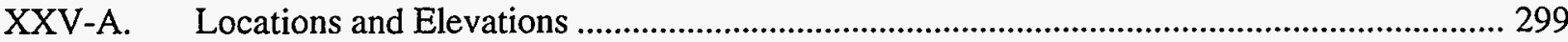

XXVI-A. Geologic Logs and Construction Data for Granite Test Hole (GT-1) and Test Holes TH-A,

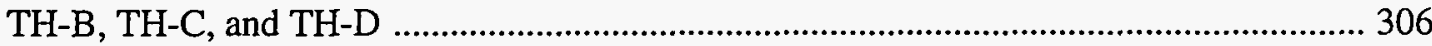

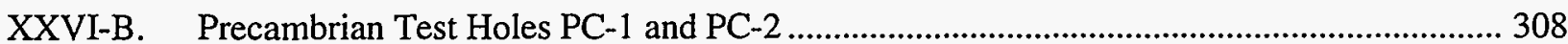

XXVI-C. Geologic Logs and Construction Data for Supply Wells at Fenton Hill ............................ 309

XXVI-D. Surface Water Quality at Water Stations in the Jemez Mountains ...................................... 310

XXVI-E. Ground Water Quality at Water Stations in the Jemez Mountains ..................................... 311

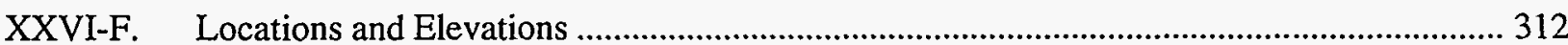

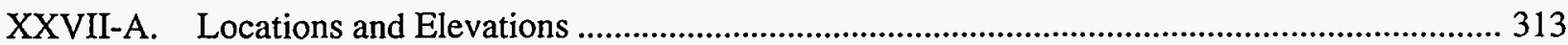

XXVIII-A. Low-Flow Measurements and Annual Runoff in Santa Clara Canyon .............................. 319

XXVIII-B. Low-Flow Measurements in Guaje Canyon ......................................................................... 320

XXVIII-C. Low-Flow Measurements in Los Alamos Canyon ............................................................. 320

XXVIII-D. Low-Flow Measurements and Annual Runoff in Frijoles Canyon ..................................... 321

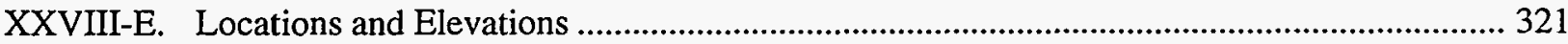

XXIX-A. Locations and Elevations of Gaging Stations ....................................................................... 325

XXX-A. Geologic Logs and Construction Data for Test Holes at TA-53 ....................................... 328

XXXI-A. Geologic Logs and Construction Data for Moisture-Access Holes in Potrillo Canyon ...... 334

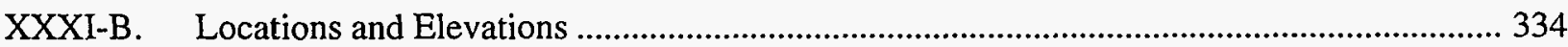




\title{
GEOLOGIC AND HYDROLOGIC RECORDS OF OBSERVATION WELLS, TEST HOLES, TEST WELLS, SUPPLY WELLS, SPRINGS, AND SURFACE WATER STATIONS IN THE LOS ALAMOS AREA
}

\author{
by
}

\section{W. D. Purtymun}

\begin{abstract}
Hundreds of holes have been drilled into the Pajarito Plateau and surrounding test areas of the Los Alamos National Laboratory since the end of World War II. They range in depth from a few feet to more than $14000 \mathrm{ft}$. The holes were drilled to provide geologic, hydrologic, and engineering information related to development of a water supply, to provide data on the likelihood or presence of subsurface contamination from hazardous and nuclear materials, and for engineering design for construction. The data contained in this report provide a basis for further investigations into the consequences of our past, present, and future interactions with the environment.
\end{abstract}

\section{INTRODUCTION}

Studies for the development of water supply, for the monitoring of the release of liquid wastes, for the disposal and storage of industrial wastes, and engineering investigations have resulted in a large number of reports. These reports have required the drilling of supply wells, test holes, test wells, and observation wells for water supply and for geologic and hydrologic information. Other test holes have been drilled for various experiments related to waste disposal and storage. Surface water investigations have been conducted to help determine the hydrology of the area. In addition, a number of stations have been established to monitor the quality of both the surface and ground water.

\section{A. Purpose and Scope}

The purpose of this report is to compile geologic logs, construction records, and locations of supply wells, observation wells, test wells, test holes and monitoring stations (both surface and ground water stations). The geology and hydrology are presented to provide a framework for understanding the geologic units that relate to the movement of surface and ground water. The original sources of the data presented in each section are referenced at the end of each section.

This report is similar to the two reports, "Records of Wells, Test Wells, Springs and Surface-Water Stations in the Los Alamos Area," by E. C. John, E. Enyart, and W. D. Purtymun, U.S. Geological Survey Open-File Report (1966) and "Geohydrology of the Pajarito Plateau with Reference to the Quality of Water 1949-1972," by W. D. Purtymun, Los Alamos Scientific Laboratory, internal EM-8 document, 1975. This document incorporates data from those documents and presents additional data collected through 1992.

Katherine D. Bennett's "Annotated Bibliography of Geologic, Hydrologic and Environmental Studies Related to Solid Waste Management Units at Los Alamos National Laboratory" Los Alamos National Laboratory document LA-UR-90-3216 presents a complete reference to geologic, hydrologic, and environmental reports available at the Environmental Community Reading Room located at 1450 Central Ave. Suite 101, Los Alamos, New Mexico. The reading room is maintained by the Laboratory as part of the operating permit granted to the Laboratory by the U.S. Environmental Protection Agency (EPA). All reports referenced in this report should be available at the reading room. 
This report includes geologic logs and construction data for the following:

(1) observation wells or test holes completed in the shallow alluvial aquifers

(2) wells or test holes constructed for special studies

(3) moisture-access holes (cased with 2-in.-diam plastic or aluminum pipe and used in conjunction with a moisture/density gauge to determine moisture and density of material adjacent to the core hole)

(4) wells or test holes completed into the main aquifer, or into perched aquifers below the alluvial aquifer and above the main aquifer

(5) supply wells completed into the main aquifer

(6) springs

(7) holes drilled for specific engineering purposes

(8) holes used for facility construction

(9) surface water data related to seepage measurements

(10) the monitoring of surface and ground water in and adjacent to the Laboratory

(11) preliminary studies and support activities such as water supply and water quality monitoring at the
In this paper we have sometimes used internal or unpublished reports or memos that relate to holes drilled for small, specific, geologic or hydrologic studies. These papers can be found in Los Alamos National Laboratory report LA-12733-MS. This report is entitled "Source Document Compilation: Los Alamos Investigations Related to the Environment, Engineering, Geology, and Hydrology, 1961-1990."

\section{B. Locations of Test Holes, Wells, and Monitoring Stations}

Two methods are used for the location of test holes, wells, and monitoring stations in this report: (1) the North American Datum 1927 coordinate system (NAD 1927) and (2) the Los Alamos National Laboratory coordinate system (LANLC). The NAD 1927 system is preferred; however, in some cases sites where the wells or stations have been originally surveyed in the LANLC, this system has been used to document the location. Each section of the report contains a reference map showing the general loca-

Fenton Hill geothermal experimental site.

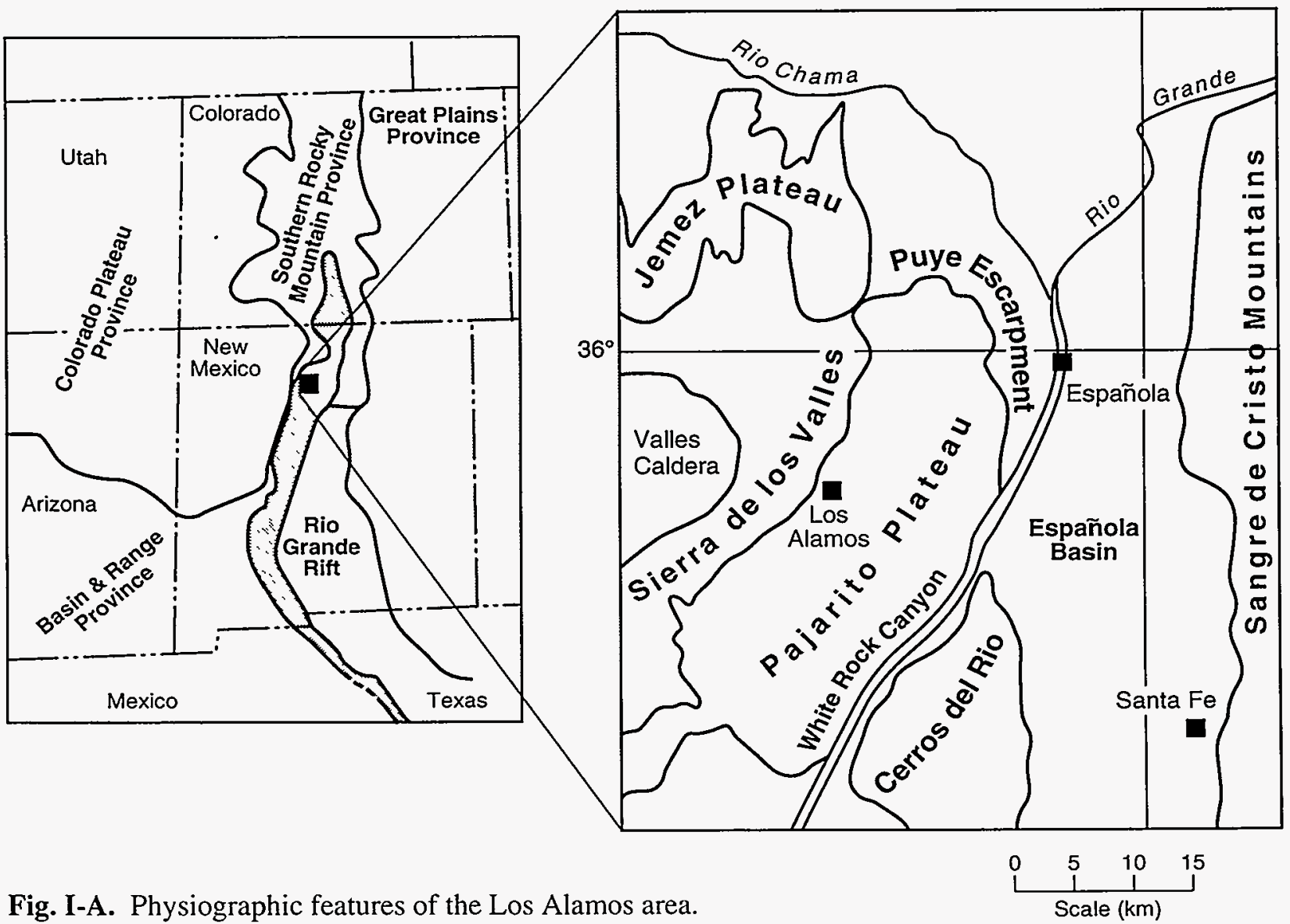


tion for the wells, test holes, or monitoring stations.

\section{Topography}

The facilities of Los Alamos National Laboratory and the communities of Los Alamos and White Rock are located on the Pajarito Plateau. The Pajarito Plateau forms an apron 8 to 16 miles wide and 30 to 40 miles long around the eastern flanks of the Sierra de los Valles (Fig. I-A). The surface of the plateau slopes gently eastward from an elevation of about $7800 \mathrm{ft}$ along the flanks of the mountains to about $6200 \mathrm{ft}$ along the eastern edge, where it terminates along the Puye Escarpment and White Rock Canyon (Fig. I-B). The plateau is drained by southeast- and eastward-trending streams that have cut deep canyons. These canyons dissect the plateau into narrow east- to southeast-trending mesas.

The Rio Grande lies along the eastern edge of the plateau. It drops from an elevation of about $5500 \mathrm{ft}$ at Otowi (at the mouth of Los Alamos Canyon) to about $5360 \mathrm{ft}$ at its junction with Frijoles Canyon. North of Otowi the Rio Grande lies in a broad valley, whereas to the south the river is confined in a deep narrow canyon (White Rock Canyon).

The mountain peaks of the Sierra de los Valles rise to an elevation of about $11500 \mathrm{ft}$ near the head of Santa Clara Canyon to the north and to an elevation of about $10200 \mathrm{ft}$ near the head of Frijoles Canyon to the south. The crest of the north/south range of peaks and ridges forms a surface water divide. Streams originating on the eastern slopes and the Pajarito Plateau flow directly into the Rio Grande. Streams originating on the western slopes flow into the Valles Caldera, an intermountain basin, which is drained mainly by the Jemez River. The Jemez enters the Rio Grande 75 miles to the south.

\section{Geology}

The geologic nomenclature of the rock units has evolved over the years. An effort has been made to incorporate these changes into this report. The geologic and geophysical logs of deep test holes or wells penetrating the Puye Conglomerate and Santa

Fe Group have been revised to reflect these changes. The major change is the separation of the coarse gravels, cobbles, and boulders that represent a deposition of volcanic debris from the west and granitic and metamorphic rocks from the east. These were previously logged as the upper part of the Tesuque Formation beneath the Pajarito Plateau. This unit (named the Chaquehui Formation of the Santa Fe Group) has allowed the development of a high-yield water supply on the plateau. The Chamita Formation which overlies the Tesuque Formation (and which was previously included in the early descriptions of the Tesuque Formation) is also described separately where it can be identified. There are different terminologies used in the nomenclature of the volcanic rocks of the Jemez Mountains and the Basaltic Rocks of Chino Mesa. The stratigraphic units used in this report are shown in Fig. I-C.

The drainage areas or streams that head on the flanks of the mountains cut into the rocks of the Tschicoma Formation. Canyons on the plateau cut into and are underlain by the Bandelier Tuff. Along the eastern edge of the plateau the channels cut into 


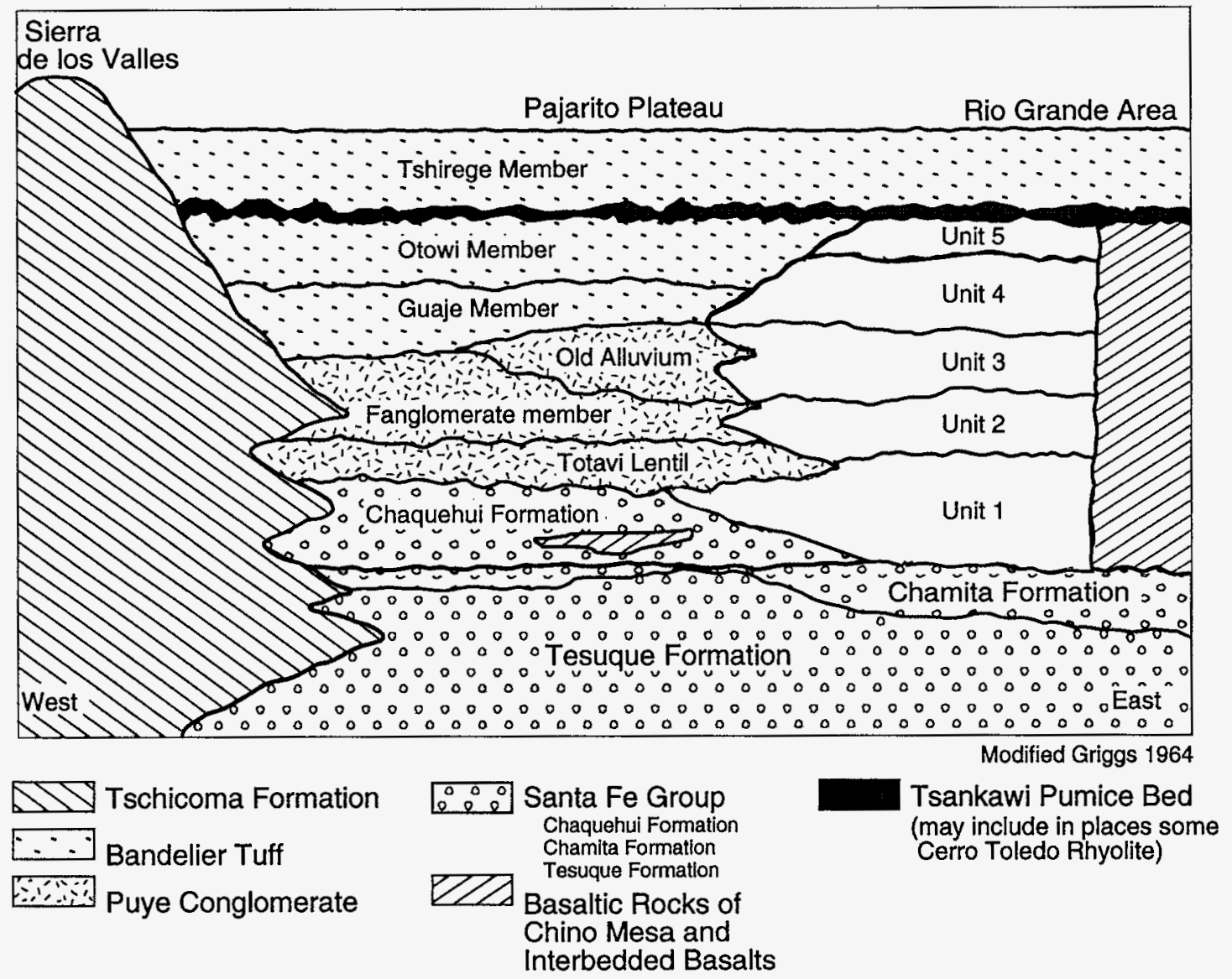

Fig. I-C. Diagram of stratigraphic units used in this report.

the Basaltic Rocks of Chino Mesa (part of the Cerros del Rio basalts) and the sediments of the Puye Conglomerate and the Santa Fe Group. These sediments floor the valley north of Otowi on the Rio Grande and form the lower canyon walls along the Rio Grande in White Rock Canyon. The Basaltic Rocks of Chino Mesa are interbedded with the sediments of the Puye Conglomerate along White Rock Canyon and beneath the Pajarito Plateau

(Fig. I-D).

The rock units, described from the oldest to the youngest, are the Santa Fe Group, Puye Conglomerate, and the Basaltic Rocks of Chino Mesa. The volcanic rocks of the Jemez Mountains include the Tschicoma Formation and the Bandelier Tuff (which includes the Cerro Toledo Rhyolites and Tsankawi Pumice Bed). A diagrammatic section of geologic units beneath the Pajarito Plateau is shown on Fig. I-F.
1. Santa Fe Group. The Santa Fe Group underlies the Puye Conglomerate and outcrops along the eastern edge of the plateau along the Rio Grande. The stratigraphic nomenclature of the Santa Fe Group and Puye Conglomerate has evolved over the past 50 years as shown in Fig. I-E. The nomenclature used in this report is shown on the right side of the figure.

The Santa Fe Group is composed of three formations in the area. The oldest is the Tesuque Formation which underlies the Chamita Formation.

The name Tesuque Formation was first used by Spiegel and Baldwin (1963) to describe the sediments at the southern end of the Española valley including the exposures in the vicinity of Otowi Bridge and along White Rock Canyon on the Rio Grande. Baltz et al. (1963) extended the name into the Los Alamos area in 1960 on the basis of lithology and stratigraphic location. Galusha and Blick (1971) split the younger 

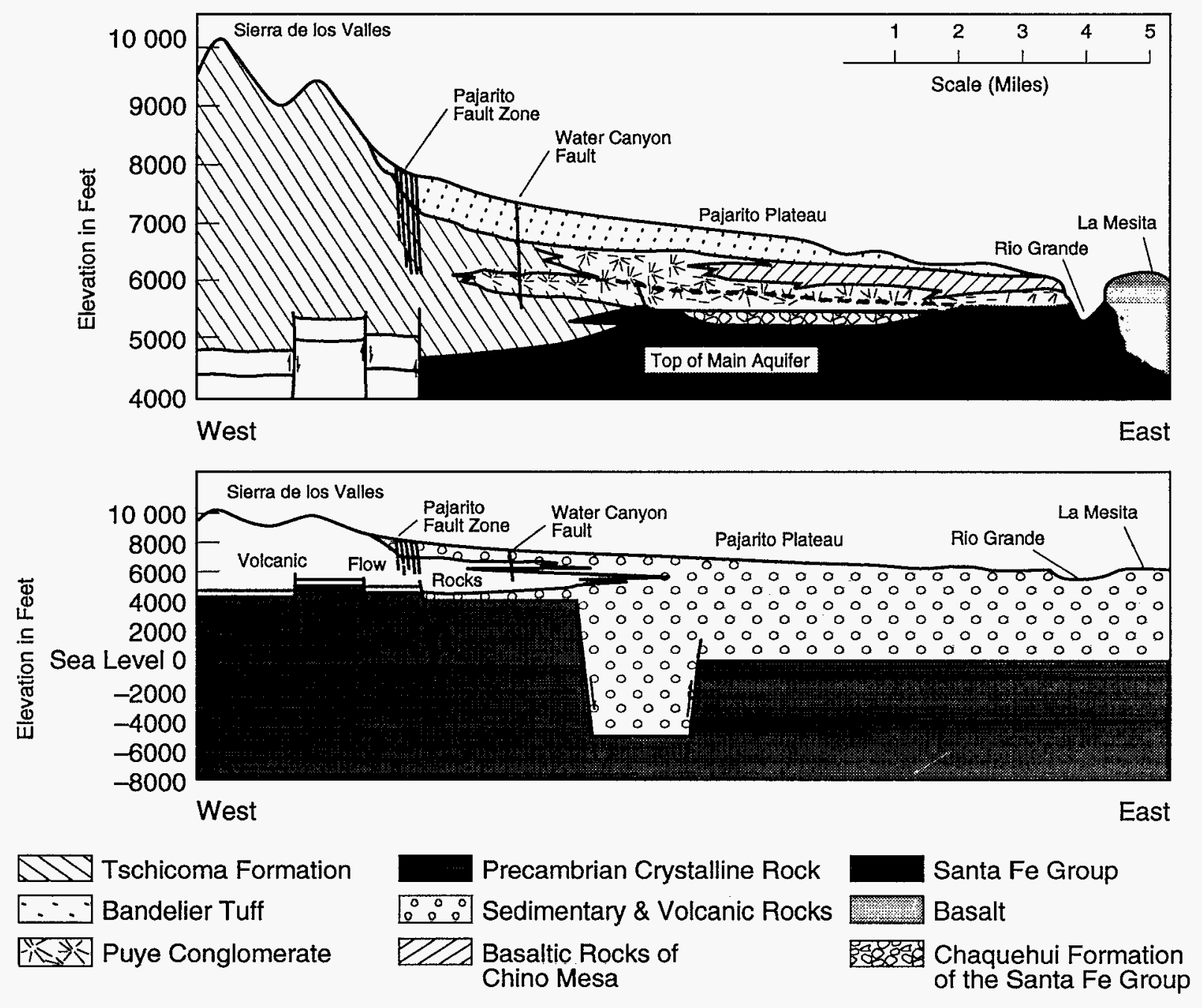

Fig. I-D. Geologic sections showing the stratigraphy and structure from the Sierra de los Valles across the Pajarito Plateau to the Rio Grande (modified Purtymun 1968). 


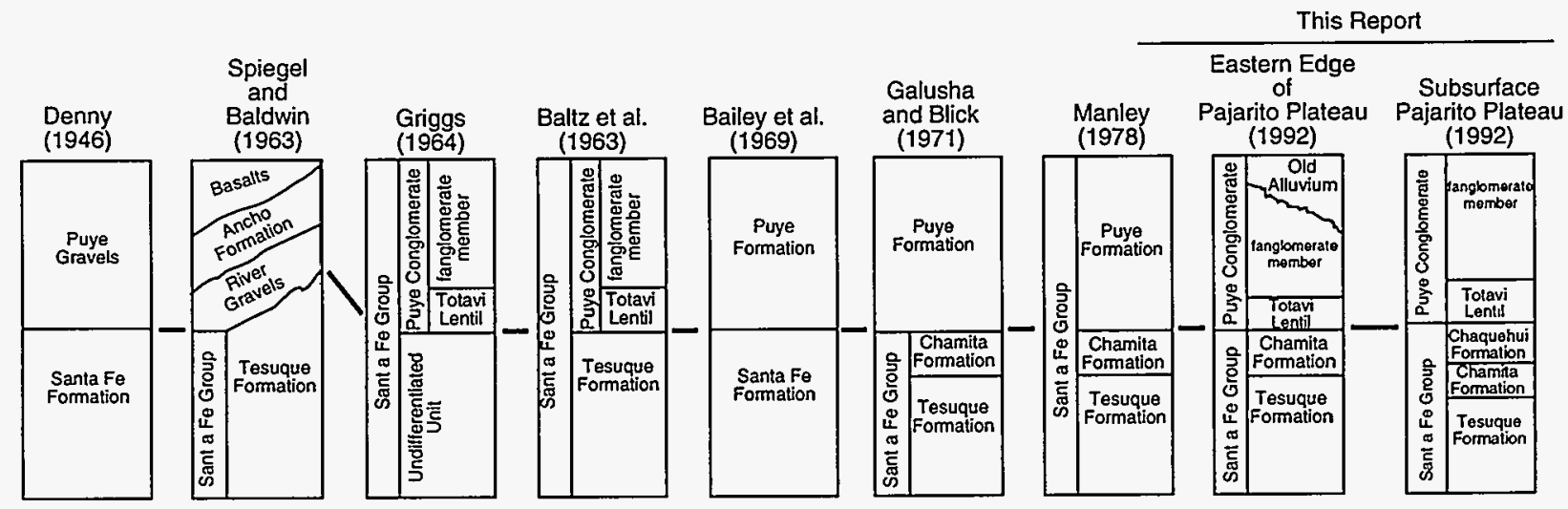

Fig. I-E. Stratigraphic nomenclature of the pre-Bandelier sediments.

Chamita Formation from the top units of the Tesuque Formation (Fig. I-E). Previous well logs considered the Chamita Formation as the upper part of the Tesuque Formation. This report separates out the Chamita Formation from the Tesuque Formation where it is present.

The Tesuque Formation is the oldest geologic formation to be considered in this report. It is a massive, thick unit consisting of arkosic sediments that are poorly to moderately cemented, light pink to buff siltstone, silty sandstone, and a few lenses of pebbly conglomerate and clay. The sand-sized particles are dominantly quartz and feldspar; minor amounts of biotite, muscovite, and magnetite are also present. Most of the beds are shallow stream or deltaic deposits with some minor amounts of windblown sand. Basalts older than the Basaltic Rocks of Chino Mesa were not encountered in the Tesuque Formation in the Pajarito Well Field; however, basalts older than the Chino Mesa basalts were encountered interbedded with the Tesuque Formation sediments in wells G-1, G-1A, and G-6 in the Guaje Field (Fig. I-F). A basalt sill at a depth of $2219 \mathrm{ft}$ in Otowi Well O-1 was found to be 12 million years old (Laughtin et al. 1993).

South of Otowi, the Tesuque Formation forms the valley along the Rio Grande and outcrops in lower canyon walls cut into the eastern edge of the Pajarito Plateau. In this area the Tesuque is overlain by a thin section of the Totavi Lentil. North of Water Canyon the Tesuque plunges beneath the younger Chaquehui Formation of the Santa Fe Group.

The Chamita Formation consists of arkosic siltstones, sandstones, and pebbly conglomerate that contains two prominent beds of white ash. These ash beds were described in the logs of Pajarito Wells PM-1, PM-2, and PM-5, and Otowi Well 0-4. The formation is thickest in the northern part of the Española Basin and thins to less than 30 feet in the area north of Otowi. It is of localized extent. In the immediate Los Alamos area, it is absent in the supply wells in lower Los Alamos and Guaje Canyons, and only thin remnants are found in a few of the supply wells completed on the Pajarito Plateau (Fig. I-F). The bulk of the Chamita Formation has been stripped off by erosion or was not deposited in the area. The lithology and physical characteristics of the Chamita are similar to the Tesuque Formation, and thus do not contribute any measurable change to the hydrologic properties of the Santa Fe Group.

The Chaquehui Formation of the Santa Fe Group is composed of a mixture of volcanic debris from the Sierra de los Valles and arkosic and granitic debris from the highlands to the north and east. It contains the only aquifer in the Los Alamos area that is capable of providing a municipal and industrial water supply. The early basalt flows of the Cerros del Rio basalts formed a constriction at the southern end of the Española Basin, forcing the river west of the volcanic centers (Kelley 1948; Theis 1950). The volcanic debris mixed with granitic debris carried by the river and filled the basin. This deposition of coarse sediments was contemporaneous with the intrusion of basalts and basalt flows, which are interbedded with the sediments and are older than the Basaltic Rocks of Chino Mesa. In Otowi Well O-4 


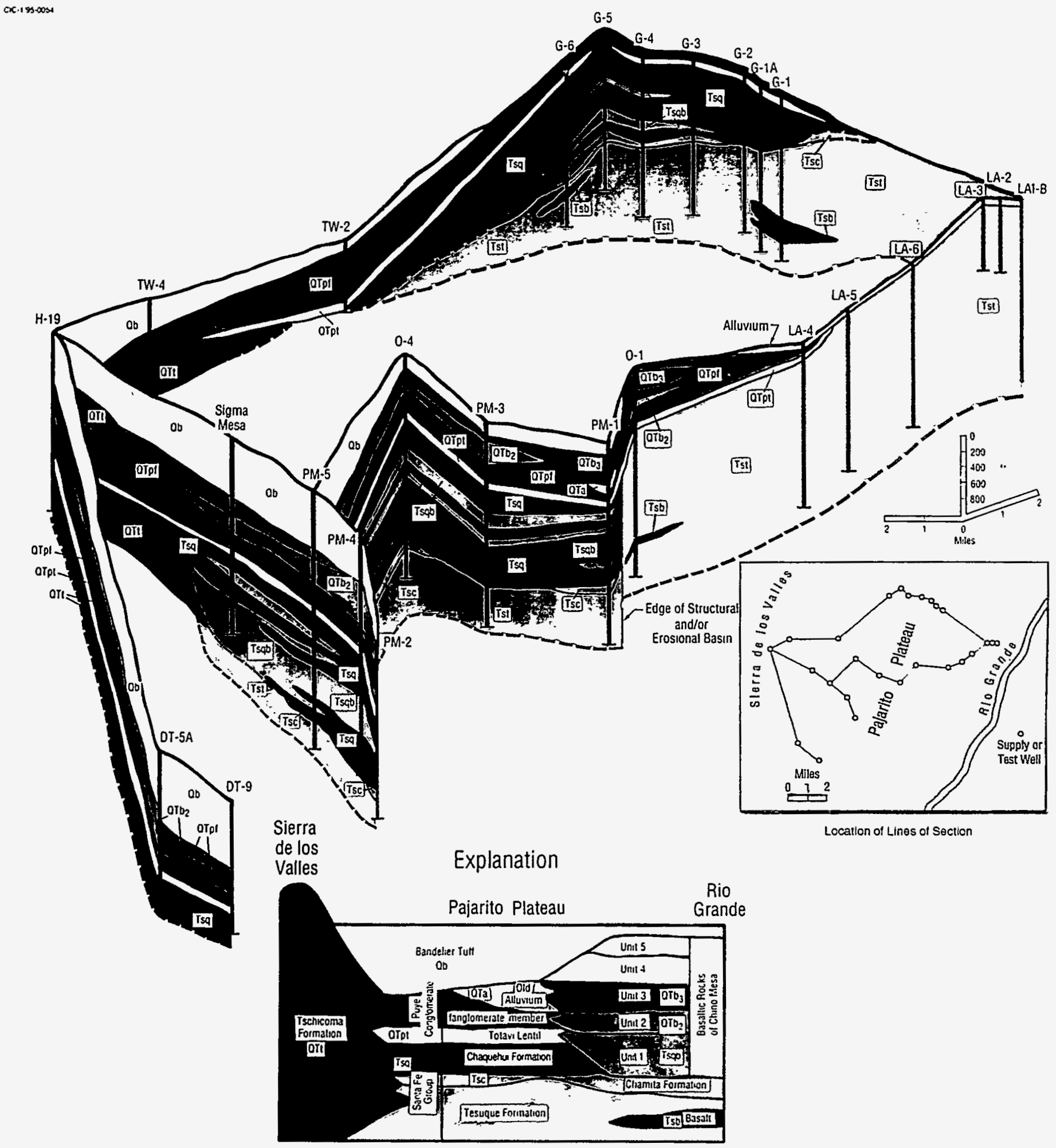

Fig. I-F. Diagrammatic section showing stratigraphy beneath the Pajarito Plateau. 
, 


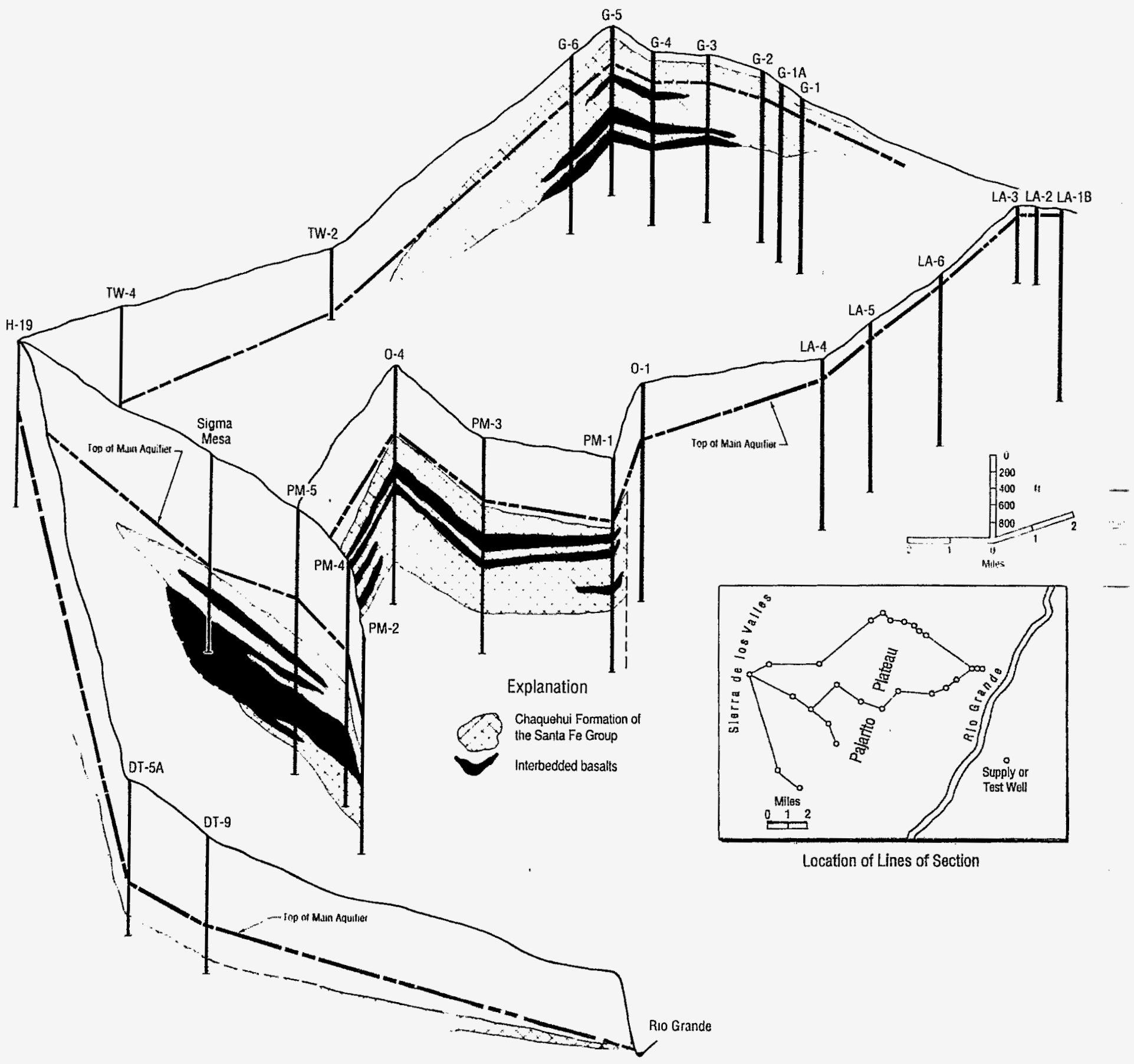

Fig. I-G. Diagrammatic section showing the distribution of the Chaquehui Formation of the Santa Fe Group and interbedded basalts beneath the Pajarito Plateau. 
there are interbedded basalts between the depths of 1140 and $1392 \mathrm{ft}$ that were dated as being 8 to 9 million years old (Laughtin et al. 1993), or about equivalent in age to the Chamita Formation. Several of the wells on the plateau show, however, that the Chamita Formation consistently underlies the Chaquehui Formation.

The coarse sediments of the Chaquehui Formation contain volcanic rock fragments of basalt, latite, rhyolite, tuff, and pumice derived from the west as well as rhyolite, gneiss, limestone, and quartzite derived from the highlands to the north and east. The formation is found in the subsurface beneath the plateau and outcrops in a thin section in White Rock Canyon (Fig. I-G). It is transitional between the rest of the Santa Fe Group (encompassing also the Chamita and Tesuque Formations) and the volcanic rocks of the Jemez Mountains. The presence of the coarse-grained sediments of the Chaquehui was first noted by Griggs (1964) as arkosic quartz sands, latite gravels, and volcanic debris derived from the east and west sources in the subsurface of the Guaje Well Field. He also noted their presence in White Rock Canyon to the south of Water Canyon. The formation is named after the small Chaquehui Canyon that drains into White Rock Canyon at the south end of the outcrop described by Griggs.

Overlying the Chaquehui Formation in White Rock Canyon are mixtures of sediments, quartzites, basalts, and volcanic sediments described as maar deposits (a mixture of sediments and volcanic material resulting from a volcanic eruption through an aquifer or shallow lake). Aubele (1978) noted Precambrian granitic and metamorphic chert, quartzite and granitic fragments interbedded with the basalts of the Cerros del Rio Volcanic Field. Heiken et al. (1989) also described the maar deposits in White Rock Canyon. However, these maar deposits are below the Totavi Lentil in Ancho Canyon and below the Unit 1 Basaltic Rocks of Chino Mesa (Figs. I-H and I-I). Dethier (in press 1994) indicated that the maar deposits at the mouth of Chaquehui Canyon are older than 2.6 million years, the age of the Basaltic Rocks of Chino Mesa. The maar deposits have not been dated and may be similar in age to the Chaquehui Formation ( 8 to 9 million years old).

Weir and Purtymun (1962) encountered the coarse-grained sediments of the Chaquehui Formation beneath the Totavi Lentil and recognized the potential of the formation for the development of a water supply. Based on aquifer tests at TA-49, Purtymun and Cushman (1961) located the first of the Pajarito wells on the eastern edge of the Pajarito Plateau, followed by Purtymun and John (1964) locating the second well near the center of the plateau. The coarse-grained cuttings encountered in both wells beneath the Totavi Lentil outlined a trough of coarsegrained sediments that would allow the development of high-yield wells (with yields greater than 1000 $\mathrm{gpm}$ ). Five additional well-site locations were laid out by Purtymun and Cooper (1965). Three additional wells were drilled from 1966 to 1982 to complete the five wells in the Pajarito Field. Four of the five were high-yield wells while the fifth (the first well drilled) was limited in its production by its completed diameter rather than by its hydrologic characteristics. The other four wells in the field were completed with a larger diameter so as to accommodate high-yield pumps.

Purtymun and Stoker (1988) laid out locations for four wells in the Otowi Well Field. Two wells were completed in 1990. One well was a high-yield well penetrating more than $1500 \mathrm{ft}$ of coarse sediments and basalts below the Totavi Lentil. In trying to get proper spacing between the wells in the field, the other well was located outside the area underlain by the Chaquehui Formation. This well penetrated only fine-grained sediments below the Totavi Lentil, and has a probable yield of less than $1000 \mathrm{gpm}$. Other wells with limited penetration of the coarse-grained sediments of the Santa Fe Group include the wells in the Guaje Well Field, test wells at TA-49, and Sigma Mesa Hole. Wells in the Los Alamos field also failed to penetrate the coarse-grained sediments.

Purtymun and Cooper (1969) indicated a facies change in the Santa Fe Group from fine-grained sediments in the east to coarse-grained sediments in the west beneath the Pajarito Plateau. Griggs (1964) called the Santa Fe Group the Undifferentiated Unit while Baltz (1963) referred to it as the Tesuque Formation. Geologic logs of the supply wells and test holes referred to the coarse-grained sediments underlying the Totavi Lentil as the Tesuque Formation. The thin section of the Chamita Formation described by Galusha and Blick (1971) was included in the Tesuque Formation. The development of the high-yield wells in the coarse-grained sediments beneath the plateau contrasts with the low-yield wells (less than $600 \mathrm{gpm}$ ) in the fine sediments in Los Alamos Canyon. There was only partial penetration 


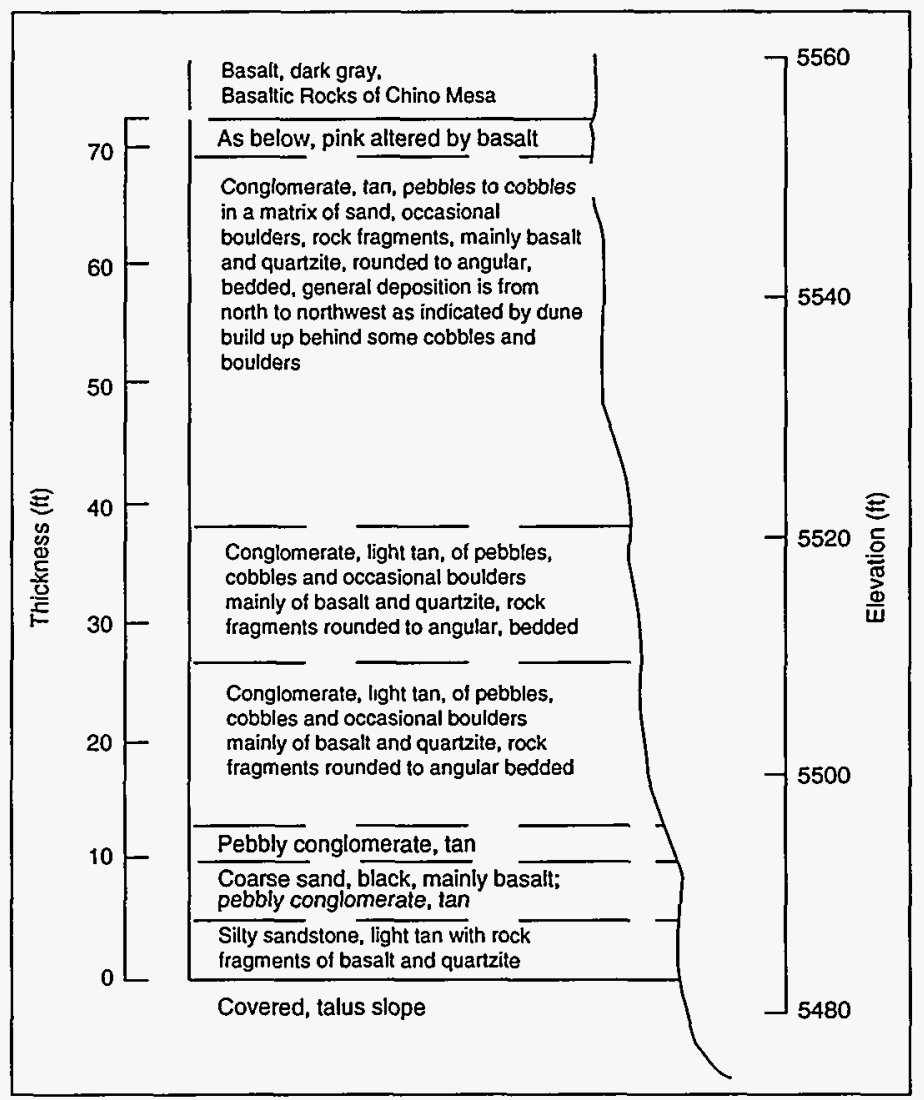

Fig. I-H. Type section of the maar sediments on the south wall of Chaquehui Canyon at the Rio Grande.

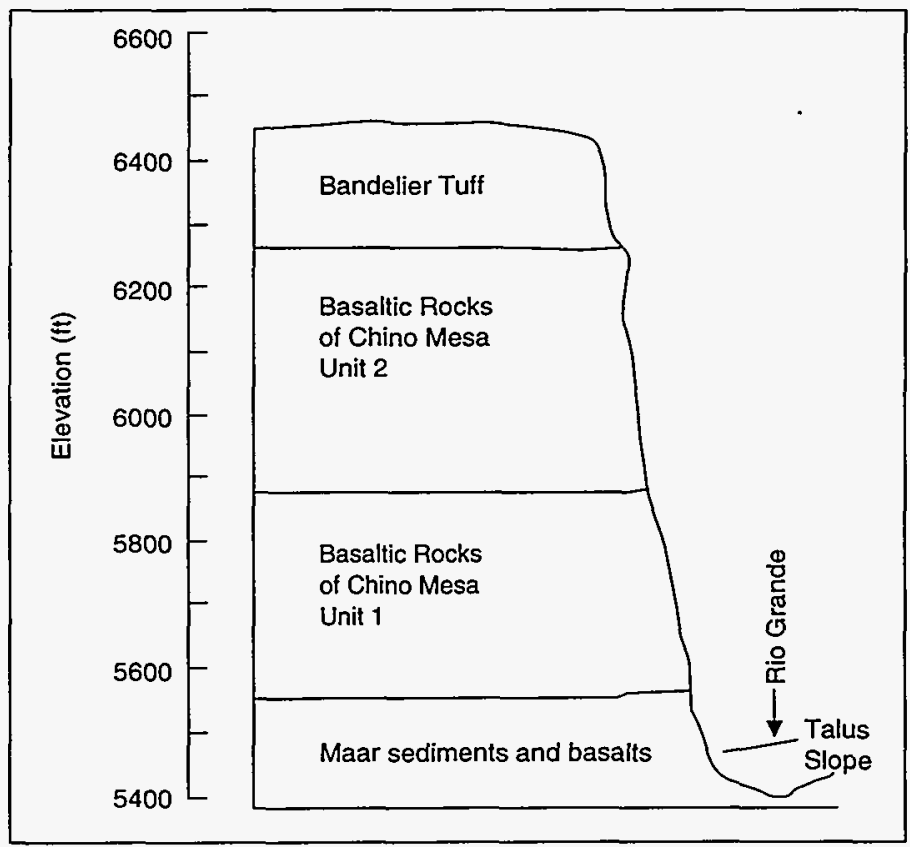

Fig. I-I. Generalized geologic section on the south wall of Chaquehui Canyon at the Rio Grande showing the maar sediments and basalts overlain by the Basaltic Rocks of Chino Mesa and Bandelier Tuff. 


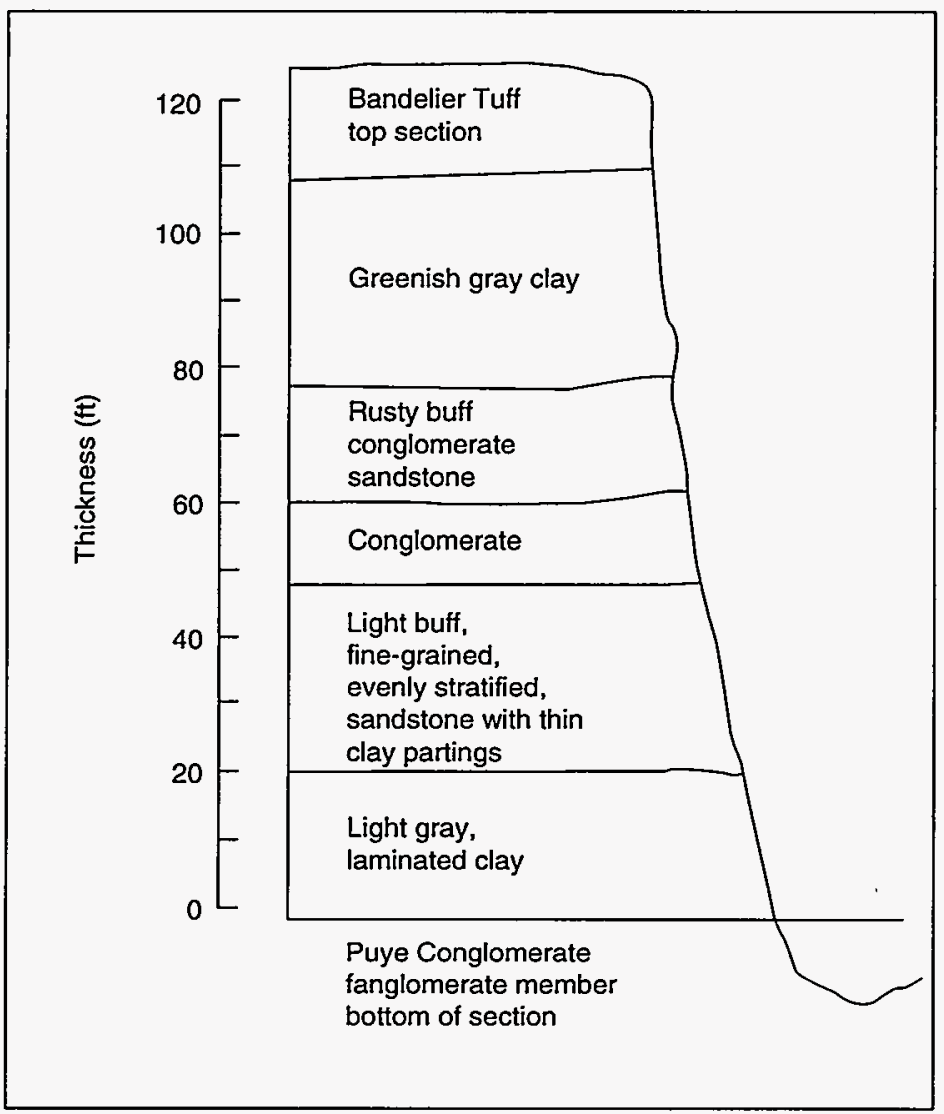

Fig. I-J. Generalized section showing the thickness of Old Alluvium in road cut near Totavi.

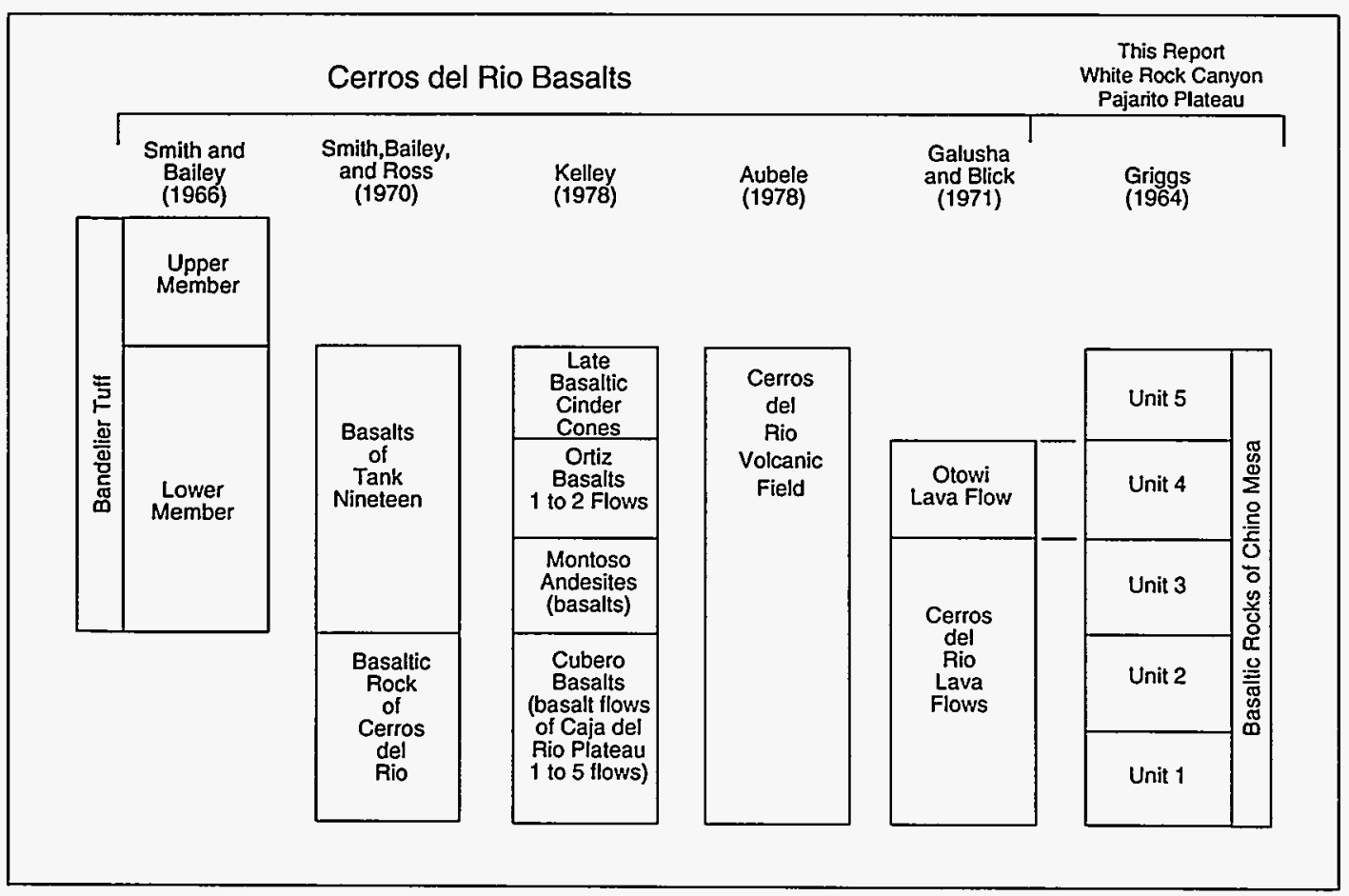

Fig. I-K. Stratigraphic nomenclature of the Cerros del Rio basalts. 
of coarse sediments in the upper saturated section of the wells in Guaje Canyon. This indicated a major lithologic change, a change that was noted in the cuttings, geophysical logs, and geologic logs of wells drilled on the Pajarito Plateau.

A review was made of the geophysical and geologic logs to separate out the Chamita Formation and the overlying Chaquehui Formation (with its coarse-grained sediments) from the Tesuque Formation. The Chamita Formation was identified through the prominent white ash beds in four of the wells in the Pajarito Field. The Chaquehui Formation is a mappable unit that occurs in the subsurface beneath the plateau. It is a trough filled with coarse sediments as much as $1500 \mathrm{ft}$ thick, 3 to 4 miles wide, and extending 7 to 8 miles from the northeast to the southwest.

It is an important formation, containing the main aquifer of the Los Alamos area, the only aquifer capable of municipal and industrial supply. The saturated section of the Chaquehui Formation can support the development of high-yield wells. The drilling of test holes and water supply wells which penetrate the main aquifer should be performed so as to prevent contamination of this crucial resource.

2. Puye Conglomerate. The sediments of the Santa Fe Group are overlain by the Puye Conglomerate. The Puye is composed of three members or units: the Totavi Lentil, the Old Alluvium, and the upper fanglomerate member. The past stratigraphic nomenclature and the nomenclature used in this report are shown on Fig. I-E.

Overlying the Chaquehui Formation of the Santa Fe Group in the subsurface beneath the Pajarito Plateau is the Totavi Lentil. It consists of a poorly consolidated, channel-fill deposit of granitic debris, quartzite, gneiss, and occasional schist, and boulders to cobbles in a matrix of sand. The lentil is about $50 \mathrm{ft}$ thick. The lentil is overlain by the fanglomerate member of the Puye Conglomerate. The Totavi outcrops along the eastern edge of the Pajarito Plateau between the Santa $\mathrm{Fe}$ Group and the overlying fanglomerate member of the Puye Conglomerate. South of Water Canyon the Totavi Lentil is underlain by the Chaquehui Formation and wedges out between the Basaltic Rocks of Chino Mesa Unit 2 and the Chaquehui Formation south of Ancho Canyon.

The fanglomerate member of the Puye Conglom- erate overlies the Totavi Lentil. It is volcanic debris composed of latite, quartzite latite, rhyolite, tuff, dacite, and pumice cobbles to boulders in a matrix of silts, clays, and sands. The cobbles to boulders are angular to subangular. Lenses of silt, clay, and pumice are common. The fanglomerate was derived from the volcanic pile to the west and is interbedded with the younger flow rocks of the Tschicoma Formation beneath the western edge of the plateau. The volcanic debris is also interbedded with Unit 2 of the Basaltic Rocks of Chino Mesa from the east. The fanglomerate is widespread in the subsurface beneath the plateau and forms the bold cliffs that occur along the Rio Grande north of Otowi.

The Old Alluvium of Griggs (1964) is composed of lake clays and gravels deposited in ancient stream channels cut into the fanglomerate member. Unit 3 of the Basaltic Rocks of Chino Mesa flowed into these channels, forming lakes that accumulated sediments (Figs. I-F and I-J). The lake clays and gravels outcrop in lower Los Alamos Canyon and extend northward in discontinuous outcrops for several miles. They are of limited extent beneath the plateau as they were identified in only one well (PM-1) near the eastern edge of the plateau.

3. Basaltic Rocks of Chino Mesa. The Basaltic Rocks of Chino Mesa represent a small number of basalt flows from the Cerros del Rio Volcanic Field located east of the Rio Grande. They extend from Otowi to the upper headwaters of Cochiti Reservoir, a distance of more than 15 miles.

The stratigraphic nomenclature of the Cerros del Rio Volcanic Field has varied with different workers (Figs. I-C and I-K). Smith, Bailey, and Ross (1970) mapped two units of the Cerros del Rio basalts, the older Basaltic Rocks of Cerros del Rio and the younger basalts of Tank Nineteen. The Tank Nineteen basalts are 1 million to 1.5 million years old and overlie the Otowi Member of the Bandelier Tuff. Through the use of aerial photographs, Kelley (1978). mapped four different units of the Cerros del Rio basalts, one of which (the Cubero Basalts) includes the five units of the Chino Mesa Basalts of Griggs (1964). According to Laughtin et al. (1993) they range in age from 2.5 million to 4 million years old. Aubele (1978) describes the basalts of the Cerros del Rio field as did Galusha and Blick (1971). The Otowi lava flows of Galusha and Blick are equivalent to the 

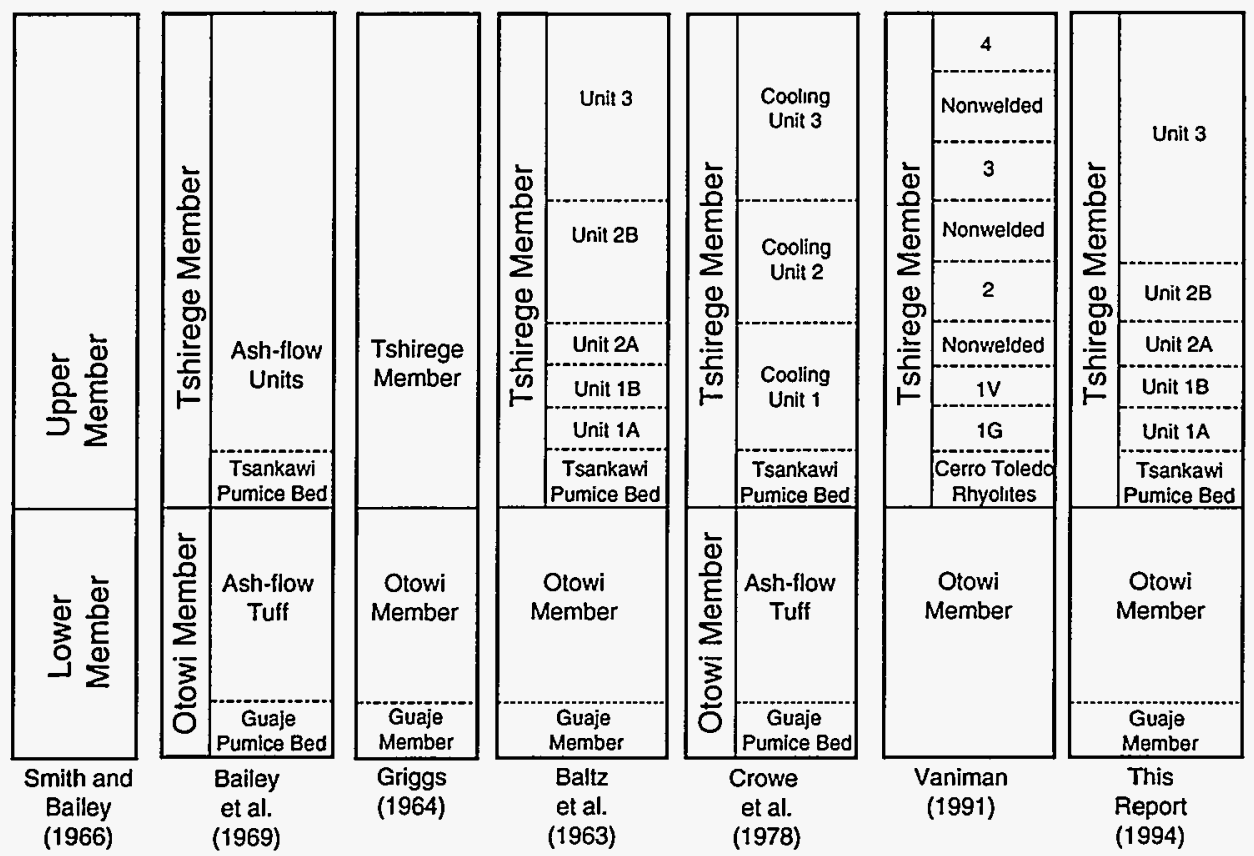

Fig. I-L. Stratigraphic nomenclature of the Bandelier Tuff.

Unit 4 Basaltic Rocks of Chino Mesa of Griggs (1964).

The nomenclature of the basalts used by Griggs (1964) is most appropriate to describe the relationship of the basalts and volcanic sediments in the subsurface of the Pajarito Plateau and adjacent White Rock Canyon (Figs. I-C and I-K).

The Basaltic Rocks of Chino Mesa consist of a thick sequence of basaltic to andesite rocks and interflow breccias. These flowed from vents in the vicinity of Chino Mesa, which is located east of the Rio Grande opposite Chaquehui and Ancho Canyons. The Chino Mesa basalts flowed north along the Rio Grande, and northwest and west into the area of the Pajarito Plateau, where they are found in the subsurface interbedded with the Chaquehui Formation of the Santa $\mathrm{Fe}$ Group and the fanglomerate member of the Puye Conglomerate. Though some of the basalts found in the subsurface may not have originated from vents in the vicinity of Chino Mesa, they are equivalent in age. The Basaltic Rocks of Chino Mesa consist of five mappable units in the Los Alamos area (Fig. I-C).

The lower unit, Unit 1, outcrops in the lower wall of White Rock Canyon (Figs. I-G and I-I). The basalts are dark gray to black, porphyritic, and contain small phenocrysts of olivine which may be as long as $1 / 4$ in.
- Unit 2 overlies Unit 1 and forms the main cliffs along White Rock Canyon (Fig. I-I). The unit is composed of a series of flows and interflow breccias that thins to the west and northwest in the subsurface beneath the plateau where it interdigitates with the fanglomerate member of the Puye Conglomerate. It ranges in color from gray to dark gray and is generally lighter in color than the underlying unit. The flows contain small phenocrysts of olivine.

Unit 3 consists of a series of flows deposited in an old river channel, and crops out in lower Los Alamos, Sandia, and Mortandad Canyons west of the Rio Grande. It is a series of flows of dark gray basalt containing large to small phenocrysts of olivine and some of plagioclase. It is up to $120 \mathrm{ft}$ thick in lower Los Alamos Canyon where it blocked the ancient stream channel and formed a lake. This led to the deposition of the Old Alluvium lake clays and gravels.

Unit 4 consists of two flows that cap the mesa south of Los Alamos Canyon where they overlie the Puye Conglomerate and Tesuque Formation. The basalt is dark gray and contains some phenocrysts of olivine, with some small quartz (generally with radiating crystals of augite). The combined thickness of the two flows can range up to $240 \mathrm{ft}$.

Unit 5 consists of cinder cones and local basalt 


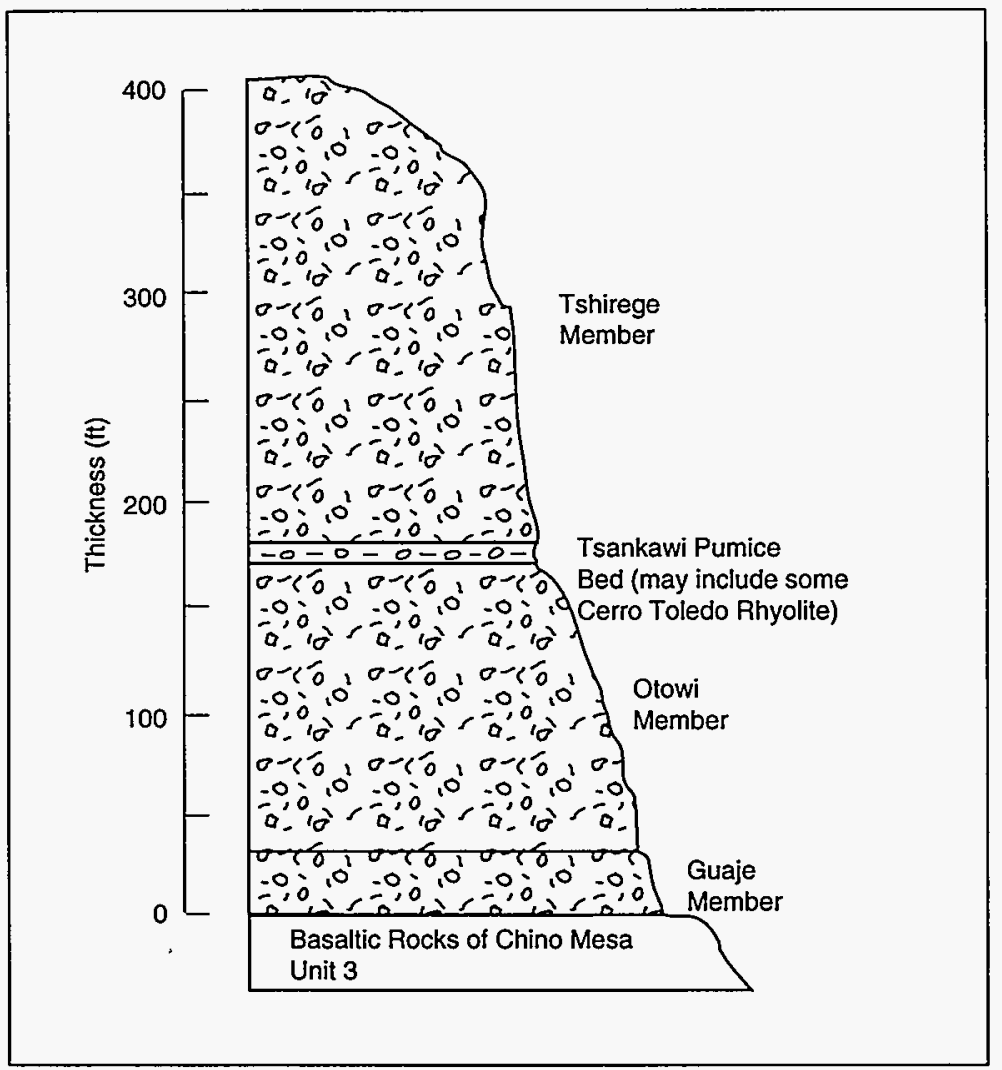

Fig. I-M. Type section showing the thickness of members of the Bandelier Tuff near the junction of State Roads 4 and 502.

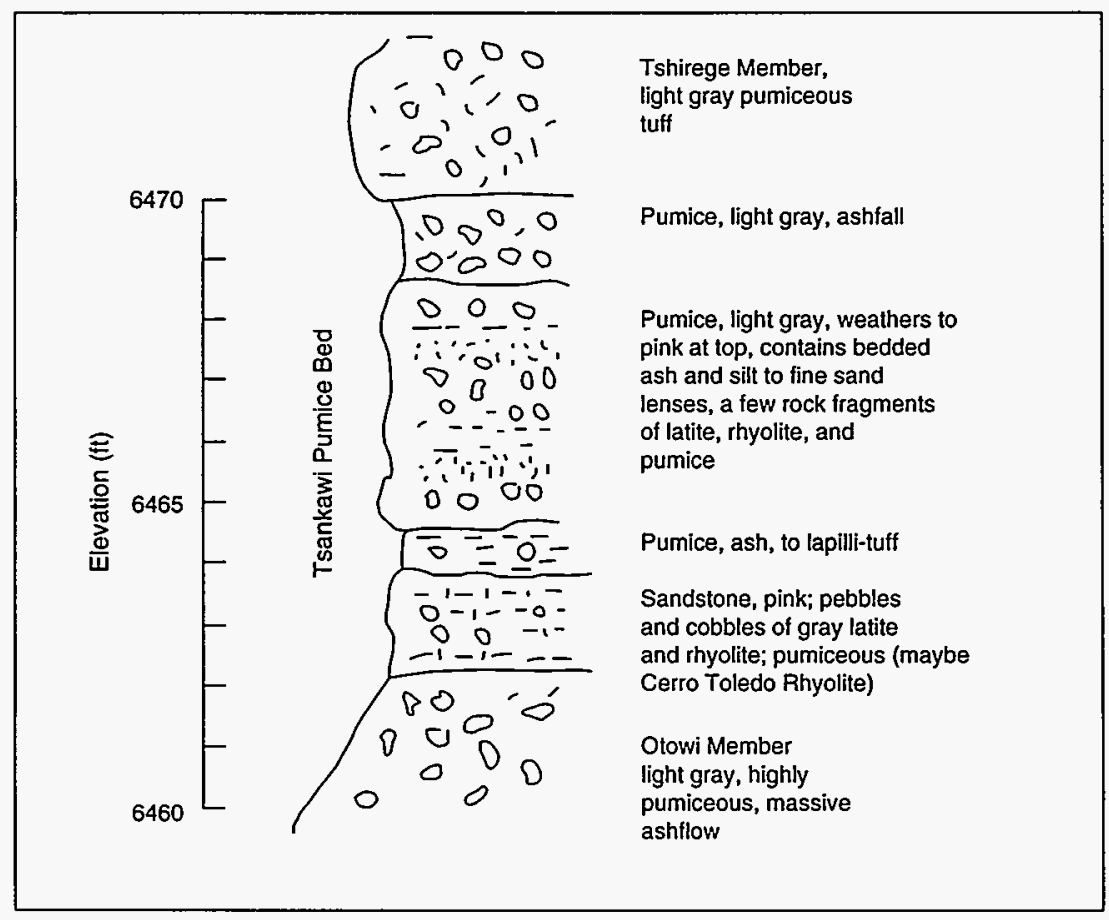

Fig. I-N. Geologic section of the Tsankawi Pumice Bed near the junction of State Roads 4 and 502. 
flows on Chino Mesa and on the mesa between lower Ancho Canyon and Chaquehui Canyon. The rocks of the flows and cinder cones are black and are slightly vesicular. They contain tiny phenocrysts of olivine and labradorite.

\section{Volcanic Rocks of the Jemez Mountains.} The volcanic rocks of the Jemez Mountains consist of the older Tschicoma Formation and the Bandelier Tuff.

The flow of the Tschicoma Formation forms the mountain mass of the Sierra de los Valles. The flows are composed of undifferentiated latites, quartz latites, and dacites, which are in places highly fractured and jointed. The flows range from gray to dark gray and some range to reddish brown. These rocks form the Sierra de los Valles that separates the interbasin caldera and the plateau (Fig. I-B). Some of these latite flows interdigitate to the west beneath the plateau within the gravels of the fanglomerate member of the Puye Conglomerate. The fanglomerate is made up of the older Tschicoma rocks that eroded from the mountain mass as it was building.

The Bandelier Tuff is composed chiefly of ashfalls and ashflows of rhyolite tuff with some thin beds of water-laid sediments and some surge beds of blast-laid volcanics and sediments.

The stratigraphic nomenclature of the Bandelier Tuff has varied according to different workers in the area as shown in Fig. I-L. The division similar to Griggs (1964) and further subdivision of the Tshirege Member by Baltz et al. (1963) are most appropriate for this report as they have similar lithology, degrees of welding, and stratigraphic position.

The Bandelier Tuff has been divided into three members: Guaje, Otowi, and Tshirege Members from oldest to youngest (Fig. I-C). The Bandelier Tuff forms the upper surface of the Pajarito Plateau, lapping onto the Tschicoma Formation along the western margin of the plateau and truncated by erosion at the eastern edge along the rim of White Rock Canyon (Fig. I-M). Included in the Bandelier Tuff are the Tsankawi Pumice Bed (in some places) and the cobbles and boulders of the Cerro Toledo Rhyolites. The Tsankawi and Cerro Toledo Rhyolites lie between the Tshirege Member and the underlying Otowi Member.

The Guaje Member of the Bandelier Tuff is an ashfall of pumice with some water-laid or surge-bed pumiceous tuff that rests unconformably on older rocks. The base of the unit contains gray lumppumice fragments as much as $2 \mathrm{in}$. long. Glass shards and crystals of quartz and sanidine are present in the cellular structure of the partly devitrified pumice. Rounded, pebble-sized fragments of light red rhyolite are present near the top of the member.

The Otowi Member of the Bandelier Tuff is a light gray, nonwelded, pumiceous rhyolite tuff that weathers to a gentle slope; it is conformable with the underlying Guaje. Quartz and sanidine crystals and crystal fragments, glass shards, minor amounts of mafic minerals, along with varying amounts of rock fragments of latite, rhyolite, quartz latite, and pumice fragments are found in a fine-grained ash matrix. The Otowi may consist of several ashflows laid down in rapid succession.

The Tsankawi Pumice Bed (Bailey et al. 1969) is a thin pumice fall with some surge deposits and possibly water-laid material of latite and rock fragments with an abundance of quartz and sanidine crystals in an ash matrix. It is deposited between the lower Otowi Member and the overlying Tshirege Member (Fig. I-N). The Tsankawi may include a thin section of blast-laid debris of rock fragments of latite, rhyolite, and pumice of the Cerro Toledo Rhyolites.

The Tsankawi Pumice bed and the Cerro Toledo Rhyolites in general are quite thin, absent in places, and may thicken in others to as much as $30 \mathrm{ft}$. They are probably present in deep test holes or wells drilled on the Pajarito Plateau but were not identified in the cuttings (these wells and test holes were not cored) and are not included in the older geologic logs. In some areas such as the middle reaches of Los Alamos Canyon, Sandia Canyon and Mortandad Canyon, the Tsankawi Pumice may include some gravels, cobbles, and boulders of the Cerro Toledo Rhyolites. In other areas such as in the upper and middle reaches of Cañada del Buey and Ancho Canyon only a thin section of the pumice and no apparent gravels of the Cerro Toledo Rhyolites are evident.

The Tshirege Member of the Bandelier Tuff forms the upper surface of the Pajarito Plateau. It consists of a series of nonwelded to welded ashflows and ashfalls that are composed of quartz and sanidine crystals and crystal fragments, a few rock fragments of dacite, latite, rhyolite, and pumice in a gray to dark gray ash matrix. The ashflows vary in amounts and size of the minerals and rock fragments and as to the degree of welding. Blast debris, sand, gravel, and boulders may be found between the flows (Weir and 
Purtymun 1962).

The Tshirege Member, as a series of ashflows and ashfalls of rhyolite tuff, has been classified according to degrees of welding (i.e., as nonwelded, moderately welded, and welded). The nonwelded tuff has a high porosity, only light cohesion, little deformation of glassy fragments, and crumbly fracture. The moderately welded tuff has less porosity, moderate cohesion, slight deformation of glassy fragments, and somewhat brittle fracture. The welded tuff has low porosity, good cohesion, a high degree of deformation by flattening of glassy fragments, and brittle fracture. Most if not all of the pores are capillary in size. There can be a considerable overlay in porosity range in each classification (Purtymun and Kennedy 1971).

\section{Degree of Welding}

Nonwelded tuff Moderately welded tuff Welded tuff

The degree of welding can change in a vertical section of an ashflow (zone of denser welding, lower porosity near the middle of the flow) and distance from source (denser near caldera and becoming progressively less dense, with higher porosity, further from the caldera). The degree of welding is an important determinant of the hydrologic characteristics and engineering properties of the tuff. Only slight changes in welding can drastically change the hydrologic characteristics or engineering properties of the tuff (Weir and Purtymun 1962; Abrahams 1963; Purtymun and Koopman 1965; Purtymun 1966a; Keller 1968; Purtymun et al. 1974; Purtymun et al. 1989; Stoker et al. 1991; and Purtymun 1994 chapter 31).

Working with Weir and Purtymun in 1962, Baltz divided the Tshirege Member at TA-49 into seven units, 1A, 1B, 2, 3, 4, 5, and 6 (see Section IX). After additional work in Mortandad Canyon Baltz revised the nomenclature to correspond to his observations in Mortandad Canyon. He believed the Mortandad Canyon nomenclature best represented the units that make up the Tshirege Member. Other workers in the area have used different terminology in describing the Bandelier Tuff (Fig. I-L). Baltz's terminology is used throughout this report; where a difference occurs, it is discussed in that section. The descriptions of the units that follow are from a type section in Mortandad Canyon as described by Baltz. The units can be followed across the Pajarito Plateau; however, as previously stated the degree of welding and the thickness of the units will vary across the plateau (from the source area in the west to the east along White Rock Canyon on the Rio Grande).

Unit 1 consists of two ledge-forming subunits of pumiceous tuff breccia that are generally similar in lithology but are slightly different in color and weathering characteristics.

The lower layer, Unit $1 \mathrm{~A}$, is a massive, orangeweathering, pumiceous tuff breccia that forms a low ledge above the alluvium in Mortandad Canyon and is a widespread unit that persists over most of the plateau. The unit is composed of pink to light salmon colored fragments of pumice ranging from $1 / 8$ in. to 6 in. in length. The pumice fragments with tiny subhedral quartz crystals and some rock fragments of obsidian and rhyolite are in a matrix of fine glassy ash. The unit is non- to moderately welded. Unit $1 \mathrm{~A}$ is probably an explosive volcanic breccia laid down as an ashflow. The outer 1 to $3 \mathrm{in}$. of the unit weathers to a hard rind that protects the unweathered rock from erosion. In Mortandad Canyon, Unit $1 \mathrm{~A}$ thins as one moves eastward from about $105 \mathrm{ft}$ at test well TW-8 to about $10 \mathrm{ft}$ (Baltz et al. 1963) near State Road 4 (SR 4).

Unit $1 \mathrm{~B}$ rests conformably on Unit $1 \mathrm{~A}$ and weathers to dull grayish brown, pink, and light orange. The unit is a tuff breccia with a fine-grained pink ash matrix similar to $1 \mathrm{~A}$; however, the pumice fragments are smaller, and 15 to $20 \%$ of the unit consists of quartz crystal fragments and rock fragments of rhyolite and latite in an ash matrix. The unit is moderately welded. In most places the unit has slightly less resistance to erosion than Unit $1 \mathrm{~A}$, and forms a rounded ledge set back from the top of Unit 1A, while at other places the two units form a nearly vertical cliff. The units are then separated by a slight notch in the cliff. In Mortandad Canyon Unit 1B is fairly uniform in thickness, ranging from 18 to $20 \mathrm{ft}$ thick.

Unit 2 of the Tshirege Member of the Bandelier Tuff rests conformably on Unit $1 \mathrm{~B}$ and seems to be transitional into it. Unit 2 consists of two units, $2 \mathrm{~A}$ and overlying $2 \mathrm{~B}$, that are separated by an erosional unconformity or surge bed. In the eastern part of the plateau these two units are moderately welded; 
however, westward across the plateau toward the source of the ashflows the degree of welding increases, so that in the western third of the plateau the two units become densely welded and appear as a single unit.

The lower Unit 2A is a light gray, pumiceous tuff. The tuff consists of slightly welded pumiceous ash containing angular rock fragments of pumice, dense rhyolite and latite as much as 4 in. long. The ash matrix also contains quartz and sanidine crystals and crystal fragments. The unit weathers to dull gray and grayish brown with a hard rind several inches thick and with rounded slopes set back from Unit $1 B$. In Mortandad Canyon, Unit $2 \mathrm{~A}$ is about $80 \mathrm{ft}$ thick near test well TW-8 and thins eastward to about $55 \mathrm{ft}$ near SR-4.

The overlying Unit $2 \mathrm{~B}$ is a tan- to brownweathering tuff composed of crystal and crystal fragments of quartz and sanidine with rock fragments of pumice, rhyolite, and latite. The unit is probably composed of several ashflows, separated by blastlaid or surge deposits of reworked tuff (sands and gravels) and rock fragments of rhyolite and latite. The unit is resistant to erosion and forms ledges and benches above the more rounded slopes of Unit 2A. In Mortandad Canyon the unit is about $40 \mathrm{ft}$ thick near test well TW-8 and thins eastward to about $20 \mathrm{ft}$ near SR-4 as its top is eroded off.

Unit 3 rests conformably on Unit $2 B$. Unit 3 consists of mainly light gray, light tan, pink, and white moderately welded pumiceous rhyolite tuff breccia. The unit is composed of crystal and crystal fragments of quartz and sanidine, rock fragments of pumice, latite, and rhyolite in an ash matrix of fine pumice fragments and glassy shards. Rock fragments range in size from granules to cobbles. The unit weathers to form soft slopes and benches. The upper part of the unit is resistant to erosion and forms cliffs along the upper part of the plateau. The unit may consist of several ashflows. In the eastern two-thirds of the plateau Unit 3 is stratigraphically the highest part of the Bandelier Tuff. In Mortandad Canyon the unit is about $110 \mathrm{ft}$ thick near test well TW- 8 and thins eastward toward SR-4 as the unit is eroded off (Fig. I-O).

5. Alluvium and Soil. Alluvium derived from weathering and erosion of the rocks that form the Sierra de los Valles and the Pajarito Plateau has been deposited in the canyons of the plateau. The south- east-trending canyons have cut deeply into the plateau. Near the heads of the canyons and on the flanks of the Sierra de los Valles bedrock is generally exposed. Along the western edge of the plateau the canyons deepen and are narrow with thin alluvium. The alluvium thickens as one moves eastward, and along the eastern edge of the plateau the canyons widen and canyon walls generally decrease in height. Along the eastern edge of the plateau all stream channels cut down to the top of the Basaltic Rocks of Chino Mesa, to Unit 3 in Pueblo and Los Alamos Canyons and to Unit 2 in the remainder of the canyons. The thickness of the alluvium varies, but is generally less than $20 \mathrm{ft}$ in most canyons. The thickest section observed is $76 \mathrm{ft}$, penetrated by test holes in Mortandad Canyon.

Test holes and observation wells have been drilled into or through the alluvium in a number of canyons, generally for water quality or hydrologic studies (Fig. I-P). Based on test holes or observation wells, illustrations showing sections of the stream channel have been prepared to show: the thickness of the alluvium and underlying volcanic sediments or basalt; the gradient of the stream channel; the drainage area west of the most eastern control point (usually SR-4); and whether the drainage area extends to the mountains (Sierra de los Valles) or heads on the plateau. The thickness of the alluvium shown in the figures is that adjacent to the stream channel, not that of the terrace or coalluvium in the canyons. These sections have been developed for segments of the following canyons: Pueblo (Fig. I-Q), Los Alamos (Fig. I-R), Sandia (Fig. I-S), Mortandad (Fig. I-T), Cañada del Buey (Fig. I-U), Pajarito (Fig.I -V), Potrillo (Fig. I-W), Fence (Fig. I-X), Water (Fig. I-Y), and Ancho (Fig. I-Z).

The alluvium in the canyons heading on the flanks of the Sierra de los Valles contains cobbles and boulders of dacite, latite, and rhyolite with accompanying clay, silt, sand, and gravel derived from the Tschicoma Formation and the Bandelier Tuff. The alluvium in the canyons heading on the Pajarito Plateau contains clay, silt, sand, and gravel derived from the Bandelier Tuff. The alluvium contains some water in the larger canyons; however, the amount is insufficient for water supply.

Clayey soil derived from weathering of the Bandelier Tuff covers most of the finger-like mesas of the Pajarito Plateau. The soil is thickest along the axis 


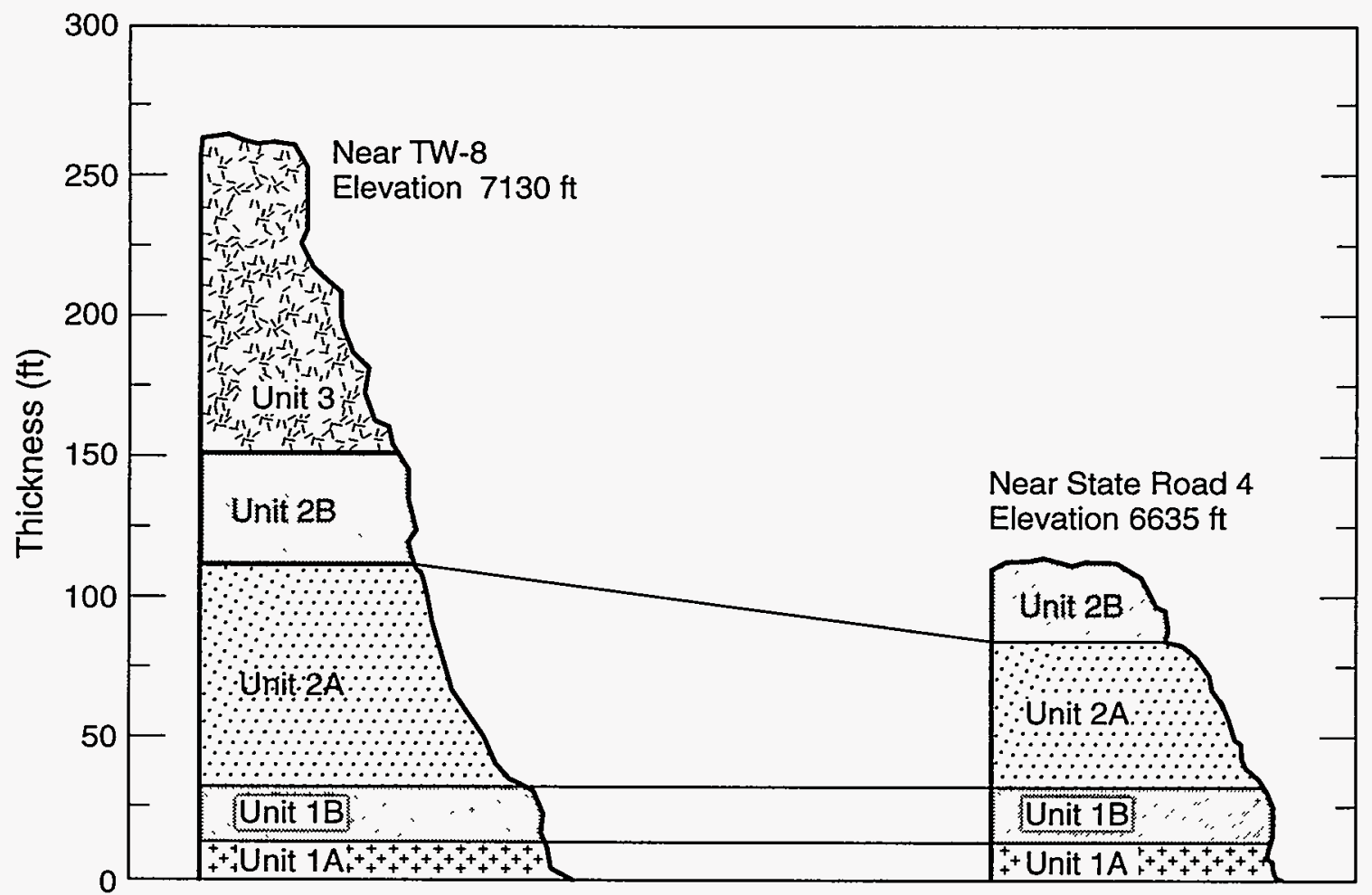

Fig. I-O. Type section of units in the Tshirege Member of the Bandelier Tuff in Mortandad Canyon.

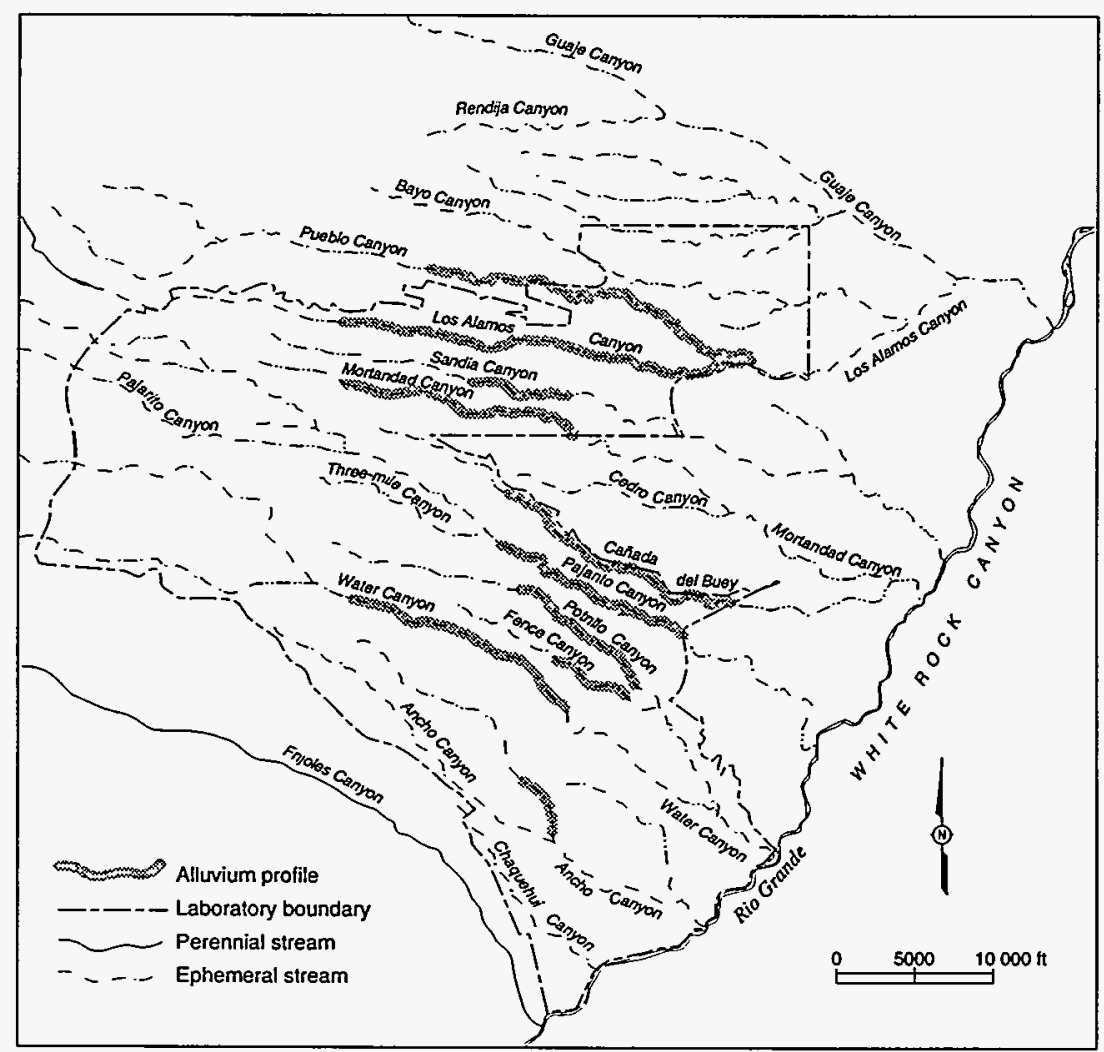

Fig. I-P. Locations of diagrammatic sections of alluvium in major canyons. 


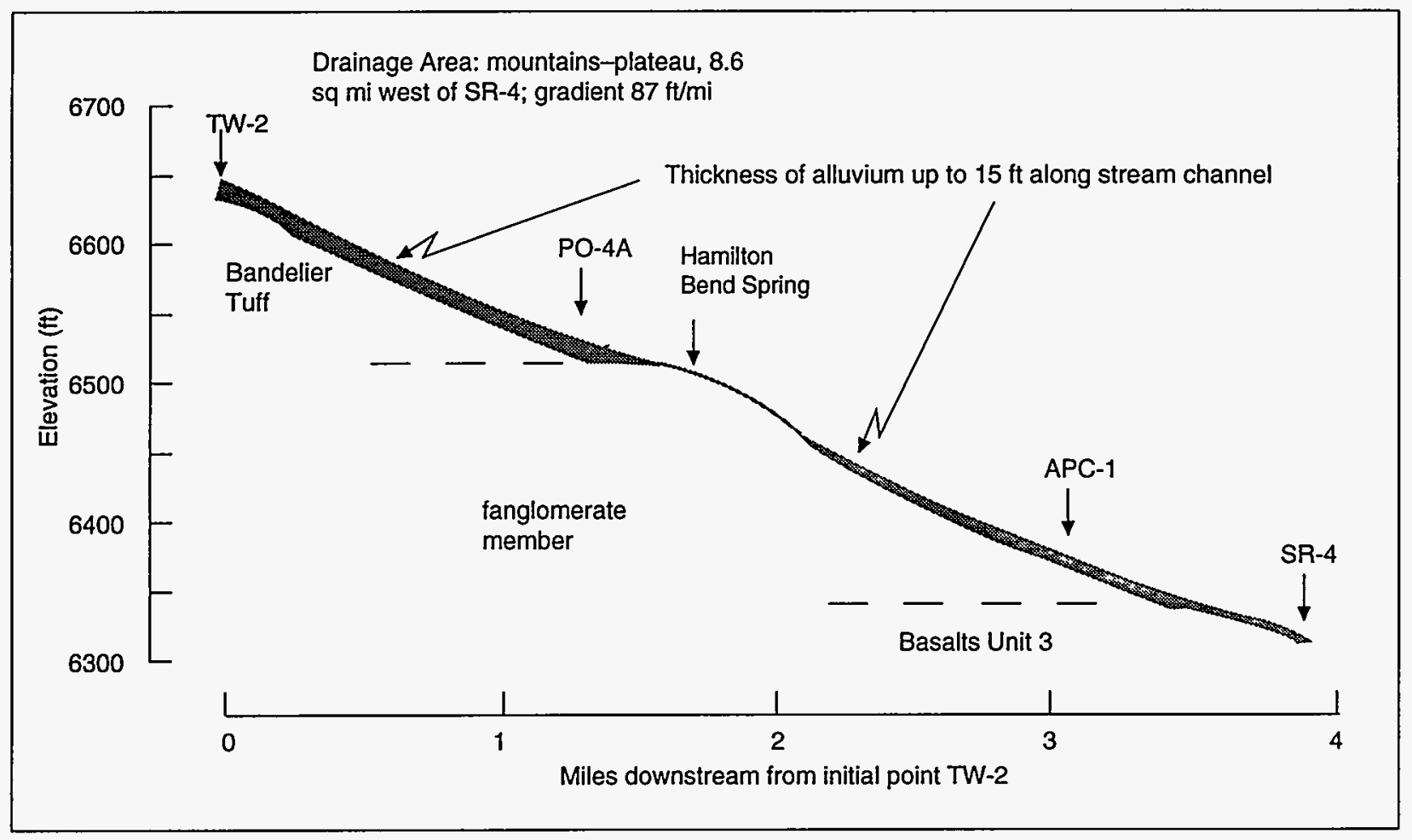

Fig. I-Q. Diagrammatic section showing rocks underlying alluvium in lower Pueblo Canyon.

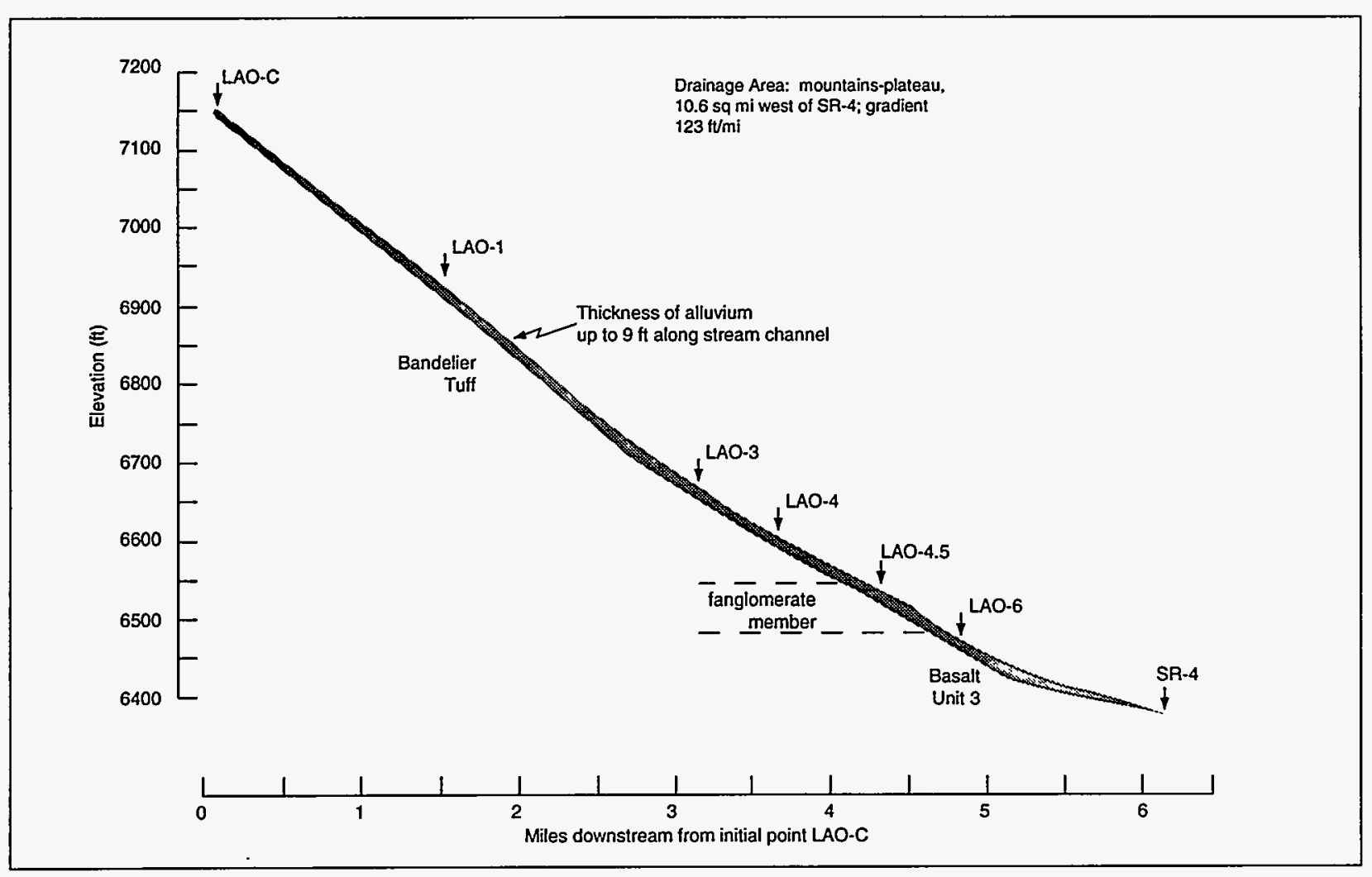

Fig. I-R. Diagrammatic section showing rocks underlying alluvium in Los Alamos Canyon. 


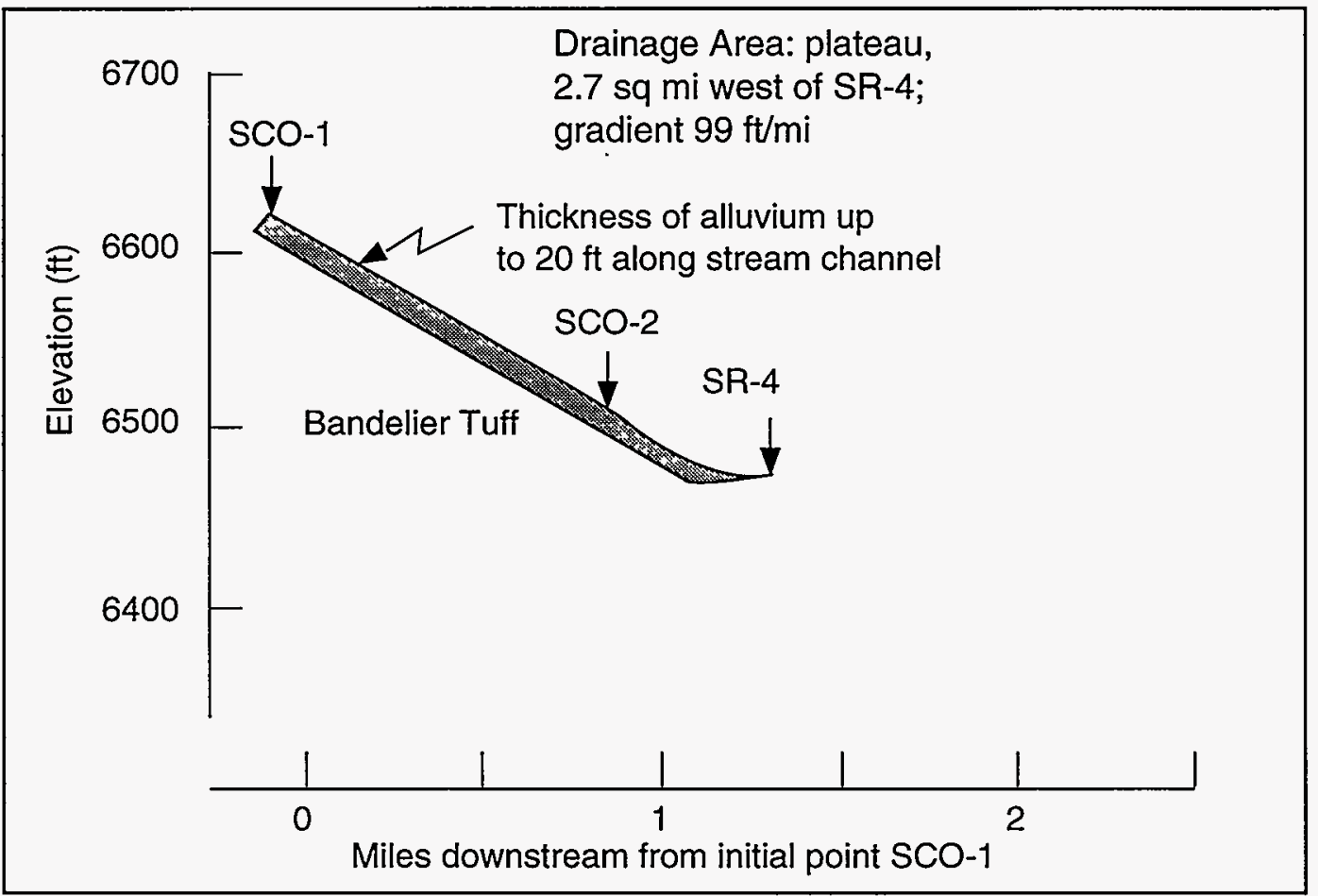

Fig. I-S. Diagrammatic section showing rocks underlying alluvium in lower Sandia Canyon.

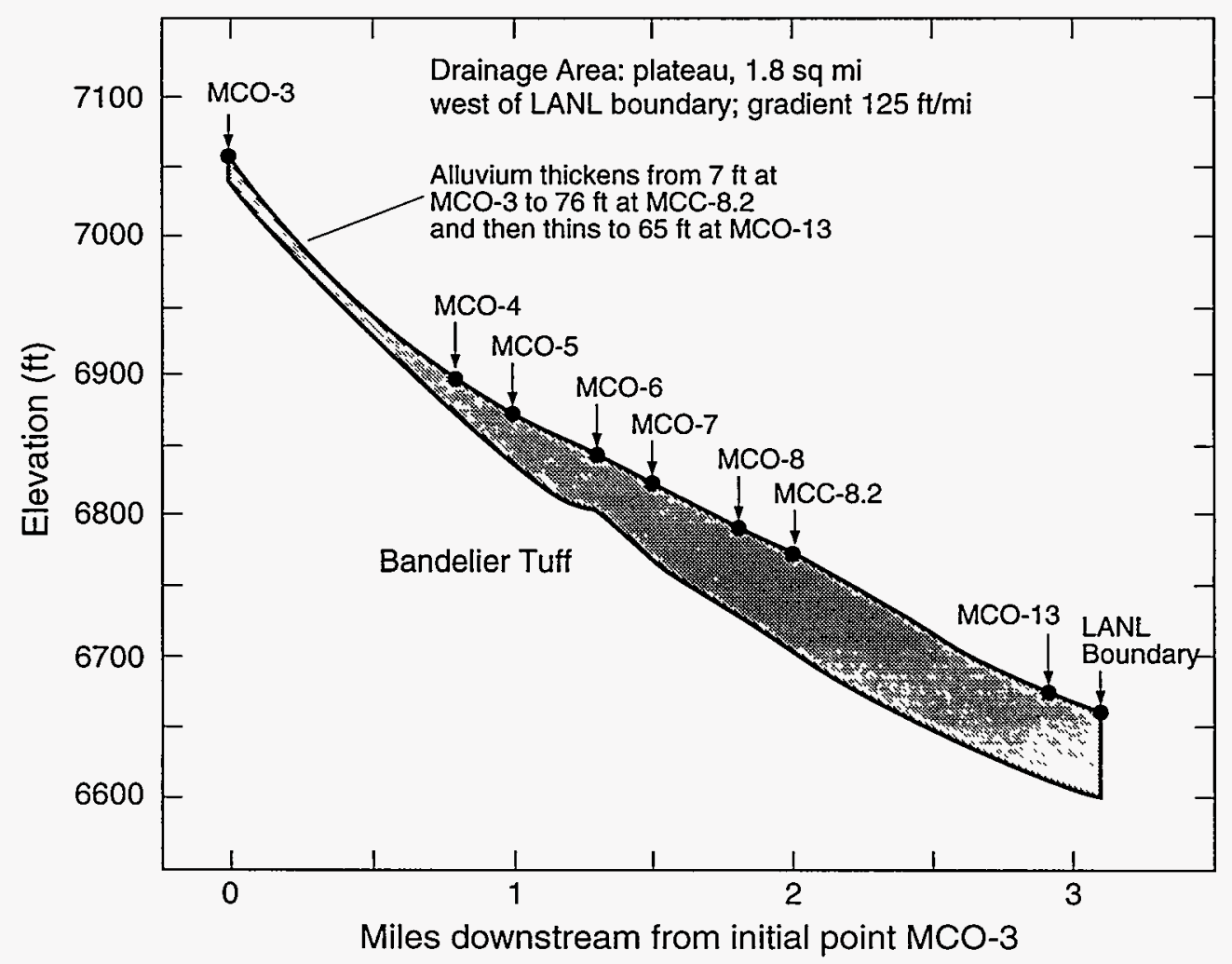

Fig. I-T. Diagrammatic section showing rocks underlying alluvium in Mortandad Canyon. 


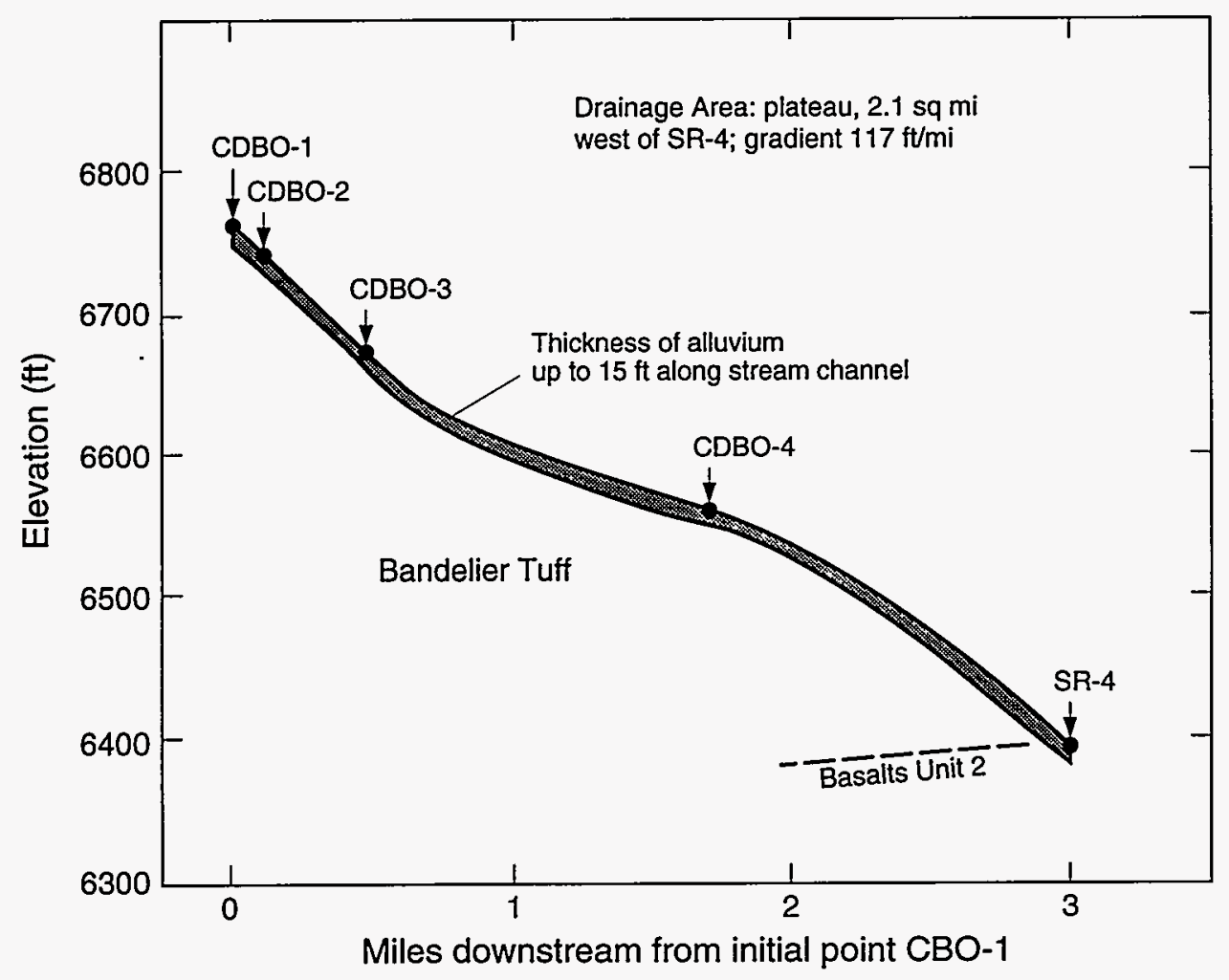

Fig. I-U. Diagrammatic section showing rocks underlying alluvium in lower Cañada del Buey.

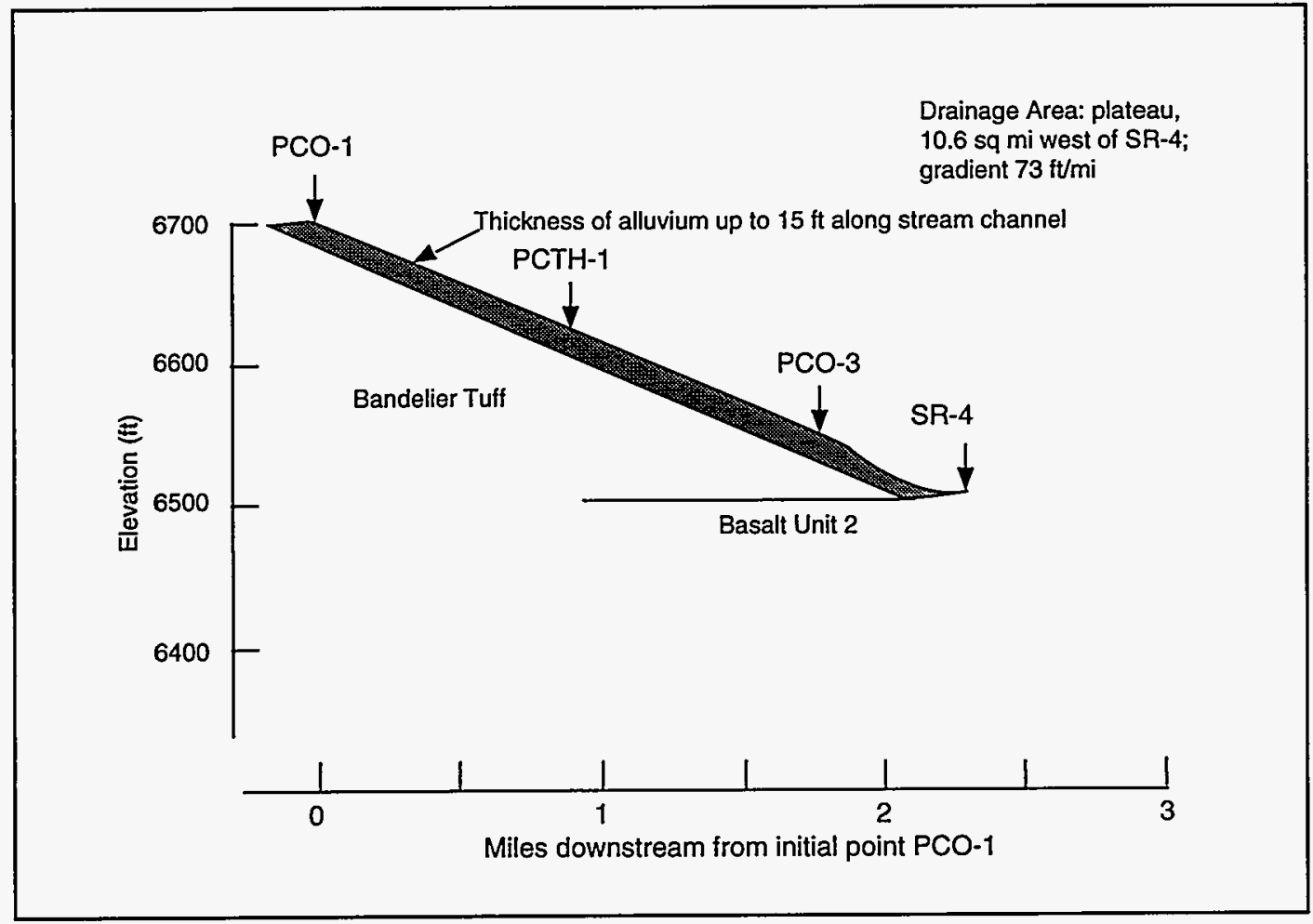

Fig. I-V. Diagrammatic section showing rocks underlying alluvium in lower Pajarito Canyon. 


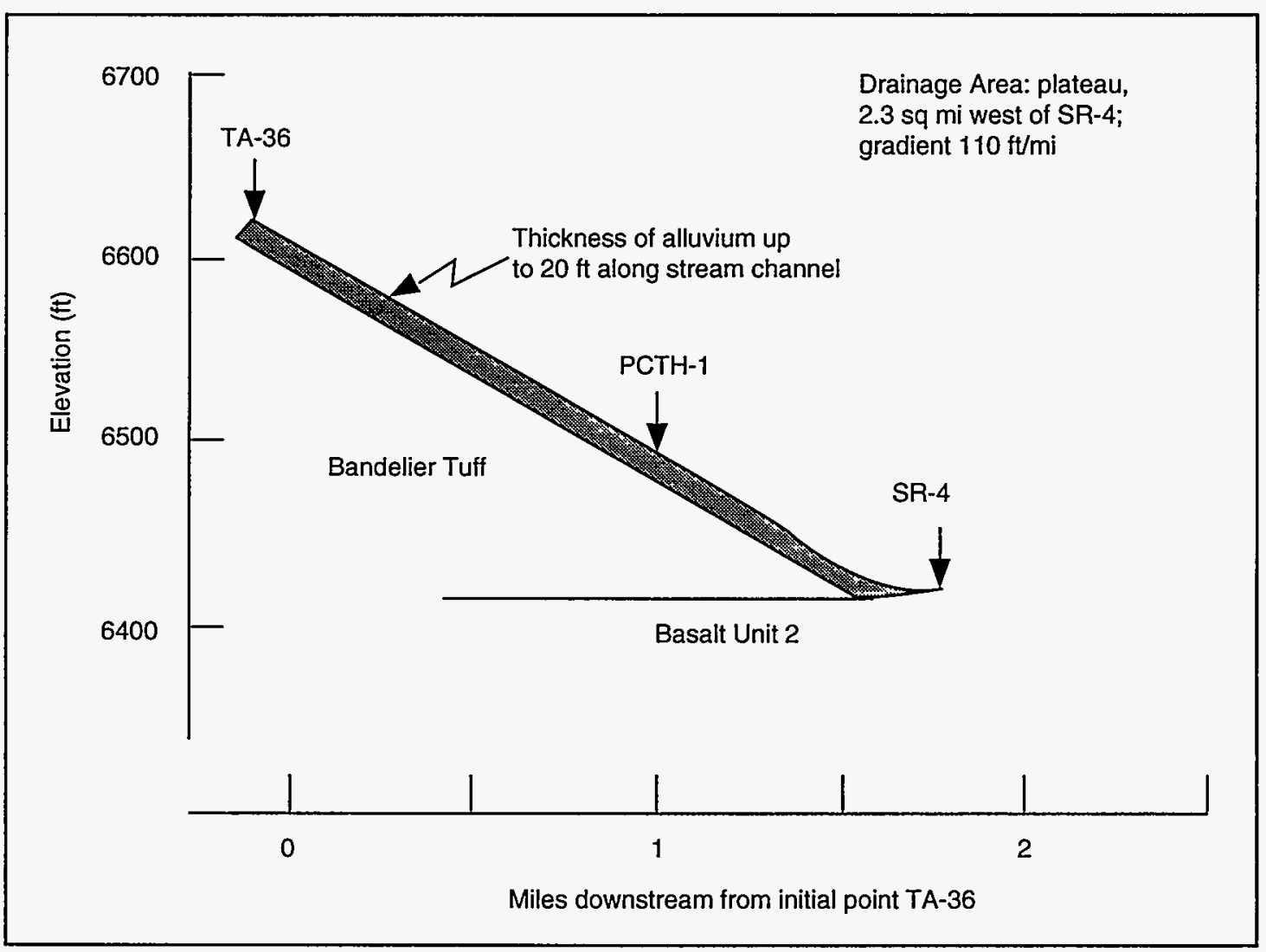

Fig. I-W. Diagrammatic section showing rocks underlying alluvium in lower Potrillo Canyon.

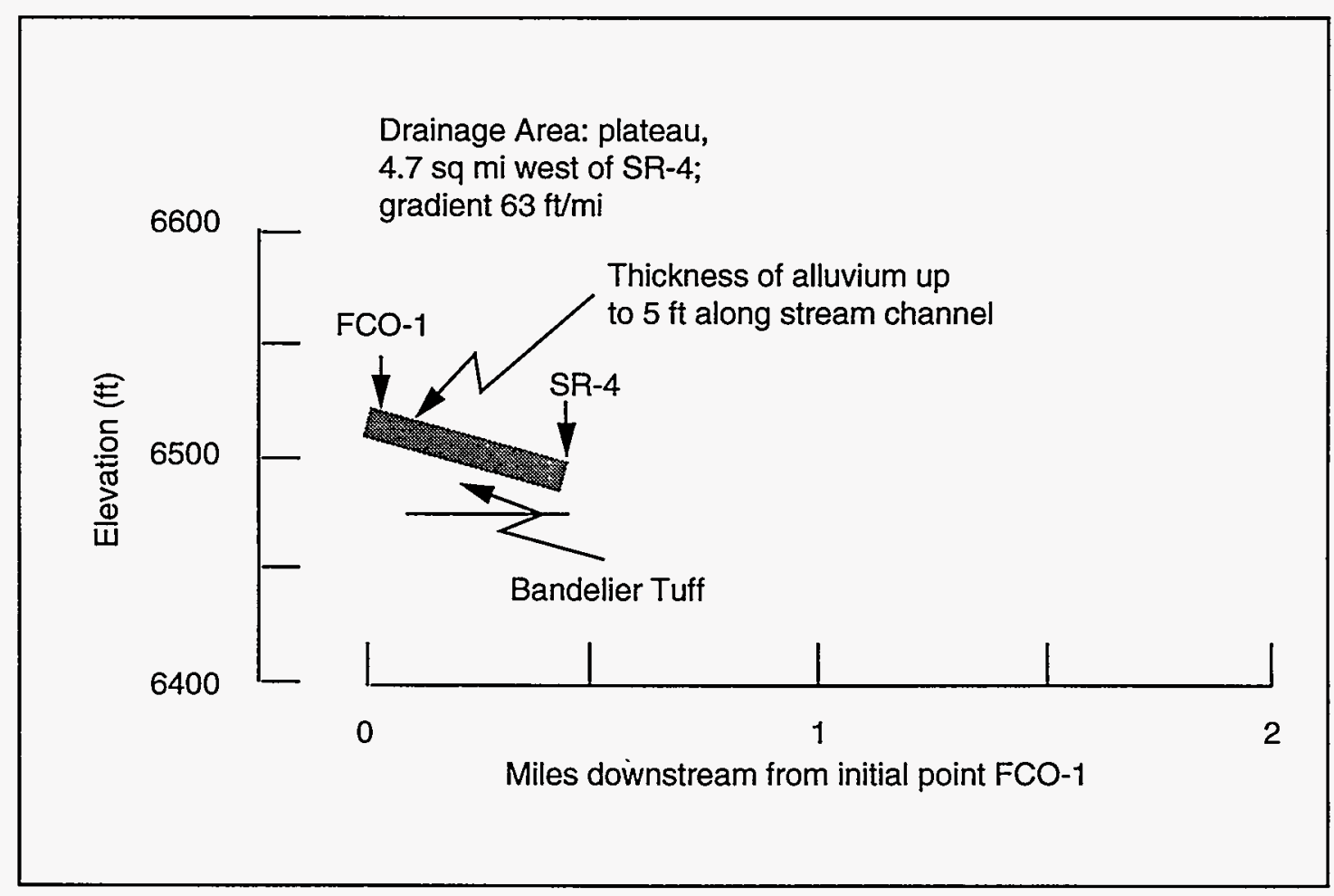

Fig. I-X. Diagrammatic section showing rocks underlying alluvium in lower Fence Canyon. 


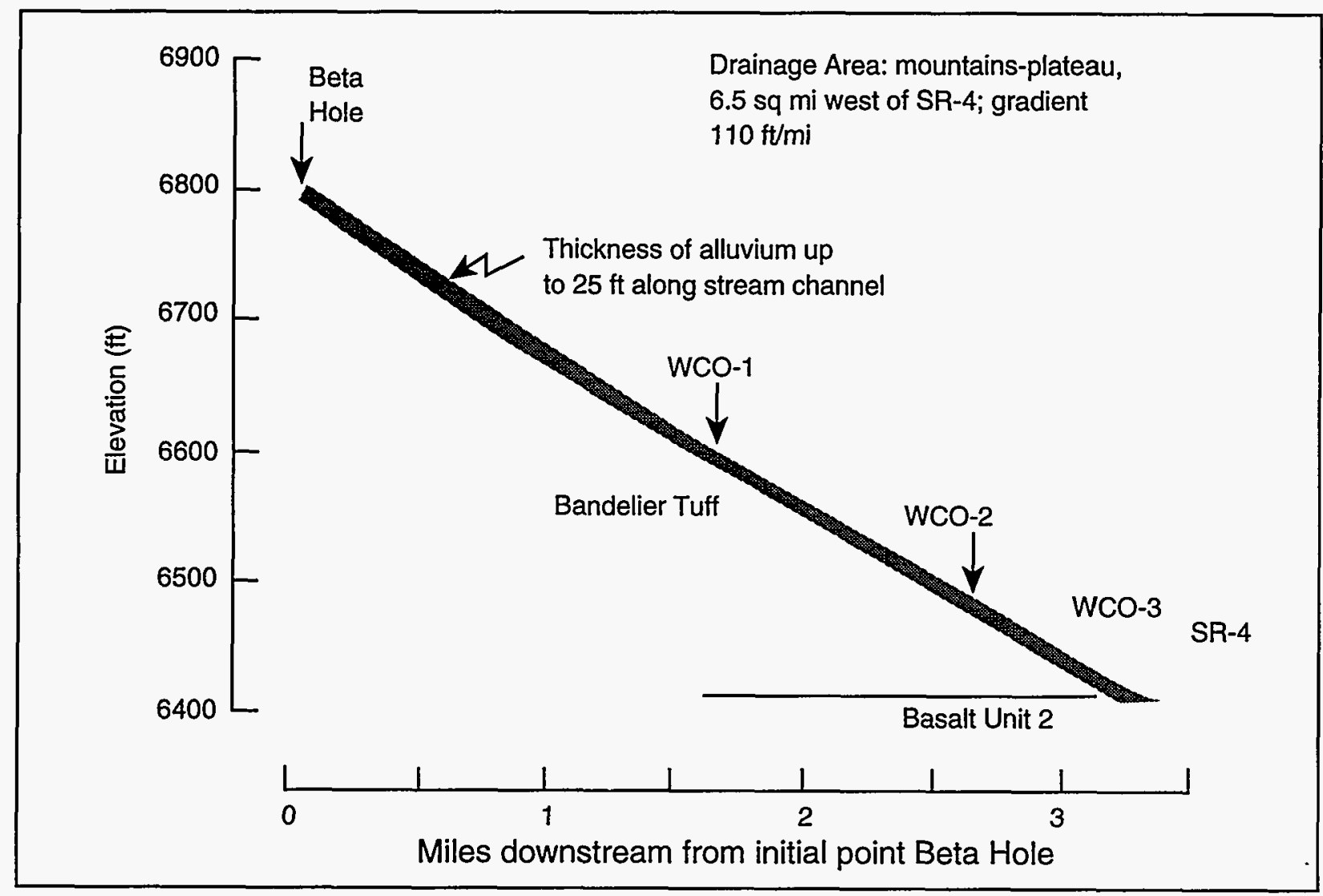

Fig. I-Y. Diagrammatic section showing rocks underlying alluvium in Water Canyon.

\section{Drainage Area: plateau, $4.7 \mathrm{sq} \mathrm{mi}$} west of TA-56; gradient $103 \mathrm{ft} / \mathrm{mi}$

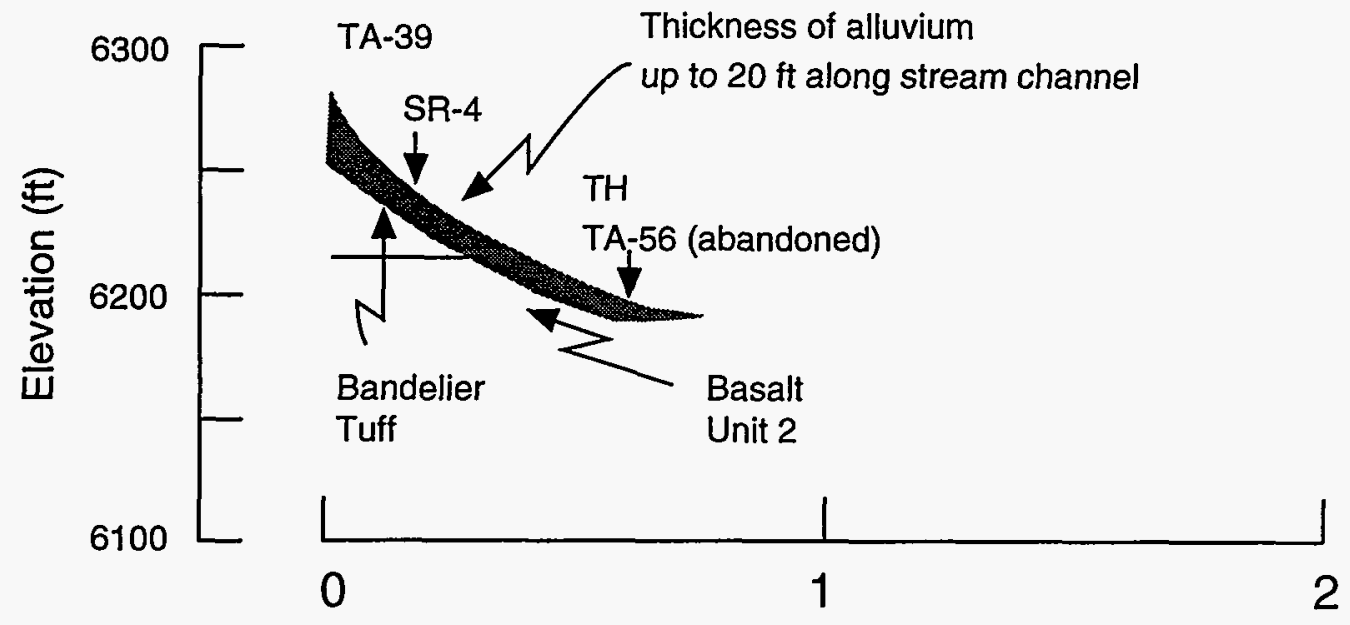

Miles downstream from initial point TA-39

Fig. I-Z. Diagrammatic section showing rocks underlying alluvium in part of Ancho Canyon. 
of the mesa and thins to the edges of the canyons where the tuff is exposed. The soil on the western edge of the plateau, and extending short distances eastward, is underlain by white ashfall pumice, a part of the $\mathrm{El}$ Cajate Pumice Fall. The pumice is thin, generally less than $3 \mathrm{ft}$. Along the fault scarp of the Pajarito Fault, the pumice attains a greater thickness. A detailed soil map of the Laboratory has been prepared by Nyhan et al. (1979).

\section{E. Hydrology}

The Rio Grande is the master stream in northcentral New Mexico. All surface water drainage from the plateau and ground water discharge is into the Rio Grande. The Rio Grande at Otowi, just east of Los Alamos, has a drainage area of $14300 \mathrm{sq}$ mi in southern Colorado and northern New Mexico. The discharge for the period of record has ranged from a minimum of 60 cubic $\mathrm{ft} / \mathrm{sec}$ (cfs) in 1902 to $24400 \mathrm{cfs}$ in 1920 . The river transports about one million tons of suspended sediments past Otowi annually (Purtymun 1975).

Ground water occurs in three modes in the Los Alamos area: (1) water in shallow alluvium in some of the larger canyons, (2) perched water (a ground water body above an impermeable layer that separates it from the underlying main body of ground water by an unsaturated zone), and (3) the main aquifer of the Los Alamos area.

1. Surface Water. Los Alamos surface water occurs primarily as intermittent streams. Springs on the flanks of the Sierra de los Valles supply base flow into upper reaches of some of the canyons (Guaje, Los Alamos, Pajarito, Canyon de Valle and Water Canyon), but the amount is insufficient to maintain surface flow across the plateau before it is depleted by evaporation, transpiration, and infiltration. Runoff from heavy thunderstorms or heavy snowmelt reaches the Rio Grande several times a year in some drainages. Effluents from sanitary sewage, industrial waste treatment plants, and cooling-tower blowdown are released into some canyons at rates sufficient to maintain surface flow for short distances on the Pajarito Plateau (Purtymun 1975).

Spring discharge in lower Pajarito and Ancho Canyons is of sufficient volume to support perennial flow into White Rock Canyon and the Rio Grande.

2. Ground Water in the Alluvium.

Intermittent stream flow in canyons of the plateau has deposited alluvium that ranges from less than $3 \mathrm{ft}$ in thickness to as much as $76 \mathrm{ft}$. The alluvium is more permeable than the underlying volcanic tuff and sediments. The natural runoff and release of waste water, sanitary effluents, and industrial effluents infiltrate the alluvium until the downward movement of the water is impeded by the less permeable tuff and volcanic sediments. This results in a shallow ground water body that moves down the gradient within the alluvium. As the water in the alluvium moves downgradient, it is depleted by evapotranspiration and movement into the underlying tuff.

Two of the best examples of alluvial aquifers are in Los Alamos and Mortandad Canyons. The alluvium in Los Alamos Canyon is composed of sands, gravels, pebbles, cobbles, and boulders derived from the Tschicoma Formation on the flanks of the mountains, and clay, silt, sand, and gravel from the Bandelier Tuff of the plateau. The alluvium in Mortandad Canyon consists mainly of clay, silt, sand, and gravel derived from the Bandelier Tuff on the plateau.

Sufficient observation wells and test holes have been drilled in the canyons to outline the aquifer in the alluvium in both canyons (Figs. I-AA, I-AB). Water levels fluctuate rapidly in Los Alamos Canyon due to varying amounts of natural recharge. The large drainage area on the flanks of the mountains provides snowmelt runoff in the spring and thunderstorm runoff in the summer. In general the water levels in the alluvium in Los Alamos Canyon are highest in the spring due to snowmelt runoff and in the early fall due to summer runoff.

Mortandad Canyon heads on the plateau. Its major source of recharge to water in the alluvium is industrial effluent. As a result the water level fluctuations are not as great as in Los Alamos Canyon. The movement of water in the alluvial aquifer was determined using tracers. The movement in the sand unit of the aquifer was about $60 \mathrm{ft} /$ day, in a silty clay unit about $14 \mathrm{ft} /$ day, and in a clay unit about $7 \mathrm{ft} /$ day (Purtymun 1974). From 1967 through 1978 the maximum amount of water in transit storage in the aquifer was about 8 million gallons in 1967 and the minimum in transit storage was about 4 million gallons in 1977 (Purtymun et al. 1983).

The alluvium in many of the other canyons contains water, especially in the western part of the plateau. The amount of water in the alluvium in the canyons of the plateau is small and not dependable, and thus is not a viable source of water supply to the Laboratory or community (Purtymun 1984). 


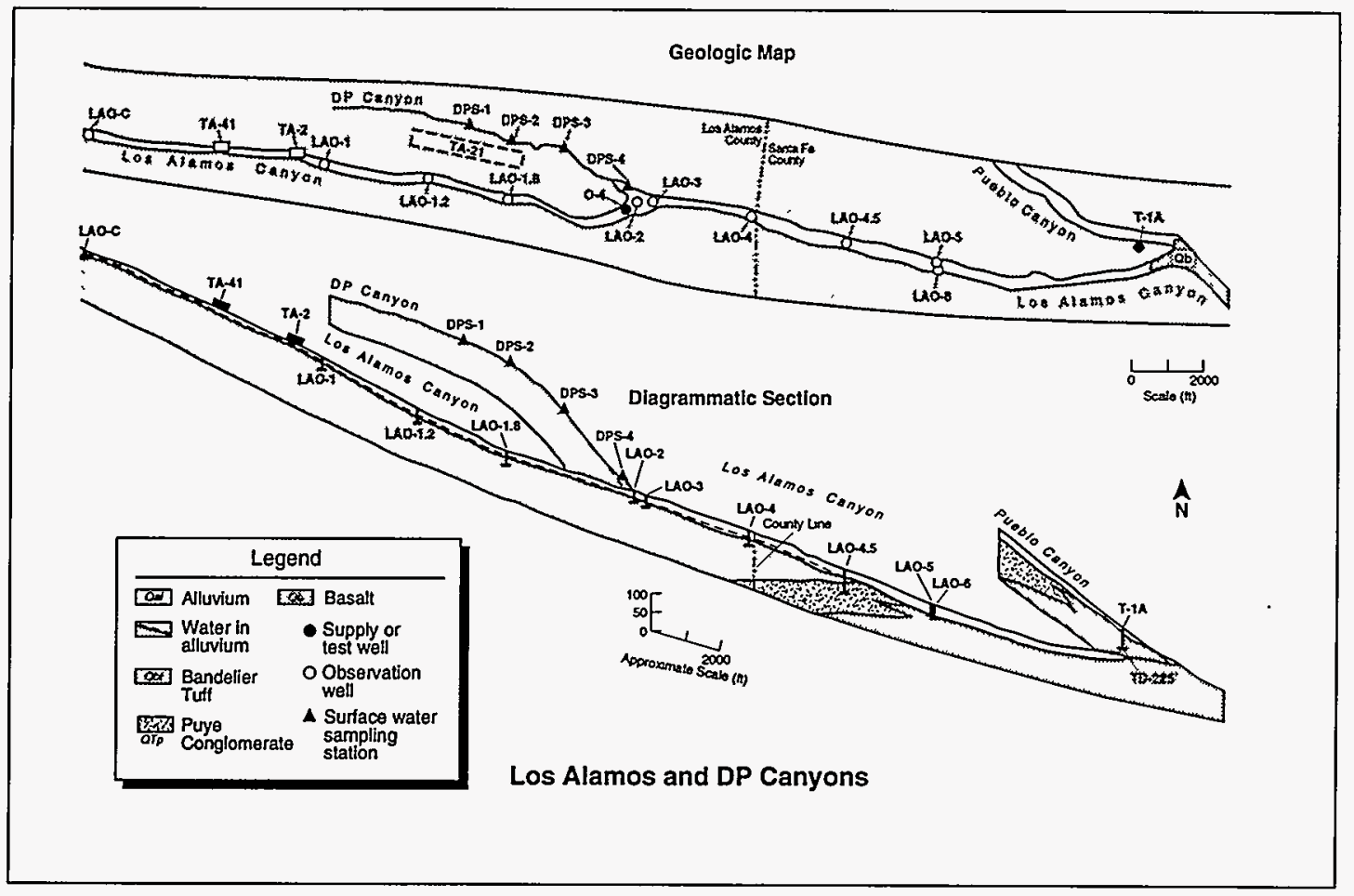

Fig. I-AA. Map showing shallow ground water in alluvium of Los Alamos and DP Canyons (Purtymun 1975).

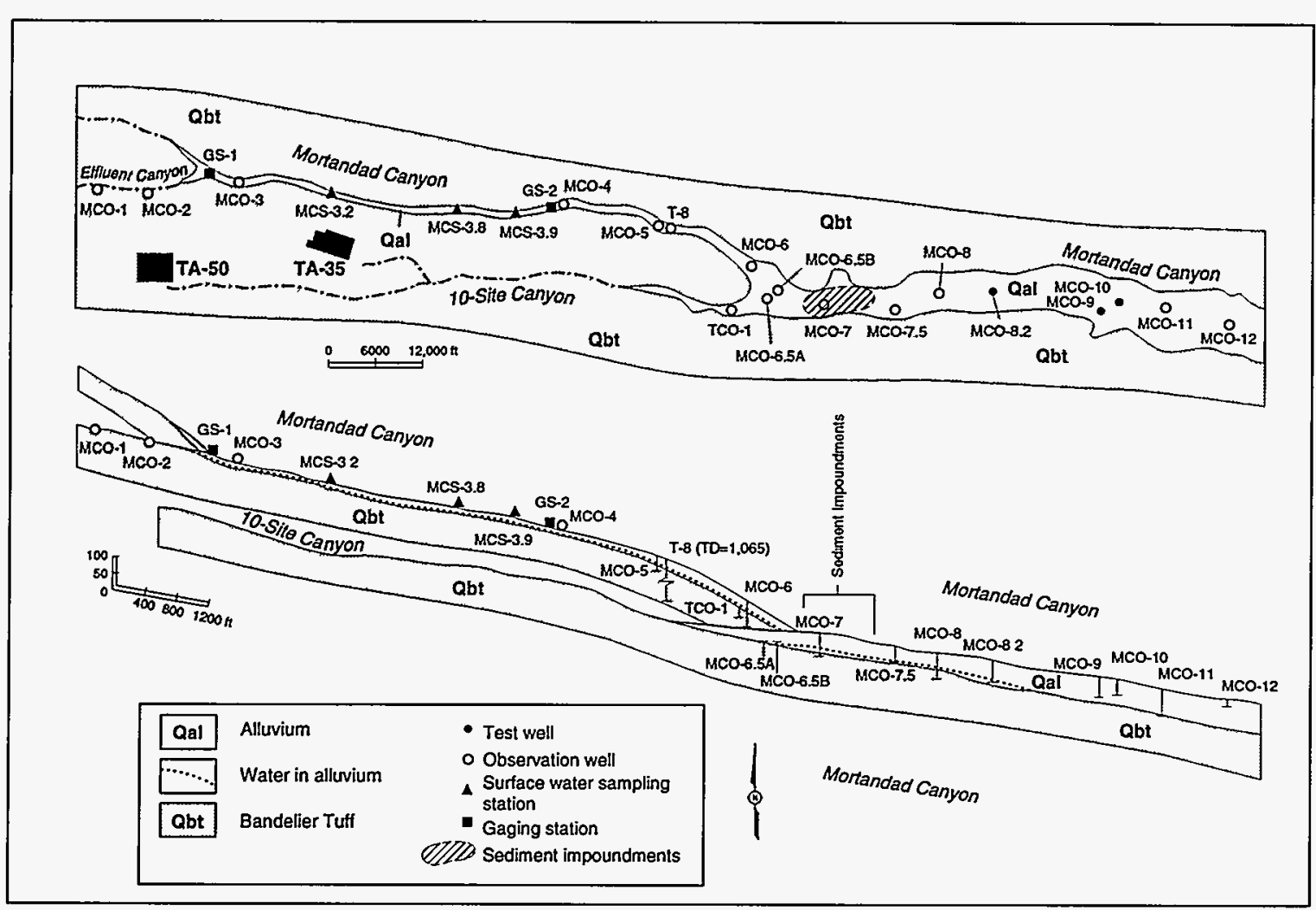

Fig. I-AB. Map showing shallow ground water in alluvium of Mortandad Canyon (Purtymun 1975). 


\section{Perched Water in Volcanic Sediments and} Basalts. Perched water occurs in the volcanic sediments of the Puye Conglomerate in the midreach of Pueblo Canyon. The perched aquifer is at a depth of about $120 \mathrm{ft}$ (TW-2A) and is of limited extent as determined by testing (Fig. I-AC). Water in the aquifer is depleted after about an hour pumping at 2 to $3 \mathrm{gpm}$. The perched water is recharged from the stream and lies in a clay lens in the fanglomerate member. The main aquifer in this area is at a depth of about $789 \mathrm{ft}$. (Weir et al. 1963; Purtymun 1982)

A second perched aquifer occurs in the midreach of Los Alamos Canyon. The perched aquifer was encountered during drilling of supply well $\mathrm{O}-4$. The aquifer is perched in the volcanic sediments of the fanglomerate member of the Puye Conglomerate at a depth of $253 \mathrm{ft}$. The aquifer is in gravels underlain by a lens of silt and clay. The aquifer is also of limited extent as it was not recognized during the drilling of test well 3 about $300 \mathrm{ft}$ east of O-4. Test well 3 was drilled with a cable tool and encountered no water at that depth (Stoker et al. 1992). The top of the main aquifer in this area is at a depth of about $760 \mathrm{ft}$.

The recharge to the perched aquifers in the Puye Conglomerate (fanglomerate member) in the midreach of Pueblo (TW-2A) and Los Alamos Canyons (O-4) is probably from the intermittent stream flow in the canyons. The perched aquifers are of limited extent beneath the canyon and do not extend beneath the mesas (Purtymun 1975).

A third perched water zone occurs in the lower reach of Pueblo Canyon and its junction with Los Alamos Canyon. Perched water was encountered in the drilling of supply well O-1 in the lower reach of Pueblo Canyon at a depth of about $183 \mathrm{ft}$ in the fanglomerate member of the Puye Conglomerate. The gravels of the Puye Conglomerate are about $17 \mathrm{ft}$ above Unit 2 of the Basaltic Rocks of Chino Mesa. At test well TW-1A about $400 \mathrm{ft}$ to the east the same aquifer was encountered at a depth of about $180 \mathrm{ft}$ in Unit 2. To the south in Sandia Canyon, supply well PM-1 encountered perched water at a depth of about $450 \mathrm{ft}$ in Unit 3 of the Basaltic Rocks of Chino Mesa (Purtymun et al. 1993). Unit 3 is a series of basalt flows that flowed into a river channel, producing a dam that collected lake sediments and gravels (Old Alluvium). This third perched aquifer discharges to the east in Los Alamos Canyon at Basalt Spring along the base of Unit 3, the channel-fill basalt (Fig. I-AD). The discharge ranges from 15 to $40 \mathrm{gpm}$. South of Pueble Canyon movement of the water in the aquifer is to the southwest, where a part of the water is discharged in the Sandia Spring seep area. Discharge into the channel increases from 10 to $30 \mathrm{gpm}$ as one moves eastward in the canyon.
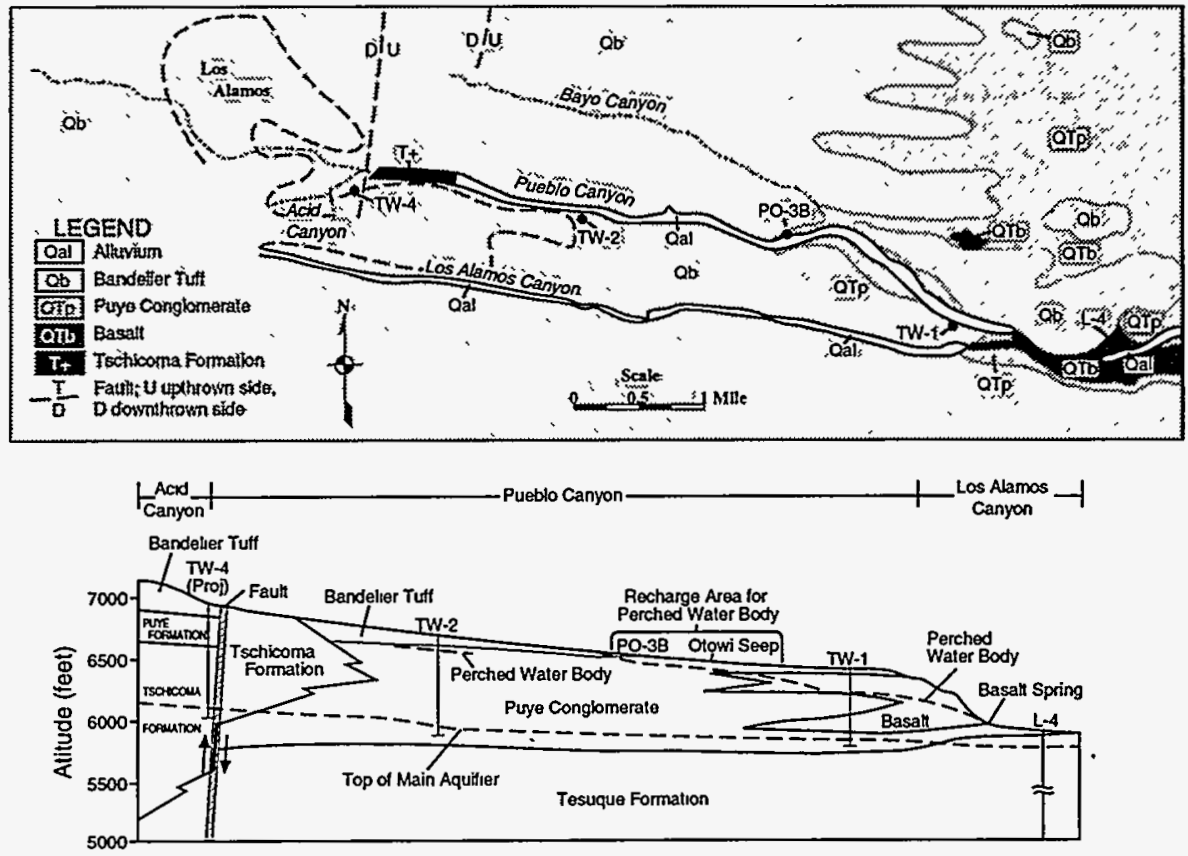

Fig. I-AC. Map with cross section along Pueblo Canyon showing perched water in volcanic sediments in the middle and lower reaches of Pueblo Canyon. 


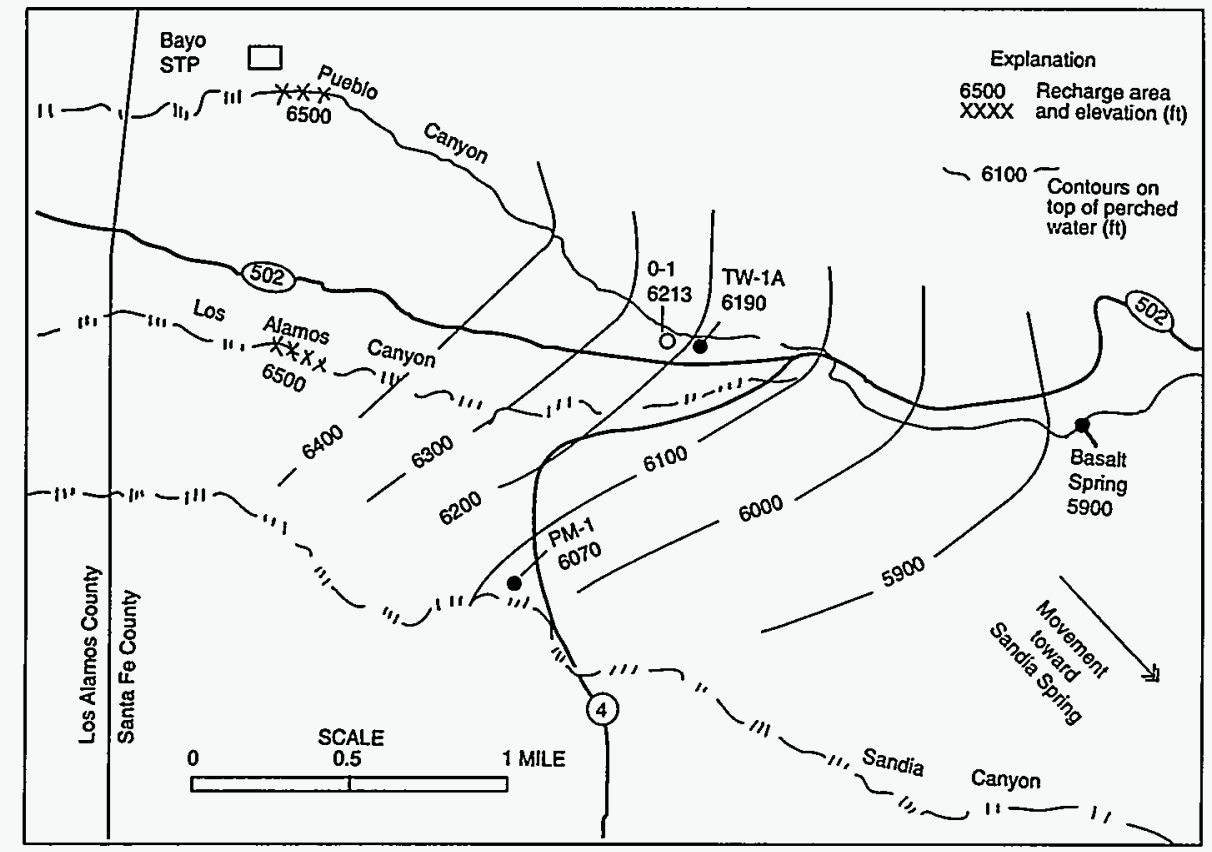

Fig. I-AD. Water level contours of the top of the perched aquifer in volcanic sediments and basalts in lower Pueblo Canyon and the midreach of Los Alamos Canyon.

The major recharge to this aquifer occurs in Pueblo Canyon where the channel cuts through the Bandelier Tuff and is underlain by the fanglomerate member of the Puye Conglomerate in the vicinity of Hamilton Bend Spring at an elevation of about 6500 $\mathrm{ft}$ (Fig. I-AD and I-Q). Surface water losses into the fanglomerate increase east of Hamilton Bend. There is and has been a large amount of water (sanitary effluent and storm runoff) available in this part of the canyon for the past 40 years (Purtymun 1975).

A minor area of recharge to this aquifer is in Los Alamos Canyon where the channel cuts through the Bandelier Tuff and is underlain by a thin section of fanglomerate which is underlain by the Unit 2 Basaltic Rocks of Chino Mesa. During the spring and late fall when the alluvium in the canyon is saturated or near saturation, stream flow returns to the surface in this area for a short distance, indicating thinning of the alluvium over the fanglomerate and basalts (Figs. I-AD and I-R). The elevation is about the same as in Pueblo Canyon (about $6500 \mathrm{ft}$ ). There is probably a minor amount of recharge to the aquifer from the alluvium in Sandia Canyon.

Based on the chemical quality of the water, which is similar to the quality of the sanitary effluent in Pueblo Canyon, and water level fluctuations in test well TW-1A, the rate of movement in the aquifer has been estimated to be about $60 \mathrm{ft} /$ day or about 6 months from recharge to discharge (Weir et al. 1963; Purtymun 1975).

4. Main Aquifer of the Los Alamos Area. The main aquifer of the Los Alamos area is the only aquifer in the area that is capable of municipal water supply. The surface of the aquifer rises westward from the Rio Grande within the Santa Fe Group into the lower part of the Puye Conglomerate beneath the central and western part of the plateau. Depth of the aquifer decreases from about $1200 \mathrm{ft}$ along the western margin of the plateau to about $600 \mathrm{ft}$ at the eastern margin (Fig. I-AE). The main aquifer is separated from the water in the alluvium and perched water in the volcanics by 350 to $620 \mathrm{ft}$ of tuff and volcanic sediments. There appears to be little if any hydrologic connection between the water in the alluvium and the main aquifer.

The water in the main aquifer is under watertable conditions in the western and central part of the plateau and under artesian and semiartesian conditions in the eastern part along the Rio Grande. The gradient on the piezometric surface of the main aquifer across the plateau indicates a recharge area to the west. The recharge is considered to be from the flanks of the Sierra de los Valles or canyons cut into the western edge of the plateau (Theis 1950; Theis and Conover 1962; Griggs 1964; and Cushman $1965)$. There is a possibility that there is some 


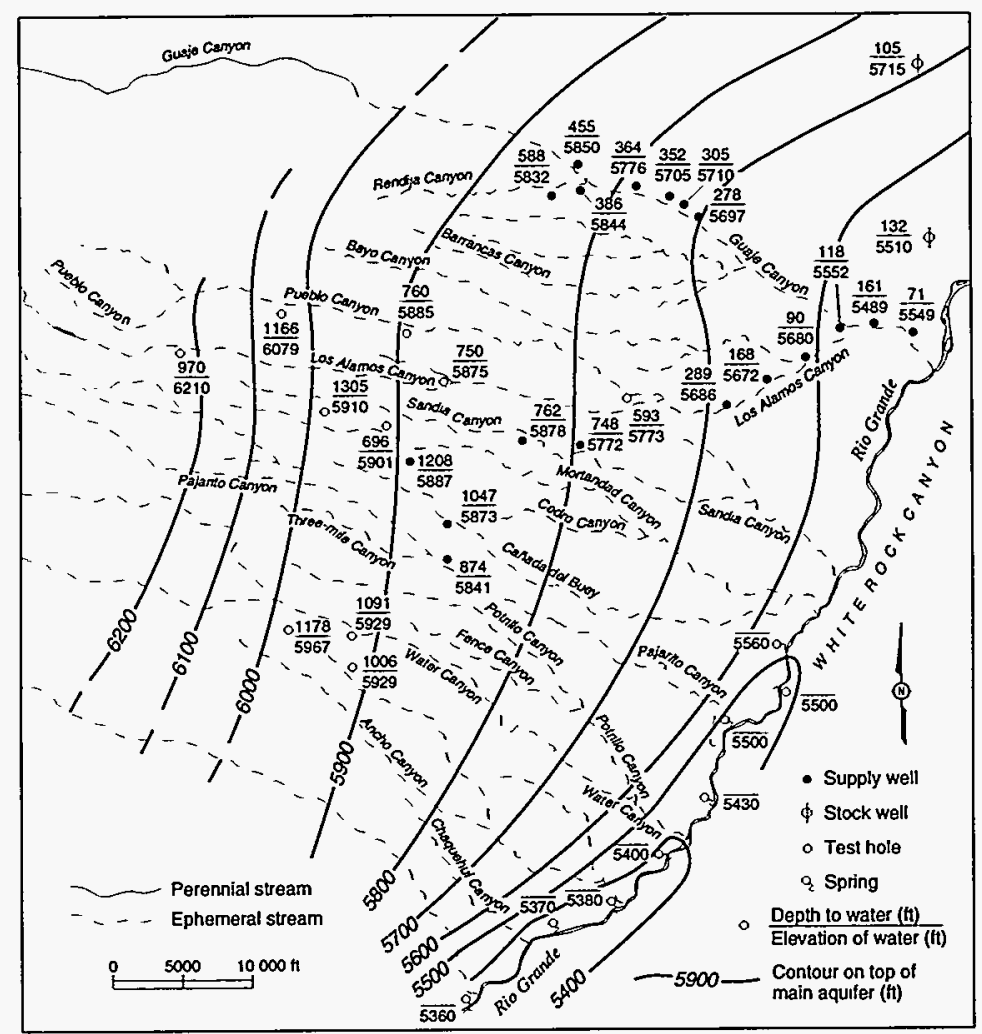

Fig. I-AE. Generalized water-level contours of the top of the main aquifer (Purtymun 1984).

recharge from intermountain basins such as the Valle Grande (Purtymun 1984).

Goff and Sayer (1980) indicated through deuterium and oxygen-18 ratios that deep supply wells LA$1 \mathrm{~B}$ and LA- 6 in the Los Alamos well field may be recharged from the east on the mountain slopes of the Sangre de Cristos. Additional investigations using isotope ratios were in progress in 1992.

Preliminary results based on low-level tritium and carbon-14 measurements indicate the age of the water in the main aquifer ranges from a few thousand years old to more than 40000 years old. Youngest water occurs to the west, near the Sierra de los Valles and the oldest was found to the east near the Rio Grande. This is compatible with the direction of ground water flow based on water level contours on the top of the main aquifer (Stoker et al. 1993).

The movement of the water in the main aquifer is from the recharge area in the west to the east and southeast, where a part is discharged through seeps and springs into White Rock Canyon on the Rio Grande (Fig. I-AF). The 11-mile reach of the Rio Grande in White Rock Canyon from Otowi to Frijoles Canyon receives an estimated 5500 acre-ft annual discharge from the main aquifer through these springs
(Purtymun 1966, Purtymun et al. 1980).

There were 21 supply wells and 10 test wells completed into the main aquifer on or adjacent to the Pajarito Plateau. The 21 supply wells are in four well fields. The Los Alamos field is no longer being used for water supply. It contained 7 wells, all of which are now either plugged or maintained as observation wells. The Guaje field contains 7 wells, the Pajarito field 5 , and the Otowi field 2 wells. Not all wells are operational. Well G-3 in the Guaje field is now used for observation. Of the test wells 8 are equipped with pumps and are used for monitoring purposes while the remaining 2 wells are abandoned $(\mathrm{H}-19$ and Sigma Mesa). Hydrologic characteristics of the main aquifer were determined at all of the supply wells and 8 of the test wells (Table I-A).

The hydrologic characteristics of the aquifer in the wells and test wells in the various fields differ due to the lithology of the aquifer and the thickness of the penetrated geologic section. The poorest wells are completed in the lower part of the Santa Fe Group, mainly the Tesuque Formation. The best-producing wells are completed in the sediments and interbedded basalts of the Chaquehui Formation (Purtymun and Stoker 1988). 


\begin{tabular}{|c|c|c|c|c|c|c|c|c|c|}
\hline \multicolumn{10}{|c|}{ TABLE I-A. Hydrologic Characteristics of Supply and Test Wells Completed in Main Aquifer } \\
\hline & \multicolumn{4}{|c|}{ Saturated Thickness } & \multirow[b]{2}{*}{$\begin{array}{c}\text { Pumping } \\
\text { Rate } \\
\text { (gpm) }\end{array}$} & \multirow[b]{2}{*}{$\begin{array}{c}\text { Drawdown } \\
\text { (ft) }\end{array}$} & \multirow[b]{2}{*}{$\begin{array}{c}\text { Specific } \\
\text { Capacity } \\
\text { (gpm/ft of } \\
\text { drawdown) }\end{array}$} & \multirow[b]{2}{*}{$\begin{array}{c}\text { Transmissivity } \\
\times 10^{3} \\
(\mathrm{gpd} / \mathrm{ft})\end{array}$} & \multirow[b]{2}{*}{$\begin{array}{c}\text { Field } \\
\text { Coefficient of } \\
\text { Permeability } \\
\left(\mathrm{gpd} / \mathrm{ft}^{2}\right)\end{array}$} \\
\hline & Year & $\begin{array}{c}\begin{array}{c}\text { Puye } \\
\text { Conglomerate }\end{array} \\
\text { (ft) }\end{array}$ & $\begin{array}{c}\text { Chaquehui } \\
\text { Formation } \\
\text { (ft) }\end{array}$ & $\begin{array}{l}\text { Chamita and } \\
\text { Tesuque } \\
\text { Formations } \\
\text { (ft) }\end{array}$ & & & & & \\
\hline \multicolumn{10}{|l|}{ Los Alamos Field } \\
\hline LA-1 & 1950 & 0 & 0 & 830 & 366 & 203 & 0.8 & - & - \\
\hline LA-1B & 1982 & 0 & 0 & 1680 & 486 & 109 & 4.5 & 15.7 & 9.3 \\
\hline LA-2 & 1982 & 0 & 0 & 710 & 269 & 187 & 1.4 & 2.5 & 3.5 \\
\hline LA-3 & 1982 & 0 & 0 & 750 & 247 & 128 & 1.9 & 2.5 & 3.3 \\
\hline LA-4 & 1981 & 0 & 0 & 1680 & 579 & 104 & 5.6 & 9.6 & 5.7 \\
\hline LA-5 & 1982 & 0 & 0 & 1580 & 467 & 136 & 3.4 & 4.8 & 3.0 \\
\hline LA-6 & 1981 & 0 & 0 & 1700 & 580 & 57 & 10.2 & 15.5 & 9.1 \\
\hline Average & & & & 1275 & & & 4.0 & 8.4 & 5.6 \\
\hline \multicolumn{10}{|l|}{ Guaje Field } \\
\hline G-1 & 1982 & 0 & 400 & 1420 & 313 & 165 & 1.9 & 12.0 & 7.0 \\
\hline $\mathrm{G}-1 \mathrm{~A}$ & 1982 & 0 & 560 & 1210 & 505 & 42 & 12.0 & 11.0 & 9.1 \\
\hline $\mathrm{G}-2$ & 1982 & 0 & 570 & 1080 & 476 & 47 & 10.1 & 15.0 & 9.1 \\
\hline G-3 & 1982 & 0 & 720 & 910 & 239 & 112 & 2.1 & 7.5 & 5.3 \\
\hline G-4 & 1982 & 0 & 770 & 850 & 297 & 192 & 1.5 & 17.5 & 11.3 \\
\hline G-5 & 1982 & 0 & 750 & 790 & 522 & 55 & 9.5 & 12.0 & 8.7 \\
\hline G-6 & 1982 & 0 & 880 & 535 & 281 & 81 & 3.5 & 6.3 & 6.7 \\
\hline Average & \multicolumn{6}{|c|}{$660(40 \%) 970(60 \%)$} & 5.8 & 11.6 & 8.2 \\
\hline \multicolumn{10}{|l|}{ Pajarito Field } \\
\hline PM-1 & 1982 & 20 & 1030 & 700 & 589 & 22 & 26.8 & 55.0 & 31 \\
\hline PM-2 & 1982 & 540 & 960 & 230 & 1386 & 60 & 23.1 & 40.0 & 28 \\
\hline $\mathrm{PM}-3$ & 1982 & 255 & 1045 & 490 & 1402 & 23 & 60.9 & 320.0 & 179 \\
\hline $\mathrm{PM}-4$ & 1982 & 370 & 1500 & 0 & 1473 & 40 & 36.8 & 44.0 & 24 \\
\hline PM-5 & 1982 & 340 & 1230 & 340 & 1225 & 144 & 8.5 & 10.0 & 5.3 \\
\hline Average & \multicolumn{6}{|c|}{$305(17 \%) 1153(64 \%) 352(19 \%)$} & 31.2 & 93.8 & 53.4 \\
\hline \multicolumn{10}{|l|}{ Otowi Field } \\
\hline $0-1$ & 1990 & 65 & 0 & 1755 & 1000 & 123 & 8.1 & 9.0 & 4.7 \\
\hline $0-4$ & 1990 & 110 & 1530 & 200 & 1500 & 33 & 46.2 & 62.0 & 30 \\
\hline \multicolumn{10}{|l|}{ Test Well } \\
\hline DT-5A (TA-49) & 1960 & 349 & 294 & 0 & 81 & 14 & 6 & 11.0 & 17 \\
\hline DT-9 (TA-49) & 1960 & 354 & 144 & 0 & 88 & 4 & 22 & 61.0 & 122 \\
\hline DT-10 (TA-49) & 1960 & 317 & 7 & 0 & 78 & 5 & 16 & 36.1 & 111 \\
\hline TW-1 & 1951 & 49 & 0 & 0 & 2.4 & 39 & $<1.0$ & 0.2 & 4.0 \\
\hline TW-2 & 1951 & 30 & 0 & 0 & 6.7 & 7 & 1.0 & 7.0 & 241 \\
\hline TW-3 & 1951 & 65 & 0 & 0 & 6.6 & 15 & 0.5 & 7.8 & 120 \\
\hline TW-4 & 1951 & 0 & 0 & 0 & 2.8 & 5 & 0.6 & 0.7 & 19 \\
\hline TW-8 & 1960 & 95 & 0 & 0 & 16 & 8 & 2.0 & 2.4 & 25 \\
\hline H-19 & 1949 & - & & - & - & - & - & - & - \\
\hline Sigma Mesa & 1979 & - & & - & - & - & - & - & - \\
\hline
\end{tabular}


The average saturated thickness of the aquifer in the wells in the Los Alamos field is about $1275 \mathrm{ft}$ in the Tesuque Formation of the Santa Fe Group. The aquifer consists of mainly siltstone and sandy siltstone; thus, the hydrologic characteristics of the aquifer are low. The average specific capacity is about $4 \mathrm{gpm} / \mathrm{ft}$ of drawdown, transmissivity is 8400 gallons per day (gpd)/ft, and the field coefficient of permeability is $5.6 \mathrm{gpd} / \mathrm{ft}^{2}$ (Purtymun 1977, 1984).

The average saturated thickness of the aquifer in the Guaje field is about $1630 \mathrm{ft}$; however, of the saturated section about $660 \mathrm{ft}$ or about $40 \%$ is within the Chaquehui Formation and associated basalts. The lower $970 \mathrm{ft}$ or $60 \%$ is within the Tesuque Formation. The hydrologic characteristics of the aquifer in the Guaje field are slightly greater than in the Los Alamos field, with an average specific capacity of 5.8 $\mathrm{gpm} / \mathrm{ft}$ and a field coefficient of permeability of 8.2 $\mathrm{gpd} / \mathrm{ft}^{2}$ (Griggs 1964).
The most productive wells are located in the Pajarito field where wells penetrated large thicknesses of the Chaquehui Formation and associated basalts. The average saturated thickness of the aquifer is 1810 $\mathrm{ft}$. About $1153 \mathrm{ft}$ or $64 \%$ of the saturated thickness is the Chaquehui Formation and basalts and $352 \mathrm{ft}$ or $19 \%$ is within the Chamita and Tesuque Formations. The average specific capacity of the field is about $31.2 \mathrm{gpm} / \mathrm{ft}$ of drawdown, transmissivity $93800 \mathrm{gpd} / \mathrm{ft}$, with a field coefficient of permeability of $53.4 \mathrm{gpd} / \mathrm{ft}^{2}$.

Four of the test wells are completed into the top of the main aquifer within the Puye Conglomerate while three others are completed within the Puye Conglomerate and the Chaquehui Formation. The hydrologic characteristics vary with the depth of penetration of the saturated section (Table I-A). Test well 4 was completed into the Tschicoma Formation. The hydrologic characteristics were not determined for test wells H-19 and Sigma Mesa.

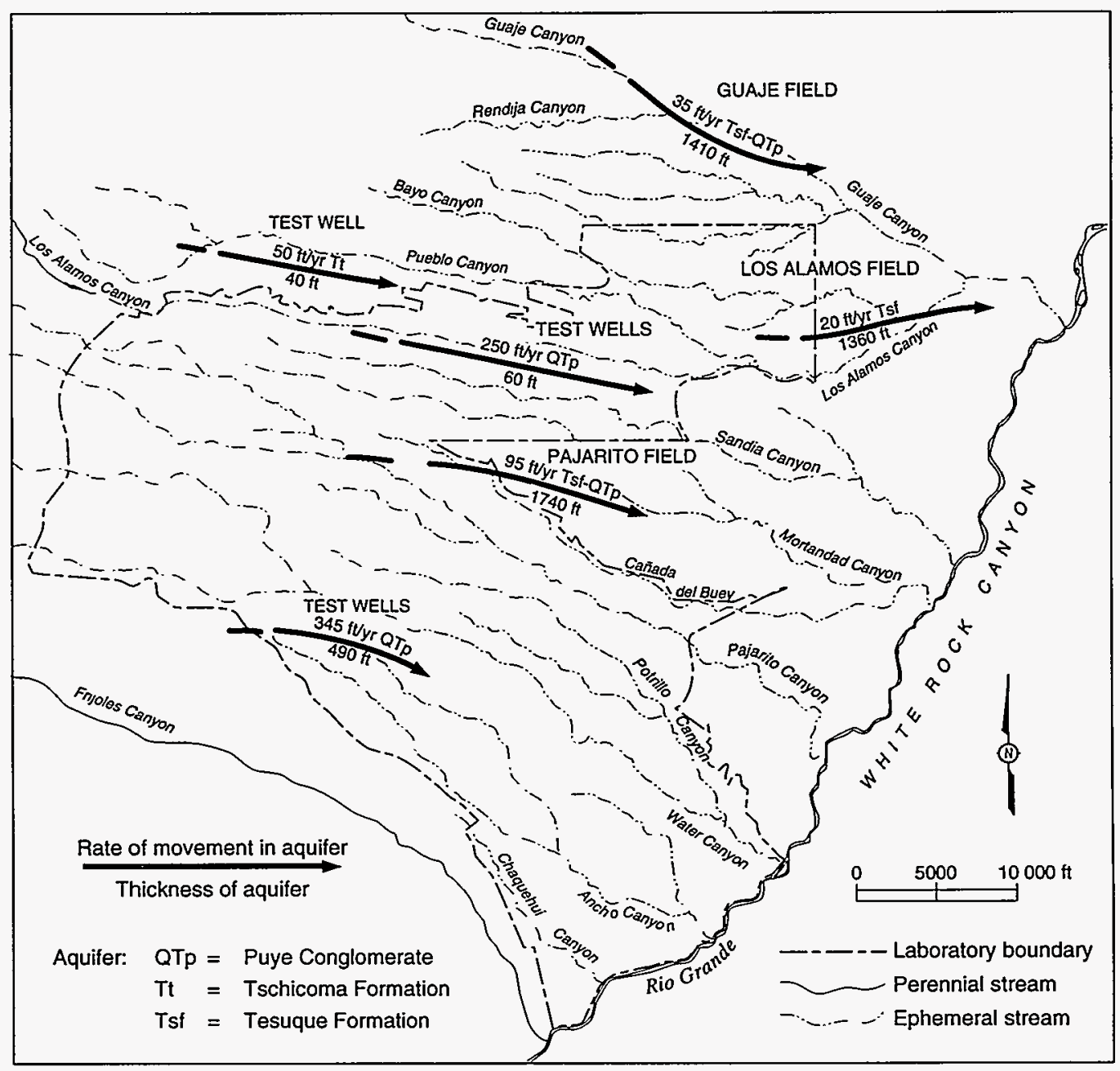

Fig. I-AF. Rate of movement of water in the main aquifer (Purtymun 1984). 
The hydrologic characteristics of the supply and test wells were used to determine the rate of movement in the top of the main aquifer (Fig. I-AF). The rates of movement ranged from $20 \mathrm{ft} /$ year in the Tesuque Formation to as much as $345 \mathrm{ft} / \mathrm{yr}$ in the Puye Conglomerate (Purtymun 1984).
Water-level measurements in the supply and test wells have been compiled indicating general waterlevel declines in the area (Table I-B). The amount of water-level decline related to production is indicative of the hydrologic characteristics of the aquifer. The lower permeability and porosity of the Tesuque

\begin{tabular}{|c|c|c|c|c|}
\hline \multicolumn{5}{|c|}{ TABLE I-B. Water Levels in Supply and Test Wells } \\
\hline Los Alamos Field & $\begin{array}{c}\text { Water Level } \\
\text { at } \\
\text { Completion }\end{array}$ & Completion & $\begin{array}{c}\text { Most Recently } \\
\text { Recorded } \\
\text { Water Level }\end{array}$ & Year \\
\hline LA-1 & flowing & $(1946)$ & 10 & $(1991)$ \\
\hline LA-1B & flowing & $(1960)$ & 55 & (1991) \\
\hline LA-2 & flowing & (1946) & 123 & (1991) \\
\hline LA-3 & flowing & (1947) & 112 & (1991) \\
\hline LA-4 & 189 & (1948) & 244 & (1991) \\
\hline LA-5 & 71 & (1948) & 158 & (1991) \\
\hline LA-6 & 3 & (1948) & 96 & $(1991)$ \\
\hline Average & 38 & & 114 & \\
\hline \multicolumn{5}{|l|}{ Guaje Field } \\
\hline G-1 & 192 & (1951) & 282 & (1991) \\
\hline G-1A & 265 & (1955) & 325 & (1991) \\
\hline G-2 & 279 & (1952) & 369 & (1991) \\
\hline G-3 & 310 & (1952) & 347 & (1991) \\
\hline G-4 & 357 & (1952) & 382 & (1991) \\
\hline G-5 & 417 & (1952) & 487 & (1991) \\
\hline G-6 & 570 & (1964) & 591 & (1991) \\
\hline Average & 342 & & 398 & \\
\hline \multicolumn{5}{|l|}{ Pajarito Field } \\
\hline PM-1 & 746 & (1965) & 752 & (1991) \\
\hline PM-2 & 826 & (1966) & 855 & (1991) \\
\hline PM-3 & 743 & (1968) & 768 & (1991) \\
\hline PM-4 & 1050 & (1982) & 1081 & (1991) \\
\hline PM-5 & 1208 & (1982) & 1239 & (1991) \\
\hline Average & 915 & & 939 & \\
\hline \multicolumn{5}{|l|}{ Test Well } \\
\hline DT-5A (TA-49) & 1173 & (1960) & 1178 & (1964) \\
\hline DT-9 (TA-49) & 1003 & (1960) & 1006 & (1982) \\
\hline DT-10 (TA-49) & 1085 & (1960) & 1089 & (1962) \\
\hline TW-1 & 585 & (1950) & 535 & (1992) \\
\hline TW-2 & 759 & (1950) & 792 & (1992) \\
\hline TW-3 & 743 & (1949) & 778 & (1992) \\
\hline TW-4 & 1171 & (1950) & 1173 & (1992) \\
\hline TW-8 & 968 & (1960) & 992 & (1992) \\
\hline $\mathrm{H}-19$ & 970 & (1949) & - & \\
\hline Sigma Mesa & 1330 & (1979) & - & \\
\hline
\end{tabular}

Source: Purtymun et al. 1984. 
Formation in the Los Alamos field has resulted in the greatest water-level decline. As the hydrologic characteristics improve, the amount of production per foot of water-level decline increases. Water level fluctuation in the main aquifer occurs during diurnal pressure changes, changes in atmospheric pressure, seismic events (earthquakes), and earth tides (Purtymun et al. 1974). Test holes, test wells, and supply wells that penetrate the tuff or volcanic sediments and basalt above the main aquifer draw in or expel air in response to atmospheric pressure changes.

The average water-level decline in the Los Alamos field has been about $76 \mathrm{ft}$ (Table I-B). The production from the field from 1947 through 1991 has been about 16.4 billion gallons or about 220 million gallons per foot of water-level decline for the period.

The average water-level decline in the Guaje field has been $56 \mathrm{ft}$ from 1965 through 1991, while the production from the field has been about 19.2 billion gallons or about 340 million gallons per foot of water-level decline.

The average water-level decline in the Pajarito field has been about $24 \mathrm{ft}$ from 1965 through 1991 while the production from the field has been 18.8 billion gallons or about 780 million gallons per foot of water-level decline.

Most of the test wells are removed beyond the influence of pumping in the well fields; however, all show water-level declines that indicate a regional water-level decline on the plateau (Table I-B).

The rate of movement of water in the upper section of the aquifer varies, dependent on the aquifer materials (Purtymun 1984). Aquifer tests indicate that the movement ranges from $20 \mathrm{ft} / \mathrm{yr}$ in the Tesuque Formation to $345 \mathrm{ft} / \mathrm{yr}$ in the more permeable Puye Conglomerate and Chaquehui Formation (Fig. I-AF).

The Chaquehui Formation of the Santa Fe Group beneath the Pajarito Plateau is an important part of the main aquifer in the development of water supply at Los Alamos. The coarse volcanic and granitic debris within the Chaquehui Formation yields water readily to wells and in part allows the development of high-yield, low-drawdown wells in the area. The formation attains its greatest thickness in a north-south trending basin beneath the central part of the plateau as shown in Figs. I-F and I-G. The location of future wells in this basin should be chosen carefully because wells located too far west will encounter volcanic rocks of the Tschicoma Formation and wells located too far to the east will encounter rocks of the Tesuque Formation that do not yield water as readily as the coarser sediments of the Chaquehui Formation (Figs. I-F and I-AG).

Two supply wells, Otowi 1 and Otowi 4, were drilled in the fall of 1989 and were tested by the late summer of 1990. The main completion of Otowi 4 was in the Chaquehui Formation, while Otowi 1 lay at the edge of the Chaquehui coarse-sediment basin and was completed in the Tesuque Formation (Table I-A). A comparison of the yields of the two wells indicate that Otowi 4, completed in the Chaquehui Formation, is a high-yield well at $1500 \mathrm{gpm}$ (Stoker et al. 1992). Otowi 1, completed in the Tesuque, is a marginal high-yield well at $1000 \mathrm{gpm}$ (Fig. I-AH).

The quality of water from the main aquifer is monitored from the supply and test wells and from the springs that discharge from the aquifer in White Rock Canyon. The quality of water from a well or spring depends on the lithology of the aquifer and the amount of yield from the individual beds within the aquifer. The quality of water from the individual wells and springs varies because of local conditions within the same aquifer. The variation in the general chemical quality of water from wells and springs is presented in graphic form (Figs. I-AI, I-AJ, and I-AK) showing the concentrations of calcium, sodium, hardness, bicarbonate, and total dissolved solids (concentrations in $\mathrm{mg} / \mathrm{L}$ ). Hardness is dissolved calcium-magnesium, with a hardness classification 1 to $60 \mathrm{mg} / \mathrm{L}$ rated soft; 61 to $120 \mathrm{mg} / \mathrm{L}$ moderately hard; and 121 to $180 \mathrm{mg} / \mathrm{L}$ hard. Predominant chemicals in the water are calcium or sodium with bicarbonate; thus, the waters are of either calcium-bicarbonate or sodium-bicarbonate types.

Graphic comparison of average chemical constituents in water from the main aquifer in the Los Alamos field, the Guaje field, and the Pajarito field shows gross differences in the concentration of constituents due to the lithology of the the aquifer. All of the yield from the Los Alamos field is from the Tesuque Formation; the yield from the Guaje field is partly from the Tesuque Formation and partly from the Chaquehui Formation; and most of the yield from the Pajarito field is from the Chaquehui 


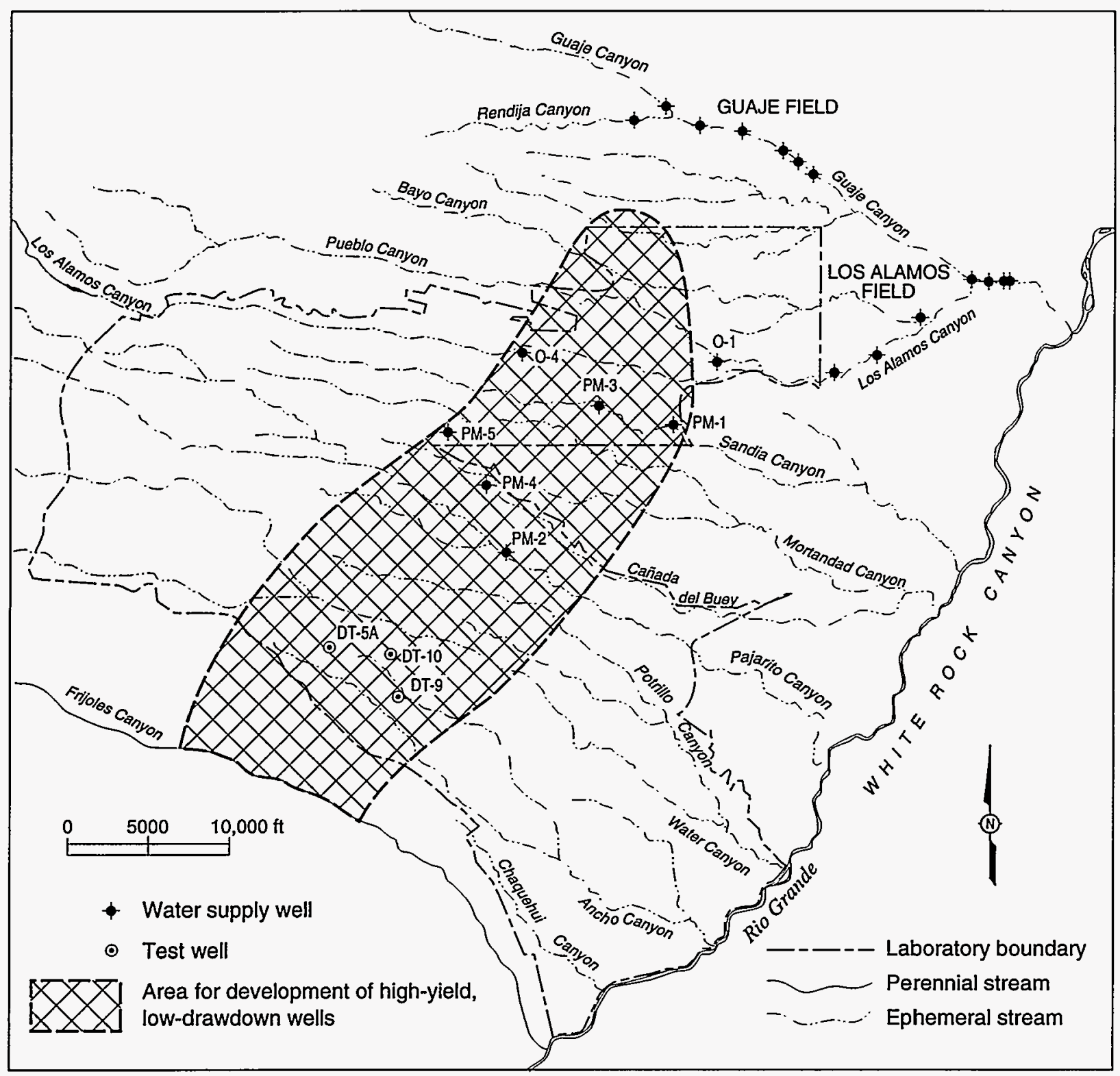

Fig. I-AG. Proposed locations for additional supply wells and area for the development of high-yield, low-drawdown wells (Purtymun 1984). 


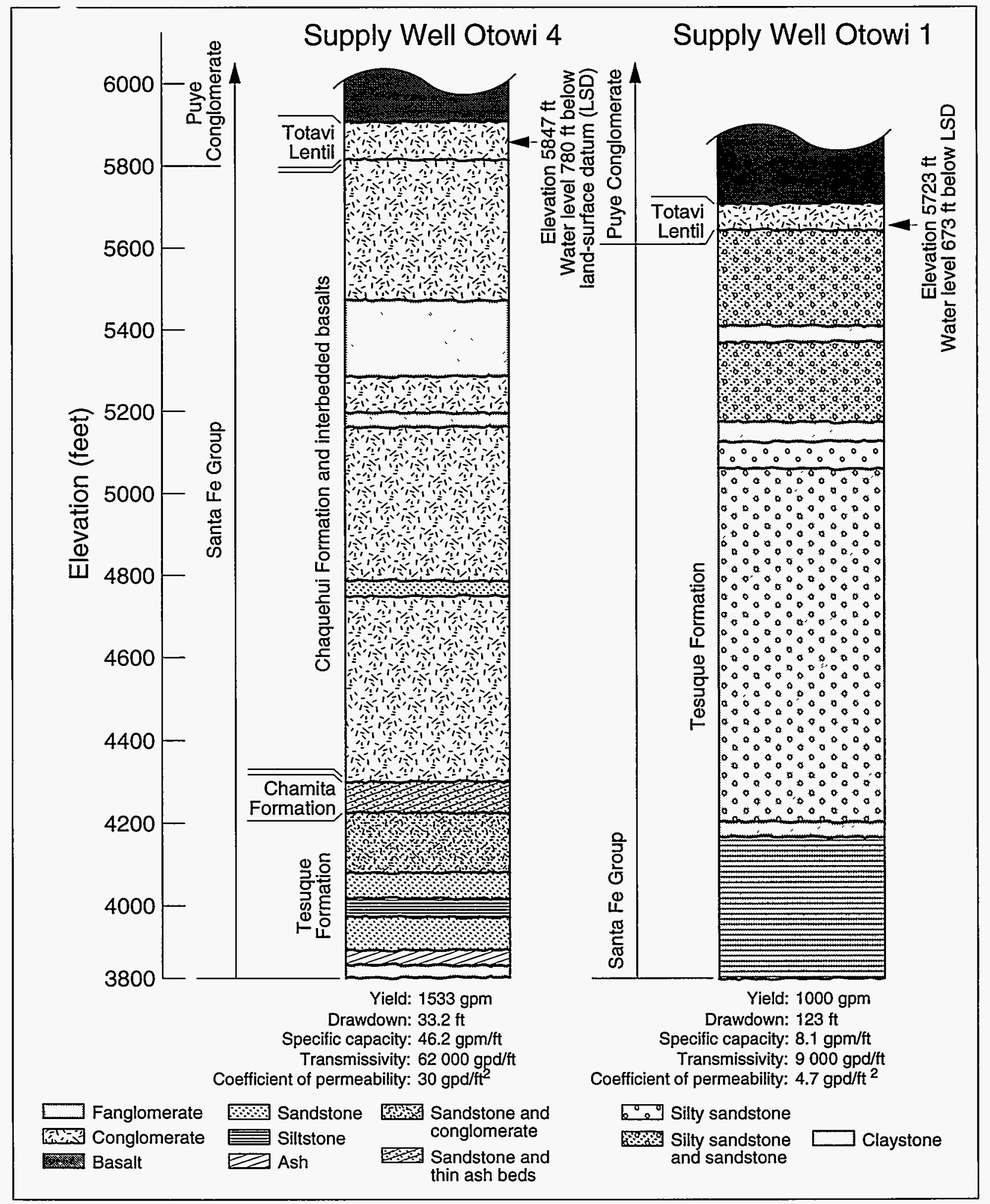

Fig. I-AH. Partial geologic logs of supply wells Otowi 1 and 4 showing equivalent saturated sections (main aquifer) in the Puye Conglomerate and Santa Fe Group and a comparison of their hydrologic characteristics (Purtymun 1993). See Figs. XXI-T and XXI-U for complete logs. 


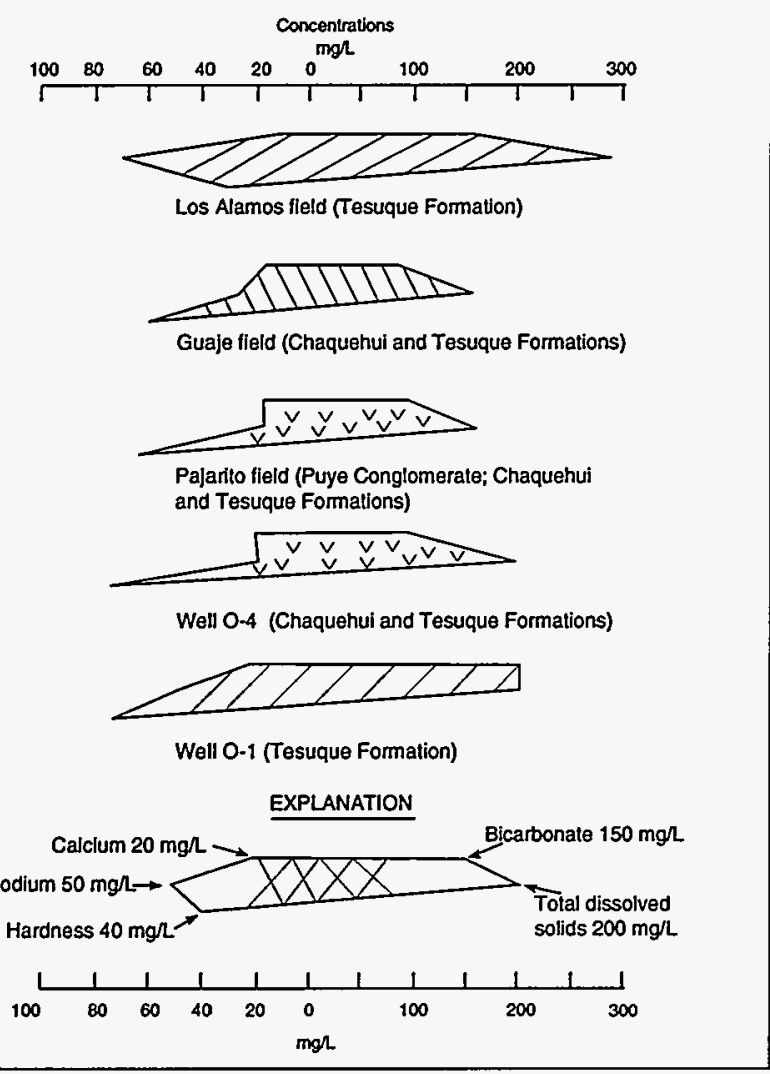

Fig. I-AI. Graphic comparsion of average chemical constituents in water in supply wells from the main aquifer (Purtymun 1993, Purtymun et al. 1994).

Fig. I-AJ. Graphic comparsion of average chemical constituents in water in test wells from the main aquifer (Purtymun 1993).

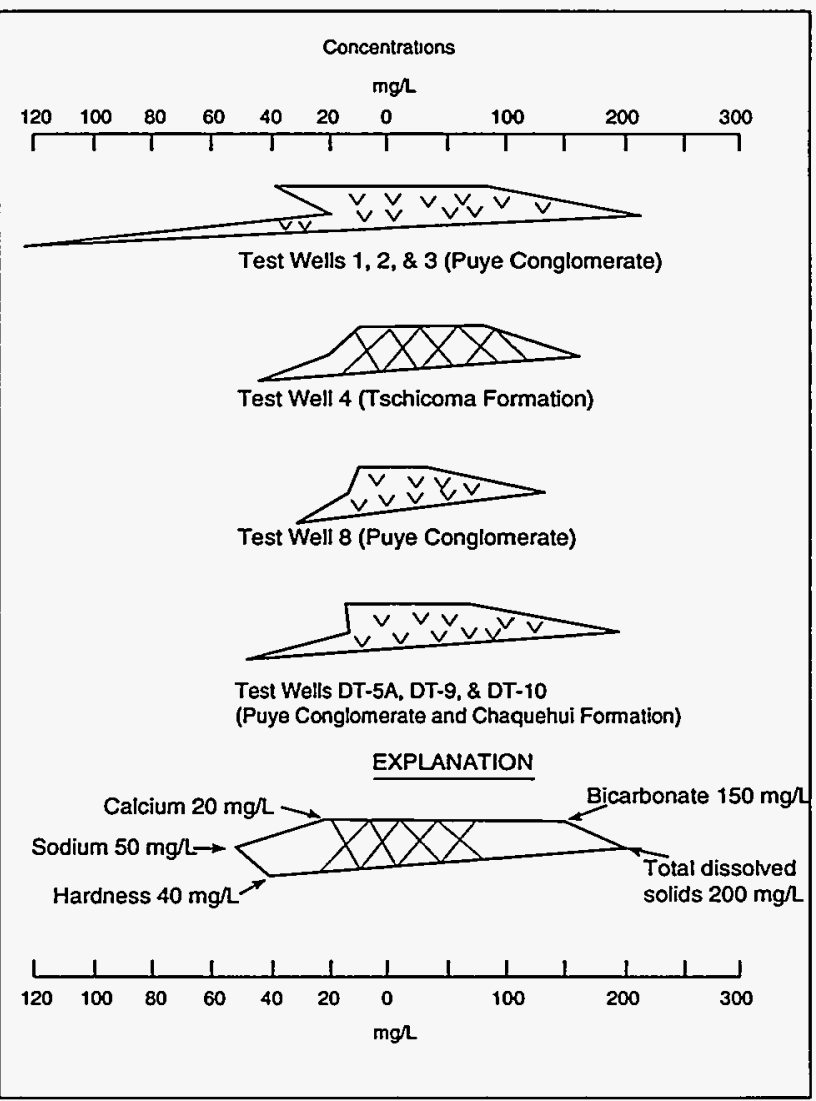




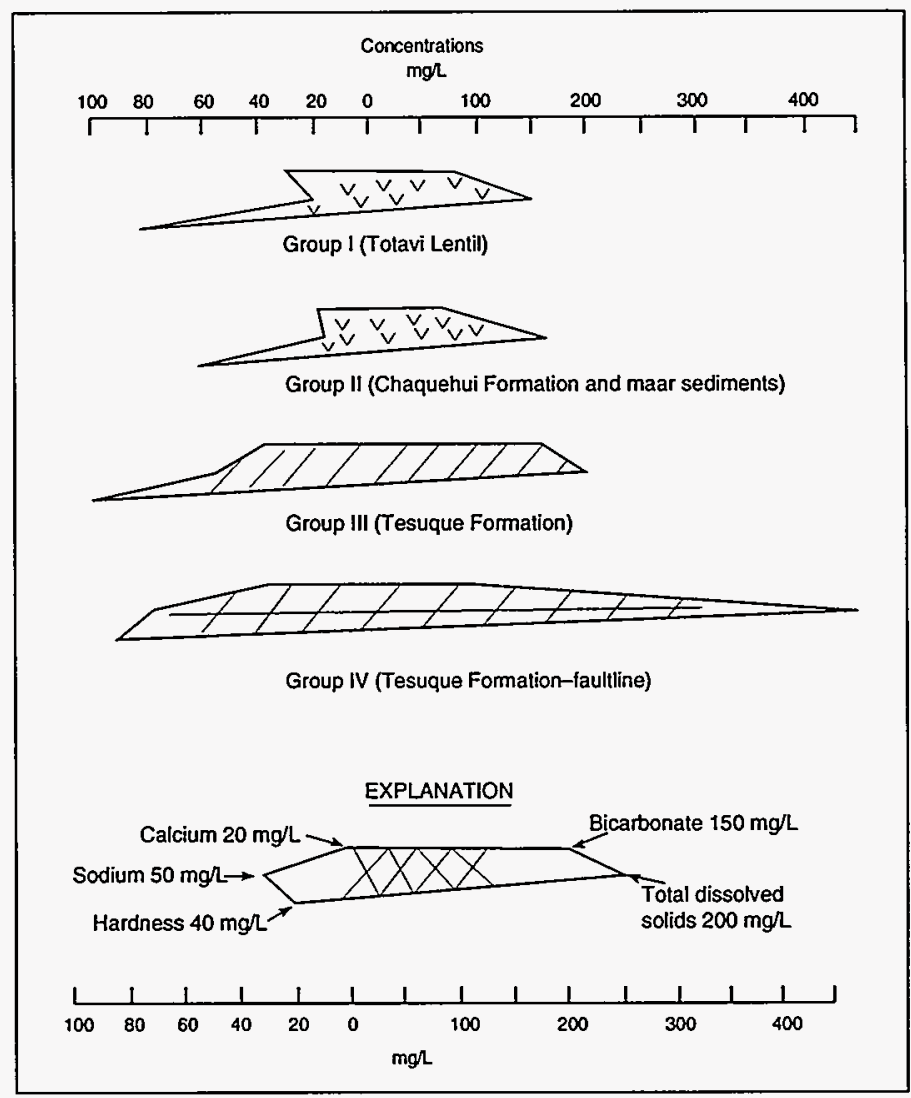

Fig. I-AK. Graphic comparison of average chemical constituents in water from the main aquifer in springs, in and adjacent to White Rock Canyon (Purtymun 1966, Purtymun et al. 1980, Purtymun 1993).

Formation (Fig. I-AI). A graphic comparison of chemical constituents from the wells in the Otowi field, $\mathrm{O}-1$ and $\mathrm{O}-4$, shows the difference due to the yield from the Chaquehui Formation (O-4) and the Tesuque Formation (O-1).

Graphic comparison of the average chemical constituents in water from the main aquifer in test wells shows large differences in the concentrations of constituents in the Puye Conglomerate (Fig. I-AJ). This is probably due in part to the differences in the saturated thickness penetrated by the test well and in part to the changes in lithology of the conglomerate on the plateau. Test well 4 was completed in the Tschicoma Formation (Purtymun 1993; Purtymun et al. 1994).

Graphic comparison of the average chemical constituents in water from springs that discharge from the main aquifer in and adjacent to White Rock Canyon shows slight varations in the concentrations of chemical constituents due to the lithology of the aquifer. The average concentration of constituents in the water from the Group I and II springs differs, depending upon whether the water discharges from the Totavi Lentil or the Chaquehui Formation. The 7 Group I springs contain water from the Totavi Lentil, while the 11 Group II springs discharge from the Chaquehui Formation and in some cases are associated with the maar sediments (Fig. I-AK). The agreement of concentrations within each group is significantly greater than between the groups, although the concentrations of the constituents of all 18 springs are similar. Also shown on the figure are the average concentrations of constituents from three Group III springs that discharge from the fine-grained Tesuque Formation of the Santa Fe Group as well as four Group IV springs that discharge from along probable faults in the fine-grained sediments of the Tesuque Formation (Purtymun 1966; Purtymun et al. 1980, Purtymun et al. 1993). 


\section{REFERENCES}

J. H. Abrahams, "Physical Properties of and Movement of Water in the Bandelier Tuff, Los Alamos and Santa Fe Counties, New Mexico," U.S. Geological Survey Admin. Report (1963).

J. H. Abrahams, "Hydrology and the Chemical and Radiochemical Quality of Surface and Ground Water at Los Alamos, New Mexico, January 1956 through June 1957," U.S. Geological Survey Admin. Report (1966).

J. H. Abrahams, E. H. Baltz, and W. D. Purtymun, "Movement of Perched Ground Water in Alluvium near Los Alamos, New Mexico," U.S. Geological Survey Professional Paper 450-B (1962).

J. Aubele, "Geology of the Cerros del Rio Volcanic Field," in Guidebook of the Rio Grande Rift in New Mexico and Colorado, New Mexico Bureau of Mines and Mineral Resources, Circular 163 (1978).

R. A. Bailey, R. L. Smith, and C. S. Ross, "Stratigraphic Nomenclature of the Volcanic Rocks of the Jemez Mountains, New Mexico," U.S. Geological Survey Bulletin 1274-P (1969).

E. H. Baltz, J. H. Abrahams, and W. D. Purtymun, "Preliminary Report on the Geology and Hydrology of Mortandad Canyon near Los Alamos, New Mexico-With Special Reference to Disposal of Liquid Low-Level Radioactive Wastes," U.S. Geological Survey Open-File Report (1963).

K. D. Bennett, "Annotated Bibliography of Geologic, Hydrologic and Environmental Studies Related to Solid Waste Management Units at Los Alamos National Laboratory," Los Alamos National Laboratory document LA-UR-90-3216.

B. M. Crowe, G. W. Linn, G. Heiken, and M. L. Bevier, "Statigraphy of the Bandelier Tuff in the Pajarito Plateau, Applications to Waste Management," Los Alamos Scientific Laboratory report LA7225-MS (1978).

R. L. Cushman, "An Evaluation of Aquifer and Well Characteristics of Municipal Wells in Los Alamos and Guaje Canyons near Los Alamos, New Mexico," U.S. Geological Survey Water-Supply Paper 1809-D (1965).
C. S. Denny, "Santa Fe Formation in the Española Valley, New Mexico," Geological Society of America Bulletin 51 (1940).

D. P. Dethier, "Geology of the White Rock Quadrangle, Santa $\mathrm{Fe}$ and Los Alamos Counties, New Mexico," New Mexico Bureau of Mines and Mineral Resources, in press, 1994.

Environmental Surveillance Group (ESG), "Formerly Utilized MED/AEC Sites Remedial Program, Radiological Survey of the Bayo Canyon, Los Alamos, New Mexico," U.S. Dept. of Energy report DOE/EV0005/15 (1979).

Environmental Surveillance Group (H-8), "Formerly Utilized MED/AEC Sites Remedial Action Program; Radiological Survey of the Site of a Former Radioactive Liquid Waste Treatment Plant (TA-45) and Effluent Receiving Areas of Acid, Pueblo, and Los Alamos Canyons, Los Alamos, New Mexico," U.S. Dept. of Energy report DOE/EV-0005/30, Los Alamos National Laboratory report LA-8890ENV (1981).

R. W. Ferenbaugh, T. E. Buhl, A. K. Stoker, and W. R. Hansen, "Environmental Analysis of Bayo Canyon (TA-10) Site, Los Alamos New Mexico," Los Alamos National Laboratory report LA-9252-MS (1982).

Ford, Bacon, and Davis Inc., "Engineering Evaluation of The Bayo Canyon Site," Bechtel report No. OR/44/01 (1981); in Purtymun (1994) chapters 1 and 97.

R. Galusha and J. C. Blick, "Stratigraphy of the Santa Fe Group, New Mexico," American Museum of National History Bulletin 144, (1971).

F. E. Goff and S. Sayer, "Geothermal Investigation of Springs and Well Water in the Los Alamos Region, New Mexico," Los Alamos Scientific Laboratory report LA-8326-MS (1980).

R. L. Griggs, "Geology and Ground-Water Resources of the Los Alamos Area, New Mexico," U.S. Geological Survey Open-File Report to the U.S. Atomic Energy Commission (1955). Note: this open-file report contains a number of geologic logs not found in the water-supply paper. 
R. L. Griggs, "Geology and Ground-Water Resources of the Los Alamos Area, New Mexico," U.S. Geological Survey Water-Supply Paper 1753 (1964).

G. Heiken, K. Wohletz, R. V. Fisher, and D. P. Dethier, "Maar Volcanoes of White Rock CanyonInteraction of Ground and Surface Water with Basaltic Volcanoes of the Rio Grande Rift, New Mexico," Los Alamos National Laboratory document LA-UR-89-1917.

E. C. John, E. Enyart, and W. D. Purtymun, "Records of Wells, Test Wells, Springs and Surface-Water Stations in the Los Alamos Area," U.S. Geological Survey Open-File Report (1966).

M. D. Keller, "Geologic Studies and Material Properties Investigations of Mesita de Los Alamos," Los Alamos Scientific Laboratory report LA-3728 (1968).

V. C. Kelley, "Geology and Pumice Deposits of the Pajarito Plateau, Sandoval, Santa Fe, and Rio Arriba Counties, New Mexico," Los Alamos ProjectPumice Investigations for the Operations Division, Los Alamos Scientific Laboratory (1948).

V. C. Kelley, "Geology of Española Basin, New Mexico," New Mexico Bureau of Mines and Mineral Resources, Geologic Map 48 (1978).

A. W. Laughtin, W. Woldegabriel, and D. Dethier, "Volcanic Stratigraphy of the Pajarito Plateau," Preliminary Report FY93, Los Alamos National Laboratory, unpublished EES-1 document, 1993.

K. Manley, "Cenozoic Geology of the Española Valley," in Guidebook to the Rio Grande Rift in New Mexico and Colorado, New Mexico Bureau of Mines and Mineral Resources, Circular 163 (1978).

J. W. Nyhan, L. W. Hacker, T. E. Calhoun, and D. L. Young, "Soil Survey of Los Alamos County, New Mexico," Los Alamos Scientific Laboratory report LA-6779-MS (1979).

W. D. Purtymun, "Geology and Hydrology of White Rock Canyon from Otowi to the Confluence of Frijoles Canyon, Los Alamos and Santa Fe Counties, New Mexico," U.S. Geological Survey Admin. Report (1966a).

W. D. Purtymun, “Geology and Physical Properties of the Near-Surface Rocks at Mesita de Los Alamos," U.S. Geological Survey Open-File Report (1966b).

W. D. Purtymun, "Geology of the Micro-Seismograph Station At S-Site," U.S. Geological Survey Admin. Report (1968).

W. D. Purtymun, "Dispersion and Movement of Tritium in a Shallow Aquifer in Mortandad Canyon at the Los Alamos Scientific Laboratory," Los Alamos Scientific Laboratory report LA-5716MS (1974).

W. D. Purtymun, "Geohydrology of the Pajarito Plateau with Reference to the Quality of Water 19491972," Los Alamos Scientific Laboratory, Group H-8 document, 1975.

W. D. Purtymun, "Hydrologic Characteristics of the Los Alamos Well Field with Reference to the Occurrence of Arsenic in Well LA-6," Los Alamos Scientific Laboratory report LA-7012-MS (1977).

W. D. Purtymun, Los Alamos National Laboratory, unpublished data, 1982.

W. D. Purtymun, "Hydrologic Characteristics of the Main Aquifer in the Los Alamos Area: Development of Ground Water Supplies," Los Alamos National Laboratory report LA-9967-MS (1984).

W. D. Purtymun, "Chemical Description of the Los Alamos Main Aquifer," abstract from the Rocky Mountain Ground Water Conference proceedings and 6th Annual Conference New Mexico Section, Albuquerque (1993).

W. D. Purtymun, "Source Document Compilation: Los Alamos Investigations Related to the Environment, Engineering, Geology, and Hydrology 19611990," Los Alamos National Laboratory report LA12733-MS (1994).

W. D. Purtymun, J. R. Buchholz, and T. E. Hakonson, "Chemical Quality of Effluents and Their Influence on Water Quality in a Shallow Aquifer," Journal of Environmental Quality 6 No. 1 (Jan-Mar 1977).

W. D. Purtymun and J. B. Cooper, "Site Locations for Five Water-Supply Wells," U.S. Geological Survey Admin. Report (1965). 
W. D. Purtymun and J. B. Cooper, "Development of Ground Water Supplies on the Pajarito Plateau, Los Alamos County, New Mexico," U.S. Geological Survey Professional Paper 650-B (1969).

W. D. Purtymun and R. L. Cushman, "Site Location for a Supply Well Adjacent to State Road 4," U.S. Geological Survey Admin. Report (1961).

W. D. Purtymun, E. A. Enyart, and S. G. McLin, "Hydrologic Characteristics of the Bandelier Tuff as Determined through an Injection Well System," Los Alamos National Laboratory report LA-11511-MS (1989).

W. D. Purtymun, W. R. Hansen, and R. J. Peters, "Radiochemical Quality of Water in the Shallow Aquifer in Mortandad Canyon 1967-1978," Los Alamos National Laboratory report LA-9675-MS (1983).

W. D. Purtymun and C. E. John, "Site Location for a Supply Well in Pajarito Canyon," U.S. Geological Survey Admin. Report (1964).

W. D. Purtymun and W. R. Kennedy, "Geology and Hydrology of Mesita del Buey," Los Alamos Scientific Laboratory report LA-4660 (1971).

W. D. Purtymun and F. C. Koopman, "Physical Properties of the Tshirege Member of the Bandelier Tuff with Reference to Use as Building and Ornamental Stone," U.S. Geological Survey Open-File Report (1965).

W. D. Purtymun, F. C. Koopman, S. Barr, and W. E. Clements, "Air Volume and Energy Transfer through Test Holes and Atmospheric Pressure Effects on the Main Aquifer," Los Alamos Scientific Laboratory report LA-5725-MS (1974).

W. D. Purtymun, S. G. McLin, A. K. Stoker, M. N. Maes, and B. G. Hammock, "Water Supply at Los Alamos During 1990," Los Alamos National Laboratory report LA-12471-PR (1993).

W. D. Purtymun, S. G. Mclin, A. K. Stoker, and M. N. Maes, "Water Supply at Los Alamos during 1991," Los Alamos National Laboratory report LA12770-PR (1994).

W. D. Purtymun, R. J. Peters, and J. W. Owens, "Geohydrology of White Rock Canyon of the Rio
Grande from Otowi to Frijoles Canyon," Los Alamos Scientific Laboratory report LA-8635-MS (1980).

W. D. Purtymun and A. K. Stoker, "Water Supply at Los Alamos: Current Status of Wells and Future Water Supply," Los Alamos National Laboratory report LA-11332-MS (1988).

R. L. Smith and R. A. Bailey, "Bandelier Tuff-A Study of Ash Flow Eruption Cycle from Zoned Magma Chamber," Bulletin of Volcanology Series 2 29, (1966).

R. L. Smith, R. A. Bailey, and C. S. Ross, "Geologic Map of the Jemez Mountains, New Mexico," U.S. Geological Survey Miscellaneous Investigations Series Map I-571 (1970).

Z. Spiegel and B. Baldwin, "Geology and Water Resources of the Santa Fe Area, New Mexico," U.S. Geological Survey Water-Supply Paper 1525 (1963).

A. K. Stoker, F. Goff, and R. Spangler, "Age of Water in the Los Alamos Main Aquifer," abstract from the Rocky Mountain Ground Water Conference proceedings New Mexico Section, Albuquerque (1993).

A. K. Stoker, S. G. Mclin, W. D. Purtymun, M. N. Maes, and B. G. Hammock, "Water Supply at Los Alamos During 1989," Los Alamos National Laboratory report LA-12276-PR (1992).

A. K. Stoker, W. D. Purtymun, S. G. McLin, and M. N. Maes, "Extent of Saturation in Mortandad Canyon," Los Alamos National Laboratory document LA-UR-91-1660.

C. V. Theis, "Geologic Background of Waste and Water-Supply Problems at Los Alamos," U.S. Atomic Energy Commission, Meeting of AEC Waste Processing Committee at Los Alamos, New Mexico, TID-460 (1950).

C. V. Theis and C. S. Conover, "Pumping Tests in the Los Alamos Canyon Well Field near Los Alamos, New Mexico," U.S. Geological Survey Water-Supply Paper 1619-I (1962).

D. Vaniman, "Revisions to Report EES-1SA-90-17 Stratigraphic Terms to Be Used for Upper Bandelier Tuff," Los Alamos National Laboratory memorandum EES-15H9112, to J. Gardner (July 29, 1991). 
J. E. Weir, J. H. Abrahams, J. R. Waldon, and W. D. Purtymun, "Chemical and Radiochemical Quality of Surface and Ground Water 1949-1955," U.S. Geo-

logical Survey Admin. Report (1963).

J. E. Weir and W. D. Purtymun, "Geology and Hydrology of Technical Area 49, Frijoles Mesa, Los Alamos County, New Mexico," U.S. Geological Survey Admin. Report (1962). 


\section{BAYO CANYON}

Bayo Canyon heads on the Pajarito Plateau at an elevation of $6680 \mathrm{ft}$ with a drainage area of about 3.7 sq mi. Because the canyon heads on the plateau, the alluvium consists mainly of sand and gravel derived from the weathering of the tuff. The stream flow in the canyon is intermittent, with the largest percentage of runoff occurring during the summer from heavy thunderstorms. This runoff is of short duration, usually lasting less than two hours. There is no effluent discharge into the canyon. Before 1965 a technical area (TA-10) used for testing was located in the canyon. Water was hauled to the site. The site was abandoned and the area cleaned up in 1965. Additional cleanup has been performed in the canyon since 1965 (Environmental Surveillance Group 1979) and remediators are currently investigating the site to see if additional work is needed.

Four test holes were augered in the canyon in 1961 to determine if water occurred in the alluvium or tuff at the Puye Conglomerate contact (Fig. II-A and Tables II-A and II-B). The test holes were dry with no indication of water in the alluvium or tuff at the Puye contact. In 1973 three holes were augered to collect samples. These holes were also dry (Ferenbaugh et al. 1982; FBD Inc. 1981; Purtymun 1994).
The top of the main aquifer lies at a depth of about $780 \mathrm{ft}$ near the center of the former site (Environmental Surveillance Group 1979).

\section{REFERENCES}

Environmental Surveillance Group (H-8), "Formerly Utilized MED/AEC Sites Remedial Program, Radiological Survey of the Bayo Canyon, Los Alamos, New Mexico," U.S. Dept. of Energy report DOE/EV005/15 (1979).

R. W. Ferenbaugh, T. E. Buhl, A. K. Stoker, and W. R. Hansen, "Environmental Analysis of Bayo Canyon (TA-10)) Site, Los Alamos New Mexico," Los Alamos National Laboratory report LA-9252-MS (1982).

FBD, Inc. (Ford, Bacon, and Davis Inc.), "Engineering Evaluation of the Bayo Canyon Site," Bechtel report No. OR/44/01 (1981).

W. D. Purtymun, "Source Documentation Compilation: Los Alamos Investigations Related to the Environment, Engineering, Geology, and Hydrology, 1961-1990," Los Alamos National Laboratory report LA-12733-MS (1994), chapters 1 and 97.

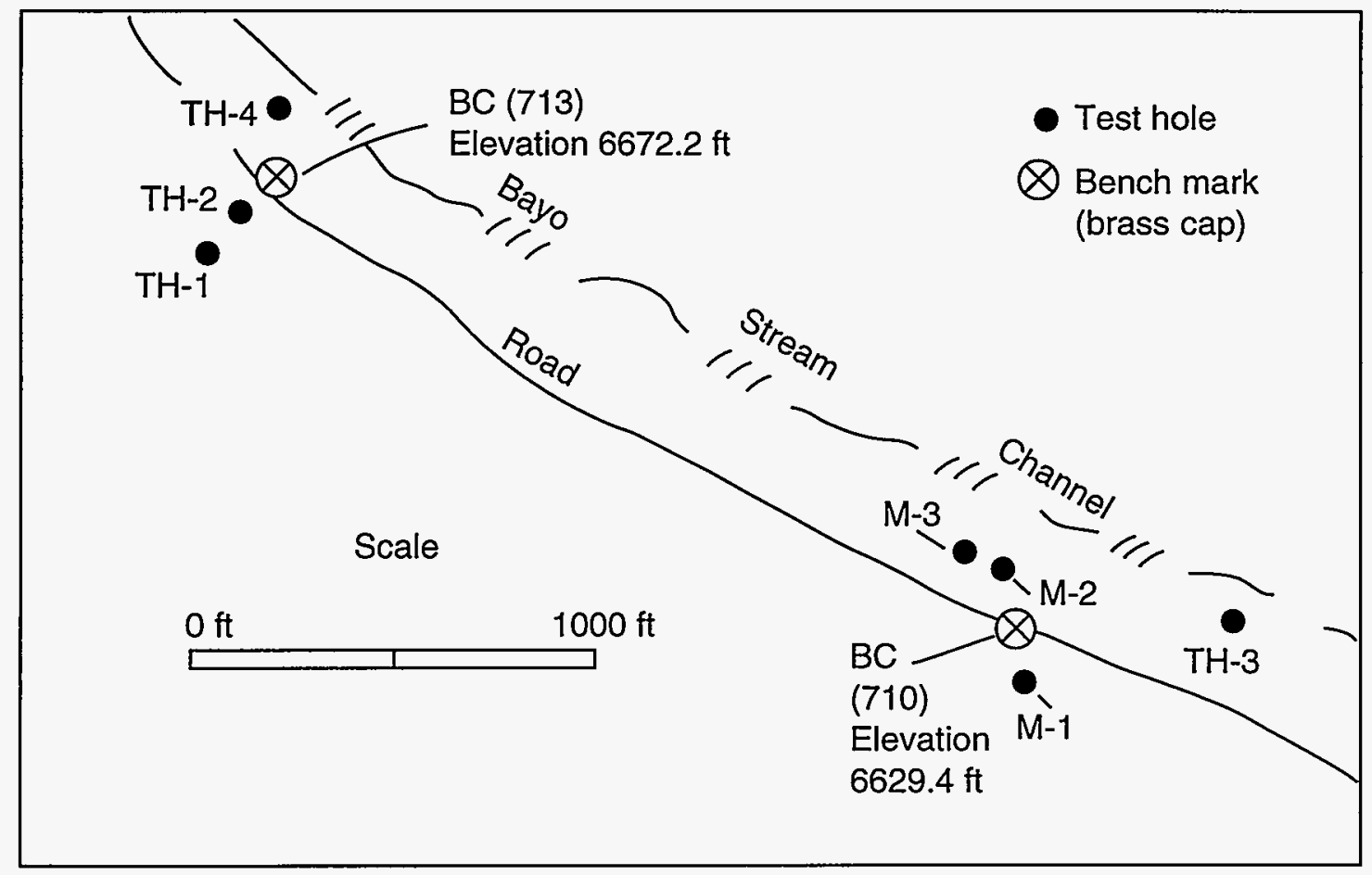

Fig. II-A. Generalized location of test holes in Bayo Canyon. 
TABLE II-A. Records of Test Holes at Bayo Canyon Site, 1961 and 1973

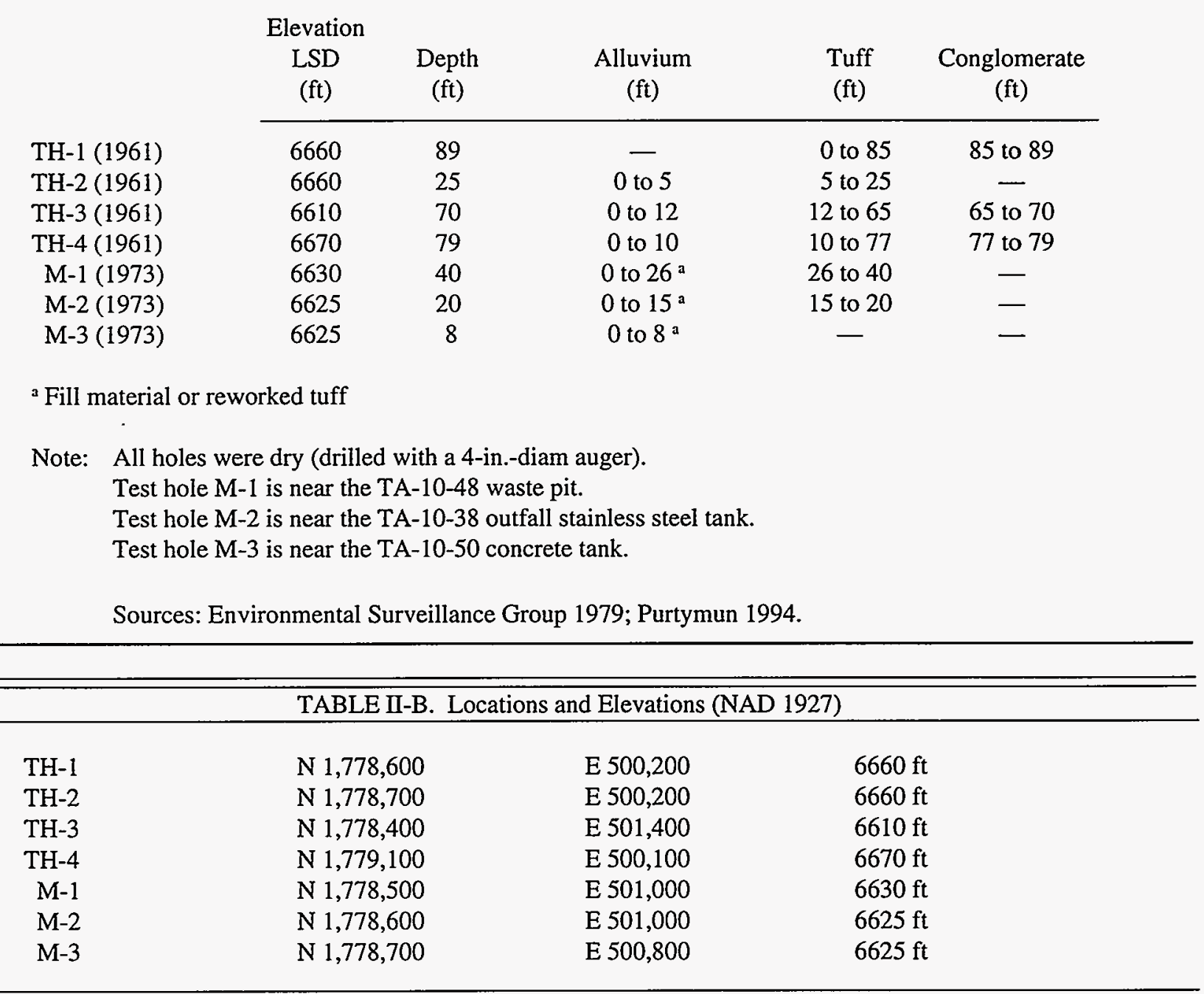




\section{ACID/PUEBLO CANYON}

Pueblo Canyon heads on the flanks of the mountains west of the Laboratory at an elevation of $8990 \mathrm{ft}$ and has a drainage area of $8.6 \mathrm{sq}$ mi west of SR-4. Unlike other canyons heading on the mountains, Pueblo Canyon has no springs to create a stream flow. The alluvium in the canyons is composed of sand, gravel, cobbles, and boulders derived from the Tschicoma Formation (Fig. I-Q), the Bandelier Tuff, and in the lower part of the canyon, the fanglomerate member of the Puye Conglomerate. Stream flow in the canyon is intermittent, derived from effluent release of sanitary treatment plants and runoff from summer thunderstorms and snow melt.

Radioactive wastes were released into Acid Canyon (a tributary to Pueblo Canyon) from 1943 to 1950. From 1950 to 1964 the radioactive wastes were treated before release (Purtymun 1994). Sanitary effluents were and are now released into the canyon. The Pueblo plant that treated industrial wastes operated until 1964, when the new plant (TA-50) began operations. The Pueblo Sanitary Treatment Plant in upper Pueblo Canyon has released effluent into Pueblo Canyon from 1947 until the present (1991). The Central Sanitary Sewage Treatment Plant, located just west and north of the airport terminal, operated from the 1940s through 1964 and released effluent into the midreach of Pueblo Canyon. The Bayo Sanitary Treatment Plant that began operations in 1964 continues to release effluent into the canyon near Hamilton Bend Spring (Fig. III-A).

To monitor the chemical and radiochemical quality of the water, 6 surface water stations and 17 shallow ground water stations (wells) were established in Acid-Pueblo Canyon during the period 1950 through 1964 (Fig. III-A and Table III-A). Four of the surface water stations are still being used to monitor the quality of surface water (Acid Weir, Pueblo 1, Pueblo 2, and Pueblo 3). Some of the shallow wells consisted of 8-in.-diam corrugated metal pipe perforated in the lower $2 \mathrm{ft}$ and dug 3 to $4 \mathrm{ft}$ into the alluvium. They were equipped with locking caps. The other wells were 2 -in.-diam galvanized pipe equipped with a 2 - $\mathrm{ft}$ sandpoint, driven about $3 \mathrm{ft}$ into the alluvium. Some of these wells were in place in 1952; some were added and replaced, but all were washed out or destroyed by 1972 (Weir et al. 1963; H-8 1981).
The stream in Pueblo Canyon has cut a small meander near Hamilton Bend Spring, where the channel cuts through the tuff onto the hard rocks of the fanglomerate member of the Puye Conglomerate (Fig. III-B). During the mid-1950s Hamilton Bend Spring flowed year-round, and there was a small seep (Otowi Seep) in the channel about $0.25 \mathrm{mi}$ east of the spring. At that time sanitary effluent from the Pueblo and Central Plants, with periodic discharge from TA45, maintained flow to about Hamilton Bend. In the fall of 1956, 14 shallow test holes were drilled in the area of Otowi Seep to determine if the flow from the spring and seep was connected with the alluvium in Bayo Canyon or with effluent flow in Pueblo Canyon (Table II-B). Of the 14 wells, only 3 wells-PO-3B (Fig. III-C), PO-4A (Fig. III-D), and PO-4B (Fig. IIIE)-are presently in condition for use as observation wells. Alluvium was reported in only these test holes: PO-3B (26 ft), PO-4A (43 ft), and PO-4B ( $37 \mathrm{ft}$ ).

These holes were drilled on a terrace above the stream channel. The alluvium reported may be a combination of reworked stream channel alluvium or coalluvium from the slope at the base of the cliffs. The rest of these test holes began in and were completed in the fanglomerate member of the Puye Conglomerate. Geologic logs of wells and test holes are shown in Table III-C. The study indicated that recharge to Hamilton Bend Spring and Otowi Seep was from the effluent flow and storm runoff in Pueblo Canyon (Abrahams 1966). Since the mid-1960s stream flow has extended to State Road 502 because of discharge from the Bayo Treatment Plant. Reduced flow from the Pueblo plant in the upper canyon extends eastward to near test well TW.-2.

The holes were augered with a 5-in.-diam auger to various depths. Most were abandoned upon completion, but those with water were cased (Table III-B). The cased wells were not gravel packed. Those that were cased are sealed at the surface with cement and with a locked plate to prevent access. The screen sections of the plastic pipes were perforated and the steel pipe was torch slotted.

\section{REFERENCES}

J. H. Abrahams, "Hydrology and the Chemical and Radiochemical Quality of Surface and Ground Water at Los Alamos, New Mexico, January 1956 through June 1957," U.S. Geological Survey Administration Report (1966). 
Environmental Surveillance Group (H-8), "Formerly Utilized MED/AEC Sites Remedial Action Program: Radiological Survey of the Site of a Former Radioactive Liquid Waste Treatment Plant (TA-45) and Effluent Receiving Areas of Acid, Pueblo, and Los Alamos Canyons, Los Alamos, New Mexico," U.S. Dept. of Energy report DOE/EV-0005/30. Los Alamos National Laboratory report LA-8890-ENV (1981).

W. D. Purtymun, "Geohydrology of the Pajarito Plateau with Reference to the Quality of Water 1949 1972," Los Alamos Scientific Laboratory, Group H-8 document, 1975.

W. D. Purtymun, "Source Document Compilation: Los Alamos Investigations Related to the Environment, Engineering, Geology, and Hydrology, 19611990." Los Alamos National Laboratory report LA-12733-MS (1994) chapters 42 and 43.

J. E. Weir, J. H. Abrahams, J. R. Waldon, and W. D. Purtymun, "Chemical and Radiochemical Quality of Surface and Ground Water 1949-1955," U.S. Geological Survey Admin. Report (1963). 


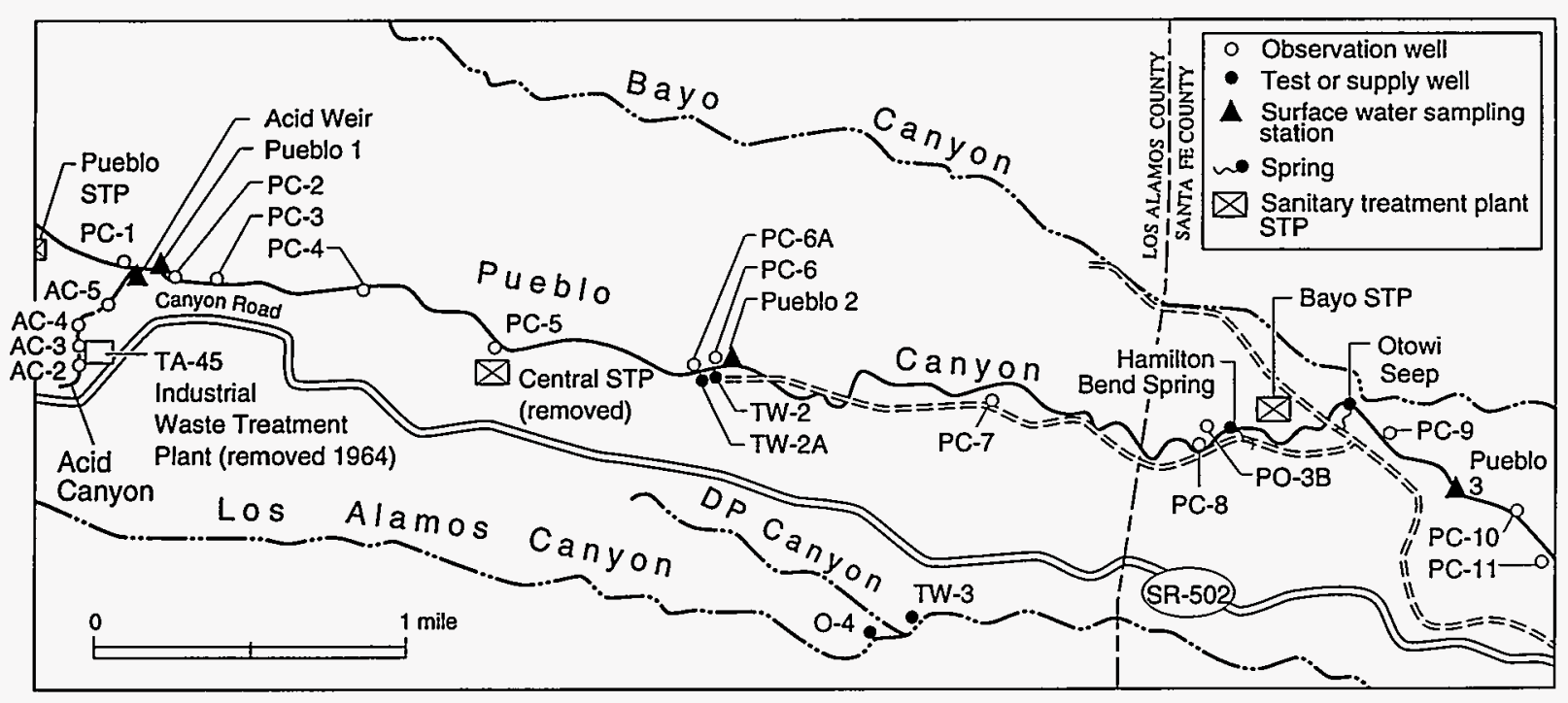

Fig. III-A. Generalized location of surface water sampling stations, shallow wells, and the spring sampling stations in Acid and Pueblo Canyons (Weir et al. 1963; Purtymun 1975).

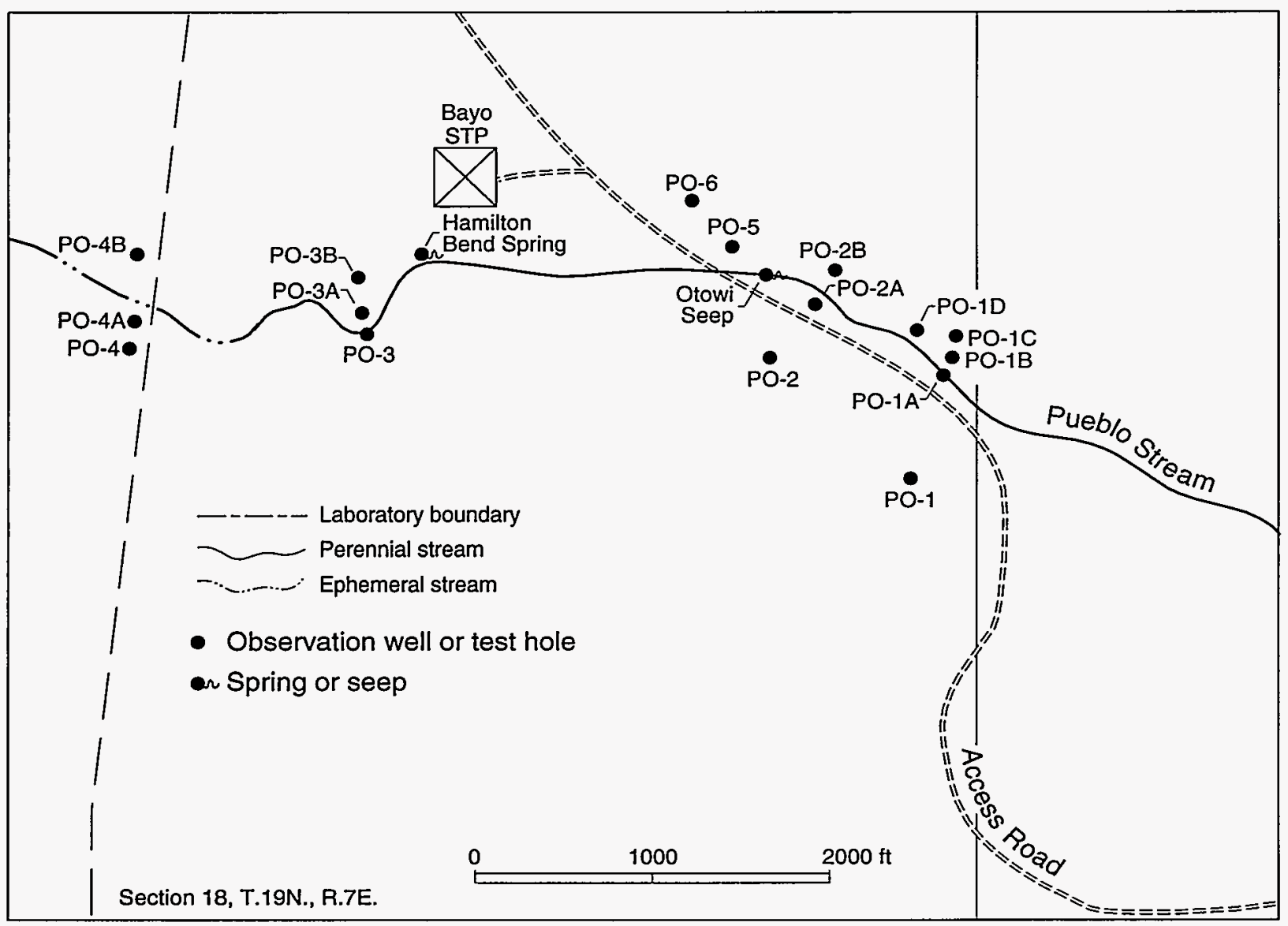

Fig. III-B. Location of observation wells and test holes in the vicinity of Hamilton Bend Spring and Otowi Seep in Pueblo Canyon (Abrahams 1966). 


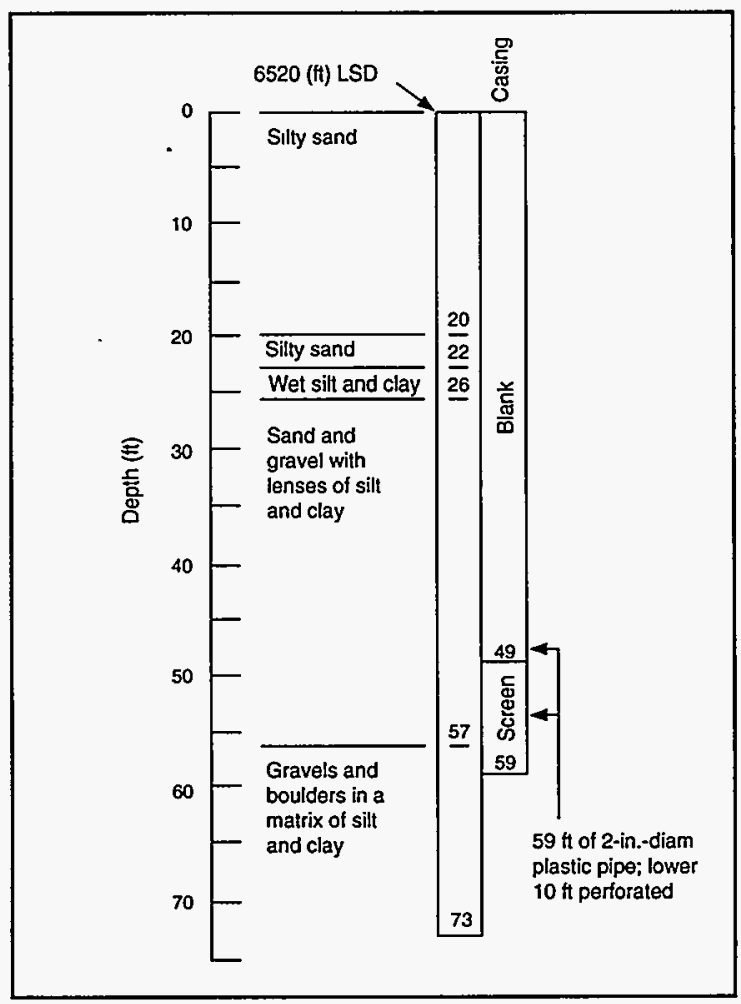

Fig. III-C. Pueblo Canyon observation well PO-3B, completed April 1956, water level $50 \mathrm{ft}$ (Abrahams 1966).

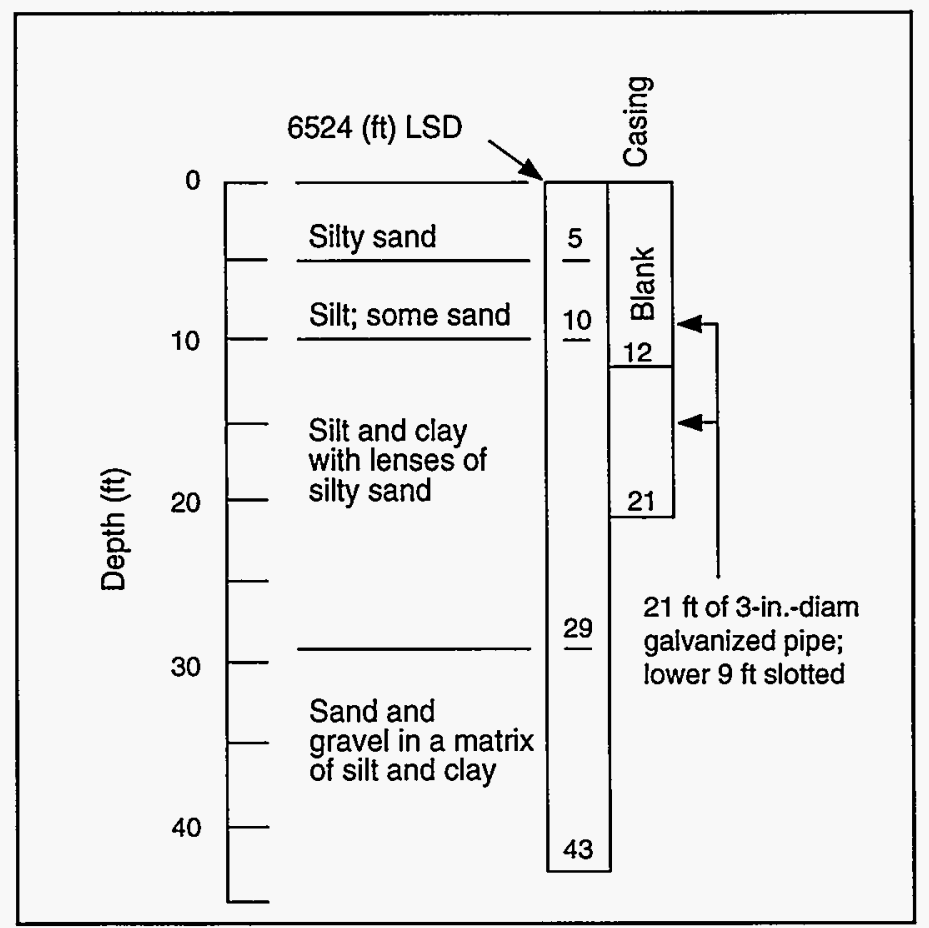

Fig. III-D. Pueblo Canyon observation well PO-4A, completed April 1956, water level $18 \mathrm{ft}$ (Abrahams 1966). 


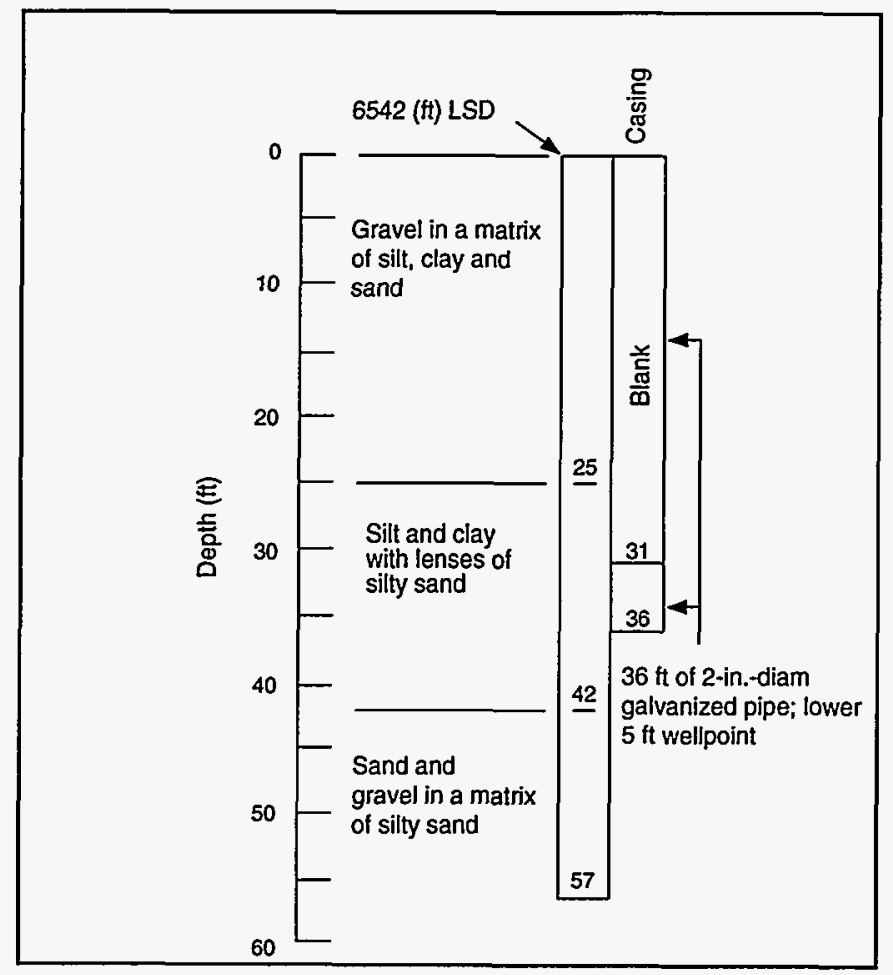

Fig. III-E. Pueblo Canyon observation well PO-4B, completed April 1956, water level $24.0 \mathrm{ft}$ (Abrahams 1966). 
TABLE III-A. Surface Water Stations and Shallow Wells in Acid/Pueblo Canyon

Surface Water Stations

Acid Weir: $\quad$ elevation $6990 \mathrm{ft}$ (current monitoring station)

Pueblo 1: $\quad$ elevation $6960 \mathrm{ft}$ (current monitoring station)

Pueblo 2: $\quad$ elevation $6630 \mathrm{ft}$ (current monitoring station)

Pueblo 3: $\quad$ elevation $6423 \mathrm{ft}$ (current monitoring station)

Otowi Seep: $\quad$ elevation $6470 \mathrm{ft}$ (dropped from the monitoring network in 1964)

Hamilton Bend Spring: $\quad$ elevation $6500 \mathrm{ft}$ (current monitoring station)

Notes: Pueblo 1 1953-1973: sampled below confluence with Acid Canyon; 1974 to present: sampled above confluence. Pueblo 3 collected samples 1952-1964 at the end of the flow, generally between Hamilton Bend Spring and well PC-11. Since 1964, with the completion of the Bayo Sanitary Treatment Plant (STP), samples have been collected near PC-10. Otowi Seep has been covered by sanitary effluent release from Bayo STP since 1964. Hamilton Bend Spring has been generally dry since 1964, when Central STP near the airport closed.

Shallow Well Stations

Acid Canyon

AC-1

$\mathrm{AC}-2$

$\mathrm{AC}-3$

$\mathrm{AC}-4$

AC-5

Pueblo Canyon

PC-1

PC-2

$\mathrm{PC}-3$

PC-4

PC-5

PC-6

PC-6A

PC-7

PC-8

PC-9

PC-10

PC-11
Remarks

corrugated metal pipe (CMP)
CMP
CMP
CMP
CMP

Note: Sampling wells were in place by 1952; some were replaced after washouts. All were destroyed or washed out by 1972. CMP: 6-in.-diam. Sandpoint and drive pipe: 2-in.-diam galvanized.

Sources: Abrahams 1966; Purtymun 1975. 


\begin{tabular}{lccccl}
\hline \hline \multicolumn{5}{c}{ TABLE III-B. Records of Observation Wells and Test Holes in the Vicinity of Hamilton Bend Spring in } \\
Pueblo Canyon
\end{tabular}

Notes: Holes augered with a 4-in.-diam bit; drilled and constructed April-May 1956.

Source: Abrahams 1966. 
TABLE III-C. Geologic Logs and Construction Data of Observation Wells and Test Holes in the Vicinity of Hamilton Bend Spring in Pueblo Canyon (16 Obs. Wells and Test Holes)

1. Observation Well PO-1 (TH)

Elevation (LSD) $6460 \mathrm{ft}$

Geologic Log

Silt, sand, gravel, and boulders

Water level (WL)-Dry (1956)

Thickness Depth

$\frac{(\mathrm{ft})}{16} \quad \frac{(\mathrm{ft})}{16}$

Construction

Uncased.

2. Observation Well PO-1A

Elevation (LSD) $6442 \mathrm{ft}$

Geologic Log

Sand, gravel, and boulders

Silt and gravel

WL—Dry (1956)

Thickness Depth

$\frac{(\mathrm{ft}) \quad(\mathrm{ft})}{17}$

$17 \quad 17$

$19 \quad 36$

Construction

$18 \mathrm{ft}$ of 3-in.-diam steel pipe, lower $8 \mathrm{ft}$ perforated; hole plugged and abandoned 1969.

3. Observation Well PO-1B (TH)

Elevation (LSD) $6441 \mathrm{ft}$

Geologic Log

Clay, sand, and gravel (moist)

Silts and gravel (dry)

WL—Dry (1956)

Thickness Depth

(ft) $\quad(\mathrm{ft})$

$15 \quad 15$

Construction

Uncased.

4. Observation Well PO-1C (TH)

Elevation (LSD) $6446 \mathrm{ft}$

WL—Dry (1956)

Thickness Depth

Geologic Log

Clay, sand, and gravel (moist)

Sand, gravel, and boulders (consolidated)

$(\mathrm{ft}) \quad(\mathrm{ft})$

$15 \quad 15$

Construction

Uncased.

5. Observation Well PO-1D (TH)

Elevation (LSD) $6450 \mathrm{ft}$

WL—Dry (1956)

Thickness Depth

Geologic Log

Sand and gravel (dry)

(ft)

$23 \quad 23$

Construction

Uncased.

Source: Abrahams 1966. 


\section{Observation Well PO-2 (TH)}

Elevation (LSD) $6478 \mathrm{ft}$

Geologic Log

Tuff

Silt, sand, gravel, and boulders

$\begin{array}{cc}\begin{array}{c}\text { WL-Dry (1956) } \\ \text { Thickness }\end{array} & \begin{array}{c}\text { Depth } \\ (\mathrm{ft})\end{array} \\ \frac{(\mathrm{ft})}{13} & 13 \\ 17 & 30\end{array}$

Construction

Uncased.

\section{Observation Well PO-2A}

Elevation (LSD) $6452 \mathrm{ft}$

$\begin{array}{cc}\text { WL-2.0 ft (1956) } \\ \text { Thickness } \\ \frac{(\mathrm{ft})}{14} & \begin{array}{c}\text { Depth } \\ (\mathrm{ft})\end{array}\end{array}$

Geologic Log

Silt and clay; boulders

$\frac{(\mathrm{ft})}{14}$

(ft)

Construction

$8 \mathrm{ft}$ of $1 \frac{1}{2}$-in.-diam pipe with 2-ft sandpoint. Well destroyed in flood 1959.

8. Observation Well PO-2B (TH)

Elevation (LSD) $6456 \mathrm{ft}$

Geologic Log

Silt, sand, and gravel; boulders

Construction

Uncased.
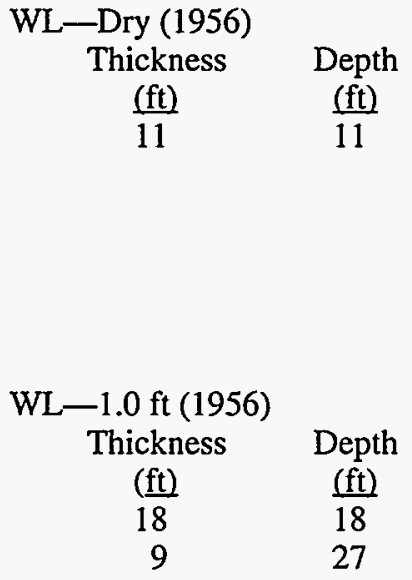

27

Geologic Log

Silt, sand, and gravel

Interbedded gravel, clay, and sand

Construction

$12 \mathrm{ft}$ of $1 \frac{1}{2}$-in.-diam pipe with 2 -ft sandpoint. Hole dry several days after completion. Well destroyed in flood 1959.

10. Observation Well PO-3A

Elevation (LSD) $6513 \mathrm{ft}$

Geologic Log

Gravel and sand

Interbedded gravel, clay, and sand

$\begin{array}{cc}\begin{array}{c}\text { WL-10 ft (1956) } \\ \text { Thickness } \\ (\mathrm{ft})\end{array} & \begin{array}{c}\text { Depth } \\ (\mathrm{ft})\end{array} \\ 11 & 11 \\ 22 & 33\end{array}$

Source: Abrahams 1966. 
TABLE III-C. Geologic Logs and Construction Data of Observation Wells and Test Holes in the Vicinity of

Hamilton Bend Spring in Pueblo Canyon (16 Obs. Wells and Test Holes) (Continued)

10. Observation Well PO-3A (Continued)

Construction

$22 \mathrm{ft}$ of $1 \frac{1}{2}$-in.-diam. pipe with 2 -ft sandpoint. Hole dry several days after completion.

11. Observation Well PO-3B

Elevation (LSD) $6520 \mathrm{ft}$

WL-50.5 ft (April 1956)

WL-50.8 ft (February 12, 1991)

Thickness Depth

\section{Geologic Log}

Alluvium

Silty sand

Gravel

2020

Wet silt and clay

222

Puye Conglomerate (fanglomerate member)

Sand and gravel with lenses of silt and clay

Gravel and boulders in a matrix of silt and clay

426

$31 \quad 57$

$16 \quad 73$

Construction

$59 \mathrm{ft}$ of 2- in.-diam plastic pipe with lower $10 \mathrm{ft}$ perforated. Depth $54.8 \mathrm{ft}$ 1991. Measuring point (MP): top of casing (TC). Distance of MP (TC) to $L S D=0.0 \mathrm{ft}$.

\section{Observation Well PO- 4}

Elevation $6524 \mathrm{ft}$

Geologic Log

Sand and gravel

Tuff (weathered)

Gravel with clay and sand layers (gravel and sand wet $18-25 \mathrm{ft}$ )

Cobbles and boulders

$\mathrm{WL}-25.8 \mathrm{ft}(1956)$

Thickness Depth

(ft) $\quad(\mathrm{ft})$

$5 \quad 5$

$5 \quad 10$

$30 \quad 40$

$3 \quad 43$

Construction

$27 \mathrm{ft}$ of $1 \frac{1}{2}$ - in.-diam pipe with 2-ft sandpoint. Water level dropped after completion until hole was dry.

\section{Observation Well PO-4A}

Elevation (LSD) $6524 \mathrm{ft}$

Geologic Log

Alluvium

Silty sand

Silt, some sand

Silt and clay with lenses of silty sand

Sand and gravel in a matrix of silt and clay
WL-18 ft (April 1956)

WL-Dry (February 12, 1991)

Thickness Depth

(ft) (ft)

$5 \quad 5$

$5 \quad 10$

1929

$14 \quad 43$

Construction

$21 \mathrm{ft}$ of 3-in.-diam galvanized pipe with lower $6 \mathrm{ft}$ slotted. Depth $18.9 \mathrm{ft} 1991$ [MP (TC) to LSD $=0.0 \mathrm{ft}$ ].

Source: Abrahams 1966. 
TABLE III-C. Geologic Logs and Construction Data of Observation Wells and Test Holes in the Vicinity of

Hamilton Bend Spring in Pueblo Canyon (16 Obs. Wells and Test Holes) (Continued)

14. Observation Well PO-4B

Elevation (LSD) $6542 \mathrm{ft}$

WL-24 ft (April 1956)

WL-Dry (February 12, 1991)

Thickness Depth

Geologic Log

(ft) $\quad(\mathrm{ft})$

Alluvium

Gravel in a matrix of silt, clay, and sand

Silt and clay with lenses of silty sand

$25 \quad 25$

Sand and gravel in matrix of silty sand

$17 \quad 42$

$15 \quad 57$

Construction (April 1956)

$31 \mathrm{ft}$ of 2-in. galvanized pipe set 0 to $31 \mathrm{ft}, 5 \mathrm{ft}$ wellpoint 31 to $36 \mathrm{ft}$. Depth $34.5 \mathrm{ft}$ in 1991

$[\mathrm{MP}(\mathrm{TC})$ to $\mathrm{LSD}=0.0 \mathrm{ft}]$.

15. Observation Well PO-5 (TH)

Elevation (LSD) $6475 \mathrm{ft}$

$\begin{array}{cc}\begin{array}{c}\text { WL_Dry (1956) } \\ \text { Thickness }\end{array} & \begin{array}{c}\text { Depth } \\ (\mathrm{ft})\end{array} \\ \frac{(\mathrm{ft})}{18} & 18 \\ 4 & 22\end{array}$

Silt, sand, and gravel

Cobbles and boulders

Construction

Uncased.

16. Observation Well PO-6

Elevation (LSD) $6520 \mathrm{ft}$

WL_Dry (1956)

Geologic Log

Thickness Depth

Tuff and pumice

$\underline{(\mathrm{ft}) \quad(\mathrm{ft})}$

Sand and gravel

13

$5 \quad 18$

Construction

Uncased.

Source: Abrahams 1966. 
TABLE III-D. Locations and Elevations (NAD 1927)

\section{A. Surface Water Stations}

Acid Weir

Pueblo 1

Pueblo 2

Pueblo 3

Otowi Seep

Hamilton Bend Spring
N $1,778,600$

N $1,778,800$

N $1,777,300$

N $1,776,100$

N 1,776,161

B. Springs, Observation Wells and Test Holes
AC-1

AC-2

AC-3

AC-4

AC-5

PC-1

PC-2

PC-3

PC-4

PC-5

PC-6

PC-6A

PC-7

PC-8

PC-9

PC-10

PC-11

PO-1

PO-1A

PO-1B

PO-1C

PO-1D

PO-2

PO-2A

PO-2B

PO-3

PO-3A

PO-3B

PO-4

PO-4A

PO-4B

PO-5

PO-6
N $1,777,300$

N $1,777,500$

N $1,777,900$

N $1,778,000$

N $1,778,200$

N $1,778,800$

N $1,778,700$

N 1,778,600

N $1,778,900$

N $1,777,600$

N $1,777,300$

N $1,777,300$

N $1,776,800$

N $1,775,800$

N $1,775,600$

N $1,774,500$

N $1,773,800$

N $1,774,800$

N $1,775,100$

N $1,775,400$

N $1,775,600$

N $1,775,800$

N $1,775,500$

N $1,775,600$

N 1,175,700

N 1,775,600

N 1,775,800

N $1,776,000$

N $1,775,600$

N $1,775,700$

N $1,775,900$

N $1,776,200$

N $1,776,600$
E 484,100

E 484,400

E 494,000

E 504,600

E 502,420

E 483,200

E 483,200

E 483,200

E 483,100

E 483,500

E 483,900

E 484,600

E 485,900

E 488,200

E 490,300

E 493,600

E 493,600

E 496,000

E 502,200

E 505,300

E 507,400

E 508,000

E 505,400

E 505,600

E 505,700

E 505,800

E 505,500

E 504,900

E 505,000

E 505,100

E 502,200

E 502,200

E 502,200

E 500,800

E 500,800

E 500,900

E 504,400

E 504,200
$6990 \mathrm{ft}$

$6950 \mathrm{ft}$

$6630 \mathrm{ft}$

$6470 \mathrm{ft}$

$6500 \mathrm{ft}$

$7160 \mathrm{ft}$

$7140 \mathrm{ft}$

$7120 \mathrm{ft}$

$7100 \mathrm{ft}$

$7060 \mathrm{ft}$

$6960 \mathrm{ft}$

$6940 \mathrm{ft}$

$6900 \mathrm{ft}$

$6810 \mathrm{ft}$

$6720 \mathrm{ft}$

$6660 \mathrm{ft}$

$6660 \mathrm{ft}$

$6610 \mathrm{ft}$

$6505 \mathrm{ft}$

$6450 \mathrm{ft}$

$6420 \mathrm{ft}$

$6390 \mathrm{ft}$

$6460 \mathrm{ft}$

$6442 \mathrm{ft}$

$6641 \mathrm{ft}$

$6446 \mathrm{ft}$

$6450 \mathrm{ft}$

$6478 \mathrm{ft}$

$6452 \mathrm{ft}$

$6456 \mathrm{ft}$

$6499 \mathrm{ft}$

$6513 \mathrm{ft}$

$6520 \mathrm{ft}$

$6524 \mathrm{ft}$

$6524 \mathrm{ft}$

$6542 \mathrm{ft}$

$6475 \mathrm{ft}$

$6520 \mathrm{ft}$ 


\section{LOS ALAMOS CANYON}

The Los Alamos Canyon drainage area extends to the drainage divide that lies in the mountains west of the Laboratory at an elevation of $10400 \mathrm{ft}$. The canyon has a drainage area of $10.6 \mathrm{sq} \mathrm{mi}$ at SR-4. The alluvium in the canyon is composed of sand, gravel, cobbles, and boulders derived from the Tschicoma Formation and the Bandelier Tuff (Fig. I-R).

Perennial surface water occurs in the upper reach of the canyon on the flanks of the mountains. A part of this surface flow is impounded at Los Alamos Reservoir. Surface flow across the plateau is intermittent.

DP Canyon is tributary to Los Alamos Canyon near the center of the plateau. Stream flow in the canyon is from the release of sanitary effluents from TA-21 and from storm runoff. Four surface water sampling stations were established in the canyon in 1967 (Fig. IV-A). Two of these surface water stations (DPS- 1 and DPS-4) are still used as part of the monitoring net.

DP spring in the midreach of DP Canyon between DPS-2 and DPS-3 (N 1,774,300 E 495,500; $6930 \mathrm{ft}$ ) discharges 1 to $4 \mathrm{gpm}$ from a contact at the base of old stream gravels under coalluvium and above Unit $1 \mathrm{~A}$ of the Tshirege Member of the Bandelier Tuff. The spring was discovered by Braxton and Goff (ESS-1) in 1990. The flow from the spring was sampled seven times at DPS-3 between 1967 and 1970 (Purtymun 1975). Thermal and radiochemical qualities of the water indicate recharge from the stream in the canyon.

The alluvium in Los Alamos Canyon ranges from 10 to $20 \mathrm{ft}$ in thickness. It contains a small body of perched water in the upper reach of the canyon. Recharge to the alluvial aquifer in the canyon is from storm runoff, past release of industrial effluents, and sanitary effluents (TA-21). The shallow ground water is perched in the alluvium on top of the tuff. The eastward extent of the saturation depends on the amount of surface water recharge. Water in the alluvium moves eastward toward the edge of the plateau.

During the period 1966 through 1970, 10 observation wells were constructed in the canyon to determine the thickness of the alluvium (Tables IV-A and IV-B) (John et al. 1967; Purtymun 1969, 1970). Geologic logs and casing schedules for 10 observation wells are shown in Figs. IV-B through IV-K. Wells LAO-C, $-1,-2,-3,-4,-4.5,-5$, and -6 are used as part of the monitoring network. Locations of surface water stations, gaging stations, and observation wells are shown in Table IV-C.

The holes were augered using a 4.5-in.-diam auger and all were cased with 3 -in.-diam plastic pipe. The screen section of the pipe was perforated. Wells were not gravel packed. The surface of the hole was sealed with cement and a pad was constructed.

\section{REFERENCES}

E. C. John, E. Enyart, and W. D. Purtymun, "Records of Wells, Test Holes, Springs, and Surface Water Stations in the Los Alamos Area," U.S. Geological Survey Open-File Report (1967).

W. D. Purtymun, Los Alamos Scientific Laboratory, unpublished data (U.S.G.S. field notes), 1966.

W. D. Purtymun, Los Alamos Scientific Laboratory, unpublished data (U.S.G.S. field notes), 1969.

W. D. Purtymun, Los Alamos Scientific Laboratory, unpublished data (LASL field notes), 1970.

W. D. Purtymun, "Geohydrology of the Pajarito Plateau with Reference to the Quality of Water 19491972," Los Alamos Scientific Laboratory, Group H-8 document, 1975. 


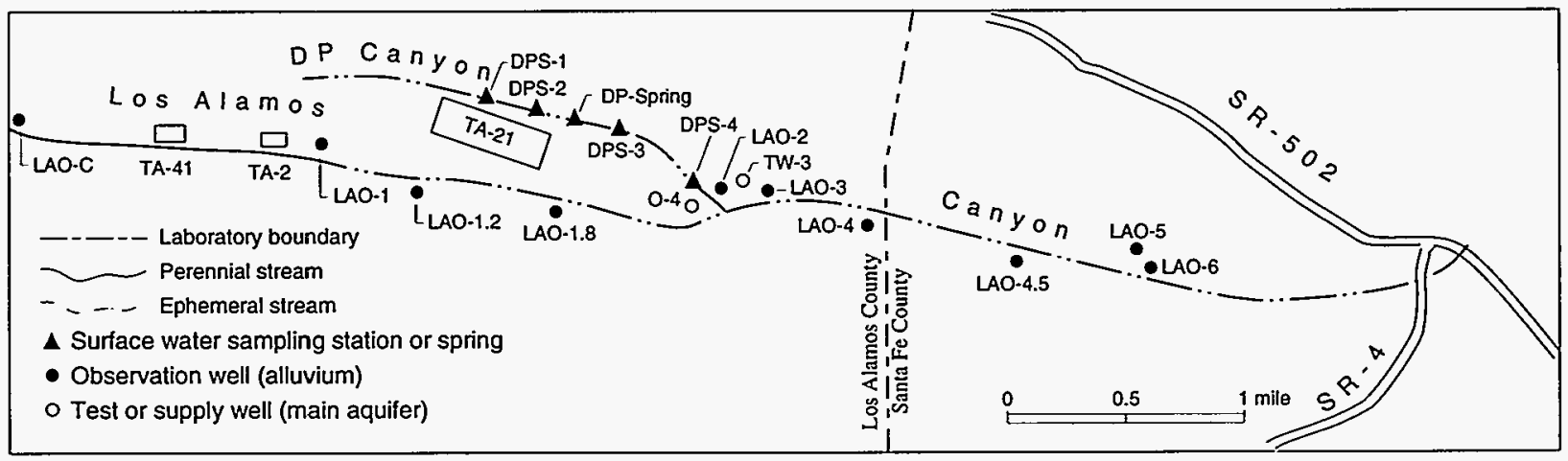

Fig. IV-A. Location of observation wells, test wells, and a supply well in Los Alamos Canyon (John et al. 1967; Purtymun 1975).

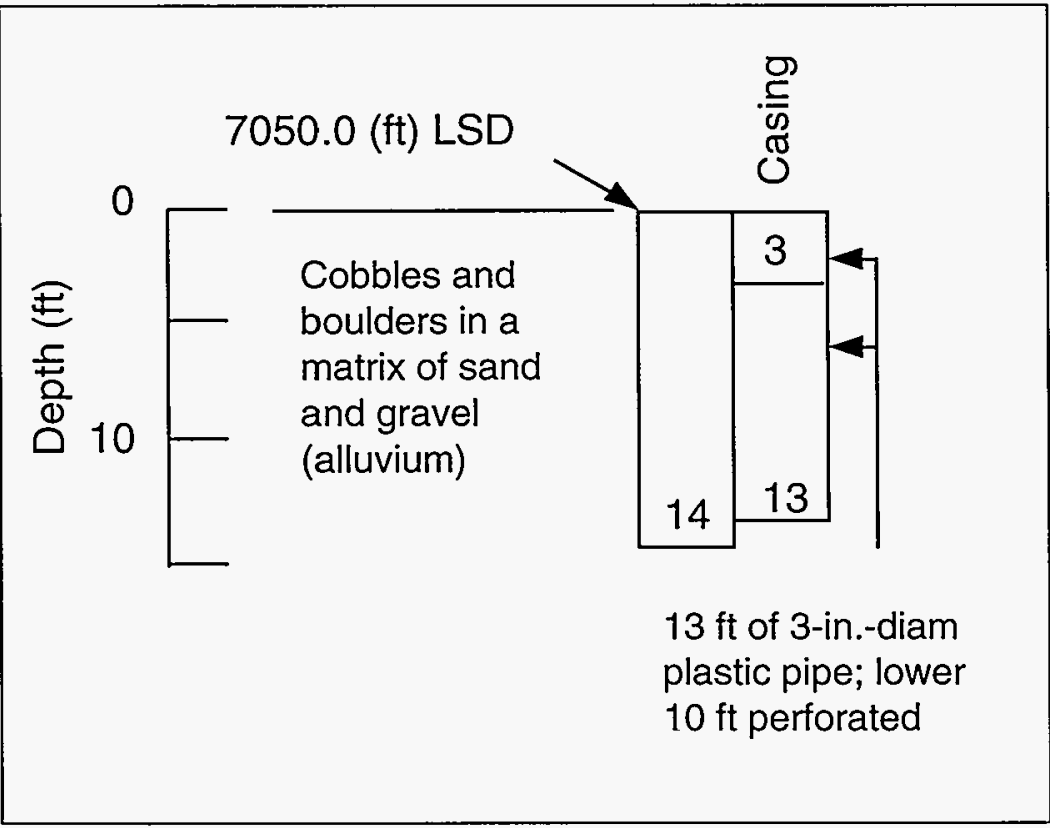

Fig. IV-B. Los Alamos Canyon observation well LAO-C, completed August 1970, water level $2.5 \mathrm{ft}$ (Purtymun 1970). 


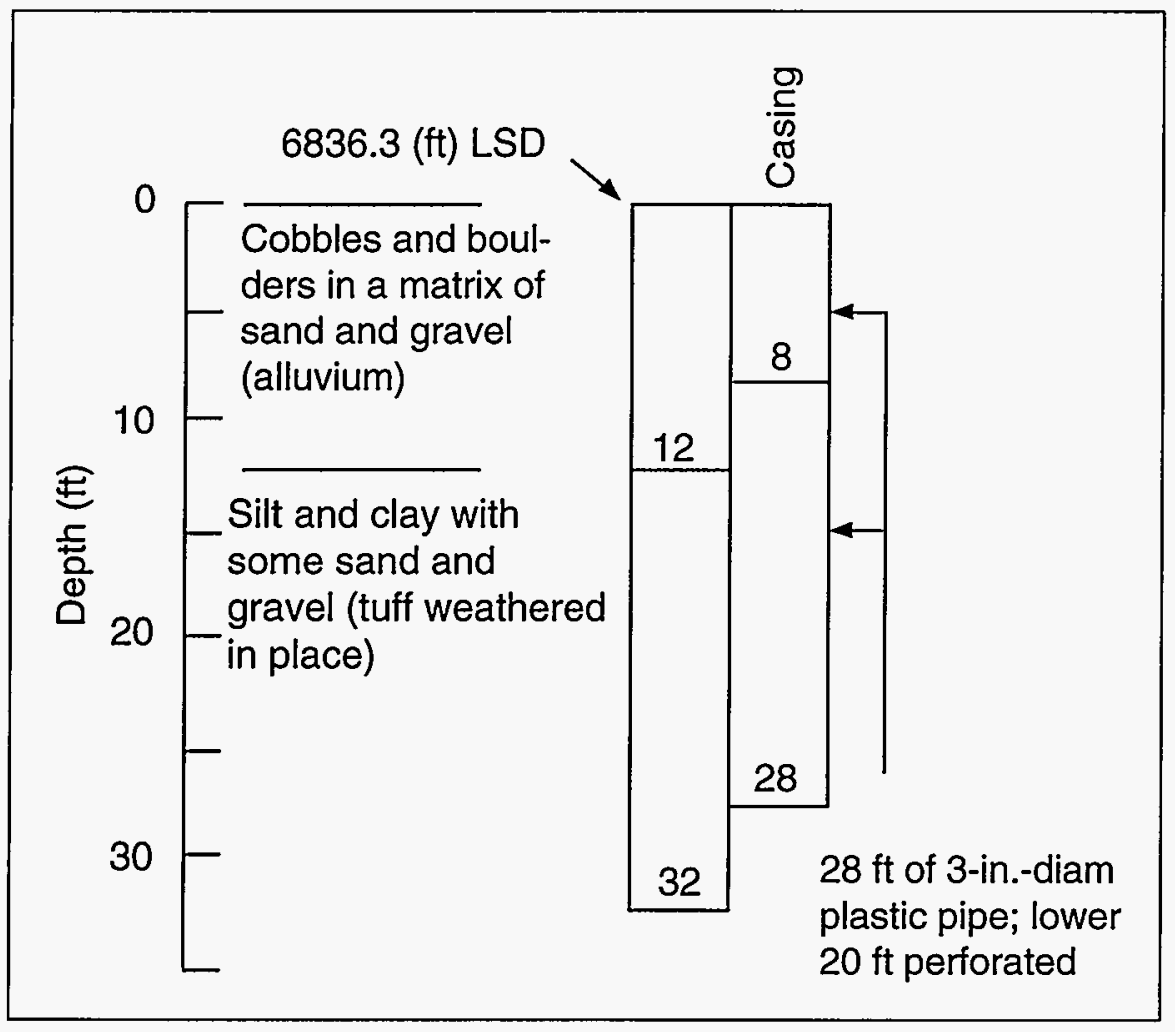

Fig. IV-C. Los Alamos Canyon observation well LAO-1, completed February 1966, water level $4.6 \mathrm{ft}$ (John et al. 1967; Purtymun 1966).

Fig. IV-D. Los Alamos Canyon observation well LAO-1.2, completed August 1969, water level $6.3 \mathrm{ft}$ (Purtymun 1969).

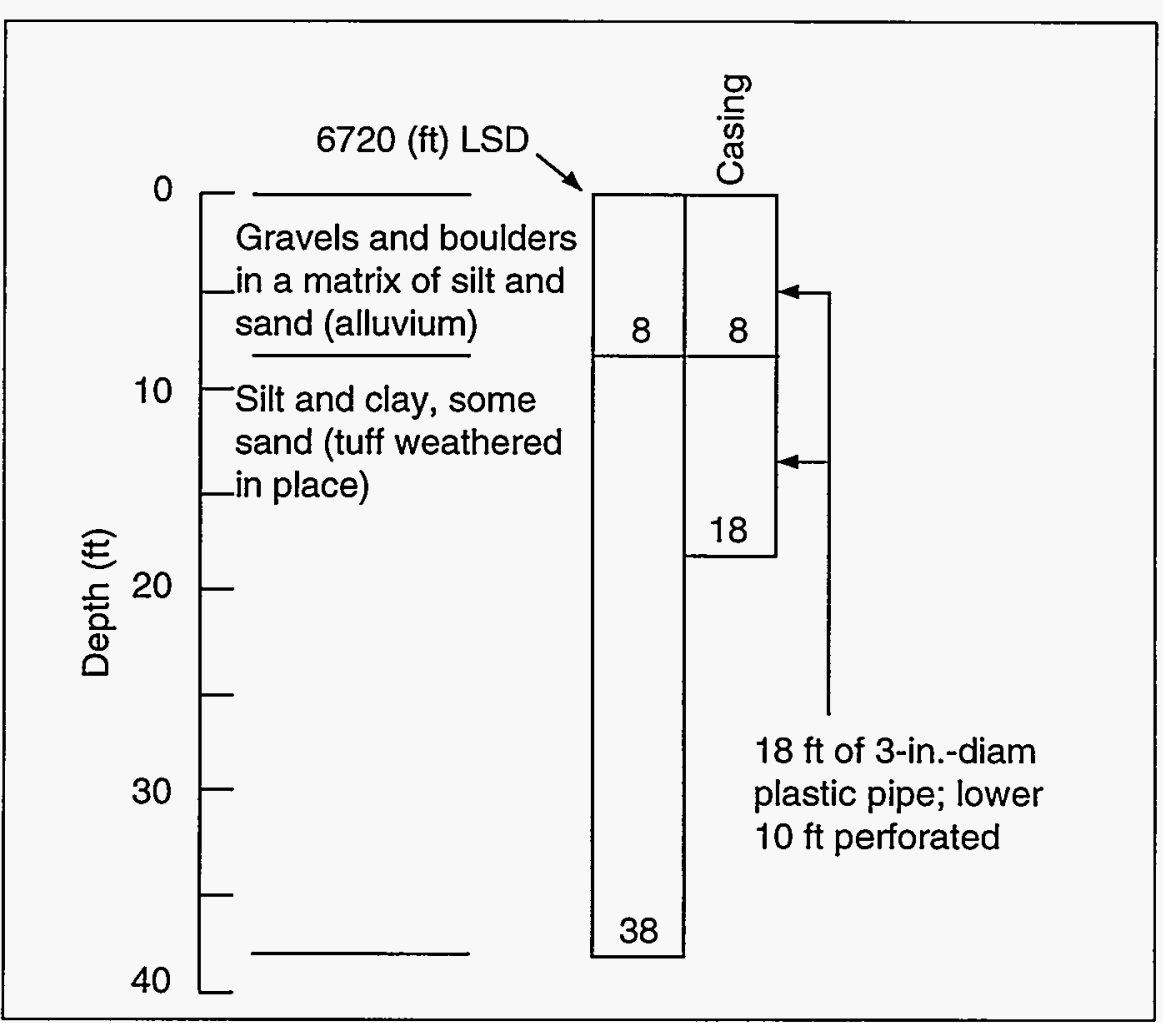




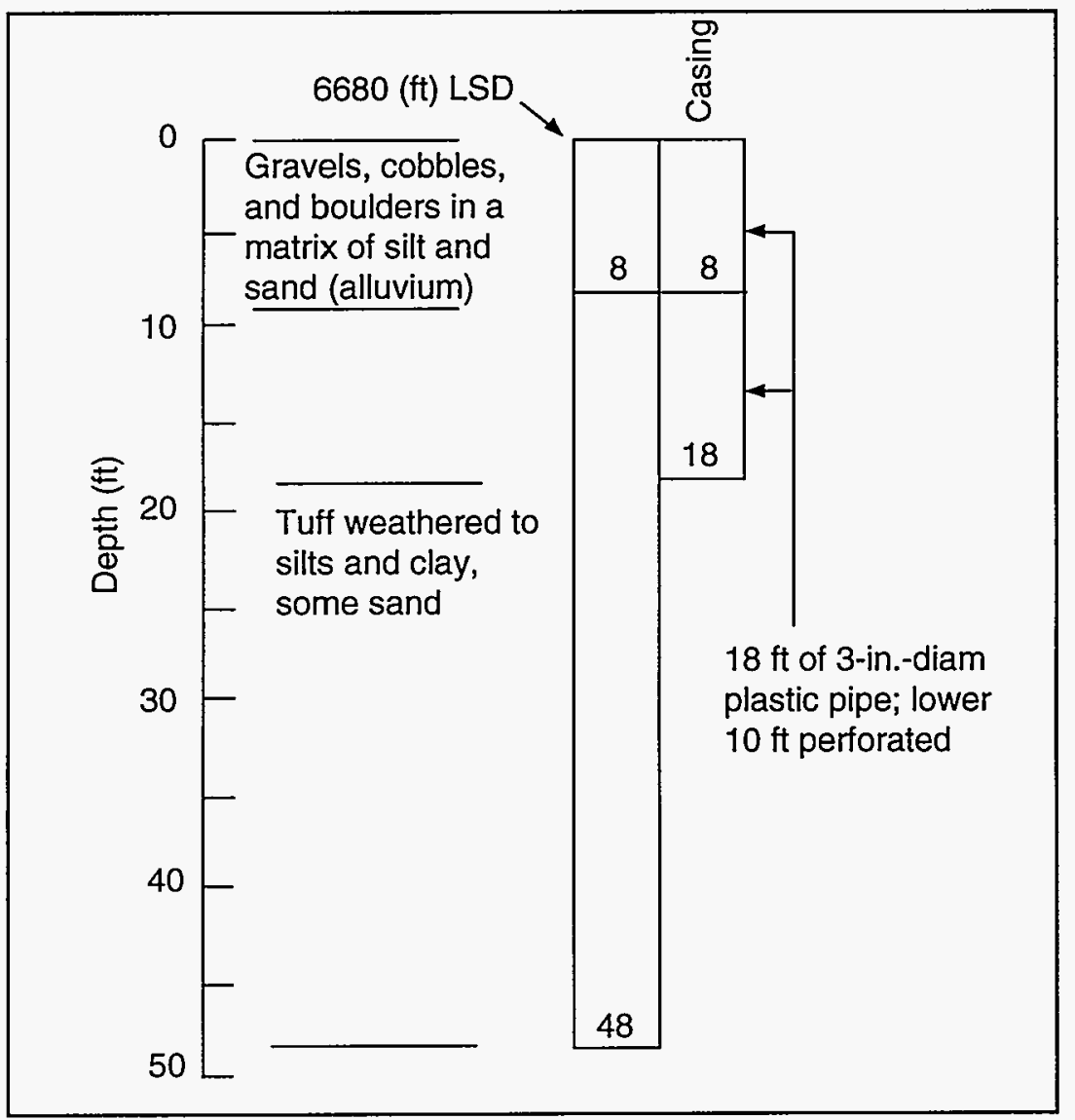

Fig. IV-E. Los Alamos Canyon observation well LAO-1.8, completed April 1969, water level $10.0 \mathrm{ft}$ (Purtymun 1969).

Fig. IV-F. Los Alamos Canyon observation well LAO-2, completed February 1966 , water level $11.0 \mathrm{ft}$ (John et al. 1967).

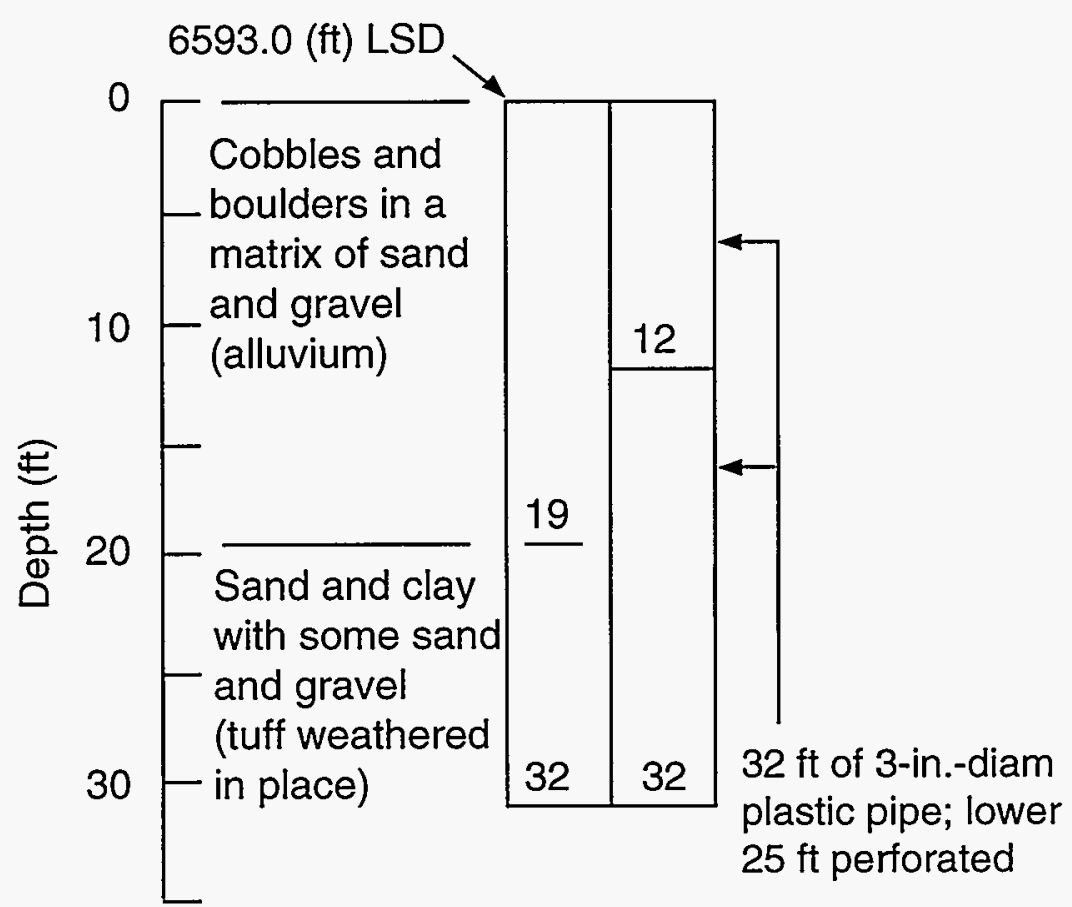




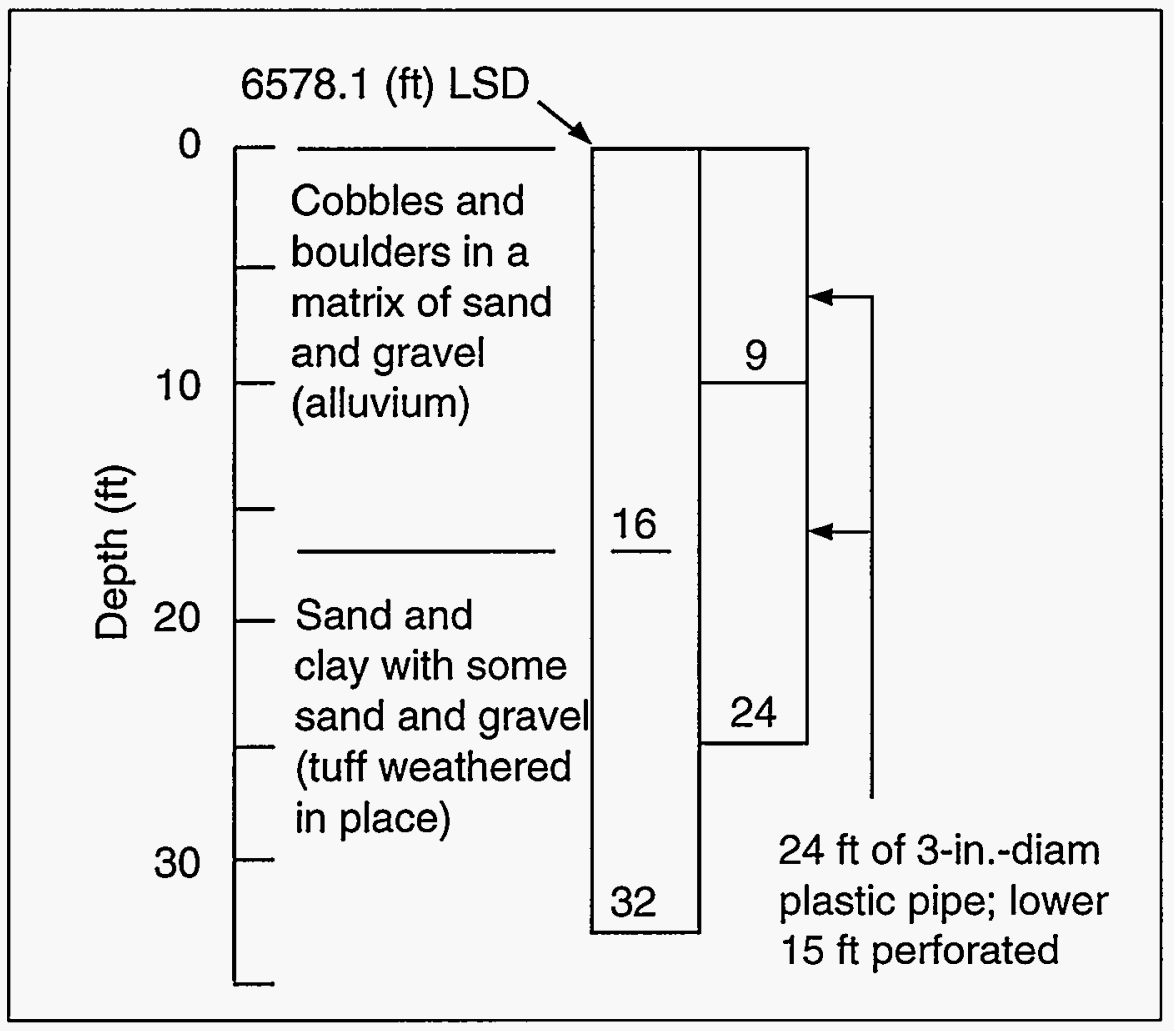

Fig. IV-G. Los Alamos Canyon observation well LAO-3, completed February 1966, water level $6.5 \mathrm{ft}$ (John et al. 1967; Purtymun 1966).

Fig. IV-H. Los Alamos Canyon observation well LAO-4, completed February 1966, water level $12.6 \mathrm{ft}$ (John et al. 1967; Purtymun 1966).

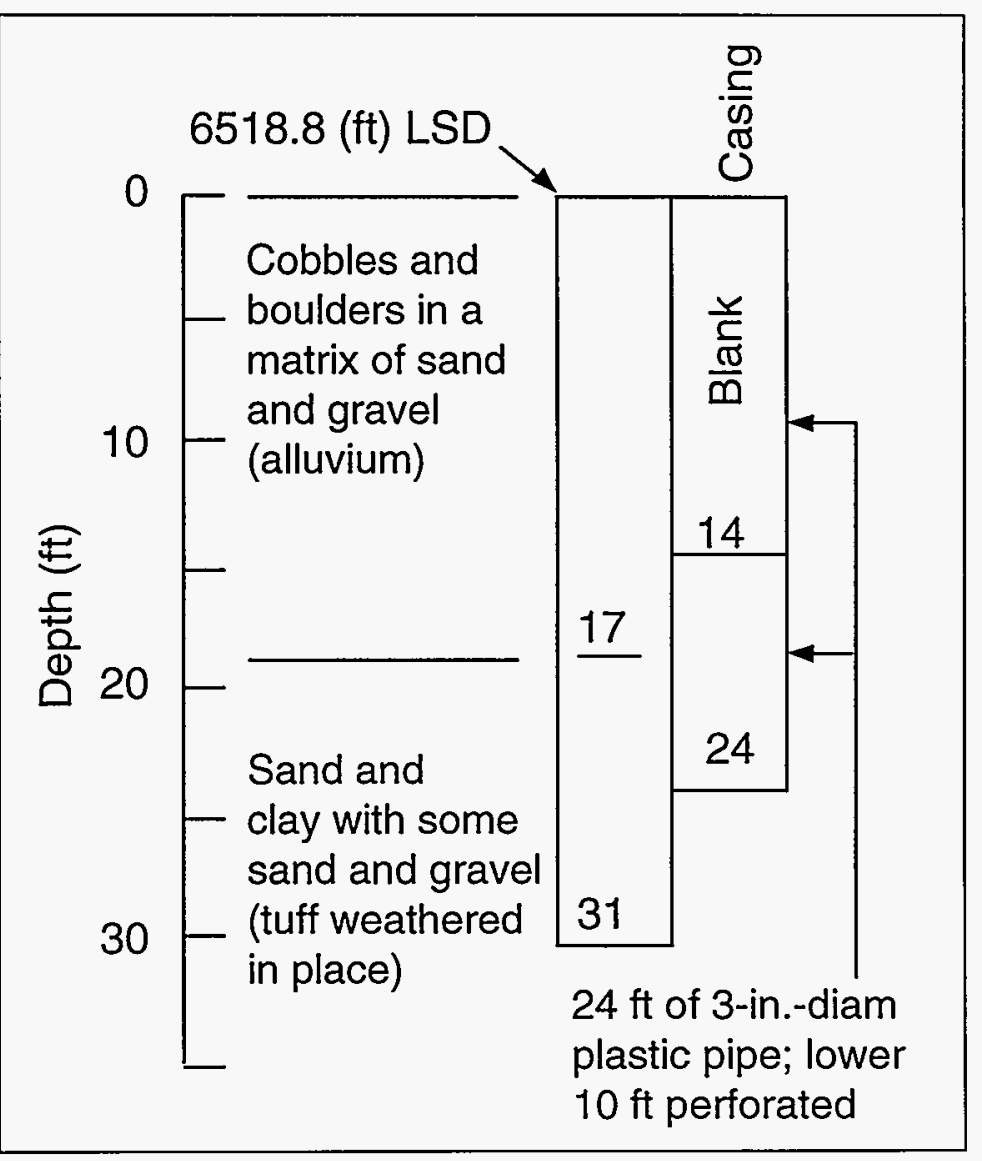




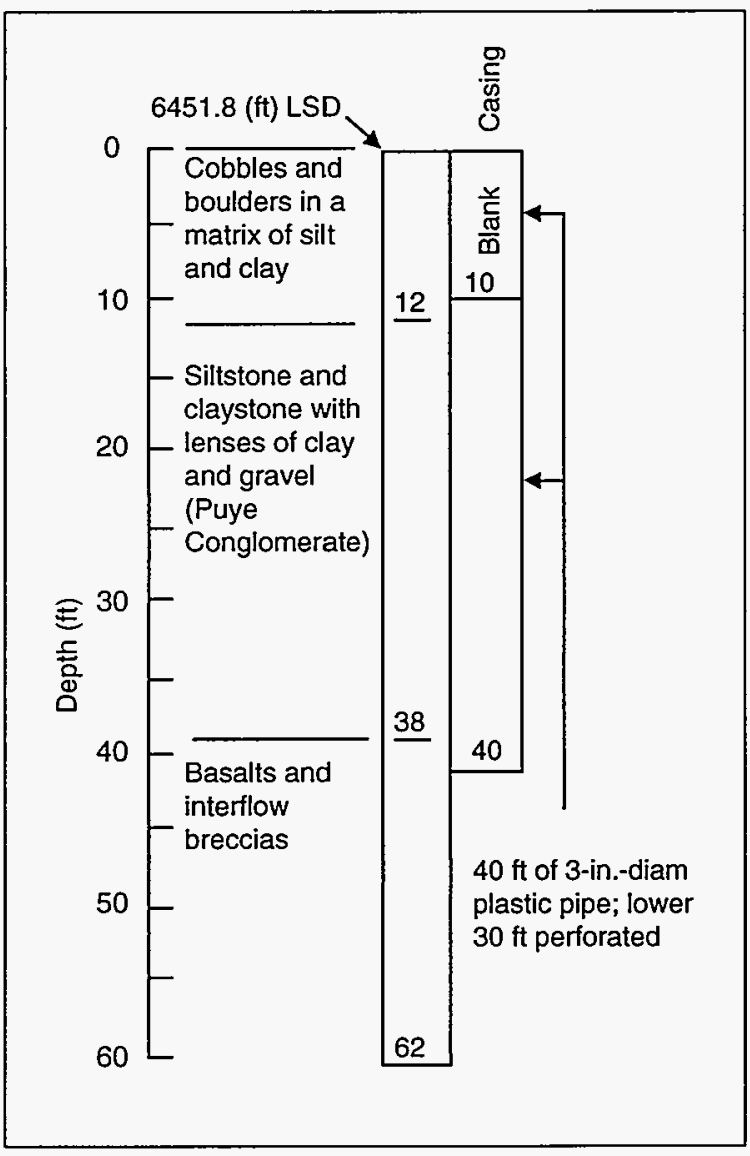

Fig. IV-I. Los Alamos Canyon observation well LAO-4.5, completed April 1969, water level $4.5 \mathrm{ft}$ (Purtymun 1969).

Fig. IV-J. Los Alamos Canyon observation well LAO-5, completed February 1966, dry (John et al. 1967; Purtymun 1966).

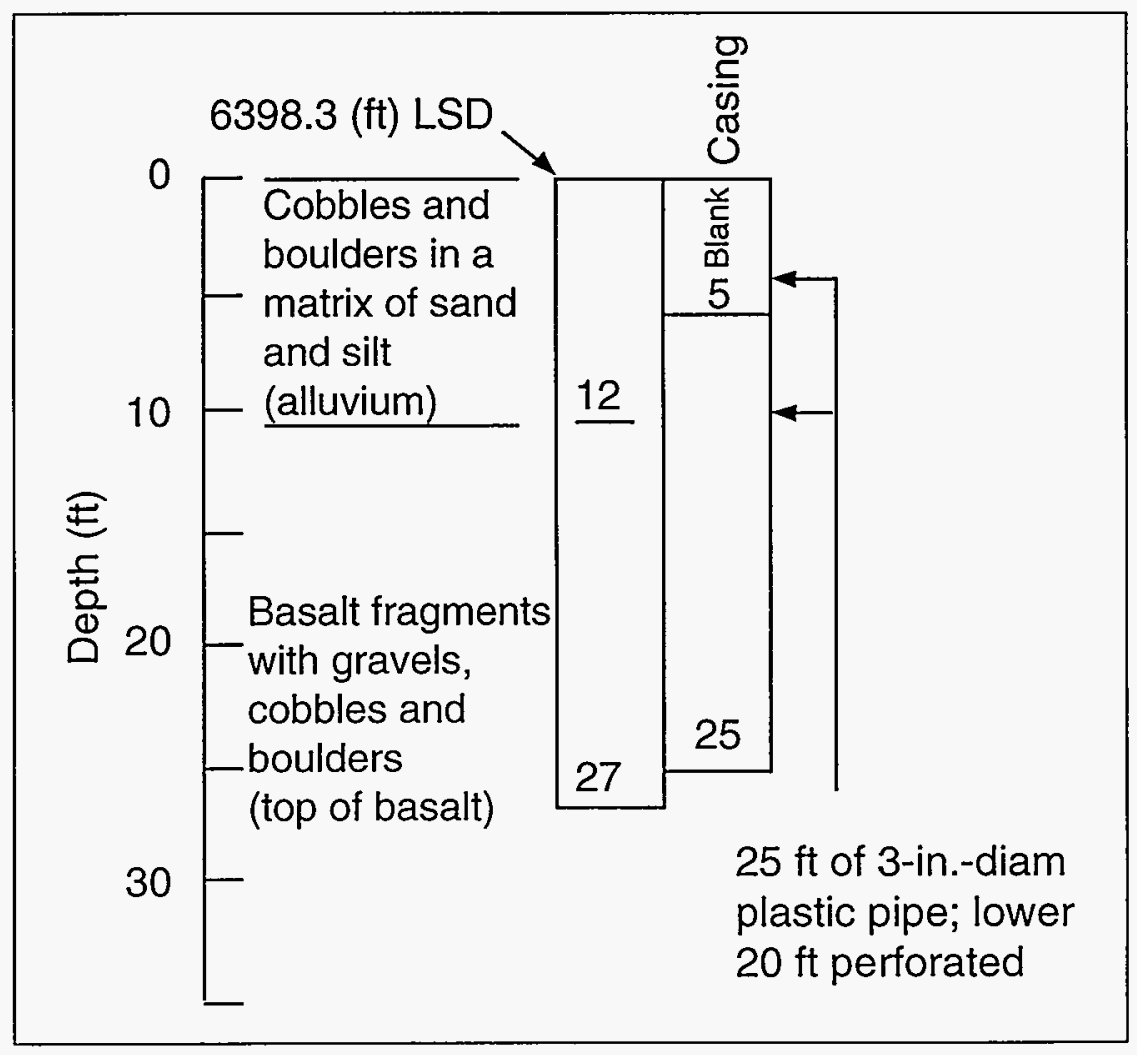




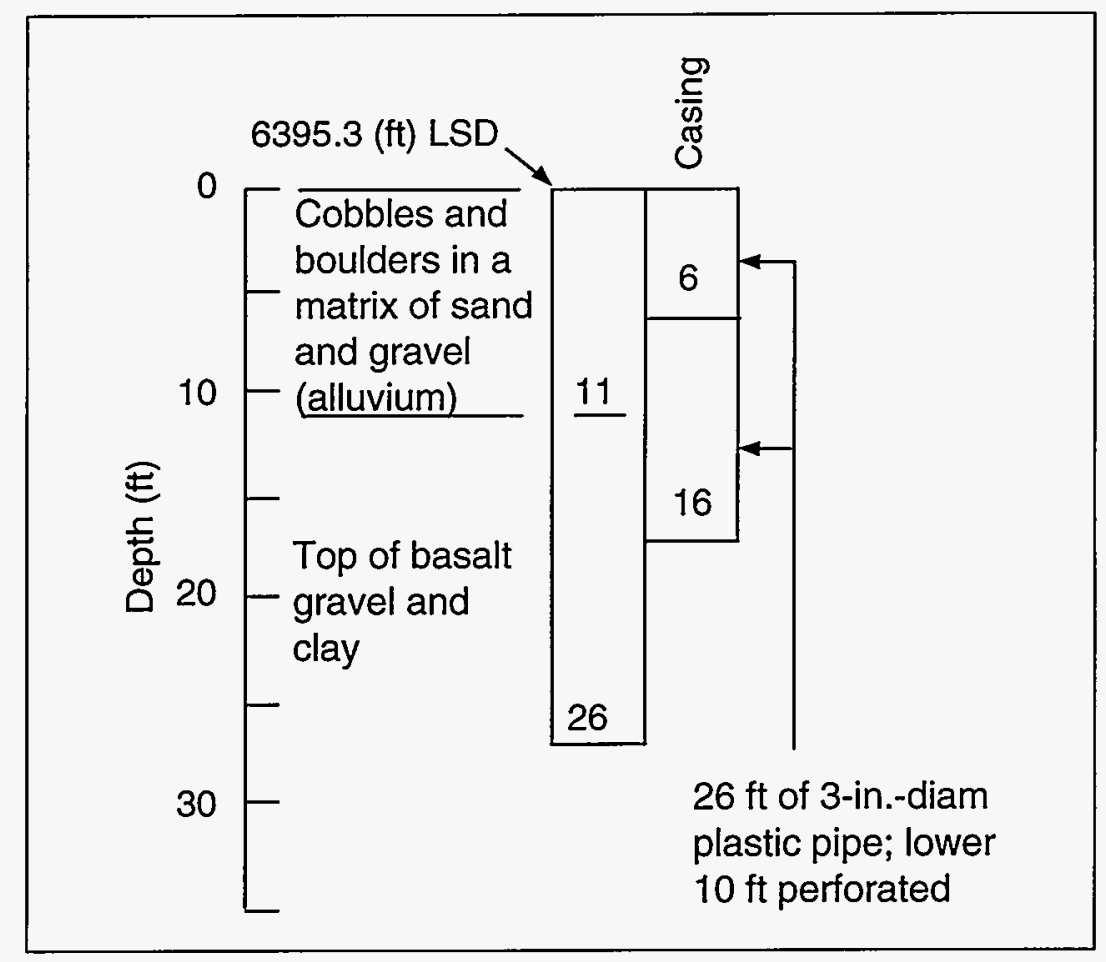

Fig. IV-K. Los Alamos Canyon observation well LAO-6, completed February 1966, dry (John et al. 1967; Purtymun 1966).

TABLE IV-A. Records of Observation Wells in Los Alamos Canyon

\begin{tabular}{lcccccc}
$\begin{array}{c}\text { Observation } \\
\text { Well }\end{array}$ & $\begin{array}{c}\text { Date } \\
\text { Drilled }\end{array}$ & $\begin{array}{c}\text { Elevation } \\
\text { LSD } \\
(\mathrm{ft})\end{array}$ & $\begin{array}{c}\text { Depth } \\
\text { Drilled } \\
(\mathrm{ft})\end{array}$ & $\begin{array}{c}\text { Depth } \\
\text { Completed } \\
(\mathrm{ft})\end{array}$ & $\begin{array}{c}\text { Water level } \\
\text { at Completion } \\
(\mathrm{ft})\end{array}$ & Remarks \\
\hline LAO-C & $9 / 70$ & 7049.98 & 14 & 13 & 2.5 & \\
LAO-1 & $2 / 66$ & 6836.24 & 32 & 28 & 4.6 & \\
LAO-1.2 & $4 / 69$ & 6720 & 38 & 18 & 6.3 & \\
LAO-1.8 & $4 / 69$ & 6680 & 48 & 18 & 10.0 & \\
LAO-2 & $2 / 66$ & 6592.97 & 32 & 32 & 11.0 & \\
LAO-3 & $2 / 66$ & 6578.10 & 32 & 24 & 6.5 & \\
LAO-4 & $2 / 66$ & 6518.73 & 31 & 24 & 12.6 & Obstruction in well (1990) \\
LAO-4.5 & $4 / 69$ & 6451.75 & 62 & 40 & 4.5 & \\
LAO-5 & $2 / 66$ & 6398.33 & 27 & 25 & dry & \\
LAO-6 & $2 / 66$ & 6395.28 & 26 & 16 & dry & \\
\hline
\end{tabular}

Sources: John et al. 1967; Purtymun 1966, 1969, and 1970. 
TABLE IV-B. Geologic Logs and Construction Data of Observation Wells in Los Alamos Canyon (10 Obs. Wells)

1. Observation Well LAO-C

Water level (WL)-2.5 ft

(September 1970)

Elevation (LSD) $7049.98 \mathrm{ft}$

WL-2.12 ft (February 12, 1991)

Thickness Depth

Geologic Log

$(\mathrm{ft})$

(ft)

Alluvium

Cobbles and boulders in a matrix of sand and gravel

14

14

Construction

$13 \mathrm{ft}$ of 3-in.-diam plastic pipe, lower $10 \mathrm{ft}$ perforated. Depth $12.2 \mathrm{ft}$ (1991). Measuring point (MP) is top of casing (TC); distance to LSD is $0.03 \mathrm{ft}$.

2. Observation Well LAO-1

Elevation (LSD) $6836.24 \mathrm{ft}$

Geologic Log

- $4.6 \mathrm{ft}$ (February 1966)

WL-7.4 ft (February 12, 1991)

Thickness

Depth

Alluvium

Cobbles and boulders in a matrix of sand and gravel

(ft)

(ft)

Tuff (weathered in place)

Silt and clay with some sand and gravel

12

12

20

32

Construction

$28 \mathrm{ft}$ of 3-in.-diam plastic pipe, lower $20 \mathrm{ft}$ perforated. Depth $25.4 \mathrm{ft}$ (1991). MP (TC) to LSD $0.25 \mathrm{ft}$.

\section{Observation Well LAO-1.2}

Elevation (LSD) $6720 \mathrm{ft}$

$\begin{array}{cc}\begin{array}{c}\text { WL-6.3 ft (April 1969) } \\ \text { Thickness }\end{array} & \text { Depth } \\ \underline{(\mathrm{ft})} & \underline{(\mathrm{ft})} \\ 8 & 8 \\ 30 & 38\end{array}$

Geologic Log

Alluvium

Gravel and boulders in a matrix of silt and sand

Tuff (weathered)

Silt and clay, some sand

Construction

$18 \mathrm{ft}$ of 3-in.-diam plastic pipe, lower $10 \mathrm{ft}$ perforated.

\section{Observation Well LAO-1.8}

Elevation (LSD) $6680 \mathrm{ft}$

\section{Geologic Log}

Alluvium

Gravel, cobbles, and boulders in a matrix of silt and sand Tuff (weathered)

Silt and clay, some sand

$\begin{array}{cc}\begin{array}{c}\text { WL-10.0 ft (April 1969) } \\ \text { Thickness } \\ \text { (ft) }\end{array} & \begin{array}{l}\text { Depth } \\ (\mathrm{ft})\end{array} \\ 18 & 18 \\ 30 & 48\end{array}$

Construction

$18 \mathrm{ft}$ of 3-in.-diam plastic pipe, lower $10 \mathrm{ft}$ perforated. 
TABLE IV-B. Geologic Logs and Construction Data of Observation Wells in Los Alamos Canyon (10 Obs. Wells) (Continued)

\section{Observation Well LAO-2}

Elevation (LSD) $6592.97 \mathrm{ft}$

Geologic Log

Alluvium

Cobbles and boulders in a matrix of sand and gravel

Tuff (weathered in place)

Silt and clay with some lenses of sand and gravel

WL-11.0 ft (February 1966)

WL-Dry (February 12, 1991)

Thickness Depth

(ft) $\quad(\mathrm{ft})$

$19 \quad 19$

$13 \quad 32$

Construction

$32 \mathrm{ft}$ of 3-in.-diam plastic pipe, lower $20 \mathrm{ft}$ perforated. Depth $29 \mathrm{ft}$ (1991). MP (TC) to LSD $0.07 \mathrm{ft}$.

\section{Observation Well LAO-3}

Elevation (LSD) $6578.10 \mathrm{ft}$

Geologic Log

Alluvium

Cobbles and boulders in a matrix of silt, sand, and gravel

Tuff (weathered in place)

Silt and clay, some sand and gravel

WL-6.5 ft (February 1966)
$\begin{aligned} & \text { WL-13.22 ft (February 12, 1991) } \\ & \begin{array}{c}\text { Thickness } \\ \text { (ft) }\end{array}\end{aligned}$
$\begin{aligned} & \text { Depth } \\ & \text { (ft) }\end{aligned}$
16
16

Construction

$24 \mathrm{ft}$ of 3-in.-diam plastic pipe, lower $15 \mathrm{ft}$ perforated. Depth $19.2 \mathrm{ft}$ (1991). MP (TC) to LSD $0.50 \mathrm{ft}$.

7. Observation Well LAO-4

Elevation (LSD) $6518.73 \mathrm{ft}$

Geologic Log

Alluvium

Cobbles and boulders in a matrix of silt, sand, and gravel

Tuff (weathered in place)

Silt and clay with some sand and gravel

WL-12.6 ft (February 1966)

WL-13.02 ft (February 12, 1991)

Thickness Depth

(ft) $\quad(\mathrm{ft})$

$17 \quad 17$

$14 \quad 31$

Construction

$24 \mathrm{ft}$ of 3-in.-diam plastic pipe, lower $10 \mathrm{ft}$ perforated. Depth $25 \mathrm{ft}$ (1991). MP (TC) to LSD $0.49 \mathrm{ft}$.

\section{Observation Well LAO-4.5}

Elevation (LSD) $6451.75 \mathrm{ft}$

Geologic Log

Alluvium

Cobbles and boulders in a matrix of sand, silt, and clay

Puye Conglomerate (fanglomerate member)

Siltstones and claystone with some gravel and sand

Basalt (interflow breccias)

Rock fragments of basalt with cobbles and boulders in sand and silt

WL-4.5 ft (September 1969)

WL-Dry (February 12, 1991)

Thickness Depth

(ft) $\quad(\mathrm{ft})$

$12 \quad 12$

$26 \quad 38$

$24-62$

Sources: John et al. 1967; Purtymun 1966, 1969, and 1970. 
TABLE IV-B. Geologic Logs and Construction Data of Observation Wells in Los Alamos Canyon (10 Obs. Wells) (Continued)

8. Observation Well LAO-4.5 (Continued)

Construction

$40 \mathrm{ft}$ of 3-in.-diam plastic pipe, lower $30 \mathrm{ft}$ perforated. Well plugged with cement fragments at a depth of $7.8 \mathrm{ft}$. MP (TC) to LSD $0.08 \mathrm{ft}$.

\section{Observation Well LAO-5}

Elevation (LSD) $6398.33 \mathrm{ft}$

Geologic Log

Alluvium

Cobbles and boulders in a matrix of sand and silt Basalt

Basalt fragments with gravel, cobbles, and boulders

Construction

$25 \mathrm{ft}$ of 3-in.-diam plastic pipe, lower $20 \mathrm{ft}$ perforated. Depth $23.7 \mathrm{ft}$ (1991). MP (TC) to LSD $0.00 \mathrm{ft}$.
WL-Dry (February 1966)

WL-17.38 ft (February 12, 1991)

Thickness Depth

(ft) $\quad \underline{(\mathrm{ft})}$

1212

$15 \quad 27$

10. Observation Well LAO-6

Elevation (LSD) $6395.28 \mathrm{ft}$

Geologic Log

Alluvium

Cobbles and boulders in a matrix of silt, sand, and gravel $\quad 11 \quad 11$ Basalt

Basalt fragments with gravel, cobbles, and boulders

$\begin{array}{cc}\begin{array}{c}\text { WL_Dry (1966) } \\ \text { Thickness } \\ (\mathrm{ft})\end{array} & \begin{array}{c}\text { Depth } \\ (\mathrm{ft})\end{array} \\ 11 & 11 \\ 15 & 26\end{array}$

Construction

$16 \mathrm{ft}$ of 3-in.-diam plastic pipe, lower $10 \mathrm{ft}$ perforated. Depth $14.6 \mathrm{ft}$ (1991). MP (TC) to LSD $0.00 \mathrm{ft}$.

Sources: John et al. 1967; Purtymun 1966, 1969, and 1970.

TABLE IV-C. Locations and Elevations (NAD 1927)

A. Surface Water and Gaging Stations

\begin{tabular}{|c|c|c|c|}
\hline $\begin{array}{l}\text { DPS-1 } \\
\text { DPS-2 } \\
\text { DPS-3 } \\
\text { DPS-4 } \\
\text { DPGS-1 } \\
\text { LAGS-1 } \\
\text { LAGS-2 }\end{array}$ & $\begin{array}{l}\text { N } 1,774,796 \\
\text { N } 1,774,700 \\
\text { N } 1,774,400 \\
\text { N } 1,773,228 \\
\text { N } 1,773,300 \\
\text { N } 1,770,827 \\
\text { N } 1,770,900\end{array}$ & $\begin{array}{l}\text { E } 493,081 \\
\text { E } 494,200 \\
\text { E } 494,500 \\
\text { E } 497,258 \\
\text { E } 497,300 \\
\text { E } 507,907 \\
\text { E } 507,800\end{array}$ & $\begin{array}{l}7032 \mathrm{ft} \\
7005 \mathrm{ft} \\
6960 \mathrm{ft} \\
6597 \mathrm{ft} \\
6680 \mathrm{ft} \\
6350 \mathrm{ft} \\
6390 \mathrm{ft}\end{array}$ \\
\hline \multicolumn{4}{|c|}{ B. Observation Wells } \\
\hline $\begin{array}{l}\text { LAO-C } \\
\text { LAO-1 } \\
\text { LAO-1.2 } \\
\text { LAO-1.8 } \\
\text { LAO-2 } \\
\text { LAO-3 } \\
\text { LAO-4 } \\
\text { LAO-4.5 } \\
\text { LAO-5 } \\
\text { LAO-6 }\end{array}$ & $\begin{array}{l}\text { N } 1,775,187.6 \\
\text { N } 1,773,894.3 \\
N 1,173,300 \\
\text { N } 1,172,600 \\
\text { N } 1,773,033.8 \\
N 1,773,036.3 \\
\text { N } 1,772,667.4 \\
\text { N } 1,772,025.6 \\
\text { N } 1,771,362.6 \\
\text { N } 1,771,267.4\end{array}$ & $\begin{array}{l}\text { E 481,913.6 } \\
\text { E 489,150.7 } \\
\text { E 492,400 } \\
\text { E 495,200 } \\
\text { E 497,363.4 } \\
\text { E 497,766.3 } \\
\text { E 500,507.7 } \\
\text { E 503,414.8 } \\
\text { E 505,958.8 } \\
\text { E 505,977.9 }\end{array}$ & $\begin{array}{l}7050.0 \mathrm{ft} \\
6836.2 \mathrm{ft} \\
6720 \mathrm{ft} \\
6680 \mathrm{ft} \\
6592.9 \mathrm{ft} \\
6578.1 \mathrm{ft} \\
6518.7 \mathrm{ft} \\
6451.8 \mathrm{ft} \\
6398.3 \mathrm{ft} \\
6395.3 \mathrm{ft}\end{array}$ \\
\hline
\end{tabular}

Sources: John et al. 1967; Purtymun 1966, 1969, and 1970. 


\section{SANDIA CANYON}

Sandia Canyon heads on the western edge of the Pajarito Plateau at an elevation of about $7515 \mathrm{ft}$ and has a drainage area of about $2.7 \mathrm{sq} \mathrm{mi}$ west of SR-4. The alluvium in the canyon is made up of sands and gravels derived from the Bandelier Tuff (Fig. I-S).

The stream flow in the canyon is intermittent, from storm runoff, waste water from the power plant, and sanitary effluent from the treatment plant at

TA-3.

Stream flow recharges a perched aquifer in the alluvium in the western part of the plateau; however, the amount of water is not sufficient to maintain saturation within the alluvium in the eastern half of the plateau.

Three surface water stations are used to monitor the quality of surface flow in the canyon (Fig. V-A).
Two wells (SCO-1 and SCO-2) were drilled and cased in 1966 in the eastern part of the canyon. Both were dry. The wells were augered using a 4.5-in.-diam bit and were cased with $20 \mathrm{ft}$ of 2-in.diam plastic pipe with the lower $10 \mathrm{ft}$ perforated. The wells were damaged; they have been plugged and abandoned and replaced by two new wells (SCO-1 and SCO-2) described in Section VIII. Locations of surface water stations and observation wells are shown in Table V-A.

\section{REFERENCE}

W. D. Purtymun, "Geohydrology of the Pajarito Plateau with Reference to Quality of Water, 19491972," Los Alamos Scientific Laboratory, Group H-8 document, 1975.

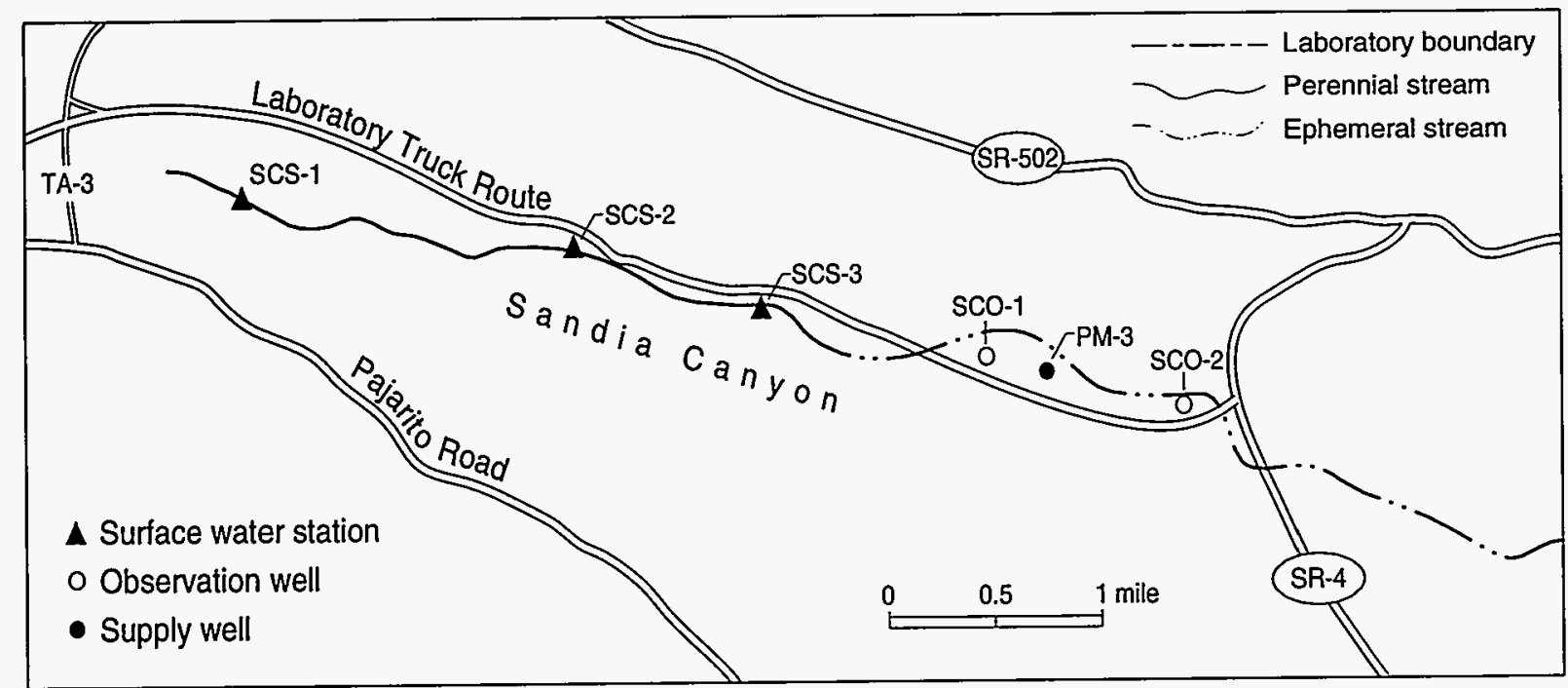

Fig. V-A. Location of sampling stations in Sandia Canyon (Purtymun 1975).

TABLE V-A. Locations and Elevations (NAD 1927)

\section{A. Surface Water Stations}

SCS-1

SCS-2

SCS-3
N $1,773,872.1$

N $1,771,081.3$

N $1,770,207.0$
E 490,978.1

E 492,581.2

E 495,654.8
$7240.8 \mathrm{ft}$

$6834.3 \mathrm{ft}$

$6744.5 \mathrm{ft}$

B. Observation Wells

SCO-1 (1966)
SCO-2 (1966)

N 1,769,440.1

N $1,767,801.8$
E 502,053.4

E 507,014.9
$6618.7 \mathrm{ft}$

$6500.7 \mathrm{ft}$

Source: Purtymun 1975. 


\section{MORTANDAD CANYON}

Mortandad Canyon heads along the western edge of the plateau at an elevation of about $7500 \mathrm{ft}$ and has a drainage area of $1.8 \mathrm{sq}$ mi west of the boundary between the Laboratory and San Ildefonso Pueblo. The alluvium is derived from the weathering of the Bandelier Tuff, and consists of silt, sand, and gravel. Perennial surface flow occurs in the midreach of the canyon with the release of waste water from TA-46 and treated effluent from the treatment plant at TA-50. Mortandad Canyon is the major release area for treated radioactive effluents. The surface water, effluents, and storm runoff recharge an aquifer perched in the alluvium. The recharge is only sufficient to maintain an aquifer of limited extent. The surface flow and water in the alluvium is contained within the Laboratory due to the small drainage area and thick section of unsaturated alluvium (Fig. I-T).

\section{A. Observation Wells}

The geology and hydrology of the canyon was partly outlined through the construction of $21 \mathrm{MCO}$ - and TSCO-series observation wells (Fig. VI-A). Some of these wells contained water, others were dry. The wells were constructed during the period 1960 through 1974 (Table VI-A). Seven of these wells are used for monitoring.

The earlier holes were augered using a 4.5-in.-diam bit. For casing, 2-in.-diam and 3-in.-diam plastic pipe was used. These wells were not gravel packed. The casing was placed in the hole, and the annulus between the casing and the hole wall was sealed with cuttings from the hole. Later wells (1974) were constructed using a 7.25-in. auger and set with 4-in. plastic pipe. These wells were gravel packed. The screen section of the plastic pipe was perforated with a 1/4-in. drill bit. At the surface the hole was sealed with cement and a security cap installed. Geologic logs and construction data are shown in Table VI-B. Geologic logs and casing schedules for 20 of these observation wells are shown in Figs. VI-B through VI-V.

\section{B. Test Holes}

To monitor the special conditions of the occurrence and movement of water in the alluvium and the underlying tuff, 14 special test holes (the MCM-, MCC-, and MT-series) were drilled to collect samples of the aquifer sediments and tuff underlying the aquifer, and to construct moisture-access holes (Fig. VI-W and Table VI-C). The investigations were to determine the movement of water into the unsaturated tuff below the aquifer (Table VI-C). The special holes were needed to determine the geology and hydrology of the canyon with reference to the distribution and movement of the wastes released into the canyon from the treatment plant at TA-50.

Special construction was necessary to complete the holes. Geologic logs and casing schedules for 13 of these test holes are shown in Figs. VI-X through VI-AJ. The holes were all augered. Deep, double-cased holes (to be used as moisture-access holes) were augered through casing set through the alluvium or through a larger hollow-stem auger set through the alluvium. The casings were sealed at the surface with cement and a pad constructed.

Two deep test holes were cored on sacred land of the San Ildefonso Pueblo in Mortandad Canyon east of the Laboratory boundary. They were cored in cooperation with San Ildefonso Pueblo and the Bureau of Indian Affairs.

Test hole SIMO, cored in September 1990 (Fig. VI-AK and Table VI-D Log 14), was completed at a depth of $104 \mathrm{ft}$. The hole was dry.

Test hole SIMO-1 was cored about $50 \mathrm{ft}$ north of SIMO (see log of SIMO-1, Table VI-D Log 18). The hole was dry. Lithology was about the same as that of SIMO; both holes contain screen sections at various depths.

Test holes MCM-10-1, MCM-10-2, MCM-10-3A, and MCM-10-3B were drilled in lower Mortandad Canyon in 1991 (Fig. VI-AM and Table VI-D). The holes were drilled in areas that a seismic survey indicated should contain shallow perched water (Reynolds et al. 1990, 1991). The holes were dry.

Formation names are used to describe the material penetrated by the holes. At the base of the Tshirege Member in Mortandad Canyon is a water-laid or surge unit of coarse, crudely bedded ash and pumice lapilli, and pebbly gravels of latite and rhyolite in a matrix of sandy ash. This unit has been designated the Tsankawi Pumice Bed. It is an important unit in observation wells in Sandia and Mortandad Canyons because it underlies the alluvium in Sandia and the perched aquifer in the alluvium of the Mortandad Canyon. The following description of the alluvium, the Bandelier Tuff Unit 1A, the Tsankawi Pumice Bed, and the underlying Otowi Member was taken from a hole cored through the alluvium and into the three units mentioned above in Mortandad Canyon (MCM-5.9A, Fig. VI-AC). 
1. Alluvium. The alluvium consists of silty sand, composed of crystals and crystal fragments of quartz and sanidine. Small rock fragments of pumice, tuff and rhyolite are also present in a matrix of sand and clay.

2. Tshirege Member of the Bandelier Tuff. This member consists of Unit 1A tuff, nonwelded to moderately welded, light gray, of quartz and sanidine crystals and crystal fragments, rock fragments of pumice, latite, and rhyolite in a matrix of gray ash. The weathered tuff is gray, buff, light to dark brown in color, and contains pumice and ash weathered to clay. The unit is about $60 \mathrm{ft}$ thick.

3. Tsankawi Pumice Bed. This layer consists of thin lenses of silt and sand, gravels of pumice, quartz and sanidine crystal, rock fragments of latite and rhyolite ranging in color from gray to dark brown, and ash and some pumice weathered to clay. This layer represents a pumice fall, erosion, and the deposition of rock fragments of rhyolite, probably Cerro Toledo Rhyolite, on top of a massive ash flow (the Otowi Member). Thickness of the Tsankawi is about $20 \mathrm{ft}$.

4. Otowi Member. The Otowi Member consists of tuff, nonwelded to moderately welded, gray to dark brown when weathered, made up of quartz and sanidine crystals and crystal fragments, numerous pumice fragments up to $2 \mathrm{in.} \mathrm{long,} \mathrm{and} \mathrm{rock} \mathrm{fragments} \mathrm{of} \mathrm{latite}$ and rhyolite in an ash matrix. The ash matrix and some of the pumice is weathered to silt and clay. The thickness of the member in the test hole exceeds $76 \mathrm{ft}$.

\section{Moisture-Access Holes}

In 1960 and 1961 we constructed 25 moistureaccess holes in Mortandad Canyon, adding 2 more in 1971 and 1 in 1989 (Fig. VI-AM). The holes were completed in the alluvium or tuff (Table VI-E). Some of the holes were drilled across the canyon from an observation well, so as to transect the canyon, and some were completed as single moisture-access holes. The access holes were to be logged with the neutron moisture/density gauge to measure the distribution of moisture in the alluvium and tuff.

The moisture-access holes were drilled using a 4.5-in.-diam auger and were cased with 2-in.-diam plastic pipe with a plug in the bottom. This plug kept water out when the alluvial aquifer was penetrated. The annulus between the plastic pipe and the hole wall was packed with cuttings from the hole.

Test holes and moisture-access holes in the lower reach of the canyon were used to construct two views of the alluvium and underlying tuff. Figure VI-AN follows the axis of the canyon and shows the aquifer thinning eastward, while Fig. VI-AO shows a cross section of the canyon.

Locations of surface water stations, observation wells, test holes, and moisture-access holes are shown in Table VI-F.

\section{REFERENCES}

E. H. Baltz, J. H. Abrahams, and W. D. Purtymun, "Preliminary Report of the Geology and Hydrology of Mortandad Canyon near Los Alamos, New Mexico," U.S. Geological Survey Open-File Report (1963).

W. D. Purtymun, "Progress Report on Hydrology of Mortandad Canyon Disposal System for Treated LowLevel Radioactive Wastes, June 1961 to June 1963," U.S. Geological Survey Admin. Report (1964).

W. D. Purtymun, "Disposal of Low-Level Radioactive Effluents in Mortandad Canyon at Los Alamos, New Mexico," U.S. Geological Survey Admin. Report (1968).

W. D. Purtymun, Los Alamos Scientific Laboratory, unpublished data (U.S.G.S. field notes), 1963, 1964, 1970, 1971a.

W. D. Purtymun, Los Alamos Scientific Laboratory, unpublished data (LASL field notes), 1971b, 1973, 1974.

W. D. Purtymun, Los Alamos National Laboratory, unpublished data (LANL field notes), 1988-1992.

Charles B. Reynolds and Associates, "Shallow Seismic Refraction Survey, Mortandad Canyon Area, Los Alamos, New Mexico," report from Reynolds and Associates Consulting Geophysicists and Geologists, 4409 San Andres Avenue NE, Albuquerque, New Mexico (Oct. 19, 1990 and Oct. 8, 1991).

A. K. Stoker, W. D. Purtymun, S. G. McLin, and M. N. Maes, "Extent of Saturation in Mortandad Canyon," Los Alamos National Laboratory document LA-UR-91-1660. 


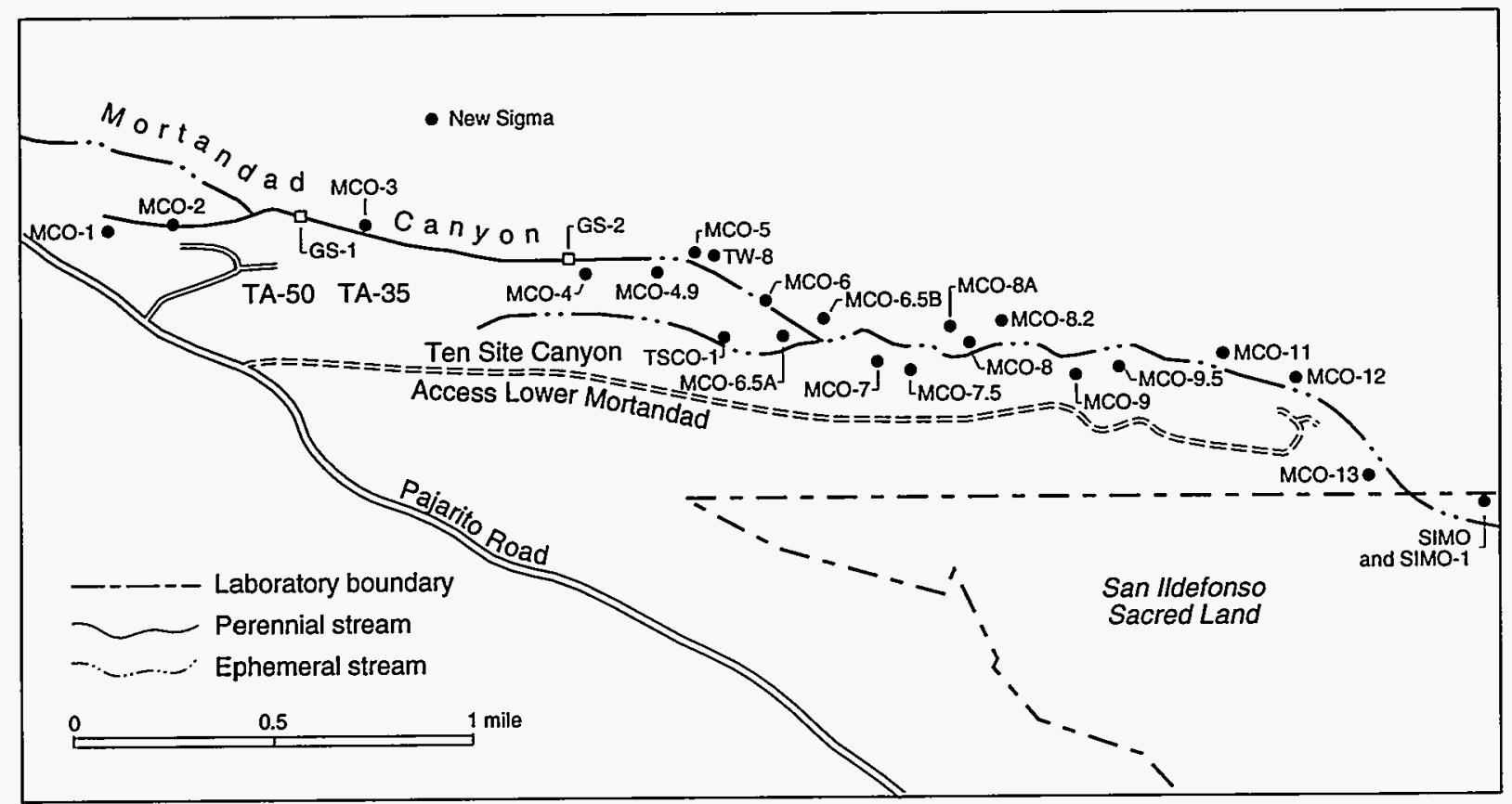

Fig. VI-A. Location of observation wells in Mortandad Canyon.

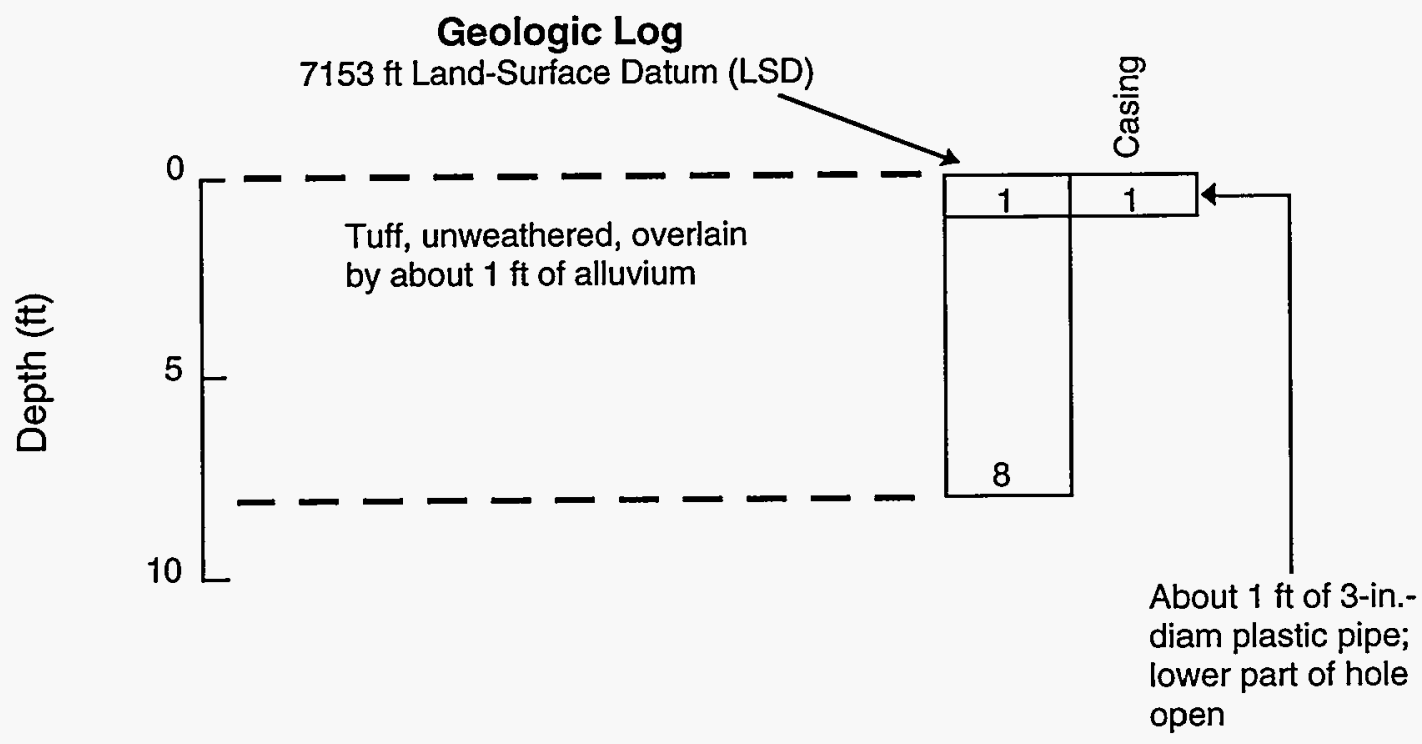

Fig. VI-B. Mortandad Canyon observation well MCO-1, completed November 1960, water level $2.8 \mathrm{ft}$; unable to locate in 1991 (Baltz et al. 1963). 


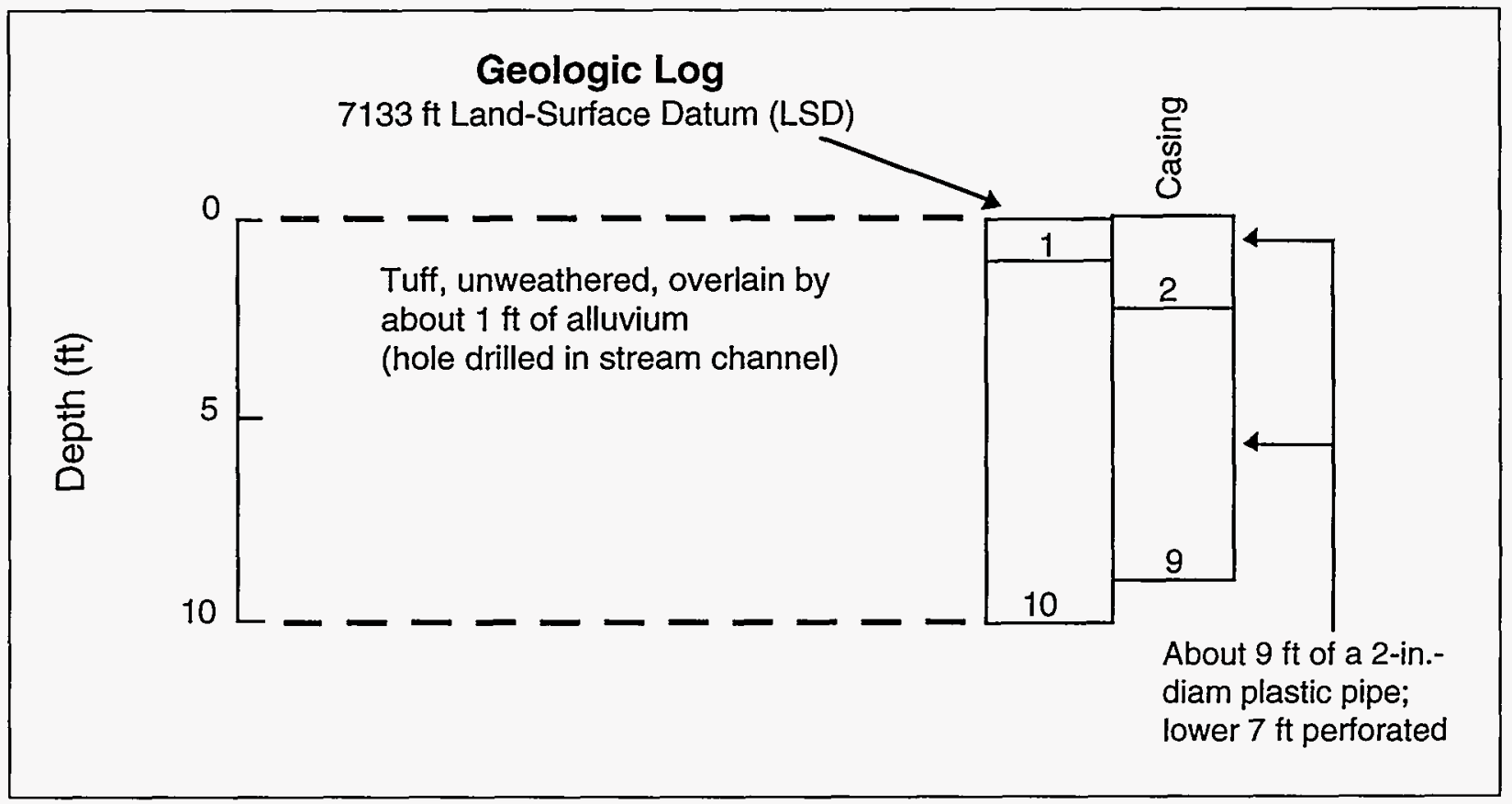

Fig. VI-C. Mortandad Canyon observation well MCO-2, completed November 1960, water level $0.3 \mathrm{ft}$ (Baltz et al. 1963).

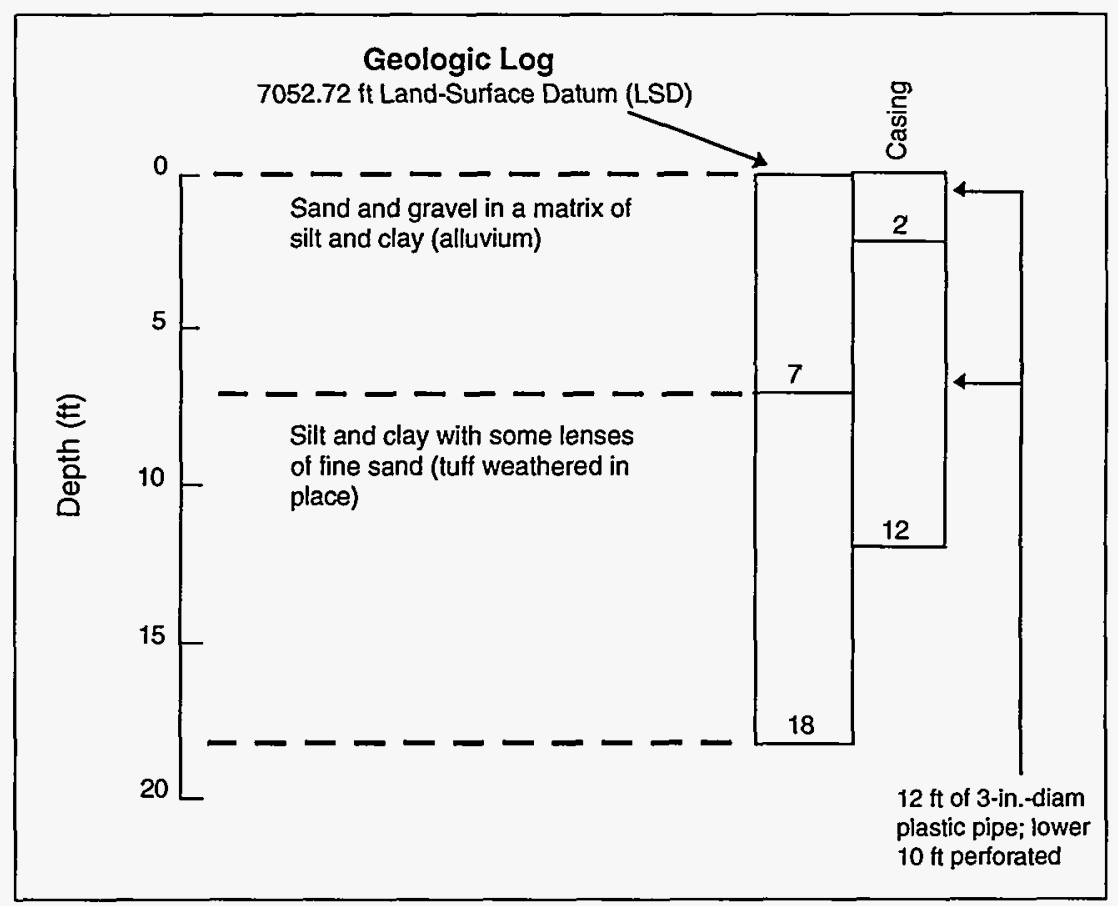

Fig. VI-D. Mortandad Canyon observation well MCO-3, redrilled March 1967 and completed with 3-in.-diam casing, water level 4.4 ft (Baltz et al. 1963; Purtymun 1964). 


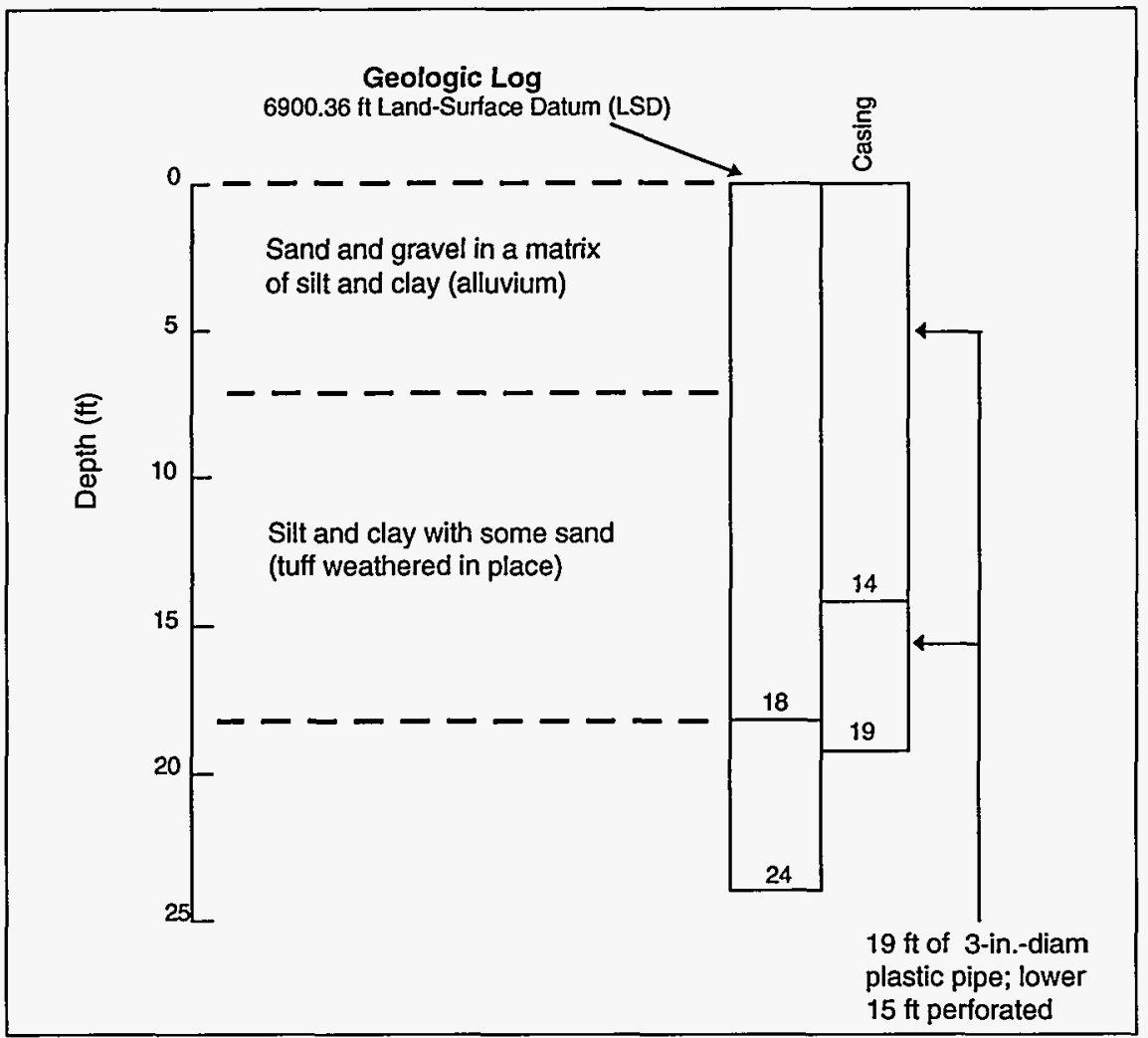

Fig. VI-E. Mortandad Canyon observation well MCO-4, redrilled October 1963, water level $3.3 \mathrm{ft}$ (Baltz et al. 1963;

Purtymun 1963).

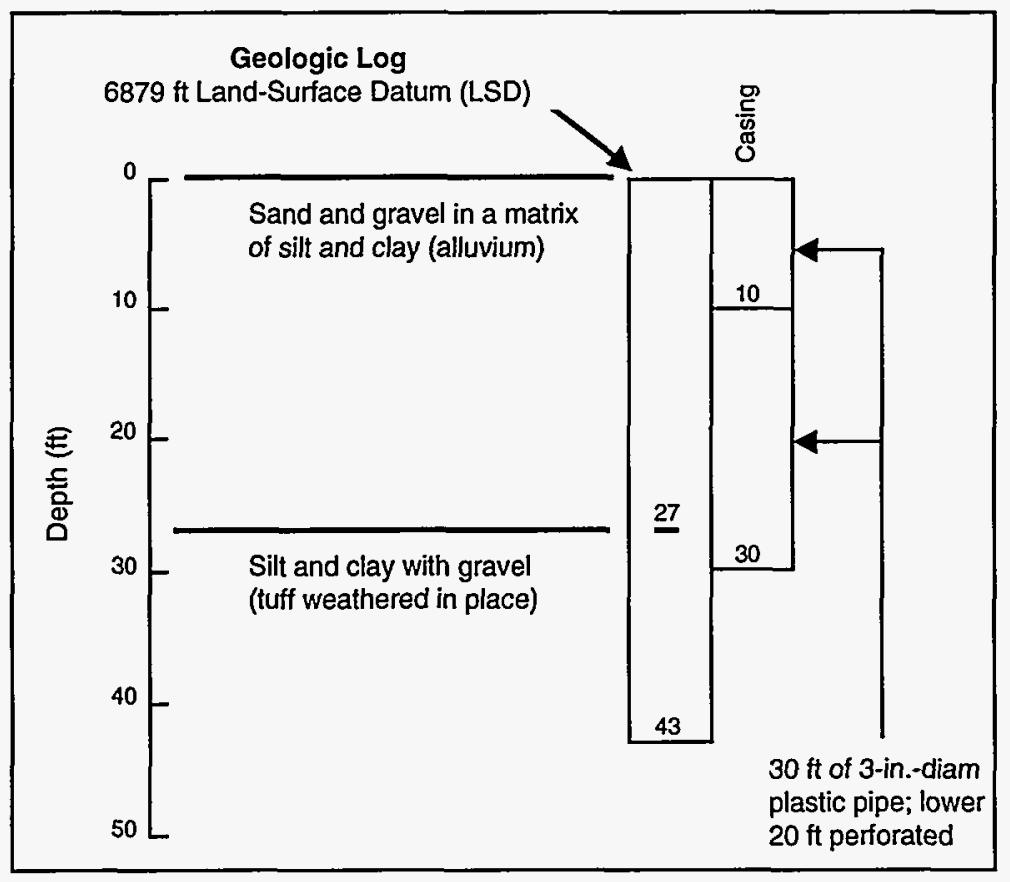

Fig. VI-F. Mortandad Canyon observation well MCO-4.9, completed July 1973, water level $23.7 \mathrm{ft}$ (Purtymun 1973). 


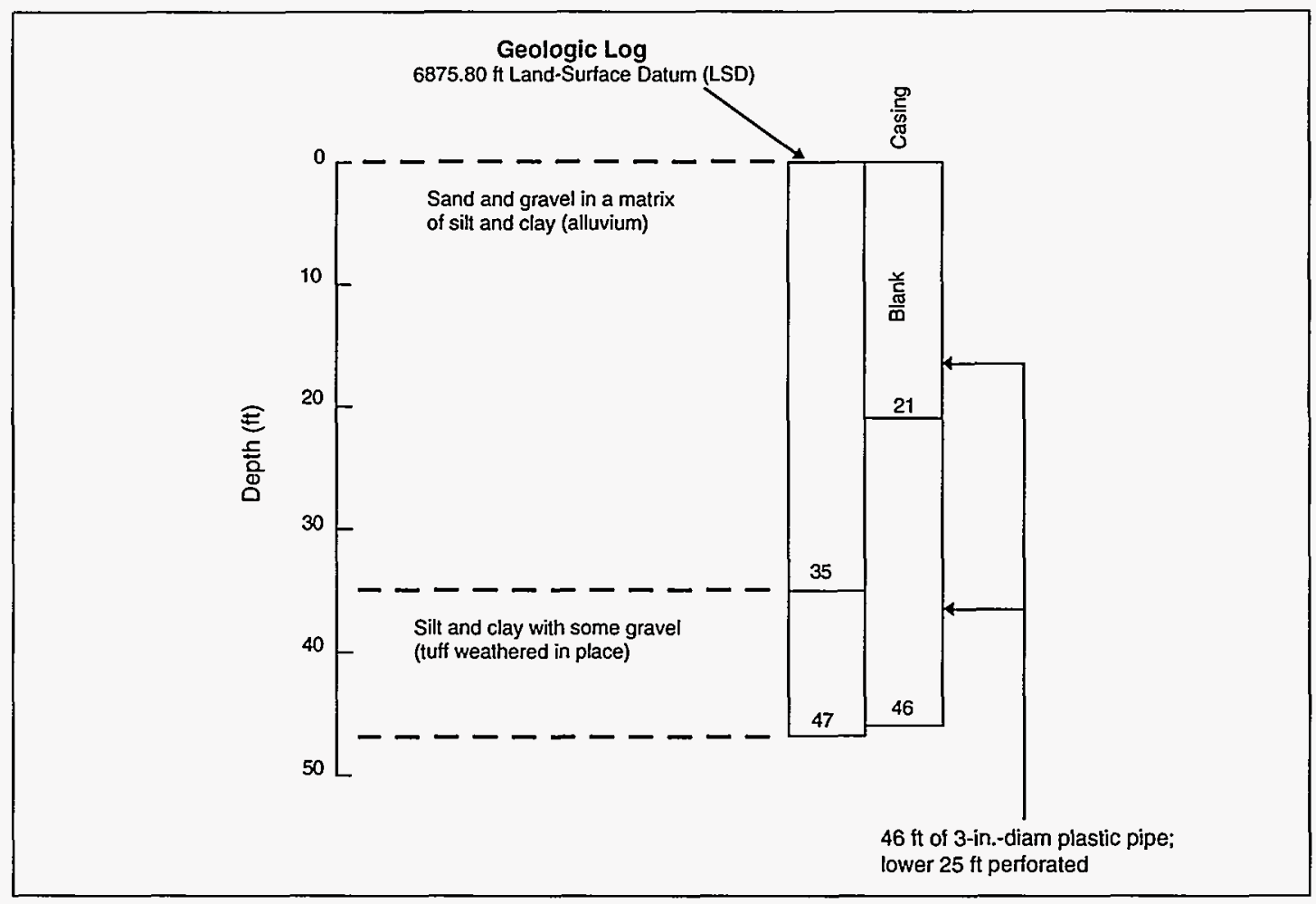

Fig. VI-G. Mortandad Canyon observation well MCO-5, completed October 1960, water level $24.6 \mathrm{ft}$ (Baltz et al. 1963).

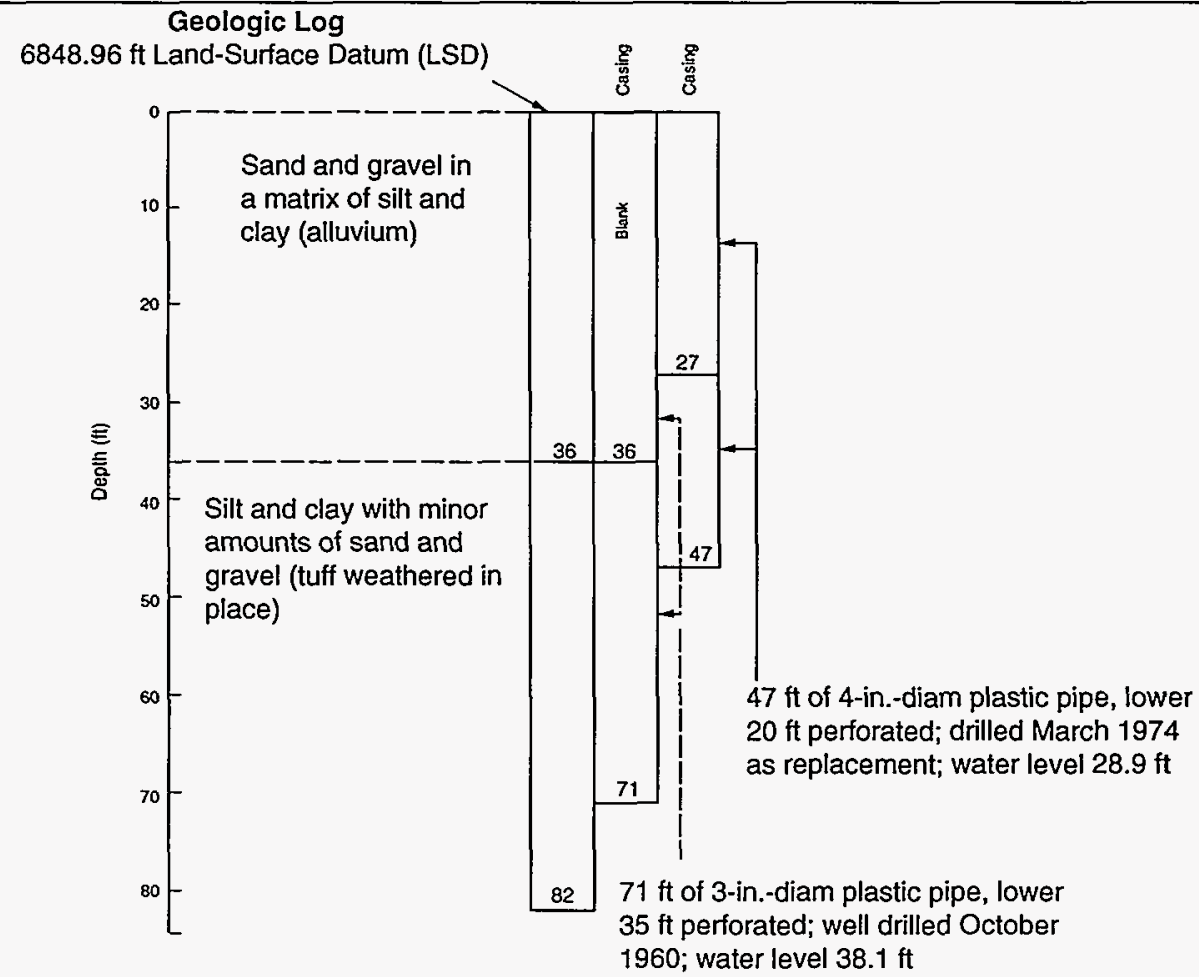

Fig. VI-H. Mortandad Canyon observation well MCO-6, completed October 1960, replaced March 1974 (Baltz et al. 1963, Purtymun 1974). 


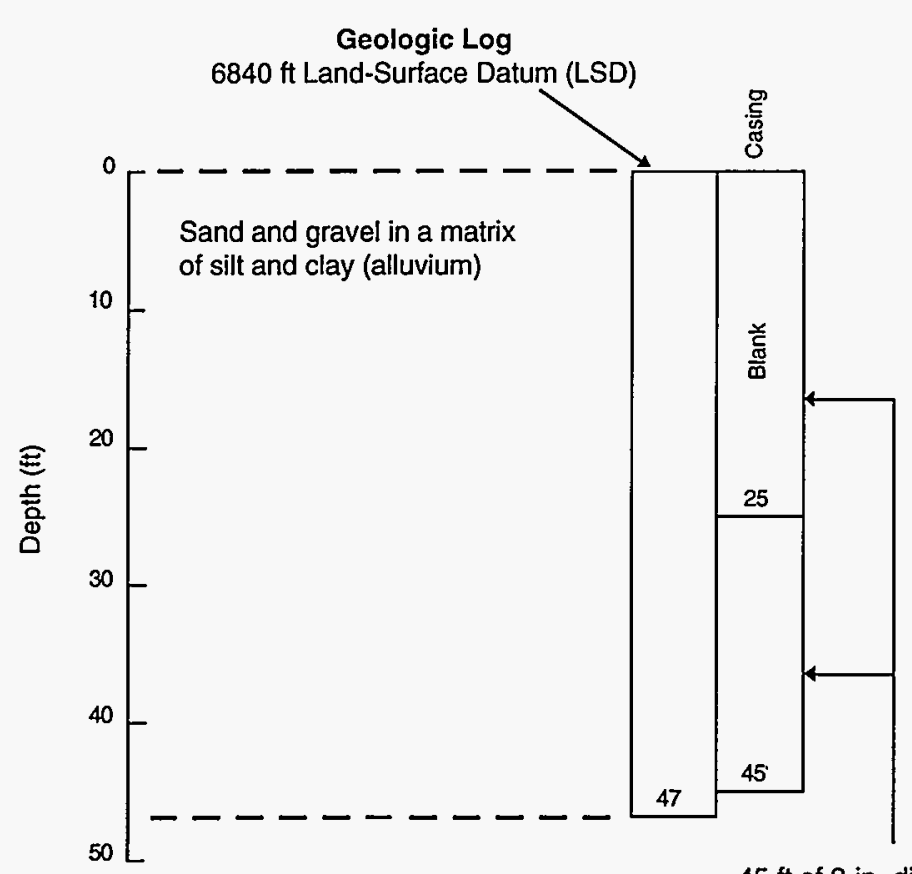

$45 \mathrm{ft}$ of 2-in.-diam plastic pipe; lower $20 \mathrm{ft}$ perforated

Fig. VI-I. Mortandad Canyon observation well MCO-6.5A, completed November 1961, water level $41.0 \mathrm{ft}$ (Purtymun 1964).

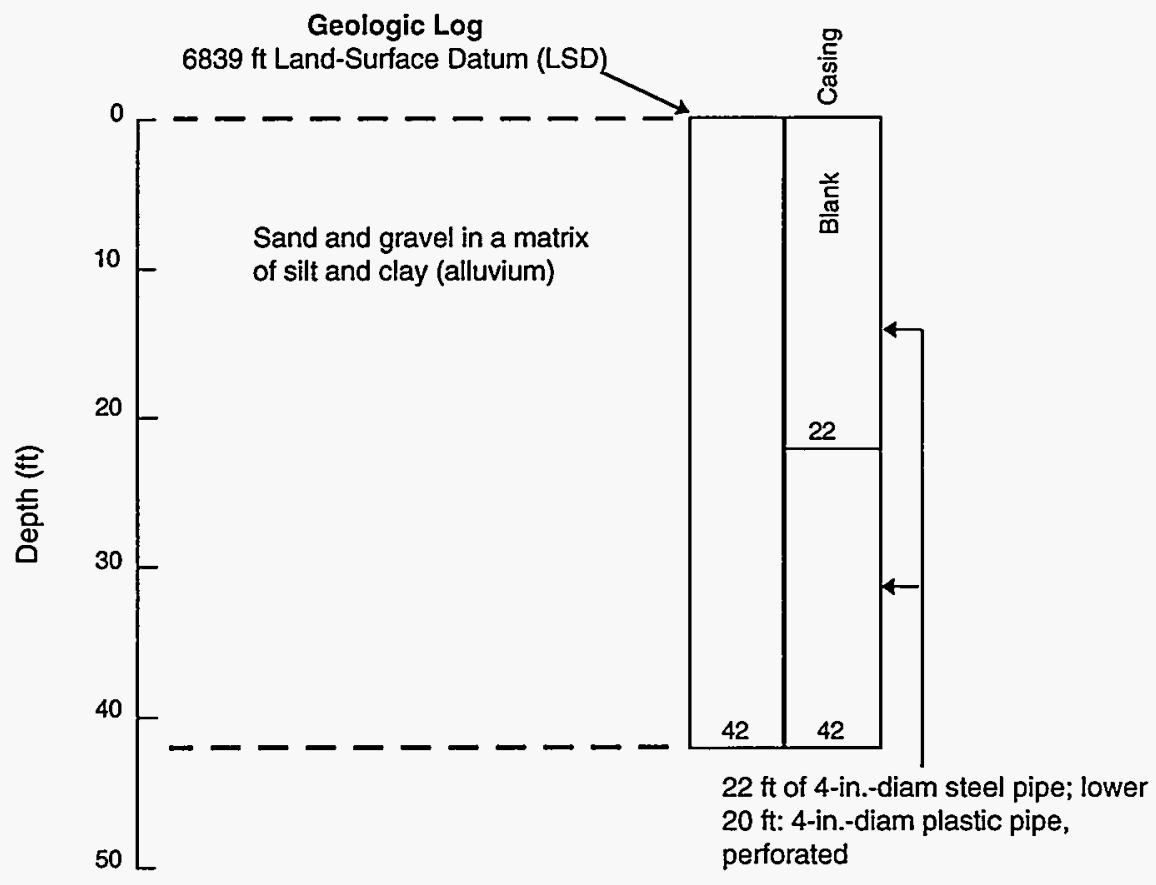

Fig. VI-J. Mortandad Canyon observation well MCO-6.5B, completed November 1961, water level $36.3 \mathrm{ft}$ (Purtymun 1964). 


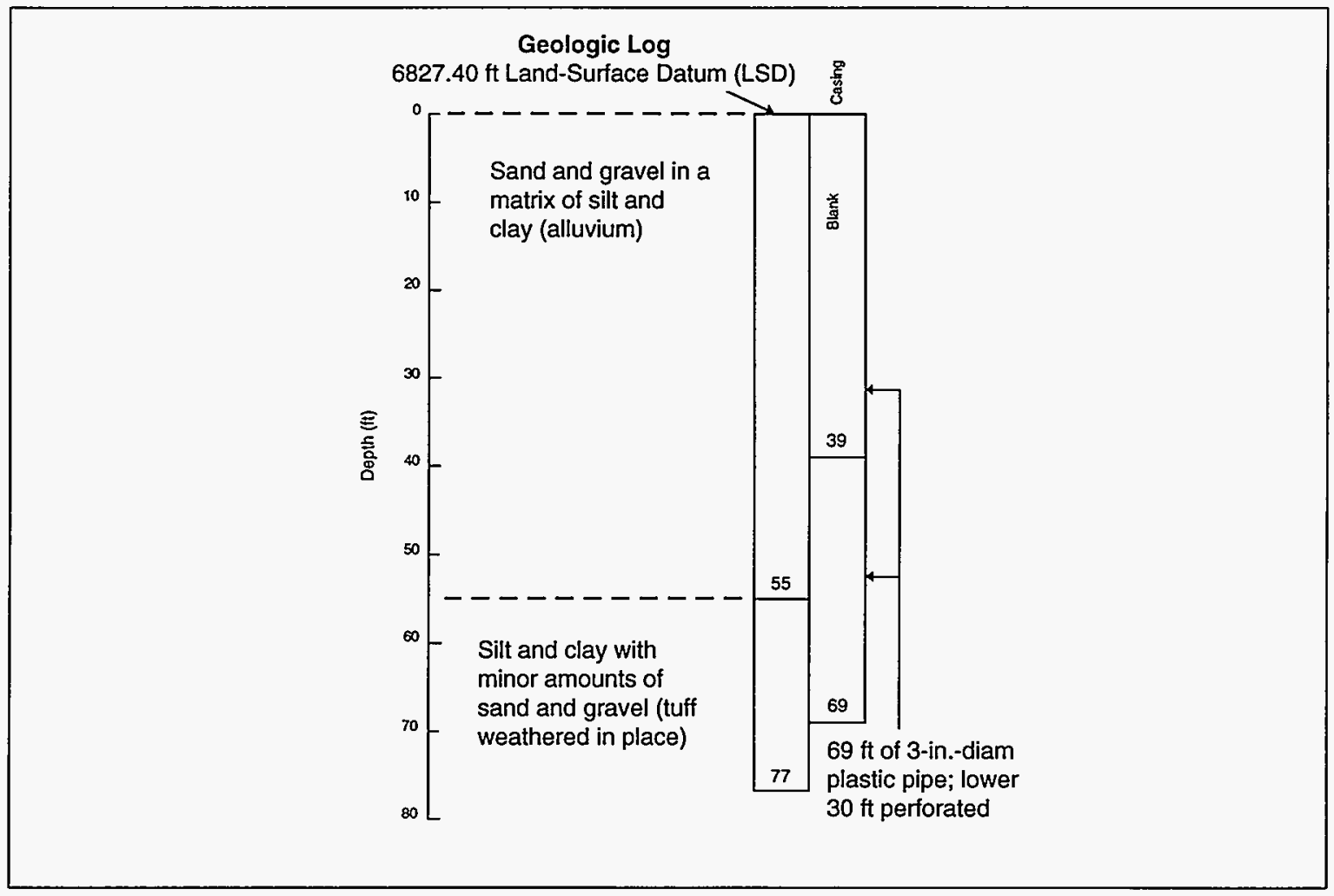

Fig. VI-K. Mortandad Canyon observation well MCO-7, completed October 1960, water level $39.7 \mathrm{ft}$ (Baltz et al. 1963).

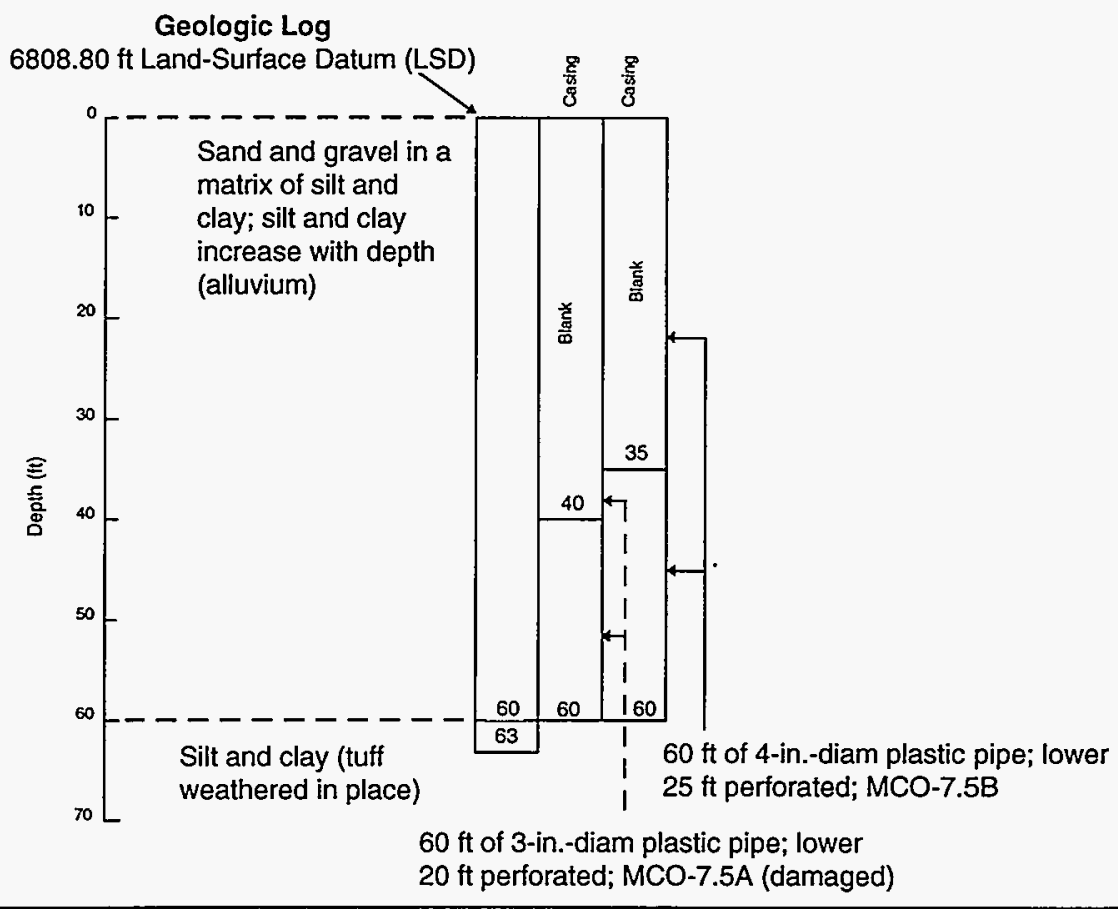

Fig. VI-L. Mortandad Canyon observation well MCO-7.5A (damaged), completed November 1961, water level $41.2 \mathrm{ft}$; and adjacent well MCO-7.5B, completed April 1974, water level $42.1 \mathrm{ft}$ (Purtymun 1964, 1974). 


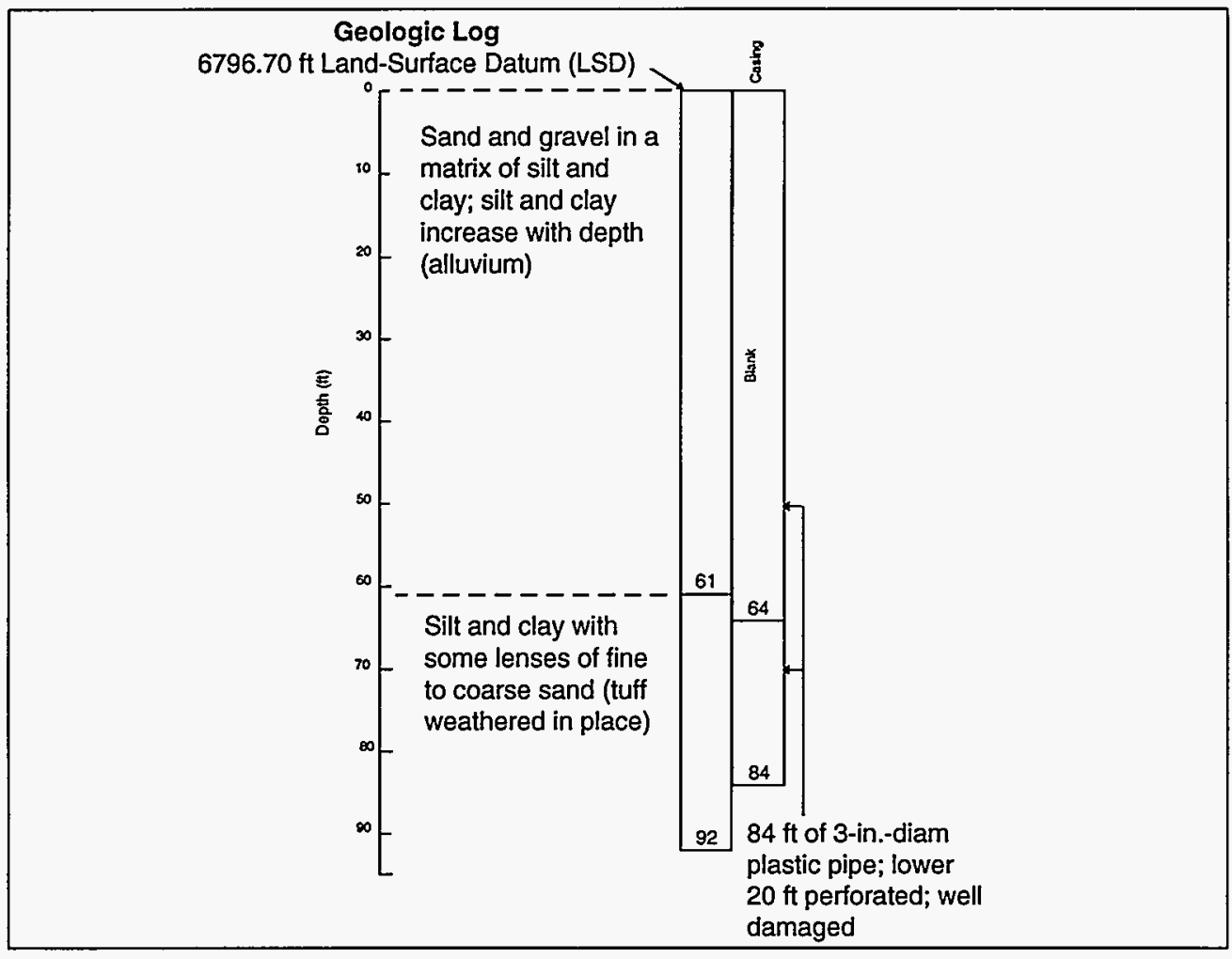

Fig. VI-M. Mortandad Canyon observation well MCO-8, completed October 1960, water level $61.6 \mathrm{ft}$; damaged beyond repair November 1976 (Baltz et al. 1963).

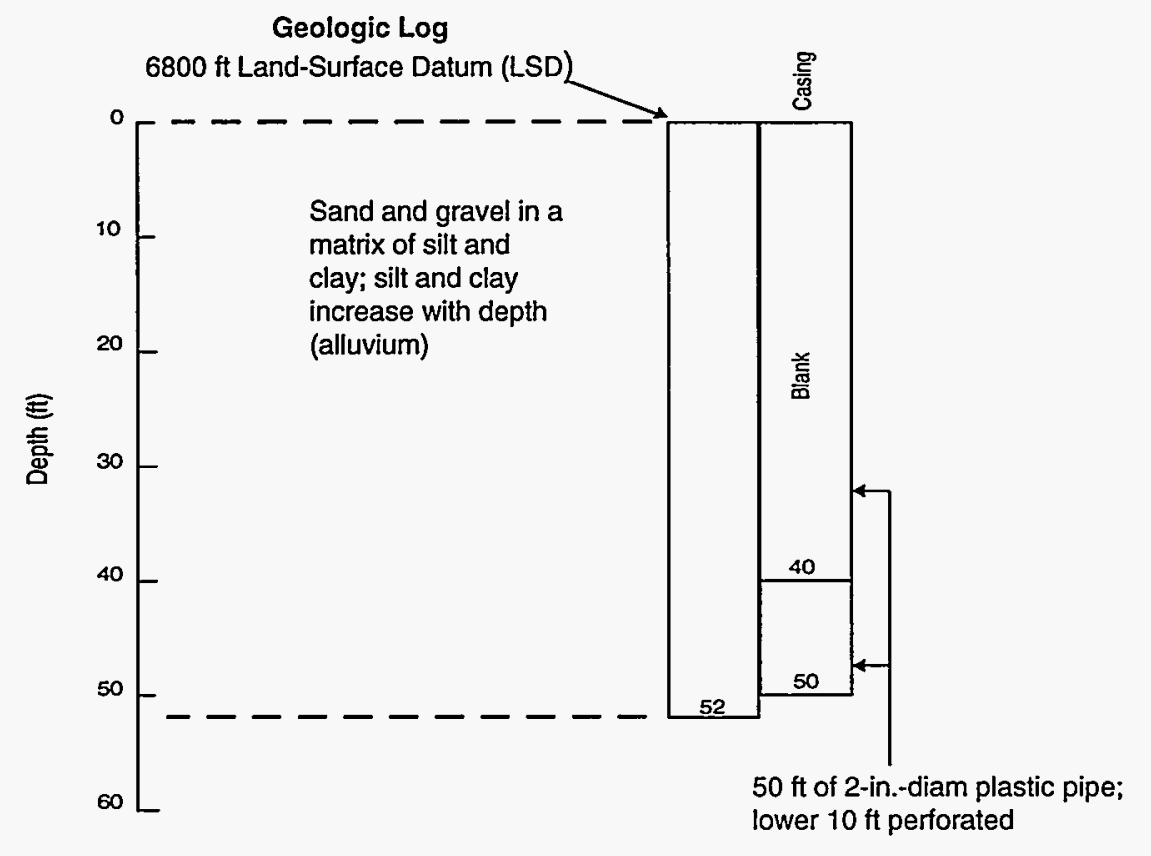

Fig. VI-N. Mortandad Canyon observation well MCO-8A, completed November 1961, dry (Purtymun 1964). 


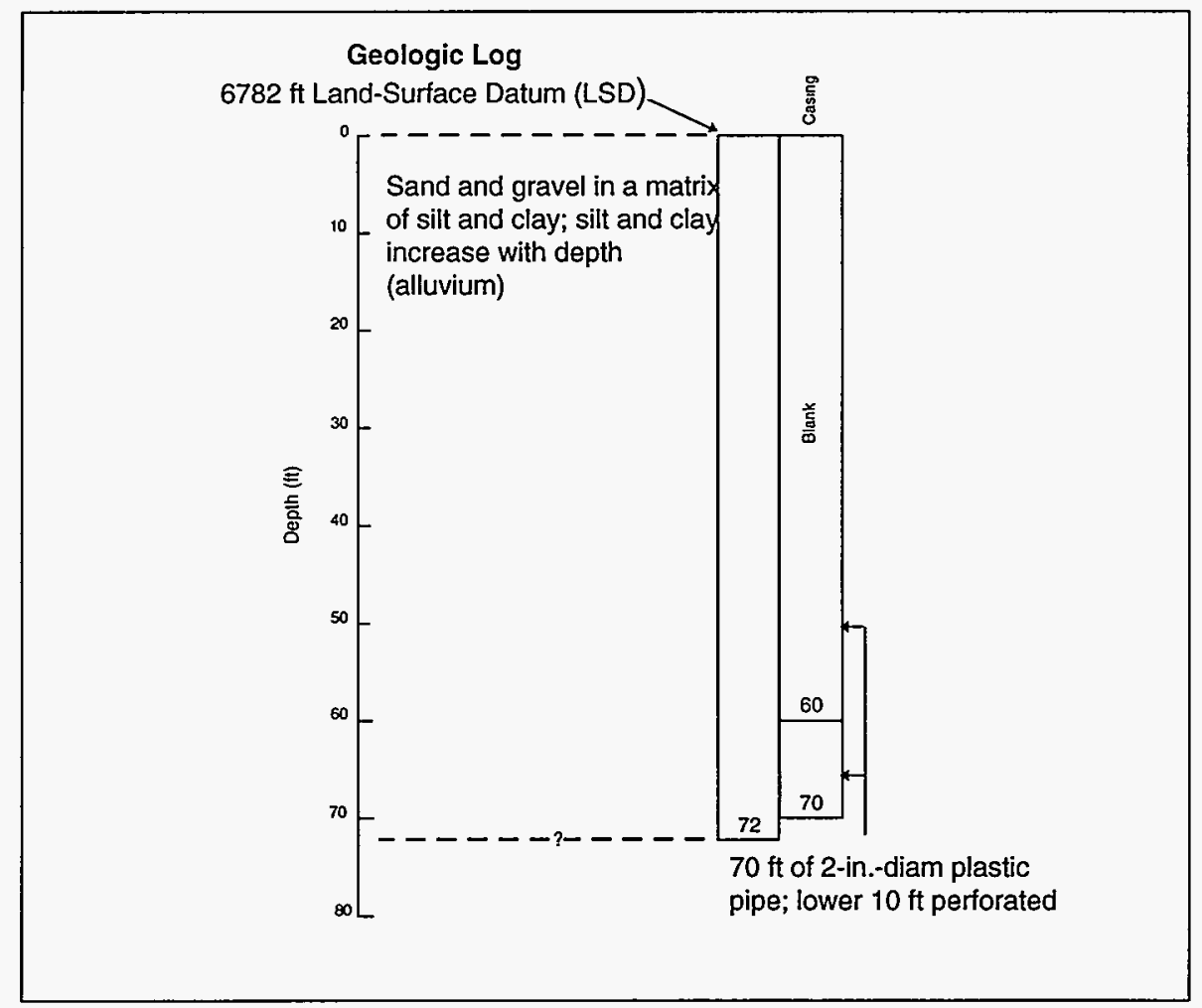

Fig. VI-O. Mortandad Canyon observation well MCO-8.2, completed November 1961, water level $59.2 \mathrm{ft}$ (Purtymun 1964).

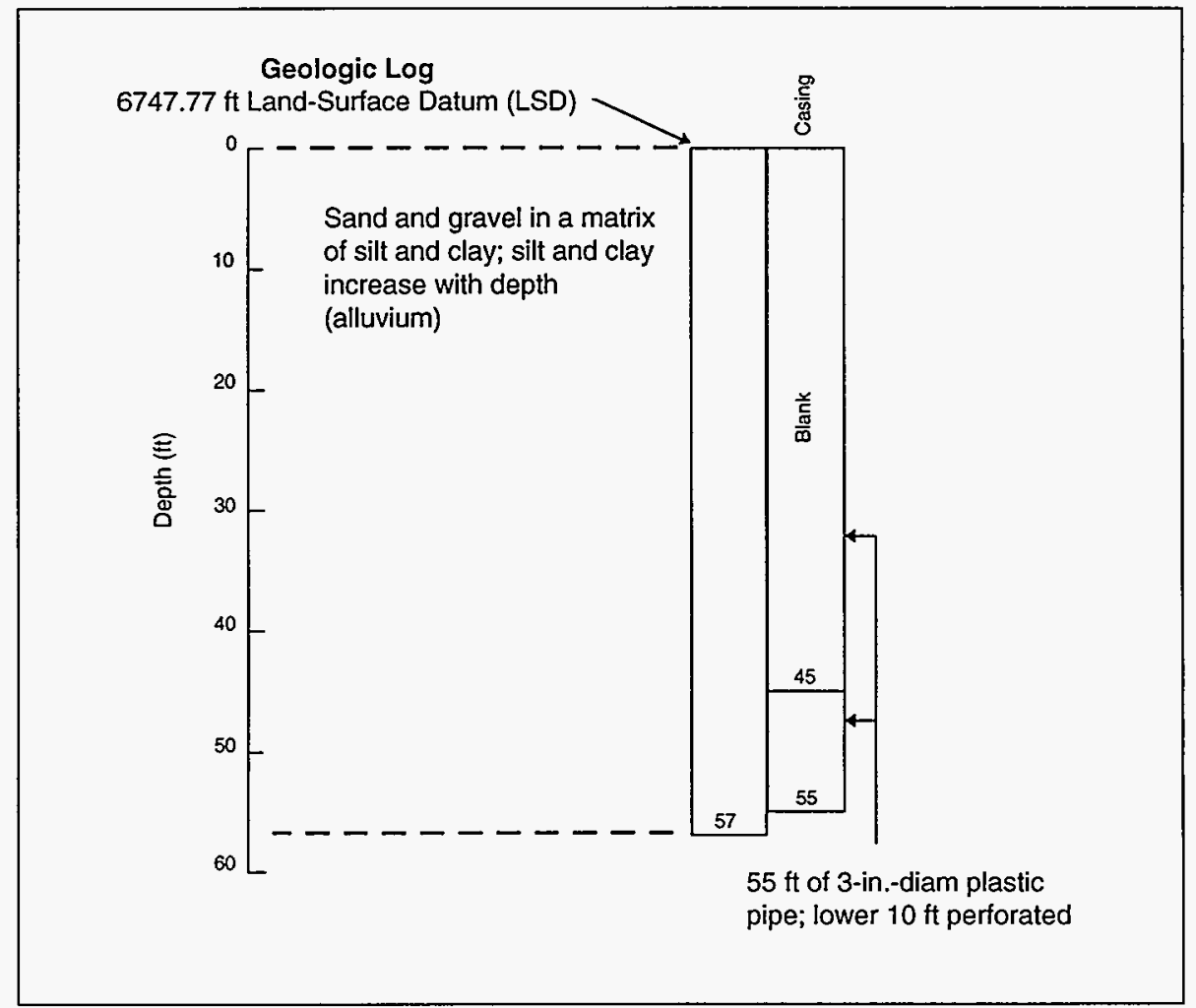

Fig. VI-P. Mortandad Canyon observation well MCO-9, completed November 1961, dry (Purtymun 1964). 


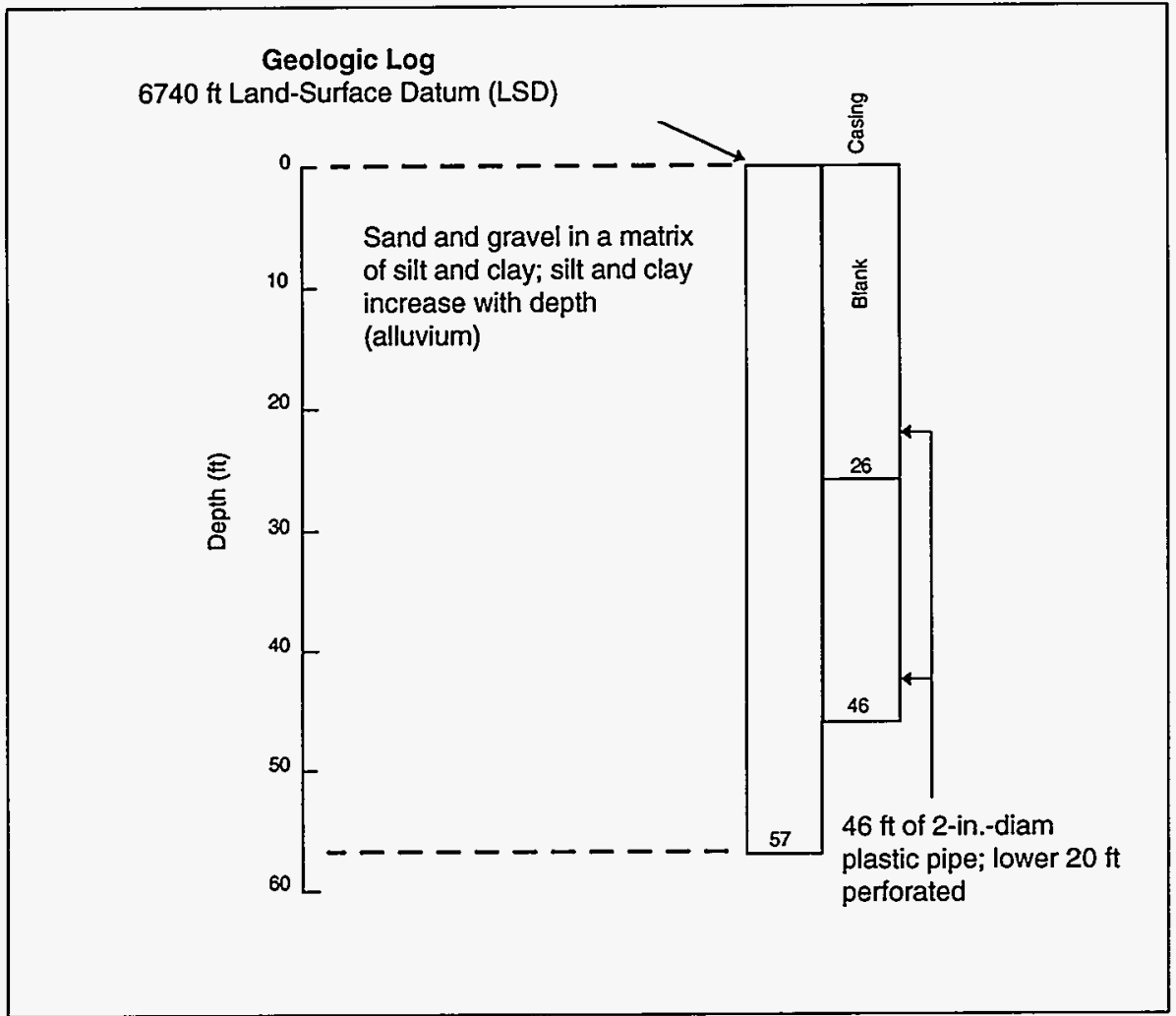

Fig. VI-Q. Mortandad Canyon observation well MCO-9.5, completed November 1961, dry (Purtymun 1964). 


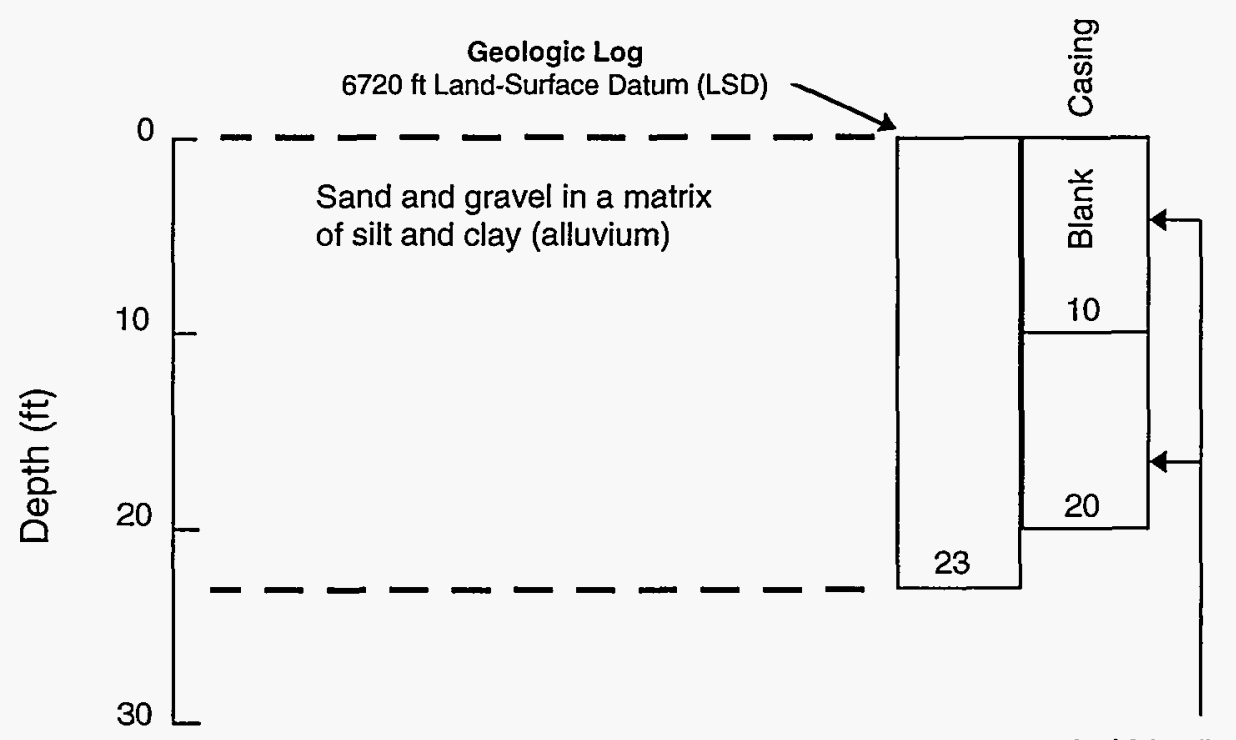

$20 \mathrm{ft}$ of 2-in.-diam plastic pipe; lower $10 \mathrm{ft}$ perforated

Fig. VI-R. Mortandad Canyon observation well MCO-11, completed November 1961, dry; unable to locate, February 1991 (Purtymun 1964).

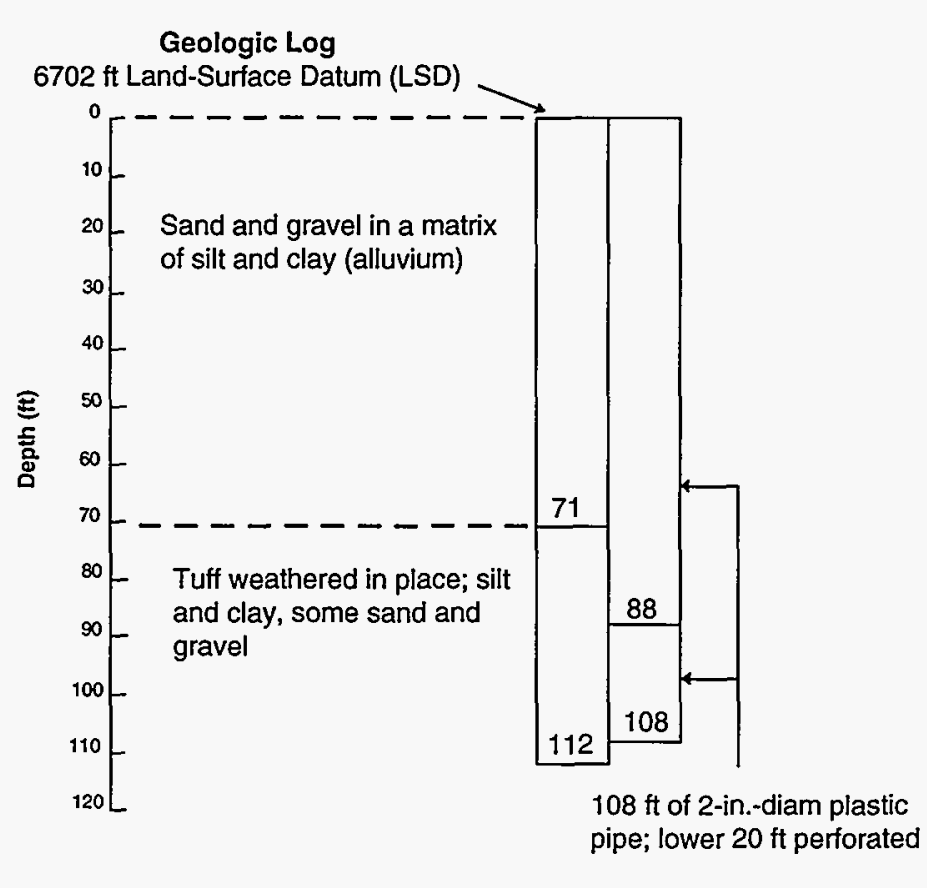

Fig. VI-S. Mortandad Canyon observation well MCO-12, completed June 1971, dry; replaced previous well MCO-12 (see Fig. VI-T.), which was plugged and abandoned about $12 \mathrm{ft}$ to the south (Purtymun 1971b). 


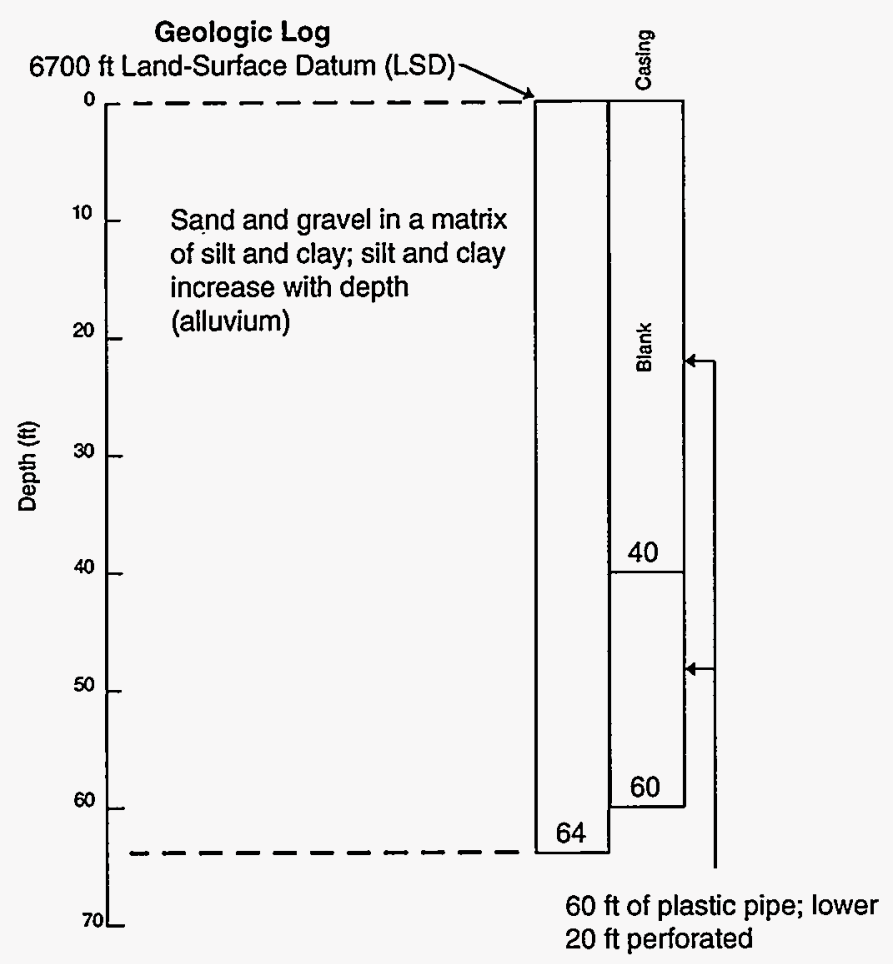

Fig. VI-T. Mortandad Canyon observation well, MCO-12, completed

November 1961, dry; June 1971, well was dry, casing was pulled, well was abandoned, plugged, and relocated to the north about $12 \mathrm{ft}$ (Purtymun 1964).

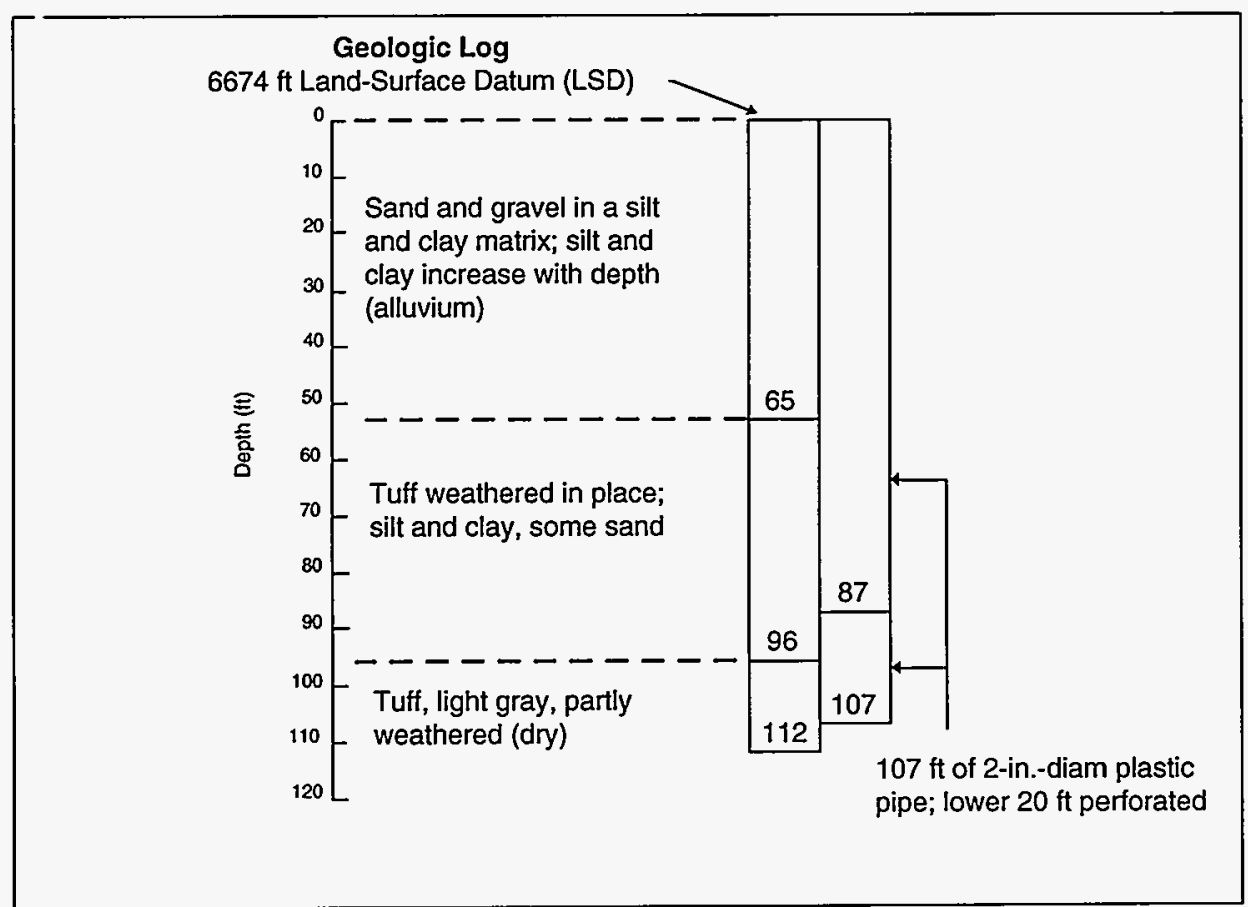

Fig. VI-U. Mortandad Canyon observation well MCO-13, completed July 1970, dry (Purtymun 1970). 


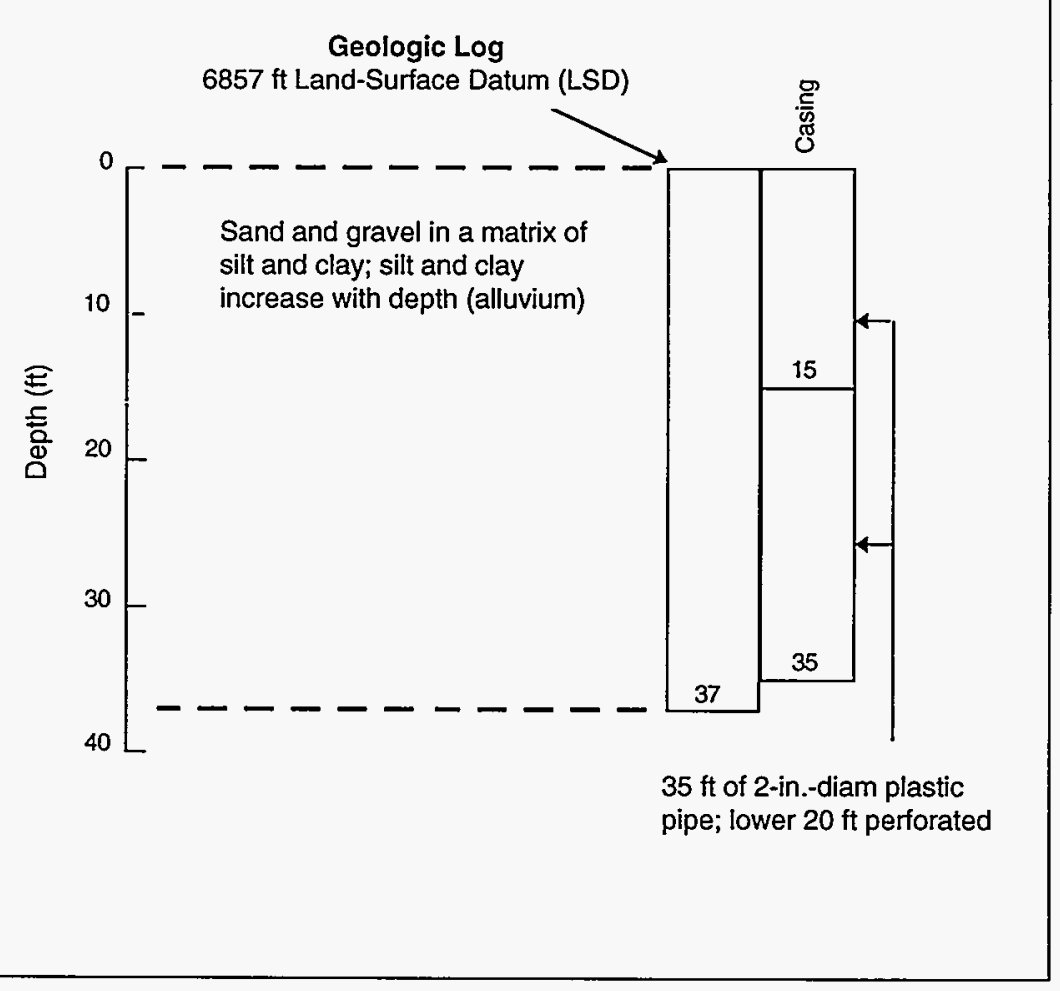

Fig. VI-V. Ten Site Canyon observation well TSCO-1, completed November 1961, dry (Purtymun 1964).

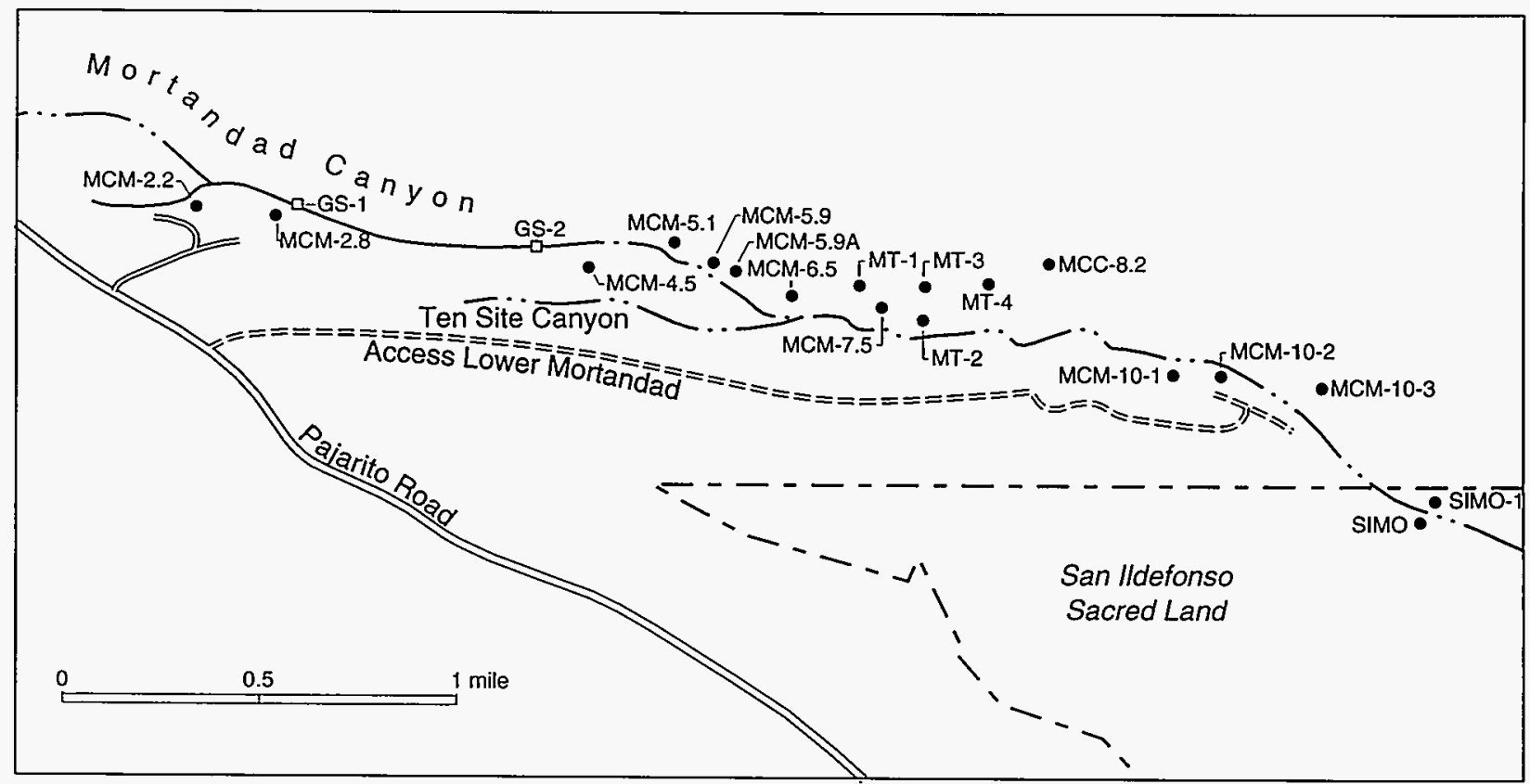

Fig. VI-W. Location of test holes and special moisture-access holes in Mortandad Canyon. 


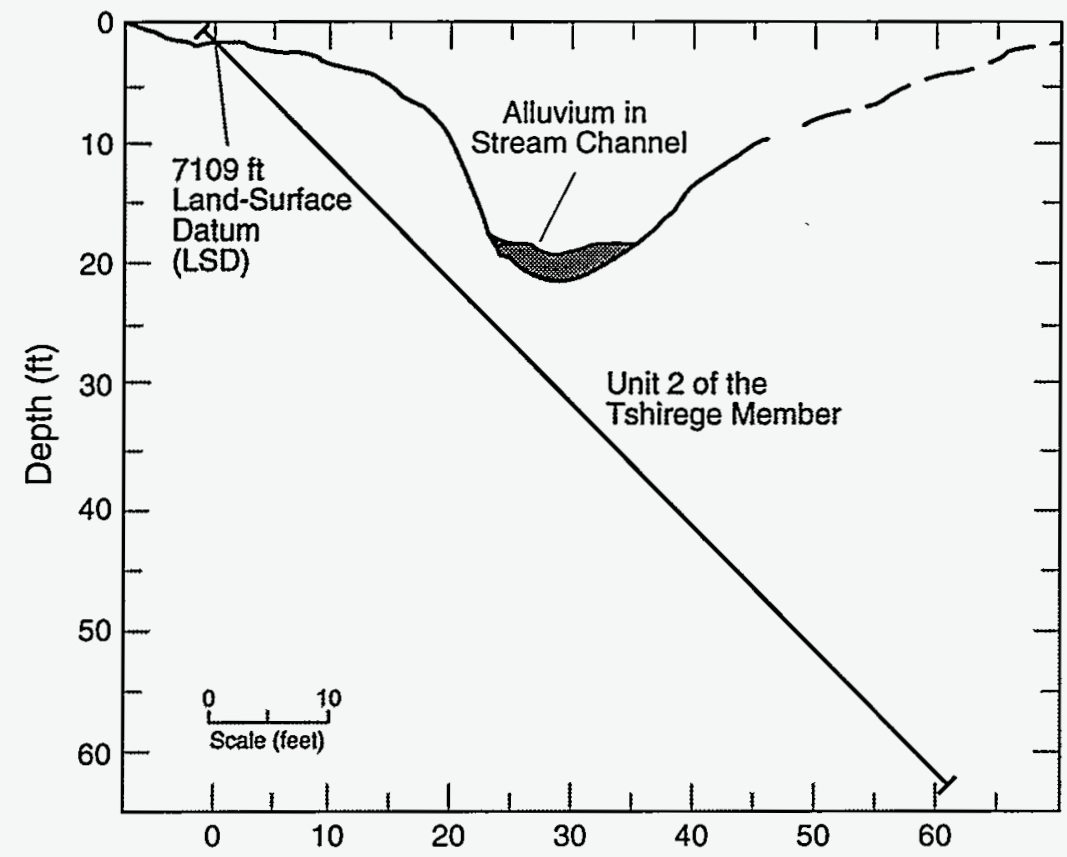

Horizontal Distance in Feet from Top of Casing

Fig. VI-X. Cross section across stream channel showing Mortandad test hole MCM-2.2 (Purtymun 1964). See Fig. VI-W and Table VI-D.

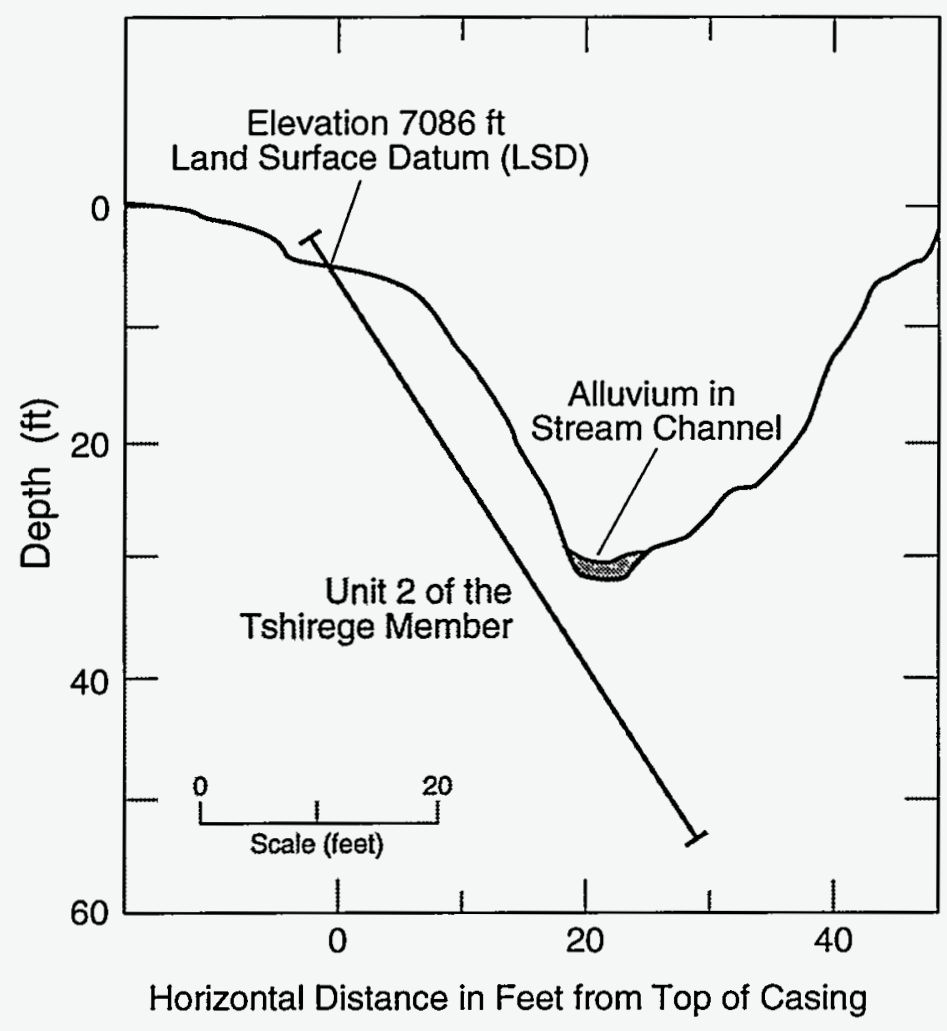

Fig. VI-Y. Cross section across stream channel showing Mortandad test hole MCM-2.8 (Purtymun 1964). See Fig. VI-W and Table VI-D. 


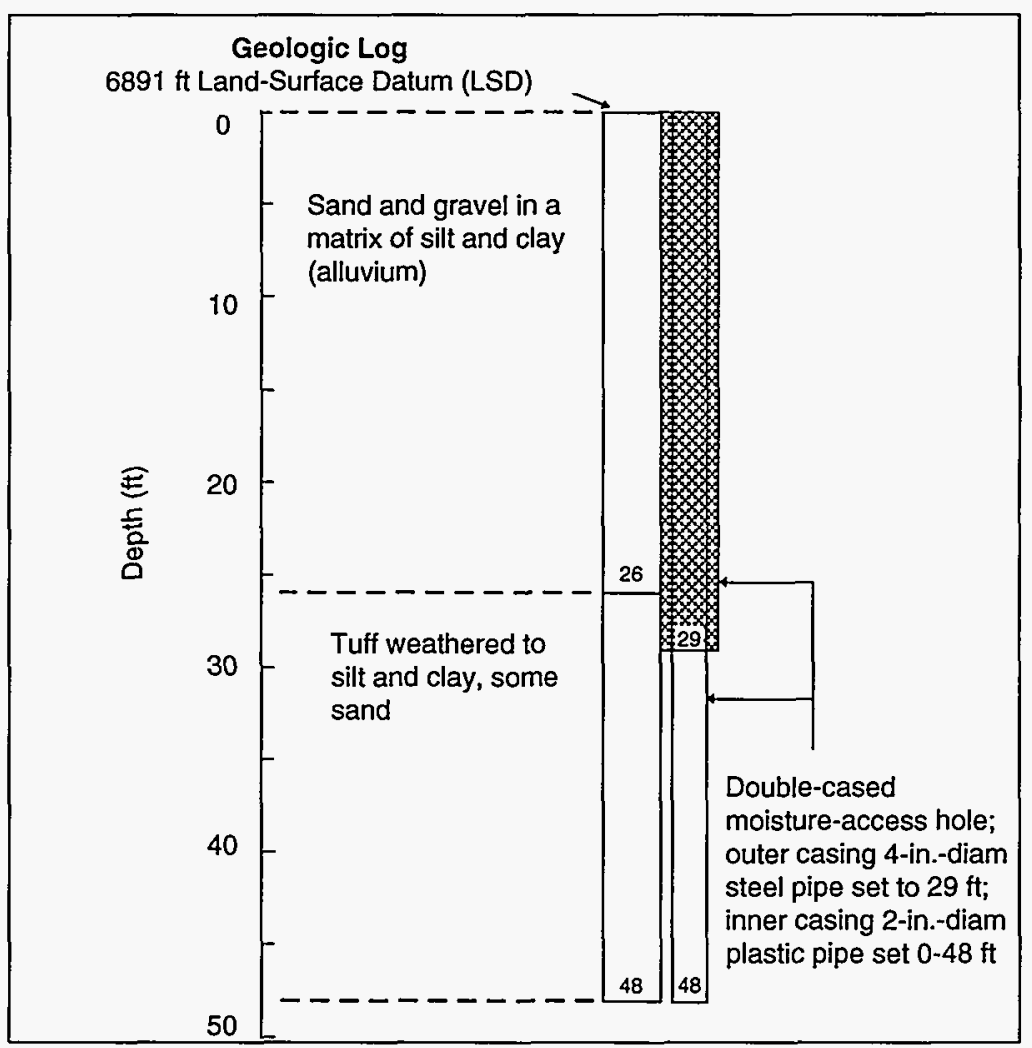

Fig. VI-Z. Mortandad test hole MCM-4.5, completed 1961, water in alluvium cased out of hole (Purtymun 1964). 


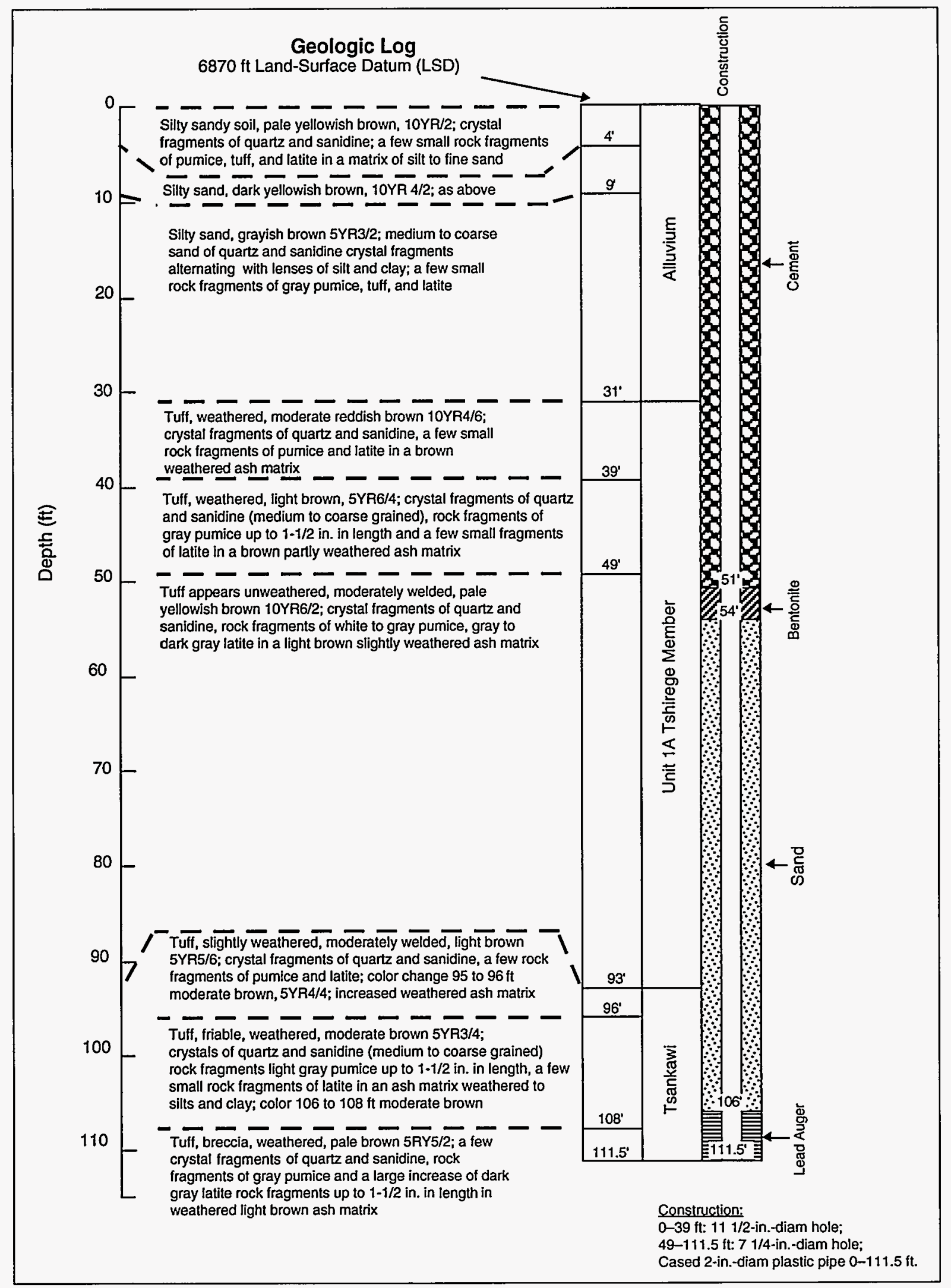

Fig. VI-AA. Mortandad test hole MCM-5.1, completed September 1990, water in alluvium cased out of hole (Stoker et al. 1991). 


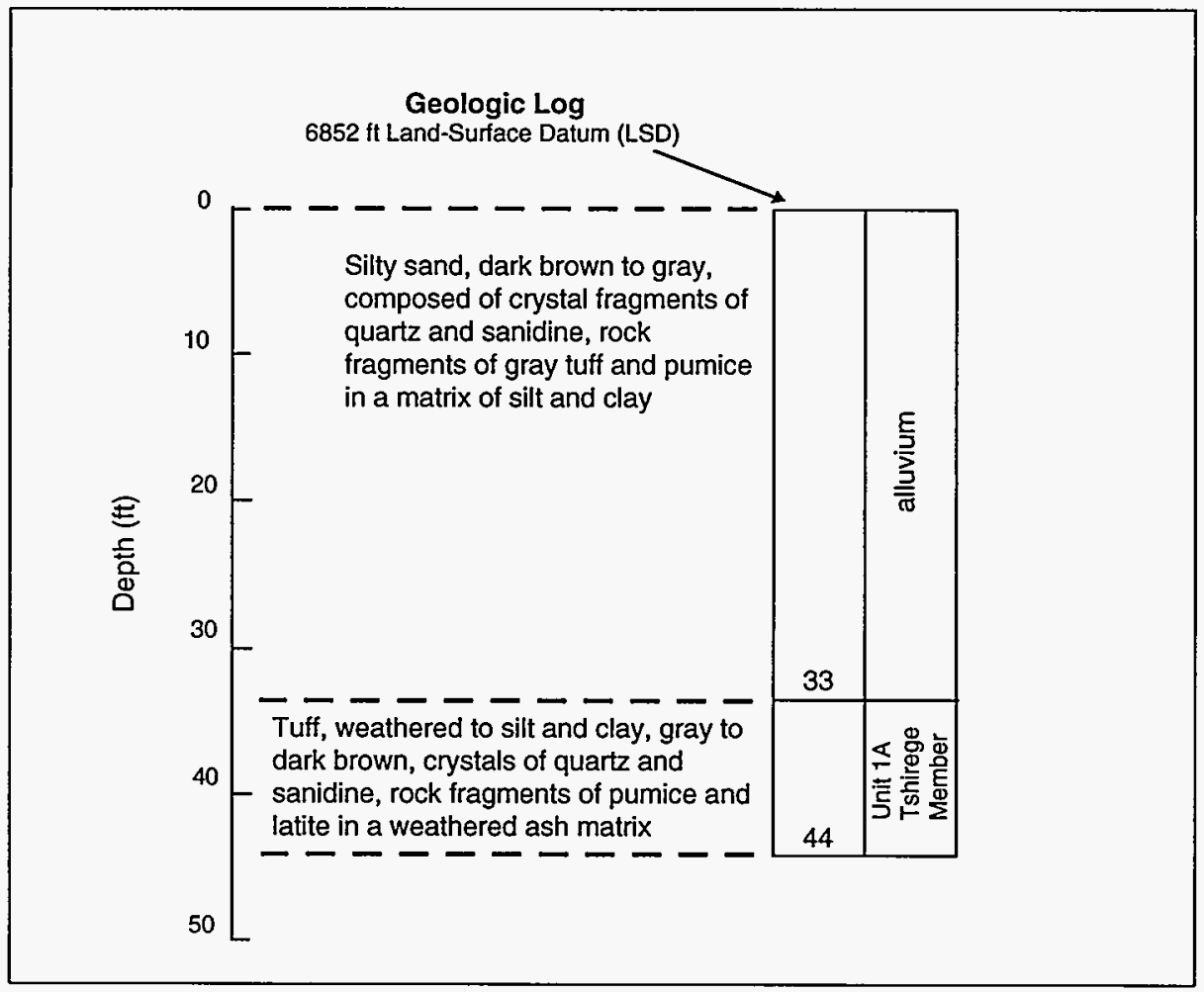

Fig. VI-AB. Mortandad test hole MCM-5.9, drilled July 1990, abandoned and plugged (Stoker et al. 1991). 


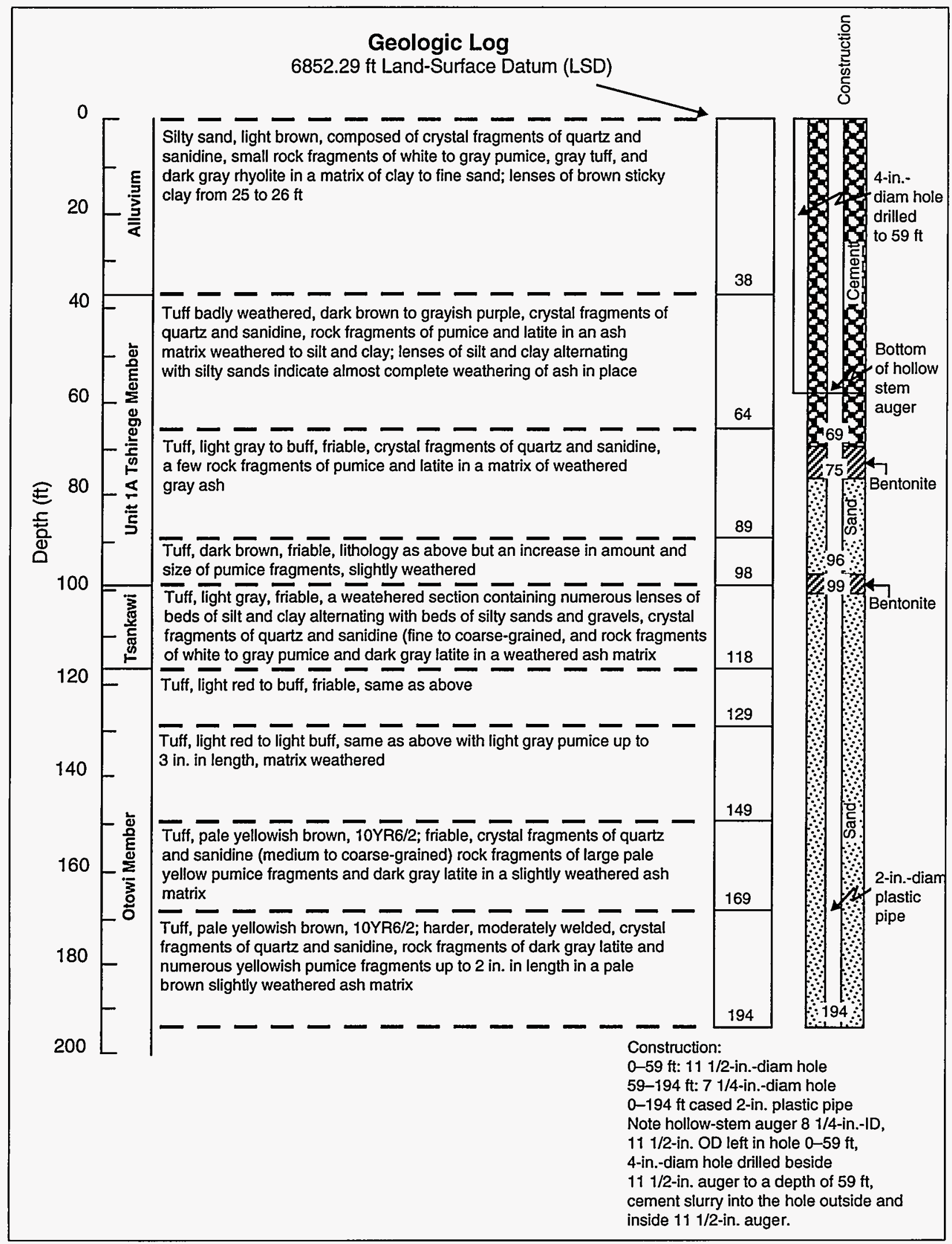

Fig. VI-AC. Mortandad test hole MCM-5.9A, completed July 1990, water in alluvium cased out of hole (Stoker et al. 1991). 


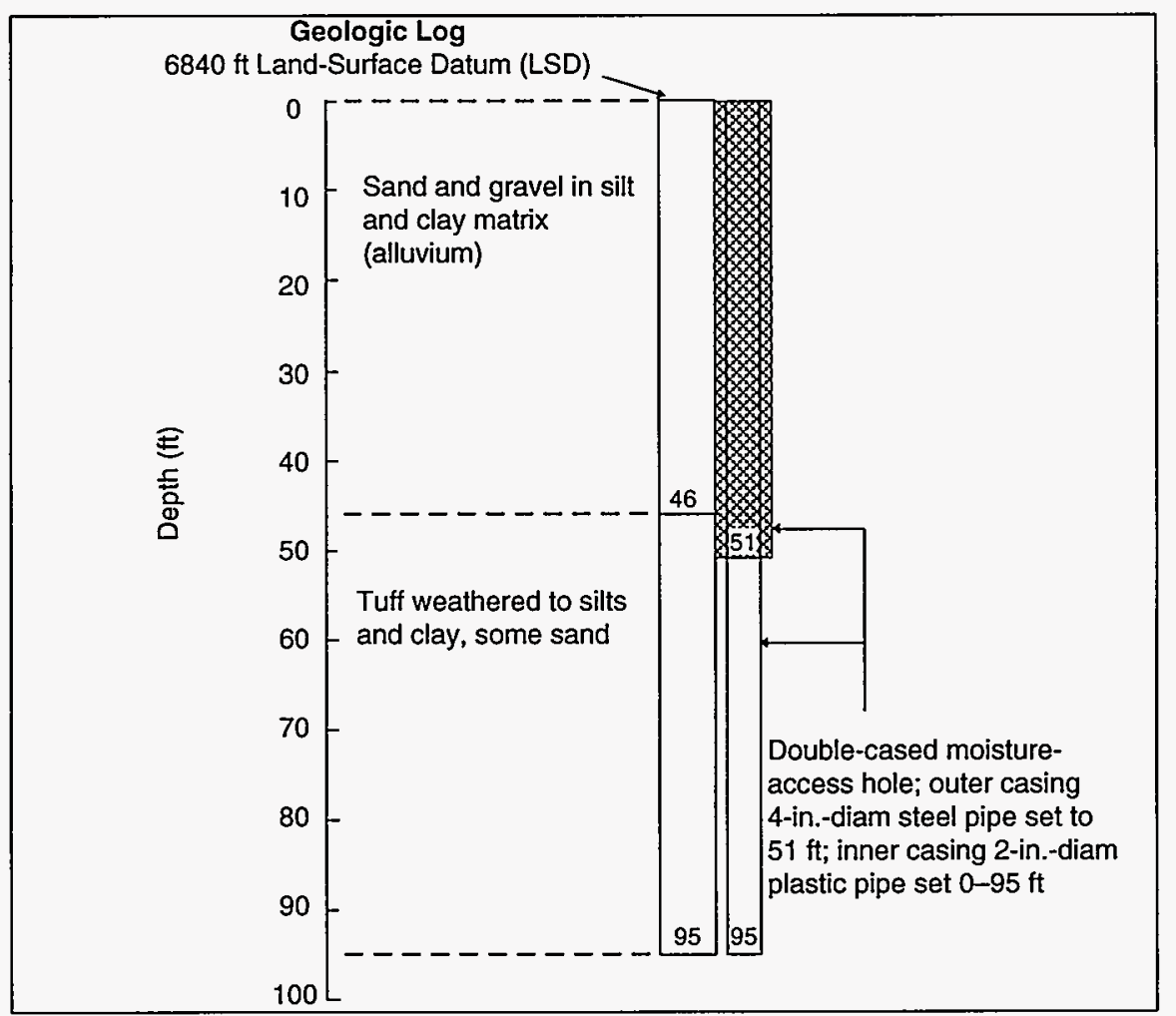

Fig. VI-AD. Mortandad test hole MCM-6.5, completed November 1961, water in alluvium cased out of hole (Purtymun 1964).

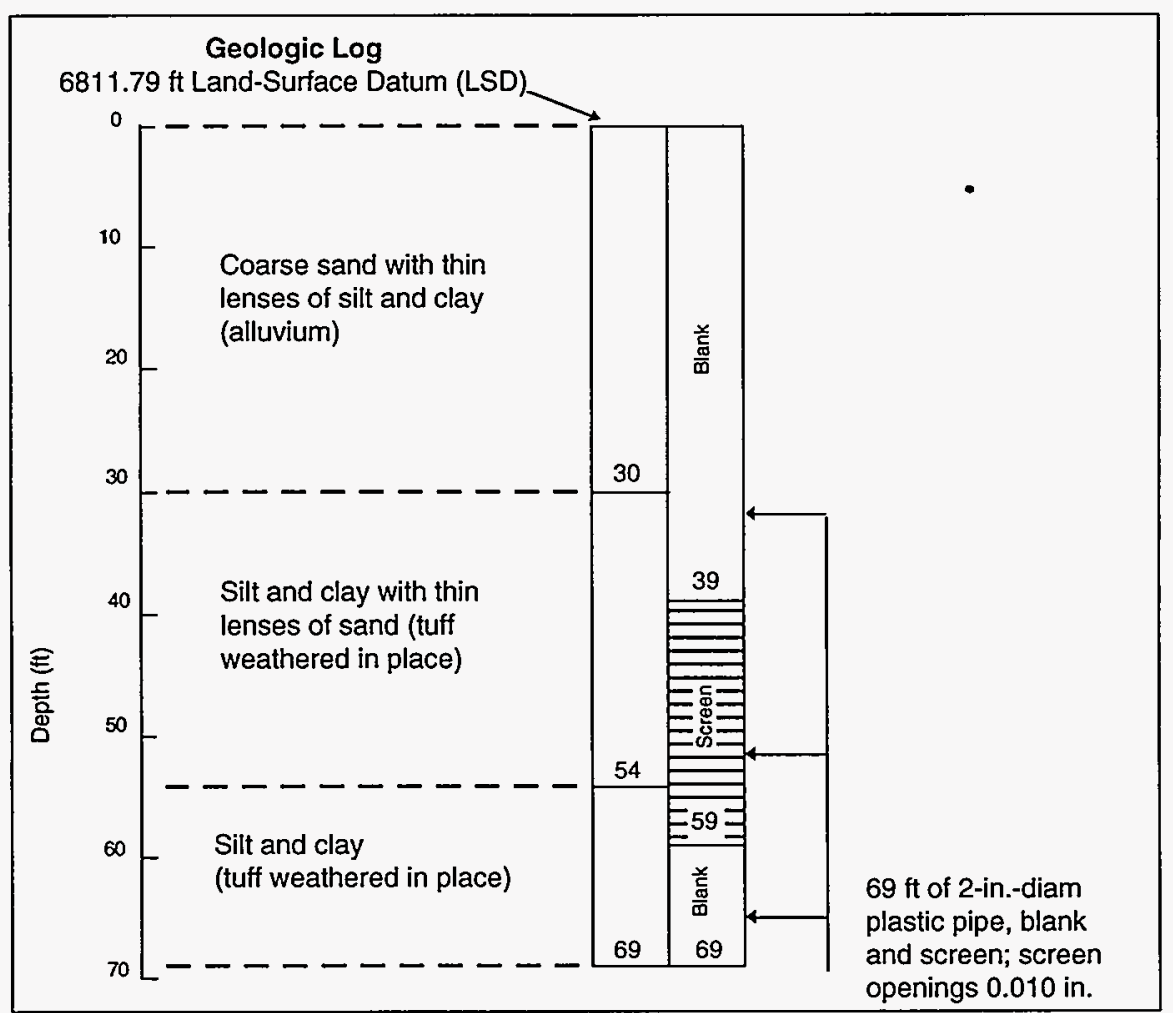

Fig. VI-AE. Mortandad test hole MT-1, completed November 1988, water level $43.0 \mathrm{ft}$ (Stoker et al. 1991). 
Geologic Log

$6796.88 \mathrm{ft}$ Land-Surface Datum (LSD)

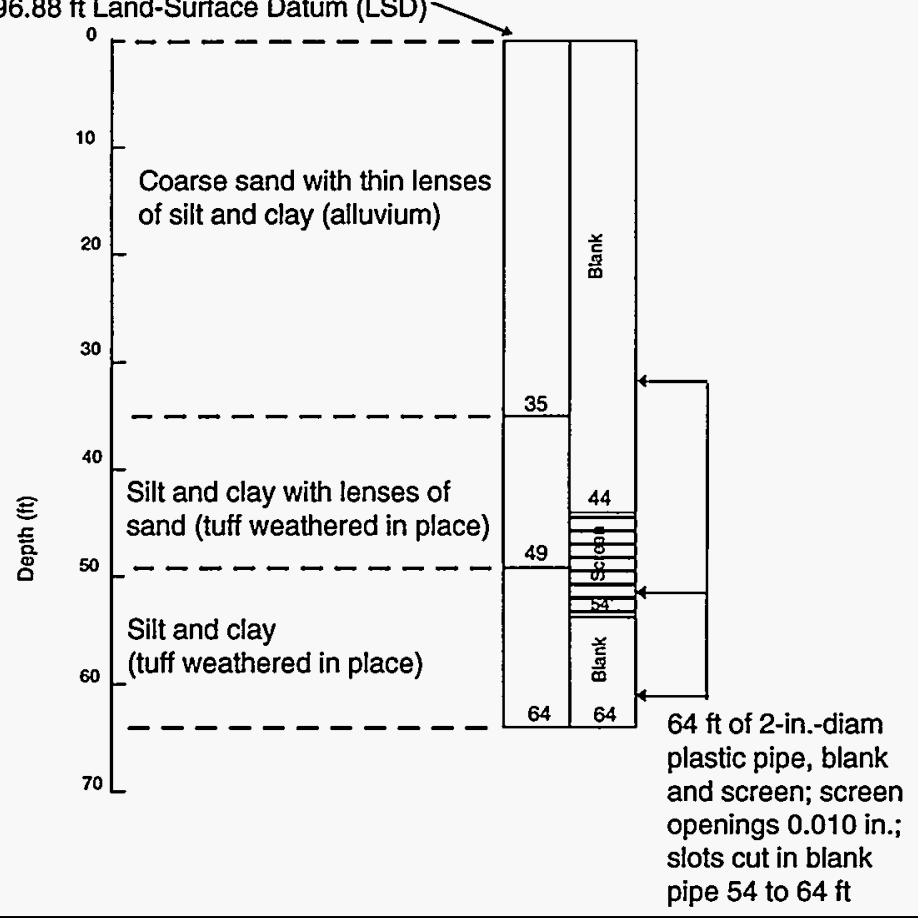

Fig. VI-AF. Mortandad test hole MT-2, completed November 1988, water level $62.0 \mathrm{ft}$ (Stoker et al. 1991).

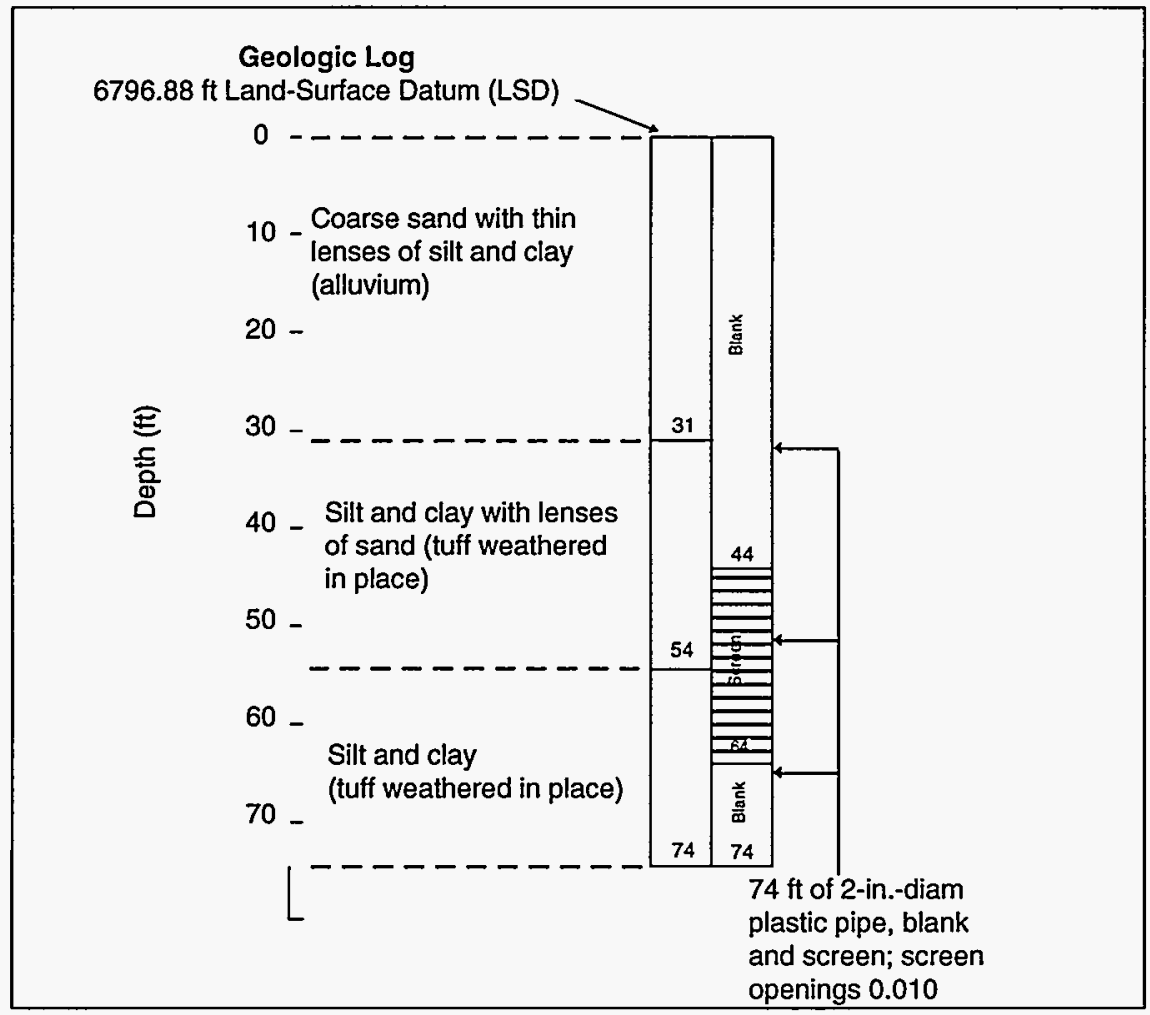

Fig. VI-AG. Mortandad test hole MT-3, completed November 1988, water level $45.0 \mathrm{ft}$ (Stoker et al. 1991). 


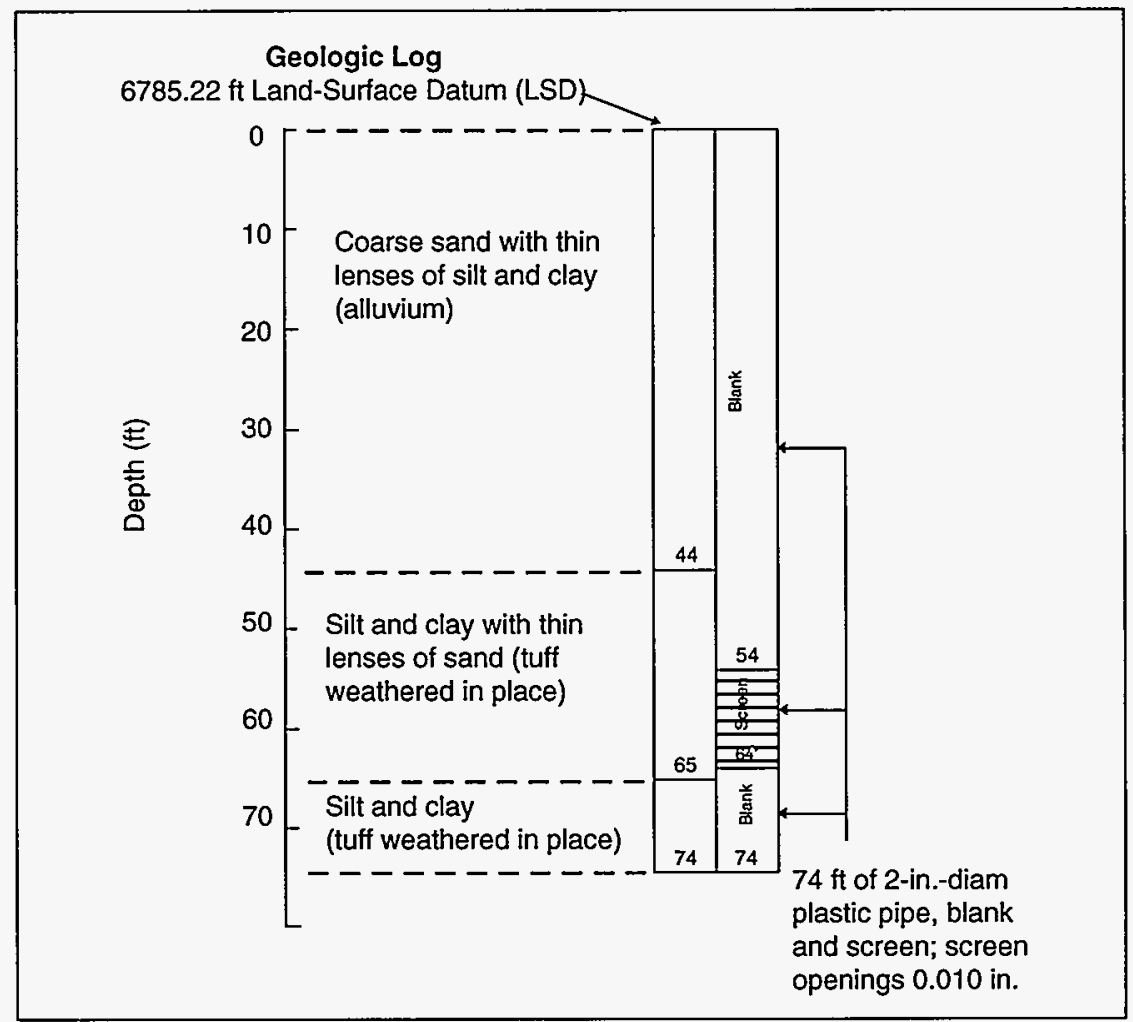

Fig. VI-AH. Mortandad test hole MT-4, completed November 1988, water level $58.0 \mathrm{ft}$ (Stoker et al. 1991).

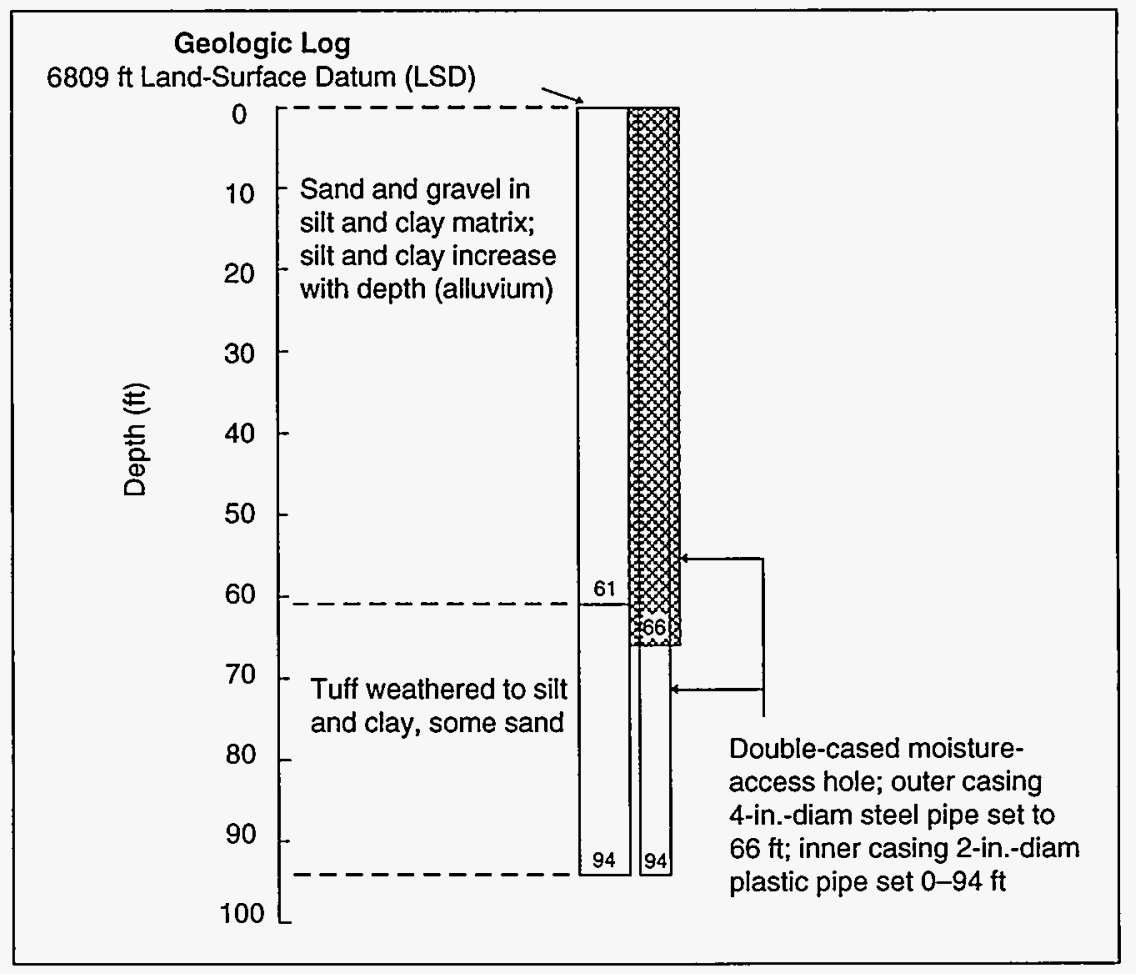

Fig. VI-AI. Mortandad test hole MCM-7.5, completed November 1961, water in alluvium cased out of hole (Purtymun 1964). 


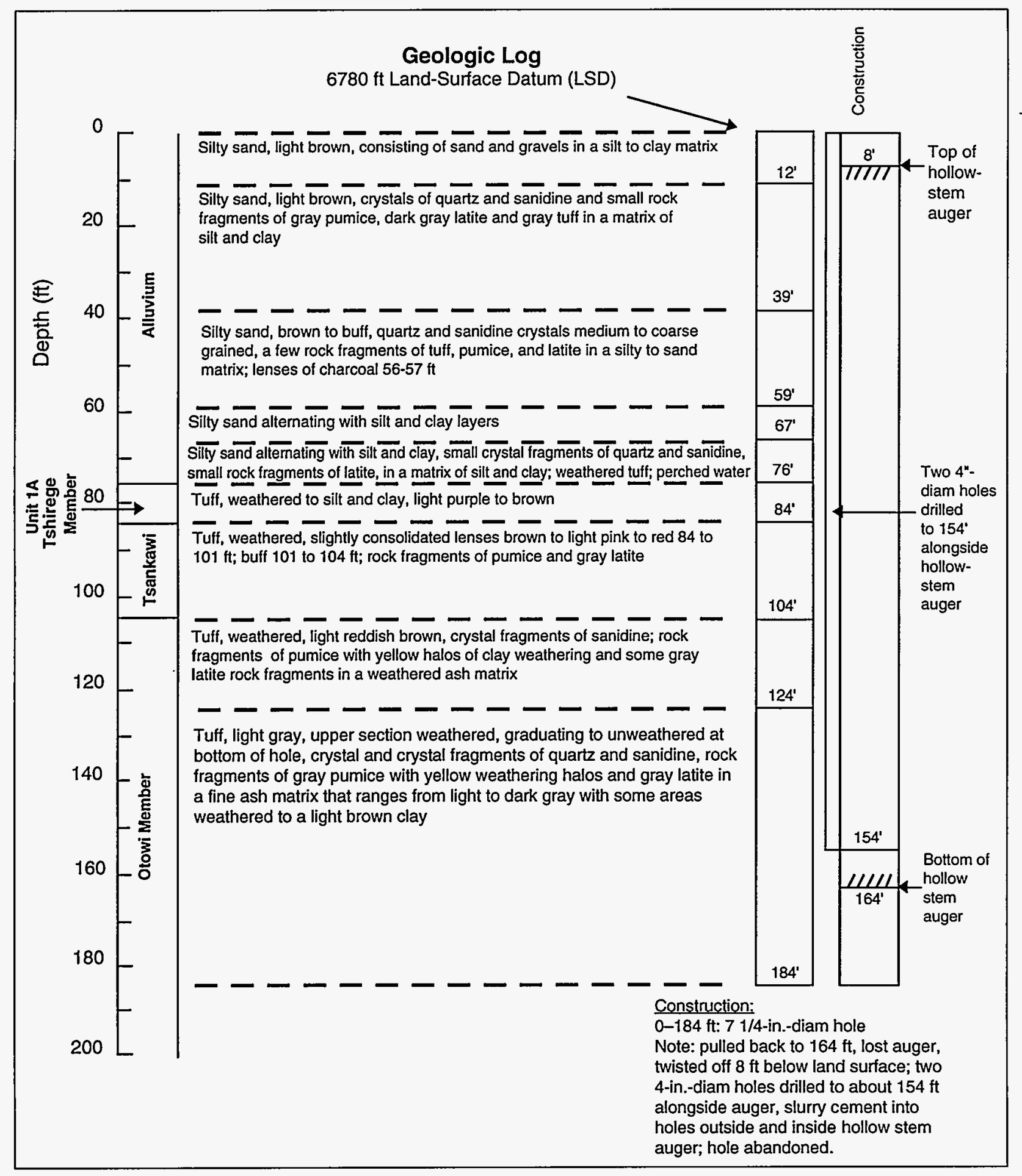

Fig. VI-AJ. Mortandad test hole MCC-8.2, core hole test April 1989, water level $73.0 \mathrm{ft}$ (Stoker et al. 1991). 


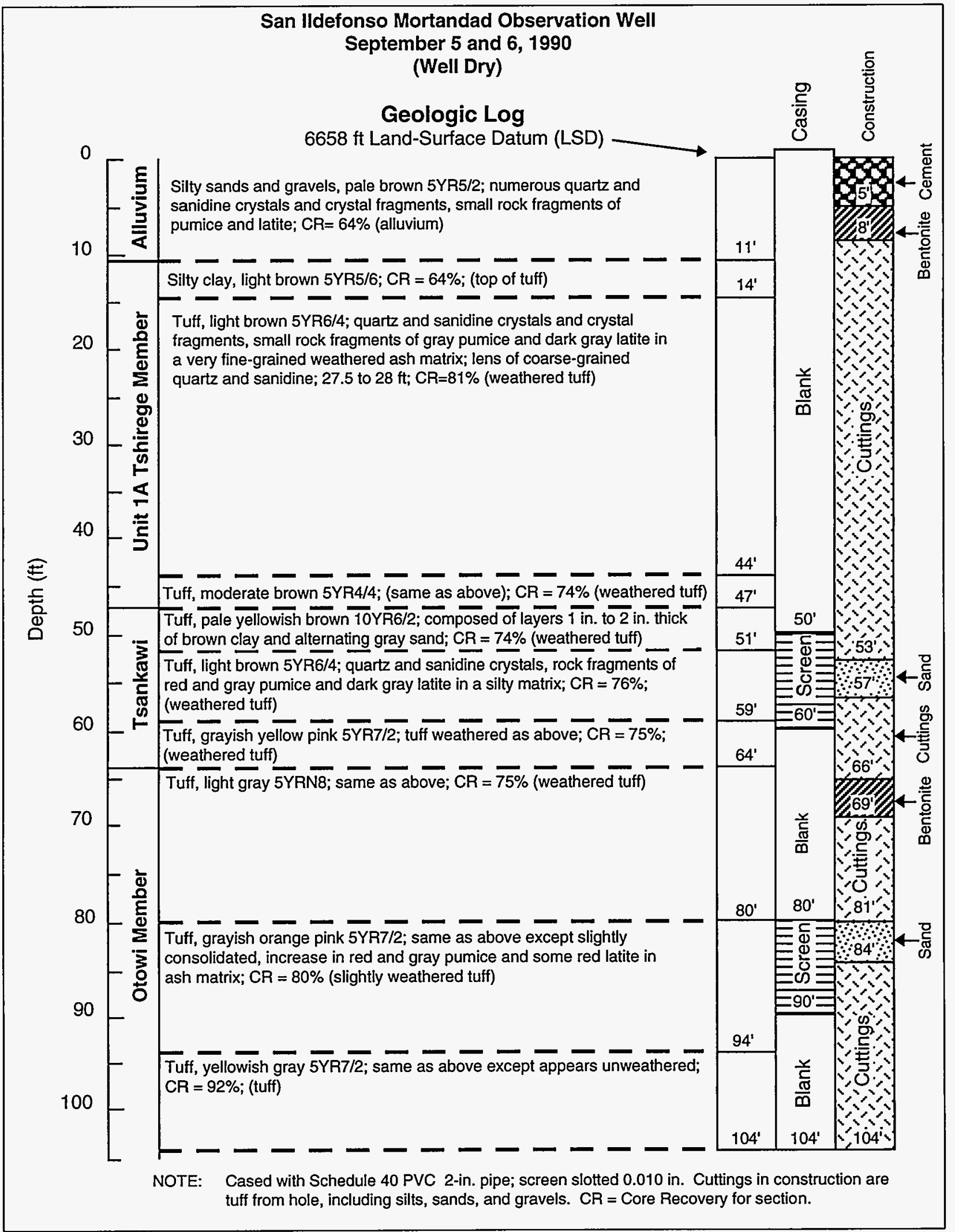

Fig. VI-AK. Mortandad test hole SIMO, drilled in cooperation with San Ildefonso Pueblo and BIA, September 1990, dry (Stoker et al. 1991). 


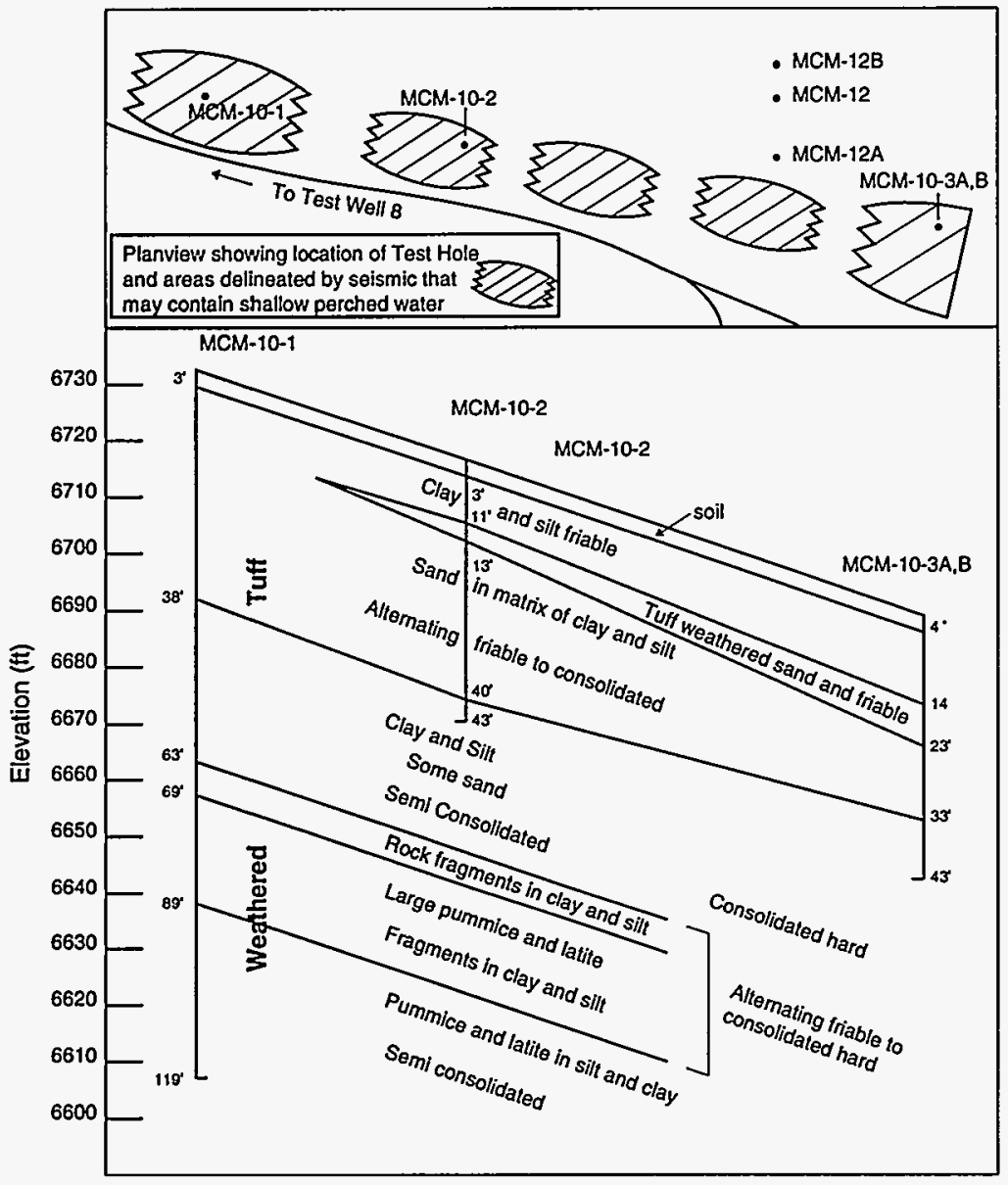

Fig. VI-AL. Mortandad test holes MCM-10-1, $\mathrm{MCM}-10-2$, and MCM-10-3A-B (Purtymun 1992).

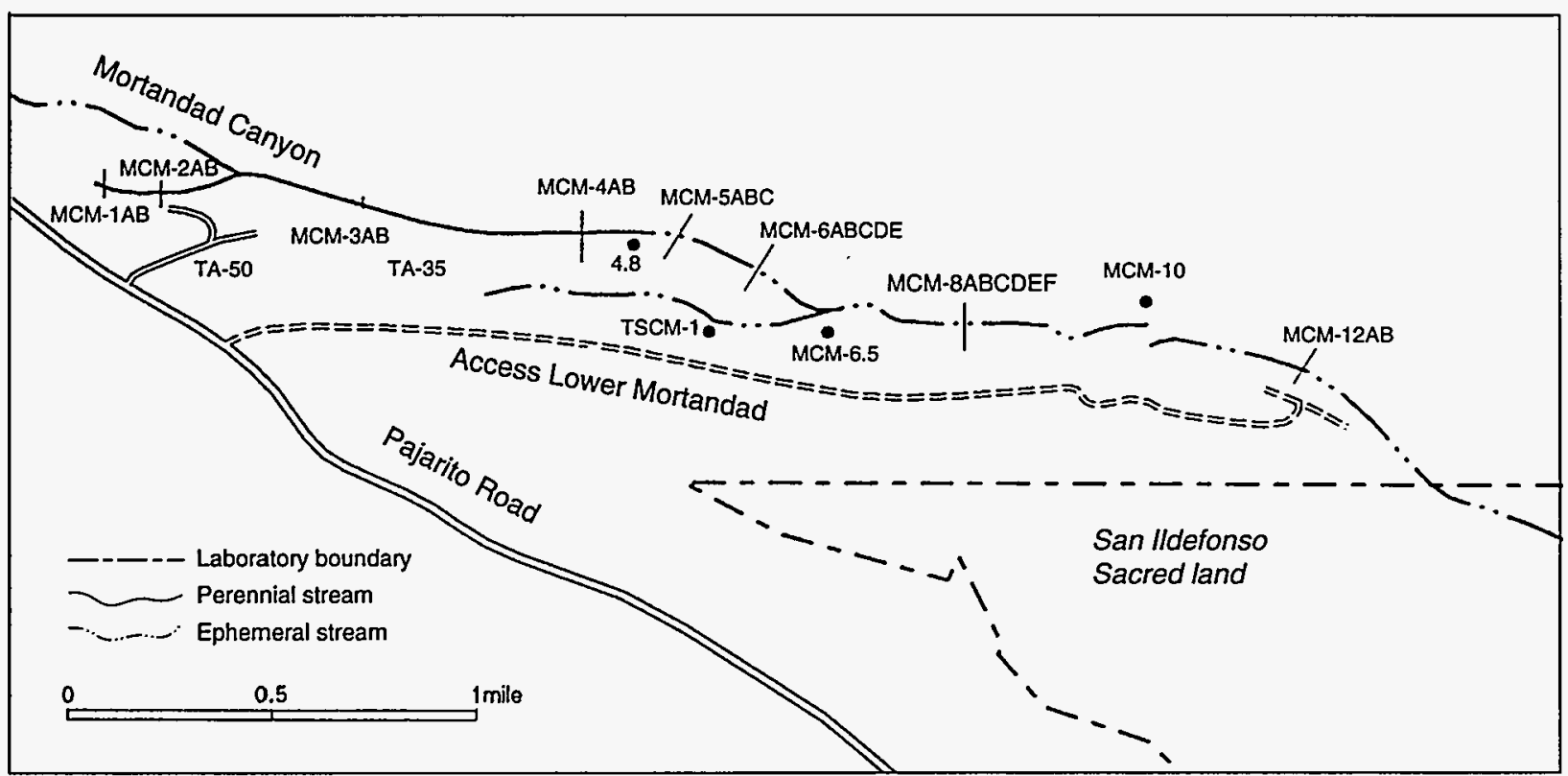

Fig. VI-AM. Locations of moisture-access holes in Mortandad Canyon (letters indicate hole designations across canyon). 


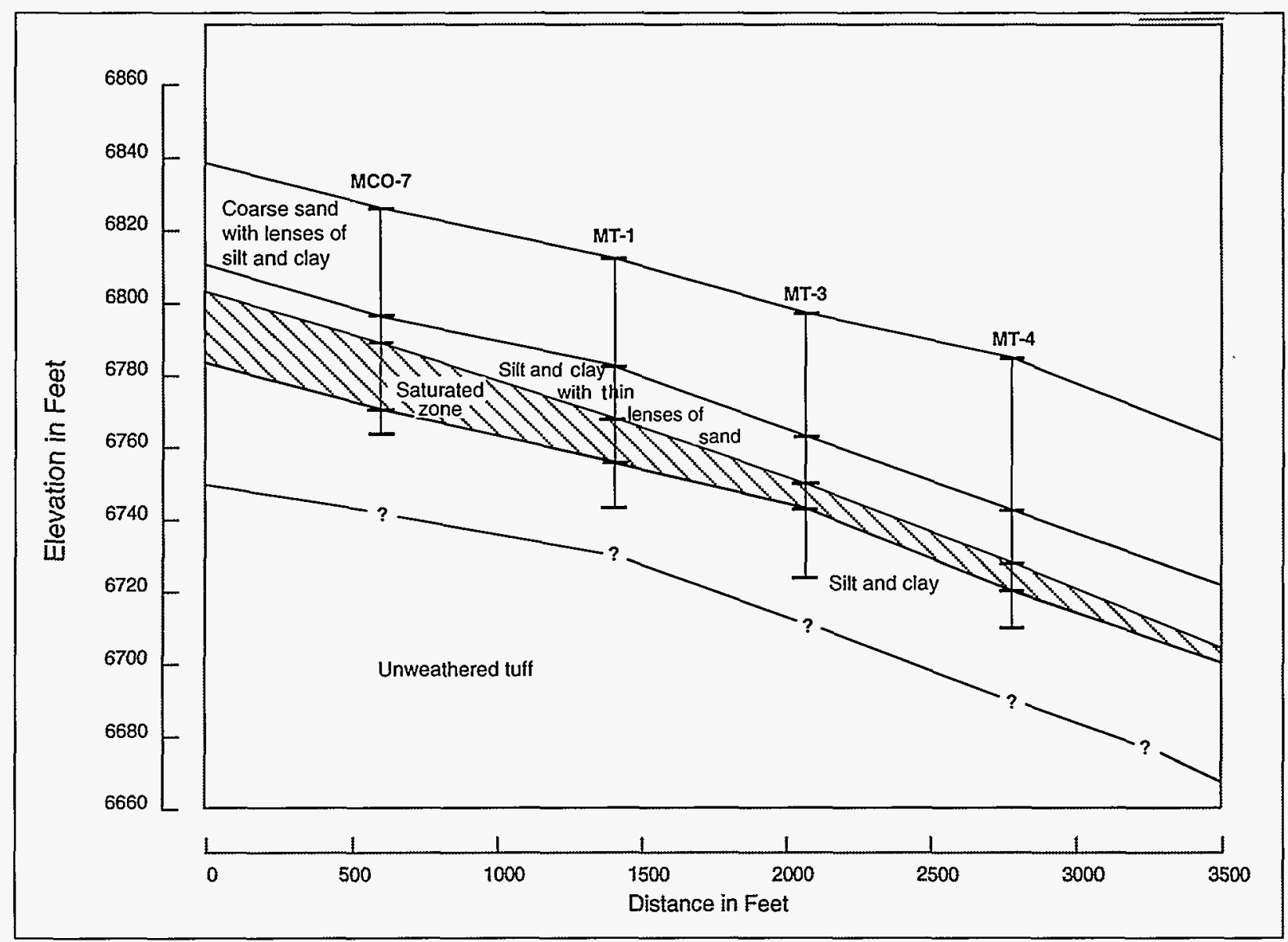

Fig. VI-AN. Geologic section showing alluvium, unweathered tuff, and the saturated zone in lower Mortandad Canyon (Stoker et al. 1991). See Figs. VI-A and VI-W for location.

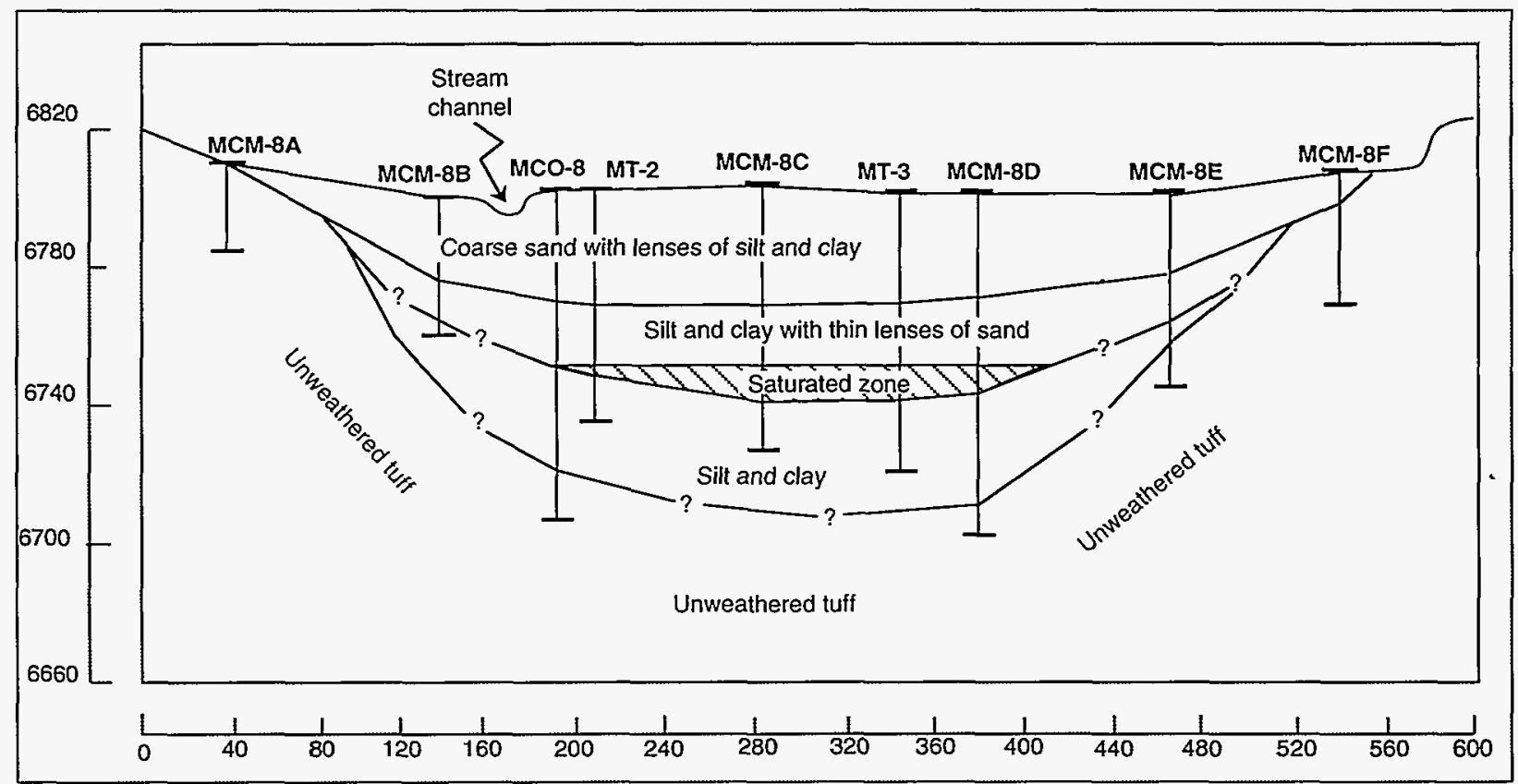

Fig. VI-AO. Geologic section showing alluvium, unweathered tuff, and the saturated zone across lower Mortandad Canyon (Stoker et al. 1991). See Fig. VI-AM for location. 
TABLE VI-A. Hydrologic Data for Observation Wells in Mortandad Canyon

\begin{tabular}{|c|c|c|c|c|c|c|c|c|c|c|}
\hline \multirow{3}{*}{$\begin{array}{l}\text { Observation } \\
\text { Wells }\end{array}$} & \multirow{3}{*}{$\begin{array}{c}\text { Date } \\
\text { Completed }\end{array}$} & \multirow{3}{*}{$\begin{array}{l}\text { Depth } \\
\text { Drilled } \\
\text { (ft) }\end{array}$} & \multirow{3}{*}{$\begin{array}{l}\text { Depth } \\
\text { Completed } \\
\text { (ft) }\end{array}$} & \multirow{3}{*}{$\begin{array}{c}\text { Depth } \\
\text { 1991 }\end{array}$} & \multicolumn{3}{|c|}{ Water Leveis } & \multirow{3}{*}{$\begin{array}{c}\text { Elevation } \\
\text { Land-Surface } \\
\text { Datum (LSD) } \\
\text { (ft) }\end{array}$} & \multirow{2}{*}{\multicolumn{2}{|c|}{$\begin{array}{l}\text { Top of Casing } \\
\text { (Measuring Point) } \\
\text { to Land Surface }\end{array}$}} \\
\hline & & & & & \multirow{2}{*}{$\begin{array}{c}\text { At } \\
\text { Completion } \\
\text { (ft) }\end{array}$} & \multirow{2}{*}{$\begin{array}{c}\text { At } \\
\text { Present } \\
\text { Date }\end{array}$} & \multirow[b]{2}{*}{$(\mathrm{ft})$} & & & \\
\hline & & & & & & & & & Datum & Remarks \\
\hline MCO-1 & $11 / 60$ & 8 & 8 & - & 2.8 & 一 & 一 & 7153 & - & Unable to locate in \\
\hline 1991 & & & & & & & & & & \\
\hline MCO-2 & $11 / 60$ & 10 & 9 & 7.5 & 0.3 & $4 / 91$ & 5.06 & 7133 & 2.00 & \\
\hline MCO-3 & $3 / 67$ & 18 & 12 & 10.1 & 4.4 & $4 / 91$ & 3.36 & 7052.72 & 1.54 & $\begin{array}{l}\text { Originally drilled } \\
11 / 60 ; \text { redrilled and } \\
\text { cased } 3 / 67\end{array}$ \\
\hline $\mathrm{MCO}-4$ & $10 / 63$ & 24 & 19 & 16.3 & 3.3 & $4 / 91$ & 7.19 & 6900.36 & 1.02 & \\
\hline $\mathrm{MCO}-4.9$ & $7 / 73$ & 42 & 30 & 23.4 & - & $4 / 91$ & 22.10 & 6879.31 & 1.25 & \\
\hline $\mathrm{MCO} .5$ & $10 / 60$ & 47 & 46 & 44.9 & 24.6 & $2 / 91$ & 20.75 & 6875.80 & 1.95 & \\
\hline MCO-6 & $10 / 60$ & 82 & 71 & - & 38.1 & - & - & 6849 & - & $\begin{array}{l}\text { Plugged and abandoned } \\
\text { (relocated) }\end{array}$ \\
\hline MCO-6 & $3 / 74$ & 47 & 47 & 41.5 & 28.9 & $2 / 91$ & 33.75 & 6848.96 & 2.34 & \\
\hline $\mathrm{MCO}-6.5 \mathrm{~A}$ & $11 / 61$ & 47 & 45 & 33.3 & 41.0 & $2 / 91$ & Dry & 6840 & 2.15 & \\
\hline MCO-6.5B & $11 / 61$ & 42 & 42 & 36.0 & 36.3 & $2 / 91$ & Dry & 6839 & 0.70 & \\
\hline $\mathrm{MCO}-7$ & $10 / 60$ & 77 & 69 & 54.7 & 39.7 & $2 / 91$ & 37.47 & 6827.40 & 1.24 & \\
\hline MCO-7.5A & $11 / 61$ & 63 & 60 & - & 41.2 & - & - & 6809 & - & $\begin{array}{l}\text { Well damaged } \\
\text { (relocated) }\end{array}$ \\
\hline MCO-7.5B & $4 / 74$ & 62 & 60 & 56.0 & 42.1 & $2 / 91$ & 43.71 & 6808.80 & 1.28 & \\
\hline $\mathrm{MCO}-8$ & $10 / 60$ & 92 & 84 & 22.7 & 61.6 & & - & 6796.70 & 0.25 & Obstruction in well \\
\hline $\mathrm{MCO}-8 \mathrm{~A}$ & $11 / 61$ & 52 & 50 & 48.5 & Dry & $2 / 91$ & Dry & 6800 & 0.61 & \\
\hline MCO-8.2 & $11 / 61$ & 72 & 70 & 60.3 & 59.2 & $2 / 91$ & Dry & 6782 & 2.00 & \\
\hline MCO-9 & $11 / 60$ & 57 & 55 & 54.6 & Dry & $2 / 91$ & Dry & 6747.77 & 1.44 & \\
\hline MCO-9.5 & $11 / 61$ & 57 & 46 & 40.3 & Dry & $2 / 91$ & Dry & 6740 & 2.00 & \\
\hline MCO-11 & $11 / 61$ & 23 & 20 & - & Dry & - & - & 6720 & - & $\begin{array}{l}\text { Unable to locate in } \\
1991\end{array}$ \\
\hline $\mathrm{MCO}-12$ & $11 / 61$ & 64 & 60 & - & Dry & - & - & 6700 & - & $\begin{array}{l}\text { Casing pulled; hole } \\
\text { plugged (relocated) }\end{array}$ \\
\hline MCO- 12 & $6 / 71$ & 112 & 108 & 96.2 & Dry & $2 / 91$ & Dry & 6702 & 0.62 & \\
\hline $\mathrm{MCO}-13$ & $7 / 70$ & 112 & 107 & 106.2 & Dry & $2 / 91$ & Dry & 6674 & 0.67 & \\
\hline TSCO-1 & $11 / 61$ & 37 & 35 & 23.1 & Dry & $2 / 91$ & 8.93 & 6857 & 0.97 & \\
\hline
\end{tabular}

Sources: Baltz et al. 1963; Purtymun 1964, 1971, and 1974. 
TABLE VI-B. Geologic Logs and Construction Data for Observation Wells in Mortandad Canyon (20 Obs. Wells)

\section{Observation Well MCO-1}

Geologic Log

Thickness

(ft)

8

Depth

Tuff, unweathered, overlain by about $1 \mathrm{ft}$ of silt and sand

Note: Well abandoned, in stream channel.

\section{Observation Well MCO-2}

Geologic Log

Tuff, unweathered, overlain by about $1 \mathrm{ft}$ of silt and sand

Note: Well abandoned: in stream channel.

\section{Observation Well MCO-3}

Geologic Log

Alluvium

Sand and gravel in a matrix of silt and clay

Tuff (weathered in place)

Silt and clay with some lenses

of sand and gravel

Construction

$12 \mathrm{ft}$ of 3-in.-diam plastic pipe, lower $10 \mathrm{ft}$ perforated.

\section{Observation Well $\mathrm{MCO}-4$}

Geologic Log

Alluvium

Sand and gravel in a matrix of silt and clay

Tuff (weathered in place)

Silt and clay with lenses of sand

Construction

$19 \mathrm{ft}$ of 3-in.-diam plastic pipe, lower $15 \mathrm{ft}$ perforated.

\section{Observation Well $\mathrm{MCO}-4.9$}

Geologic Log

Alluvium

Sand and gravel in a matrix of silt and clay

Tuff (weathered in place) silt and clay with gravel

Thickness

(ft)

18

6

Depth

(ft)

(ft)

10

10

Thickness

(ft)

7

11
Depth

18

18

Depth

(ft)

7

(ft)

24

\section{Construction}

$30 \mathrm{ft}$ of 3-in.-diam plastic pipe, lower $20 \mathrm{ft}$ perforated.

Thickness

(ft)

27

16
Depth

(ft)

27

43 
TABLE VI-B. Geologic Logs and Construction Data for Observation Wells in Mortandad Canyon (20 Obs. Wells)(Continued)

\section{Observation Well MCO-5}

Geologic Log

Alluvium

Sand and gravel with lenses of silt and clay

Tuff (weathered in place)

Silt and clay with some lenses

of sand and gravel

Construction

$46 \mathrm{ft}$ of 3-in.-diam plastic pipe, lower $25 \mathrm{ft}$ perforated.
Thickness Depth

(ft) $\quad \underline{(\mathrm{ft})}$

$35 \quad 35$

12

47

\section{Observation Well MCO-6}

Geologic Log

Thickness

(ft)

Depth

Alluvium

Sand, gravel, and occasional cobbles in a

matrix of silt and clay

Tuff (weathered in place)

Silt and clay with minor amounts

of sand and gravel

36

36

46

82

Construction

$71 \mathrm{ft}$ of 3-in.-diam plastic pipe, lower $35 \mathrm{ft}$ perforated, well drilled October 1960 . Well destroyed by flood, summer 1973; redrilled and constructed as a new well about $10 \mathrm{ft}$ to the northeast (March 1974): $47 \mathrm{ft}$ of 4-in.-diam plastic pipe, lower $20 \mathrm{ft}$ perforated.

\section{Observation Well MCO-6.5A}

Geologic Log

Thickness Depth

Alluvium

Sand and gravel in a matrix of silt and clay

(ft)

(ft)

onstruction

$45 \mathrm{ft}$ of 2-in.-diam plastic pipe, lower $20 \mathrm{ft}$ perforated.

\section{Observation Well MCO-6.5B}

Geologic Log

Alluvium

Sand and gravel in a matrix of silt and clay
Thickness

(ft)

42
Depth

(ft)

42

Construction

$42 \mathrm{ft}$ of casing, upper $22 \mathrm{ft}$ of 4-in.-diam steel pipe; lower $20 \mathrm{ft}$ of 4-in.-diam plastic pipe, perforated. 
TABLE VI-B. Geologic Logs and Construction Data for Observation Wells in Mortandad Canyon (20 Obs. Wells)(Continued)

\section{Observation Well MCO-7}

\section{Geologic Log}

Alluvium

Sand and gravel in a silt and clay matrix

Tuff (weathered in place)

Silt and clay with lenses

of sand and gravel

Construction

$69 \mathrm{ft}$ of 3-in.-diam plastic pipe, lower $30 \mathrm{ft}$ perforated.

$\begin{array}{cc}\begin{array}{c}\text { Thickness } \\ (\mathrm{ft})\end{array} & \begin{array}{c}\text { Depth } \\ (\mathrm{ft})\end{array} \\ 55 & 55 \\ & \\ 22 & 77\end{array}$

Depth

55

7

\section{Observation Well MCO-7.5A/7.5B}

\section{Geologic Log}

Alluvium

Sand and gravel in a matrix of silt and clay; silt and clay increase with depth

Tuff (weathered in place) silt and clay

$\begin{array}{cc}\begin{array}{c}\text { Thickness } \\ \text { (ft) }\end{array} & \begin{array}{c}\text { Depth } \\ (\mathrm{ft})\end{array} \\ & \\ 60 & 60 \\ 3 & 63\end{array}$

Construction

November 1961, $60 \mathrm{ft}$ of 3-in.-diam plastic pipe, lower $20 \mathrm{ft}$ perforated; well destroyed by falling tree, replaced April 1974 about $6 \mathrm{ft}$ to the west: $60 \mathrm{ft}$ of 4 -in.-diam plastic pipe, lower $25 \mathrm{ft}$ perforated.

\section{Observation Well MCO-8}

Geologic Log

Alluvium

Sand and gravel in a matrix of silt and

clay; silt and clay increase with depth

Tuff (weathered in place)

Silt and clay with lenses of fine to coarse sand
Thickness

(ft)

61

31
Depth

(ft)

61

92

Construction

$84 \mathrm{ft}$ of 3-in.-diam plastic pipe, lower $20 \mathrm{ft}$ perforated; well damaged, bailer stuck at about $23 \mathrm{ft}$.

\section{Observation Well MCO-8A}

Geologic Log

Alluvium

Sand and gravel in a matrix of silt and

clay; silt and clay increase with depth

Construction

$50 \mathrm{ft}$ of 2-in.-diam plastic pipe, lower $10 \mathrm{ft}$ perforated.
Thickness Depth

(ft) $\quad(\mathrm{ft})$

$52 \quad 52$ 
TABLE VI-B. Geologic Logs and Construction Data for Observation Wells in Mortandad Canyon (20 Obs. Wells)(Continued)

14. Observation Well MCO-8.2

Geologic Log

Thickness

(ft)

72

clay; silt and clay increase with depth

Construction

$70 \mathrm{ft}$ of 2-in.-diam plastic pipe, lower $10 \mathrm{ft}$ perforated.

\section{Observation Well MCO-9}

\section{Geologic Log}

Alluvium

Sand, some gravel in a matrix of silt and

clay; silt and clay increase with depth

Construction

$55 \mathrm{ft}$ of 3-in.-diam plastic pipe, lower $10 \mathrm{ft}$ perforated.

\section{Observation Well MCO-9.5}

\section{Geologic Log}

Alluvium

Sand and gravel in a matrix of silt and

clay; silt and clay increase with depth

Construction

$46 \mathrm{ft}$ of 2-in.-diam plastic pipe, lower $20 \mathrm{ft}$ perforated.
Thickness

(ft)

57

57

(ft)

$\begin{array}{cc}\begin{array}{c}\text { Thickness } \\ (\mathrm{ft})\end{array} & \begin{array}{c}\text { Depth } \\ (\mathrm{ft})\end{array} \\ 57 & 57\end{array}$

Depth

(ft)

72

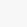


TABLE VI-B. Geologic Logs and Construction Data for Observation Wells in Mortandad Canyon (20 Obs. Wells)(Continued)

\section{Observation Well MCO-12}

\section{Geologic Log}

Thickness

(ft)

Alluvium

Sand and gravel in a matrix of silt and clay; silt and clay increase with depth

Tuff (weathered in place)

Silt and clay with some sand and gravel; near

bottom, unweathered gray tuff
71

41
Depth

(ft)

71

112

\section{Construction}

Note: This well (1971) replaces the well from 1961 that was about $64 \mathrm{ft}$ deep and was located about $12 \mathrm{ft}$ to the south (its casing was pulled and the hole was plugged); this new well was constructed in June 1971: $108 \mathrm{ft}$ of 2-in.-diam plastic pipe, lower $20 \mathrm{ft}$ perforated.

\section{Observation Well MCO-13}

\section{Geologic Log}

Alluvium

Sand and some gravel in a matrix of silt and

clay; silt and clay increase with depth

Tuff (weathered in place)

Silt and clay with lenses of sand and gravel

Tuff (unweathered) light gray

Thickness

(ft)

65

31

16
Depth

(ft)

65

96

112

Construction

$107 \mathrm{ft}$ of 2-in.-diam plastic pipe, lower $20 \mathrm{ft}$ perforated; hole gravel packed.

\section{Observation Well TSCO-1}

\section{Geologic Log}

Alluvium

Sand and gravel in a matrix of silt and clay

Construction

$35 \mathrm{ft}$ of 2-in.-diam plastic pipe, lower $20 \mathrm{ft}$ perforated.

$\begin{array}{cc}\begin{array}{c}\text { Thickness } \\ \text { (ft) }\end{array} & \begin{array}{c}\text { Depth } \\ (\mathrm{ft})\end{array} \\ 37 & 37\end{array}$

Sources: Baltz et al. 1963; Purtymun 1964, 1971, and 1974. 
TABLE VI-C. Hydrologic Data for Test Wells in Mortandad Canyon

\begin{tabular}{|c|c|c|c|c|c|c|c|c|c|c|}
\hline $\begin{array}{l}\text { Test } \\
\text { Wells }\end{array}$ & $\begin{array}{c}\text { Date } \\
\text { Completed }\end{array}$ & $\begin{array}{l}\text { Depth } \\
\text { Drilled } \\
\text { (ft) }\end{array}$ & $\begin{array}{l}\text { Depth } \\
\text { Completed } \\
\text { (ft) }\end{array}$ & $\begin{array}{l}\text { Depth } \\
1991\end{array}$ & $\frac{\text { Water }}{\text { At }} \begin{array}{c}\text { Completion } \\
\text { (ft) }\end{array}$ & Levels & $(\mathrm{ft})$ & $\begin{array}{c}\text { Elevation } \\
\text { (LSD) } \\
\text { (ft) }\end{array}$ & $\begin{array}{c}\text { Measuring } \\
\text { Point (MP) } \\
\text { Top of } \\
\text { Casing (TC) to } \\
\text { LSD (ft) }\end{array}$ & Remarks \\
\hline MCM-2.2 & $11 / 61$ & 90 & 87 & 87 & Dry & $4 / 91$ & Dry & 7109 & 2.20 & $\begin{array}{l}\text { Angle hole beneath } \\
\text { channel }\left(45^{\circ}\right)\end{array}$ \\
\hline MCM-2.8 & $11 / 61$ & 60 & 58 & 58 & Dry & $4 / 91$ & Dry & 7086 & 5.00 & $\begin{array}{l}\text { Angle hole beneath } \\
\text { channel }\left(30^{\circ}\right)\end{array}$ \\
\hline MCM-4.5 & $11 / 61$ & 48 & 48 & 35 & - & - & & 6891 & 1.70 & $\begin{array}{l}\text { Double-cased } \\
\text { moisture-access hole }\end{array}$ \\
\hline MCM-6.5 & $11 / 61$ & 95 & 95 & 95 & - & - & & 6840 & 0.20 & $\begin{array}{l}\text { Double-cased moisture- } \\
\text { access hole }\end{array}$ \\
\hline MCM-7.5 & $11 / 61$ & 94 & 94 & 94 & $\ldots$ & - & & 6809 & 1.00 & $\begin{array}{l}\text { Double-cased moisture- } \\
\text { access hole }\end{array}$ \\
\hline MT-1 & $11 / 88$ & 69 & 69 & 68 & 43.0 & $2 / 91$ & 42.92 & 6811.79 & 1.79 & \\
\hline MT-2 & $11 / 88$ & 64 & 64 & 64 & 62.0 & $2 / 91$ & Dry & 6796.88 & 1.60 & \\
\hline MT-3 & $11 / 88$ & 74 & 74 & 73 & 45.0 & $2 / 91$ & 54.72 & 6796.88 & 1.30 & \\
\hline $\mathrm{MT}-4$ & $11 / 88$ & 74 & 74 & 74 & 58.0 & $2 / 91$ & 59.84 & 6785.22 & 1.34 & \\
\hline MCM-5.1 & $9 / 90$ & 112 & 112 & 112 & - & - & - & 6870 & 0.22 & \\
\hline MCM-5.9 & $7 / 90$ & 44 & - & - & - & - & - & 6852 & - & Plugged and abandoned \\
\hline MCM-5.9A & $7 / 90$ & 194 & 194 & 194 & - & - & - & 6852.29 & 0.94 & \\
\hline MCC-8.2 & $4 / 89$ & 184 & - & - & 73 & - & - & 6780 & 一 & Plugged and abandoned \\
\hline SIMO & $9 / 90$ & 104 & 104 & - & Dry & - & - & 6658 & - & $\begin{array}{l}\text { On sacred land (San } \\
\text { Ildefonso Pueblo) }\end{array}$ \\
\hline MCM-10.1 & $8 / 91$ & 119 & 119 & - & Dry & - & - & 6730 & 1.00 & Moisture-access hole \\
\hline MCM-10.2 & $8 / 91$ & 43 & 43 & - & Dry & - & 一 & 6715 & 1.00 & Moisture-access hole \\
\hline MCM-10.3A & A $8 / 91$ & 33 & 33 & - & Dry & - & - & 6690 & 1.00 & Moisture-access hole \\
\hline MCM-10.3B & B $8 / 91$ & 43 & 43 & - & Dry & - & - & 6690 & 1.00 & Moisture-access hole \\
\hline SIMO-1 & $9 / 92$ & 116 & - & - & Dry & - & - & 6650 & - & $\begin{array}{l}\text { San Ildefonso and BIA } \\
\text { well on sacred land }\end{array}$ \\
\hline
\end{tabular}

Sources: Purtymun 1964, 1988-1992; Stoker et al. 1991. 
TABLE VI-D. Geologic Logs and Construction Data for Test Holes in Mortandad Canyon (18 Test Wells)

1. Test Hole MCM-2.2

Elevation (LSD) $7109 \mathrm{ft}$

$\begin{array}{cc}\text { Thickness } & \text { Depth } \\ (\mathrm{ft}) & (\mathrm{ft})\end{array}$

Geologic Log

Tuff, light gray to dark gray, welded, crystal and crystal fragments of quartz and sanidine, rock fragments of gray latite and rhyolite, a few devitrified pumice fragments, Unit 2 Tshirege Member

Construction

Angle hole, drilled at an angle of $45^{\circ}$ from the terrace to under the stream. Cased with $87 \mathrm{ft}$ of

2 -in.-diam blank plastic pipe with a plug in its end; extends $2 \mathrm{ft}$ above LSD. Moisture-access hole.

\section{Test Hole MCM- 2.8}

Elevation (LSD) $7086 \mathrm{ft}$

$\begin{array}{cc}\begin{array}{c}\text { Thickness } \\ \text { (ft) }\end{array} & \text { Depth } \\ & (\mathrm{ft})\end{array}$

\section{Geologic Log}

Tuff, light gray to dark gray, welded, quartz and sanidine crystals and crystal fragments, a few rock fragments, Unit 2 Tshirege Member

Construction

Angle hole, drilled at $30^{\circ}$ from the vertical from the terrace to under the stream. Cased with $58 \mathrm{ft}$ of 2-in.-diam blank plastic pipe with a plug in its end; extends $5 \mathrm{ft}$ above LSD.

Moisture-access hole.

\section{Test Hole MCM-4.5}

Elevation (LSD) $6891 \mathrm{ft}$

Geologic Log

Alluvium

Sand and gravel in a matrix of silt and clay

Tuff (weathered in place)

Silt and clay, some sand

\section{Thickness}

(ft)

26

22
Depth

$(\mathrm{ft})$

26

48

Construction

Moisture-access hole. Outer casing: 4-in.-diam steel casing set 0-29 ft into tuff to seal water out of hole; $48 \mathrm{ft}$ of 2-in.-diam plastic pipe set 0 to $48 \mathrm{ft}$. Ground tuff packed in annulus around outside of plastic pipe.

\section{Test Hole MCM-6.5}

Elevation (LSD) $6840 \mathrm{ft}$

Geologic Log

Alluvium

Sand and gravel in a matrix of silt and clay

Tuff (weathered in place)
Thickness

(ft)

46

49
Depth

(ft)

46

95 
TABLE VI-D. Geologic Logs and Construction Data for Test Holes in Mortandad Canyon (18 Test Wells) (Continued)

\section{Test Hole MCM-6.5 (Continued)}

Construction

Moisture-access hole. Outer casing 4-in.-diam steel casing set $0-51 \mathrm{ft}$ into tuff to seal water out of hole; $95 \mathrm{ft}$ of 2-in.-diam plastic pipe set 0 to $95 \mathrm{ft}$. Ground tuff packed in annulus around plastic pipe.

\section{Test Hole MCM-7.5}

Elevation (LSD) $6809 \mathrm{ft}$

Geologic Log

Alluvium

Sand and gravel in a matrix of silt and clay

Tuff (weathered in place)

Silt and clay, occasional

lenses of sand
Thickness

(ft)

61

33
Depth

(ft)

61

94

\section{Construction}

Moisture-access hole. Outer casing 4-in.-diam steel casing set 0-66 ft into tuff to seal water out of hole; $94 \mathrm{ft}$ of 2-in.-diam plastic pipe set 0 to $94 \mathrm{ft}$. Ground tuff packed in annulus around plastic pipe.

\section{Test Hole MT-1}

Elevation (LSD) $6811.79 \mathrm{ft}$

Geologic Log

Alluvium

Coarse sand with lenses of silt and clay

Tuff (weathered in place, contains aquifer)

Silt and clay with thin lenses of sand

Tuff (weathered in place) silt and clay
Thickness

(ft)

30

24

15
Depth

(ft)

30

54

69

Construction

$69 \mathrm{ft}$ of 2-in.-diam plastic pipe set from 0-69 ft; screen 39 to $59 \mathrm{ft}$, screen openings $0.010 \mathrm{in}$.

Gravel packed through screen section with 0.020 -in.-diam sand.

\section{Test Hole MT-2}

Elevation (LSD) $6796.88 \mathrm{ft}$

\section{Geologic Log}

Alluvium

Coarse sand with thin lenses of silt and clay

Tuff (weathered in place, contains aquifer)

Silt and clay with thin lenses of sand

Tuff (weathered in place) silt and clay
Thickness

(ft)

35

14

15
Depth

(ft)

35

49

64

Construction

$64 \mathrm{ft}$ of 2-in.-diam plastic pipe set from 0-64ft; screen 44 to $54 \mathrm{ft}$, screen openings $0.010 \mathrm{in}$.;

slots cut in blank pipe 54 to $64 \mathrm{ft}$. Gravel packed through screen section with 0.020 -in.-diam sand. 
TABLE VI-D. Geologic Logs and Construction Data for Test Holes in Mortandad Canyon (18 Test Wells) (Continued)

\section{Test Hole MT-3}

Elevation (LSD) $6796.88 \mathrm{ft}$

$\begin{array}{cc}\begin{array}{c}\text { Thickness } \\ \text { (ft) }\end{array} & \begin{array}{c}\text { Depth } \\ \text { (ft) }\end{array}\end{array}$

Geologic Log

Alluvium .

Coarse sand with thin lenses of silt and clay $31 \quad 31$

Tuff (weathered in place, contains aquifer)

Silt and clay with thin lenses of sand $\quad 23 \quad 54$

$\begin{array}{lll}\text { Tuff (weathered in place) silt and clay } & 20 & 74\end{array}$

Construction

$74 \mathrm{ft}$ of 2-in.-diam plastic pipe set from 0-74 ft; screen 44 to $64 \mathrm{ft}$, screen openings

$0.010 \mathrm{in}$. Gravel packed through screen section with 0.020 -in.-diam sand.

\section{Test Hole MT-4}

Elevation (LSD) $6785.22 \mathrm{ft}$

Thickness Depth

Geologic Log

(ft) $\quad(\mathrm{ft})$

Alluvium

Coarse sand with thin lenses of silt and clay $\quad 44 \quad 44$

Tuff (weathered in place, contains aquifer)

$\begin{array}{lll}\text { Silt and clay with thin sand lenses } & 21 & 65\end{array}$

$\begin{array}{lll}\text { Tuff (weathered in place) silt and clay } & 9 & 74\end{array}$

Construction

$74 \mathrm{ft}$ of 2-in.-diam plastic pipe set from 0-74 ft; screen section 54 to $64 \mathrm{ft}$, screen openings

0.010 in. Gravel packed through screen section with 0.020-in.-diam sand.

\section{Test Hole MCM-5.1}

Elevation (LSD) $6870 \mathrm{ft}$

Thickness

(ft)

Depth

Geologic Log

Alluvium

31

(ft)

Tshirege Member

Unit $1 \mathrm{~A}$

62

31

Tsankawi Member

19

93

112

Construction

Moisture-access hole. 2-in.-diam plastic pipe 0 to $112 \mathrm{ft}$. Water sealed out of hole by a cement plug from 0 to $51 \mathrm{ft}$.

\section{Test Hole MCM-5.9}

\begin{tabular}{|c|c|c|}
\hline Elevation (LSD) $6852 \mathrm{ft}$ & $\begin{array}{l}\text { Thickness } \\
\text { (ft) }\end{array}$ & $\begin{array}{l}\text { Depth } \\
\text { (ft) }\end{array}$ \\
\hline Geologic Log & & \\
\hline Alluvium & 33 & 33 \\
\hline Tshirege Member & & \\
\hline Unit $1 \mathrm{~A}$ & 11 & 44 \\
\hline
\end{tabular}

\section{Construction}

Hole abandoned and plugged. 
TABLE VI-D. Geologic Logs and Construction Data for Test Holes in Mortandad Canyon (18 Test Wells) (Continued)

\section{Test Hole MCM-5.9A}

Elevation (LSD) $6852.29 \mathrm{ft}$

$\begin{array}{cc}\begin{array}{c}\text { Thickness } \\ (\mathrm{ft})\end{array} & \begin{array}{c}\text { Depth } \\ (\mathrm{ft})\end{array} \\ 38 & 38 \\ & \\ 60 & 98 \\ 20 & 118 \\ 76 & 194\end{array}$

Geologic Log

Alluvium

Tshirege Member

Unit 1A

Tsankawi Member

Otowi Member

Construction

Moisture-access hole. 2-in.-diam plastic pipe 0 to $194 \mathrm{ft}$. Water sealed out of hole by a cement plug from 0 to $69 \mathrm{ft}$.

13. Test Hole MCC-8.2

Elevation (LSD) $6780 \mathrm{ft}$

$\begin{array}{cc}\begin{array}{c}\text { Thickness } \\ (\mathrm{ft})\end{array} & \begin{array}{c}\text { Depth } \\ (\mathrm{ft})\end{array} \\ 76 & 76 \\ & \\ 8 & 84 \\ 20 & 104 \\ 80 & 184\end{array}$

\section{Geologic Log}

Alluvium

Tshirege Member

Unit 1A

Tsankawi Member

Otowi Member

$\begin{array}{cc}\begin{array}{c}\text { Thickness } \\ \text { (ft) }\end{array} & \begin{array}{c}\text { Depth } \\ \text { (ft) }\end{array} \\ & \\ 47 & 47 \\ 17 & 64 \\ 40 & 104\end{array}$

Construction

Hole abandoned and plugged.

\section{Test Hole SIMO}

Elevation (LSD) $6658 \mathrm{ft}$

Geologic Log

Tshirege Member

Unit $1 \mathrm{~A}$

Tsankawi Member

Otowi Member
64

104

Construction

$104 \mathrm{ft}$ of 2-in.-diam plastic pipe with slotted sections 50 to $60 \mathrm{ft}$ and 80 to $90 \mathrm{ft}$.

\section{Test Hole MCM-10-1}

Elevation (LSD) $6730 \mathrm{ft}$

Geologic Log

Soil, clay, dark brown

Tuff, weathered, light brown, quartz and sanidine, a few small rock fragments of pumice, latite, and rhyolite in a matrix of silt and clay, friable to consolidated
Thickness

(ft)

4
Depth

(ft)

4 
TABLE VI-D. Geologic Logs and Construction Data for Test Holes in Mortandad Canyon (18 Test Wells) (Continued)

\section{Test Hole MCM-10-1 (Continued)}

Tuff, weathered, light gray to grayish brown, several 2-in.-thick clay layers from $39-44 \mathrm{ft}$; quartz and sanidine crystals and fragments, a few rock fragments of pumice and latite in a silt and clay matrix, semiconsolidated

Tuff, weathered, light brown, rock fragments of pumice and latite in a silt and clay matrix, friable to consolidated

Tuff, weathered, light reddish gray, quartz and sanidine crystals and rock fragments of pumice up to $1.5 \mathrm{in.} \mathrm{long} \mathrm{in} \mathrm{a} \mathrm{matrix} \mathrm{of} \mathrm{silt} \mathrm{and}$ clay, friable to consolidated

Tuff, weathered, light reddish gray, rock fragments of pumice and latite up to $0.5 \mathrm{in}$.
Thickness

(ft)

Depth

$\underline{(\mathrm{ft})}$

25

63

6

69

20

89

$30 \quad 119$

\section{Construction}

$119 \mathrm{ft}$ of 2-in.-diam plastic pipe set from 0 to $119 \mathrm{ft}$, its end plugged. Moisture-access hole.

\section{Test Hole MCM-10-2}

Elevation (LSD) $6715 \mathrm{ft}$

\section{Geologic Log}

Soil, sand, and silt, dark brown

Tuff, weathered, pale red, 10 YR 6/2, friable quartz and sanidine, a few rock fragments of pumice and latite in a silt and clay matrix, friable

Tuff, weathered, pale grayish brown, 5 YR 6/2, consists mainly of friable sand of quartz and sanidine crystals; a few rock fragments of pumice and latite

Tuff, weathered, pale reddish brown, 10 YR 5/4, quartz and sanidine crystals and crystal fragments, a few small rock fragments, consolidated silt and clay 30 to $31 \mathrm{ft}$, coarse sand and gravel-sized quartz and sanidine crystals and fragments from 37 to $38 \mathrm{ft}$

Tuff, weathered, pale reddish brown, 10 YR 5/4, quartz and sanidine crystals, unweathered tuff fragments and some pumice, consolidated
Thickness

(ft)

3

8

2

27

3
Depth

(ft)

3

11

13

40

43

\section{Construction}

$43 \mathrm{ft}$ of 2-in.-diam plastic pipe set 0 to $43 \mathrm{ft}$, its end plugged. Moisture-access hole. 
TABLE VI-D. Geologic Logs and Construction Data for Test Holes in Mortandad Canyon (18 Test Wells) (Continued)

\section{Test Hole MCM-10-3}

Elevation (LSD) $6690 \mathrm{ft}$

Geologic Log

Soil, clayey, dark brown

Tuff, weathered, greyish orange, 10 YR 7/4, quartz and sanidine crystals in a silt and clay matrix, friable, medium-grained quartz and sanidine, sand 13 to $14 \mathrm{ft}$

Tuff, weathered, light brown 5 YR 6/4, quartz and sanidine crystals and occasional pumice fragments, friable

Tuff, weathered, light brown, 5 YR 6/4, quartz and sanidine crystals in alternating clay and silt, friable to consolidated

Tuff, weathered, light brown, 5 YR 6/4, quartz and sanidine crystals in a matrix of hard clay, consolidated, hard to auger
Thickness Depth

$\frac{(\mathrm{ft})}{3} \quad \frac{(\mathrm{ft})}{3}$

11

14

9

10

10

43

Construction

2 holes drilled at site. First hole MCM-10-3A, total depth $33 \mathrm{ft}$, cased with $34 \mathrm{ft}$ of 2-in.-diam plastic pipe 0 to $33 \mathrm{ft}$; moisture-access hole, annulus between hole and pipe filled with drill cuttings. Second hole drilled $12 \mathrm{ft}$ west, MCM-10-3B, to a depth of $43 \mathrm{ft}$, cased with $43 \mathrm{ft}$ of 2-in.-diam plastic pipe 0 to $43 \mathrm{ft}$; moisture-access hole, annulus between hole and pipe filled with 0.010 - to 0.020 -in.-diam sand. End of both casings plugged.

\section{Test Hole SIMO-1}

Elevation (LSD) $6650 \mathrm{ft}$

Geologic Log

Tuff, light brown, weathered to silt and clay; clay $6 \%$ to $8 \%$ moisture by volume

Tuff, brown weathered mainly clay; dry, $10 \%$ to $15 \%$ moisture by volume

Tuff, light brown, silt and clay weathered, quartz and sanidine sand-sized crystals and crystal fragments; dry

Tuff, brown; weathered clay increases; dry, $10 \%$ to $15 \%$ moisture by volume

Tuff, light gray, unweathered quartz and sanidine crystals and crystal fragments; a few rock fragments of gray latite and pumice in a gray ash matrix (Tshirege-Otowi contact 53-58 ft); dry

Tuff, light gray, unweathered, much as above; some increase in pumice; dry

Tuff, light orange gray, some quartz and sanidine crystal fragments, large rock fragments gray latite and minor amounts of pumice; dry

Samples 118-133 ft (auger): 118-123 ft, large pumice fragments; $128-133 \mathrm{ft}$, change in color to light brown; dry

$\begin{array}{cc}\begin{array}{c}\text { Thickness } \\ \text { (ft) }\end{array} & \begin{array}{c}\text { Depth } \\ \text { (ft) }\end{array} \\ 13 & 13 \\ 5 & 18\end{array}$

03


TABLE VI-D. Geologic Logs and Construction Data for Test Holes in Mortandad Canyon (18 Test Wells) (Continued)

18. Test Hole SIMO-1 (Continued)

Thickness Depth

Tuff, gray, moderately welded to nonwelded, friable,

(ft) a few small rock fragments of latite and quartz latite and pumice; dry

5

Sample 138-158 ft (auger): samples; dry

Tuff, medium gray, unweathered, moderately welded to nonwelded, rock fragments of dark gray latite; some quartz latite, pumice with white, small, and light yellow pumice fragments up to 1 in. long; dry

Note: Logged in plastic sleeve; in some cores the driller raised the core barrel to clean the hole, resulting in contamination of the core with cuttings.

Core runs were $5 \mathrm{ft}$; cores collected in two 2.5 -ft plastic sleeves.

$\begin{array}{cccc}\begin{array}{c}\text { Run } \\ \text { No. }\end{array} & \begin{array}{c}\text { Depth } \\ \text { (ft) }\end{array} & \begin{array}{c}\text { Core } \\ (\mathrm{ft})\end{array} & \begin{array}{c}\text { Recovery } \\ \%\end{array} \\ 2 & 3-8 & 3.0 & 60 \\ 3 & 8-13 & 3.5 & 70 \\ 4 & 13-18 & 4.0 & 80 \\ 5 & 18-23 & 3.0 & 60 \\ 6 & 23-28 & 3.0 & 60 \\ 7 & 28-33 & 4.5 & 90 \\ 8 & 33-38 & 4.0 & 80 \\ 9 & 38-43 & 4.0 & 80 \\ 10 & 43-48 & 2.0 & 40 \\ 11 & 48-53 & 3.0 & 60 \\ 12 & 53-58 & 2.0 & 40 \\ 13 & 58-63 & 3.0 & 60 \\ 14 & 63-68 & 4.0 & 80 \\ 15 & 68-73 & 4.0 & 80 \\ 16 & 73-78 & 4.0 & 80 \\ 17 & 78-83 & 4.0 & 80 \\ 18 & 83-88 & 4.0 & 80 \\ 19 & 88-93 & 4.0 & 80 \\ 20 & 93-98 & 4.0 & 80 \\ 21 & 98-103 & 4.0 & 40 \\ 22 & 103-108 & 4.0 & \text { bag sample } \\ \text { auger } & 108-118 & 4.0 & \text { bag sample } \\ \text { auger } & 118-123 & & \text { bag sample } \\ \text { auger } & & & 100 \\ 23 & 133-138 & 5.0 & \text { bag sample } \\ \text { auger } & & & \text { bag sample } \\ \text { auger } & & & \text { bag sample } \\ \text { auger } & & 5.0 & \text { bag sample } \\ \text { auger } & 158-163 & & 100 \\ 24 & & & \end{array}$

Sources: Purtymun 1964, 1988-1992; Stoker et al. 1991. 
TABLE VI-E. Geologic Logs and Construction Data for Moisture-Access Holes in Mortandad Canyon (28 Moisture-Access Holes)

\begin{tabular}{|c|c|c|c|c|c|c|c|}
\hline $\begin{array}{l}\text { Moisture- } \\
\text { Access Hole }\end{array}$ & $\begin{array}{l}\text { Construction } \\
\text { Date }\end{array}$ & $\begin{array}{c}\text { Elevation } \\
\text { LSD } \\
\text { (ft) }\end{array}$ & $\begin{array}{c}\text { Plastic } \\
\text { Casing } \\
\text { Diam } \\
\text { (in.) }\end{array}$ & $\begin{array}{l}\text { Length of } \\
\text { Casing } \\
\text { LSD } \\
(\mathrm{ft})\end{array}$ & $\begin{array}{l}\text { Alluvium } \\
\text { (ft) }\end{array}$ & $\begin{array}{c}\text { Bandelier } \\
\text { Tuff } \\
\text { (ft) }\end{array}$ & Remarks \\
\hline MCM-1A & $11 / 60$ & 7156 & 2 & 12 & 0 & 12 & \\
\hline MCM-1B & $11 / 60$ & 7155 & 2 & 11 & 0 & 11 & \\
\hline MCM-2A & $11 / 60$ & 7139 & 2 & 11 & 0 & 11 & \\
\hline MCM-2B & $11 / 60$ & 7134 & 2 & 1 & 0 & 1 & \\
\hline MCM-3A & $11 / 60$ & 7049 & 2 & 13 & 10 & 3 & \\
\hline MCM-3B & $11 / 60$ & 7048 & 2 & 10 & 10 & 0 & \\
\hline MCM-4A & $11 / 60$ & 6901 & 2 & 9 & 9 & 0 & \\
\hline MCM-4B & $11 / 60$ & 6900 & 2 & 24 & 18 & 6 & \\
\hline MCM-4.8 & $11 / 61$ & 6887 & 2 & 33 & 30 & 3 & \\
\hline MCM-5A & $10 / 60$ & 6881 & 2 & 25 & 22 & 3 & \\
\hline MCM-5B & $10 / 60$ & 6879 & 2 & 30 & 25 & 5 & \\
\hline MCM-5C & $10 / 60$ & 6878 & 2 & 37 & 30 & 7 & \\
\hline MCM-6A & $10 / 60$ & 6852 & 2 & 18 & 10 & 8 & \\
\hline MCM-6B & $10 / 60$ & 6851 & 2 & 52 & 37. & 15 & \\
\hline MCM-6C & $10 / 60$ & 6851 & 2 & 57 & 47 & 10 & \\
\hline MCM-6D & $10 / 60$ & 6850 & 2 & 35 & 35 & 0 & \\
\hline MCM-6E & $10 / 60$ & 6851 & 2 & 21 & 12 & 9 & \\
\hline MCM-6.5A & $8 / 89$ & 6839 & 2 & 23 & 23 & - & alum. casing \\
\hline MCM-8A & $10 / 60$ & 6807 & 2 & 20 & 3 & 17 & \\
\hline MCM-8B & $10 / 60$ & 6797 & 2 & 30 & 30 & 0 & \\
\hline MCM-8C & $10 / 60$ & 6797 & 2 & 66 & 57 & 9 & \\
\hline MCM-8D & $10 / 60$ & 6796 & 2 & 86 & 59 & 27 & \\
\hline MCM-8E & $10 / 60$ & 6797 & 2 & 53 & 32 & 21 & \\
\hline MCM-8F & $10 / 60$ & 6799 & 2 & 23 & 4 & 19 & \\
\hline MCM-10 & $10 / 60$ & 6731 & 2 & 67 & 62 & 5 & \\
\hline MCM-12A & $6 / 71$ & 6718 & 2 & 98 & 93 & 5 & \\
\hline MCM-12B & $6 / 71$ & 6705 & 2 & 79 & 79 & 0 & \\
\hline TSCM-1 & $11 / 61$ & 6859 & 2 & 22 & 22 & 0 & \\
\hline
\end{tabular}

Sources: Baltz et al. 1963; Purtymun 1964 and 1971b. 
TABLE VI-F. Locations and Elevations (NAD 1927)

A. Surface Water and Gaging Stations

MCS-3.9
MCGS-1
MCGS-2
$\quad$ B. Observation Wells

\begin{abstract}
MCO-1
MCO-2

MCO-3

MCO-4

MCO-4.9

MCO-5

MCO-6

MCO-6

MCO-6.5A

MCO-6.5B

$\mathrm{MCO}-7$

MCO-7A

MCO-7.5A

$\mathrm{MCO}-7.5 \mathrm{~B}$

MCO-8

MCO-8A

MCO-8.2

MCO-9

MCO-9.5

MCO-11

MCO-12

MCO-12

MCO-13

TSCO-1
\end{abstract}

C. Test Holes

\author{
E 490,479.7 \\ E 486,502.3 \\ E 491,800
}

$6907.9 \mathrm{ft}$ $7065.9 \mathrm{ft}$ $6900 \mathrm{ft}$

\section{E 485,200 \\ E 485,700 \\ E 487,118.3 \\ E 490,970.1 \\ E 492,127.5 \\ E 492,221.9 \\ E 493,391 \\ E 493,391.1 \\ E 493,800 \\ E 493,900 \\ E 494,273.6 \\ E 494,259.2 \\ E 495,210 \\ E 495,210.6 \\ E 495,776.5 \\ E 495,800 \\ E 495,800 \\ E 497,813.6 \\ E 498,600}

unable to locate 1991

N $1,768,100$

N $1,768,100$

N $1,767,200$

N $1,768,400$
E 500,200
E 500,200
E 500,900
E 493,100
$7153 \mathrm{ft}$

$7133 \mathrm{ft}$

$7052.7 \mathrm{ft}$

$6900.4 \mathrm{ft}$

$6880.3 \mathrm{ft}$

$6875.8 \mathrm{ft}$

$6850 \mathrm{ft}$

$6849.0 \mathrm{ft}$

$6840 \mathrm{ft}$

$6839 \mathrm{ft}$

$6827.4 \mathrm{ft}$

$6827.7 \mathrm{ft}$

$6809 \mathrm{ft}$

$6808.8 \mathrm{ft}$

$6796.7 \mathrm{ft}$

$6800 \mathrm{ft}$

$6782 \mathrm{ft}$

$6747.77 \mathrm{ft}$

$6740 \mathrm{ft}$

$6700 \mathrm{ft}$

$6702 \mathrm{ft}$

$6674 \mathrm{ft}$

$6857 \mathrm{ft}$

$\begin{array}{ll}\text { E 486,200 } & 7109 \mathrm{ft} \\ \text { E 486,600 } & 7086 \mathrm{ft} \\ \text { E 492,000 } & 6891 \mathrm{ft} \\ \text { E 493,900 } & 6840 \mathrm{ft} \\ \text { E 495,300 } & 6809 \mathrm{ft} \\ \text { E 495,019.0 } & 6811.8 \mathrm{ft} \\ \text { E 495,777.5 } & 6796.8 \mathrm{ft} \\ \text { E 495,737.9 } & 6796.9 \mathrm{ft} \\ \text { E 496,314.5 } & 6785.2 \mathrm{ft} \\ \text { E 492,500 } & 6870 \mathrm{ft} \\ \text { E 493,358.7 } & 6852.3 \mathrm{ft} \\ \text { E 496,600 } & 6780 \mathrm{ft} \\ \text { E 501,600 } & 6658 \mathrm{ft} \\ \text { E 501,600 } & 6650 \mathrm{ft} \\ \text { E 498,700 } & 6730 \mathrm{ft} \\ \text { E 498,900 } & 6715 \mathrm{ft} \\ \text { E 500,400 } & 6690 \mathrm{ft} \\ \text { E 500,400 } & 6690 \mathrm{ft}\end{array}$


TABLE VI-F. Locations and Elevations (NAD 1927)(Continued)

D. Moisture-Access Holes

$\begin{array}{llll}\text { MCM-1A,-1B } & \text { N } 1,770,100 & \text { E 485,200 } & 7150 \mathrm{ft} \\ \text { MCM-2A,-2B } & \text { N } 1,770,000 & \text { E 485,700 } & 7130 \mathrm{ft} \\ \text { MCM-3A,-3B } & \text { N } 1,770,200 & \text { E 487,100 } & 7050 \mathrm{ft} \\ \text { MCM-4A,-4B } & \text { N } 1,769,700 & \text { E 491,000 } & 6890 \mathrm{ft} \\ \text { MCM-4.8 } & \text { N } 1,769,636.3 & \text { E 491,645.2 } & 6889.1 \mathrm{ft} \\ \text { MCM-5A,-5B,-5C } & \text { N } 1,769,500 & \text { E 492,200 } & 6880 \mathrm{ft} \\ \text { MCM-6A,-6B,-6C,-6D,-6E } & \text { N } 1,768,950 & \text { E 493,400 } & 6850 \mathrm{ft} \\ \text { MCM-6.5A } & \text { N } 1,768,400 & \text { E 494,200 } & 6839 \mathrm{ft} \\ \text { MCM-8A,-8B,-8C,-8D, } & \text { N } 1,768,500 & \text { E 495,800 } & 6800 \mathrm{ft} \\ -8 E,-8 F & & & \\ \text { MCM-10 } & \text { N } 1,768,400 & \text { E 499,100 } & 6731 \mathrm{ft} \\ \text { MCM-12A } & \text { N } 1,767,900 & \text { E 500,200 } & 6718 \mathrm{ft} \\ \text { MCM-12B } & \text { N 1,768,100 } & \text { E 500,200 } & 6705 \mathrm{ft} \\ \text { TSCM-1 } & \text { N } 1,768,400 & \text { E 493,100 } & 6859 \mathrm{ft}\end{array}$




\section{CAÑADA DEL BUEY AND PAJARITO CANYON}

Observation wells and moisture-access holes were constructed in Cañada del Buey and Pajarito Canyon (Fig.VII-A). The wells and test holes were part of a study to determine if water perched in the alluvium was present, and to determine whether any existing perched zone extended under the adjacent Mesita del Buey that lies between the two canyons (Purtymun and Kennedy 1971; Purtymun 1994).

The holes were drilled with a 7-in.-diam auger and cased with 4-in.-diam plastic pipe, with the lower sections perforated and wrapped with a stainless steel screen. The wells were gravel packed. For typical construction and well security see Fig. VII-B.

Homestead Spring in Pajarito Canyon on the western third of the plateau (N 1,768,100 E 474,300; $7390 \mathrm{ft}$ ) discharges 2 to $5 \mathrm{gpm}$ from a surface sheet of densely welded tuff. The spring (discovered by Terry Foxx) is in the Tshirege Member of the Bandelier Tuff and is probably recharged from stream flows in Pajarito Canyon to the west.

\section{A. Cañada del Buey (1985)}

Cañada del Buey heads on the Pajarito Plateau at an elevation of about $7200 \mathrm{ft}$ and has a small drainage area of about $1.3 \mathrm{sq}$ mi west of SR-4. The canyon cuts into the Bandelier Tuff; thus the alluvium in the canyon is composed of silt, sand, and gravel (Fig. $\mathrm{I}-\mathrm{U})$. Stream flow in the canyon is intermittent, from storm runoff. The intermittent stream has cut a southeast-trending canyon north of the waste processing, storage, and disposal Areas G and L at TA-54.

Five test holes were drilled at the head of Cañada del Buey as part of an investigation for a proposed location for a sanitary landfill (Purtymun 1994). Three test holes were drilled in the canyon adjacent to Area $L$ in a canyon tributary to Cañada del Buey, and one test hole further to the east in Cañada del Buey itself, to determine if the canyon contained a perched water body in the alluvium (Fig VII-A). All nine holes were dry; however, four were completed as observation wells to monitor the alluvium for possible water in the future (Table VII-A). Geologic logs and casing schedules for the four observation wells are shown in Figs. VII-D through VII-G.

\section{B. Pajarito Canyon (1985)}

Pajarito Canyon heads on the drainage divide on the flanks of the mountains at an elevation of 10400 $\mathrm{ft}$ and has a drainage area of $12.8 \mathrm{sq}$ mi west of SR-4. The alluvium in the canyon consists of sand, gravel, cobbles, and boulders derived from the Tschicoma Formation and the Bandelier Tuff. Stream flow in the canyon is intermittent, from the release of some waste water and from storm runoff. The intermittent stream has cut a southeast-trending canyon south of the waste processing, storage, and disposal Areas $G$ and $\mathrm{L}$ at TA-54.

Three observation wells and four moisture-access holes were drilled in the canyon as part of the same project for which wells were constructed in Cañada del Buey (Fig. VII-A).

The three observation wells were drilled and cased in the canyon to outline the geology and provide a monitoring network of the water in the alluvium perched on the underlying tuff (Table VII-B). Geologic logs and casing schedules for the three observation wells are shown in Figs. VII-H through VII-J.

To outline the aquifer and to ensure that the aquifer was only in the alluvium and did not extend northward beneath the mesa, four test holes were drilled in the canyon floor north of the stream channel (Table VII-C). The test holes were dry. The 4.5-in.-diam holes were completed for use as moisture-access holes, open below the surface casing. Geologic logs and casing schedules for the four moisture-access holes are shown in Figs. VII-K through VII-N. (Devaurs 1985; Devaurs and Purtymun 1985; Purtymun 1985).

\section{Cañada del Buey (1992)}

A new sanitary waste-water treatment plant has been constructed on the south rim of Cañada del Buey. The plant releases treated sanitary effluent into the canyon, and became operational in September 1992. The stream flow in Cañada del Buey in early 1992 was intermittent. A series of observation wells constructed in 1985 downgradient from the plant indicated no water perched in the alluvium in that reach of the canyon (Table VII-A). To study the effect of the effluent release on the environment in 
the canyon, we installed additional observation wells and some moisture-access holes near the new treatment plant.

Five observation wells (CDB0-5 through CDBO-9) and two moisture-access holes (CDBM-1 and CDBM-2) were drilled and completed in 1992 (Figs. VII-O through VII-U). The holes were cored, producing 7.25-in.-diam holes and 3-in.-diam cores. The observation wells were gravel packed, while in the moisture-access holes the annulus between the hole wall and casing was packed with sand. Two holes, CDBO-6 and CDBO-7, encountered water perched in the alluvium (Table VII-D). This perched water is probably the result of a discharge to waste from well PM-4 that occurs when the well is started. The discharge is necessary so that the water pressure in the line can be increased gradually. Discharge directly into the line at start-up would result in a high pressure which would rupture the transmission line from the well to the tank.

Graphic presentation of logs and completion data for the observation wells and moisture-access holes are shown in Figs. VII-O to VII-U. Logs and completion data of the observation wells are found in Table VII-D and for the moisture holes in Table VII-E.

\section{REFERENCES}

M. Devaurs, "Core Analyses and Observation Well Data from Mesita del Buey Disposal Areas and in Adjacent Canyons," Los Alamos National Laboratory document LA-UR-85-4003.

M. Devaurs and W. D. Purtymun, "Hydrologic Characteristics of the Alluvial Aquifers in Mortandad, Cañada del Buey, and Pajarito Canyons," Los Alamos National Laboratory document LA-UR-85-4002.

B. Gallaher, Los Alamos National Laboratory, personal communication, 1992.

W. D. Purtymun, "Source Document Compilation: Los Alamos Investigations Related to the Environment, Engineering, Geology, and Hydrology, 19611990," Los Alamos National Laboratory document LA-12733-MS (1994), chapters 128, 138, and 155.

W. D. Purtymun, Los Alamos National Laboratory, unpublished data (field notes), 1985 and 1992.

W. D. Purtymun and W. R. Kennedy, "Geology and Hydrology of Mesita del Buey," Los Alamos Scientific Laboratory report LA-4660 (1971). 


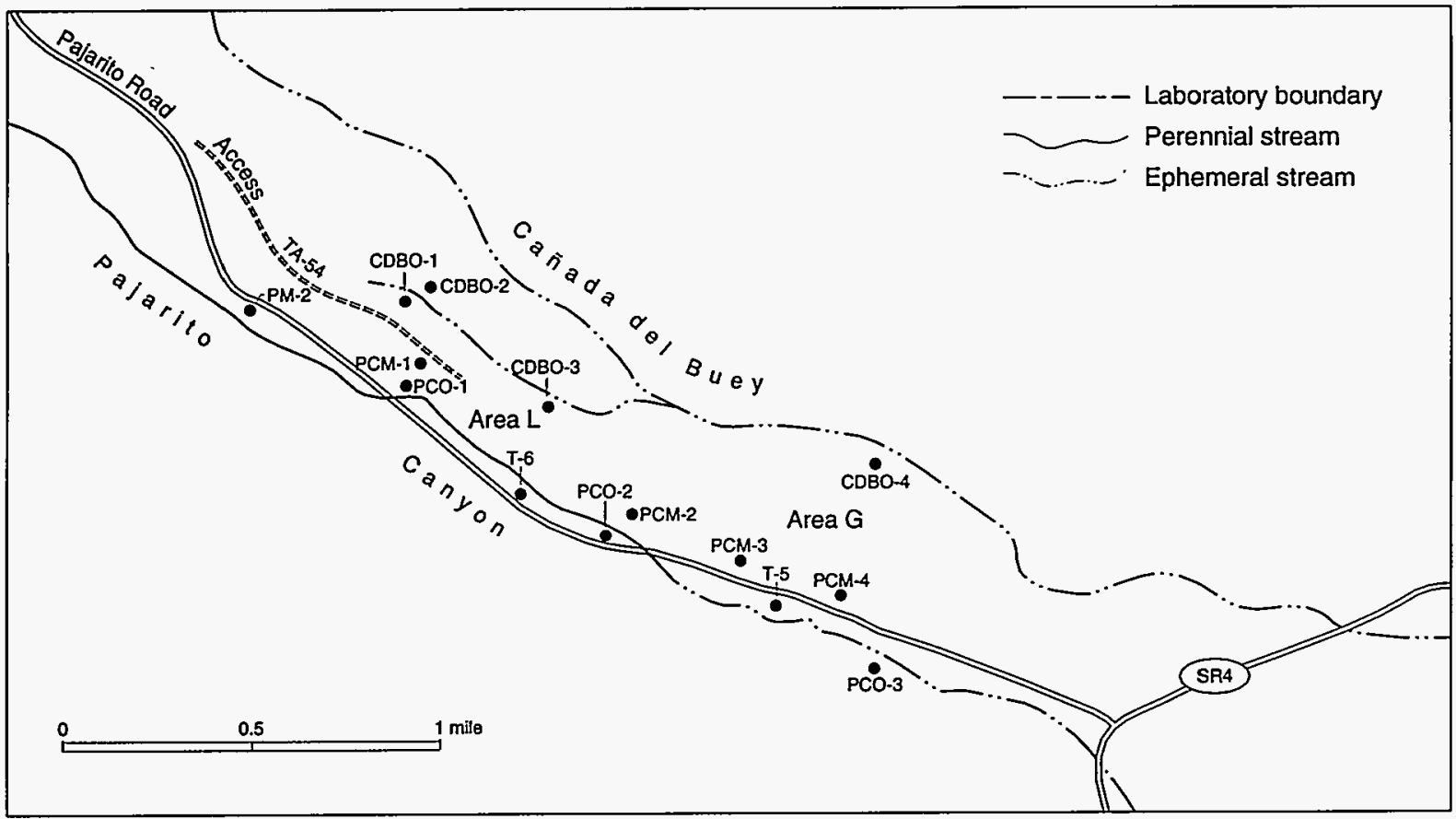

Fig. VII-A. Location of observation wells in Cañada del Buey (CDBO-series) and Pajarito Canyon (PCO-series) and moisture-access holes in Pajarito Canyon (PCM-series) (Purtymun 1985).

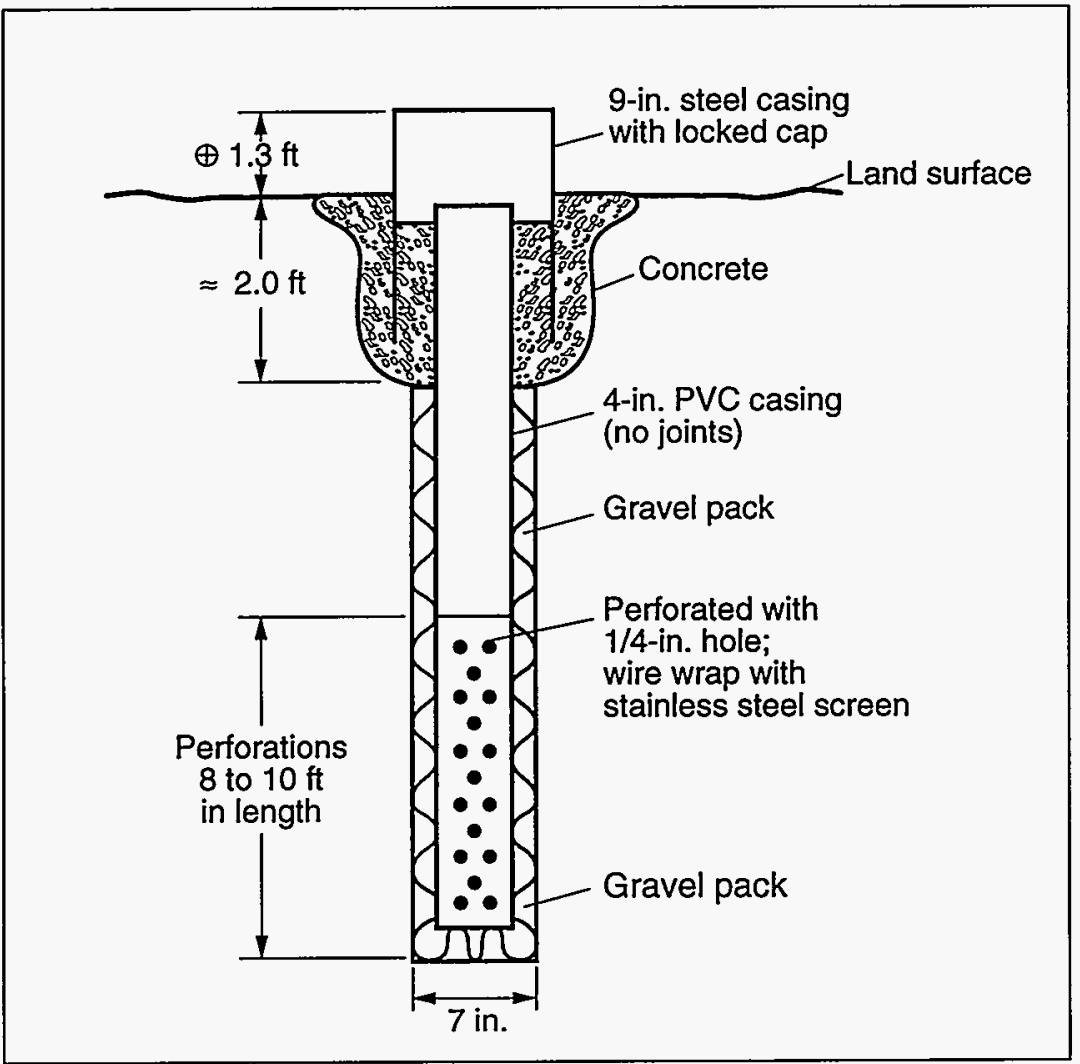

Fig. VII-B. Typical observation well construction in Cañada del Buey and Pajarito Canyon (Purtymun 1985). 


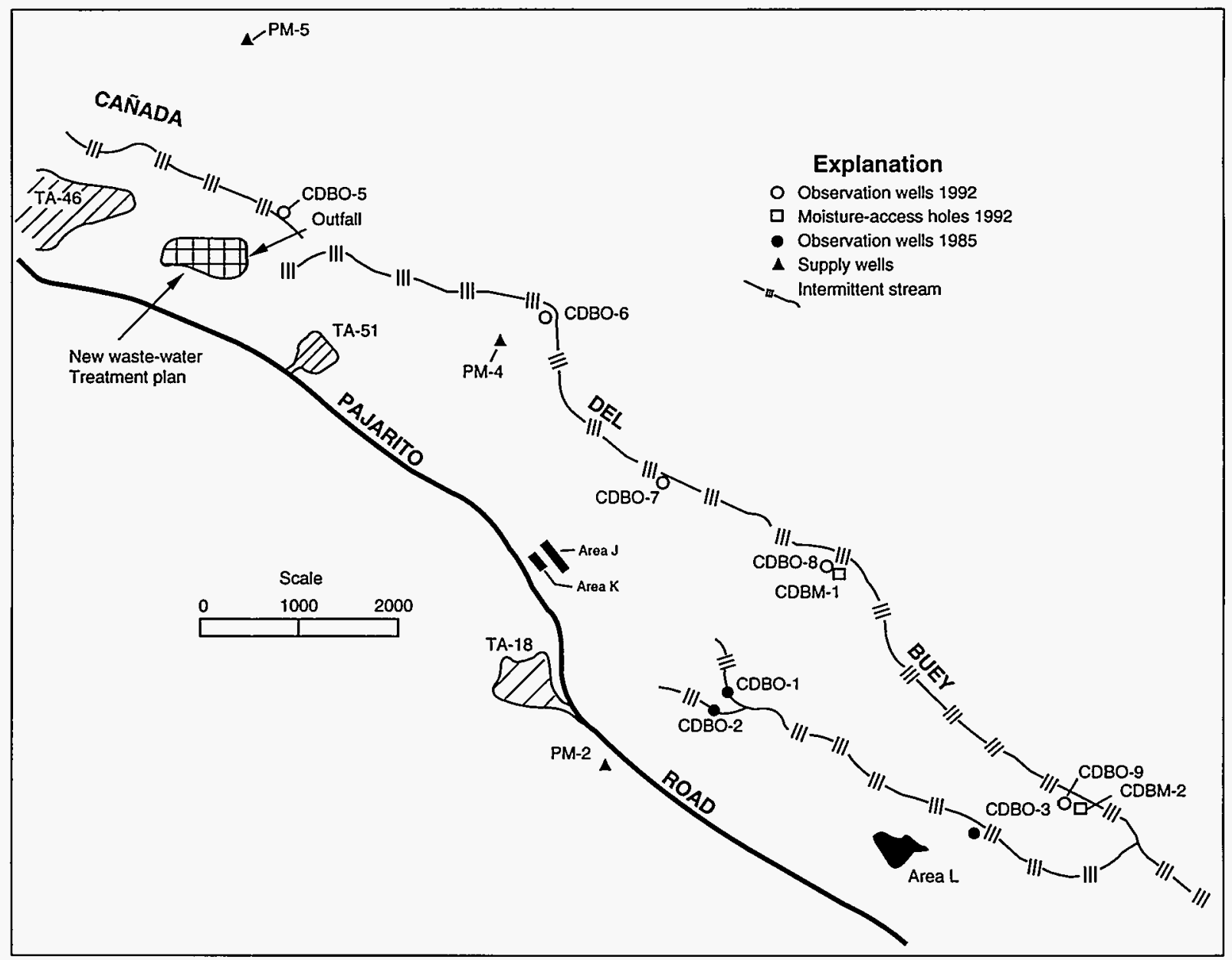

Fig. VII-C. Location of observation wells and moisture-access holes in Cañada del Buey (Purtymun 1992).

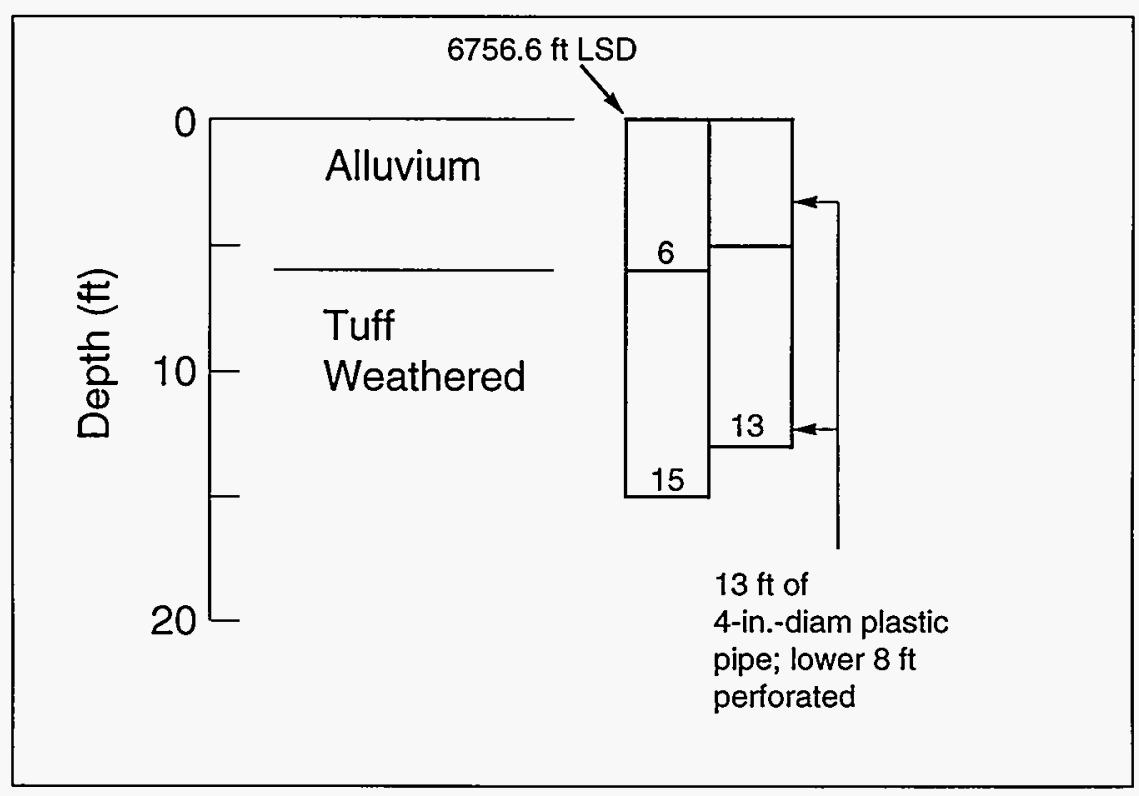

Fig. VII-D. Geologic log and casing schedule of observation well CDBO-1, dry (Purtymun 1985). 


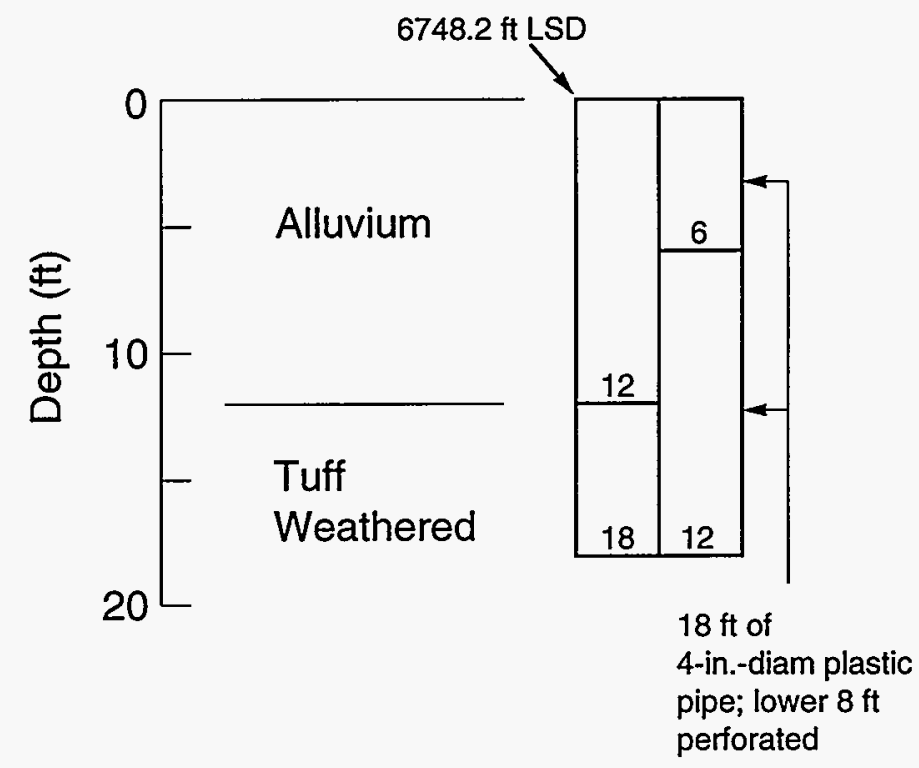

Fig. VII-E. Geologic log and casing schedule of observation well CDBO-2, dry (Purtymun 1985).

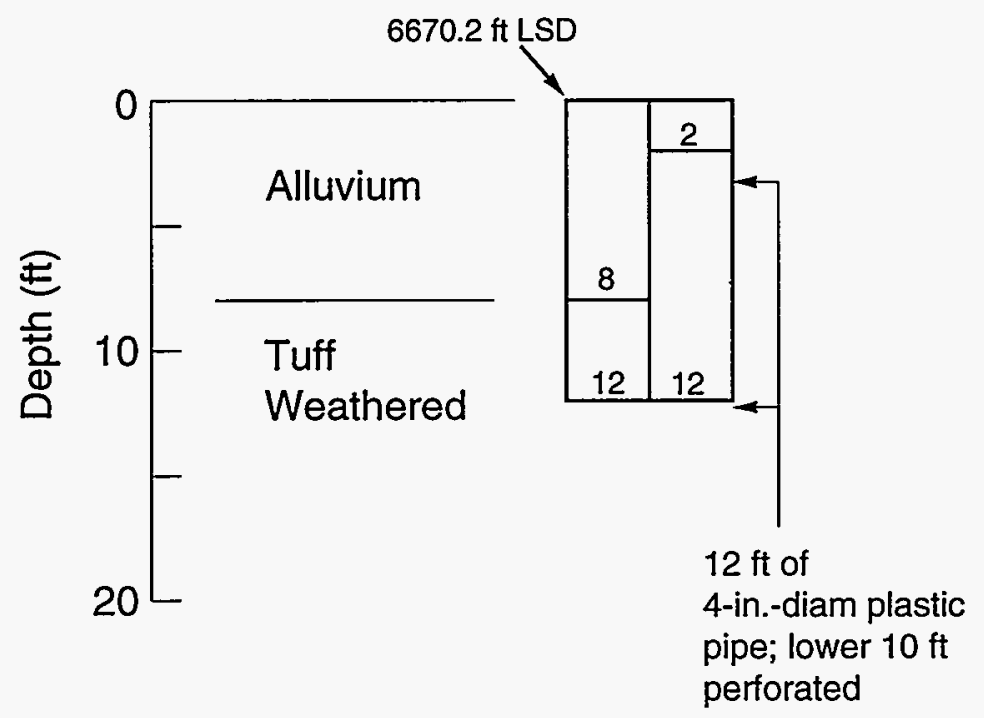

Fig. VII-F. Geologic log and casing schedule of observation well CDBO-3, dry (Purtymun 1985). 


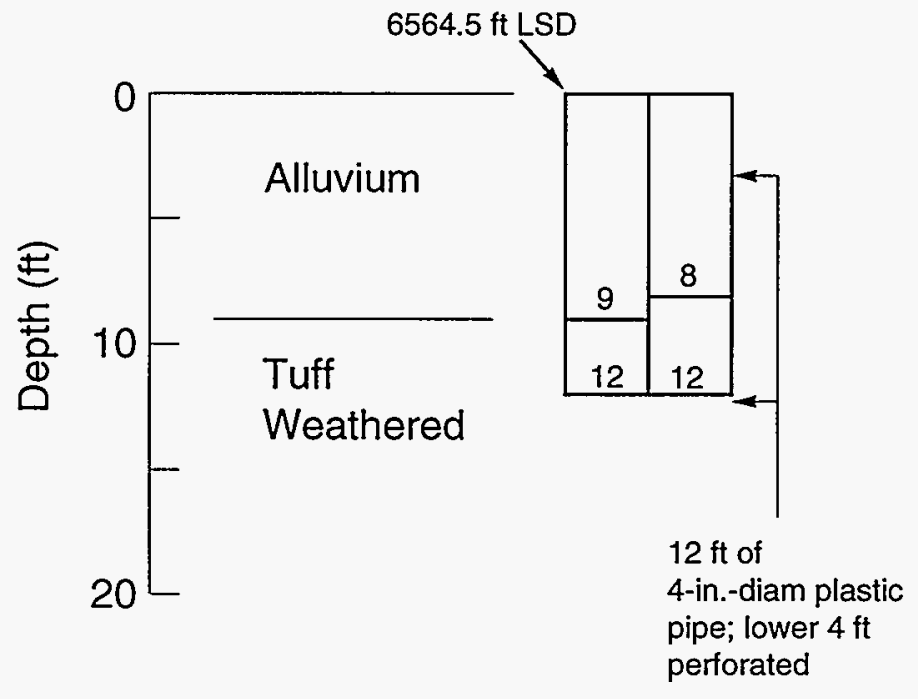

Fig. VII-G. Geologic log and casing schedule of observation well CDBO-4, dry (Purtymun 1985).

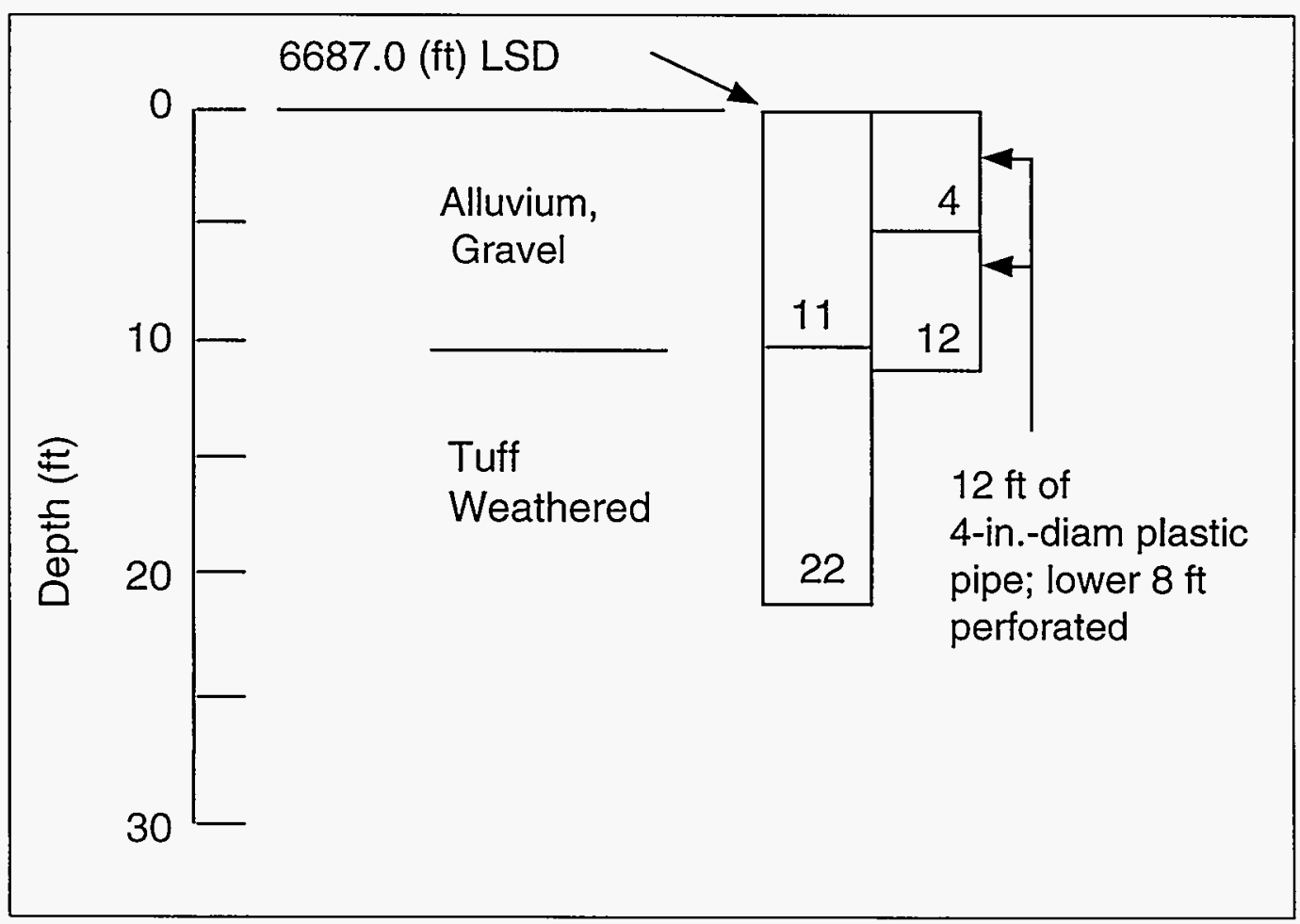

Fig. VII-H. Geologic log and casing schedule of observation well PCO-1, water level $1.3 \mathrm{ft}$ (Purtymun 1985). 


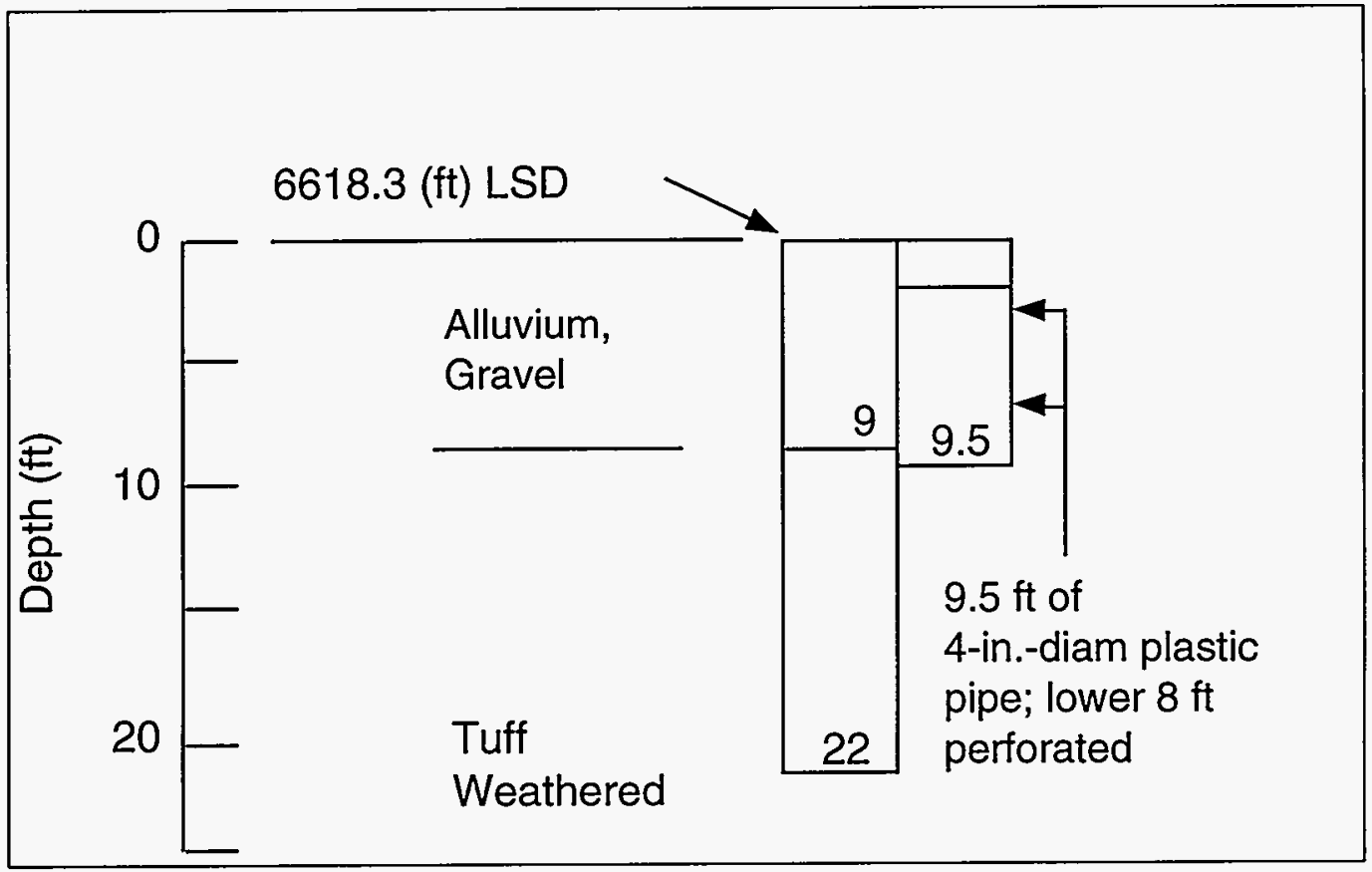

Fig. VII-I. Geologic log and casing schedule of observation well PCO-2, water level $6.3 \mathrm{ft}$ (Purtymun 1985).

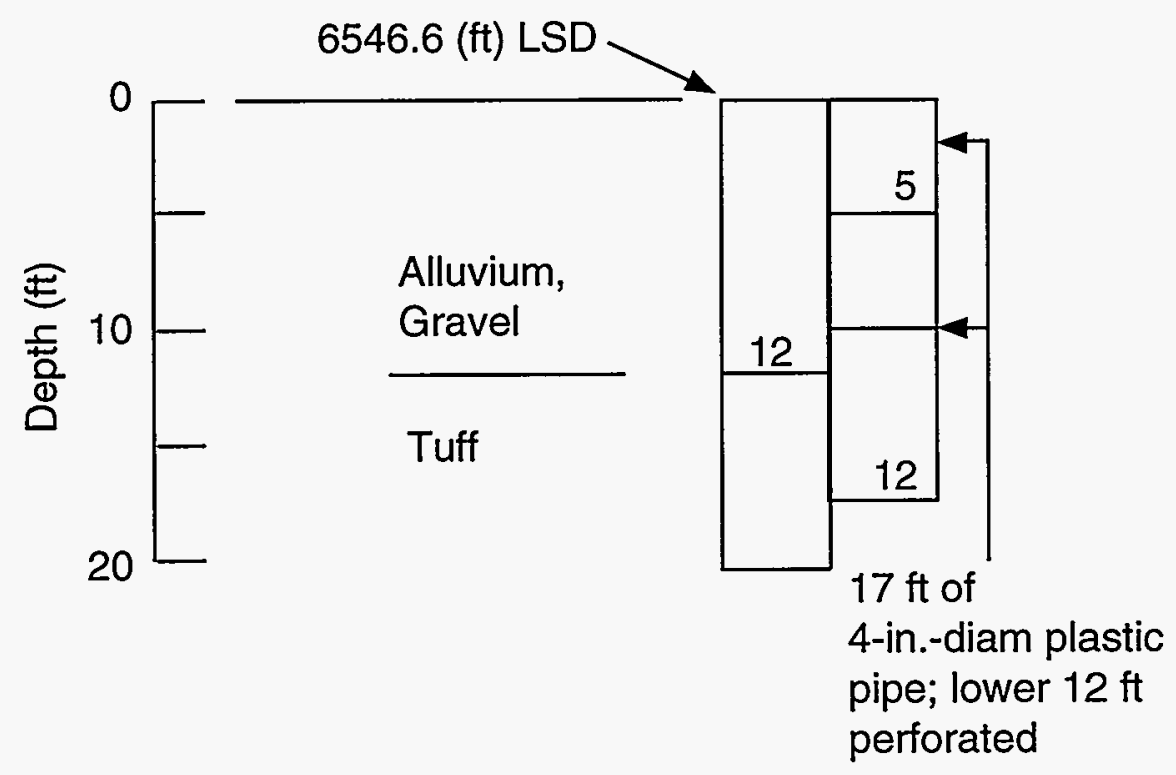

Fig. VII-J. Geologic log and casing schedule of observation well PCO-3, water level $3.1 \mathrm{ft}$ (Purtymun 1985). 


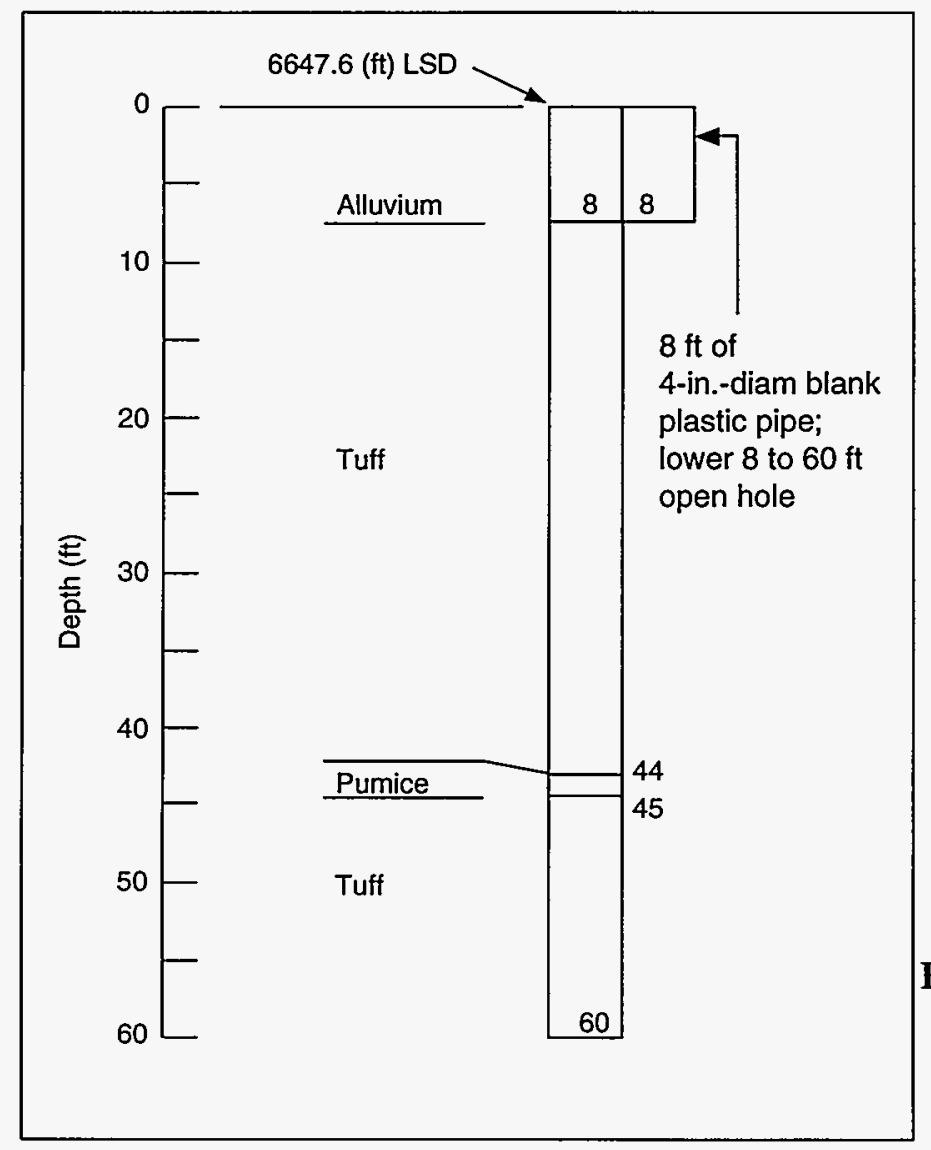

Fig. VII-K. Geologic log and casing schedule of test hole PCM-1, dry (Purtymun 1985).

Fig. VII-L. Geologic log and casing schedule of test hole PCM-2, dry (Purtymun 1985).

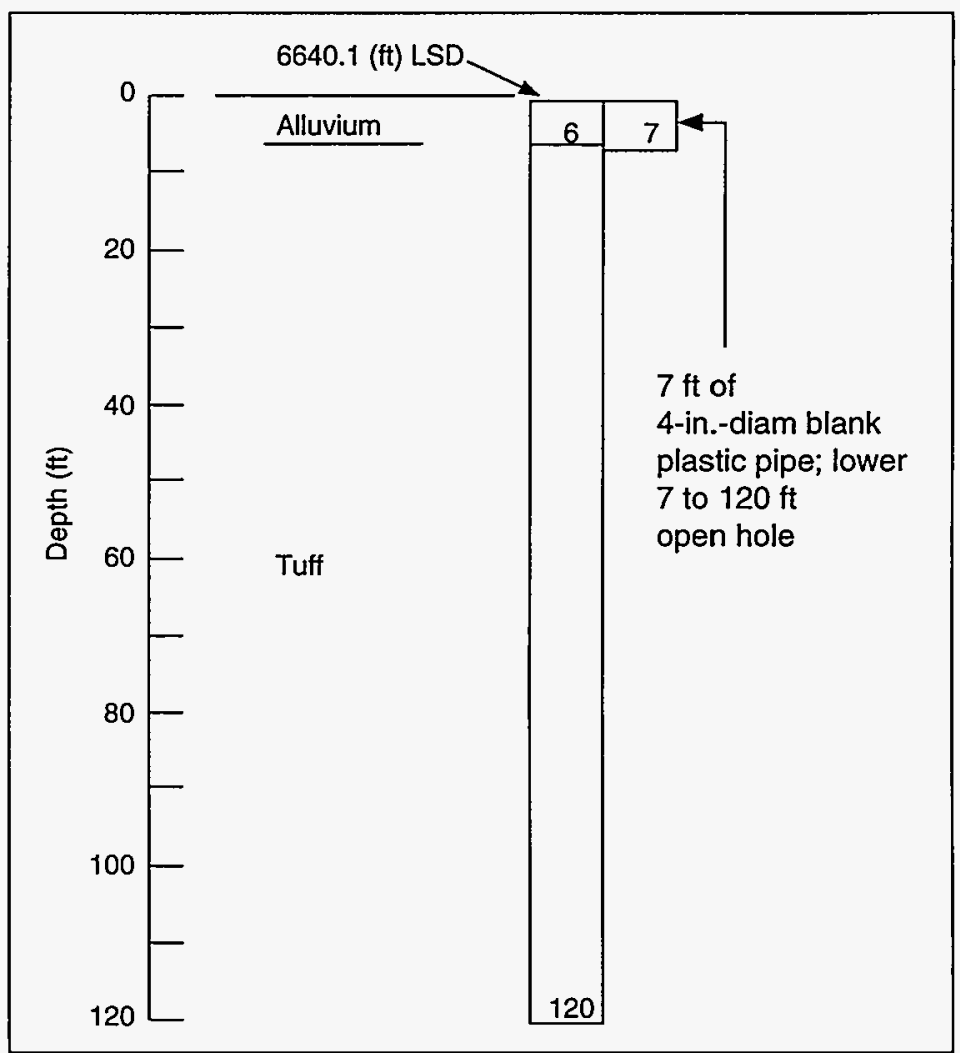




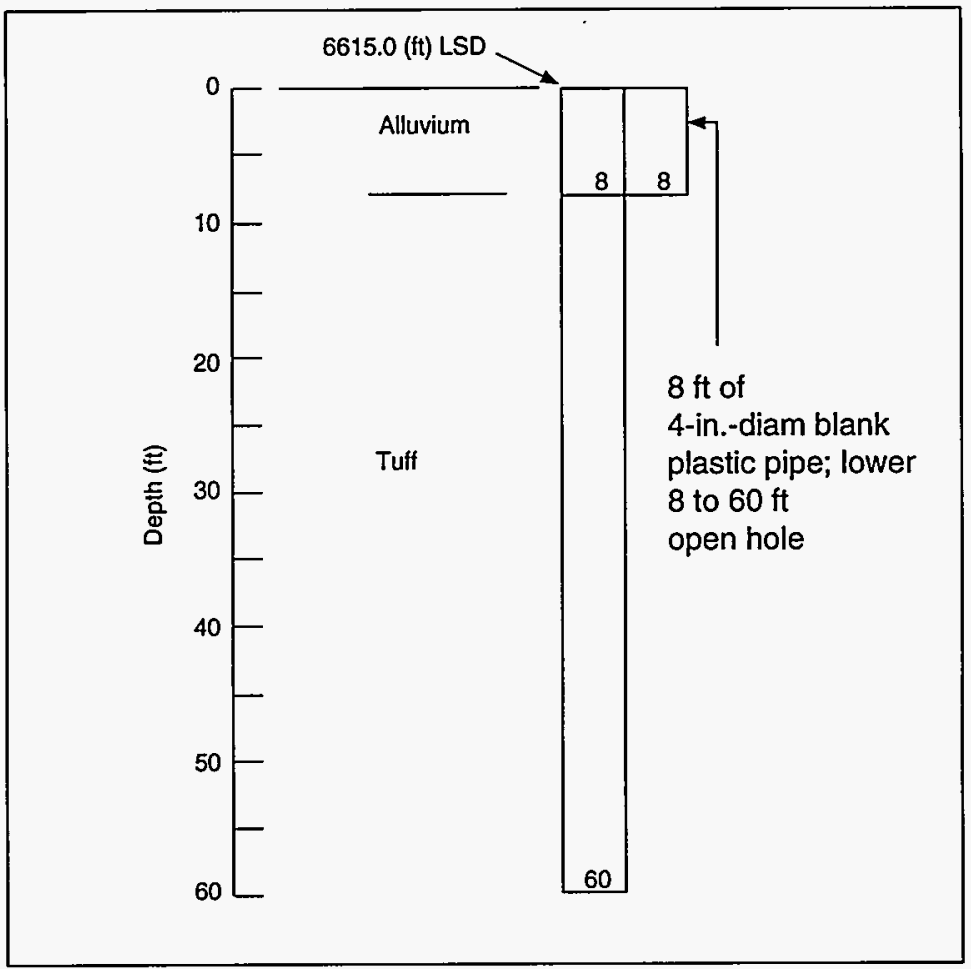

Fig. VII-M. Geologic log and casing schedule of test hole PCM-3, dry (Purtymun 1985).

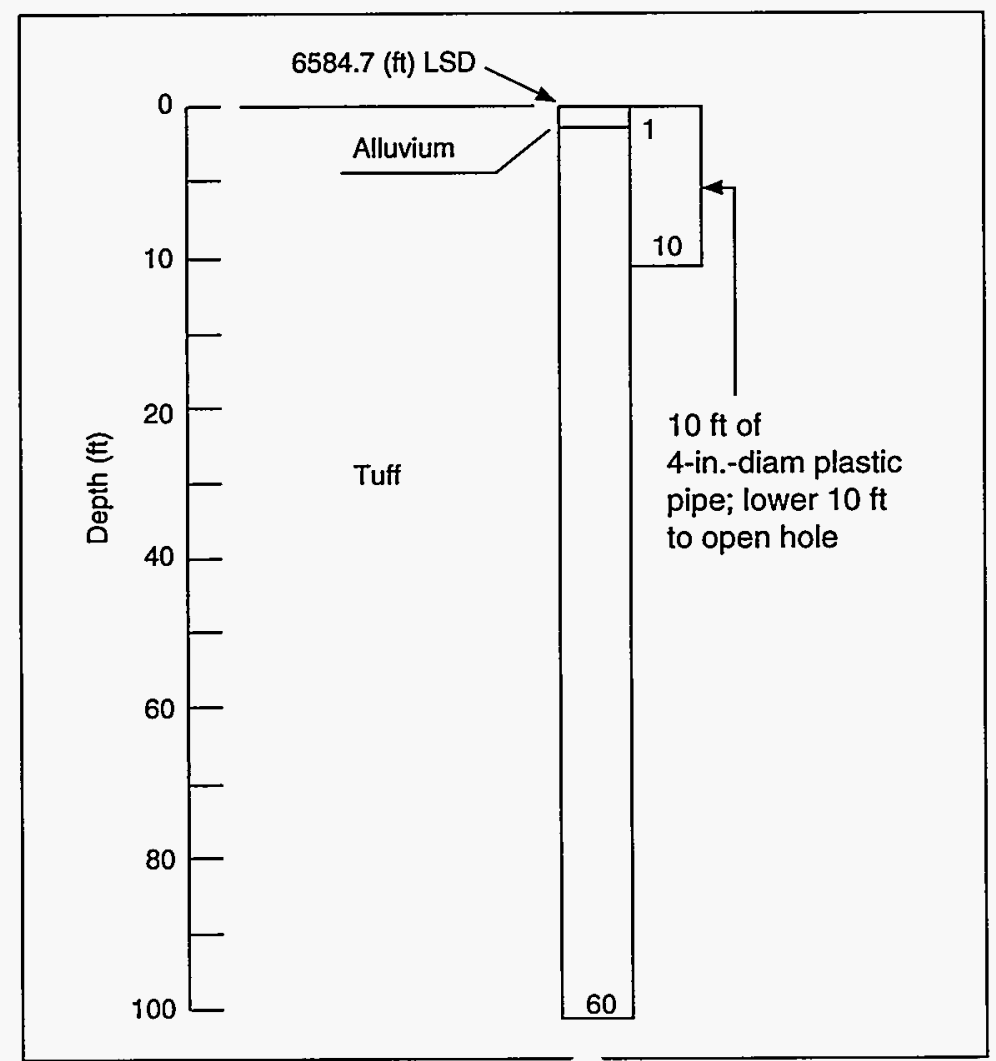

Fig. VII-N. Geologic log and casir., :chedule of test hole PCM-4, dry (Purtymun 1985). 


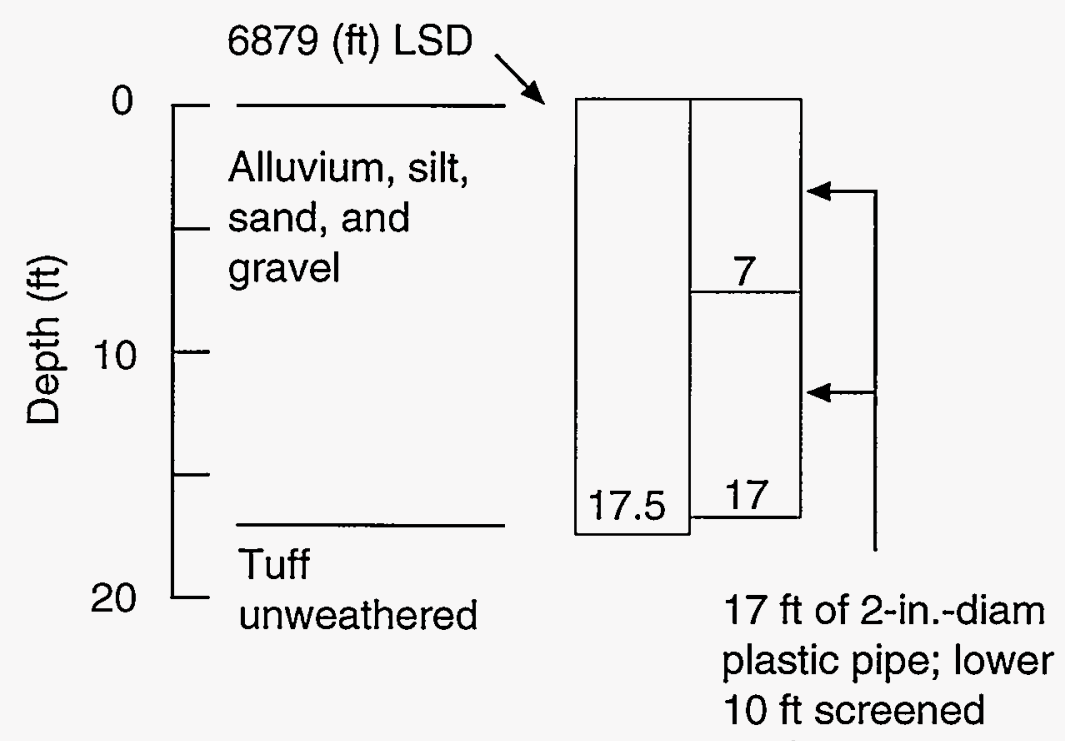

Fig. VII-O. Geologic log and casing schedule of observation well CDBO-5, dry (Purtymun 1992).

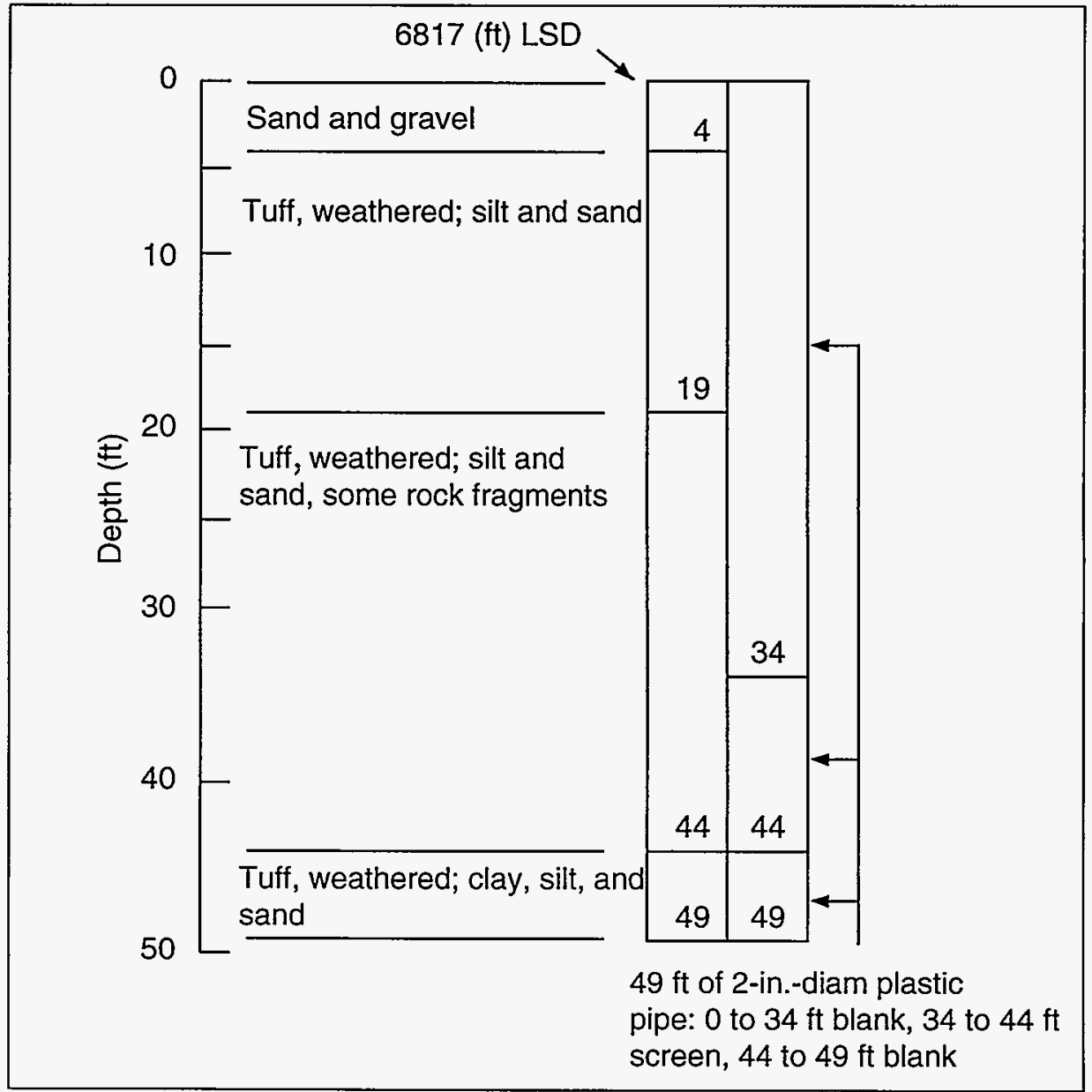

Fig. VII-P. Geologic log and casing schedule of observation well CDBO-6, perched water (Purtymun 1992). 


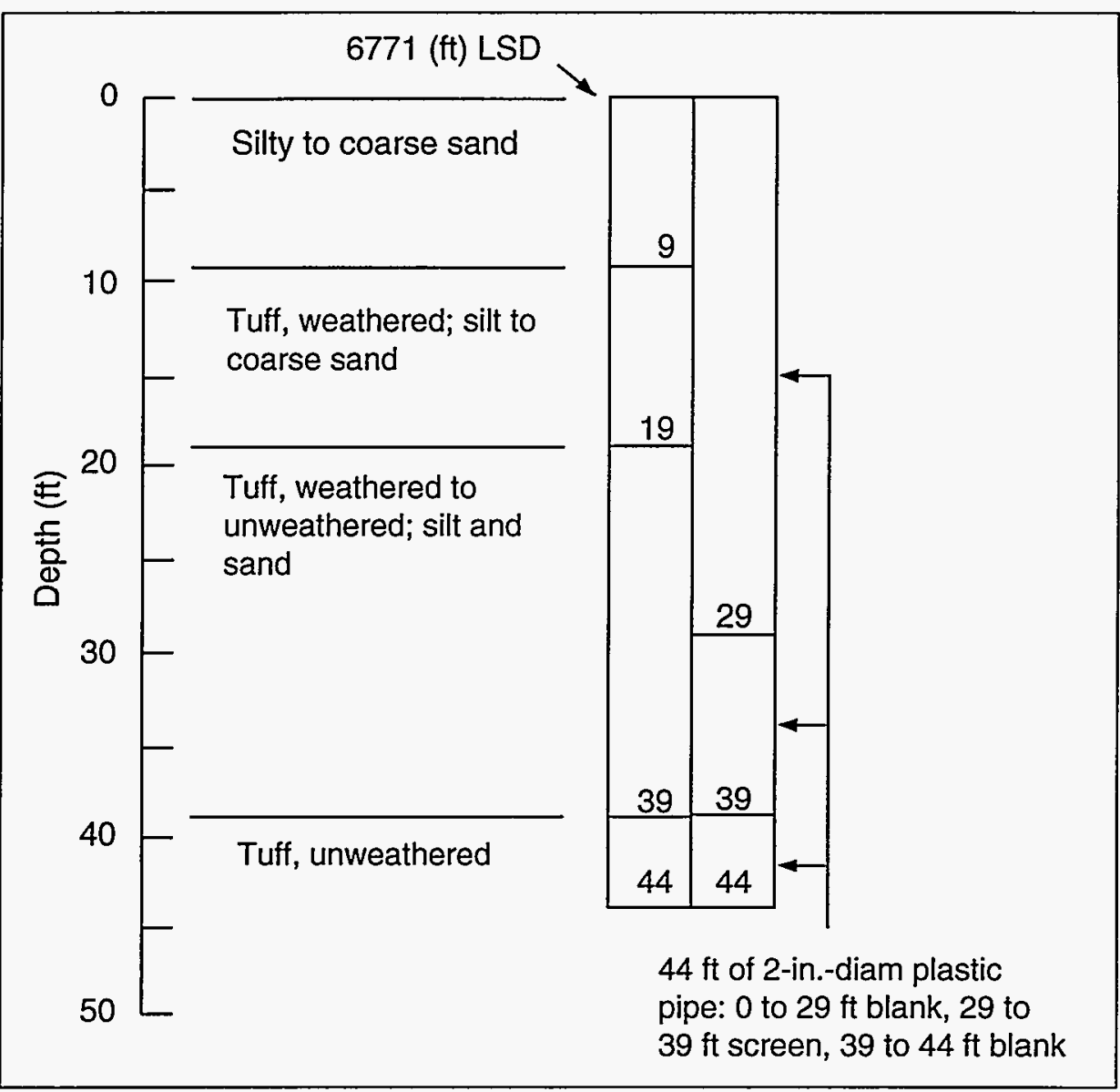

Fig. VII-Q. Geologic log and casing schedule of observation well CDBO-7, perched water (Purtymun 1992).

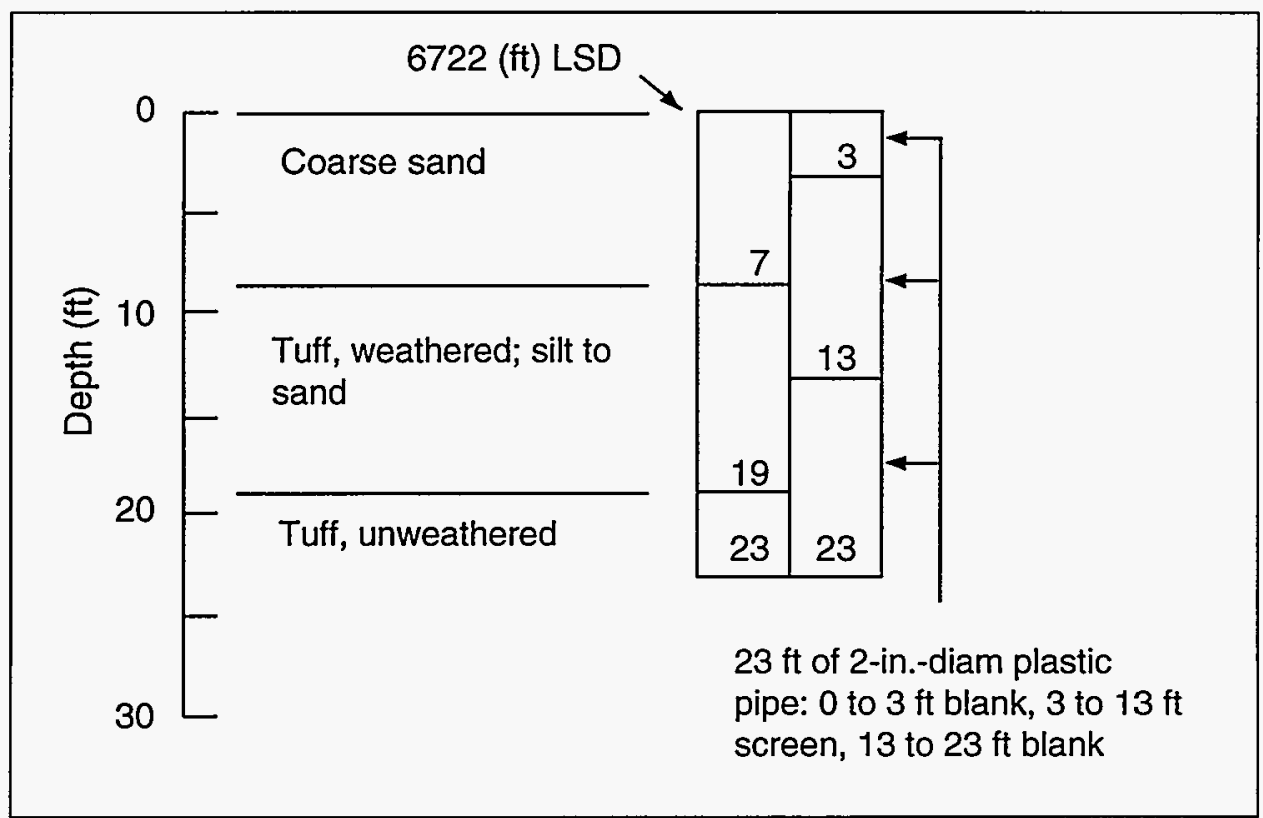

Fig. VII-R. Geologic log and casing schedule of observation well CDBO-8, dry (Purtymun 1992). 


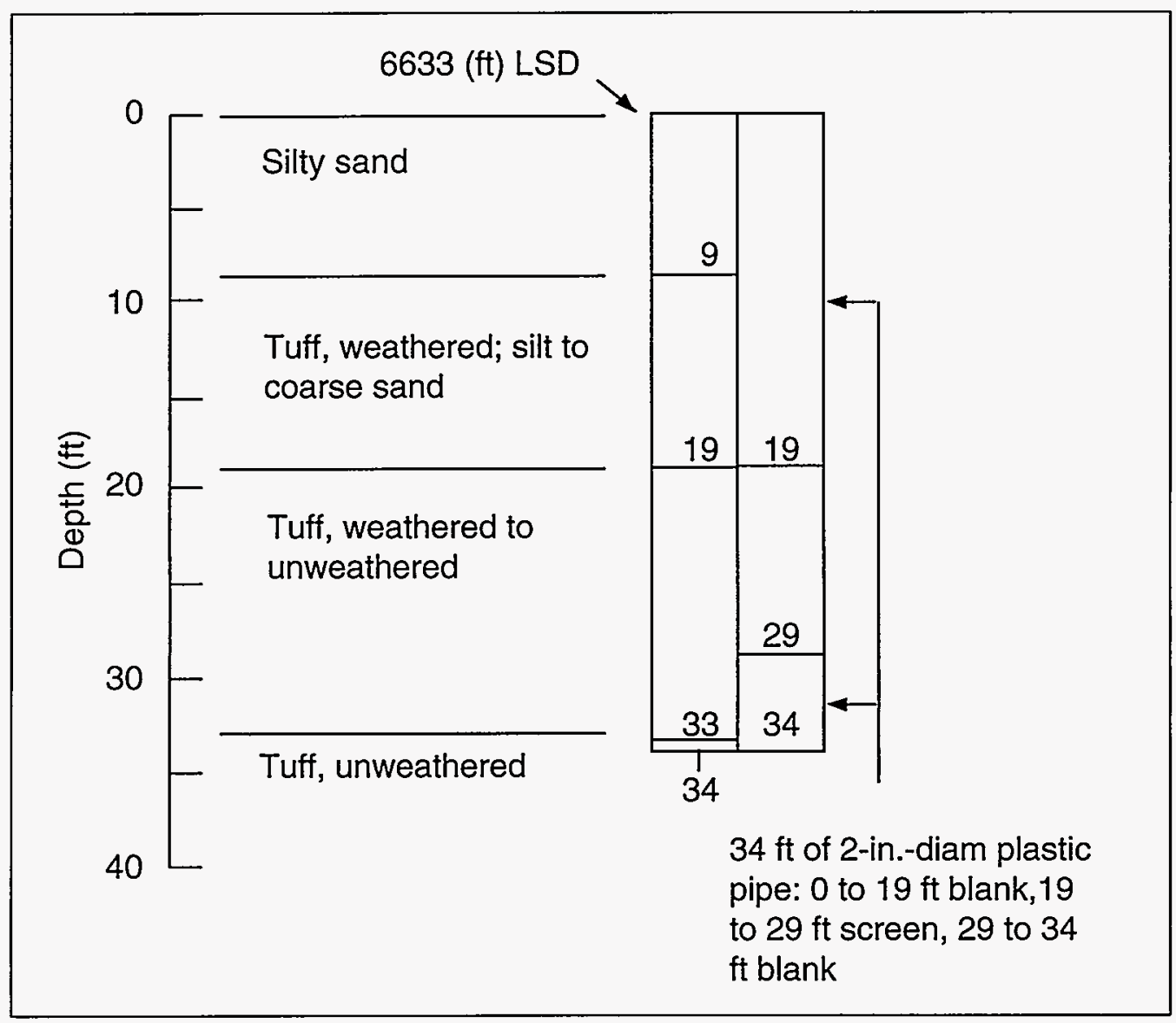

Fig. VII-S. Geologic log and casing schedule of observation well CDBO-9, dry (Purtymun 1992). 


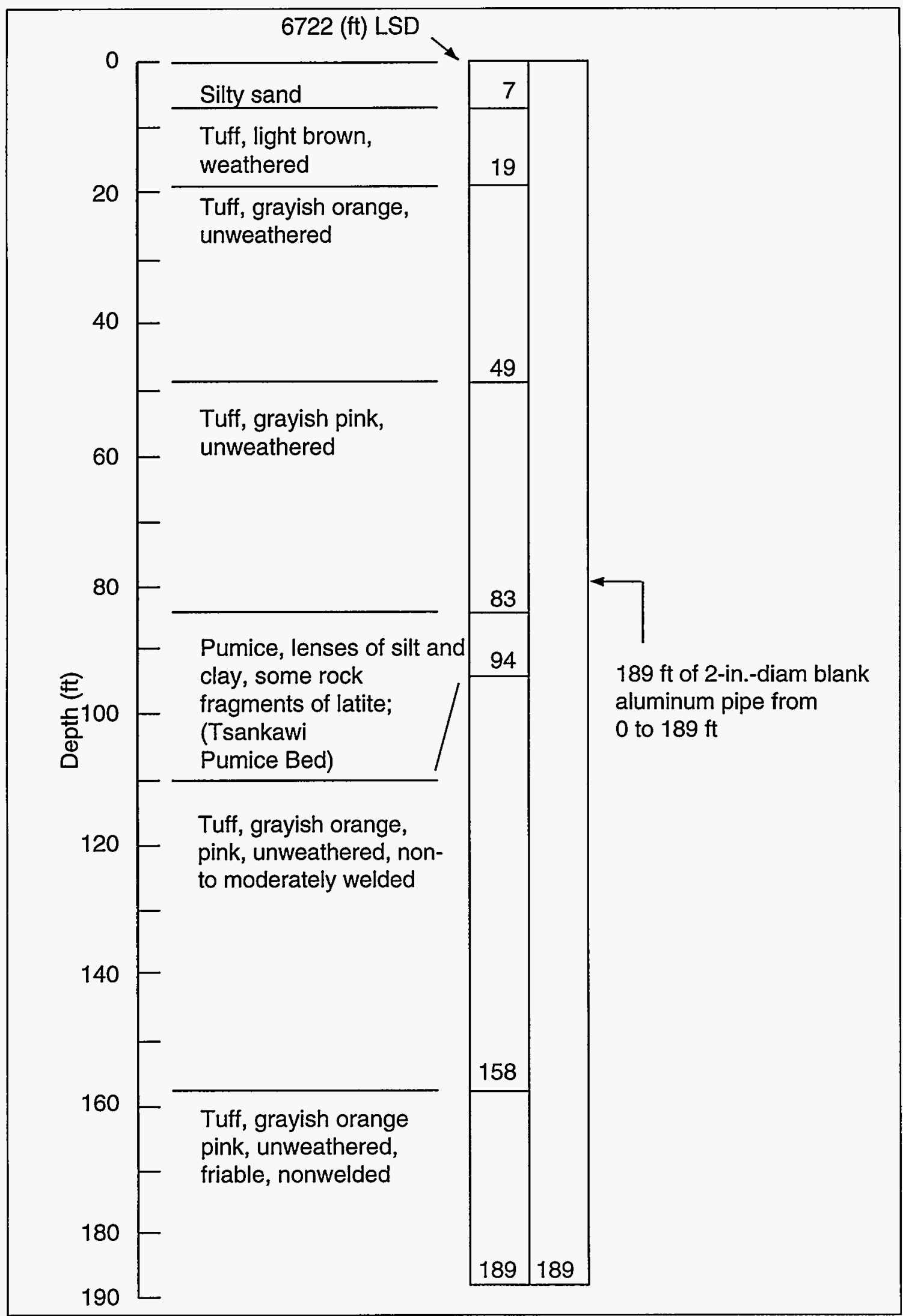

Fig. VII-T. Geologic log and casing schedule of moisture-access hole CDBM-1, dry (Purtymun 1992). 


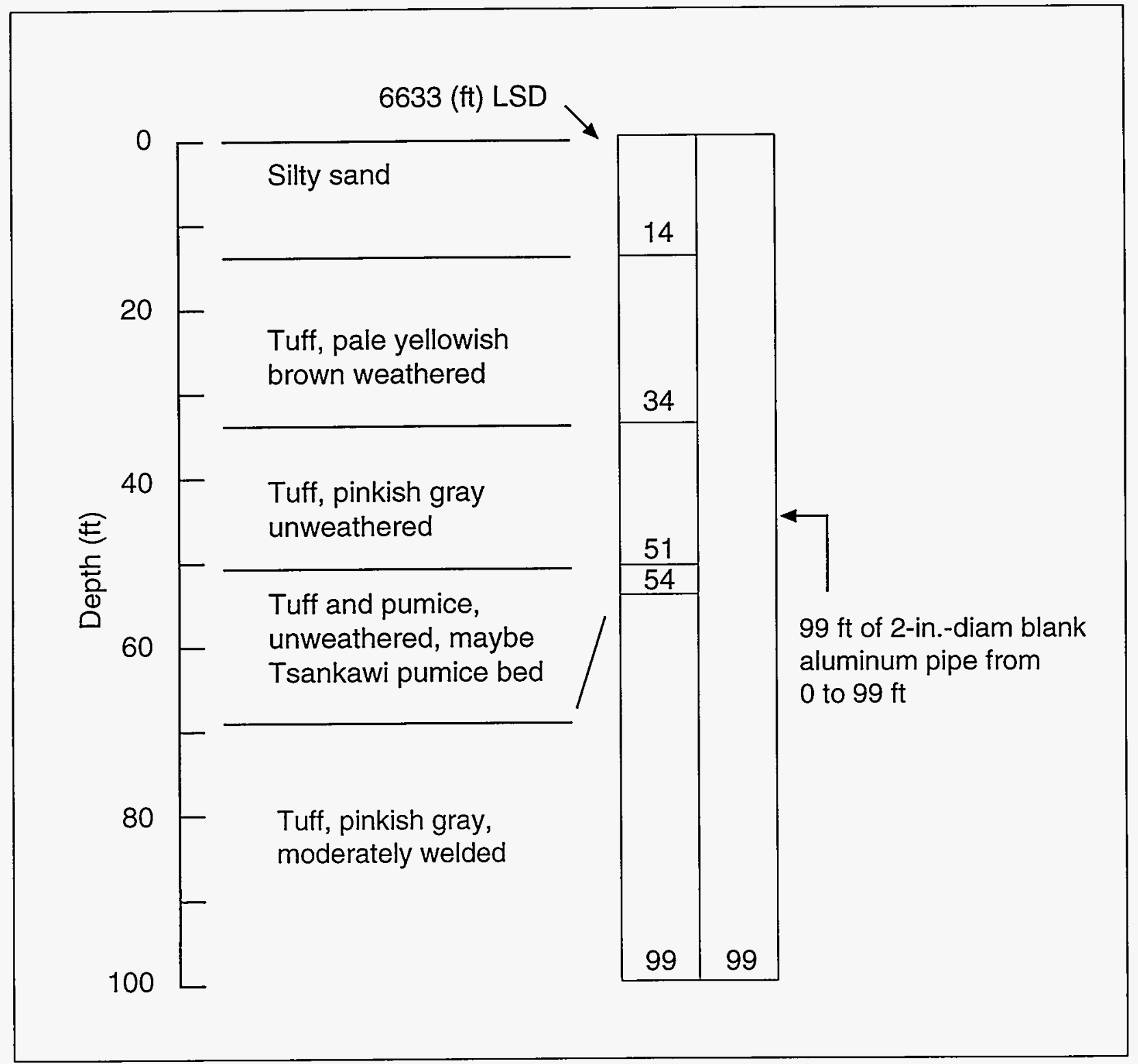

Fig. VII-U. Geologic log and casing schedule of moisture-access hole CDBM-2, dry (Purtymun 1992). 
TABLE VII-A. Geologic Logs and Construction Data for Observation Wells in Cañada del Buey (4 Obs. Wells)

1. Observation Well CDBO-1

Elevation (LSD) $6757.6 \mathrm{ft}$

Geologic Log

Alluvium,

light brown, silty sand with some clay

Tuff, brown, weathered with quartz and sanidine crystals and crystal fragments, (weathered tuff estimated 20 to $30 \%$ silt and clay)

\author{
Water Level: Dry \\ Thickness Depth \\ (ft) $\quad(\mathrm{ft})$ \\ $6 \quad 6$ \\ 9 \\ 15
}

Construction

$13.1 \mathrm{ft}$ of 4 -in.-diam plastic pipe set 0 to $13.1 \mathrm{ft}$, lower $8 \mathrm{ft}$ perforated. Cement 0 to $2 \mathrm{ft}$; gravel packed 2 to $13 \mathrm{ft}$.

2. Observation Well CDBO-2

Elevation (LSD) $6748.2 \mathrm{ft}$

Geologic Log

Alluvium, light brown

silty sand, some clay

Tuff, brown, weathered with quartz and sanidine crystals and crystal fragments; some rock fragments (weathered tuff estimated 20 to $30 \%$ silt and clay)

$\begin{array}{cc}\begin{array}{c}\text { Water Level: Dry } \\ \text { Thickness } \\ \text { (ft) }\end{array} & \begin{array}{c}\text { Depth } \\ \text { (ft) }\end{array} \\ 12 & 12 \\ & \\ 6 & 18\end{array}$

\title{
Construction
}

$17.9 \mathrm{ft}$ of 4 -in.-diam plastic pipe set 0 to $17.9 \mathrm{ft}$, lower $12 \mathrm{ft}$ perforated. Cement 0 to $2 \mathrm{ft}$; gravel packed 2 to $18 \mathrm{ft}$.

\section{Observation Well CDBO-3}

Elevation (LSD) $6670.2 \mathrm{ft}$

\section{Geologic Log}

Alluvium, light brown, silty sand, some clay

Tuff, light gray, quartz and sanidine crystals and crystal fragments, small rock fragments, slight amount of clay as a result of weathering

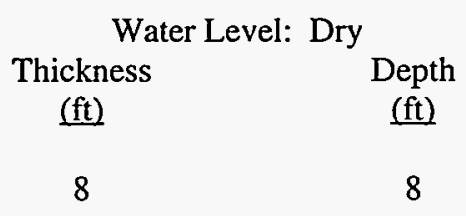
Water Level: Dry Thickness (ft) Depth

Construction

$12.4 \mathrm{ft}$ of 4 -in.-diam plastic pipe set 0 to $12.4 \mathrm{ft}$ lower $10 \mathrm{ft}$ perforated. Cement 0 to $2 \mathrm{ft}$; gravel packed 2 to $12 \mathrm{ft}$. 
TABLE VII-A. Geologic Logs and Construction Data for Observation Wells in Cañada del Buey (4 Obs. Wells) (Continued)

\section{Observation Well CDBO-4}

Elevation (LSD) $6564.5 \mathrm{ft}$

\section{Geologic Log}

Alluvium, light brown, silty sand with some clay

Tuff, light gray, quartz and sanidine crystals and crystal fragments, some small rock fragments, slight amount of clay as a result of weathering

$\begin{array}{ll}\text { Water Level: } & \text { Dry } \\ \text { Thickness } & \text { Depth } \\ \text { (ft) } & (\mathrm{ft})\end{array}$

9 9
12

\section{Construction}

$12.1 \mathrm{ft}$ of 4-in.-diam plastic pipe set 0 to $12.1 \mathrm{ft}$, lower $4 \mathrm{ft}$ perforated. Cement 0 to $2 \mathrm{ft}$; gravel packed 2 to $12 \mathrm{ft}$.

Source: Purtymun 1985. 
1. Observation Well PCO-1

Elevation (LSD) $6687.0 \mathrm{ft}$

Geologic Log

Alluvium, light brown, gravel, cobbles, and boulders in a matrix of clay, silt, and sand

Tuff, light reddish brown, weathered, quartz and sanidine crystal fragments, a few rock fragments of latite and rhyolite
Water Level: $1.3 \mathrm{ft}$ (1985) Thickness

(ft)

(ft)

11

11

11

22

Construction

$12.3 \mathrm{ft}$ of 4 -in.-diam plastic pipe set 0 to $12.3 \mathrm{ft}$, lower $8 \mathrm{ft}$ perforated. Cement 0 to $2 \mathrm{ft}$; gravel packed 2 to $12 \mathrm{ft}$.

2. Observation Well PCO-2

Elevation (LSD) $6618.3 \mathrm{ft}$

Geologic Log

Alluvium, light brown, gravels, cobbles, and boulders in a matrix of of clay, silt, and sand

Tuff, light reddish brown, nonwelded to moderately welded, quart $z$ and sanidine crystal fragments, a few small rock fragments
Water Level: $6.3 \mathrm{ft}$ (1985) Thickness

(ft)

Depth

(ft)

9

9

13

Construction

$9.5 \mathrm{ft}$ of 4-in.-diam plastic pipe set 0 to $9.5 \mathrm{ft}$, lower $8 \mathrm{ft}$ perforated. Cement 0 to $1 \mathrm{ft}$; gravel packed 1 to $9 \mathrm{ft}$.

3. Observation Well PCO-3

Elevation (LSD) $6546.3 \mathrm{ft}$

\section{Geologic Log}

Alluvium, light brown, gravel with a few cobbles in a matrix of silty sand

Tuff, light gray to light brown, weathered, some quartz and sanidine crystal fragments, a few small rock fragments in a matrix of weathered tuff, mostly silts and clay
Water Level: $3.1 \mathrm{ft}$ (1985)
Thickness

(ft)

12

8
Depth

(ft)

12
Construction

$17.7 \mathrm{ft}$ of 4 -in.-diam plastic pipe set 0 to $17.7 \mathrm{ft}$, lower $12 \mathrm{ft}$ perforated. Cement 0 to $2 \mathrm{ft}$; gravel packed 2 to $18 \mathrm{ft}$.

Source: Purtymun 1985. 
TABLE VII-C. Geologic Logs and Construction Data for Moisture-Access Holes in Pajarito Canyon (4 Moisture-Access Holes)

1. Test Hole PCM-1

Elevation (LSD) $6697.6 \mathrm{ft}$

Geologic Log

Alluvium

Tuff, reddish brown, pumice layer at $44 \mathrm{ft}$

\begin{tabular}{|c|c|}
\hline \multicolumn{2}{|c|}{ Water Level: Dry } \\
\hline Thickness & Depth \\
\hline (ft) & $(\mathrm{ft})$ \\
\hline 8 & 8 \\
\hline 52 & 60 \\
\hline
\end{tabular}

Construction

$8.3 \mathrm{ft}$ of 4-in.-diam plastic pipe cemented in hole 0 to $8.3 \mathrm{ft}$.

\section{Test Hole PCM-2}

Elevation (LSD) $6640.1 \mathrm{ft}$

$\begin{array}{cc}\begin{array}{c}\text { Water Level: } \\ \text { Thickness } \\ \text { (ft) }\end{array} & \begin{array}{c}\text { Depth } \\ \text { (ft) }\end{array} \\ 6 & 6 \\ 114 & 120\end{array}$

Geologic Log

Alluvium, weathered

tuff, silt and clay

Tuff, light gray to

pinkish brown, pumice

and rock fragments

120

Construction

$7.2 \mathrm{ft}$ of 4-in.-diam plastic pipe cemented in hole 0 to $7.2 \mathrm{ft}$.

\section{Test Hole PCM-3}

Elevation (LSD) $6615.0 \mathrm{ft}$

\section{Geologic Log}

Alluvium

Tuff, light pink, numerous rock

fragments at $13 \mathrm{ft}$

pumice fragments at $14 \mathrm{ft}$

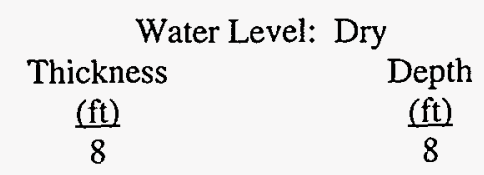

Construction

$8.3 \mathrm{ft}$ of 4 -in.-diam plastic pipe cemented in hole 0 to $8.3 \mathrm{ft}$.

\section{Test Hole PCM-4}

Elevation (LSD) $6584.7 \mathrm{ft}$

\section{Geologic Log}

Alluvium

Tuff, light grayish

pink changing to brownish gray at

$14 \mathrm{ft}$, reddish brown at $25 \mathrm{ft}$

\begin{tabular}{|c|c|}
\hline \multicolumn{2}{|c|}{ Water Level: Dry } \\
\hline Thickness & Depth \\
\hline (ft) & $(\mathrm{ft})$ \\
\hline 1 & 1 \\
\hline 59 & 60 \\
\hline
\end{tabular}

Construction

$9.7 \mathrm{ft}$ of 4-in.-diam plastic pipe cemented in hole 0 to $9.7 \mathrm{ft}$.

Source: Purtymun 1985. 
TABLE VII-D. Geologic Logs and Construction Data for Observation Wells in Cañada del Buey (1992)

\section{Obs. Well CDBO-5}

Elevation (LSD) $6879 \mathrm{ft}$

Geologic Log

Silt and sand

Silt, sand, very moist

Very coarse sand and some gravel

Tuff (unweathered)

\begin{tabular}{|c|c|}
\hline \multicolumn{2}{|c|}{ Water Level: Dry } \\
\hline Thickness & Depth \\
\hline$(\mathrm{ft})$ & $(\mathrm{ft})$ \\
\hline 10 & 10 \\
\hline 2 & 12 \\
\hline 5 & 17 \\
\hline 0.5 & 17.5 \\
\hline
\end{tabular}

Construction

$17 \mathrm{ft}$ of 2-in.-diam plastic pipe; screen (0.010-in. slots) 7 to $17 \mathrm{ft}$; blank 0 to $7 \mathrm{ft}$. Packed (0.010-0.020-in. sand) 1 to $17 \mathrm{ft}$; cement in 0 to $1 \mathrm{ft}$ with security cap.

\section{Obs. Well CDBO-6}

Elevation (LSD) $6817 \mathrm{ft}$

Geologic Log

Coarse sand with some clay to silt lenses (Alluvium)

Tuff, weathered grayish brown, silty sand

Tuff, weathered moderately yellowish brown (10 YR -5/4) to dark yellowish brown (10 YR - 4/2) quartz and sanidine crystals, some rock fragments of latite and pumice, moderately welded

Tuff, weathered, similar to above, containing silts and clays; water perched above this unit
Water Level: Perched Water Thickness

(ft)

Depth

4

15

4

19

\section{Construction}

$49 \mathrm{ft}$ of 2-in.-diam plastic pipe; 44 to $49 \mathrm{ft}$ blank, 44 to $34 \mathrm{ft}$ screen (0.010-in. slots), blank 0 to $34 \mathrm{ft}$; gravel packed with $0.010-0.020$-in. silica sand 8 to $49 \mathrm{ft}$; bentonite 3 to $8 \mathrm{ft}$; cement 0 to $3 \mathrm{ft}$ with security cap.

\section{Obs. Well CDBO-7}

Elevation (LSD) $6771 \mathrm{ft}$

\section{Geologic Log}

Silty sand to coarse sand (Alluvium)

Tuff, weathered, silty to coarse sand, friable

Tuff, weathered to unweathered, made up of quartz and sanidine crystals, rock fragments of latite, unweathered pumice fragments

Tuff, unweathered
Water Level: Perched Water

$\begin{array}{cc}\begin{array}{c}\text { Thickness } \\ (\mathrm{ft})\end{array} & \begin{array}{c}\text { Depth } \\ (\mathrm{ft})\end{array} \\ 9 & 9 \\ 10 & 19 \\ & \\ 20 & 39 \\ 5 & 44\end{array}$

Construction

$44 \mathrm{ft}$ of 2-in.-diam plastic pipe; 39 to $44 \mathrm{ft}$ blank; 29 to $39 \mathrm{ft}$ screen (0.010-in. slots), packed with $0.010-0.020$-in. silica sand 4 to $44 \mathrm{ft}$; bentonite 2.5 to $4 \mathrm{ft}$; cement $0-25 \mathrm{ft}$ with security cap. 
TABLE VII-D. Geologic Logs and Construction Data for Observation Wells in Cañada del Buey (1992)

(Continued)

\section{Obs. Well CDBO-8}

Elevation (LSD) $6722 \mathrm{ft}$

\section{Geologic Log}

Coarse sand (alluvium)

Tuff, weathered pale yellowish brown

Water Level: Dry
$\begin{aligned} & \text { Thickness } \\ & \frac{(\mathrm{ft})}{7}\end{aligned}$
$\begin{gathered}\text { Depth } \\ (\mathrm{ft})\end{gathered}$

(10 YR 6/2) containing a few rock fragments

of pumice, rounded latite, and a few chunks

of unweathered tuff

12

19

Tuff, unweathered, grayish orange pink, (5 YR

$7 / 2$ ) quartz and sanidine crystals, a few rock

fragments of latite, and some pumice

4

23

Construction

$23 \mathrm{ft}$ of 2-in.-diam plastic pipe; blank 13 to $23 \mathrm{ft}$; screen ( 0.010 in. slots) 3 to $13 \mathrm{ft}$; blank 0 to $3 \mathrm{ft}$; packed with $0.010-0.020$-in. silica sand 8 to $23 \mathrm{ft}$; bentonite 6 to $8 \mathrm{ft}$; cement surface to $6 \mathrm{ft}$ with security cap.

\section{Obs. Well CDBO-9}

Elevation (LSD) $6633 \mathrm{ft}$

\section{Geologic Log}

Silty sand with some brown clay

Tuff, weathered, silt to coarse sand (weathered in place)

Tuff, weathered to unweathered, silt to coarse sand (weathered in place)

$\begin{array}{cc}\begin{array}{c}\text { Water Level: Dry } \\ \begin{array}{c}\text { Thickness } \\ \frac{(\mathrm{ft})}{9}\end{array}\end{array} & \begin{array}{c}\text { Depth } \\ (\mathrm{ft})\end{array} \\ 10 & 9 \\ 14 & 19 \\ 1 & 33 \\ & 34\end{array}$

\section{Construction}

$34 \mathrm{ft}$ of 2-in.-diam plastic pipe: 29 to $34 \mathrm{ft}$ blank; 19 to $29 \mathrm{ft}$ screen (0.010-in. slots);

0 to $19 \mathrm{ft}$ blank; gravel packed with $0.010-0.020$-in. silica sand 7 to $34 \mathrm{ft}$; bentonite 2 to $7 \mathrm{ft}$; cement 0 to $2 \mathrm{ft}$ with a security cap.

Source: Purtymun 1992. 
TABLE VII-E. Geologic Logs and Construction Data of Moisture-Access Holes in Cañada del Buey

\section{Moisture-Access Hole CDBM-1}

Elevation (LSD) $6722 \mathrm{ft}$

Geologic Log

Silty sand (alluvium)

Tuff, weathered, light brown (5 YR

$6 / 4)$, to pale red (10R 6/2) quartz and sanidine crystals, rock fragments of pumice and some fragments of unweathered tuff (tuff weathered in place)

Tuff, unweathered, moderately welded, grayish orange (10 R 7/4) quartz and sanidine crystal and crystal fragments of gray pumice and latite, is a non- to moderately welded ash matrix (Unit 1A)

Tuff, unweathered, grayish pink ( $5 \mathrm{R} 8 / 2$ ), containing alternating beds of pumice and tuff, rock fragments of latite and quartz crystals and crystal fragments, ranges from nonwelded to moderately welded; 69 to $83 \mathrm{ft}$ tuff unweathered, very light gray $(\mathrm{N}-8)$, nonwelded to moderately welded, rock fragments of pumice and latite, with occasional quartz and sanidine fragments

Pumice, some weathering with some latite rock fragments; some lenses of clay and silt (Tsankawi Pumice Bed)

Tuff, unweathered, grayish orange pink (5 YR 7/2) non- to moderately welded, quartz and sanidine crystals and crystal fragments, rock fragments of latite, rhyolite, and white to pink pumice (Otowi Member)

Tuff, grayish orange pink, unweathered, friable, nonwelded

\author{
Water Level: Dry

$\begin{array}{cc}\begin{array}{c}\text { Thickness } \\ (\mathrm{ft})\end{array} & \begin{array}{c}\text { Depth } \\ 7\end{array} \\ \frac{(\mathrm{ft})}{7}\end{array}$

12

19

30

49

34

83

11

94

$64 \quad 158$

$31 \quad 189$

Construction

$189 \mathrm{ft}$ of 2-in.-diam aluminum pipe, 0 to $189 \mathrm{ft}$; packed with $0.010-0.020$-in. sand 19 to $189 \mathrm{ft}$; bentonite 4 to $19 \mathrm{ft}$; cement 0 to $4 \mathrm{ft}$ with security cap. 
TABLE VII-E. Geologic Logs and Construction Data of Moisture-Access Holes in Cañada del Buey (Continued)

\section{Moisture-Access Hole CDBM-2}

Elevation (LSD) $6633 \mathrm{ft}$

\section{Geologic Log}

Silty to coarse sand, pale brown (5 YR 5/2) made up of quartz and sanidine crystals and crystal fragments, rock fragments of pumice

Tuff, weathered, pale yellowish brown (10 YR 6/2), quartz and sanidine crystals and crystal fragments, rock fragments of pumice

Tuff, unweathered, pinkish gray (5 YR 8/1) quartz and sanidine crystals and crystal fragments, some rock fragments of latite and pumice

Tuff and pumice, unweathered, moderate brown (5 YR 4/4) moderately welded, quartz and sanidine crystals, a few small rock fragments of rhyolite and numerous white pumice fragments in a brown ash matrix (Tsankawi Pumice Bed)

Tuff, unweathered, pinkish gray (5 R 8/1) moderately welded, quartz and sanidine crystals and crystal fragments, rock fragments of latite up to $1 / 2$ in. long; pumice, light gray up to $1 \mathrm{in}$.

long in a brown ash matrix

$\begin{array}{cc}\begin{array}{c}\text { Water Level: Dry } \\ \begin{array}{c}\text { Thickness } \\ \text { (ft) }\end{array}\end{array} & \begin{array}{c}\text { Depth } \\ (\mathrm{ft})\end{array} \\ 14 & 14 \\ & \\ 20 & 34\end{array}$

3

54

45

99

Construction

$99 \mathrm{ft}$ of 2-in.-diam aluminum pipe 0 to $99 \mathrm{ft}$; packed with 0.010-0.020-in. silica sand 24 to $99 \mathrm{ft}$; bentonite 17 to $24 \mathrm{ft}$; cement 6 to $17 \mathrm{ft}$; cuttings 2 to $6 \mathrm{ft}$; cement 0 to $2 \mathrm{ft}$ with a security cap.

Source: Purtymun 1992. 
A. Surface Water Stations

CDB near TA-46

PCS near Sewage Lagoon

PCS at SR-4

B. Observation Wells

\section{CDBO-1 \\ CDBO-2 \\ CDBO-3 \\ CDBO-4 \\ PCO-1 \\ PCO-2 \\ PCO-3}

C. Moisture-Access Holes

\author{
N 1,766,665.5 \\ N $1,758,100$ \\ N $1,751,098$
}

N $1,760,881.9$

N 1,761,041.1

N $1,759,549.0$

N 1,758,484.9

N 1,759,928.6

N 1,757,380.0

N 1,755,427.3

\begin{abstract}
N $1,760,100$
N $1,757,700$

N $1,757,100$

N 1,756,500
\end{abstract}

E 491,630.6

E 498,900

E 505,375

E $497,724.4$

E 497,874.8

E $500,432.9$

E $505,230.8$

E 497,675.1

E $501,456.2$

E 505,844.4

E 497,700

E 501,600

E 502,800

E 504,200
$6936.4 \mathrm{ft}$

$6660.0 \mathrm{ft}$

$8484.0 \mathrm{ft}$

$6757.6 \mathrm{ft}$

$6748.2 \mathrm{ft}$

$6670.2 \mathrm{ft}$

$6564.5 \mathrm{ft}$

$6687.0 \mathrm{ft}$

$6618.3 \mathrm{ft}$

$6546.3 \mathrm{ft}$

$6697.6 \mathrm{ft}$

$6640.1 \mathrm{ft}$

$6615.0 \mathrm{ft}$

$6584.7 \mathrm{ft}$

A. Observation Wells

$\begin{array}{llll}\text { CDBO }-5 & N 1,765,756 & E 493,339 & 6879 \mathrm{ft} \\ \text { CDBO }-6 & N 1,764,698 & \text { E 495,965 } & 6817 \mathrm{ft} \\ \text { CDBO }-7 & N 1,763,239 & \text { E 497,156 } & 6771 \mathrm{ft} \\ \text { CDBO }-8 & N 1,762,304 & \text { E 499,050 } & 6722 \mathrm{ft} \\ \text { CDBO - } & N 1,759,640 & \text { E 501,874 } & 6633 \mathrm{ft}\end{array}$

B. Moisture-Access Holes

CDBM - 1

N 1,762,293

E 499,052

$6722 \mathrm{ft}$

CDBM - 2

N 1,759,635

E 501,882

$6633 \mathrm{ft}$ 


\section{OBSERVATION WELLS TO MEET SPECIAL PERMIT CONDITIONS}

The special permit conditions (dictated by the operating permit issued to the Department of Energy and the Los Alamos National Laboratory by the U.S. Environmental Protection Agency) required construction of special observation wells to monitor the quality of water in the alluvium.

Observation wells were constructed in Pueblo Canyon (one well), Los Alamos Canyon (five wells), Sandia Canyon (two wells), Mortandad Canyon (five wells), Potrillo Canyon (one core hole), Fence Canyon (one well), and Water Canyon (three wells). Generalized location of the wells and core hole are shown on Fig. VIII-A.

The observation well elevations and measuring points are shown on Table VIII-A, while well characteristics and water levels are shown on Table VIII-B. The types of wellhead security locks used on these wells are shown in Fig. VIII-B. Graphic presentations of the geologic logs and construction data are shown in Figs. VIII-C through VIII-T.

The observation wells were constructed using a hollow-stem auger. The auger had an inside diameter of $6.25 \mathrm{in}$., and an outside diameter of $9.625 \mathrm{in}$. It was used with a 10.375-in.-diam bit. The holes were cased using 2-in.-diam plastic pipe in 5- or 10-ft lengths, with flush-joint, internal-upset, threaded-type connections. The hole packing material was $0.010-0.020$-in.diam Colorado silica sand with a compatible screen slot (of 0.010 in.) in the plastic casing.

\section{REFERENCES}

R. A. Bailey, R. L. Smith, and C. S. Ross, "Stratigraphic Nomenclature of the Volcanic Rocks of the Jemez Mountains, New Mexico," U.S. Geological Survey Bulletin 1274-P (1969).

Environmental Protection Group HSE-8, "Perched Zone Monitoring Wells Analytical Results," Los Alamos National Laboratory document LA-UR-904300.

W. D. Purtymun and A. K. Stoker, "Perched Zone Monitoring Well Installation," Los Alamos National Laboratory document LA-UR-90-3230.

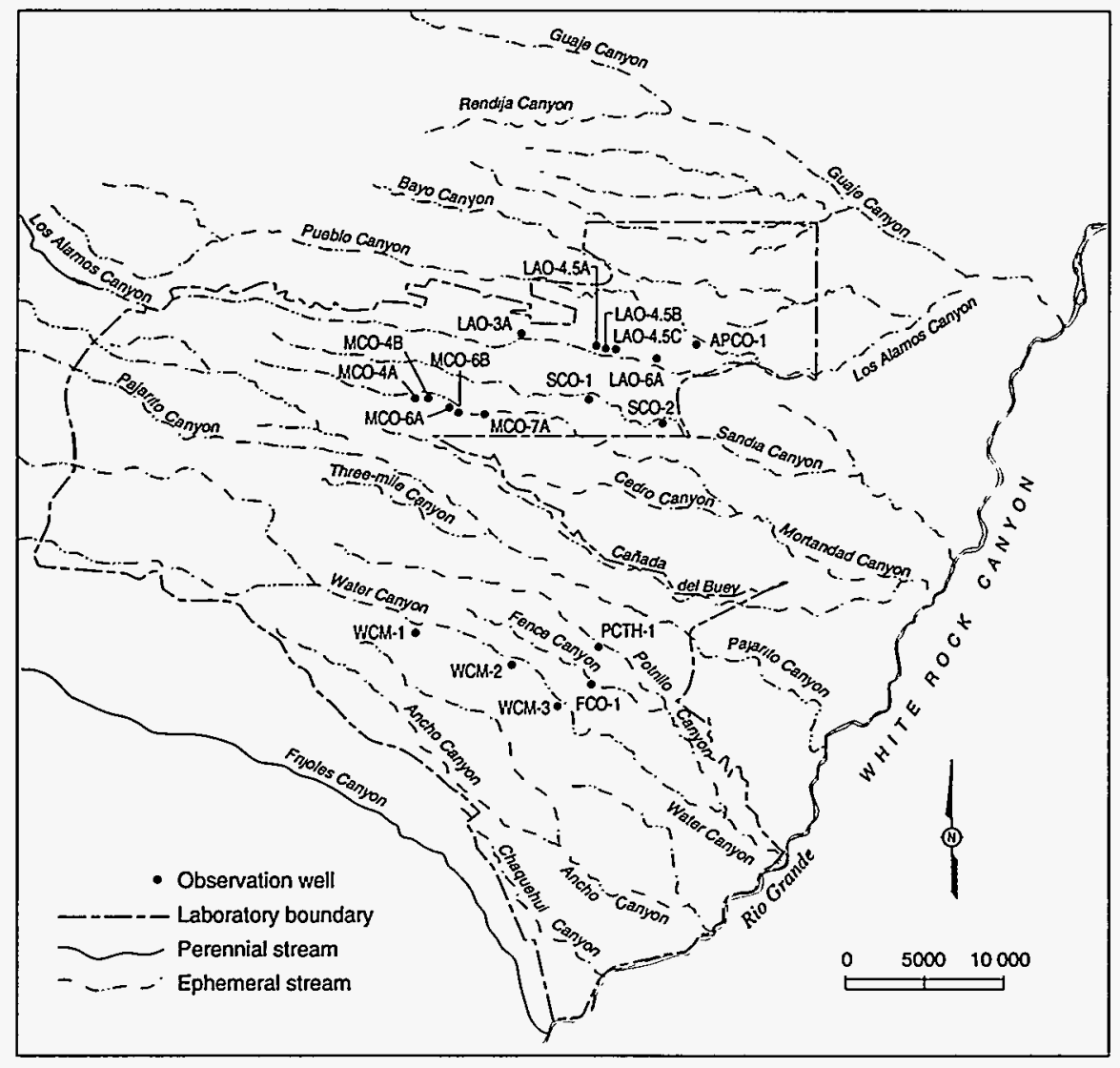

Fig. VIII-A. Locations of observation wells to meet special permit conditions. 


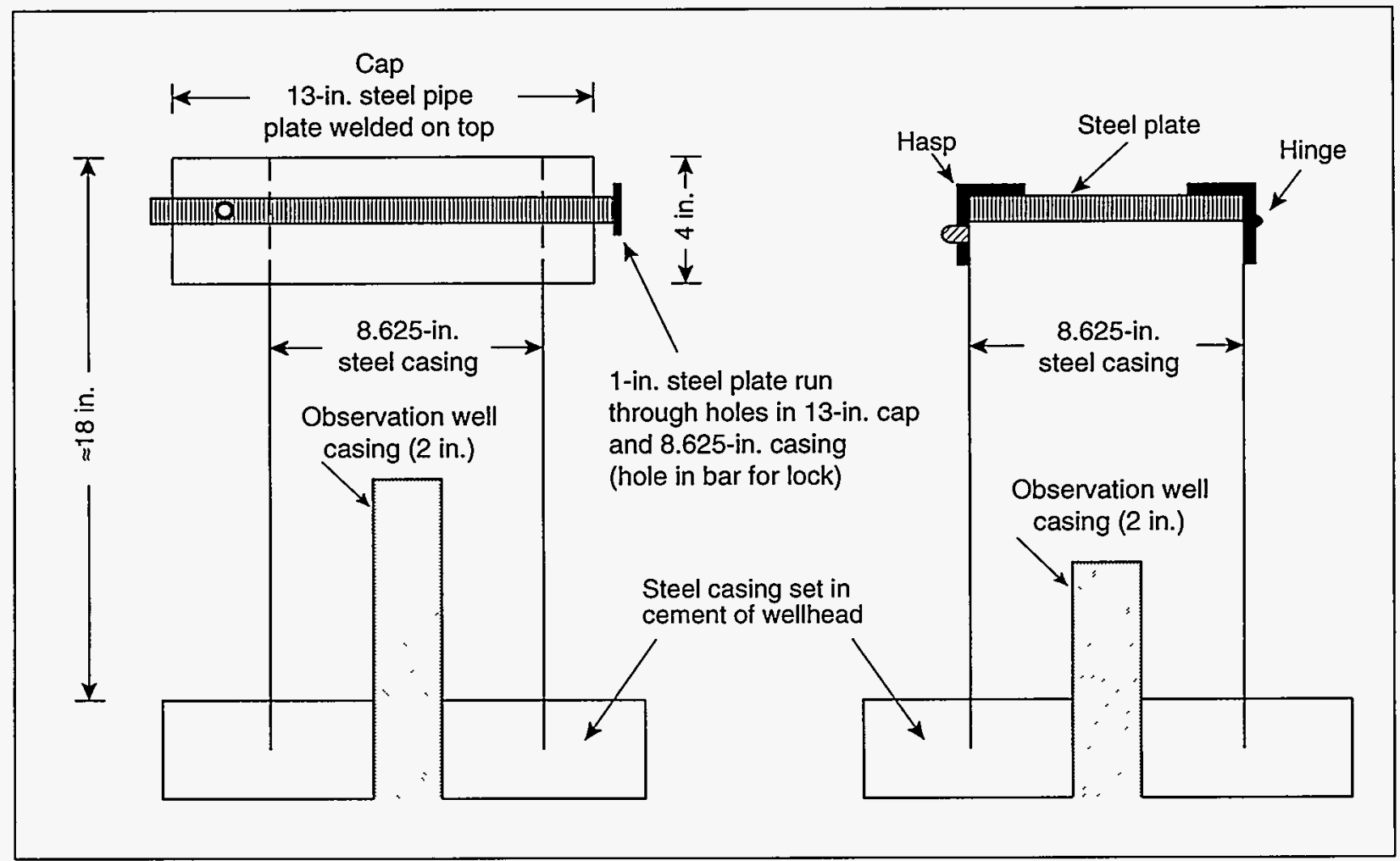

Fig. VIII-B. Type of wellhead security used on observation wells (Purtymun and Stoker 1990).

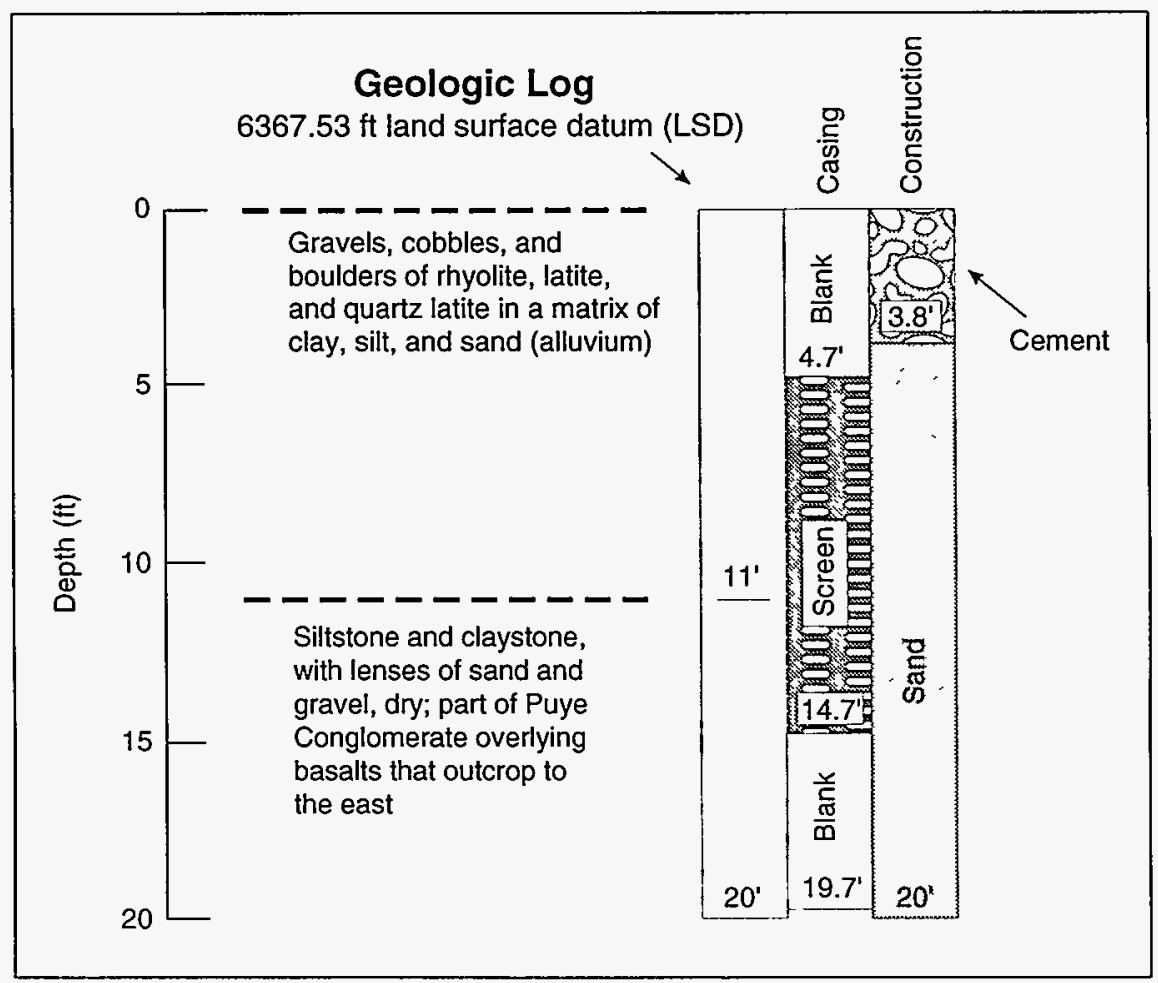

Fig. VIII-C. Pueblo Canyon observation well APCO-1, completed August 1990, water level $6.2 \mathrm{ft}$ (Purtymun and Stoker 1990). 


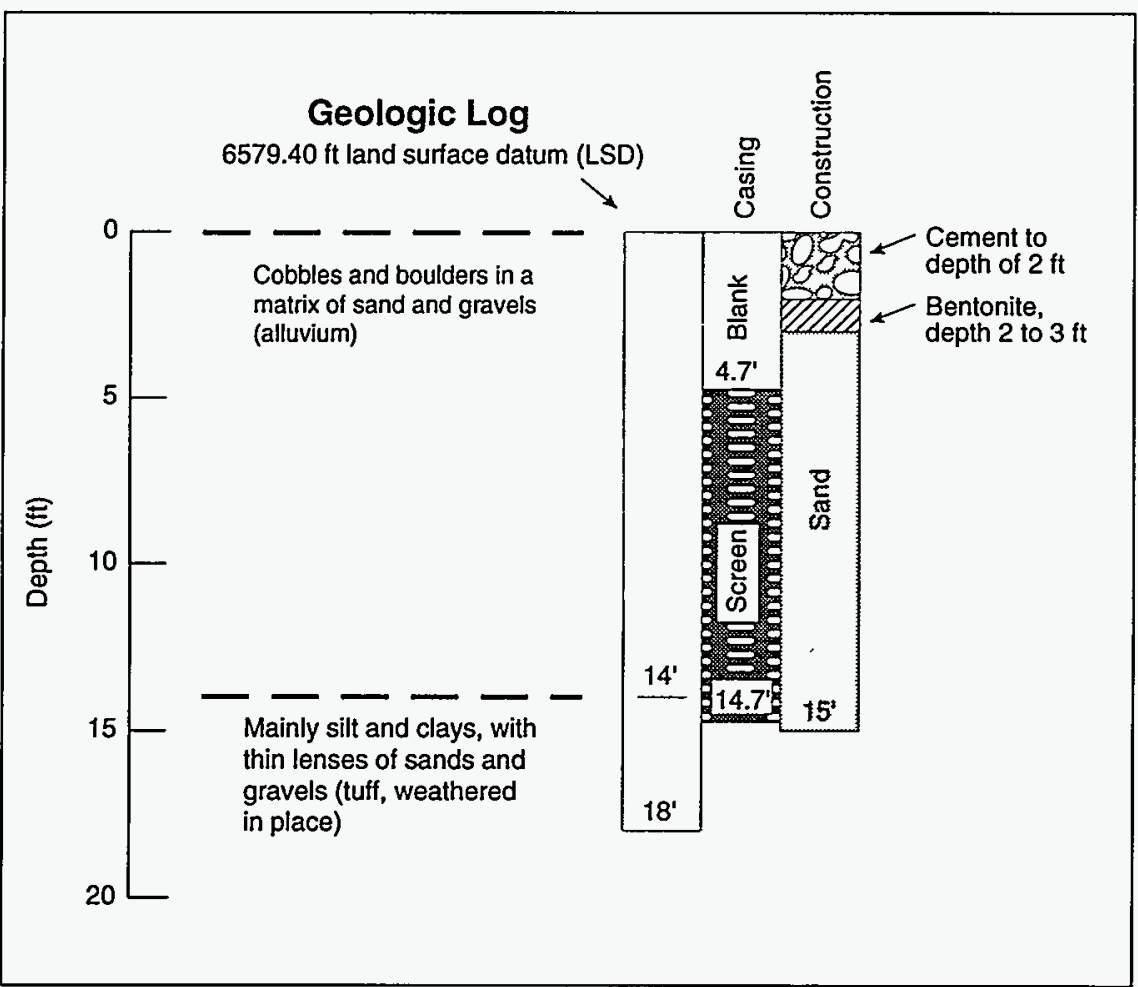

Fig. VIII-D. Los Alamos Canyon observation well LAO-3A, completed September 1989, water level $6.7 \mathrm{ft}$ (Purtymun and Stoker 1990).

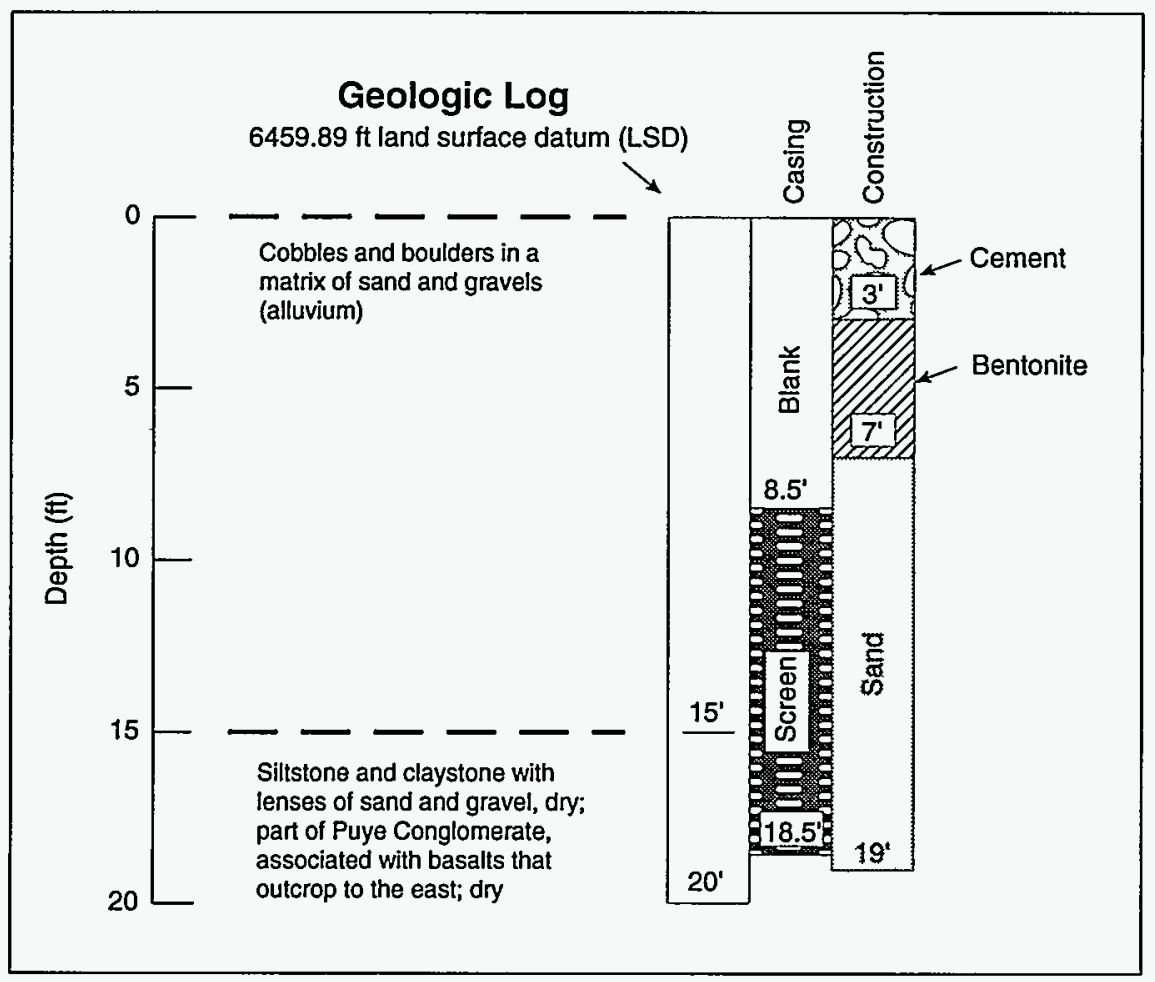

Fig. VIII-E. Los Alamos Canyon observation well LAO-4.5A, completed September 1989, dry (Purtymun and Stoker 1990). 


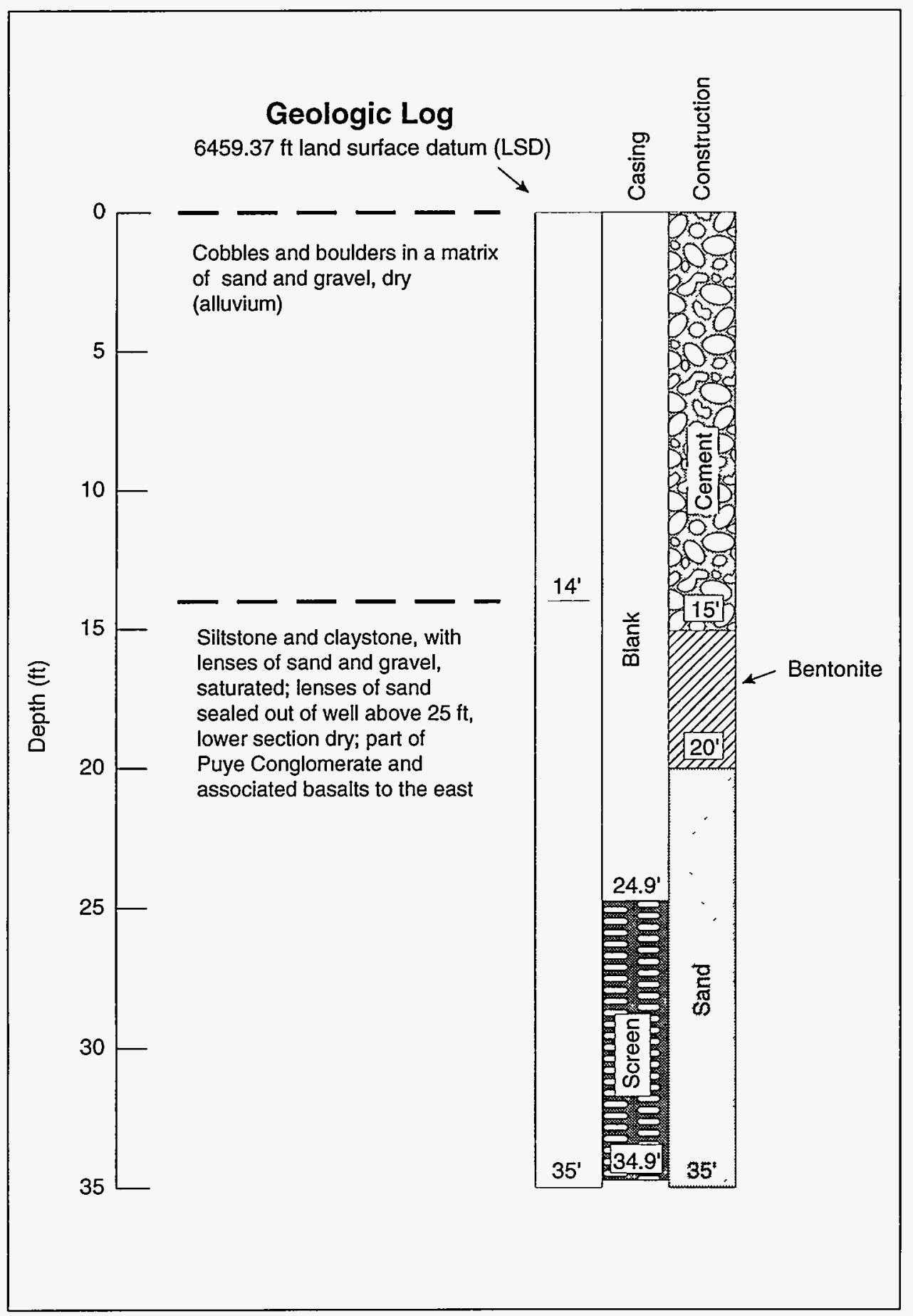

Fig. VIII-F. Los Alamos canyon observation well LAO-4.5B, completed September 1989, dry (Purtymun and Stoker 1990). 


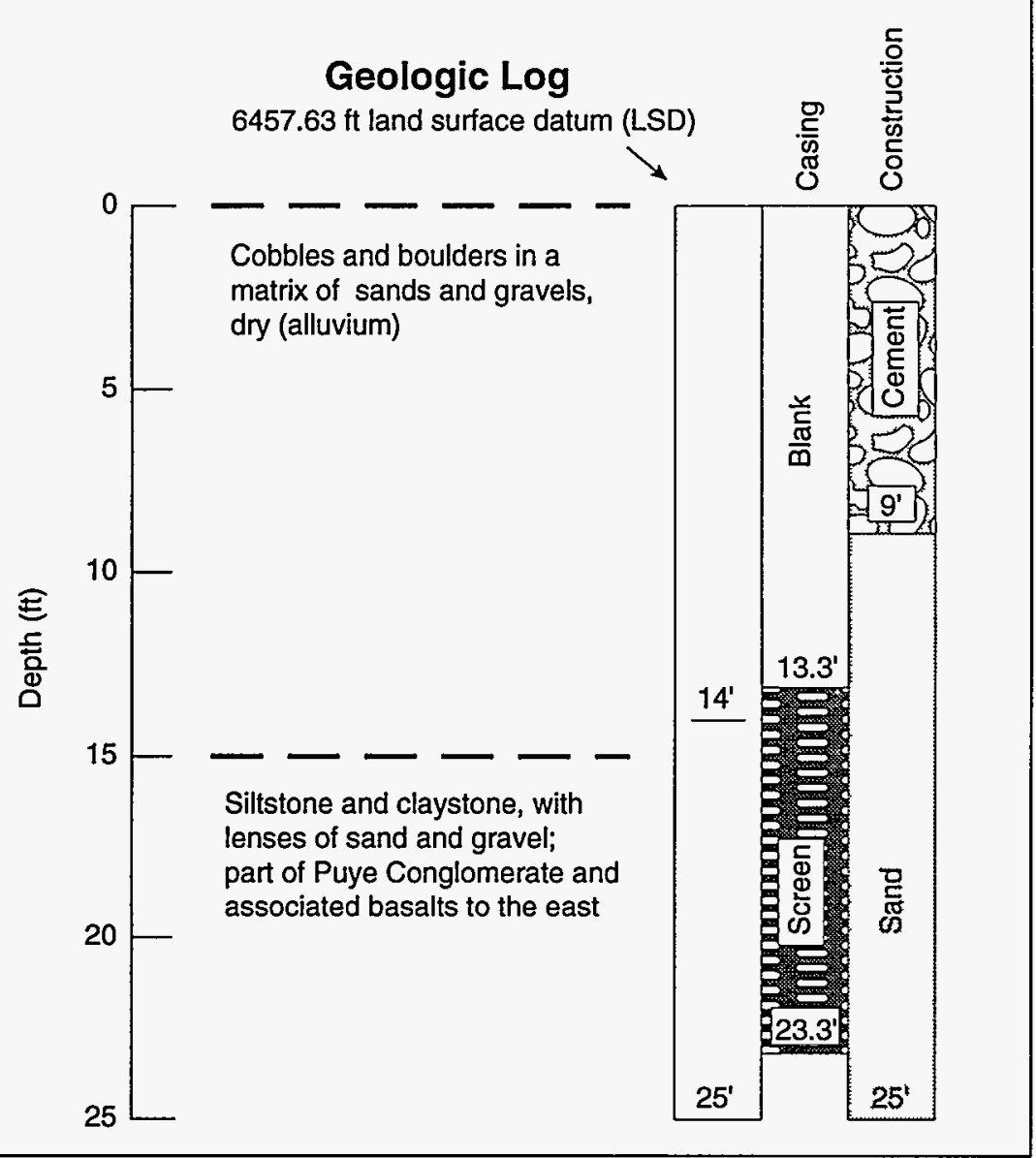

Fig. VIII-G. Los Alamos Canyon observation well LAO-4.5C, completed November 1989, water level 10.6 ft (Purtymun and Stoker 1990).

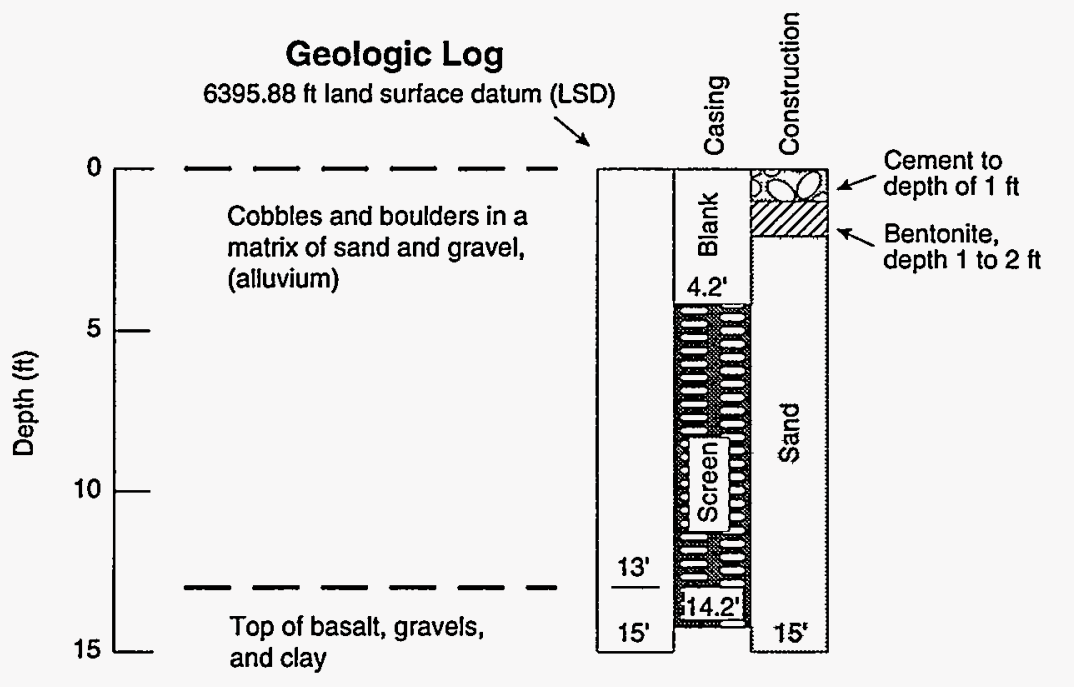

Fig. VIII-H. Los Alamos Canyon observation well LAO-6A, completed August 1989, water level $9.0 \mathrm{ft}$ (Purtymun and Stoker 1990). 


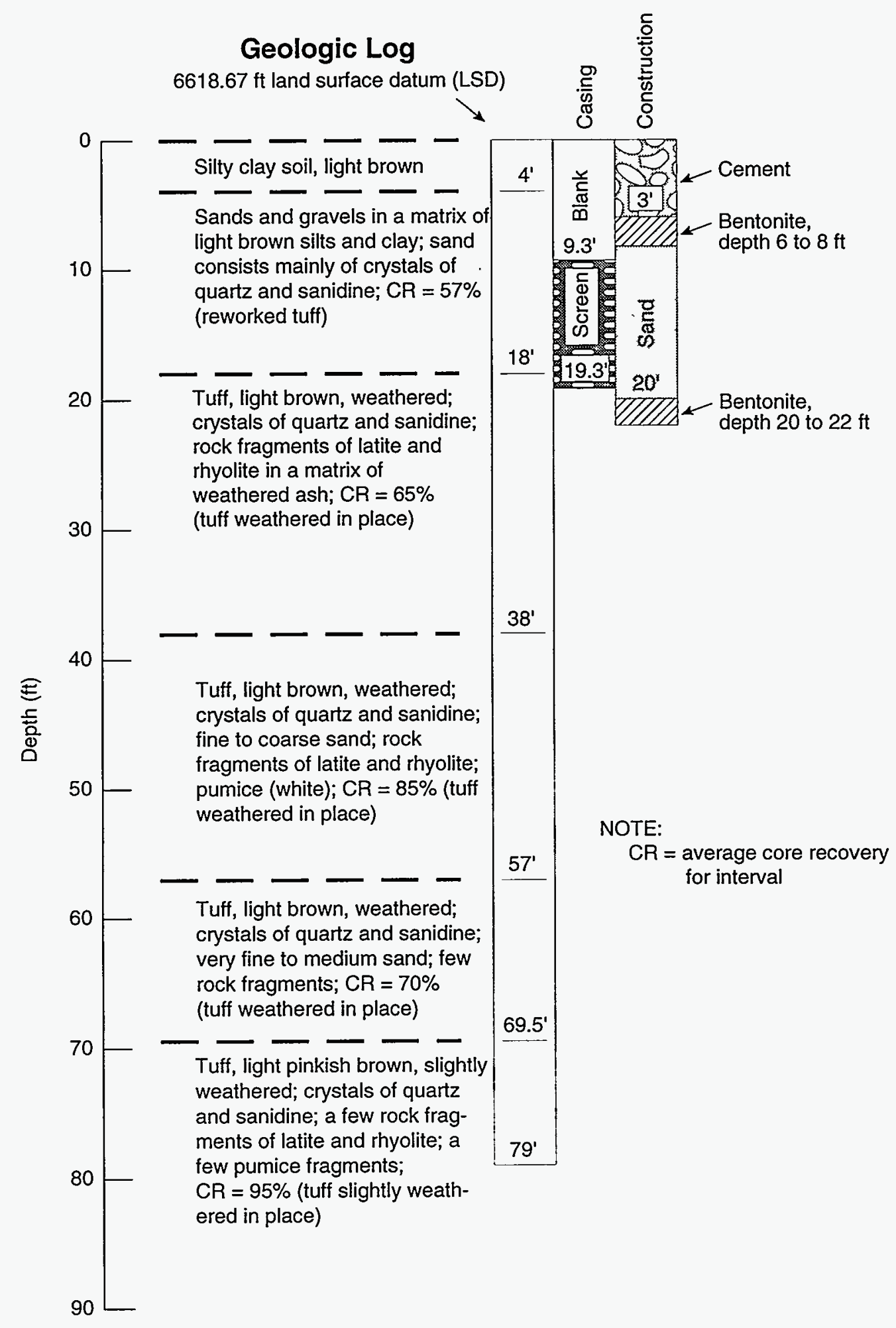

Fig. VIII-I. Sandia Canyon observation well SCO-1, completed August 1989, dry (Purtymun and Stoker 1990). 


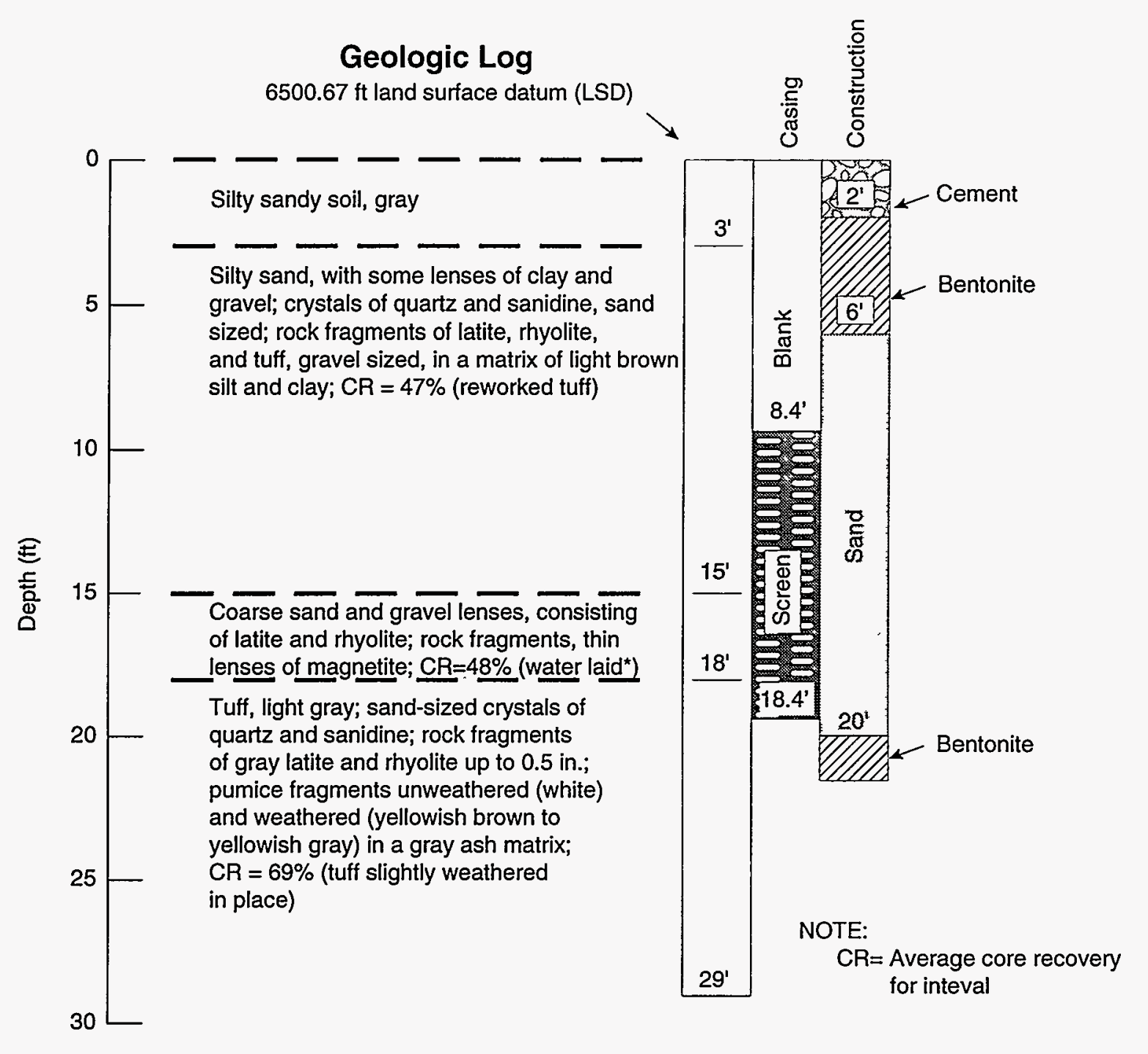

*This $3 \mathrm{ft}$ interval is apparently at the bottom of the Tshirege Member of the Bandelier Tuff.

Fig. VIII-J. Sandia Canyon observation well SCO-2, completed August 1989, dry (Purtymun and Stoker 1990). 


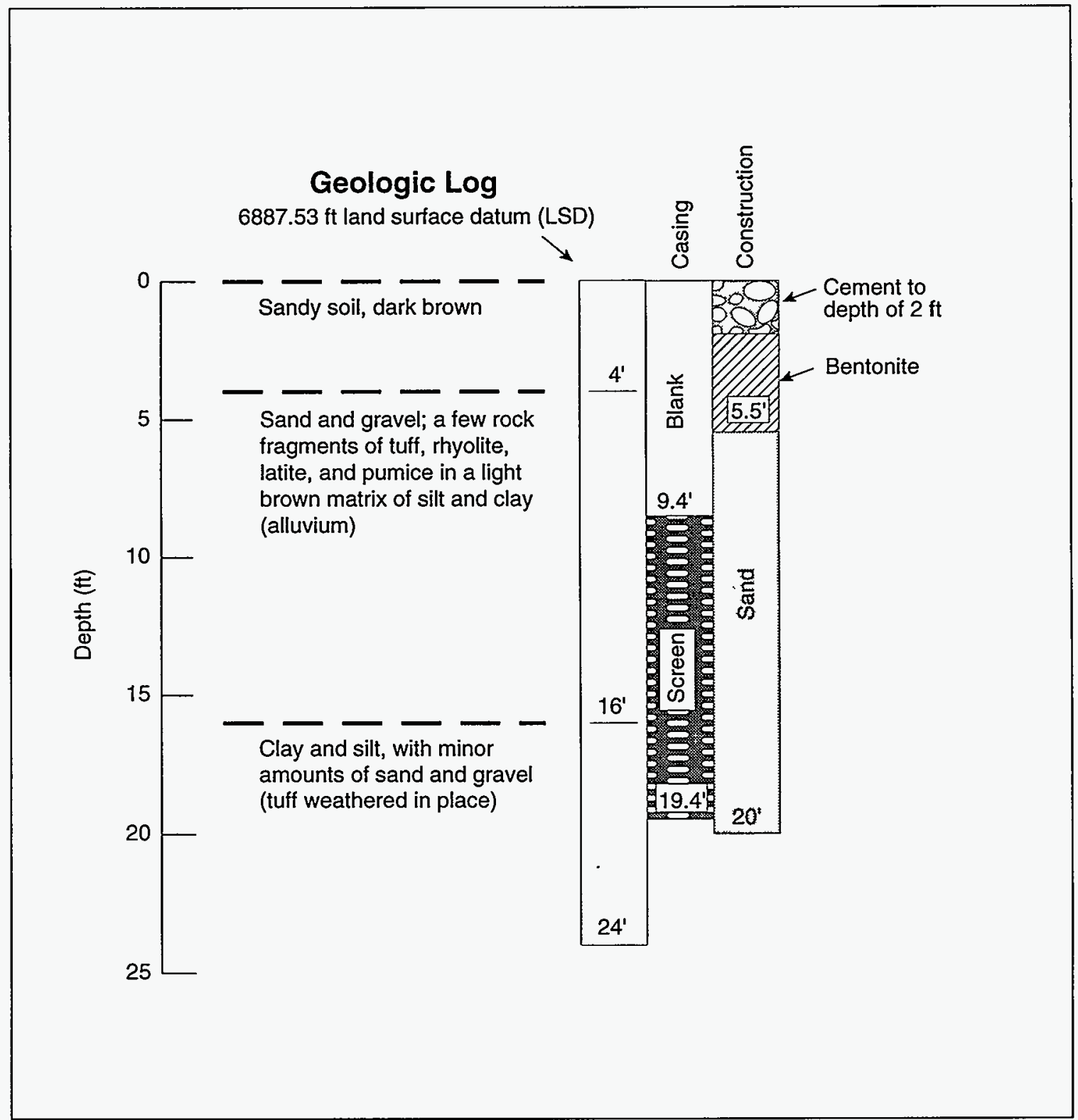

Fig. VIII-K. Mortandad Canyon observation well MCO-4A, completed November 1989, water level $5.1 \mathrm{ft}$ (Purtymun and Stoker 1990). 


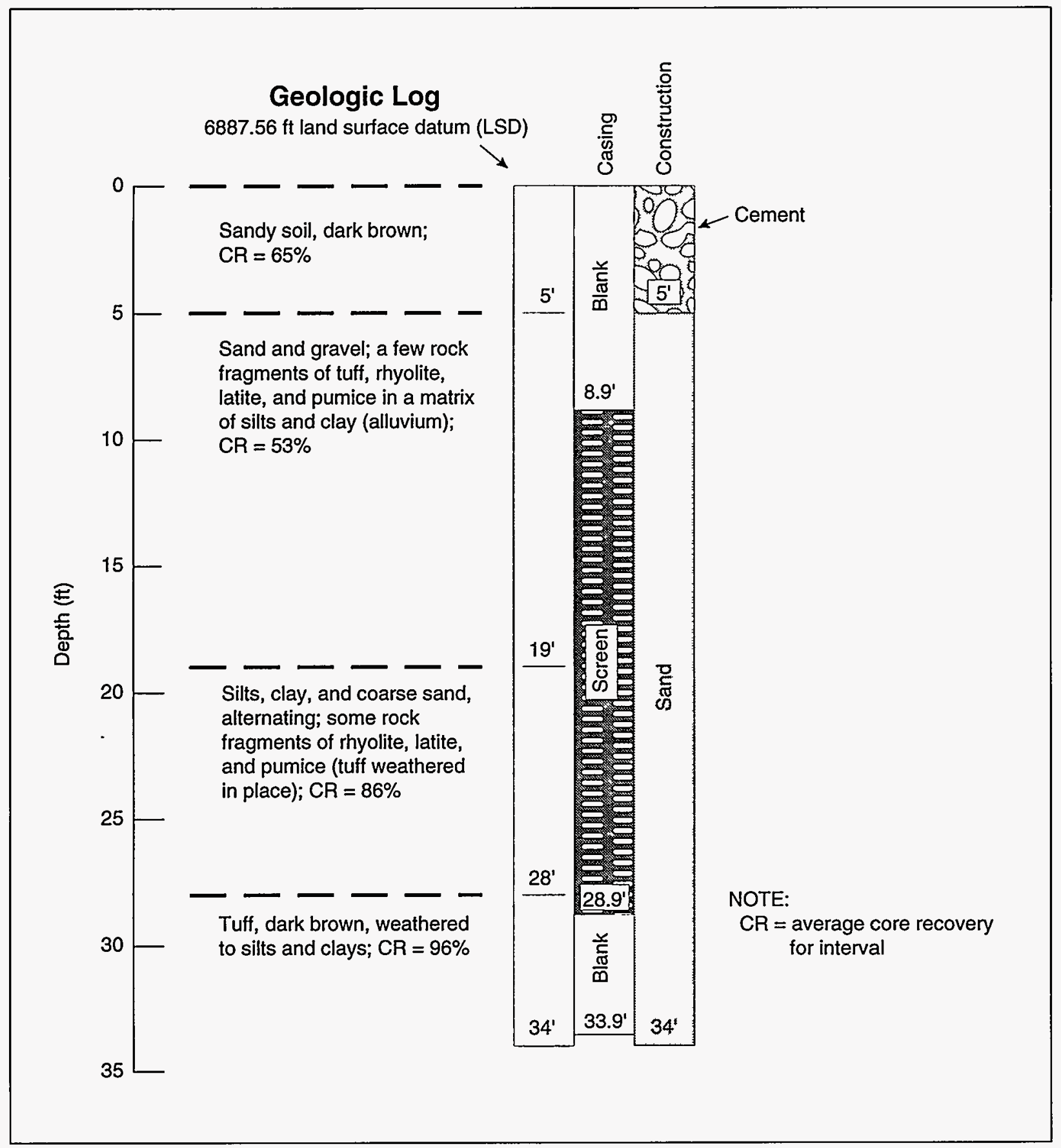

Fig. VIII-L. Mortandad Canyon observation well MCO-4B, completed August 1990, water level 21.7 ft (Purtymun and Stoker 1990). 


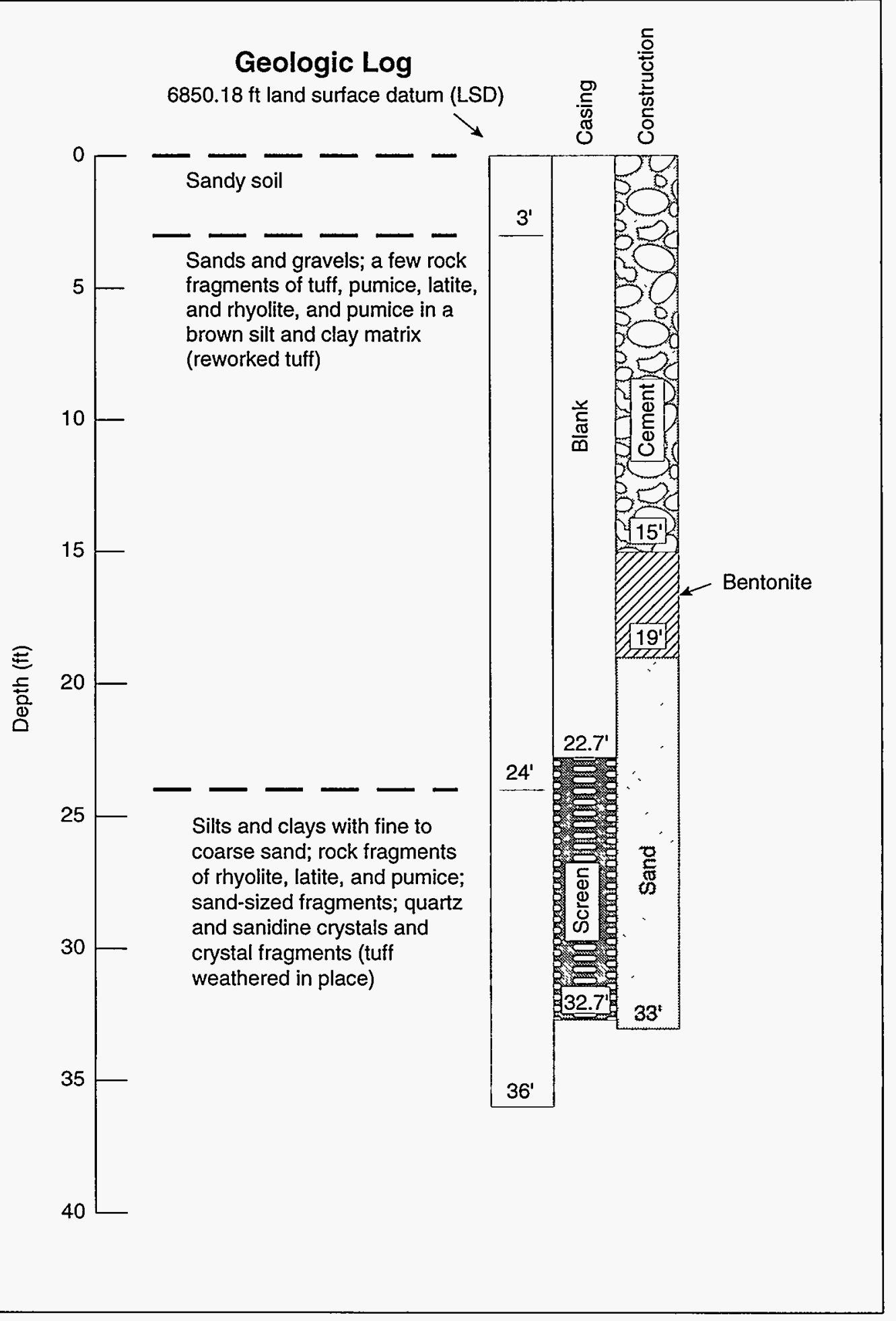

Fig. VIII-M. Mortandad Canyon observation well MCO-6A, completed November 1989, water level $30.3 \mathrm{ft}$ (Purtymun and Stoker 1990). 


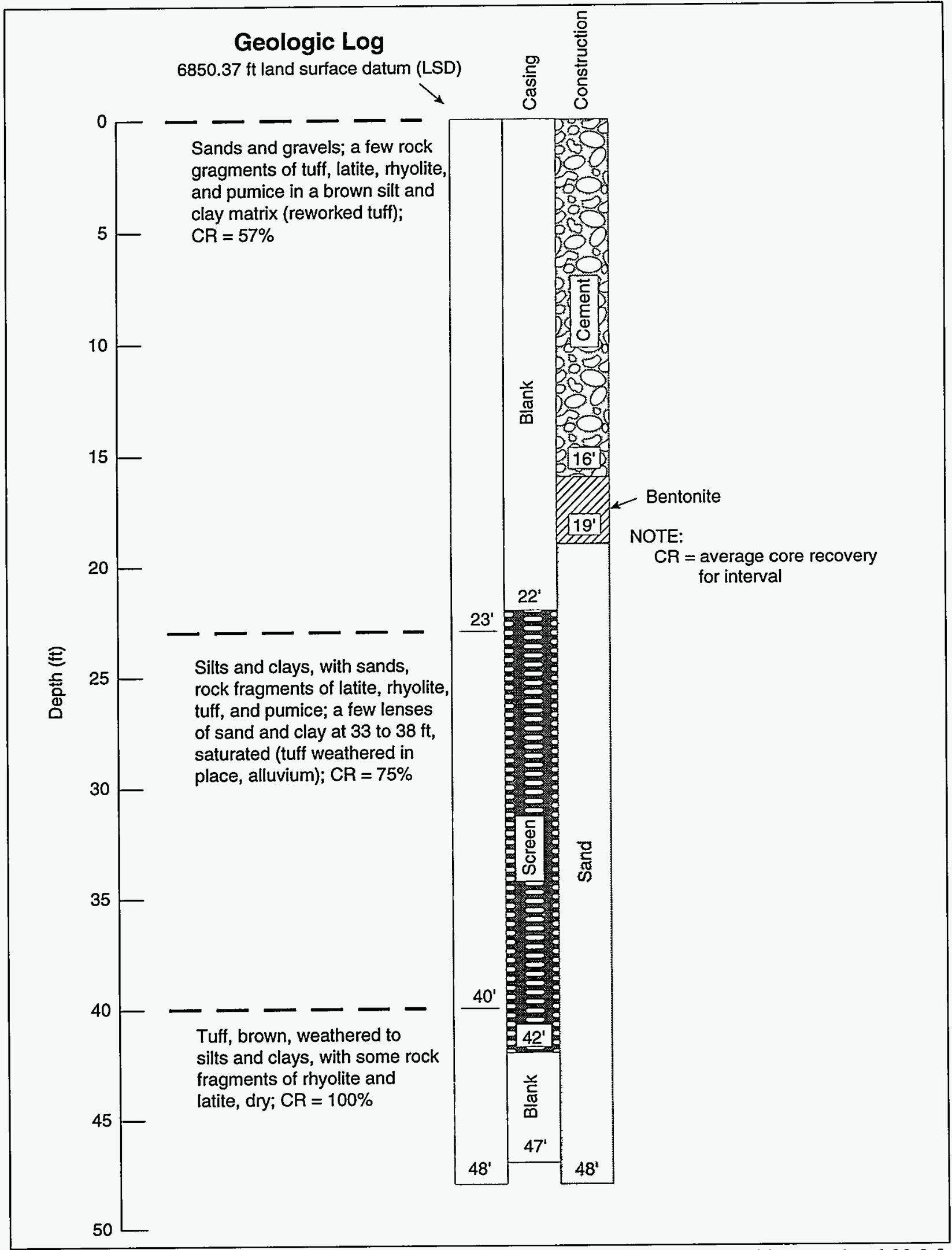

Fig. VIII-N. Mortandad Canyon observation well MCO-6B, completed August 1990, water level $32.2 \mathrm{ft}$ (Purtymun and Stoker 1990). 


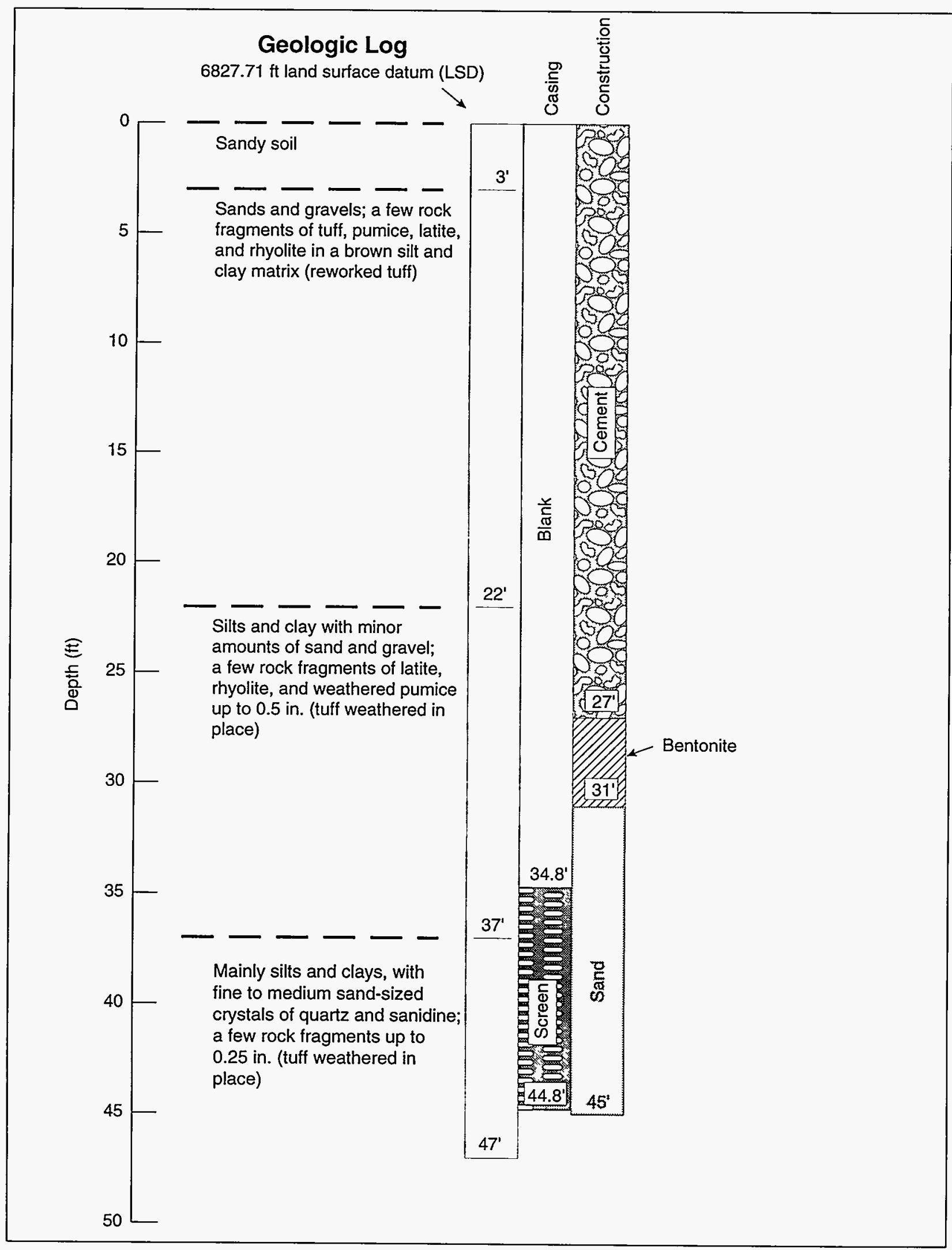

Fig. VIII-O. Mortandad Canyon observation well MCO-7A, completed November 1989, water level $35.2 \mathrm{ft}$ (Purtymun and Stoker 1990). 


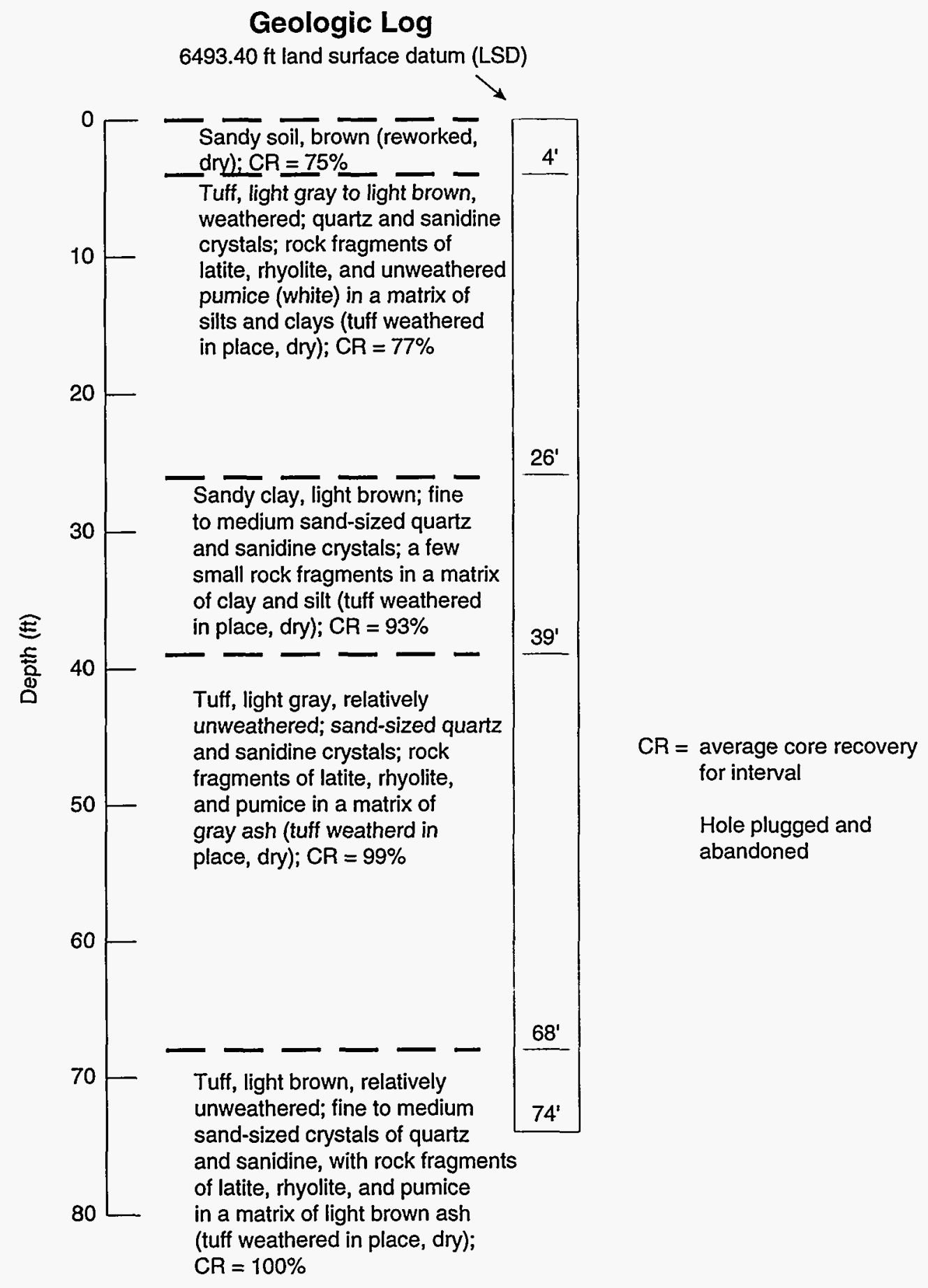

Fig. VIII-P. Potrillo Canyon test hole PCTH-1, completed October 1989, dry (Purtymun and Stoker 1990). 


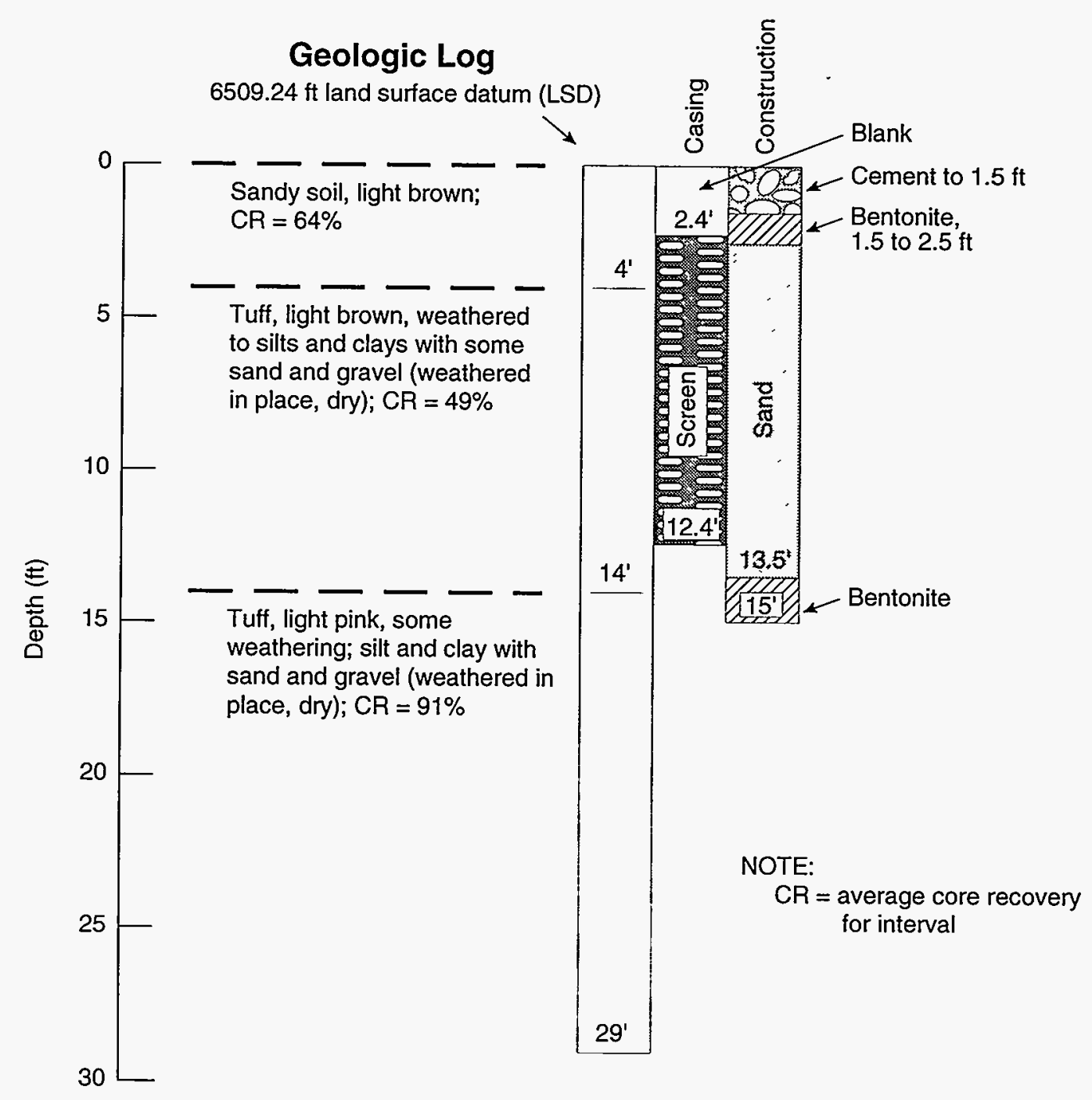

Fig. VIII-Q. Fence Canyon observation well FCO-1, completed August 1989, dry (Purtymun and Stoker 1990). 


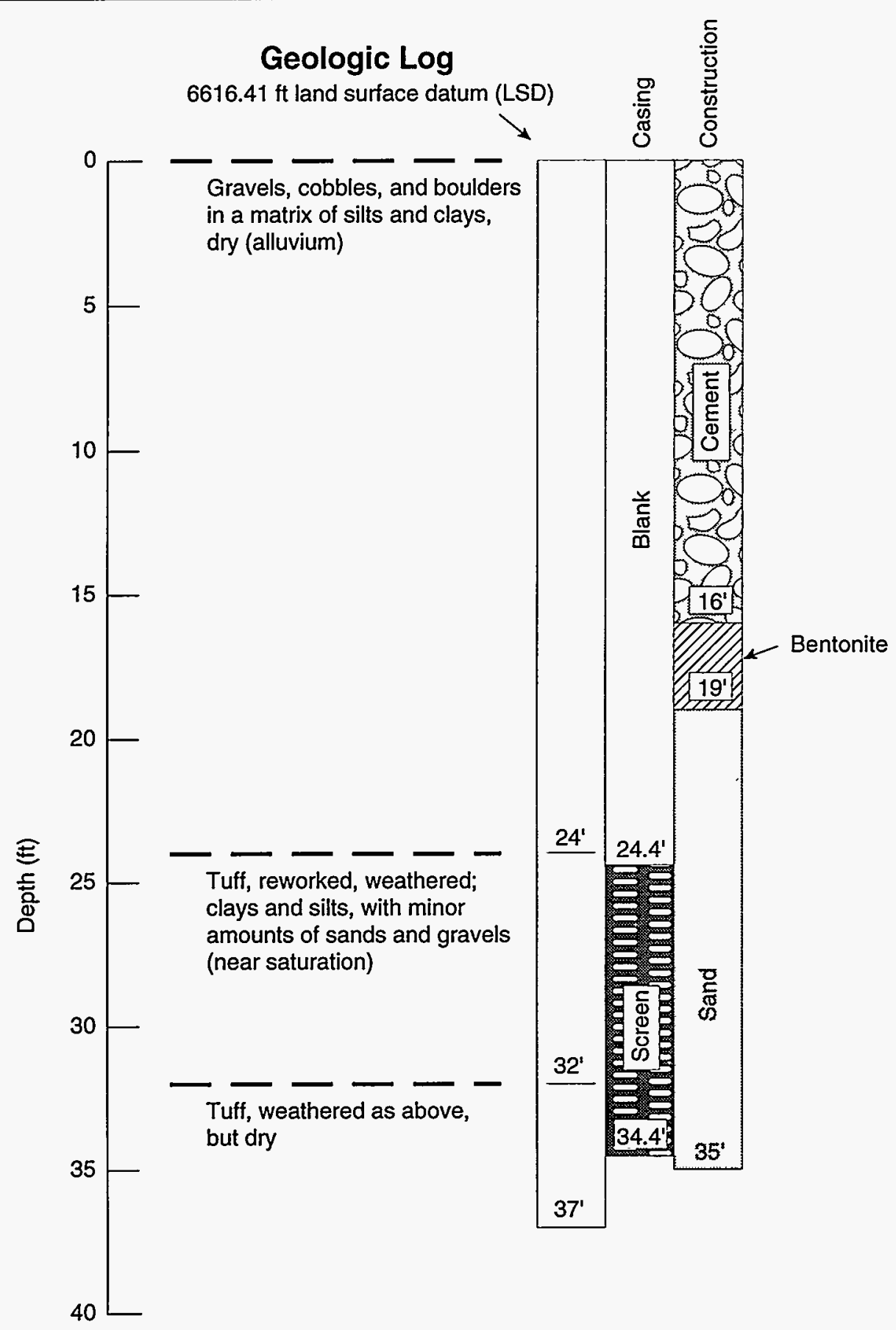

Fig. VIII-R. Water Canyon observation well WCO-1, completed October 1989, dry (Purtymun and Stoker 1990). 


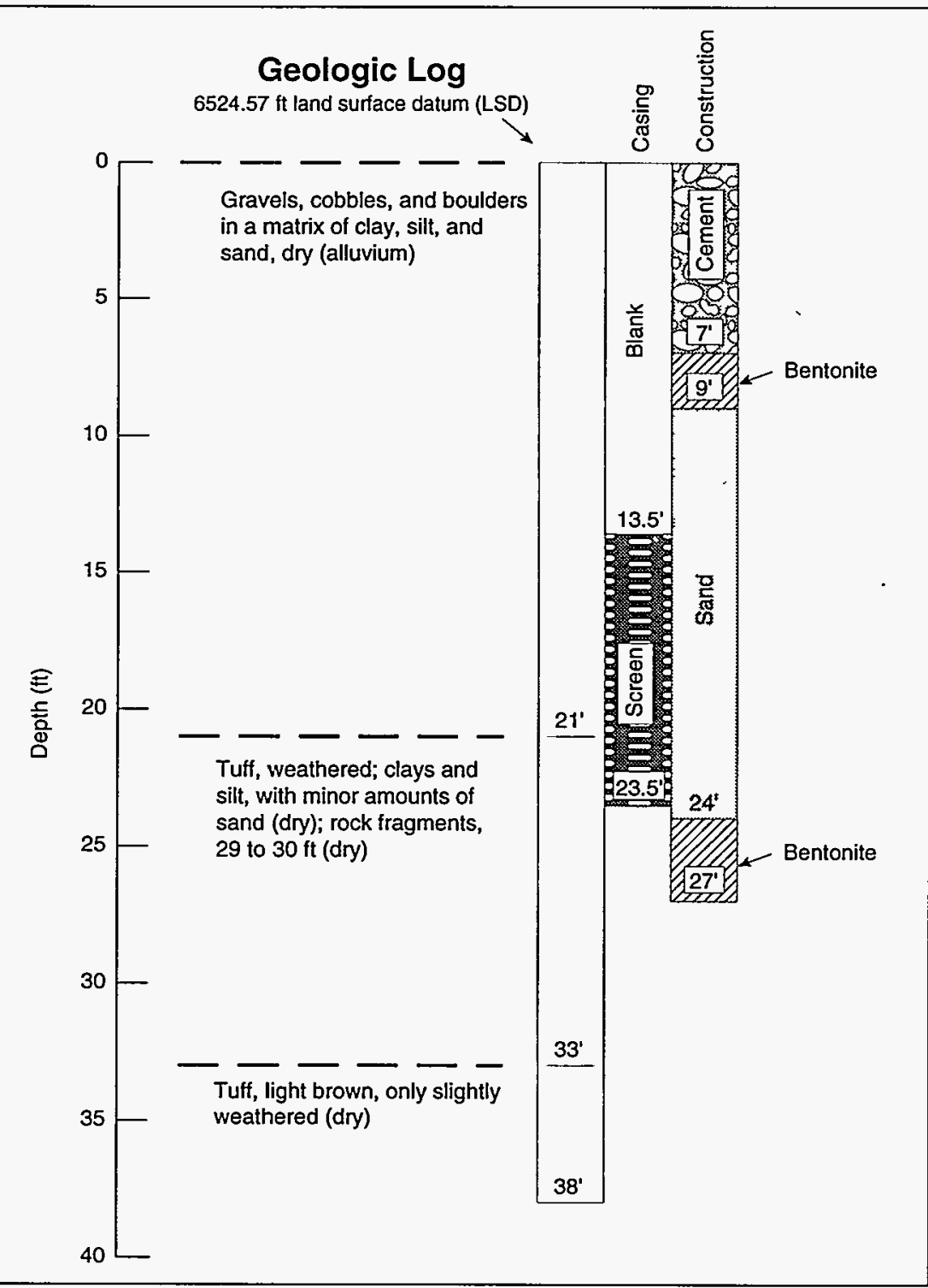

Fig. VIII-S. Water Canyon observation well WCO-2, completed October 1989, dry (Purtymun and Stoker 1990).

Fig. VIII-T. Water Canyon observation well WCO-3, completed October 1989, dry (Purtymun and Stoker 1990).

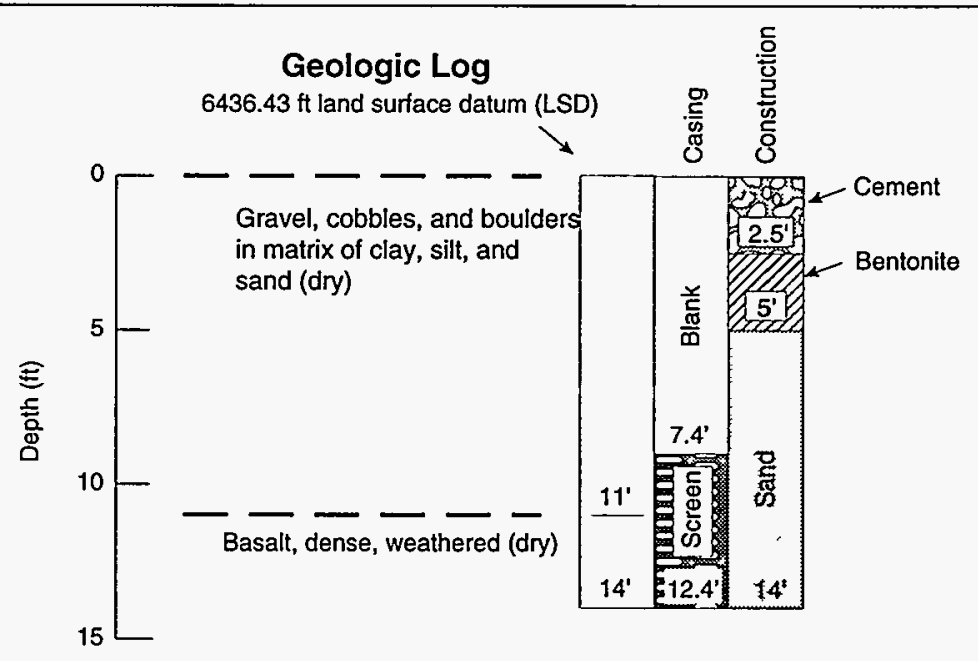


TABLE VIII-A. Locations, Elevations, and Measuring Points (NAD 1927)

PVC

Top of Casing, Land-Surface Measuring

Steel Measuring Datum of Point to Land-

Casing Point Brass Cap Surface Datum Coordinates of Brass Cap

Pueblo Canyon

6368.19

6367.53

$-0.66$

N $1,772,957.956$

E 508965.347

Los Alamos Canyon

LAO-3A

6580.38

6579.83

6579.40

$-0.43$

N 1,773,037.645

E $497,736.545$

LAO-4.5A

6461.58

6460.38

6459.89

$-0.49$

N $1,771,989.595$

E $503,255.968$

LAO-4.5B

6461.76

6459.37

$-1.22$

N 1,771,992.471

LAO-4.5C

6458.72

6457.63

N 1,772,014.413

E 503,268.080

LAO-6A

6396.73

6396.26

6395.88

$-0.38 \quad$ N $1,771,281.902$

E 503,303.058

E $505,977.349$

Sandia Canyon

SCO-1

6619.85

$6619.33 \quad 6618.67$

$-0.66$

N $1,769,440.143$

E $502,053.375$

SCO-2

6502.02

6501.52

6500.67

$-0.85$

N 1,767,801.850

E 507,014.910

Mortandad Canyon

MCO-4A

MCO-4B

6889.00

6888.24

6887.53

$-0.71$

N 1,769,638.132

E $491,784.644$

$6888.71 \quad 6887.56$

$-1.15$

N 1,769,634.899

E $491,792.173$

6851.80

6850.18

$-1.27$

N 1,768,899.886

E $493,388.651$

MCO-6B

6851.84

$6851.08 \quad 6850.37$

$-0.71$

N 1,768,921.493

E $493,386.276$

MCO-7A

6829.27

6828.75

6827.71

$-1.04$

$\mathrm{N} 1,768,447.198$

E 494,259.239

Potrillo Canyon

PCTH-1 ${ }^{\text {a }}$

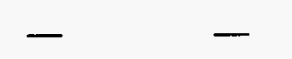

6493.40

$$
-
$$

N 1,753,105.358

E 503,902.595

\section{Fence Canyon}

FCO-1

6510.4

6509.99

6509.24

$-0.75$

N 1,751,120.043

E $502,168.229$

Water Canyon

WCO-1

WCO-2

6617.75

6617.06

6616.41

$-0.65$

N 1,755,007.161

E 492,514.547

6526.07

6525.25

6524.57

$-0.68$

N $1,753,166.432$

E 496,626.165

6437.73

6437.25

6436.43

$-0.82$

N $1,750,558.320$

E 498,968.371

${ }^{a}$ Cored test hole; plugged.

Source: Purtymun and Stoker 1990. 
TABLE VIII-B. Characteristics and Water Levels of Observation Wells

Water Level

\begin{tabular}{|c|c|c|c|c|c|c|c|}
\hline \multirow{3}{*}{$\begin{array}{c}\text { Date } \\
\text { Drilled }\end{array}$} & \multirow{3}{*}{$\begin{array}{c}\text { Date } \\
\text { Completed }\end{array}$} & \multirow{3}{*}{$\begin{array}{c}\text { Depth } \\
\text { Drilled } \\
(f t)\end{array}$} & \multirow{3}{*}{$\begin{array}{c}\text { Depth } \\
\text { Completed }\end{array}$} & \multicolumn{4}{|c|}{ (ft below Land-Surface Datum) } \\
\hline & & & & & Water & & Water \\
\hline & & & & Date & Level & Date & Level \\
\hline
\end{tabular}

\begin{tabular}{|c|c|c|c|c|c|c|c|c|}
\hline \multicolumn{9}{|c|}{ Pueblo Canyon } \\
\hline APCO-1 & $8-15-90$ & $8-17-90$ & 20 & 19.7 & - & - & $8-17-90$ & 6.2 \\
\hline \multicolumn{9}{|c|}{ Los Alamos Canyon } \\
\hline LAO-3A & $9-14-89$ & $9-14-89$ & 18 & 14.7 & $9-14-89$ & 6.7 & $6-21-90$ & 5.5 \\
\hline $\mathrm{LAO}-4.5 \mathrm{~A}$ & $9-13-89$ & $9-14-89$ & 20 & 18.5 & $9-14-89$ & Dry & $6-21-90$ & Dry \\
\hline LAO-4.5B & $9-15-89$ & $9-16-89$ & 35 & 34.9 & $9-16-90$ & Dry & $6-21-90$ & Dry \\
\hline $\mathrm{LAO}-4.5 \mathrm{C}$ & $11-21-89$ & $11-22-89$ & 25 & 23.3 & $11-22-89$ & 10.6 & $6-21-90$ & 10.7 \\
\hline $\mathrm{LAO}-6 \mathrm{~A}$ & $8-17-89$ & $8-17-89$ & 15 & 14.2 & $8-17-89$ & 9.0 & $6-21-90$ & Dry \\
\hline \multicolumn{9}{|c|}{ Sandia Canyon } \\
\hline SCO-1 & 8-14-89 & $8-15-89$ & 79 & 19.3 & $8-15-89$ & Dry & $6-22-90$ & Dry \\
\hline $\mathrm{SCO}-2$ & $8-16-89$ & $8-16-89$ & 29 & 18.4 & 8-16-89 & Dry & $6-22-90$ & Dry \\
\hline \multicolumn{9}{|c|}{ Mortandad Canyon } \\
\hline $\mathrm{MCO}-4 \mathrm{~A}$ & $11-01-89$ & $11-01-89$ & 24 & 19.4 & $11-14-89$ & 5.1 & $8-15-90$ & Dry \\
\hline $\mathrm{MCO}-4 \mathrm{~B}$ & $8-20-90$ & $8-21-90$ & 34 & 33.9 & - & - & $8-21-90$ & 21.7 \\
\hline MCO-6A & $11-02-89$ & $11-06-89$ & 33 & 32.7 & $11-09-89$ & 30.3 & $6-02-90$ & Dry \\
\hline $\mathrm{MCO}-6 \mathrm{~B}$ & $8-09-90$ & $8-13-90$ & 48 & 47.1 & - & - & $8-13-90$ & 33.2 \\
\hline MCO-7A & $11-06-89$ & $11-14-89$ & 47 & 44.8 & $11-09-89$ & 35.2 & $6-21-90$ & 37.2 \\
\hline \multicolumn{9}{|c|}{ Potrillo Canyon } \\
\hline PCTH-1 & $10-18-89$ & $10-20-89$ & 74 & - & $10-20-89$ & Dry & - & - \\
\hline \multicolumn{9}{|c|}{ Fence Canyon } \\
\hline FCO-1 & $8-22-89$ & $8-22-89$ & 29 & 12.4 & $8-22-89$ & Dry & $8-24-90$ & Dry \\
\hline \multicolumn{9}{|c|}{ Water Canyon } \\
\hline WCO-1 & $10-26-89$ & $10-31-89$ & 37 & 34.4 & $11-01-89$ & Dry & $8-24-90$ & Dry \\
\hline WCO-2 & $10-26-89$ & $10-26-89$ & 38 & 23.5 & $10-26-89$ & Dry & $8-24-90$ & Dry \\
\hline WCO-3 & $10-25-89$ & $10-25-89$ & 14 & 12.4 & $10-25-89$ & Dry & $8-24-90$ & Dry \\
\hline
\end{tabular}

${ }^{a}$ Cored test hole; plugged.

Source: Purtymun and Stoker 1990. 


\section{TECHNICAL AREA 49}

Technical Area 49 (TA-49) is an experimental area for which it was necessary to define the geology and hydrology of the mesa and adjacent canyons. TA-49 is located in the southern part of the Laboratory on Frijoles Mesa just to the north of Bandelier National Monument. The mesa is capped with a thick section of the Bandelier 'Tuff (the Tshirege Member, Otowi Member, and Guaje Member). This is underlain by the Puye Conglomerate and the Chaquehui Formation. Basalts were found interbedded with the Puye Conglomerate.

At TA-49 the Tshirege Member of the Bandelier Tuff has been subdivided into seven units that have been penetrated by test holes and test wells (Weir and Purtymun 1962). The type section of units exposed in the north wall of Water Canyon is shown in Fig. IX-A. Our subdivision of the Tshirege Member was based on the chemical and physical properties of the tuff. This was the first attempt to divide the Tshirege Member into a number of mappable units on the Pajarito Plateau. It does not correlate perfectly with the units established at Mortandad Canyon by Baltz et al. (1963), and no attempt has been made to change the terminology or units used at TA-49 to correspond to the type section at Mortandad Canyon. The correlation of units of the Bandelier Tuff at TA-49 with the type section at Mortandad is shown on Fig. IX-B.

The units penetrated in the test wells and core hole are described below from the oldest, Unit 1A, to the youngest, Unit 6.

Unit $1 \mathrm{~A}$ consists of a light gray to light pinkish gray pumiceous, friable, nonwelded, rhyolite tuff that contains quartz and sanidine crystals and crystal fragments, and rock fragments of latite, rhyolite, and pumice in an ash matrix. At TA-49 the unit is $156 \mathrm{ft}$ thick in Area 5.

Unit $1 \mathrm{~B}$ is a light gray to very light orange rhyolite tuff that contains quart $z$ and sanidine crystals and crystal fragments, large to small pumice fragments, and gray subrounded rhyolite and latite rock fragments up to cobble size. The unit was $203 \mathrm{ft}$ thick in test well DT-5P at TA-49.

Unit 2 is a light pinkish gray to purplish gray welded rhyolite tuff. It is hard, welded, and contains coarse-sand- to granule-sized phenocrysts of quartz and sanidine crystals and crystal fragments, light gray to gray rhyolite and latite rock fragments, and gray pumice fragments up to $1 / 2$-in. long in a fine-grained, glassy ash matrix. Unit 2 ranges from 94 to $111 \mathrm{ft}$ in the four core holes drilled at TA-49.

Unit 3 is a friable, nonwelded, pumiceous rhyolite tuff composed of medium to very coarse sand-sized crystals of quartz and sanidine, gray and white devitrified pumice fragments up $1 / 2$ in. long, and an abundance of gray pumice and gray rhyolite and latite rock fragments in a fine-grained glassy ash matrix. The thickness of Unit 3 ranges from 52 to $76 \mathrm{ft}$ in core holes and test wells at TA-49.

Unit 4 is a friable, nonwelded to moderately welded tuff with coarse-grain-sized crystals and crystal fragments of quartz and sanidine, some gray devitrified pumice fragments, and rock fragments of latite and rhyolite in an ash matrix. The average thickness of Unit 4 is about $50 \mathrm{ft}$.

Unit 5 is a thin layer of water-laid or blast-laid sand that is light gray, friable, and composed of coarse-grain-sized quartz and sanidine crystals and crystal fragments, a few small rock fragments of latite and rhyolite, and some white to gray pumice in a silty matrix of sand and ash. The unit has various bedding from foreset to parallel beds. In some places there are thin lenses of clay weathered to dark brown. The thickness of the unit varies from a knife edge between ash flows to a thickness of 6 to $8 \mathrm{ft}$ (where it is in a scoured joint or fracture in a shaft in Area 10).

Unit 6 is a light gray moderately welded tuff with fine- to medium-sized quartz and sanidine crystals and crystal fragments, and some tan to gray pumice fragments, gray devitrified pumice fragments, and some light red and gray rhyolite rock fragments in a fine-grained light gray ash matrix. The average thickness of the unit is about $70 \mathrm{ft}$.

\section{A. Deep Test Wells}

The locations of deep test wells (DT-series), core holes (CH-series), and test holes (TH-series) are shown in Fig. IX-C, and construction and hydrologic data are shown in Table IX-A.

Two deep test holes, DT-5P (Fig. IX-D) and DT-5 (Fig. IX-E) were drilled for geologic and hydrologic information, but did not reach the main aquifer. Three other deep test holes, DT-5A (Fig. IX-F), DT-9 (Fig.IX-G), and DT-10 (Fig. IX-H) were drilled into the main aquifer. The geologic logs and construction data for these five holes are found in Table IX-B. In the original presentation of the geologic logs of these last three holes (Weir and Purtymun 1962), a flow was penetrated and was logged as the Tschicoma Formation. It is unlikely that the Tschicoma Formation, which is found as massive flows containing latite and dacite near the flanks of the Sierra de los Valles, would be present so far away from the mountains. It is more likely that this unit was composed of the Basaltic Rocks of Chino Mesa Unit 2. This identification was confirmed by an examination of the exposed cuttings from the wells, especially those from well DT-9. The logs of DT-5A, DT- 9 , and DT-10 have been revised accordingly. The 
basalts may not be from vents at Chino Mesa but are equivalent in age, as the basalts are interbedded with the fanglomerate member. These three wells that were completed as test wells into the main aquifer allowed us to determine the hydrologic characteristics of the aquifer.

\section{B. Core and Test Holes}

Four core holes, $\mathrm{CH}-1, \mathrm{CH}-2, \mathrm{CH}-3$, and $\mathrm{CH}-4$ (Figs. IX-I, IX-J, IX-K, and IX-L, respectively) were cored in four experimental areas to determine some of the physical and hydrologic properties of the tuff. Alpha, Beta (located on the floor of Water Canyon), and Gamma holes were drilled for geologic information (Figs. IX-M, IX-N, and IX-O, respectively).

Five shallow test holes, test holes $1,2,3,4$, and 5 were drilled to determine if there was infiltration of precipitation into the soil and tuff around experimental Area 2 (Figs. IX-P, IX-Q, IX-R, IX-S, and IX-T, respectively). All wells and test holes were sealed at the surface with cement. The geologic logs and construction data for these test holes are presented in Table IX-C. Test holes and wells in Water Canyon north of TA-49 are shown in Fig. IX-U. In Water Canyon near Beta Hole there is a routine surface water sampling station.

\section{Moisture-Access Holes}

To study and monitor the soil moisture on the surface of the mesa and in the experimental areas, 23 moisture-access holes were completed on the mesa (Fig. IX-V). We completed 2 shallow observation holes (WCM-1 and WCM-2) into the alluvium of Water Canyon to the north of the experimental areas (Fig. IX-U). Geologic logs and construction data for the 23 moisture-access holes and 2 shallow observation wells are presented on Table IX-D.

\section{REFERENCES}

E. H. Baltz, J. H. Abrahams, and W. D. Purtymun "Preliminary Report on the Geology and Hydrology of Mortandad Canyon near Los Alamos, New Mexico with Special Reference to Disposal of Liquid LowLevel Radioactive Wastes," U.S. Geological Survey Open-File Report (1963).

W. D. Purtymun, "Distribution of Moisture in the Soil and Underlying Tuff at Technical Area 49, Frijoles Mesa, Los Alamos County, New Mexico," U.S. Geol. Survey Admin. report (1962).

W. D. Purtymun, "Source Document Compilation: Los Alamos Investigations Related to the Environment, Engineering, Geology, and Hydrology,
1961-1990," Los Alamos National Laboratory report LA-12733-MS (1994), chapter 92.

W. D. Purtymun and A. K. Stoker, "Environmental Status of Technical Area 49, Los Alamos, New Mexico," Los Alamos National Laboratory report LA-11135-MS (1987).

J. E. Weir and W. D. Purtymun, "Geology and Hydrology of Technical Area 49, Frijoles Mesa, Los Alamos County, New Mexico," U.S. Geol. Survey Admin. report (1962).

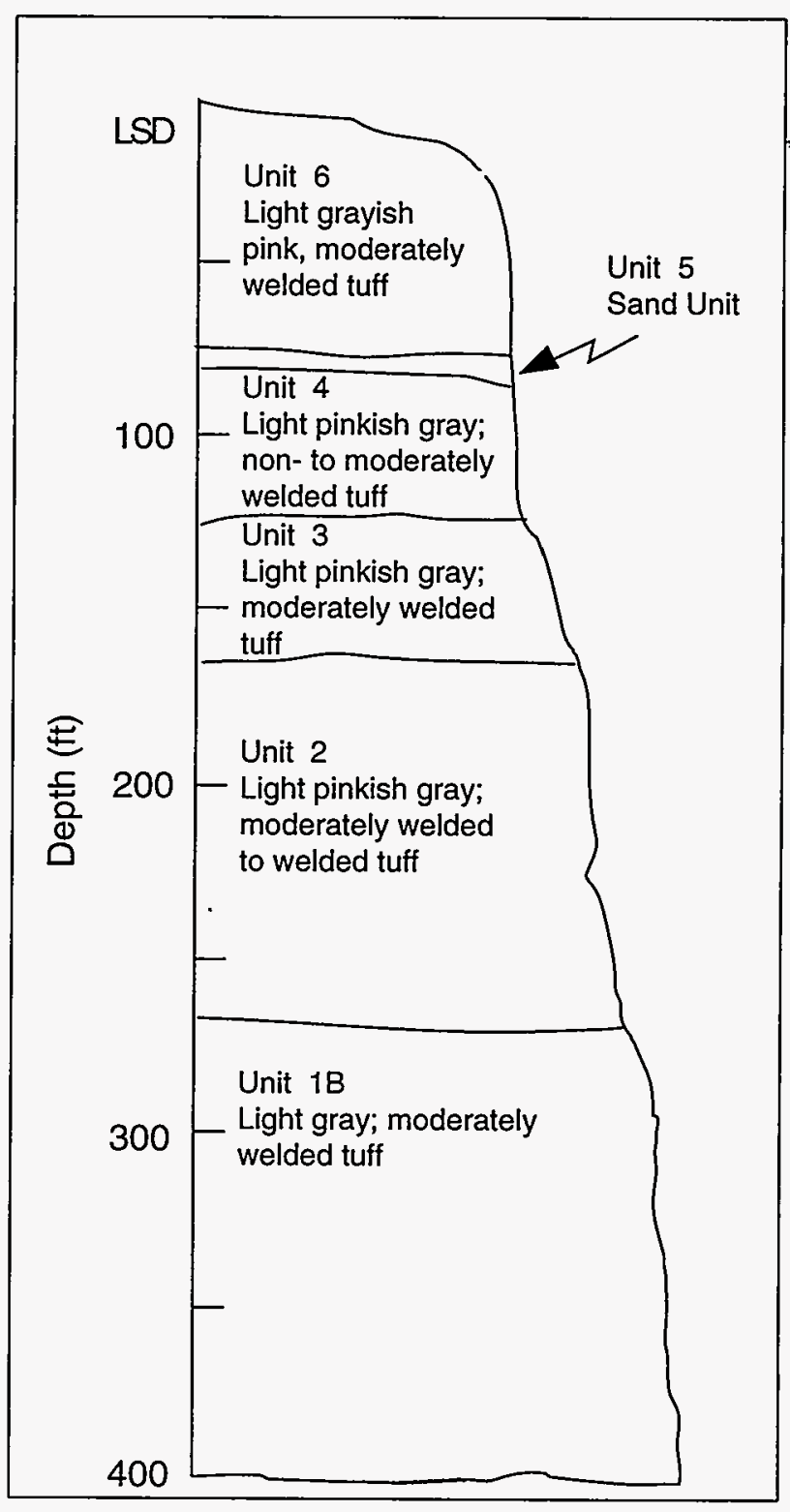

Fig. IX-A. Type section of the Tshirege Member of the Bandelier Tuff in Water Canyon north of TA-49 (Weir and Purtymun 1962). 


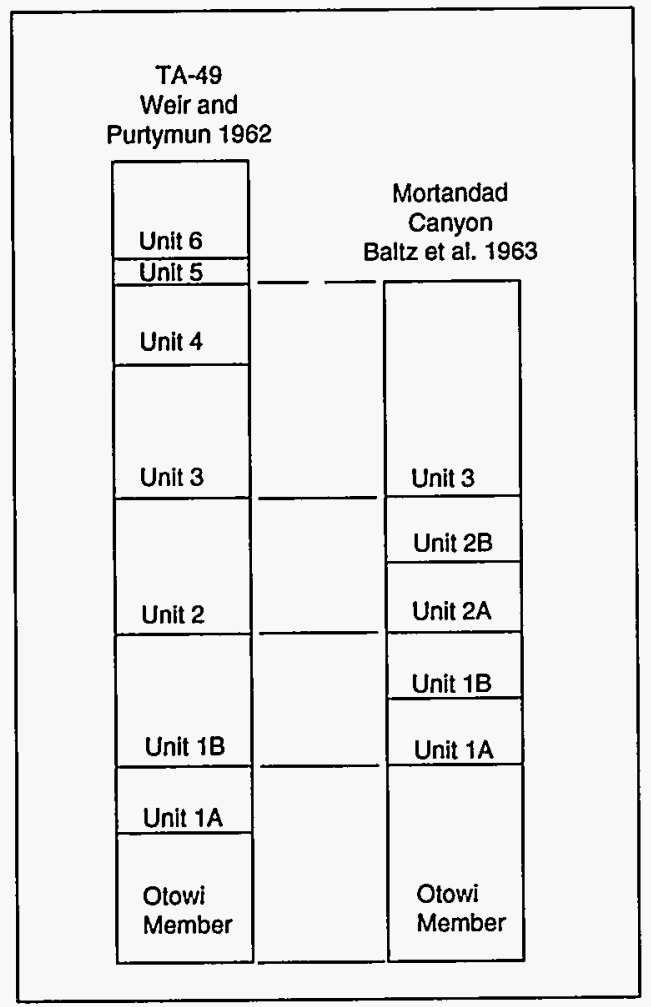

Fig. IX-B. Correlation of the units of the Tshirege Member of the Bandelier Tuff at TA-49 with the type section in Mortandad Canyon.

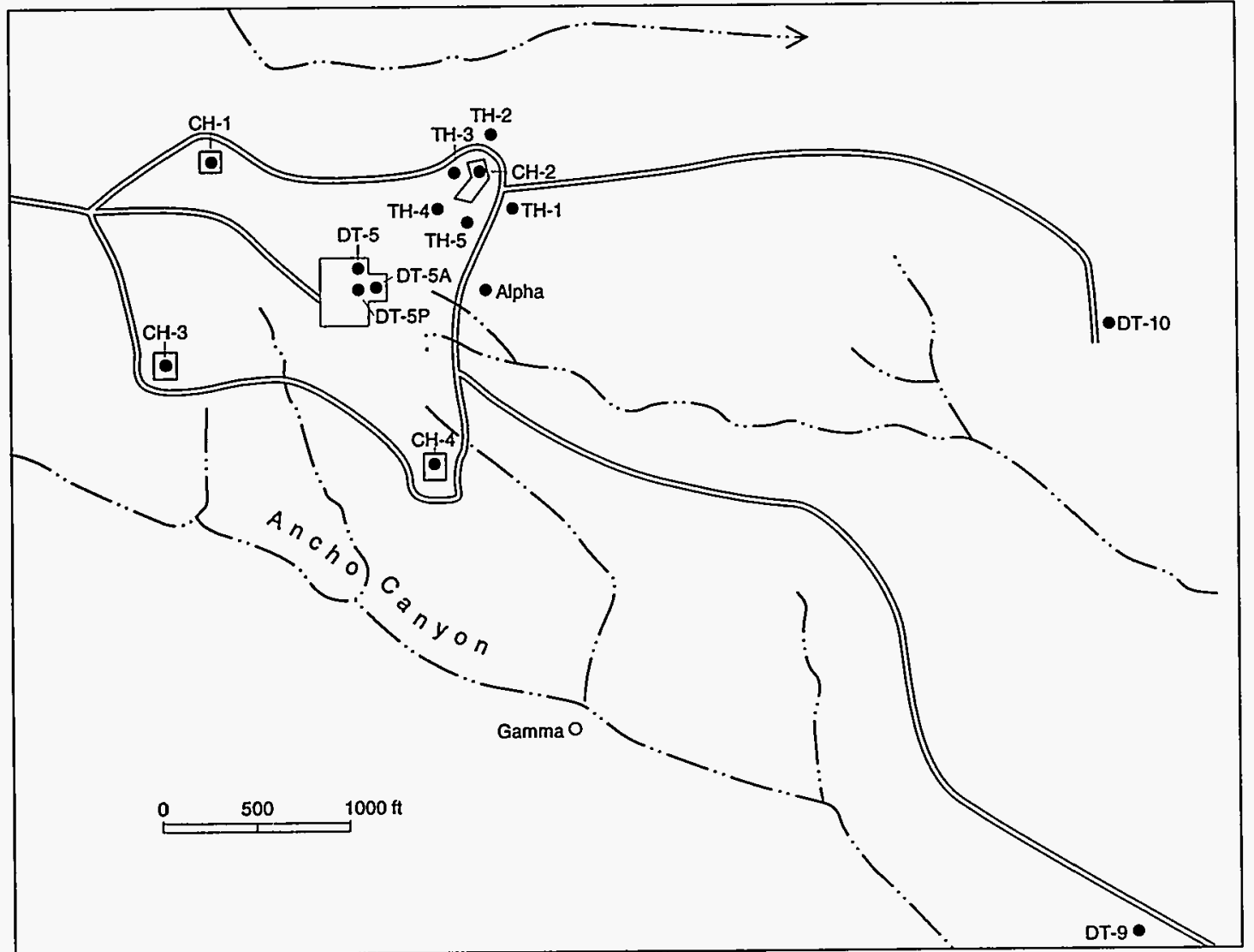

Fig. IX-C. Location of deep test wells (DT-series), core holes (CH-series), and test holes (TH-series) (Purtymun 1994). 


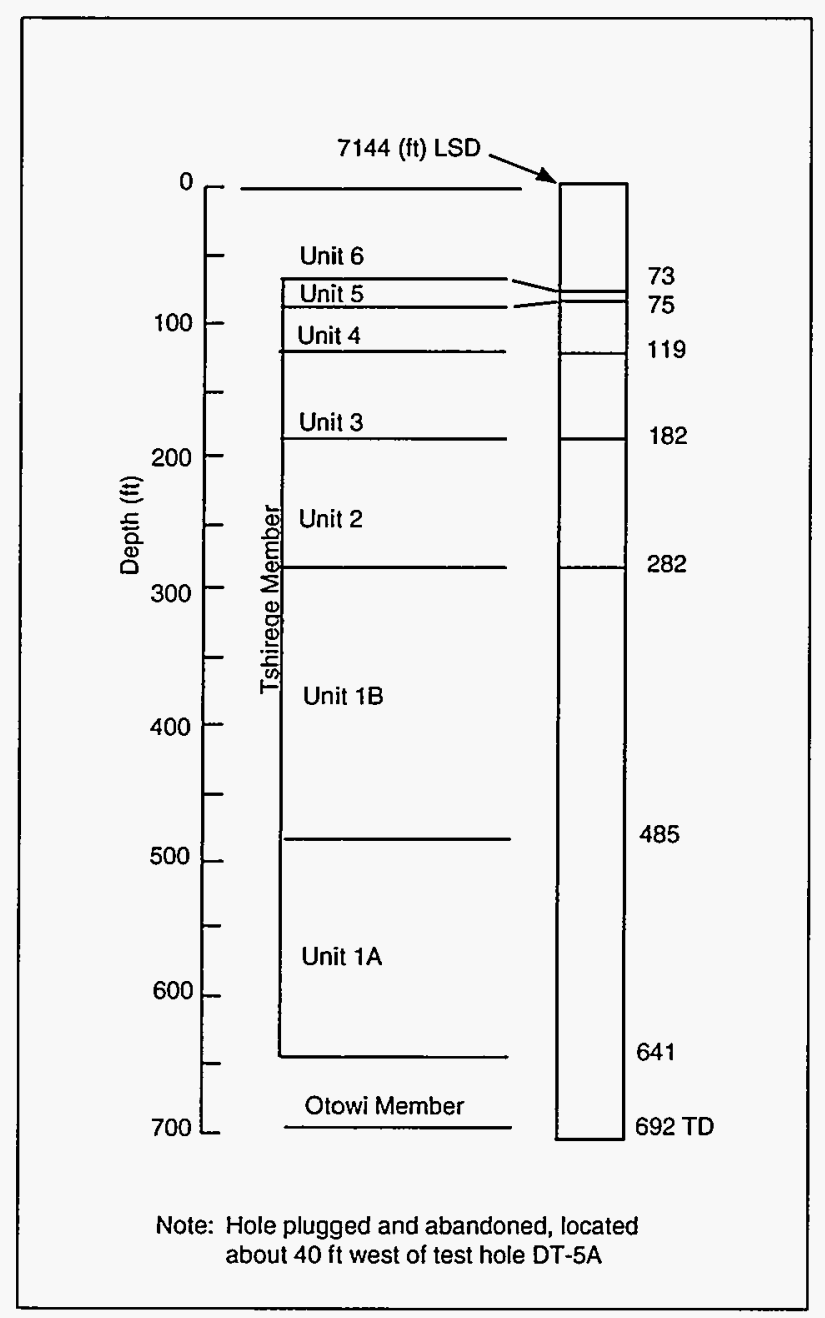

Fig. IX-D. Test hole DT-5P, completed October 1959, dry (Weir and Purtymun 1962).

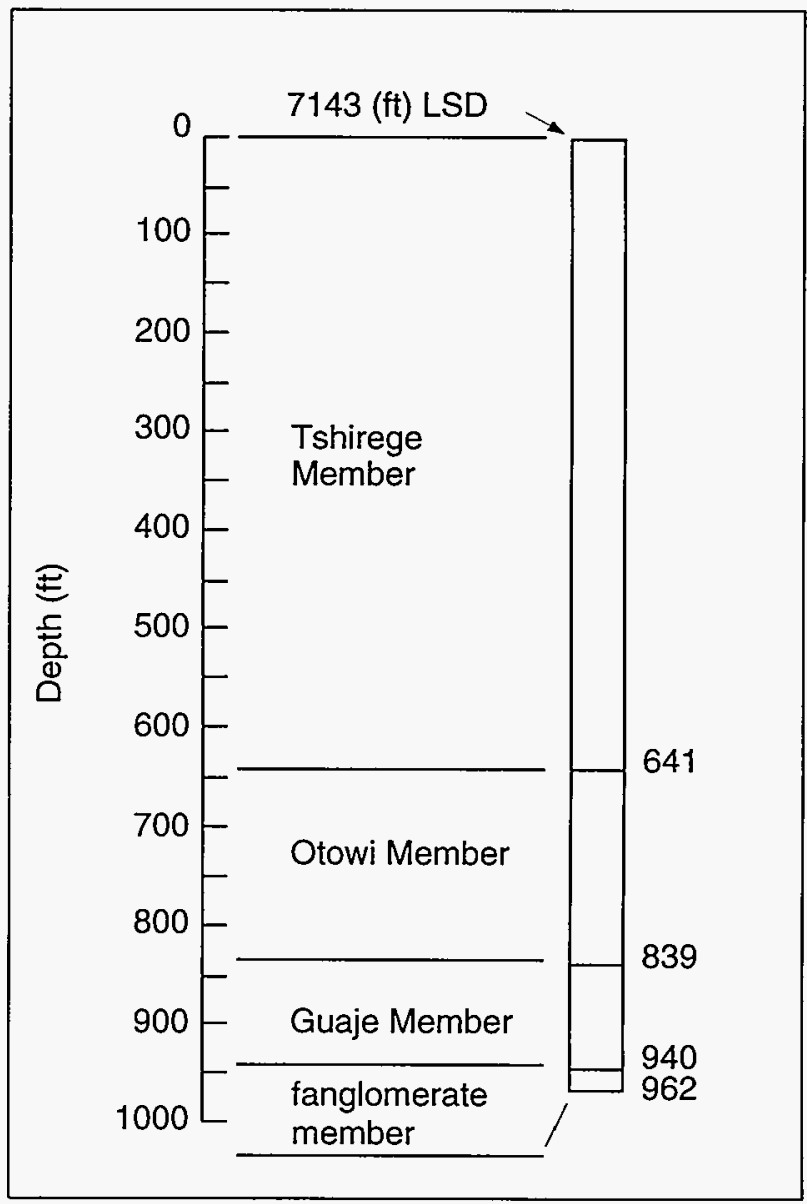

Fig. IX-E. Geologic log of test hole DT-5, completed November 1959, dry (Weir and Purtymun 1962). 

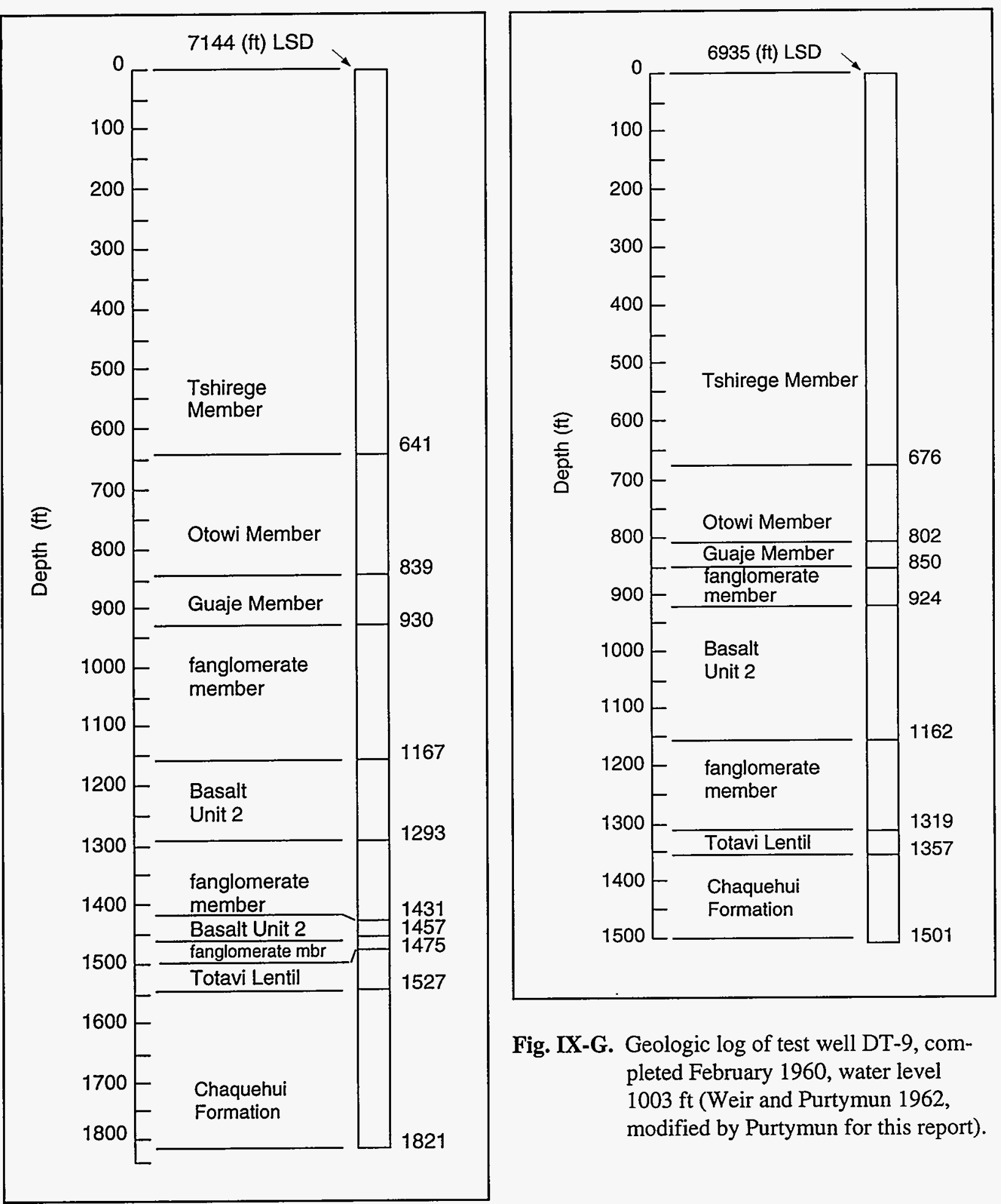

Fig. IX-G. Geologic log of test well DT-9, completed February 1960, water level $1003 \mathrm{ft}$ (Weir and Purtymun 1962, modified by Purtymun for this report).

Fig. IX-F. Geologic log of test well DT-5A, completed January 1960, water level $1173 \mathrm{ft}$ (Weir and Purtymun 1962, modified by Purtymun for this report). 


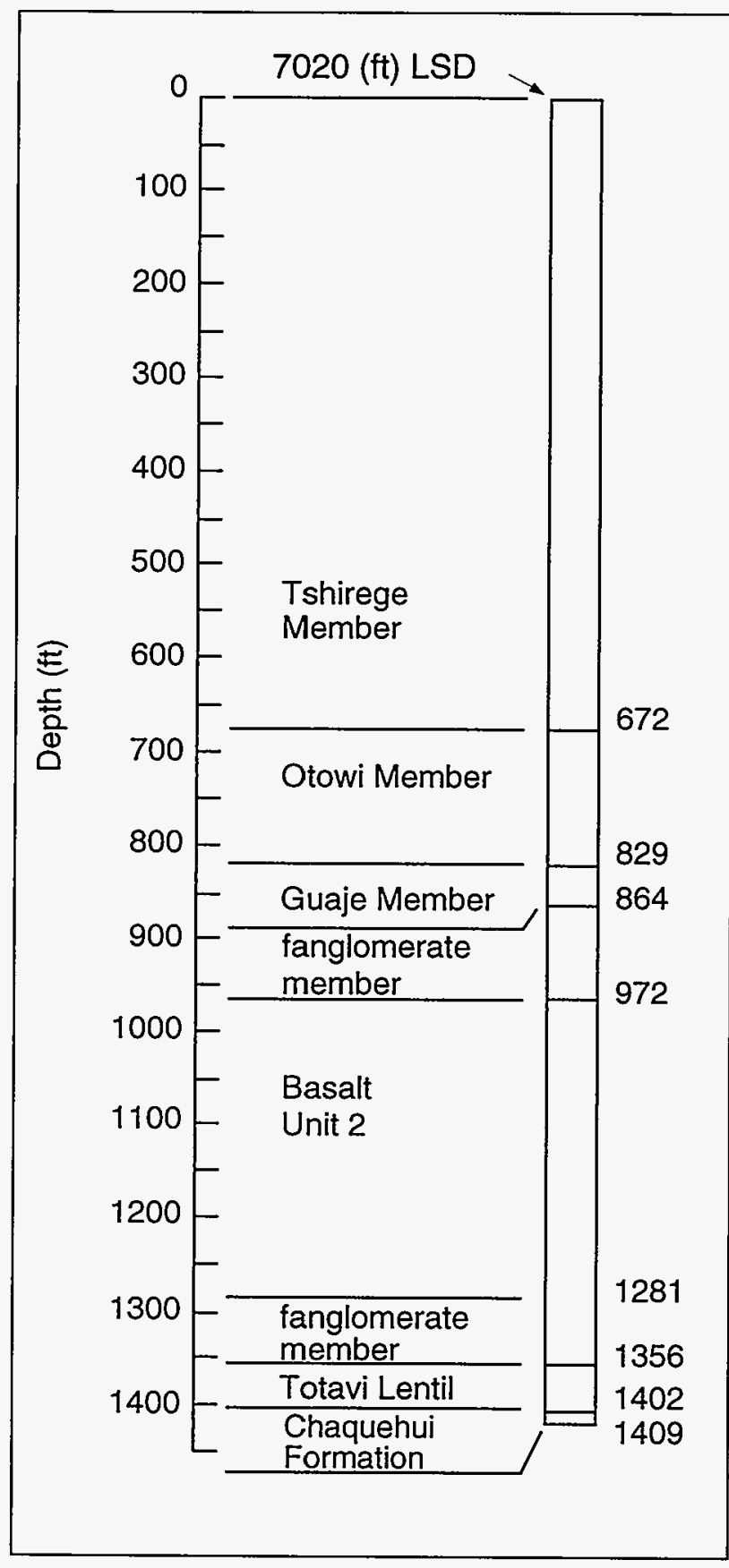

Fig. IX-H. Geologic log of test well DT-10, completed March 1960, water level $1085 \mathrm{ft}$ (Weir and Purtymun 1962, modified by Purtymun for this report).

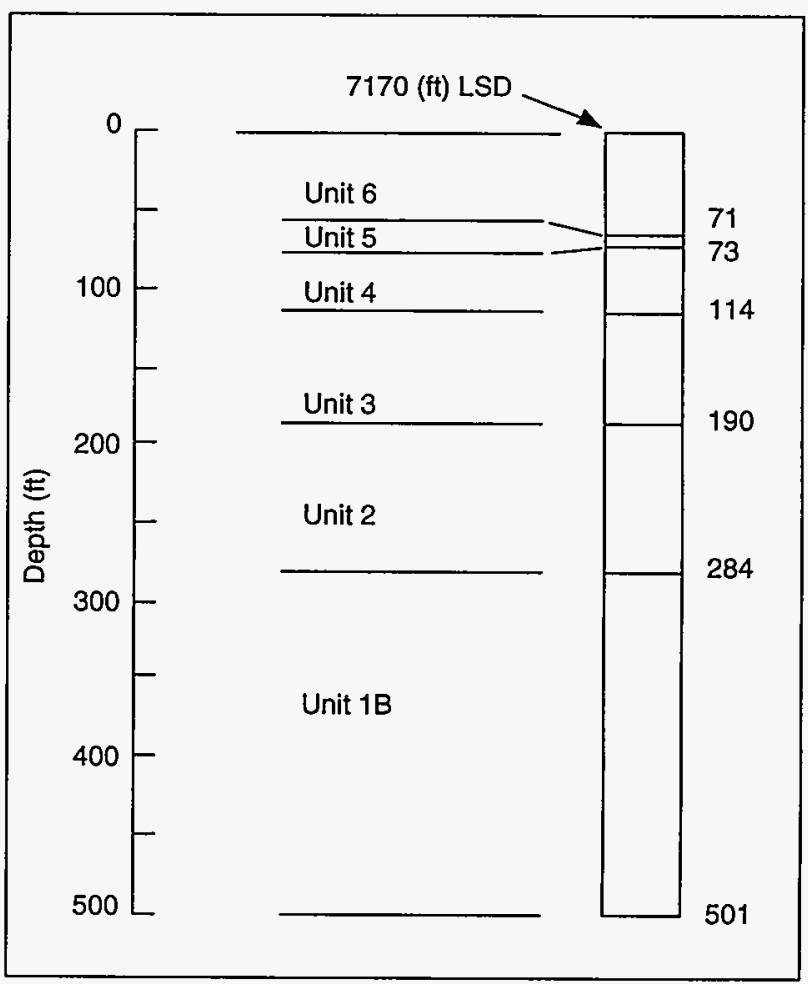

Fig. IX-I. Geologic log of core hole CH-1, completed December 1959, dry (Weir and Purtymun 1962). 


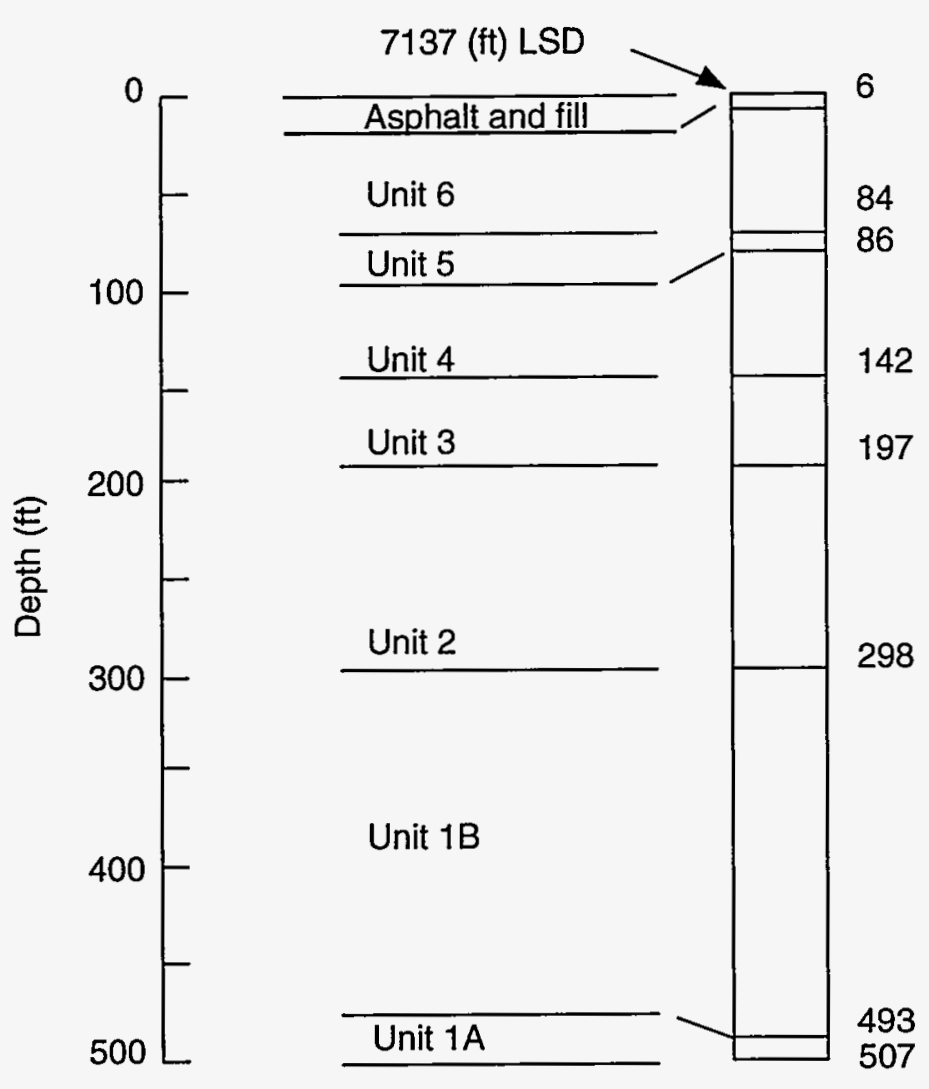

Fig. IX-J. Geologic log of core hole CH-2, completed November 1959, dry (Weir and Purtymun 1962).

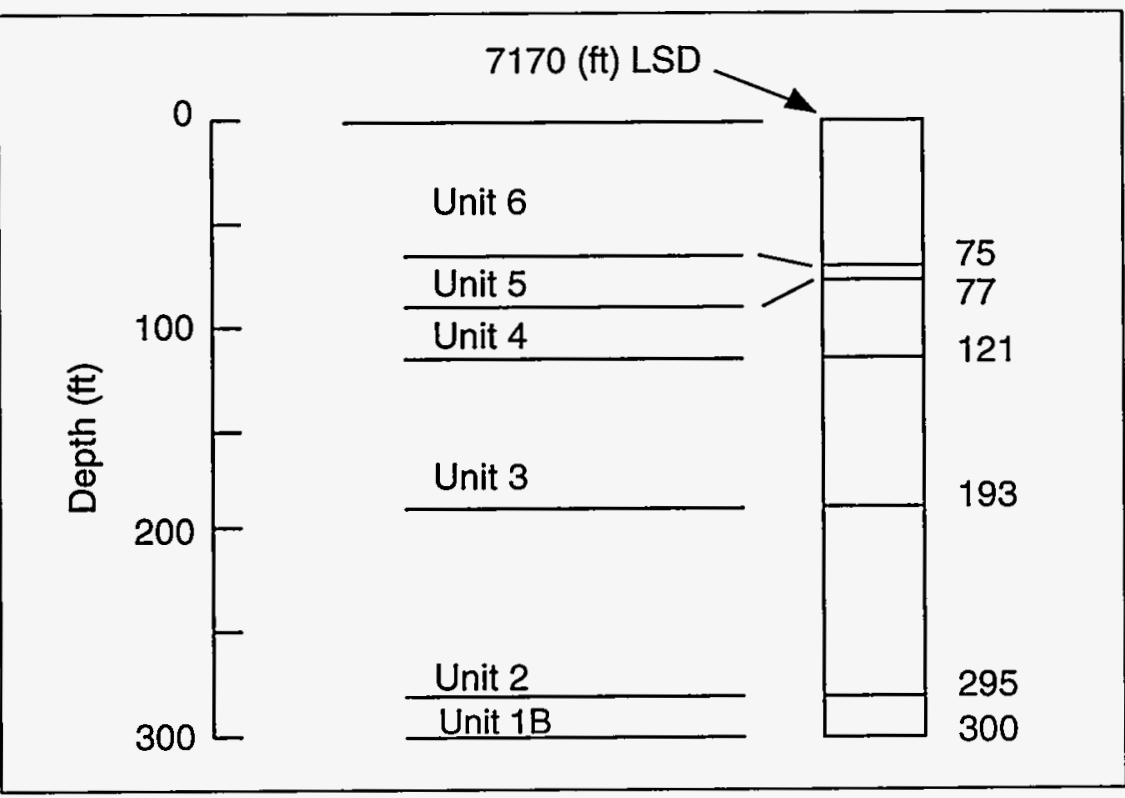

Fig. IX-K. Geologic log of core hole CH-3, completed February 1960, dry (Weir and Purtymun 1962). 


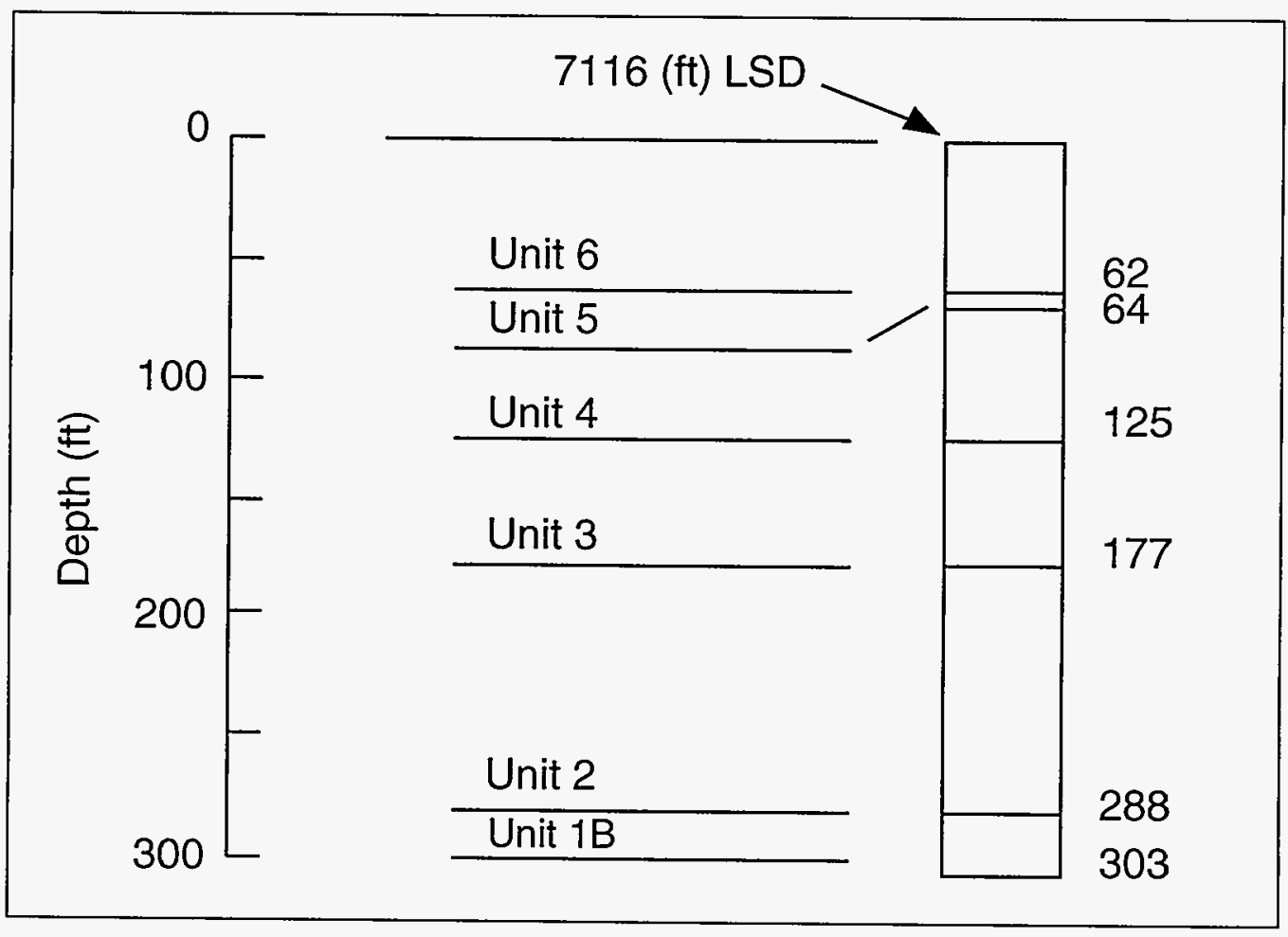

Fig. IX-L. Geologic log of core hole CH-4, completed February 1960, dry (Weir and Purtymun 1962).

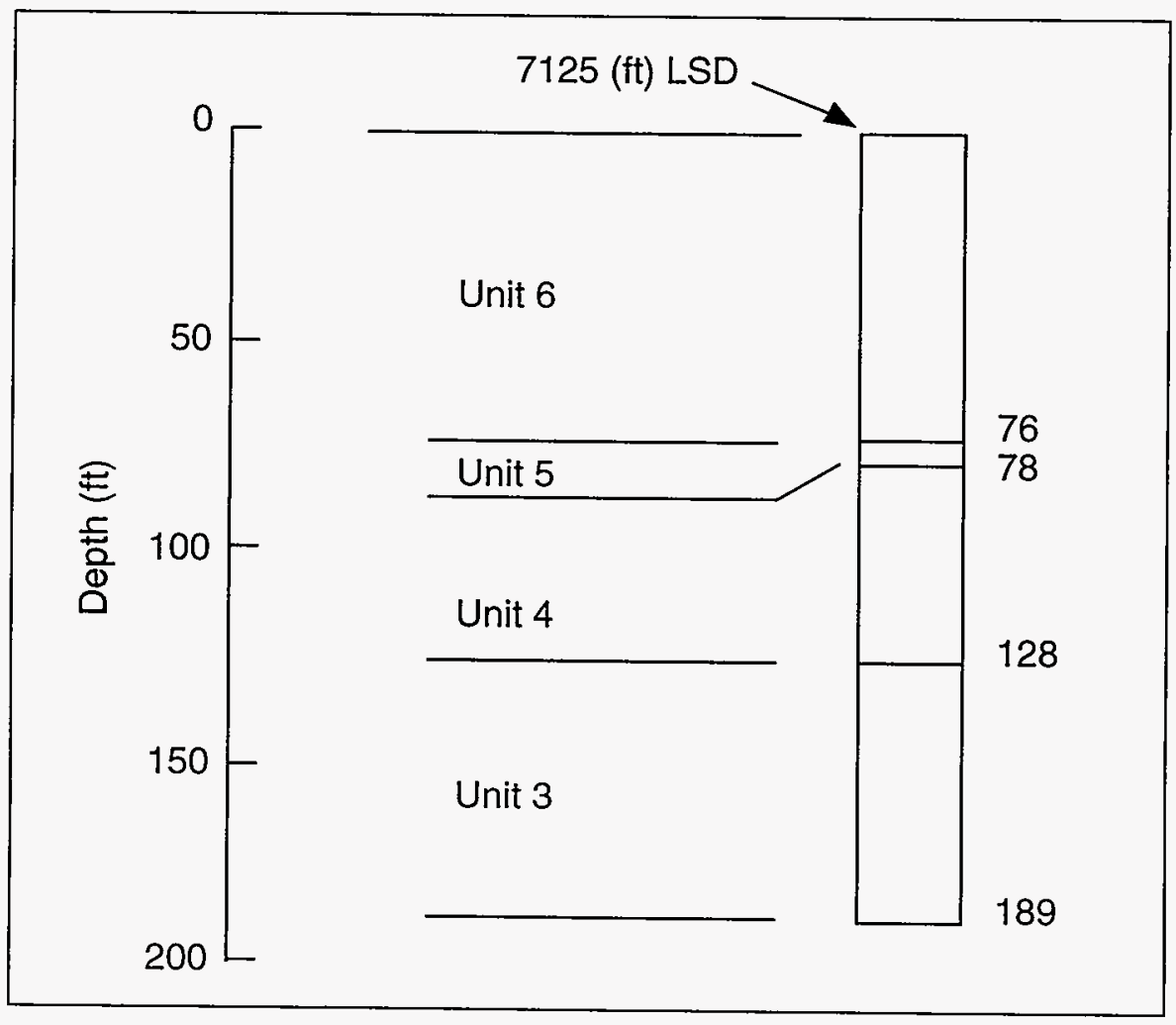

Fig. IX-M. Geologic log of Alpha Hole, completed February 1960, dry (Weir and Purtymun 1962). 


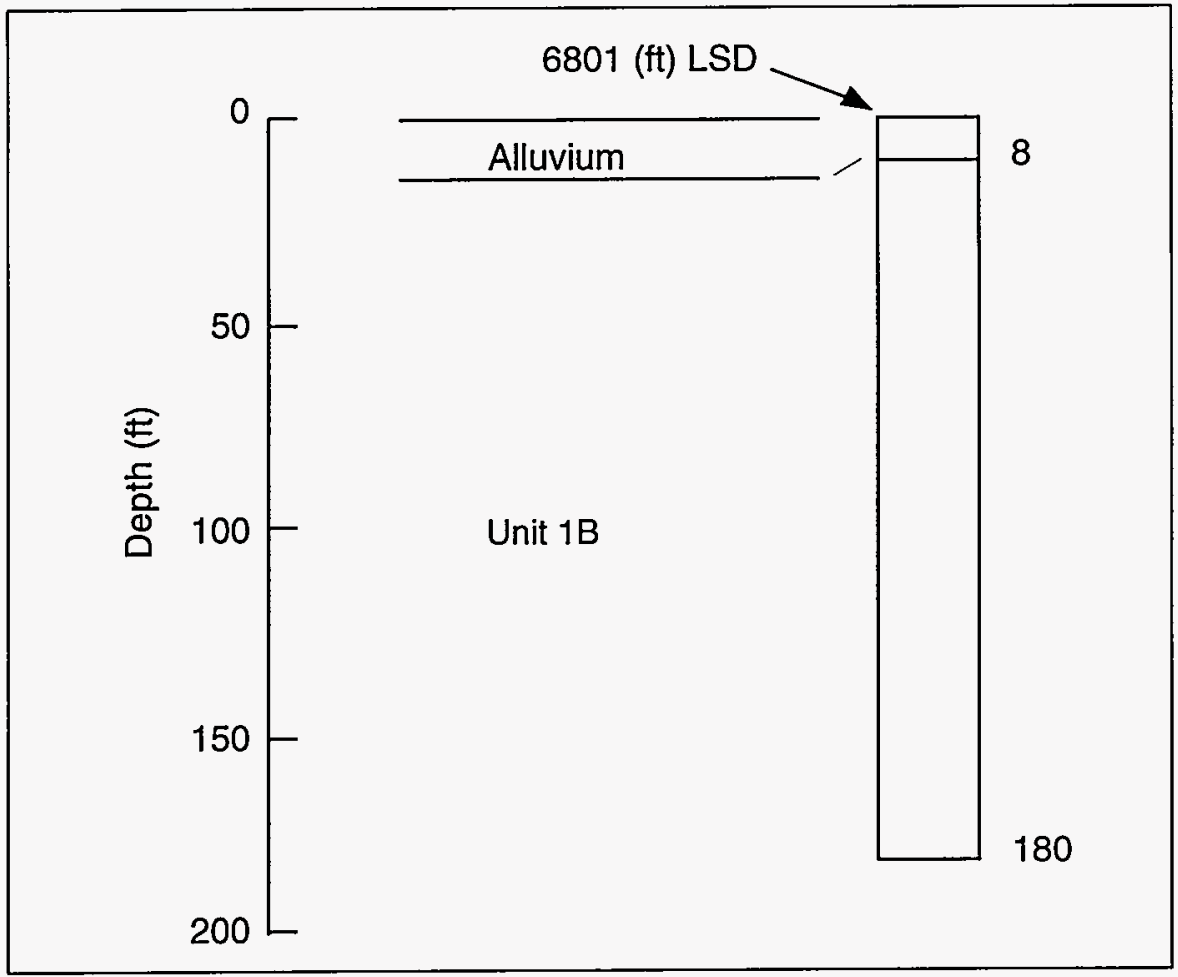

Fig. IX-N. Geologic log of Beta Hole, completed February 1960, dry (Weir and Purtymun 1962).

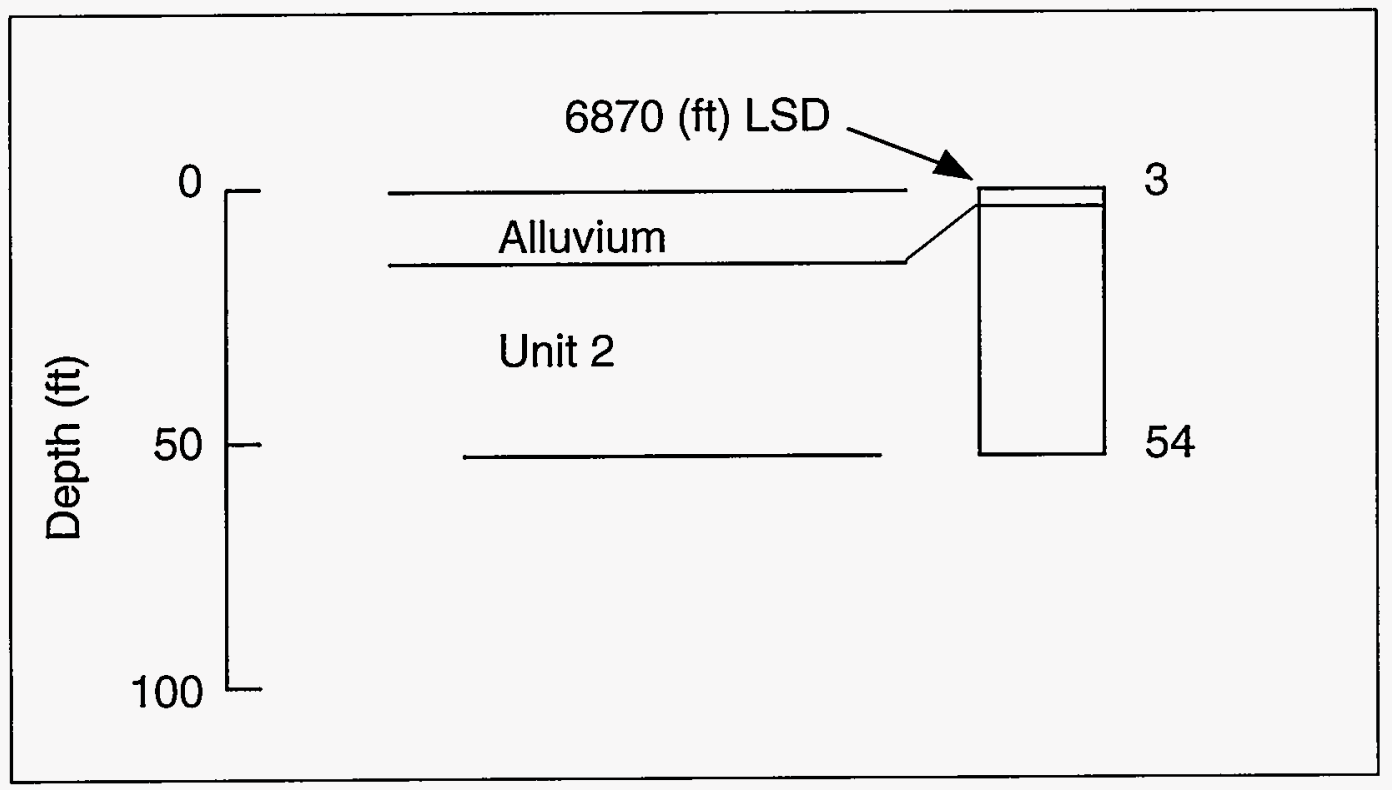

Fig. IX-O. Geologic log of Gamma Hole, completed March 1960, dry (Weir and Purtymun 1962). 


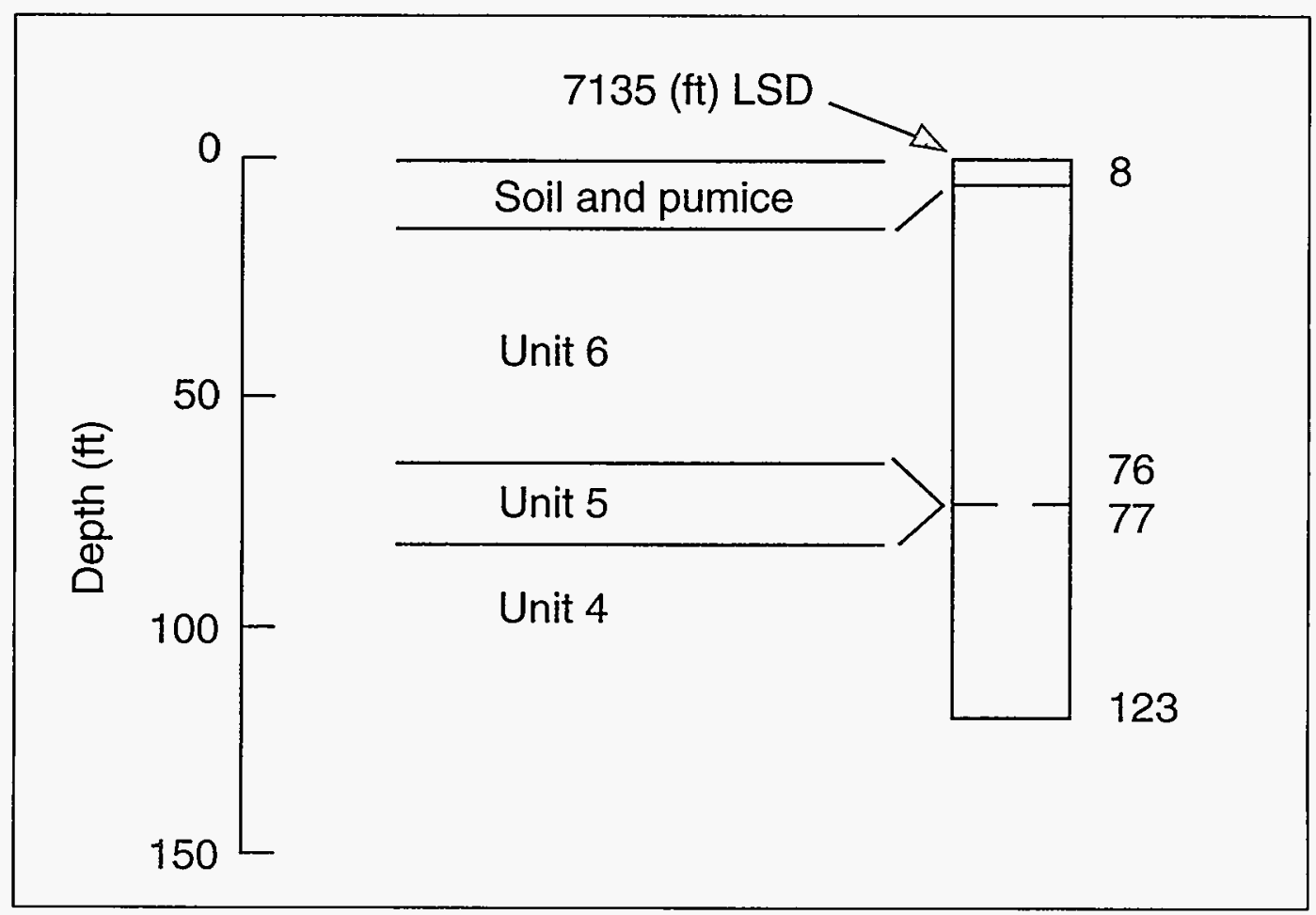

Fig. IX-P. Geologic log of Area 2 Test Hole 1, completed May 1980, dry (Purtymun 1994). 


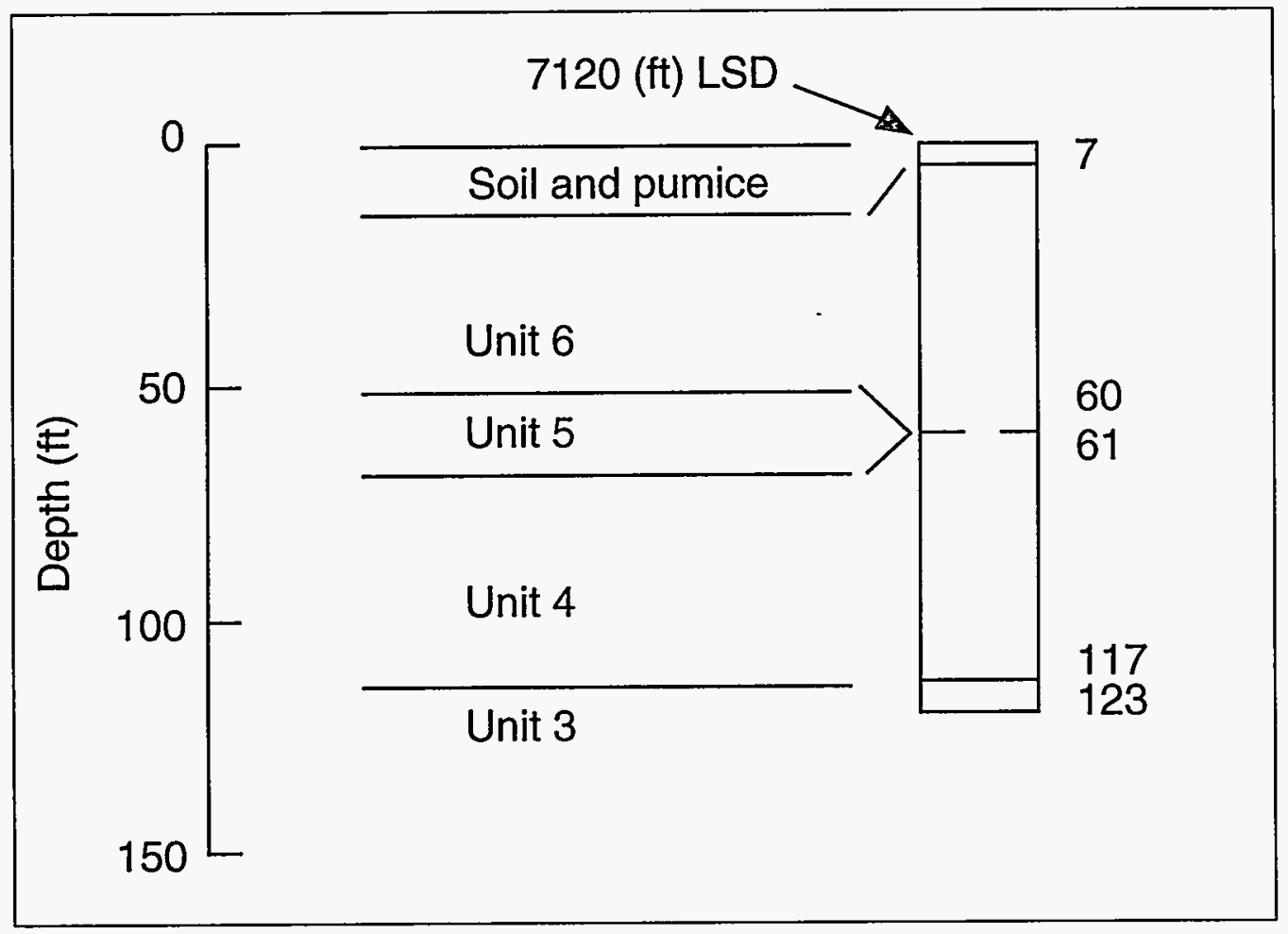

Fig. IX-Q. Geologic log of Area 2 Test Hole 2, completed May 1980, dry (Purtymun 1994).

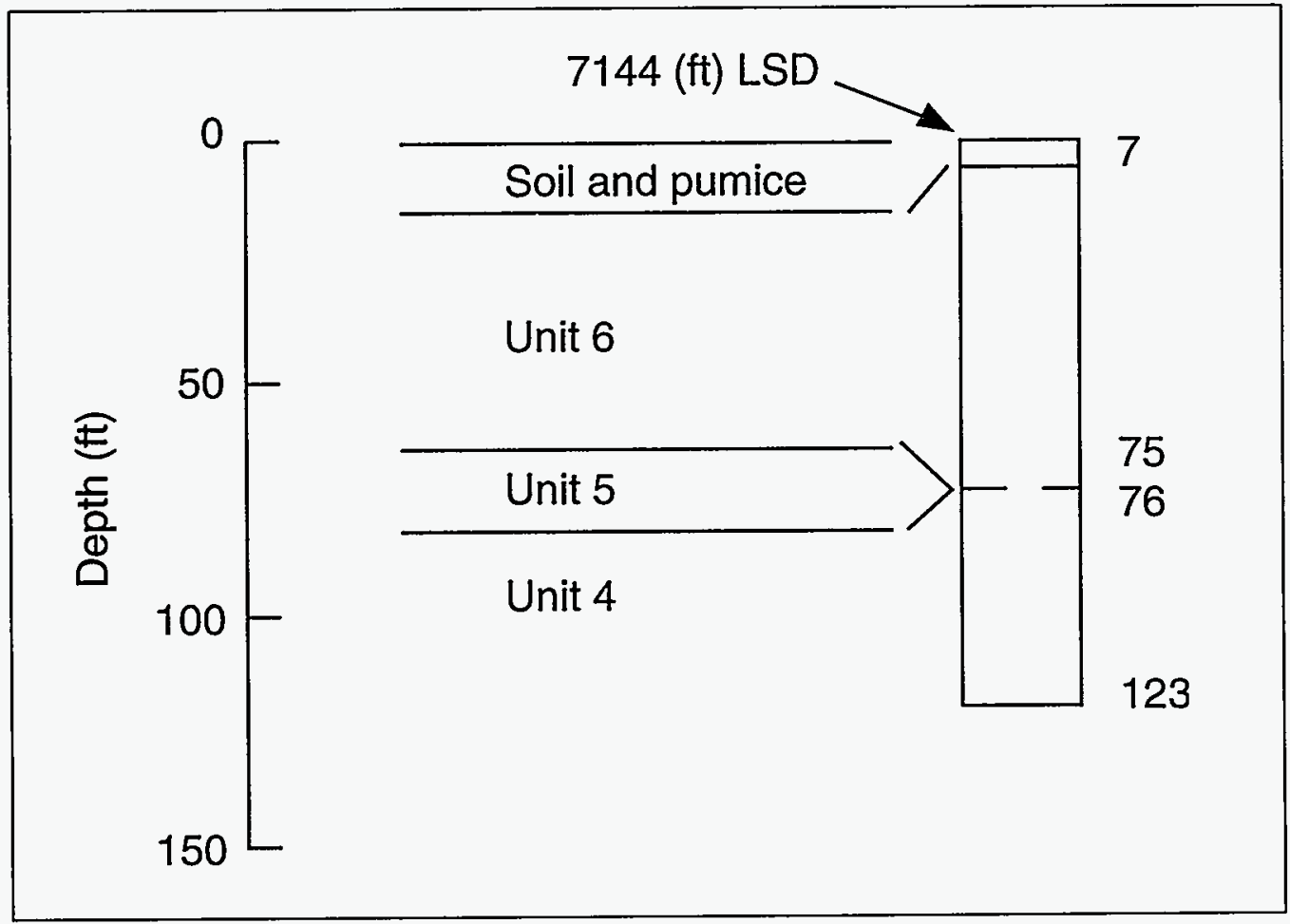

Fig. IX-R. Geologic log of Area 2 Test Hole 3, completed May 1980, dry (Purtymun 1994). 


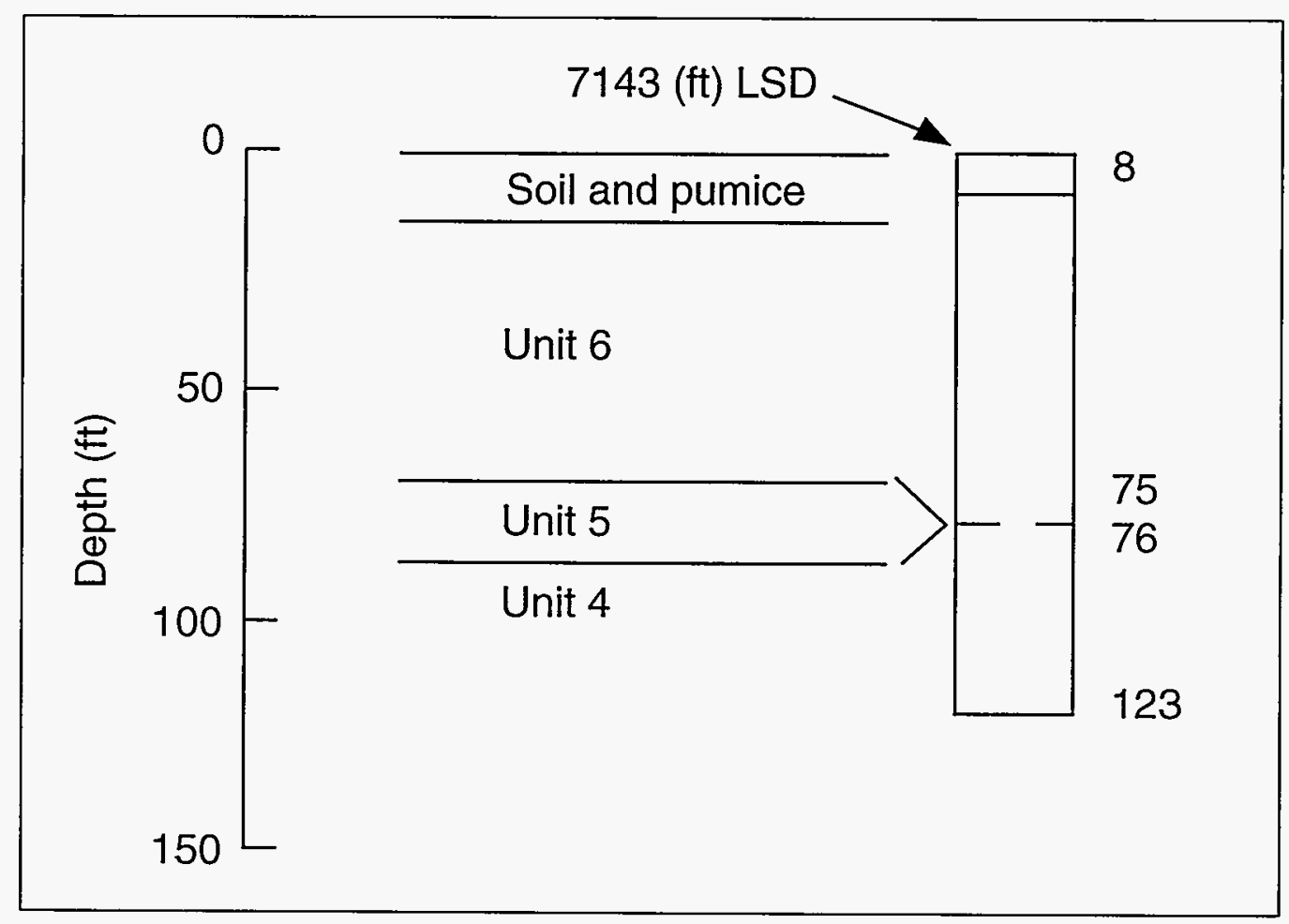

Fig. IX-S. Geologic log of Area 2 Test Hole 4, completed May 1980, dry (Purtymun 1994).

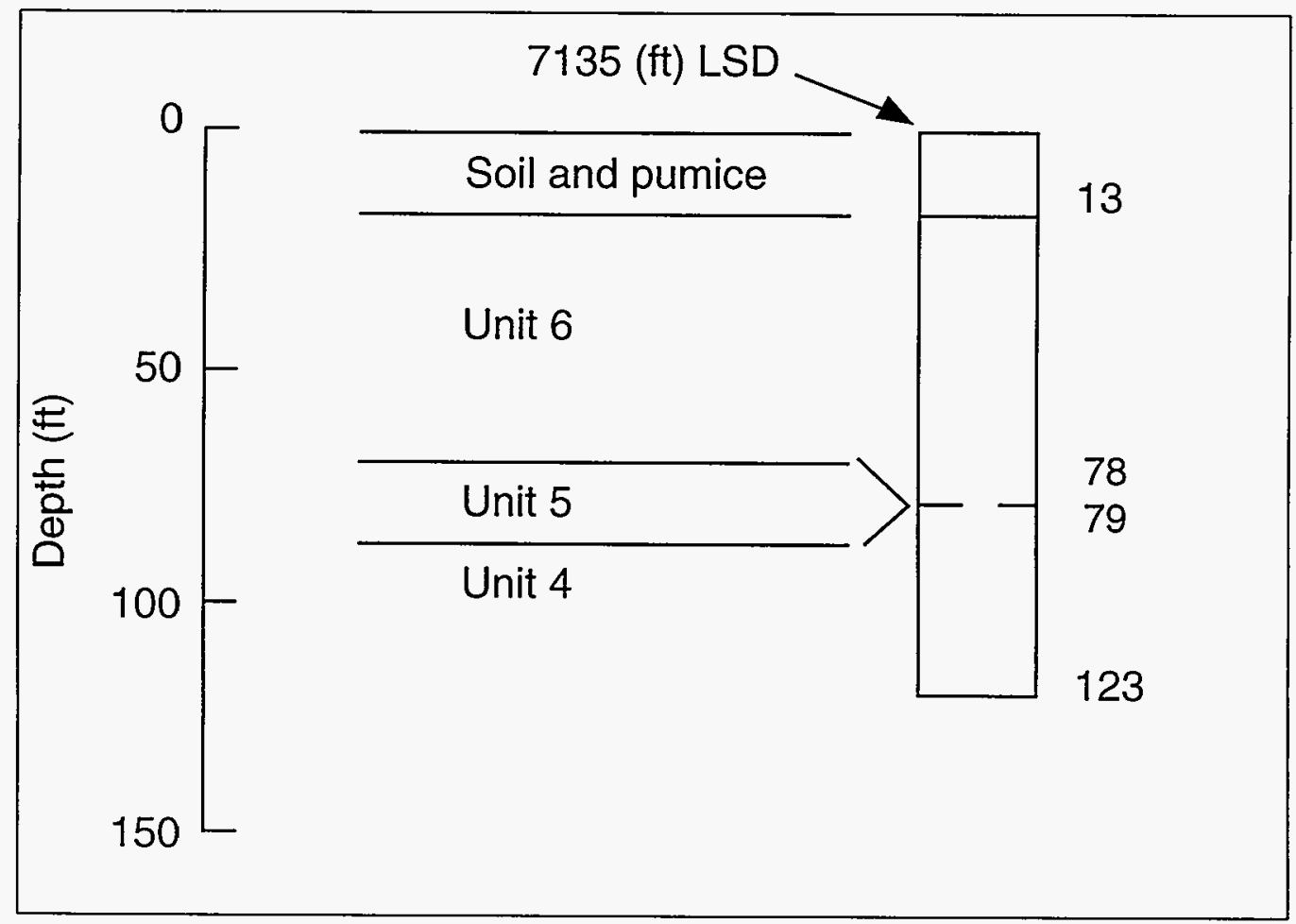

Fig. IX-T. Geologic log of Area 2 Test Hole 5, completed May 1980, dry (Purtymun 1994). 


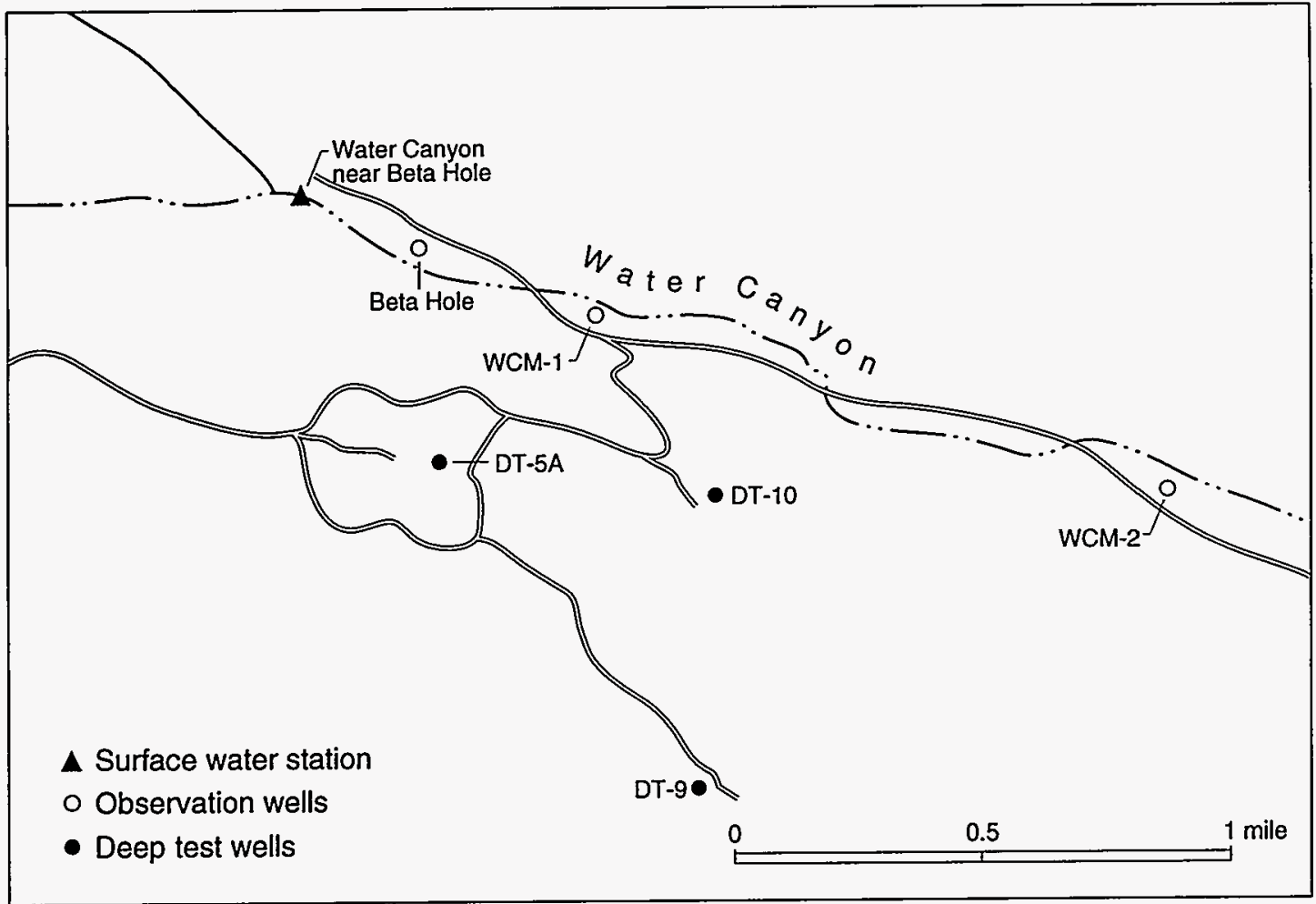

Fig. IX-U. Locations of wells, holes, and a surface water sampling station in Water Canyon north of TA-49.

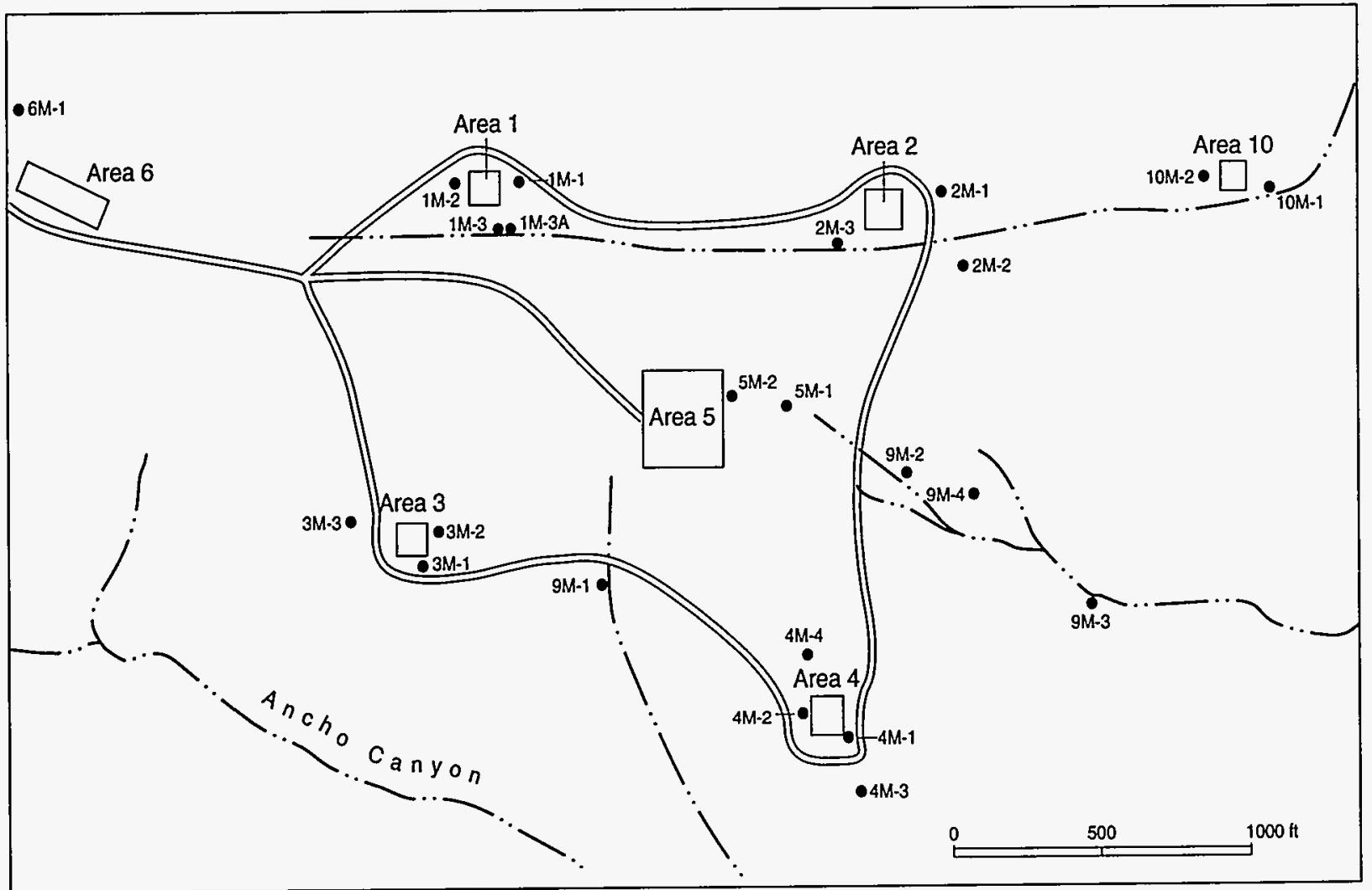

Fig. IX-V. Locations of moisture-access holes at TA-49. 
TABLE IX-A. Construction and Hydrologic Data for Test Holes, Test Wells, and Core Holes at TA-49

\begin{tabular}{lccccc} 
& $\begin{array}{c}\text { Year } \\
\text { Drilled }\end{array}$ & $\begin{array}{c}\text { Elevation } \\
(\mathrm{ft})\end{array}$ & $\begin{array}{r}\text { Depth } \\
(\mathrm{ft})\end{array}$ & $\begin{array}{c}\text { Water Level } \\
\text { Completion } \\
(\mathrm{ft})\end{array}$ & Remarks \\
\hline Test Hole DT-5P & 1959 & 7144 & 692 & Dry & \\
Test Hole DT-5 & 1959 & 7143 & 962 & Dry & \\
Test Well DT-5A & 1959 & 7144 & 1821 & 1173 & pump equipped \\
Test Well DT-9 & 1960 & 6935 & 1501 & 1003 & pump equipped \\
Test Well DT-10 & 1960 & 7020 & 1409 & 1085 & pump equipped \\
Core Hole CH-1 & 1959 & 7170 & 501 & Dry & \\
Core Hole CH-2 & 1959 & 7137 & 507 & Dry & \\
Core Hole CH-3 & 1960 & 7170 & 300 & Dry & \\
Core Hole CH-4 & 1960 & 7116 & 303 & Dry & \\
Alpha Hole & 1960 & 7125 & 189 & Dry & \\
Beta Hole & 1960 & 6801 & 180 & Dry & \\
Gamma Hole & 1960 & 6870 & 54 & Dry & \\
Area 2 Test Hole 1 & 1980 & 7135 & 123 & Dry & \\
Area 2 Test Hole 2 & 1980 & 7120 & 123 & Dry & \\
Area 2 Test Hole 3 & 1980 & 7144 & 123 & Dry & \\
Area 2 Test Hole 4 & 1980 & 7143 & 123 & Dry & \\
Area 2 Test Hole 5 & 1980 & 7135 & 123 & Dry & \\
\hline
\end{tabular}

Sources: Weir and Purtymun 1962; Purtymun 1994.

TABLE IX-B. Geologic Logs and Construction Data for Test Holes and Test Wells (5 Test Holes and Wells)

\section{Test Hole DT-5P}

Elevation (LSD) $7144 \mathrm{ft}$

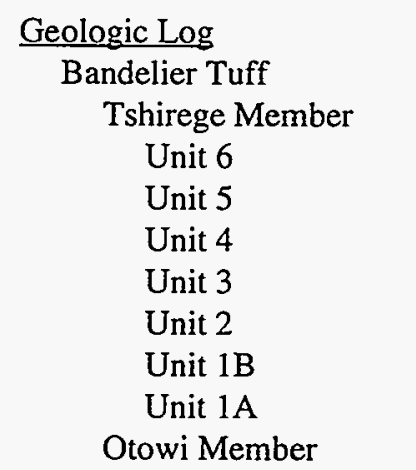

\begin{tabular}{cc}
\multicolumn{2}{c}{ Water Level: Dry } \\
$\begin{array}{c}\text { Thickness } \\
\text { (ft) }\end{array}$ & $\begin{array}{c}\text { Depth } \\
\text { (ft) }\end{array}$ \\
& \\
73 & 73 \\
2 & 75 \\
44 & 119 \\
63 & 182 \\
100 & 282 \\
203 & 485 \\
156 & 641 \\
51 & 692
\end{tabular}

Note: Hole plugged and abandoned; located about $40 \mathrm{ft}$ west of test well DT-5A. 
TABLE IX-B. Geologic Logs and Construction Data for Test Holes and Test Wells (5 Test Holes and Wells) (Continued)

\section{Test Hole DT-5}

Elevation (LSD) $7143 \mathrm{ft}$

Thickness

Geologic Log

Bandelier Tuff

Tshirege Member

Otowi Member

Guaje Member

Puye Conglomerate

Fanglomerate member
Water Level: Dry Depth

(ft)

(ft)

$641 \quad 641$

$198 \quad 839$

$101 \quad 940$

$22 \quad 962$

Casing Schedule

$180 \mathrm{ft}$ of 8-in.-diam steel casing set 0-180 ft; open hole 180-962 ft.

Geophysical Logs

Gamma-ray/neutron, induction-electrical, and temperature logs.

\section{Test Well DT-5A}

Elevation (LSD) $7144 \mathrm{ft}$

Geologic Log

Bandelier Tuff

Tshirege Member

Otowi Member

Guaje Member

Puye Conglomerate

Fanglomerate member

Basaltic Rocks of Chino Mesa

Unit $2^{\mathrm{a}}$

Puye Conglomerate

Fanglomerate member

Basaltic Rocks of Chino Mesa

Mesa Unit $2^{\mathrm{a}}$

Puye Conglomerate

Fanglomerate member

Totavi Lentil

Santa Fe Group

Chaquehui Formation
Water Level: $1173 \mathrm{ft}$, April 1960

Thickness Depth

(ft)

(ft)

$641 \quad 641$

$198 \quad 839$

$91 \quad 930$

$237 \quad 1167$

$126 \quad 1293$

$138 \quad 1431$

$26 \quad 1457$

$18 \quad 1475$

$52 \quad 1527$

$294 \quad 1821$

Casing Schedule

$525 \mathrm{ft}$ of 12 -in.-diam steel casing cemented in $0-525 \mathrm{ft} ; 1821 \mathrm{ft}$ of 8 -in.-diam steel casing hung 0 to $1821 \mathrm{ft}$ with a total of $220 \mathrm{ft}$ of torch-cut slots throughout the area below $1172 \mathrm{ft}$.

Geophysical Log

Gamma-ray/neutron, induction-electrical, temperature, microlog-caliper, laterlog, and sonic logs.

aLogged by Weir and Purtymun (1962) as Tschicoma Formation (see text). 
TABLE IX-B. Geologic Logs and Construction Data for Test Holes and Test Wells (5 Test Holes and Wells) (Continued)

\section{Test Well DT-9}

\begin{tabular}{|c|c|c|}
\hline \multirow[t]{2}{*}{ Elevation (LSD) $6935 \mathrm{ft}$} & \multicolumn{2}{|c|}{ Water Level: $1003 \mathrm{ft}$, February 1960} \\
\hline & Thickness & Depth \\
\hline \multirow{2}{*}{\multicolumn{3}{|c|}{$\frac{\text { Geologic Log }}{\text { Bandelier Tuff }}$}} \\
\hline & & \\
\hline Tshirege Member & 676 & 676 \\
\hline Otowi Member & 126 & 802 \\
\hline Guaje Member & 48 & 850 . \\
\hline \multicolumn{3}{|l|}{ Puye Conglomerate } \\
\hline Fanglomerate member & 74 & 924 \\
\hline \multicolumn{3}{|c|}{ Basaltic Rocks of Chino Mesa } \\
\hline Unit $2^{\mathbf{a}}$ & 238 & 1162 \\
\hline \multicolumn{3}{|l|}{ Puye Conglomerate } \\
\hline Fanglomerate member & 157 & 1319 \\
\hline Totavi Lentil & 38 & 1357 \\
\hline \multicolumn{3}{|l|}{ Santa Fe Group } \\
\hline Chaquehui Formation & 144 & 1501 \\
\hline
\end{tabular}

Casing Schedule

$1335 \mathrm{ft}$ of 12 -in.-diam steel casing set $0-1335 \mathrm{ft}$, lower $295 \mathrm{ft}$ torch slotted; $186 \mathrm{ft}$ of 8-in.-diam steel casing swaged into the 12 -in. casing at $1315 \mathrm{ft}$, set on bottom with $183 \mathrm{ft}$ of torch-cut slots.

\section{Geophysical Log}

Gamma-ray/neutron, induction-electrical, temperature, laterlog, and sonic logs.

\section{Test Well DT-10}

Elevation (LSD) $7020 \mathrm{ft}$

Geologic Log

Bandelier Tuff Tshirege Member Otowi Member Guaje Member

Puye Conglomerate Fanglomerate member

Basaltic Rocks of Chino Mesa Unit $2^{\mathrm{a}}$

Puye Conglomerate Fanglomerate member Totavi Lentil Santa Fe Group Chaquehui Formation

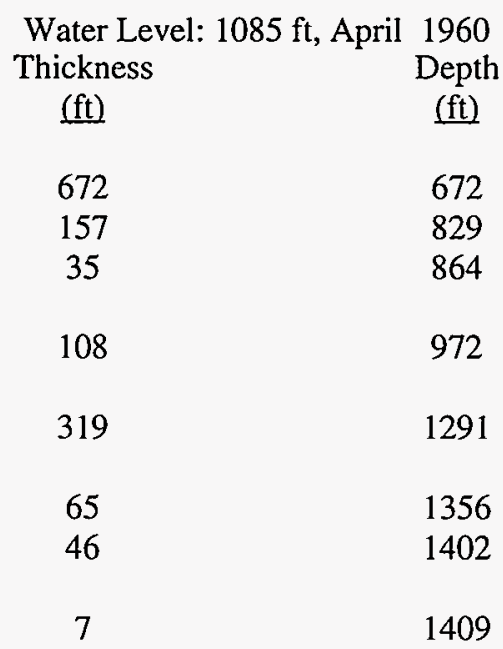

Casing Schedule $1130 \mathrm{ft}$ of 12 -in.-diam steel casing set $0-1130 \mathrm{ft}$, lower $50 \mathrm{ft}$ torch slotted; $310 \mathrm{ft}$ of 8 -in.-diam casing set swaged into the 12-in.-diam casing at $1098 \mathrm{ft}$, set on bottom with a total of $141 \mathrm{ft}$ of torch-cut slots throughout the section.

\section{Geophysical Log}

Gamma-ray/neutron, induction-electrical, temperature, and sonic logs.

aLogged by Weir and Purtymun (1962) as Tschicoma Formation (see text).

Source: Weir and Purtymun 1962, modified by Purtymun for this report. 
TABLE IX-C. Geologic Logs and Construction Data for Core and Shallow Test Holes (12 Core and Test Holes)

1. Test Hole $\mathrm{CH}-1$

\begin{tabular}{ccc} 
Elevation (LSD) $7170 \mathrm{ft}$ & $\begin{array}{c}\text { Water Level: } \\
\text { Thickness } \\
\text { (ft) }\end{array}$ & $\begin{array}{c}\text { Dry (drilled with air) } \\
\text { Depth } \\
\text { Geologic Log }\end{array}$ \\
\hline Bandelier Tuff & \multicolumn{1}{c}{$\begin{array}{c} \\
\text { Tshirege Member }\end{array}$} \\
Unit 6 & 71 & 71 \\
Unit 5 & 2 & 73 \\
Unit 4 & 41 & 114 \\
Unit 3 & 76 & 190 \\
Unit 2 & 94 & 284 \\
Unit 1B & 217 & 501
\end{tabular}

Casing Schedule

$500 \mathrm{ft}$ of 2-in.-diam galvanized pipe set 0 to $500 \mathrm{ft}$, with the lower $20 \mathrm{ft}$ slotted.

Geophysical Logs

Gamma ray.

2. Core Hole $\mathrm{CH}-2$

Elevation (LSD) $7137 \mathrm{ft}$

Geologic Log

Asphalt and fill

Bandelier Tuff

Tshirege Member

$\begin{array}{lcc}\text { Unit 6 } & 78 & 84 \\ \text { Unit 5 } & 2 & 86 \\ \text { Unit 4 } & 56 & 142 \\ \text { Unit 3 } & 55 & 197 \\ \text { Unit 2 } & 101 & 298 \\ \text { Unit 1B } & 195 & 493 \\ \text { Unit 1A } & 14 & 507\end{array}$

Casing Schedule

$507 \mathrm{ft}$ of 2-in.-diam galvanized pipe set 0 to $507 \mathrm{ft}$ with the lower $20 \mathrm{ft}$ slotted.

Geophysical Logs

Gamma-ray, gamma-ray/neutron, induction-electrical, and temperature logs.

3. Core Hole $\mathrm{CH}-3$

Elevation (LSD) $7170 \mathrm{ft}$

Water Level: Dry (drilled with air)

Geologic Log

Bandelier Tuff

Water Level: Dry (drilled with air)

Thickness Depth

$\frac{(\mathrm{ft})}{6}$

6

Tshirege Member

$\begin{array}{lll}\text { Unit } 6 & 75 & 75\end{array}$

Unit $5 \quad 2 \quad 77$

$\begin{array}{lll}\text { Unit } 4 & 44 & 121\end{array}$

"Thousands of gallons of water and drilling mud are pumped into holes for geophysical logging. 
TABLE IX-C. Geologic Logs and Construction Data for Core and Shallow Test Holes (12 Core and Test Holes) (Continued)

3. Core Hole $\mathrm{CH}-3$ (Continued)

Tshirege Member

$\begin{array}{lcl}\text { Unit } 3 & 72 & 193 \\ \text { Unit } 2 & 102 & 295 \\ \text { Unit 1B } & 5 & 300\end{array}$

Casing Schedule

$300 \mathrm{ft}$ of 12-in.-diam galvanized pipe set 0 to $300 \mathrm{ft}$ with the lower $20 \mathrm{ft}$ slotted.

Geophysical Log

Gamma ray.

4. Core Hole $\mathrm{CH}-4$

Elevation (LSD) $7116 \mathrm{ft}$

Water Level: Dry (drilled with air)

Geologic Log Thickness

Depth

Bandelier Tuff

(ft) $\quad(\mathrm{ft})$

Tshirege Member

Unit 6

$62 \quad 62$

Unit 5

$2 \quad 64$

Unit 4

$61 \quad 125$

Unit $3 \quad 52 \quad 177$

Unit $2+111 \quad 288$

$\begin{array}{lll}\text { Unit 1B } & 15 & 303\end{array}$

Casing Schedule

$300 \mathrm{ft}$ of 2-in.-diam galvanized pipe set 0 to $300 \mathrm{ft}$ with the lower $20 \mathrm{ft}$ slotted.

Geophysical Log

Gamma ray.

5. Alpha Hole

Elevation (LSD) $7125 \mathrm{ft}$

Water Level: Dry (drilled with a bucket auger)

Geologic Log

Thickness Depth

(ft) $\quad(\mathrm{ft})$

Bandelier Tuff

Tshirege Member

Unit 6

Unit 5

Unit 4

Unit 3

$76 \quad 76$

$2 \quad 78$

$50-128$

$61 \quad 189$

Casing Schedule

$7 \mathrm{ft}$ of 24 -in.-diam corrugated metal pipe set from 0 to $7 \mathrm{ft}$; open hole 7 to $189 \mathrm{ft}$.

Geophysical Log

Gamma-ray/neutron and induction-electrical logs. 
TABLE IX-C. Geologic Logs and Construction Data for Core and Shallow Test Holes (12 Core and Test Holes) (Continued)

6. Beta Hole

Elevation (LSD) $6801 \mathrm{ft}$

Geologic Log

Alluvium

Bandelier Tuff

Tshirege Member Unit 1B
Water Level: Dry (drilled with a bucket auger)

Thickness

$(\mathrm{ft})$

8

$\underline{(\mathrm{ft})}$

8

172

180

Casing Schedule

$13 \mathrm{ft}$ of 24-in.-diam corrugated metal pipe set from 0 to $13 \mathrm{ft}$; open hole 13 to $180 \mathrm{ft}$.

7. Gamma Hole

Elevation (LSD) $6870 \mathrm{ft}$

Geologic Log

Alluvium

Bandelier Tuff

Tshirege Member

Unit 2

$\begin{array}{lc}\begin{array}{l}\text { Water Level: Dry } \\ \text { Thickness } \\ \frac{(\mathrm{ft})}{3}\end{array} & \begin{array}{c}\text { Depth } \\ (\mathrm{ft})\end{array} \\ & 3 \\ 51 & 54\end{array}$

Casing Schedule

$8 \mathrm{ft}$ of 4-in.-diam steel casing set 0 to $8 \mathrm{ft}$, open hole 8 to $54 \mathrm{ft}$.

8. Area 2 Test Hole 1

Elevation (LSD) $7135 \mathrm{ft}$

Geologic Log

Soil and pumice

Bandelier Tuff

Tshirege Member

Unit 6

Unit 5

Unit 4

\section{Area 2 Test Hole 2}

Elevation (LSD) $7120 \mathrm{ft}$

\section{Geologic Log}

Soil and pumice

Bandelier Tuff

Tshirege Member

Unit 6

Unit 5
Water Level: Dry (drilled with 4-in.-diam auger)

$\begin{array}{cc}\begin{array}{c}\text { Thickness } \\ (\mathrm{ft})\end{array} & \begin{array}{c}\text { Depth } \\ 8\end{array} \\ \frac{(\mathrm{ft})}{8}\end{array}$

Water Level: Dry (drilled with 4-in.-diam auger)

$\begin{array}{cc}\begin{array}{c}\text { Thickness } \\ (\mathrm{ft})\end{array} & \begin{array}{c}\text { Depth } \\ 7\end{array} \\ \frac{(\mathrm{ft})}{7}\end{array}$

Thickness

(ft)

7

$53 \quad 60$

$1 \quad 61$

${ }^{\mathrm{a}}$ Surface water ran in hole, spring 1960. 
TABLE IX-C. Geologic Logs and Construction Data for Core and Shallow Test Holes (12 Core and Test Holes) (Continued)

9. Area 2 Test Hole 2 (Continued)

Tshirege Member

Unit $4 \quad 56 \quad 117$

Unit $3 \quad 6 \quad 123$

Casing Schedule

$4 \mathrm{ft}$ of 4-in.-diam plastic pipe cemented in 0 to $3 \mathrm{ft}$; open hole 3 to $123 \mathrm{ft}$.

10. Area 2 Test Hole 3

Elevation (LSD) $7144 \mathrm{ft}$

Geologic Log

Soil and pumice

Bandelier Tuff

Tshirege Member

Unit 6

Unit 5

Unit 4
Water Level: Dry (drilled with a 4-in.-diam auger)

$$
\text { Thickness }
$$

$\underline{(\mathrm{ft})}$

7

Depth

$\frac{(\mathrm{ft})}{7}$

$68 \quad 75$

$1 \quad 76$

$47-123$

Casing Schedule

$4 \mathrm{ft}$ of 4-in.-diam plastic pipe cemented in 0 to $3 \mathrm{ft}$; open hole 3 to $123 \mathrm{ft}$.

11. Area 2 Test Hole 4

Elevation (LSD) $7143 \mathrm{ft}$

Geologic Log

Soil and pumice

Bandelier Tuff

Tshirege Member

Unit 6

Unit 5

Unit 4

Water Level: Dry (drilled with a 4-in.-diam auger)

Thickness

$\frac{(\mathrm{ft})}{8}$

8

$67 \quad 75$

$1 \quad 76$

Casing Schedule

$4 \mathrm{ft}$ of 4 -in.-diam plastic pipe cemented in 0 to $3 \mathrm{ft}$; open hole 3 to $123 \mathrm{ft}$.

12. Area 2 Test Hole 5

Elevation (LSD) $7135 \mathrm{ft}$

Geologic Log

Soil and pumice

Bandelier Tuff

Tshirege Member

Unit 6

Unit 5

Unit 4

Water Level: Dry (drilled with a 4-in.-diam auger)

Thickness

(ft)

13

65

1
Depth

$\frac{(\mathrm{ft})}{8}$

123

Casing Schedule

$4 \mathrm{ft}$ of 4 -in.-diam plastic pipe cemented in 0 to $3 \mathrm{ft}$; open hole 3 to $123 \mathrm{ft}$.

Sources: Weir and Purtymun 1962; Purtymun 1994. 


\begin{tabular}{|c|c|c|c|c|}
\hline \multirow[b]{2}{*}{$\begin{array}{c}\text { Moisture- } \\
\text { Access } \\
\text { Hole }\end{array}$} & \multirow[b]{2}{*}{$\begin{array}{c}\text { Elevation } \\
\text { LSD } \\
\text { (ft) }\end{array}$} & \multirow{2}{*}{$\begin{array}{c}\text { Extent of } \\
\text { Casing } \\
\text { below } \\
\text { LSD } \\
\text { (ft) }\end{array}$} & \multicolumn{2}{|c|}{$\log$} \\
\hline & & & $\begin{array}{l}\text { Soil } \\
(\mathrm{ft})\end{array}$ & $\begin{array}{c}\text { Bandelier } \\
\text { Tuff } \\
\text { (ft) }\end{array}$ \\
\hline $1 \mathrm{M}-1$ & 7162 & 49 & 4.5 & 44.5 \\
\hline $1 \mathrm{M}-2$ & 7170 & 19 & 1 & 18 \\
\hline $1 \mathrm{M}-3$ & 7171 & 19 & 4 & 15 \\
\hline $1 \mathrm{M}-3 \mathrm{~A}$ & 7171 & 49 & 3 & 46 \\
\hline $2 M-1$ & 7129 & 49 & 1 & 48 \\
\hline $2 M-2$ & 7131 & 10 & 5 & 5 \\
\hline $2 M-3$ & 7141 & 19 & 5 & 14 \\
\hline $3 \mathrm{M}-1$ & 7163 & 50 & 1 & 49 \\
\hline $3 \mathrm{M}-2$ & 7169 & 19 & 2.5 & 16.5 \\
\hline $3 M-3$ & 7174 & 20 & 7 & 13 \\
\hline $4 M-1$ & 7112 & 49 & 2 & 47 \\
\hline $4 M-2$ & 7116 & 20 & 1.5 & 18.5 \\
\hline $4 \mathrm{M}-3$ & 7107 & 19 & 3 & 16 \\
\hline $4 \mathrm{M}-4$ & 7122 & 19 & 3 & 16 \\
\hline $5 \mathrm{M}-1$ & 7136 & 39 & 2.5 & 36.5 \\
\hline $5 \mathrm{M}-2$ & 7146 & 19 & 3 & 16 \\
\hline $6 \mathrm{M}-1$ & 7210 & 19 & 9 & 10 \\
\hline $9 M-1$ & 7115 & 19 & 6 & 13 \\
\hline $9 M-2$ & 7104 & 19 & 6.5 & 12.5 \\
\hline $9 M-3$ & 7049 & 19 & 4 & 15 \\
\hline $9 M-4$ & 7097 & 19 & 12.5 & 6.5 \\
\hline $10 \mathrm{M}-1$ & 7090 & 29 & 2 & 27 \\
\hline $10 \mathrm{M}-2$ & 7093 & 20 & 4 & 16 \\
\hline $\mathrm{WCM}^{\mathrm{a}} \mathrm{1}^{\mathrm{a}}$ & 6745 & 10 & 10 & - \\
\hline WCM-2a & 6650 & 10 & 10 & - \\
\hline $\begin{array}{r}\text { Note: Moisture } \\
\text { with 2-in } \\
\text { alluvium }\end{array}$ & $\begin{array}{l}\text { tic and obs } \\
\text { anyon). }\end{array}$ & $\begin{array}{l}\text { ompleted F } \\
\text { All holes dr }\end{array}$ & $\begin{array}{l}\text { rilled } w \\
-1 \text { and }\end{array}$ & $\begin{array}{l}\text { vagon drill } \\
\text { eted in the }\end{array}$ \\
\hline
\end{tabular}

a Completed as observation wells in Water Canyon, lower $5 \mathrm{ft}$ perforated (see Fig. IX-U for location).

Source: Weir and Purtymun 1962. 
A. Surface Water

Water Canyon near Beta Hole

B. Deep Test Holes
CH-1
CH-2
CH-3
CH-4
Alpha Hole
Beta Hole
Gamma Hole
TH-1
TH-2
TH-3
TH-4
TH-5
D. Moisture-Access Holes

\begin{tabular}{|c|c|c|c|}
\hline $1 \mathrm{M}-1$ & S $104+40$ & E $85+48$ & $7162 \mathrm{ft}$ \\
\hline $1 \mathrm{M}-2$ & S $104+63$ & E $83+39$ & $7170 \mathrm{ft}$ \\
\hline $1 \mathrm{M}-3$ & S $105+92$ & E $84+95$ & $7171 \mathrm{ft}$ \\
\hline $1 \mathrm{M}-3 \mathrm{~A}$ & S $105+92$ & E $85+02$ & $7171 \mathrm{ft}$ \\
\hline $2 \mathrm{M}-1$ & S $104+73$ & E $99+28$ & $7129 \mathrm{ft}$ \\
\hline $2 M-2$ & S $107+12$ & E $100+05$ & $7131 \mathrm{ft}$ \\
\hline $2 \mathrm{M}-3$ & S $106+66$ & E $96+01$ & $7141 \mathrm{ft}$ \\
\hline $3 \mathrm{M}-1$ & S $115+97$ & E $82+03$ & $7163 \mathrm{ft}$ \\
\hline $3 M-2$ & $S 114+82$ & E $82+67$ & $7169 \mathrm{ft}$ \\
\hline $3 \mathrm{M}-3$ & S $114+56$ & E $79+96$ & $7174 \mathrm{ft}$ \\
\hline $4 M-1$ & S $121+29$ & E $96+44$ & $7112 \mathrm{ft}$ \\
\hline $4 \mathrm{M}-2$ & S $120+57$ & E $94+70$ & $7116 \mathrm{ft}$ \\
\hline $4 \mathrm{M}-3$ & S $122+76$ & E $96+94$ & $7107 \mathrm{ft}$ \\
\hline $4 \mathrm{M}-4$ & $S 118+72$ & E $94+94$ & $7122 \mathrm{ft}$ \\
\hline $5 \mathrm{M}-1$ & $S 111+32$ & E $94+36$ & $7136 \mathrm{ft}$ \\
\hline $5 \mathrm{M}-2$ & $S 111+05$ & E $92+38$ & $7146 \mathrm{ft}$ \\
\hline $6 \mathrm{M}-1$ & S $102+15$ & E $68+83$ & $7210 \mathrm{ft}$ \\
\hline $9 \mathrm{M}-1$ & S $116+67$ & E $88+44$ & $7115 \mathrm{ft}$ \\
\hline $9 M-2$ & $S 113+40$ & E $98+15$ & $7104 \mathrm{ft}$ \\
\hline $9 \mathrm{M}-3$ & $S 117+02$ & E $104+57$ & $7049 \mathrm{ft}$ \\
\hline $9 \mathrm{M}-4$ & $S 113+93$ & E $100+40$ & $7097 \mathrm{ft}$ \\
\hline $10 \mathrm{M}-1$ & S $104+96$ & E $110+31$ & $7090 \mathrm{ft}$ \\
\hline $10 \mathrm{M}-2$ & S $104+54$ & E $108+69$ & $7093 \mathrm{ft}$ \\
\hline WCM-1 & S $92+20$ approx & E $111+20$ approx & $6745 \mathrm{ft}$ approx \\
\hline WCM-2 & S $102+20$ approx & E $145+00$ approx & $6650 \mathrm{ft}$ approx \\
\hline
\end{tabular}

$\begin{array}{ccc}\text { S } 111+32 & \text { E } 94+36 & 7144 \mathrm{ft} \\ \text { S } 110+99 & \text { E } 93+03 & 7143 \mathrm{ft} \\ \text { N } 1,754,727 & \text { E } 485,066 & 7144 \mathrm{ft} \\ \text { N } 1,751,431 & \text { E } 488,750 & 6935 \mathrm{ft} \\ \text { N } 1,754,387 & \text { E } 488,744 & 7020 \mathrm{ft}\end{array}$

S $104+98$

E $84+37$

$7170 \mathrm{ft}$

S $105+70$

S $114+94$

S $120+33$

S $111+16$

S $83+63$

S $133+20$

N $1,755,200$

N $1,755,500$

N $1,755,300$

N $1,755,100$

N $1,755,200$

E $97+85$

E $82+06$

E $95+68$

E $97+54$

E $91+89$

E $104+00$

E 485,700

E 485,600

E 485,400

E 485,400

E 485,500

$7137 \mathrm{ft}$

$7170 \mathrm{ft}$

$7116 \mathrm{ft}$

$7125 \mathrm{ft}$

$6801 \mathrm{ft}$

$6870 \mathrm{ft}$

$7135 \mathrm{ft}$

$7120 \mathrm{ft}$

$7144 \mathrm{ft}$

$7143 \mathrm{ft}$

$7135 \mathrm{ft}$

$7162 \mathrm{ft}$

$170 \mathrm{ft}$

$7171 \mathrm{ft}$

$7129 \mathrm{ft}$

$7131 \mathrm{ft}$

$7169 \mathrm{ft}$

$7112 \mathrm{ft}$

$7116 \mathrm{ft}$

$7107 \mathrm{ft}$

$7146 \mathrm{ft}$

$7210 \mathrm{ft}$

$7115 \mathrm{ft}$

$7097 \mathrm{ft}$

$7093 \mathrm{ft}$

$6745 \mathrm{ft}$ approx 


\section{AIR INJECTION SITE NEAR TA-52}

To study the possibility of injecting, storing, and later venting low-level short-lived radioactive gases, a site was prepared by augering four 5 -in.-diam holes into the tuff (Fig. X-A). The holes were augered to $97 \mathrm{ft}$ (Table X-A). Two plastic tubes were run to the bottom of each hole, with the lower $10 \mathrm{ft}$ of each tube perforated. These were to be used to inject air and to measure any buildup of pressure that might occur. The injection zone at the bottom of the hole was packed with pea-sized gravel. The injection zone in each hole was isolated by a cement plug.

A 4-in.-diam hole (NE-2) was drilled with air to a depth of $297 \mathrm{ft}$, north of the cluster of four holes. The hole has two injection zones, one near the bottom from 272 to $291 \mathrm{ft}$ and another at about $160 \mathrm{ft}$. These were constructed with only one tube going to each zone.
In one experiment air was pumped from the tuff, from different depths in two test holes. In NE- 2 air was pumped from the zone 272 to $291 \mathrm{ft}$ and from NE-1 air was pumped from the zone 78 to $83 \mathrm{ft}$. Both air samples were analyzed for carbon dioxide. The test revealed that the carbon that was present was of mixed origin, part atmospheric and part biogenic. Radiocarbon ages for the carbon dioxide could not be determined.

\section{REFERENCE}

J. L. Kunkler, "The Sources of Carbon Dioxide in the Zone of Aeration of the Bandelier Tuff, near Los Alamos, New Mexico," in U.S. Geol. Survey Prof. Paper 650-D (1969).

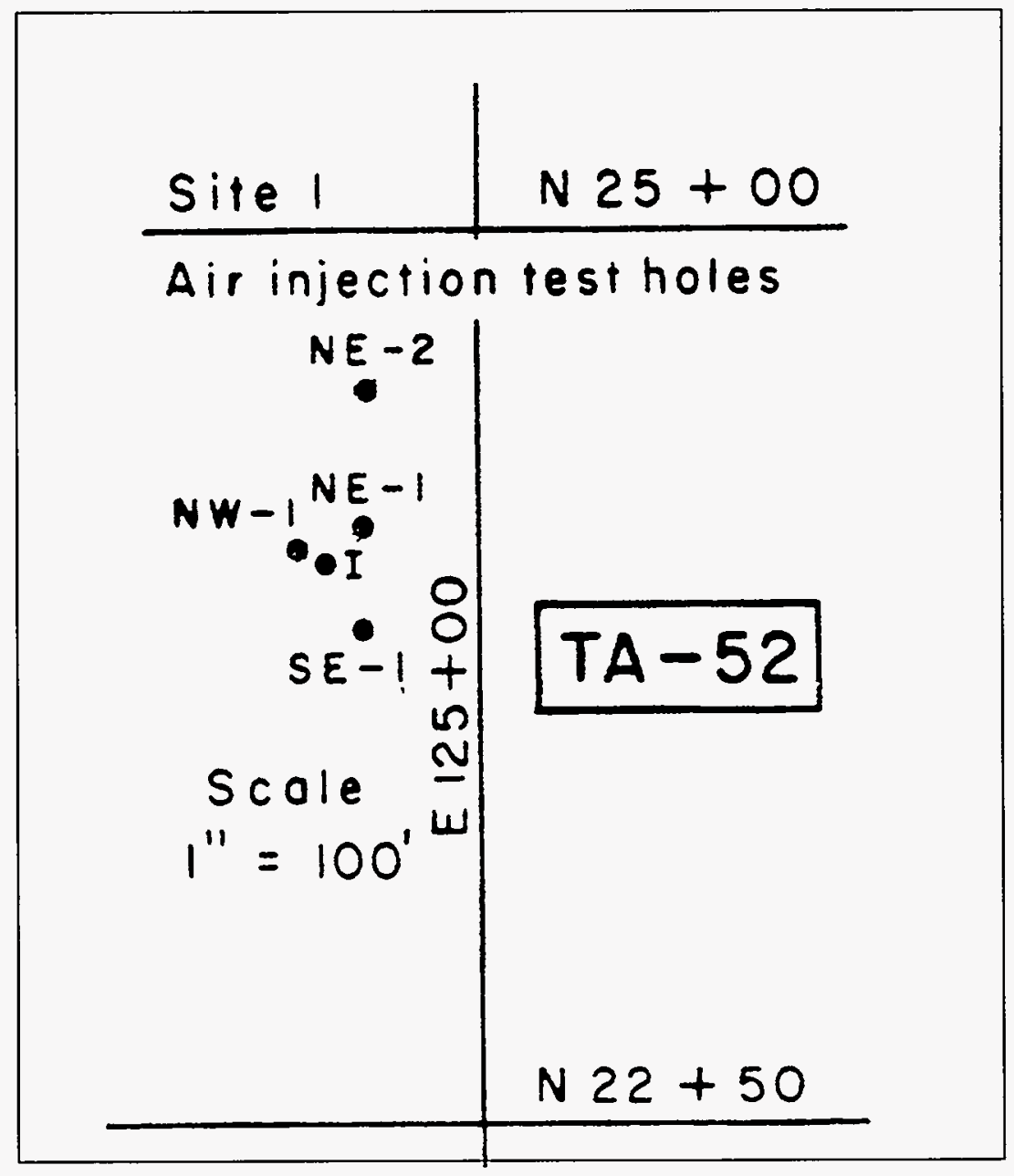

Fig. X-A. Locations of test holes at air injection site near TA-52. 
TABLE X-A. Construction Data for Test Holes at Air-Tuff Transfer Site Near TA-52

\begin{tabular}{cccccc}
$\begin{array}{c}\text { Test } \\
\text { Hole }\end{array}$ & $\begin{array}{c}\text { Structure } \\
\text { No. }\end{array}$ & $\begin{array}{c}\text { Date } \\
\text { Drilled }\end{array}$ & $\begin{array}{c}\text { Elevation } \\
\text { (LSD) } \\
\text { (ft) }\end{array}$ & $\begin{array}{c}\text { Diameter } \\
\text { (in.) }\end{array}$ & $\begin{array}{c}\text { Depth } \\
\text { (ft) }\end{array}$ \\
\hline I & TA-52-25 & $12 / 64$ & 7168.8 & 5 & 97 \\
NW-1 & TA-52-24 & $12 / 64$ & 7169.1 & 5 & 97 \\
SE-1 & TA-52-26 & $12 / 64$ & 7167.4 & 5 & 97 \\
NE-1 & TA-52-23 & $12 / 64$ & 7169.2 & 5 & 97 \\
NE-2 & TA-52-22 & $10 / 65$ & 7171.5 & 4 & 295 \\
\hline
\end{tabular}

Note: Holes I, NE-1, SE-1, and NW-1 have 6-in.-diam steel casing cemented into the top of the tuff. All holes have 10-ft-long gravel injection zones from 87 to $97 \mathrm{ft}$ with tubes extending from the injection zones to the surface. Injection zones are isolated by cement plugs. All holes were dry.

\begin{tabular}{llll}
\hline \hline \multicolumn{4}{c}{ TABLE X-B. Locations and Elevations (NAD 1927) } \\
\hline Hole I & N $1,768,138$ & E 488,802 & $7168.8 \mathrm{ft}$ \\
Hole NW-1 & N $1,768,140$ & E 488,799 & $7169.1 \mathrm{ft}$ \\
Hole SE-1 & N $1,768,119$ & E 488,811 & $7167.4 \mathrm{ft}$ \\
Hole NE-1 & N $1,768,144$ & E 488,812 & $7169.2 \mathrm{ft}$ \\
Hole NE-2 & N $1,768,182$ & E 488,816 & $7171.5 \mathrm{ft}$ \\
\hline
\end{tabular}




\section{AIR AND WATER INJECTION SITES NEAR TA-50}

At Site 1 near TA-50, eight holes were augered or drilled with air to study the effect of atmospheric pressure change in different zones within the tuff (Fig. XI-A). All were completed in Unit 3 of the Tshirege Member of the Bandelier Tuff. Construction details are presented in Table XI-A.

At Site 2 near TA-50 seven holes were augered with a 5-in.-diam to depths ranging from 67 to $118 \mathrm{ft}$ (Fig. XI-A). Two additional 4-in.-diam holes were rotary-air drilled to a depth of $295 \mathrm{ft}$ (Table XI-B). The $67 \mathrm{ft}$ hole was used as the injection well, with a 10-ft injection zone from 57 to $67 \mathrm{ft}$. Two lines were run into the injection zone, one to inject water and the second to measure the pressure at the center of the injection zone. The remaining holes were left open, with 4-in.-diam plastic pipe cemented in them. These holes were used to monitor the distribution of water and its movement out of the injection zone, through the use of a neutron moisture probe and scaler.
Additional 5-in.-diam holes (the C-series) were augered to a depth of $18 \mathrm{ft}$. These three holes were used for the calibration of the neutron probe and scaler. Each was cased with 2-in.-diam plastic tubing (Table $\mathrm{XI}-\mathrm{B})$.

All holes at both sites were destroyed during the construction of a new facility in early 1980 .

\section{REFERENCES}

J. L. Kunkler, "Measurement of Atmospheric Pressure and Subsurface-Gas Pressure in the Unsaturated Zone of the Bandelier Tuff, Los Alamos, New Mexico," in U.S. Geol. Survey Prof. Paper 650-D (1969).

W. D. Purtymun, E. Enyart, and S. G. McLin, "Hydrologic Characteristics of the Bandelier Tuff as Determined through an Injection Well System," Los Alamos National Laboratory report LA-11511-MS (1989).

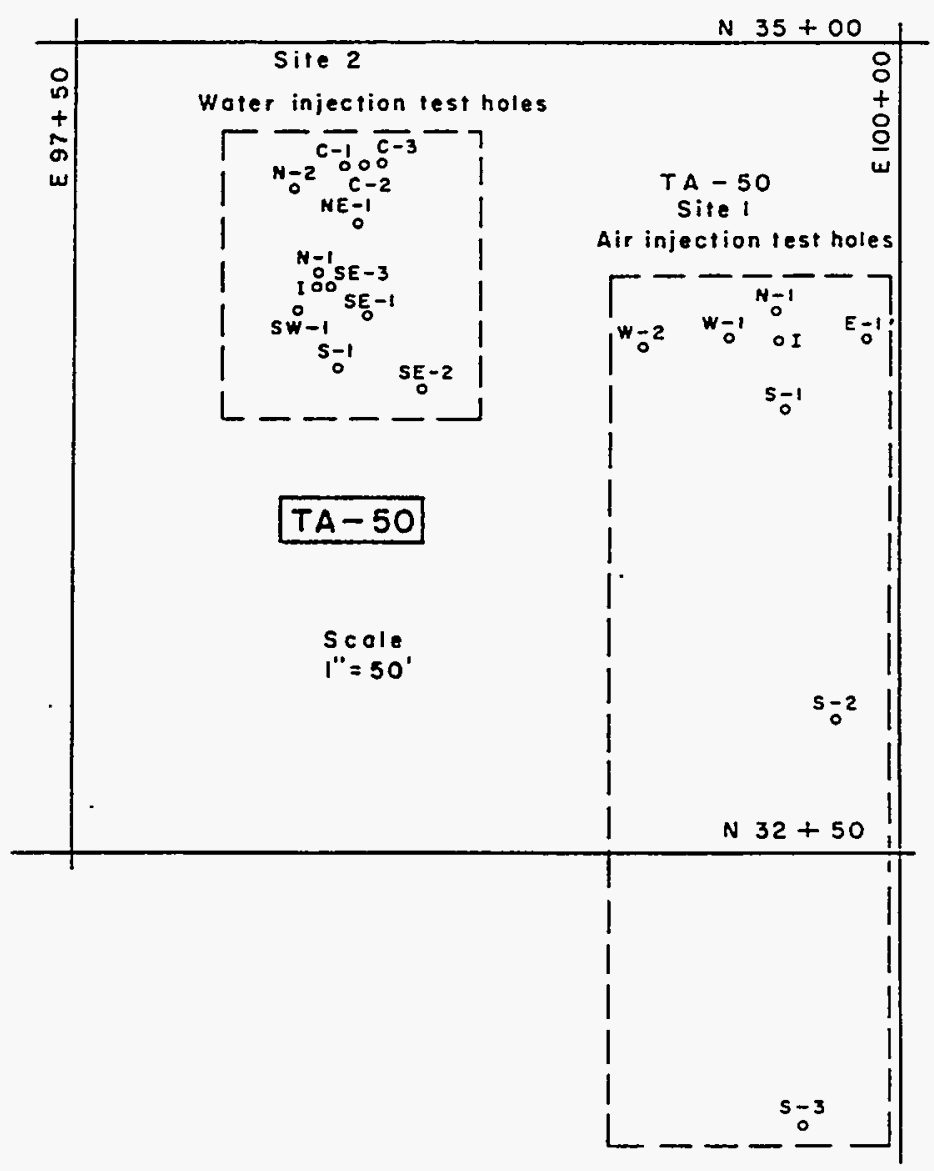

Fig. XI-A. Locations of test holes at Site 1 and Site 2 near TA-50. 
TABLE XI-A. Construction Data for Test Holes at Air-Tuff Transfer Site 1 Near TA-50

\begin{tabular}{|c|c|c|c|c|c|c|c|c|}
\hline \multirow{3}{*}{$\begin{array}{l}\text { Test } \\
\text { Holes }\end{array}$} & \multirow{3}{*}{$\begin{array}{l}\text { Elevation } \\
\text { (LSD) } \\
\text { (ft) }\end{array}$} & \multirow{3}{*}{$\begin{array}{l}\text { Diameter } \\
\text { (in) }\end{array}$} & \multirow{3}{*}{$\begin{array}{l}\text { Depth } \\
\text { (ft) }\end{array}$} & \multicolumn{4}{|c|}{ Injection Zone } & \multirow[b]{3}{*}{ Remarks } \\
\hline & & & & & Dep & & & \\
\hline & & & & No. 1 & No. 2 & No. 3 & No. 4 & \\
\hline E-1 & 7240.4 & 3 & 86 & $3-8$ & $37-43$ & $69-74$ & $81-86$ & monitoring tubes \\
\hline $\mathrm{N}-1$ & 7241.8 & 5 & 94 & $3-6$ & $25-30$ & $54-60$ & $86-94$ & injection and monitoring tubes \\
\hline W-1 & 7241.7 & 3 & 91 & $3-8$ & $39-44$ & $69-74$ & $86-91$ & monitoring tubes \\
\hline W-2 & 7241.7 & 3 & 114 & $3-8$ & $109-114$ & - & - & monitoring tubes \\
\hline I & 7241.6 & 5 & 60 & $3-8$ & $25-30$ & $55-60$ & - & injection and monitoring tubes \\
\hline S-1 & 7239.7 & 5 & 90 & $3-8$ & $24-29$ & $55-60$ & $83-90$ & injection and monitoring tubes \\
\hline S-2 & 7231.6 & 5 & 56 & $49-56$ & - & - & - & water injection test \\
\hline S-3 & 7218.3 & 5 & 43 & - & - & - & - & open hole \\
\hline
\end{tabular}

Note: Holes E-1 and W-1 drilled air-rotary; all others augered. Injection zone consists of 3/8-in.-diam gravel. Monitoring tube is $1 / 2$-in. plastic tubing perforated 1 foot from the bottom. Injection tube is $3 / 4$-in. plastic tubing perforated 3 feet from the bottom. Perforations in each tube are separated from those of other tubes by lead plate. Tubes are cemented into the gravel-pack intervals. All holes were dry.

TABLE XI-B. Construction Data for Test Holes at Liquid Injection Site 2 Near TA-50

\begin{tabular}{|c|c|c|c|c|c|}
\hline $\begin{array}{l}\text { Test } \\
\text { Hole }\end{array}$ & $\begin{array}{l}\text { Date } \\
\text { Drilled }\end{array}$ & $\begin{array}{l}\text { Elevation } \\
\quad(\mathrm{ft})\end{array}$ & $\begin{array}{l}\text { Diameter } \\
\text { (in.) }\end{array}$ & $\begin{array}{c}\text { Depth } \\
\text { (ft) }\end{array}$ & Remarks \\
\hline $\mathrm{N}-2$ & $9 / 65$ & 7247.7 & 5 & 112 & \\
\hline NE-1 & $9 / 65$ & 7246.6 & 5 & 118 & \\
\hline $\mathrm{N}-\mathrm{I}$ & $11 / 64$ & 7245.2 & 5 & 97 & \\
\hline I & $11 / 64$ & 7244.7 & 5 & 67 & injection well \\
\hline SE-3 & $10 / 65$ & 7244.6 & 4 & 295 & air rotary \\
\hline SW-1 & $11 / 64$ & 7244.4 & 5 & 97 & \\
\hline SE-1 & $11 / 64$ & 7243.9 & 5 & 97 & \\
\hline S-1 & $10 / 65$ & 7242.9 & 4 & 295 & air rotary \\
\hline SE-2 & $9 / 65$ & 7241.6 & 5 & 112 & \\
\hline C-1 & $10 / 65$ & 7248 & 5 & 18 & \\
\hline C-2 & $10 / 65$ & 7248 & 5 & 18 & \\
\hline$C-3$ & $10 / 65$ & 7248 & 5 & 18 & \\
\hline
\end{tabular}

Note: All holes were completed in the tuff. Holes SE-3 and S-1 were drilled air-rotary; all others were augered. Hole I, an injection well with a gravel-pack injection zone from 55 to $65 \mathrm{ft}$, had an injection tube and observation hole extending from the injection zone to the surface. The hole was cemented from the surface to the top of the gravel pack at $55 \mathrm{ft}$. Holes $\mathrm{C}-1, \mathrm{C}-2$, and C-3 were calibration holes, cased with 2-in. plastic tubing. All other holes were open except for a short surface casing set through the soil zone. All holes were dry when drilled. 

A. Air Study Site

Hole E-1

Hole N-1

Hole W-1

Hole W-2

Hole I

Hole S-1

Hole S-2

Hole S-3

B. Water Study Site

Hole N-2

Hole NE-1

Hole N-1

Hole I

Hole SE-3

Hole SW-1

Hole SE-1

Hole S-1

Hole SE-2

Hole C-1

Hole C-2

Hole C-3
N 1,768,243

N 1,769,251

N $1,769,243$

N 1,769,242

N 1,769,242

N 1,769,321,

N $1,769,123$

N 1,768,997

N 1,769,296

N 1,769,274

N 1,769,270

N 1,769,265

N 1,769,264

N 1,769,258

N 1,769,255

N 1,769,240

N 1,769,231

N 1,769,302

N 1,769,302

N 1,769,303
E 486,338

E 486,354

E 486,340

E 486,314

E 486,356

E 486,360

E 486,368

E 486,358

E 486,212

E 486,229

E 486,219

E 486,218

E 486,220

E 486,211

E 486,231

E 486,221

E 486,247

E 486,227

E 486,232

E 486,237
$7240.4 \mathrm{ft}$

$7241.8 \mathrm{ft}$

$7241.7 \mathrm{ft}$

$7241.7 \mathrm{ft}$

$7241.6 \mathrm{ft}$

$7239.7 \mathrm{ft}$

$7231.6 \mathrm{ft}$

$7218.3 \mathrm{ft}$
$7247.7 \mathrm{ft}$ $7246.6 \mathrm{ft}$ $7245.2 \mathrm{ft}$ $7244.7 \mathrm{ft}$ $7244.6 \mathrm{ft}$ $7244.4 \mathrm{ft}$ $7243.9 \mathrm{ft}$ $7242.9 \mathrm{ft}$ $7271.6 \mathrm{ft}$ $7248 \mathrm{ft}$

$7248 \mathrm{ft}$

$7248 \mathrm{ft}$ 


\section{TEST HOLES AT TA-21}

Thirteen test holes were drilled around the perimeter of the contaminated waste disposal pit Area B west of TA-21. The holes were augered and samples collected to determine if there had been any movement of contaminants from the pit into the adjacent tuff (Fig. XII-A). The holes were also logged using the neutron probe and scaler to determine the moisture content of the tuff in situ.

The samples were analyzed for moisture as well as gross alpha, gross beta, plutonium, and uranium. The results of the investigation indicated no lateral migration of contaminants from the waste pit into the adjacent soil or tuff. Geologic logs of the holes are found on Table XII-A.

\section{REFERENCE}

W. D. Purtymun and W. R. Kennedy, "Distribution of Moisture and Radioactivity in the Soil and Tuff at the Contaminated Waste Pit near Technical Area 21," Los Alamos, New Mexico," U.S. Geol. Survey OpenFile Report (1966).

\begin{tabular}{|c|c|c|c|c|}
\hline \multicolumn{5}{|c|}{$\begin{array}{l}\text { TABLE XII-A. Geologic Logs of Test Holes } \\
\text { Near Solid Waste Disposal Area B at TA-21 }\end{array}$} \\
\hline \multirow[b]{2}{*}{$\begin{array}{l}\text { Test } \\
\text { Hole } \\
\end{array}$} & \multirow[b]{2}{*}{$\begin{array}{c}\text { Elevation } \\
\text { (ft) }\end{array}$} & \multirow[b]{2}{*}{$\begin{array}{l}\text { Depth } \\
\text { (ft) }\end{array}$} & \multicolumn{2}{|c|}{$\log$} \\
\hline & & & $\begin{array}{l}\text { Soil } \\
(\mathrm{ft})\end{array}$ & $\begin{array}{l}\text { Bandelier Tuff } \\
\text { (ft) }\end{array}$ \\
\hline DPS-1 & 7190 & 50 & 3 & 47 \\
\hline DPS-2 & 7191 & 25 & 3 & 22 \\
\hline DPS-3 & 7194 & 50 & 3 & 47 \\
\hline DPS-4 & 7202 & 25 & 3 & 22 \\
\hline DPS-5 & 7214 & 50 & 3 & 47 \\
\hline DPS-6 & 7216 & 50 & 6 & 44 \\
\hline DPS-7 & 7185 & 25 & 3 & 22 \\
\hline DPS-8 & 7181 & 50 & 6 & 44 \\
\hline DPS-9 & 7180 & 25 & 4 & 21 \\
\hline DPS-10 & 7182 & 35 & 4 & 31 \\
\hline DPS-11 & 7192 & 50 & 4 & 46 \\
\hline DPS- 12 & 7192 & 36 & 3 & 33 \\
\hline DPS-13 & 7210 & 35 & 2 & 33 \\
\hline Note: & \multicolumn{4}{|c|}{$\begin{array}{l}\text { Holes augered February 1966; holes } 4 \text {-in. diam; } \\
\text { holes plugged and abandoned after study. } \\
\text { All holes were dry. }\end{array}$} \\
\hline
\end{tabular}

Fig. XII-A. Locations of test holes at solid waste Area B near TA-21. 


\begin{tabular}{lccc}
\hline \hline \multicolumn{4}{c}{ TABLE XII-B. Locations and Elevations (NAD 1927) } \\
\hline & N $1,775,197$ & E 489,945 & \\
DPS-1 & N $1,775,172$ & E 489,702 & $7190 \mathrm{ft}$ \\
DPS-2 & N $1,775,149$ & E 489,432 & $7191 \mathrm{ft}$ \\
DPS-3 & N $1,775,130$ & E 489,233 & $7194 \mathrm{ft}$ \\
DPS-4 & N $1,775,108$ & E 488,928 & $7202 \mathrm{ft}$ \\
DPS-5 & N $1,774,989$ & E 488,848 & $714 \mathrm{ft}$ \\
DPS-6 & N $1,775,113$ & E 490,213 & $7185 \mathrm{ft}$ \\
DPS-7 & N $1,775,028$ & E 490,447 & $7181 \mathrm{ft}$ \\
DPS-8 & N $1,775,041$ & E 490,160 & $7180 \mathrm{ft}$ \\
DPS-9 & N $1,775,056$ & E 489,796 & $7182 \mathrm{ft}$ \\
DPS-10 & N $1,775,024$ & E 489,490 & $7192 \mathrm{ft}$ \\
DPS-11 & N $1,774,997$ & E 489,159 & $7192 \mathrm{ft}$ \\
DPS-12 & N $1,774,967$ & E 488,909 & $7210 \mathrm{ft}$ \\
DPS-13 & & & \\
\hline
\end{tabular}




\section{TEST HOLES AT AREAS L AND G AT TA-54}

A study of the waste disposal area at Areas L and $\mathrm{G}$ at TA-54 was made during 1985-1986. The study was requested by the State of New Mexico Environmental Department. The Laboratory contracted with Bendix Corporation of Grand Junction, Colorado for Bendix to characterize the Bandelier Tuff. As a result of that study, the Environmental Protection Group, Hazardous and Solid Waste Section, had 10 additional holes drilled in 1988-1990 in Areas L and G. These holes were completed as pore-gas monitoring holes, to determine the extent of the organic vapor plume from Area L.

\section{A. Test Holes 1985 and 1986}

In 1985 and 1986, 18 test holes were cored or augered at Areas $\mathrm{L}$ and $\mathrm{G}$ to characterize the vadose zone in and around the chemical disposal pits and shafts (Area $L$ ) and the radioactive waste disposal pits and shafts (Area G). The holes ranged in depth from 60 to $145 \mathrm{ft}$ (Fig. XIII-A and Table XIII-A). Numerous samples of the sections cored were analyzed for organic and inorganic chemicals and radionuclides and to learn the hydrologic properties of the tuff.

Areas $L$ and $G$ are located on a narrow southeast-trending mesa that is underlain by the Bandelier Tuff. The 18 holes drilled in 1985 are located on this mesa (Fig. XIII-A). The purposes of these test holes, and their geologic logs, are found in Table XIII-A. Special construction was used in some of the core holes to allow various types of tests. The construction consisted of packing off zones in the wells to allow special testing and sampling of vapors in the tuff, as well as equipping other zones with special equipment to measure pressures, moistures, and other hydrologic parameters.

Seven additional holes were cored by Bendix in 1986. The locations of these holes are shown in Fig. XIII-B, while their geologic logs and uses are found in Table XIII-B.

The holes drilled in 1985 and 1986 were completed in the Tshirege Member of the Bandelier Tuff. The tuff has been divided into four units described from the oldest (Unit 1A) to the youngest (Unit 2B) as in the type section in Mortandad Canyon (Fig. I-O); however, the Bendix report did not recognize the same boundaries or contacts as the type section in Mortandad Canyon from Baltz et al. (1963) or Purtymun and Kennedy (1971). A correlation of the thicknesses of the units used in the Bendix reports with those of the type section in Mortandad Canyon appears in Fig. XIII-C. No attempt was made to change the thicknesses of the units described by Bendix to match those of the type section.

\section{B. Test Holes 1988-1990}

During the period 1988 through 1990 the Laboratory drilled 10 holes of 4-in. diam to monitor vapors in the tuff. A series of zones was set up with tubing to allow vapor sampling. The holes were located atop Mesita del Buey (Fig. XIII-D). All but the last 2 of the holes were drilled through the Tshirege, Otowi, and Guaje Members of the Bandelier Tuff into the top of the basalt (Purtymun 1990). The geologic logs and uses of the holes are shown in Table XIII-C. The logs in Table XIII-C reflect the description and thicknesses of the type section in Mortandad Canyon, thus the thicknesses may vary slightly from those of the logs in the Bendix report (Fig. XIII-C).

The geology used to describe the work 1988-1990 is presented in Purtymun and Kennedy (1971) and Purtymun (1990). In general, the four units thin to the southeast where the tuff was laid on top of the basalts (emplaced to the north and northwest) that came from vents east of the Rio Grande.

\section{REFERENCES}

Vadose Zone Characterization of Technical Area 54, Waste Disposal Areas G and L, Los Alamos National Laboratory, Los Alamos, New Mexico: studies undertaken by Bendix Field Engineering Corporation, Grand Junction Operations, Grand Junction, Colo., resulted in four reports:

S. M. Rush and J. J. Dexter, "Report 1: Drilling and Logging Activities," (1985a).

Bendix Field Eng. Corp., "Report 2: Down-Hole Instrumentation and Pore-Gas-Sampling/DataCollection Procedures," (1985b).

P. M. Kearl, J. J. Decker, and M. Kautsky, "Report 3: Preliminary Assessment of the Hydrologic System," (1986a).

P. M. Kearl, J. J. Dexter, and M. Kautsky, "Report 4: Preliminary Assessment of the Hydrologic System through Fiscal Year 1986," (1986b). 
E. H. Baltz, J. H. Abrahams, and W. D. Purtymun, "Preliminary Report on the Geology and Hydrology of Mortandad Canyon near Los Alamos, New Mexico with Special Reference to Disposal of Liquid LowLevel Radioactive Wastes," U.S. Geological Survey Open-File Report (1963).

W. D. Purtymun, "Geology of Mesita del Buey, Results of Drilling Pore Gas Monitoring Holes," Los Alamos National Laboratory, unpublished HSE-8 document, 1990.

W. D. Purtymun and W. R. Kennedy, "Geology and Hydrology of Mesita del Buey," Los Alamos Scientific Laboratory report LA-4600 (1971). 


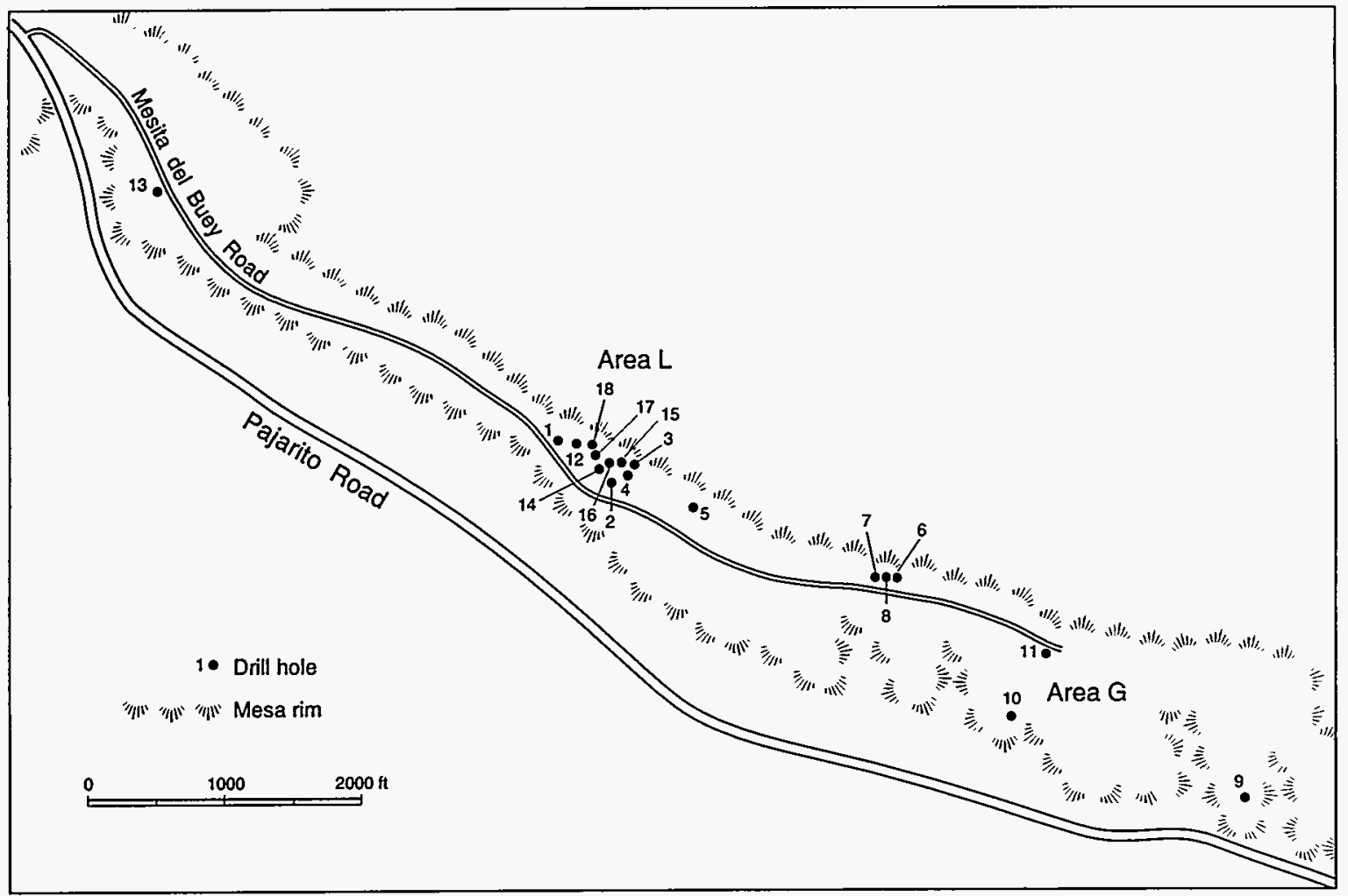

Fig. XIII-A. Locations of 18 test holes at Areas G and L on Mesita del Buey (Bendix 1985a).

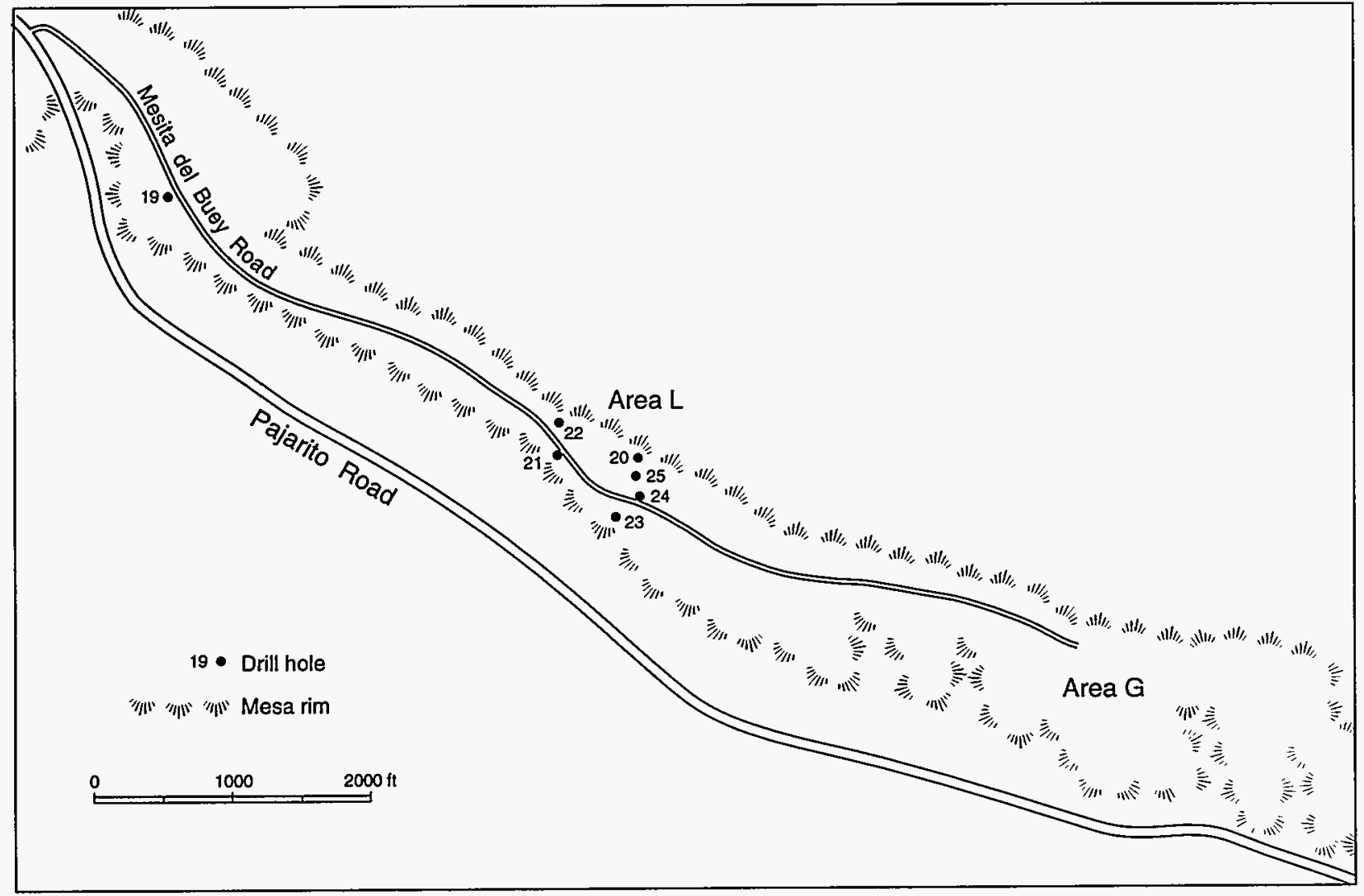

Fig. XIII-B. Locations of seven test holes on Mesita del Buey (Bendix 1986a). 


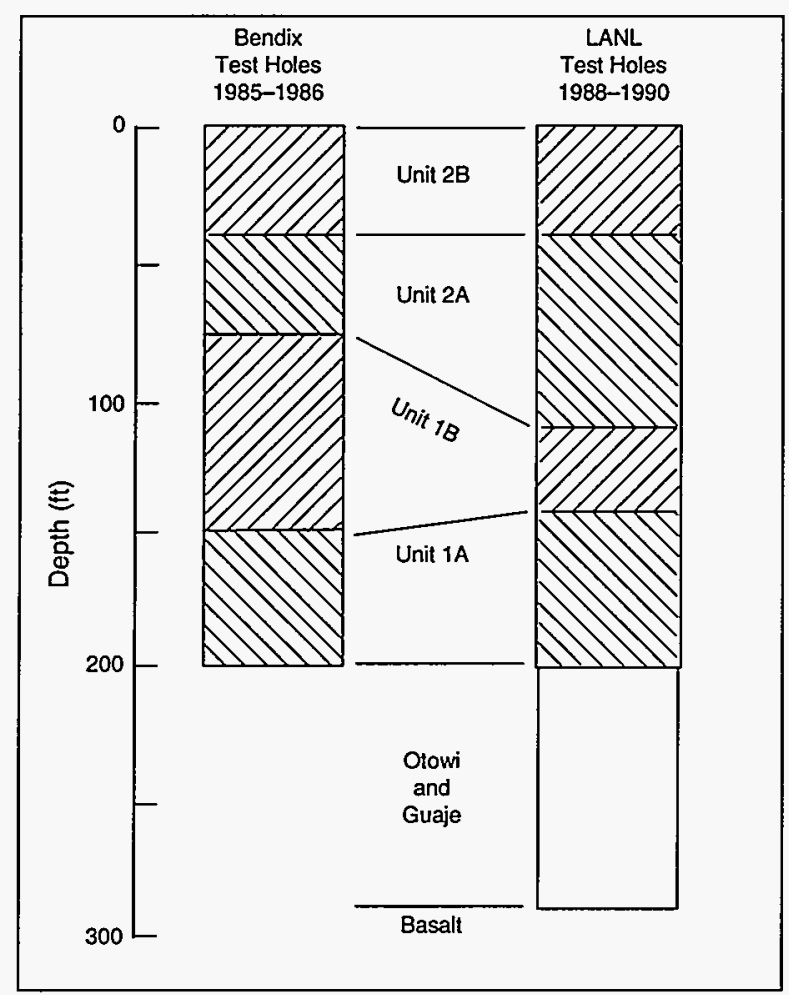

Fig. XIII-C. Correlation differences in the thicknesses of units of the Tshirege Member at Area L between Bendix test holes (1985-1986) and LANL test holes (1988-1990).

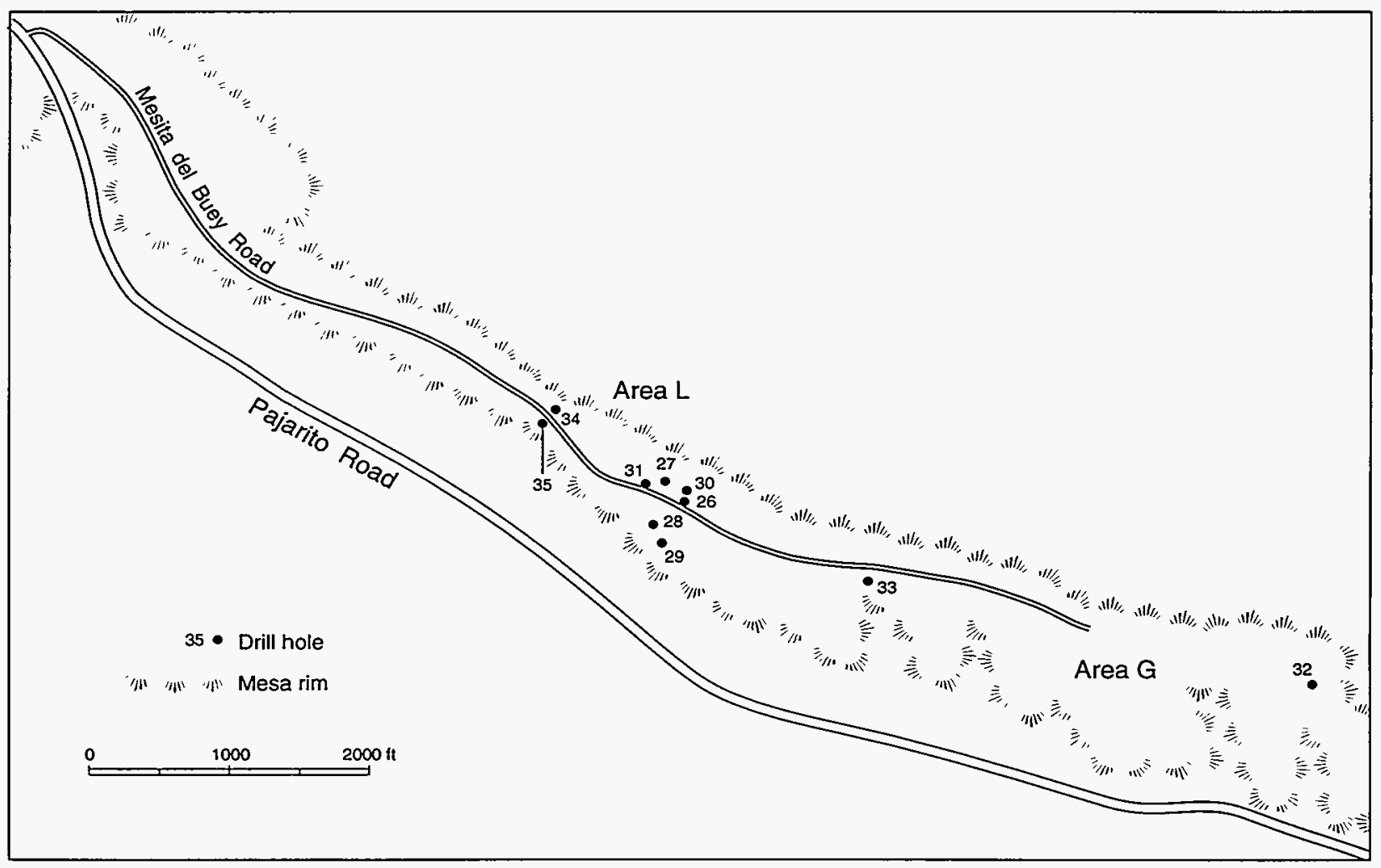

Fig. XIII-D. Locations of 10 test holes at Areas L and G on Mesita del Buey (Purtymun 1990). 
TABLE XIII-A. Geologic Logs of Test Holes at Areas G and L, TA-54, Mesita del Buey (Bendix 1985a)

\begin{tabular}{|c|c|c|c|c|c|c|c|}
\hline \multirow[b]{2}{*}{ Hole Number } & \multirow{2}{*}{$\begin{array}{l}\text { Elevation } \\
\text { (ft) }\end{array}$} & \multirow{2}{*}{$\begin{array}{l}\text { Depth } \\
\text { Cored } \\
(\mathrm{ft})\end{array}$} & \multirow{2}{*}{$\begin{array}{c}\text { Total } \\
\text { Depth } \\
\text { Drilled } \\
(\mathrm{ft})\end{array}$} & \multicolumn{4}{|c|}{ Geologic Log (ft) } \\
\hline & & & & Unit 2B & Unit 2A & Unit $1 \mathrm{~B}$ & Unit $1 \mathrm{~A}$ \\
\hline LLM-85-01 & 6797.4 & 124 & 140 & 0 to 42 & 42 to 81 & 81 to $124+$ & - \\
\hline LLM-85-02 & 6791.7 & 124 & 145 & 0 to 41 & 41 to 81 & 81 to $124+$ & - \\
\hline LLP-85-03 & 6788.7 & 99 & 120 & 0 to 48 & 48 to 98 & 98 to $99+$ & - \\
\hline LLN-85-04a & 6788.0 & 0 & 120 & 一 & - & - & - \\
\hline LLM-85-05 & 6772.5 & 124 & 145 & 0 to 39 & 39 to 74 & 74 to $124+$ & - \\
\hline LGM-85-06 & 6730.0 & 124 & 60 & 0 to 37 & 37 to 61 & 61 to 107 & 107 to $124+$ \\
\hline LGP-85-07 & 6731.7 & 49 & 60 & 0 to 32 & 32 to $49+$ & - & - \\
\hline LGN-85-08a & 6731.5 & 0 & 120 & - & - & - & - \\
\hline LGC-85-09 & 6659.9 & 99 & 120 & 0 to 28 & 28 to 44 & 44 to 74 & 74 to $99+$ \\
\hline LGC-85-10 & 6707.7 & 99 & 145 & 0 to 34 & 34 to 53 & 53 to $99+$ & - \\
\hline LGM-85-11 & 6715.6 & 124 & 120 & 0 to 38 & 38 to 63 & 63 to 103 & 103 to $124 t$ \\
\hline LLC-85-12 & 6794.7 & 99 & 120 & 0 to 42 & 42 to 81 & 81 to $99+$ & - \\
\hline LLC-85-13 & 6856.1 & 99 & 120 & 0 to 47 & 47 to 79 & 79 to $99+$ & - \\
\hline LLC-85-14 & 6791.4 & 99 & 120 & 0 to 38 & 38 to 82 & 82 to $99+$ & - \\
\hline LLC-85-15 & 6787.5 & 99 & 120 & 0 to 38 & 38 to 83 & 83 to $99+$ & - \\
\hline LLC-85-16 & 6788.0 & 99 & 120 & 0 to 42 & 42 to 82 & 82 to $99+$ & - \\
\hline LLC-85-17 & 6788.4 & 149 & 150 & 0 to 38 & 38 to 83 & 83 to 141 & 141 to $149+$ \\
\hline LLC-85-18 & 6790.4 & 99 & 120 & 0 to 42 & 42 to 82 & 82 to $99+$ & - \\
\hline \multicolumn{8}{|c|}{ Note: Cored $67 / 8$-in.-diam hole; 3-in.-diam core; Total Depth Drilled is for the geophysical logging. } \\
\hline \multicolumn{8}{|c|}{$\begin{array}{l}\text { Hole Number : first letter "L," Los Alamos; second letter "L" or "G," Areas L or G at TA-54; third letter, use o } \\
\text { hole: "M," moisture hole; "C," core and pore-gas sampling; "P," Psychrometer holes; "N," neutron moisture- } \\
\text { access holes. All holes were dry. }\end{array}$} \\
\hline a 4-in.-diam a & er hole. & & & & & & \\
\hline
\end{tabular}


TABLE XIII-B. Geologic Logs of Test Holes at Area L, TA-54, Mesita del Buey (Bendix 1986a, 1986b)

\begin{tabular}{|c|c|c|c|c|c|c|}
\hline Hole Numbers & $\begin{array}{l}\text { Elevation } \\
\text { (ft) }\end{array}$ & $\begin{array}{c}\text { Depth } \\
\text { Cored } \\
(\mathrm{ft})\end{array}$ & Unit 2B & Unit 2A & Unit IB & Unit $1 \mathrm{~A}$ \\
\hline LLC-86-19 & 6854.5 & 201 & $0-37$ & $37-107$ & $107-160$ & $160-201+$ \\
\hline LLC-86-20 & 6775.9 & 198 & $0-29$ & $29-67$ & $67-139$ & $139-198+$ \\
\hline LLC-86-21 & 6803.1 & 198 & $0-43$ & $43-74$ & $74-156$ & $156-198+$ \\
\hline LLC-86-22 & 6796.4 & 197 & $0-39$ & $39-74$ & $74-147$ & $147-197+$ \\
\hline LLC-86-23 & 6793.8 & 199 & $0-44$ & $44-86$ & $86-154$ & 154-199+ \\
\hline LLC-86-24 & 6790.6 & 198 & $0-43$ & $43-84$ & $84-153$ & $153-198+$ \\
\hline LLC-86-25 & 6787.8 & 198 & $0-39$ & $39-74$ & $74-147$ & $147-198+$ \\
\hline
\end{tabular}

Note: Cored $67 / 8$-in.-diam hole, 3-in.-diam core. All holes were dry.

Hole Number: First letter "L," Los Alamos; second "L," Area L, TA-54; third letter "C," core and pore-gas sampling.

TABLE XIII-C. Geologic Logs of Test Holes at Areas G and L, TA-54, Mesita del Buey (Purtymun 1990)

\begin{tabular}{|c|c|c|c|c|c|c|c|}
\hline \multirow[b]{2}{*}{ Hole Number } & \multirow{2}{*}{$\begin{array}{l}\text { Elevation } \\
(\mathrm{ft})\end{array}$} & \multicolumn{4}{|c|}{ Tshirege Member } & \multirow{2}{*}{$\begin{array}{l}\text { Otowi and } \\
\text { Guaje } \\
\text { Members }\end{array}$} & \multirow{2}{*}{$\begin{array}{l}\text { Top } \\
\text { of } \\
\text { Basalt }\end{array}$} \\
\hline & & Unit 2B & Unit 2A & Unit 1B & $\overline{\text { Unit } 1 \mathrm{~A}}$ & & \\
\hline LLC-88-26 & 6788.9 & $0-45$ & $45-120$ & $120-150$ & $150-198$ & - & 198 \\
\hline LLC-88-27 & 6784.5 & $0-45$ & $45-110$ & $110-140$ & $140-190$ & $190-263$ & 263 \\
\hline LLC-88-28 & 6796.2 & $0-45$ & $45-105$ & $105-135$ & $135-195$ & $195-263$ & $263-267$ \\
\hline LLC-88-29 & 6793.4 & $0-45$ & $45-120$ & $120-150$ & $150-225$ & $225-298$ & 298 \\
\hline LLC-89-30 & 6782.1 & $0-45$ & $45-115$ & $115-145$ & $145-205$ & $205-273$ & 273 \\
\hline LLC-89-31 & 6803.7 & $0-45$ & $45-125$ & $125-155$ & $155-225$ & $225-291$ & 291 \\
\hline LGC-89-32 & 6669.2 & $0-35$ & $35-85$ & $85-105$ & $105-150$ & $150-171$ & 171 \\
\hline LGC-89-33 & 6747.0 & $0-40$ & $40-105$ & $105-130$ & $130-180$ & $180-293$ & 293 \\
\hline LLC-90-34 & 6800.0 & $0-36$ & $36-115$ & $115-151$ & $151-195$ & $195-317$ & - \\
\hline LLC-90-35 & 6810.0 & $0-40$ & $40-111$ & $111-161$ & $161-201$ & $201-351$ & - \\
\hline
\end{tabular}

Note: Augered with 4 1/2-in.-diam solid-stem auger; geologic correlations based on cuttings returned, down pressure, and drilling breaks. All holes dry.

Hole Number: First letter "L," Los Alamos; second letter, "L" for Area L or "G" for Area G; third letter, "C," for core or pore-gas sampling. 
TABLE XIII-D. Locations and Elevations (NAD 1927)

A. Test Holes 1985

LLM-85-01
LLM-85-02
LLP-85-03
LLN-85-04
LLM-85-05
LGM-85-06
LGP-85-07
LGN-85-08
LGC-85-09
LGC-85-10
LGM-85-1 1
LLC-85-12
LLC-85-13
LLC-85-14
LLC-85-15
LLC-85-16
LLC-85-17
LLC-85-18

B. Test Holes 1986

N $1,759,552.34$
N $1,759,260.86$
N $1,759,269.11$
N $1,759,265.96$
N $1,758,919.02$
N $1,758,437.40$
N $1,758,462.39$
N $1,758,457.04$
N $1,756,884.15$
N $1,757,487.94$
N $1,757,977.36$
N $1,759,536.30$
N $1,761,119.07$
N $1,759,355.53$
N $1,759,315.73$
N $1,759,350.09$
N $1,759,485.35$
N $1,759,440.61$

N $1,759,260.86$

N $1,759,269.11$

N $1,759,265.96$

N $1,758,919.02$

N $1,758,437.40$

N $1,758,462.39$

N $1,758,457.04$

N $1,756,884.15$

N $1,757,487.94$

N $1,757,977.36$

N $1,759,536.30$

N $1,761,119.07$

N $1,759,315.73$

N $1,759,485.35$

N $1,759,440.61$
E $499,402.86$

E $499,853.04$

E $499,923.76$

E $499,924.24$

E $500,471.44$

E $502,239.90$

E $502,195.69$

E 502,205.42

E 504,521.44

E 502,748.67

E 502,978.01

E $499,477.89$

E 496,644.14

E $499,782.26$

E $499,895.35$

E 499,850.10

E $499,703.83$

E $499,698.48$
$6797.4 \mathrm{ft}$

$6791.7 \mathrm{ft}$

$6788.7 \mathrm{ft}$

$6788.0 \mathrm{ft}$

$6772.5 \mathrm{ft}$

$6730.0 \mathrm{ft}$

$6731.7 \mathrm{ft}$

$6731.5 \mathrm{ft}$

$6659.9 \mathrm{ft}$

$6707.7 \mathrm{ft}$

$6715.6 \mathrm{ft}$

$6794.7 \mathrm{ft}$

$6856.1 \mathrm{ft}$

$6791.4 \mathrm{ft}$

$6787.5 \mathrm{ft}$

$6788.0 \mathrm{ft}$

$6788.4 \mathrm{ft}$

$6790.4 \mathrm{ft}$
LLC-86-19

LLC-86-20

LLC-86-21

LLC-86-22

LLC-86-23

LLC-86-24

LLC-86-25
N 1,761,074.07

N $1,759,299.65$

N 1,759,469.53

N 1,759,625.55

N 1,759,020.31

N 1,759,107.27

N $1,759,276.58$
E $496,703.56$

E $500,085.17$

E 499,299.71

E 499,334.54

E $499,761.74$

E $499,988.54$

E $499,929.08$
$6854.5 \mathrm{ft}$ $6775.9 \mathrm{ft}$ $6803.1 \mathrm{ft}$ $6796.4 \mathrm{ft}$ $6793.8 \mathrm{ft}$ $6790.6 \mathrm{ft}$ $6787.8 \mathrm{ft}$

C. Test Holes 1988-1990

LLC-88-26

LLC- $88-27$

LLC-88-28

LLC-88-29

LLC-89-30

LLC-89-31

LGC-89-32

LGC-89-33

LLC-90-34

LLC-90-35
N 1,758,964.89

N $1,759,154.35$

N $1,758,866.71$

N 1,758,759.69

N 1,759,053.59

N $1,759,324.81$

N 1,757,701.88

N 1,758,382.90

hole destroyed before survey
E $500,177.78$

E 500,142.61

E $499,970.19$

E $500,031.46$

E $500,274.07$

E 499,395.23

E $504,886.63$

E 501,560.33

hole destroyed before survey
$6788.9 \mathrm{ft}$

$6784.5 \mathrm{ft}$

$6796.2 \mathrm{ft}$

$6793.4 \mathrm{ft}$

$6782.1 \mathrm{ft}$

$6803.7 \mathrm{ft}$

$6669.7 \mathrm{ft}$

$6747.0 \mathrm{ft}$

$6800.0 \mathrm{ft}$

$6810.0 \mathrm{ft}$ 


\section{TEST HOLES AT AREA P AT TA-16}

Area $\mathrm{P}$ at TA-16 has been used as an industrial landfill, and studies have been undertaken to address closure and postclosure EPA requirements. The test holes drilled in and around the landfill were part of a study to determine the type and extent of contamination.

The holes drilled at the landfill are classed into several categories: (1) exploratory holes drilled for geologic and hydrologic information (plugged and abandoned after completion); (2) a vadose monitoring system; (3) test holes completed as observation wells; and (4) test holes drilled for geologic and hydrologic information and completed as moisture-access holes (to be used to determine moisture content of the tuff).

The test holes and observation wells were drilled and completed in the Tshirege Member of the Bandelier Tuff. The tuff has been divided into five units, from oldest (Unit 2) to youngest (Unit 3D). The units are probably comparable to the type section in Mortandad Canyon (Fig. I-O). The tuff is nearer to the source, the Valles Caldera; thus, the welding is greater (the rock is denser). Unit 2 combines Unit $2 \mathrm{~A}$ and $2 \mathrm{~B}$. Unit 3 was subdivided.

Unit 2 consists of a welded to densely welded rhyolite tuff, light gray to pinkish gray, with a few rock fragments of pumice and rhyolite.

Unit $3 \mathrm{~A}$ consists of a welded rhyolite tuff, dark yellowish brown with rock fragments of pumice and porphyritic quartz latite and rhyolite.

Unit 3B consists of a welded rhyolite tuff, pale yellowish brown with rock fragments of gray and red pumice, and a few rhyolite rock fragments.

Unit $3 \mathrm{C}$ consists of a moderately welded rhyolite tuff, brownish gray to yellowish brown, with rock fragments of gray pumice and a few rhyolite rock fragments.

Unit 3D consists of a moderately welded rhyolite tuff, yellowish brown with a few gray pumice fragments and some pebble-sized rhyolite rock fragments. This unit forms the surface in the area and is overlain by a thin clayey soil, derived from weathering of the unit. There are a few scattered deposits of El Cajete Pumice mixed with the soil.

\section{A. Exploratory Holes}

Exploratory holes B-1, B-2, B-3, B-4, and $B-5$ were augered through the landfill into the underlying tuff. They were augered to determine where to site the vadose monitoring system. Test holes $\mathrm{P}-10, \mathrm{P}-11$, and $\mathrm{P}-15$ were drilled to collect samples and geologic information (Fig.XIV-A). Geologic logs and data pertaining to these eight holes are shown on Table XIV-A. The holes were plugged and abandoned (Brown et al. 1988).

\section{B. Vadose Monitoring Holes}

Vadose monitoring, consisting of eight separate wells clustered together into four well nests, was set up by drilling into and below the landfill into the tuff (Fig. XIV-B). Each well nest (Table XIV-B) consisted of either a single or dual completion of a pressure-vacuum lysimeter in one bore hole and an adjacent neutron moisture-access hole (McLin 1989).

\section{Observation Wells}

Nine test holes were completed as ground water monitoring wells (Fig. XIV-C). The depth of these holes ranged from 10 to $35 \mathrm{ft}$, with the well completion depth from 7 to $35 \mathrm{ft}$ (Table XIV-C). The wells were located above the stream channel and below the landfill. They were all completed into the tuff. All were dry and contained no free water; thus, any leachate from the landfill would be moving in the vadose zone immediately below the landfill as unsaturated flow (Brown et al. 1988).

\section{Moisture-Access Holes}

Five test holes were completed as neutron moisture-access holes (Fig. XIV-D). They were augered to depths ranging from 85 to $200 \mathrm{ft}$ (Table XIV-D). All were dry. The holes were completed as moisture-access holes to allow logging for moisture content with the neutron moisture logger and scaler (Brown et al. 1988; McLin 1989).

\section{REFERENCES}

F. Brown, W. D. Purtymun, A. Stoker, and A. Barr, "Site Geology and Hydrology of Technical Area 16, Area P," Los Alamos National Laboratory report LA11209-MS (1988).

S. G. Mclin, "Vadose Zone Monitoring Observations at the TA-16, Area P Landfill," Los Alamos National Laboratory report, Group HSE-8 document, 1989. 


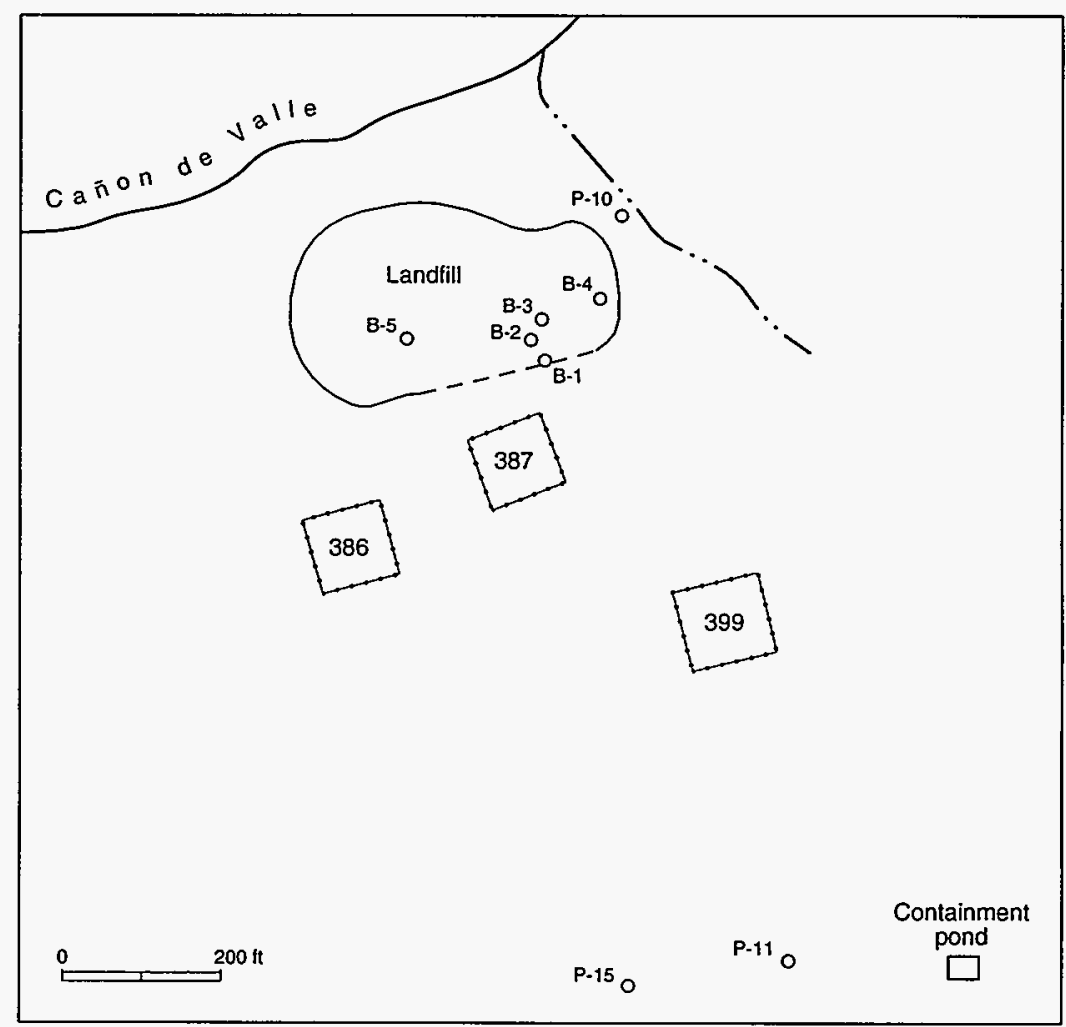

Fig. XIV-A. Locations of exploratory test holes at Area P, TA-16 (Brown et al. 1988).

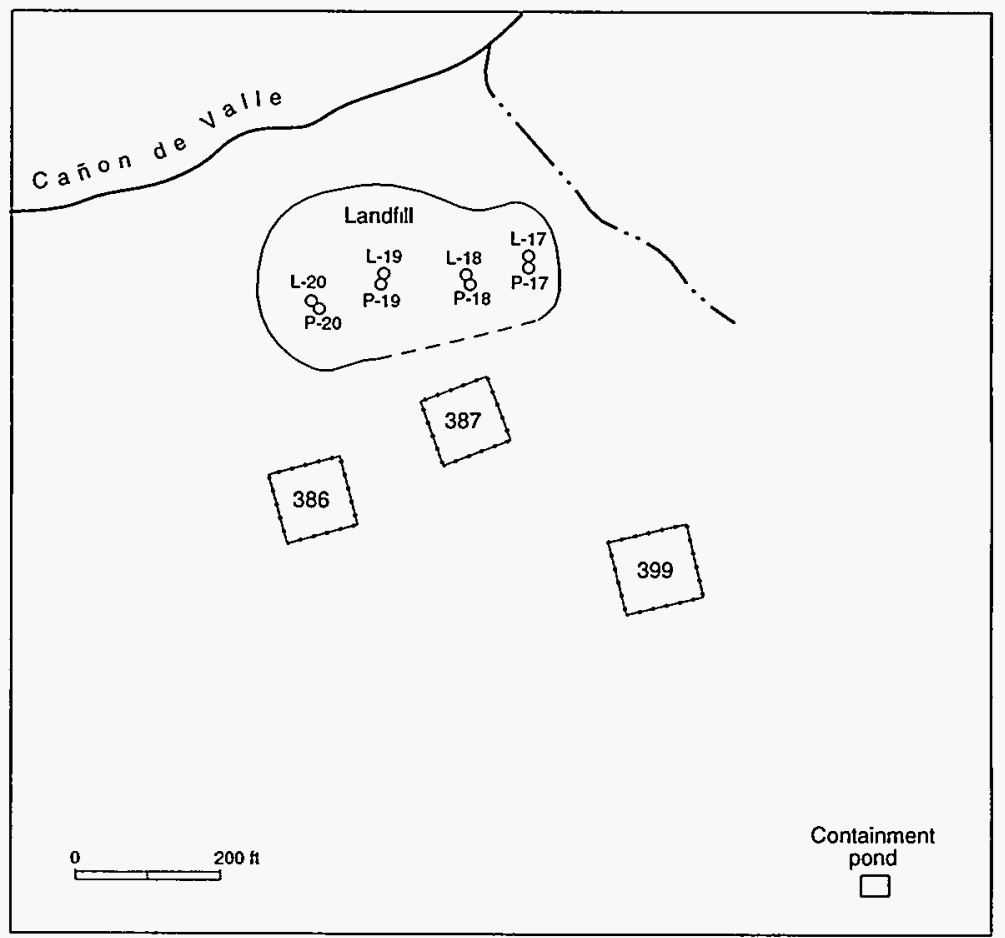

Fig. XIV-B. Locations of four sets of cluster holes ( $\mathrm{L}=$ Lysimeter hole; $\mathrm{P}=$ moisture-access hole) at Area P, TA-16 (McLin 1989). 


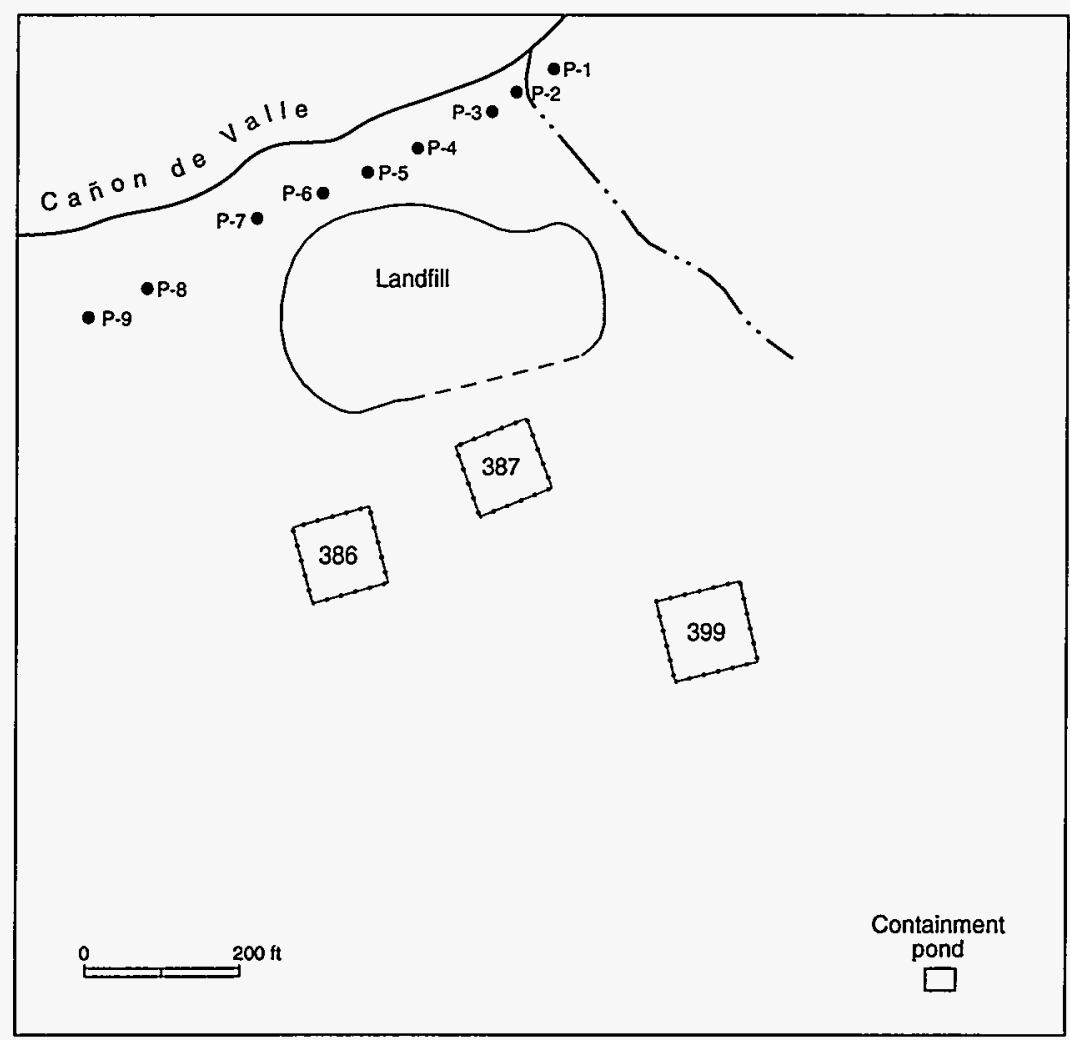

Fig. XIV-C. Locations of ground water observation wells at Area P, TA-16 (Brown et al. 1988).

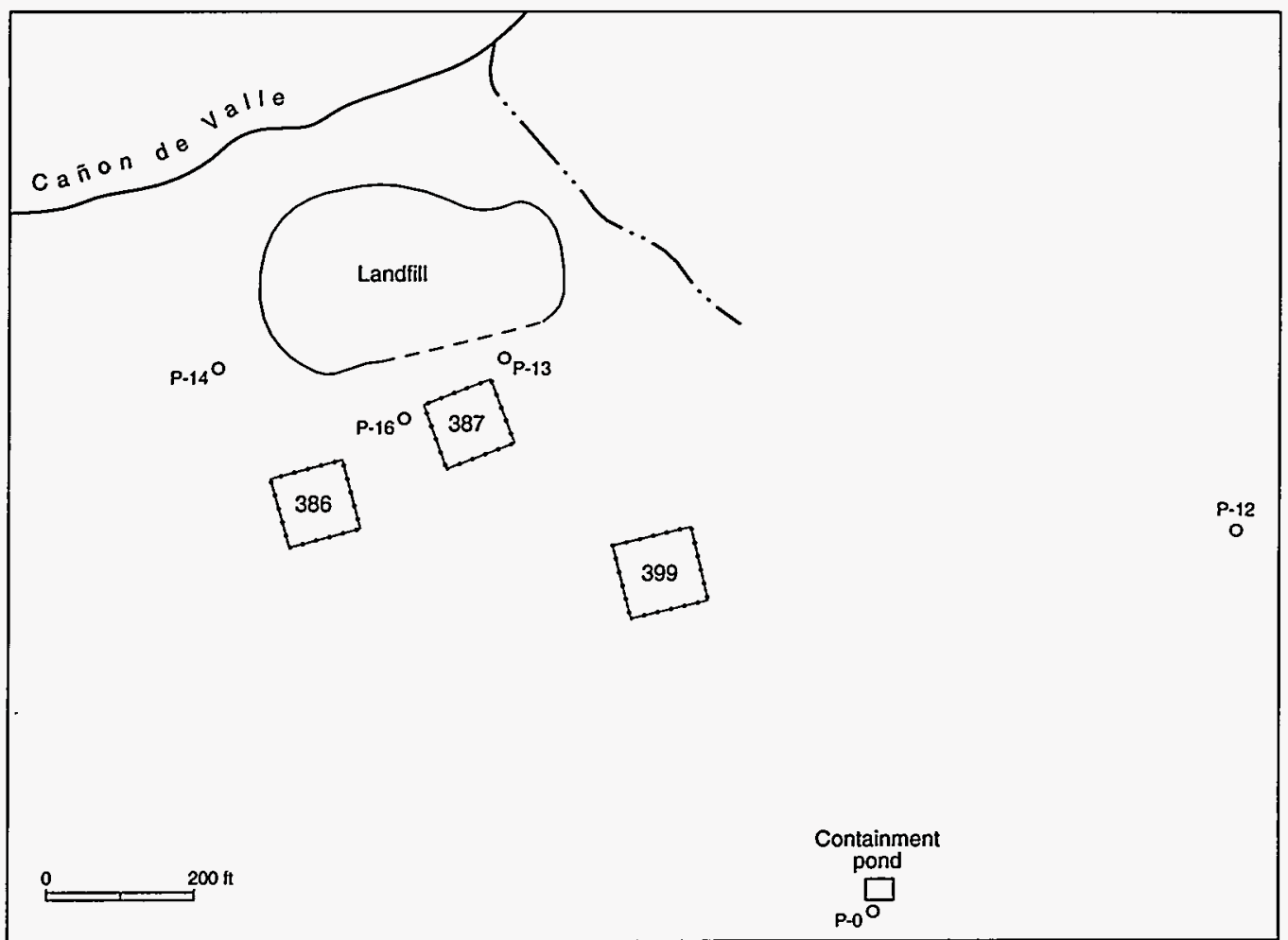

Fig. XIV-D. Locations of test holes completed as moisture-access holes at Area P, TA-16 (Brown et al. 1988; McLin 1989). 


\section{Test Hole B-1}

Date Drilled: August 26, 1988

Elevation (LSD): $7445 \mathrm{ft}$

Water Level: Dry

$\underline{\log }$

Clayey soil, dark brown, moist Thickness Depth

Note: Exploratory hole; filled with drill cuttings and bentonite; abandoned; no samples collected.

\section{Test Hole B-2}

Date Drilled: August 26, 1988

Water Level: Dry

Elevation (LSD): $7442 \mathrm{ft}$

$\underline{\log }$

Thickness

Depth

Clayey soil, dark brown, moist

(ft)

Clayey soil, sandy, dark brown, may be cover-fill material 2

2

Note: Exploratory hole; filled with drill cuttings and bentonite; abandoned; no samples collected.

\section{Test Hole B-3}

Date Drilled: August 26, 1988

Water Level: Dry

Elevation (LSD): $7438 \mathrm{ft}$

$\underline{\log }$

Cover, sandy clay, dark brown, moist

Clay, brown and sand waste, mixture; white $\mathrm{BaO}$ crystals

$\begin{array}{cc}\begin{array}{c}\text { Thickness } \\ (\mathrm{ft})\end{array} & \begin{array}{c}\text { Depth } \\ 1\end{array} \\ 3 & \frac{(\mathrm{ft})}{1} \\ & 4\end{array}$

Clay, dark brown with some gray sand; waste material, mixture of fragments of tuff and charcoal; moderate moisture 4

Clay, dark brown to black sticky, tuff fragments with wastes

Tuff, Unit 3D

4

$5 \quad 13$

1

Note: Exploratory hole; filled with drill cuttings and bentonite; abandoned; no samples collected.

\section{Test Hole B-4}

Date Drilled: August 30, 1988

Elevation (LSD): $7432 \mathrm{ft}$

$\underline{\log }$

Clay, brown with black burn debris, low moisture

Clay, brown with black burn debris, low moisture Clay, brown with sand and burn debris Tuff, Unit 3D
Water Level: Dry

$\begin{array}{cc}\begin{array}{c}\text { Thickness } \\ (\mathrm{ft})\end{array} & \begin{array}{c}\text { Depth } \\ (\mathrm{ft})\end{array} \\ 3 & \frac{3}{6} \\ 5 & 9 \\ 5 & 14 \\ & 19\end{array}$

Note: Debris at $3 \mathrm{ft}$ confirms explosives, Lab reports $<1 \%$ TNT, HMX, and RDX; exploratory hole; filled with drill cuttings and bentonite; abandoned; no other samples taken except as noted above. 


\section{Test Hole B-5}

Date Drilled: September 15, 1988

Elevation (LSD): $7450 \mathrm{ft}$

$\underline{\log }$

Cover, crushed tuff, sand and clay mixture

Tuff, brown, crushed tuff cover-fill material

Tuff, brown, crushed tuff, cover-fill material

(saturated lens 6 to $7 \mathrm{ft}$ )

Tuff, brown, dense, dry, (tuff in place)

\begin{tabular}{cc}
\multicolumn{2}{c}{ Water Level: Dry } \\
$\begin{array}{cc}\text { Thickness } \\
\frac{\text { Depth }}{(\mathrm{ft})}\end{array}$ \\
$\frac{(\mathrm{ft})}{3}$ & 1 \\
& 4 \\
4 & 8 \\
4 & 12
\end{tabular}

Note: Exploratory hole; filled with drill cuttings; abandoned.

\section{Test Hole P-10}

Date Drilled: July 30, 1987

Elevation (LSD): $7411 \mathrm{ft}$

$\underline{\log }$

Sandy loam

Tuff, Unit 3C

Tuff, Unit 3B

Tuff, Unit $3 A$

\begin{tabular}{cc}
\multicolumn{2}{c}{ Water Level: Dry } \\
Thickness & Depth \\
$\frac{(\mathrm{ft})}{3}$ & $\frac{(\mathrm{ft})}{3}$ \\
47 & 50 \\
70 & 120 \\
30 & 150
\end{tabular}

Note: Exploratory hole; filled with cuttings and abandoned.

\section{Test Hole P-11}

Date Drilled: August 27, 1987

Elevation (LSD): $7409 \mathrm{ft}$

$\underline{\log }$

Sandy loam

Tuff, Unit 3C

Tuff, Unit 3B

\begin{tabular}{cc}
\multicolumn{2}{c}{ Water Level: Dry } \\
Thickness & Depth \\
$\frac{(\mathrm{ft})}{2}$ & $\frac{(\mathrm{ft})}{2}$ \\
48 & 50 \\
20 & 70
\end{tabular}

Note: Exploratory hole; filled with cuttings and abandoned.

\section{Test Hole P-15}

Date Drilled: August 27, 1987

Elevation (LSD): $7413 \mathrm{ft}$

$\underline{\log }$

Sandy loam

Tuff, Unit $3 \mathrm{C}$

Tuff, Unit 3B

\begin{tabular}{cc}
\multicolumn{2}{c}{ Water Level: Dry } \\
Thickness & $\begin{array}{c}\text { Depth } \\
\text { (ft) }\end{array}$ \\
$\frac{(\mathrm{ft})}{4}$ & 4 \\
51 & 55 \\
15 & 70
\end{tabular}

Note: Exploratory hole; filled with cuttings and abandoned.

Source: Brown et al. 1988. 
TABLE XIV-B. Geologic Logs and Construction Data for Vadose Monitoring Holes at TA-16

(4 Sets of Holes)

1. Lysimeter Hole L-17

Moisture-Access Hole P-17

Date Drilled: September 6, 1988

Elevation (LSD): $7433 \mathrm{ft}$

$\underline{\log }$

Topsoil cover

Waste in landfill

Tuff, Unit 3D, low moisture, light brown tuff with rhyolite rock

fragments, nonwelded to moderately welded

\begin{tabular}{|c|c|}
\hline \multicolumn{2}{|c|}{ Water Level: Dry } \\
\hline Thickness & Depth \\
\hline$(\mathrm{ft})$ & $(\mathrm{ft})$ \\
\hline 1 & 1 \\
\hline 10 & 11 \\
\hline 19 & 30 \\
\hline
\end{tabular}

Construction

Hole P-17 offset $6 \mathrm{ft}$ from Hole L- 17.

Lysimeter Hole L-17

Cement 0 to $2 \mathrm{ft}$

Cuttings 2 to $4 \mathrm{ft}$

Sand 4 to $6 \mathrm{ft}$

Lysimeter 5 to $6 \mathrm{ft}$

Cement 6 to $8 \mathrm{ft}$

Cuttings 8 to $12 \mathrm{ft}$

Sand 12 to $18 \mathrm{ft}$

Lysimeter 16 to $17 \mathrm{ft}$

Cuttings 18 to $19 \mathrm{ft}$

2. Lysimeter Hole L-18

Moisture-Access Hole P-18

Date Drilled: September 8, 1988

Elevation (LSD): $7438 \mathrm{ft}$

$\underline{\log }$

Sandy soil cover, light brown

Waste, light to dark brown clay with sand stringers

Waste, dark brown to black sticky clay with gray sand, some charcoal

Tuff, Unit 3D, light gray to

light brown, nonwelded to moderately welded

Construction

Hole P-18 offset $6 \mathrm{ft}$ from Hole L-18.

Moisture-Access Hole P-17

2- in.-diam aluminum pipe set 0 to $30 \mathrm{ft}$; set in 4-in.-diam hole; annulus between pipe and hole filled with medium silica sand. Pipe cemented in 0 to $1 \mathrm{ft}$.

$\begin{array}{cc}\begin{array}{c}\text { Water Level: Dry } \\ \begin{array}{c}\text { Thickness } \\ \frac{(\mathrm{ft})}{1}\end{array}\end{array} & \begin{array}{c}\text { Depth } \\ (\mathrm{ft})\end{array} \\ 3 & 1 \\ 9 & 4 \\ 17 & 13 \\ & 30\end{array}$


TABLE XIV-B. Geologic Logs and Construction Data for Vadose Monitoring Holes at TA-16 (4 Sets of Holes) (Continued)

2. Lysimeter Hole L-18 (Continued)

Moisture-Access Hole P-18

Lysimeter Hole L-18

$\begin{array}{lr}\text { Cement } & 0 \text { to } 2 \mathrm{ft} \\ \text { Cuttings } & 2 \text { to } 5 \mathrm{ft} \\ \text { Sand } & 5 \text { to } 6 \mathrm{ft} \\ \text { Lysimeter } & 5 \text { to } 6 \mathrm{ft} \\ \text { Cement } & 6 \text { to } 10 \mathrm{ft} \\ \text { Cuttings } & 10 \text { to } 12 \mathrm{ft} \\ \text { Sand } & 12 \text { to } 18 \mathrm{ft} \\ \text { Lysimeter } & 17 \text { to } 18 \mathrm{ft} \\ \text { Cuttings } & 18 \text { to } 19 \mathrm{ft}\end{array}$

3. Lysimeter Hole L-19

Moisture-Access Hole P-19

Date Drilled: September 14, 1988

Elevation (LSD): $7448 \mathrm{ft}$

$\underline{\log }$

Sandy soil cover, dry

Crushed tuff fill, moderately dry

Crushed tuff fill, no waste apparent

Tuff, Unit 3D; light brown tuff with rhyolite rock fragements, nonwelded to moderately welded

Construction

Hole P-19 offset $6 \mathrm{ft}$ from Hole L-19.

Lysimeter Hole L-19

Cement

Cuttings

Sand

Lysimeter

Cuttings
Moisture-Access Hole P-18

2-in.-diam aluminum pipe set 0 to $30 \mathrm{ft}$; set in 4-in.-diam hole; annulus between pipe and hole filled with medium silica sand. Pipe cemented in 0 to $1 \mathrm{ft}$.

\begin{tabular}{|c|c|}
\hline \multicolumn{2}{|c|}{ Water Level: Dry } \\
\hline Thickness & Depth \\
\hline$(\mathrm{ft})$ & (ft) \\
\hline 1 & 1 \\
\hline 3 & 4 \\
\hline 10 & 14 \\
\hline 16 & 30 \\
\hline
\end{tabular}

Moisture-Access Hole P-19

2-in.-diam aluminum pipe set 0 to $30 \mathrm{ft}$; set in 4-in.-diam hole; annulus between pipe and hole filled with medium silica sand. Pipe cemented in 0 to $1 \mathrm{ft}$. 
TABLE XIV-B. Geologic Logs and Construction Data for Vadose Monitoring Holes at TA-16 (4 Sets of Holes) (Continued)

4. Lysimeter Hole L-20

Moisture-Access Hole P-20

Date Drilled: September 15, 1988

Elevation (LSD): $7446 \mathrm{ft}$

$\underline{\log }$

Crushed tuff and soil mixture, sandy to sandy clay, light brown to dark brown; does not appear to be waste

Waste, tuff, and sand with charcoal fragments

Clay, brown, weathered in place

Tuff, Unit 3D; nonwelded, low moisture

$\begin{array}{lc}\text { Water Level: Dry } \\ \text { Thickness } & \text { Depth } \\ \text { (ft) } & \underline{(\mathrm{ft})}\end{array}$

Construction

Hole P-20 offset $6 \mathrm{ft}$ from Hole L-20.

Lysimeter Hole L-20

$15 \quad 15$

6221

122

$8 \quad 30$

$\begin{array}{lr}\text { Cement } & 0 \text { to } 1 \mathrm{ft} \\ \text { Cuttings } & 1 \text { to } 2 \mathrm{ft} \\ \text { Sand } & 2 \text { to } 9 \mathrm{ft} \\ \text { Lysimeter } & 8 \text { to } 9 \mathrm{ft} \\ \text { Cuttings } & 9 \text { to } 22 \mathrm{ft} \\ \text { Cement } & 22 \text { to } 23 \mathrm{ft} \\ \text { Cuttings } & 23 \text { to } 27 \mathrm{ft} \\ \text { Sand } & 27 \text { to } 29 \mathrm{ft} \\ \text { Lysimeter } & 28 \text { to } 29 \mathrm{ft}\end{array}$

Moisture-Access Hole P-20

2-in.-diam aluminum pipe set 0 to $30 \mathrm{ft}$;

set in 4-in.-diam hole; annulus between pipe

and hole filled with medium silica sand.

Pipe cemented in 0 to $1 \mathrm{ft}$.

Source: McLin 1989. 
TABLE XIV-C. Geologic Logs and Construction Data for Observation Wells at TA-16 (9 Obs. Wells)

1. Observation Well P-1

Date Drilled: July 29, 1987

Elevation (LSD): $7344 \mathrm{ft}$

$\underline{\log }$

Top soil

Tuff, Unit 3B

\begin{tabular}{|c|c|}
\hline \multicolumn{2}{|c|}{ Water Level: Dry } \\
\hline Thickness & Depth \\
\hline$(\mathrm{ft})$ & (ft) \\
\hline 4 & 4 \\
\hline 31 & 35 \\
\hline
\end{tabular}

Construction

Bore hole diam $67 / 8$ in.; $35 \mathrm{ft}$ of 2-in.-diam teflon pipe with the lower $20 \mathrm{ft}$ slotted (0.010-in.-wide slots) set in hole; cement $0-13 \mathrm{ft}$; bentonite 13 to $15 \mathrm{ft}$; medium-grained silica sand 15 to $35 \mathrm{ft}$.

\section{Observation Well P-2}

Date Drilled: July 23, 1987.

Elevation (LSD): $7341 \mathrm{ft}$

$\underline{\log }$

Sandy soil

Tuff, Unit 3B

\begin{tabular}{cc}
\multicolumn{2}{c}{ Water Level: Dry } \\
$\begin{array}{cc}\text { Thickness } & \text { Depth } \\
\frac{(\mathrm{ft})}{3} & \frac{(\mathrm{ft})}{3} \\
7 & 10\end{array}$
\end{tabular}

Construction

Well plugged and abandoned.

3. Observation Well P-3

Date drilled: July 23, 1987

Elevation (LSD): $7342 \mathrm{ft}$

$\underline{\log }$

Sandy soil

Tuff, Unit 3B

\begin{tabular}{cc}
\multicolumn{3}{c}{ Water Level: Dry } \\
Thickness & Depth \\
$\frac{(\mathrm{ft})}{3}$ & $\frac{(\mathrm{ft})}{3}$ \\
6 & 9
\end{tabular}

\section{Construction}

Bore hole diam $67 / 8 \mathrm{in}$; $7 \mathrm{ft}$ of 2-in.-diam teflon pipe with the lower $5 \mathrm{ft}$ slotted (0.010-in.-wide slots) set in hole; cement and bentonite 0 to $2 \mathrm{ft}$; medium-grained silica sand 2 to $9 \mathrm{ft}$.

\section{Observation Well P-4}

Date drilled: July 28, 1987

Elevation (LSD): $7348 \mathrm{ft}$

$\underline{\log }$

Sandy soil

Tuff, Unit 3B

\begin{tabular}{|c|c|}
\hline \multicolumn{2}{|c|}{ Water Level: Dry } \\
\hline Thickness & Depth \\
\hline$(\mathrm{ft})$ & $(\mathrm{ft})$ \\
\hline 4 & 4 \\
\hline 6 & 10 \\
\hline
\end{tabular}

\section{Construction}

Bore hole diam $67 / 8 \mathrm{in}$; $8 \mathrm{ft}$ of 2 -in.-diam teflon pipe with the lower $5 \mathrm{ft}$ slotted (0.010-in.-wide slots) set in hole; cement and bentonite 0 to $3 \mathrm{ft}$; medium-grained silica sand 3 to $10 \mathrm{ft}$.

\section{Observation Well P-5}

Date drilled: July 29, 1987

Elevation (LSD): $7353 \mathrm{ft}$

$\underline{\log }$

Sandy soil

Tuff, Unit 3B

\begin{tabular}{cc}
\multicolumn{2}{c}{ Water Level: Dry } \\
Thickness & Depth \\
$\frac{(\mathrm{ft})}{3}$ & $\frac{(\mathrm{ft})}{3}$ \\
32 & 35 \\
\hline
\end{tabular}


TABLE XIV-C. Geologic Logs and Construction Data for Observation Wells at TA-16 (9 Obs. Wells) (Continued)

\section{Observation Well P-5 (Continued)}

\section{Construction}

Bore hole diam $67 / 8$ in.; $35 \mathrm{ft}$ of 2 -in.-diam teflon pipe with the lower $20 \mathrm{ft}$ slotted ( 0.010 -in.-wide slots) set in hole; cement 0 to $13 \mathrm{ft}$; bentonite 13 to $15 \mathrm{ft}$; medium-grained silica sand 15 to $35 \mathrm{ft}$.

\section{Observation Well P-6}

Date Drilled: July 28,1987

Elevation (LSD): $7352 \mathrm{ft}$

$\underline{\log }$

Sandy soil

Tuff, Unit 3B

\begin{tabular}{cc}
\multicolumn{2}{c}{ Water Level: Dry } \\
Thickness & Depth \\
$\frac{(\mathrm{ft})}{4}$ & $\frac{(\mathrm{ft})}{4}$ \\
6 & 10
\end{tabular}

Construction

Bore hole diam $67 / 8$ in.; $7 \mathrm{ft}$ of 2-in.-diam teflon pipe (with the lower $5 \mathrm{ft}$ slotted) set in hole; cement and bentonite 0 to $2 \mathrm{ft}$; medium-grained silica sand 2 to $10 \mathrm{ft}$.

\section{Observation Well P-7}

Date Drilled: July 29, 1987

Elevation (LSD): $7356 \mathrm{ft}$

$\underline{\log }$

Sandy soil

Tuff, Unit 3B

\begin{tabular}{cc}
\multicolumn{2}{c}{ Water Level: Dry } \\
Thickness & Depth \\
$\frac{(\mathrm{ft})}{2}$ & $\frac{(\mathrm{ft})}{2}$ \\
33 & 35
\end{tabular}

\section{Construction}

Bore hole diam $67 / 8 \mathrm{in.;} 35 \mathrm{ft}$ of 2-in.-diam teflon pipe with the lower $20 \mathrm{ft}$ slotted (0.010-in.-wide slots) set in hole; cement 0 to $13 \mathrm{ft}$; bentonite 13 to $15 \mathrm{ft}$; medium-grained silica sand 15 to $35 \mathrm{ft}$.

\section{Observation Well P-8}

Date Drilled: July 28, 1987

Elevation (LSD): $7370 \mathrm{ft}$

$\underline{\log }$

Sandy soil

Tuff, Unit 3B

\begin{tabular}{cc}
\multicolumn{2}{c}{ Water Level: Dry } \\
Thickness & Depth \\
$\frac{(\mathrm{ft})}{3}$ & $\frac{(\mathrm{ft})}{3}$ \\
7 & 10
\end{tabular}

Construction

Bore hole diam $67 / 8$ in.; $7 \mathrm{ft}$ of 2 -in.-diam teflon pipe with the lower $5 \mathrm{ft}$ slotted (0.010-in.-wide slots) set in hole; cement and bentonite 0 to $2 \mathrm{ft}$; medium-grained silica sand 2 to $10 \mathrm{ft}$.

9. Observation Well P-9

Date Drilled: July 29, 1987

Elevation (LSD): $7376 \mathrm{ft}$

$\underline{\log }$

Sandy soil

Tuff, Unit 3C

Tuff, Unit 3B

\begin{tabular}{cc}
\multicolumn{2}{c}{ Water Level: Dry } \\
Thickness & Depth \\
$\frac{(\mathrm{ft})}{3}$ & $\frac{(\mathrm{ft})}{3}$ \\
12 & 15 \\
20 & 35 \\
\hline
\end{tabular}


TABLE XIV-C. Geologic Logs and Construction Data for Observation Wells at TA-16 (9 Obs. Wells) (Continued)

\section{Observation Well P-9 (Continued)}

Construction

Bore hole diam $67 / 8 \mathrm{in}$; $35 \mathrm{ft}$ of 2-in.-diam teflon pipe with the lower $20 \mathrm{ft}$ slotted (0.010-in.-wide slots) set in hole; cement 0 to $13 \mathrm{ft}$; bentonite 13 to $15 \mathrm{ft}$; medium-grained silica sand 15 to $35 \mathrm{ft}$.

Source: Brown et al. 1988.

TABLE XIV-D. Geologic Logs and Construction Data for Moisture-Access Holes at TA-16 (5 Moisture-Access Holes)

\section{Test Hole P-0}

Date Drilled: July 21, 1987

Elevation (LSD): $7399 \mathrm{ft}$

$\underline{\log }$

Top soil

Tuff, Unit 3C

Tuff, Unit 3B

Tuff, Unit $3 A$

\begin{tabular}{cc}
\multicolumn{2}{c}{ Water Level: Dry } \\
Thickness & Depth \\
$\frac{(\mathrm{ft})}{3}$ & $\frac{(\mathrm{ft})}{3}$ \\
37 & 40 \\
70 & 110 \\
25 & 135
\end{tabular}

Construction

Bore hole diam $67 / 8$ in.; cored; 2-in.-diam aluminum pipe set in hole 0 to $120 \mathrm{ft}$; cemented $0-1 \mathrm{ft}$; tuff cuttings from 1 to $135 \mathrm{ft}$ around and below pipe.

\section{Test Hole P-12}

Date Drilled: August 21, 1987

Elevation (LSD): $7448 \mathrm{ft}$ $\underline{\log }$

Top soil

Tuff, Unit 3D

Tuff, Unit 3C

Tuff, Unit 3B

Tuff, Unit 3A

Tuff, Unit 2

\begin{tabular}{|c|c|}
\hline \multicolumn{2}{|c|}{ Water Level: Dry } \\
\hline Thickness & Depth \\
\hline$(\mathrm{ft})$ & $(\mathrm{ft})$ \\
\hline 3 & 3 \\
\hline 47 & 50 \\
\hline 52 & 102 \\
\hline 71 & 173 \\
\hline 22 & 195 \\
\hline 5 & 200 \\
\hline
\end{tabular}

Construction

Bore hole diam $67 / 8$ in.; cored; $171 \mathrm{ft}$ of 2-in.-diam aluminum pipe 0 to $173 \mathrm{ft}$; cemented 0-1 ft; tuff cuttings from 1 to $200 \mathrm{ft}$ around and below pipe. 


\section{Test Hole P-13}

Date Drilled: October 3, 1987

Elevation (LSD): $7445 \mathrm{ft}$

$$
\begin{aligned}
& \text { Log } \\
& \text { Top soil } \\
& \text { Tuff, Unit 3D } \\
& \text { Tuff, Unit 3C } \\
& \text { Tuff, Unit 3B }
\end{aligned}
$$

\begin{tabular}{|c|c|}
\hline \multicolumn{2}{|c|}{ Water Level: Dry } \\
\hline Thickness & Depth \\
\hline$(\mathrm{ft})$ & $(\mathrm{ft})$ \\
\hline 1 & 1 \\
\hline 37 & 38 \\
\hline 46 & 84 \\
\hline 19 & 103 \\
\hline
\end{tabular}

\section{Construction}

Bore hole diam $67 / 8$ in.; cored; $92 \mathrm{ft}$ of 2-in.-diam aluminum pipe set 0 to $92 \mathrm{ft}$; cemented 0-1ft; tuff cuttings from 1 to $103 \mathrm{ft}$ around and below pipe.

\begin{tabular}{|c|c|}
\hline \multicolumn{2}{|c|}{ Water Level: Dry } \\
\hline Thickness & Depth \\
\hline$(\mathrm{ft})$ & $\underline{(\mathrm{ft})}$ \\
\hline 4 & 4 \\
\hline 26 & 30 \\
\hline 45 & 75 \\
\hline 10 & 85 \\
\hline
\end{tabular}

\section{Test Hole P-14}

Date Drilled: September 28, 1987

Elevation (LSD): $7437 \mathrm{ft}$

$$
\begin{aligned}
& \text { Log } \\
& \text { Top soil } \\
& \text { Tuff, Unit 3D } \\
& \text { Tuff, Unit 3C } \\
& \text { Tuff, Unit 3B }
\end{aligned}
$$

\section{Construction}

Bore hole diam $67 / 8$ in.; cored; $79 \mathrm{ft}$ of 2-in.-diam aluminum pipe set 0 to $79 \mathrm{ft}$; cemented $0-1 \mathrm{ft}$; tuff cuttings from 1 to $85 \mathrm{ft}$ around and below pipe.

\section{Test Hole P-16}

Date Drilled: September 4, 1987

Elevation (LSD): $7452 \mathrm{ft}$

$$
\begin{aligned}
& \text { Log } \\
& \text { Top soil } \\
& \text { Tuff, Unit 3D } \\
& \text { Tuff, Unit 3C } \\
& \text { Tuff, Unit 3B }
\end{aligned}
$$

\begin{tabular}{cc}
\multicolumn{2}{c}{ Water Level: Dry } \\
Thickness & Depth \\
$\frac{(\mathrm{ft})}{7}$ & $\frac{(\mathrm{ft})}{7}$ \\
35 & 42 \\
45 & 87 \\
18 & 105
\end{tabular}

Construction

Bore hole diam $67 / 8$ in.; cored; $88 \mathrm{ft}$ of 2 -in.-diam aluminum pipe set 0 to $88 \mathrm{ft}$; cemented $0-1 \mathrm{ft}$; tuff cuttings from 1 to $105 \mathrm{ft}$ around and below pipe.

Sources: Brown et al. 1988; McLin 1989. 
TABLE XIV-E. Locations and Elevations (NAD 1927)

A. Exploratory Holes

$\begin{array}{llll}\text { B-1 } & \text { N } 1,764,300 & \text { E } 475,700 & 7445 \mathrm{ft} \\ \text { B-2 } & \text { N } 1,764,325 & \text { E 475,700 } & 7442 \mathrm{ft} \\ \text { B-3 } & \text { N } 1,764,350 & \text { E } 475,700 & 7438 \mathrm{ft} \\ \text { B-4 } & \text { N } 1,764,375 & \text { E 475,775 } & 7432 \mathrm{ft} \\ \text { B-5 } & \text { N } 1,764,325 & \text { E } 475,600 & 7450 \mathrm{ft} \\ \text { P-10 } & \text { N } 1,764,473 & \text { E 475,814 } & 7411 \mathrm{ft} \\ \text { P-11 } & \text { N } 1,763,584 & \text { E } 475,991 & 7409 \mathrm{ft} \\ \text { P-15 } & \text { N } 1,763,520 & \text { E } 475,803 & 7413 \mathrm{ft}\end{array}$

B. Vadose Monitoring Holes

L-17; P-17

L-18; P-18

L-19; P-19

L-20; P-20

C. Observation Wells
E 475,750

E 475,675

E 475,550

E 475,475
$7433 \mathrm{ft}$ $7438 \mathrm{ft}$ $7448 \mathrm{ft}$ $7446 \mathrm{ft}$
E $475,756 \quad 7344 \mathrm{ft}$

E 475,708 $\quad 7341 \mathrm{ft}$

E 475,676 $7342 \mathrm{ft}$

E 475,588 $\quad 7348 \mathrm{ft}$

E 475,520 $\quad 7353 \mathrm{ft}$

E $475,467 \quad 7352 \mathrm{ft}$

E 475,381 $\quad 7356 \mathrm{ft}$

E 475,257 $\quad 7370 \mathrm{ft}$

E 475,183 $7376 \mathrm{ft}$

D. Moisture-Access Holes

$\begin{array}{llll}\text { P-12 } & \text { N } 1,764,036 & \text { E } 476,664 & 7448 \mathrm{ft} \\ \text { P-13 } & \text { N } 1,764,264 & \text { E 475,720 } & 7445 \mathrm{ft} \\ \text { P-14 } & \text { N } 1,764,251 & \text { E 475,365 } & 7437 \mathrm{ft} \\ \text { P-16 } & \text { N } 1,764,200 & \text { E } 475,550 & 7452 \mathrm{ft} \\ \text { P-0 } & \text { N } 1,763,523 & \text { E 476,215 } & 7399 \mathrm{ft}\end{array}$

Sources: Brown et al. 1988; McLin 1989. 
XV. U.S. GEOLOGICAL SURVEY TEST HOLE NEAR TA-52

The U.S. Geological Survey cored an experimental hole to test the use of wireline-rotary air-coring techniques in the Bandelier Tuff. A modified standard wireline core-barrel system was used. The hole was located just east of Waste Disposal Area C (Fig. $\mathrm{XV}-\mathrm{A}$ ). The modified equipment was used to collect uncontaminated cores of unconsolidated ash and indurated tuff to a depth of $210 \mathrm{ft}$. Core recovery was $92 \%$. The hole was completed to study the characteristics of the vadose zone (Table $\mathrm{XV}-\mathrm{A}$ ).

\section{REFERENCE}

W. E. Teasdale and R. E. Pemberton, "WirelineRotary Air Coring of the Bandelier Tuff, Los Alamos, New Mexico," U.S. Geol. Survey Water Resources Investigation Report 84-4176 (1984).

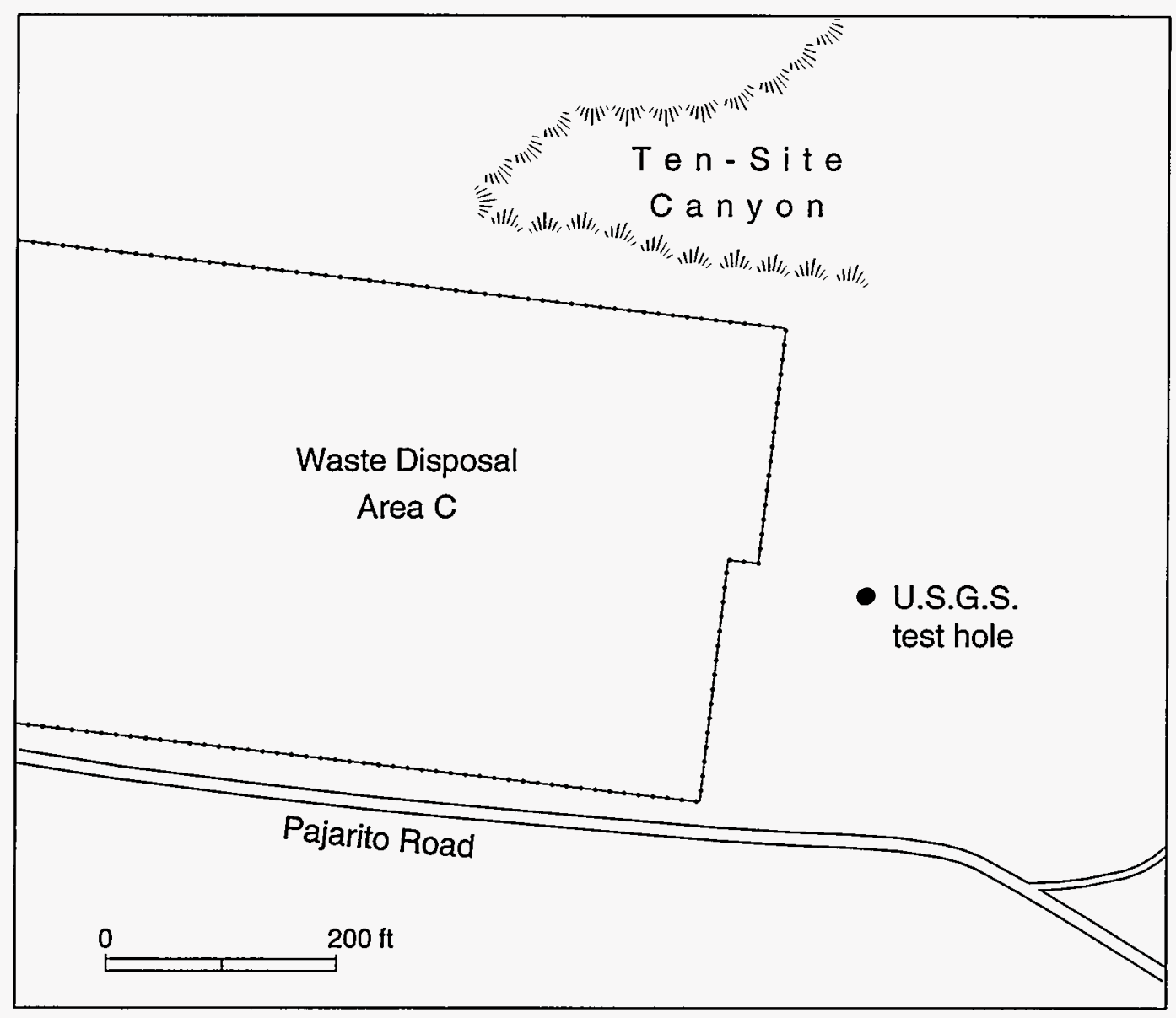

Fig. XV-A. Location of U.S. Geological Survey test hole east of Waste Disposal Area C. 
TABLE XV-A. Geologic Log and Construction Data for U.S. Geological Survey Test Hole near Waste Disposal Area C

Elevation (LSD) $7220 \mathrm{ft}$

Drilled: September 1983

Geologic Log

Bandelier Tuff

Tshirege Member

Unit 3, light gray moderately welded tuff

Unit 2, dark gray

welded tuff
Water Level: Dry
Thickness

(ft)

110

100
Depth

(ft)

\section{Construction}

Completed as a vadose monitoring test hole.

Screen 1190 to $195 \mathrm{ft}$

Screen $2 \quad 140$ to $145 \mathrm{ft}$

Screen 3105 to $110 \mathrm{ft}$

Screen $4 \quad 78$ to $83 \mathrm{ft}$

Screen 550 to $55 \mathrm{ft}$.

Screen 625 to $30 \mathrm{ft}$

Instruments were set in screen sections, each section of screen sealed off with a mixture of grout (cement) and dry cuttings. Surface to $22 \mathrm{ft}$ sealed with cement. Heat dissipation probe set in cuttings 118 to $122 \mathrm{ft}$. Electrical leads extend from instruments in screen section to land surface.

Geophysical Logs

Bulk density, neutron, gamma-ray, and caliper. Files available from the ESH-18 Geohydrology section. 


\section{CARBON ISOTOPE PRODUCTION HOLES AT TA-21 AND TA-46}

Carbon isotope production holes were drilled at TA-21 and TA-46 (Fig. XVI-A). The holes were used as part of a carbon 13 production plant using carbon monoxide distillation (Armstrong et al. 1970).

The preliminary testing and production of carbon 13 occurred at TA-21 building SM-3. In 1969 a hole to hold the distillation column was drilled in the northwest stairwell. The 36-in.-diam hole was augered to a depth of $125 \mathrm{ft}$. An 18-in.-diam casing was cemented in the hole. The casing extended about $15 \mathrm{ft}$ above the floor level. The hole was completed in the Tshirege Member of the Bandelier Tuff. The hole was dry.
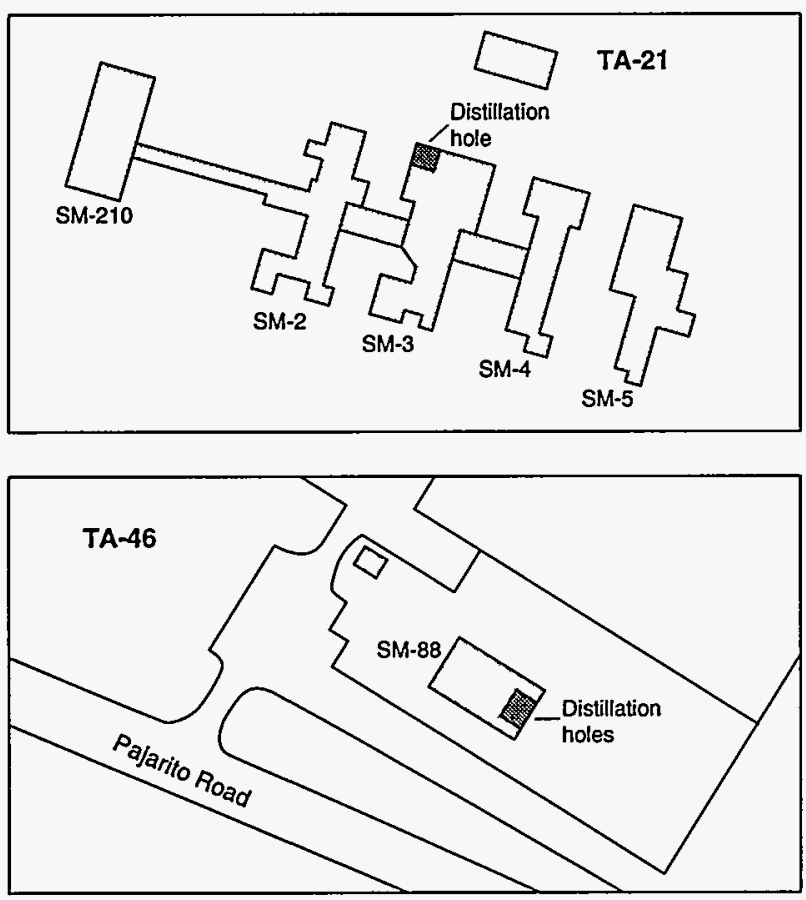

Fig. XVI-A. Distillation holes at TA-21 and TA-46.
A production plant was built at TA-46 in building SM-88 in 1971. The eastern end of the building contained a large bay about $38 \mathrm{ft}$ in height. The holes were drilled in the bay with a spacing of about $20 \mathrm{ft}$. The holes were reamed out to a 16-in. diameter to a depth of about $747 \mathrm{ft}$ using a mud rotary. A 13 3/8in.-diam casing was cemented in the holes.

The holes at TA-46 penetrated the total thickness of the Bandelier Tuff and were completed into the top of the Puye Conglomerate. The holes were dry (Purtymun 1994).

\section{Geologic Log of TA-46 Holes}

\section{Elevation $7105 \mathrm{ft}$}

\section{Thickness Depth}

Bandelier Tuff

$\begin{array}{lcc}\text { Tshirege Member } & 360 & 360 \\ \text { Otowi Member } & 335 & 695 \\ \text { Guaje Member } & 32 & 727 \\ \text { Puye Conglomerate } & & \end{array}$

Puye Conglomerate

Sand, gravel, and boulders $\quad 20 \quad 747$

\section{REFERENCES}

D. E. Armstrong, A. C. Briesmeister, B. B. McInteer, and R. M. Potter, "A Carbon 13 Production Plant Using Carbon Monoxide Distillation," Los Alamos Scientific Laboratory report LA-4391 (1970).

W. D. Purtymun, "Source Document Compilation: Los Alamos Investigations Related to the Environment, Engineering, Geology, and Hydrology, 19611990," Los Alamos National Laboratory report LA12733-MS (1994), chapters 21 and 76.

TABLE XVI-A. Locations and Elevations (NAD 1927)

$\begin{array}{llll}\text { TA-21 } & \text { N 1,774,500 } & \text { E 492,000 } & 7150 \mathrm{ft} \\ \text { TA-46 } & \text { N 1,765,500 } & \text { E 499,500 } & 7105 \mathrm{ft}\end{array}$




\section{TEST WELLS AND TEST HOLES ON THE PAJARITO PLATEAU}

Test holes and test wells were drilled into the Pajarito Plateau to provide geologic and hydrologic information (Fig. XVII-A and Table XVII-A). The test wells provide monitoring of perched aquifers and the main aquifer. Geologic logs and casing schedules of the test wells are shown in Table XVII-B.

Test wells TW-1 (Fig. XVII-B) and TW-2 (Fig. XVII-C) were drilled and completed to monitor the water in the main aquifer in Pueblo Canyon downgradient from the waste treatment plant at TA-45 (which was removed in 1964). Perched water was encountered in the basalts at TW-1 and in the fanglomerate member at TW-2. To monitor the water in the perched aquifers, offset wells TW-1A and TW-2A were drilled and completed as monitoring wells (Figs. XVII-B and XVII-C). Test hole TH-2B in Pueblo Canyon was an attempt to isolate a zone of perched water above the main aquifer and the water in the alluvium in the canyon. The perched aquifer was not there or was of such limited extent that it could not be located (Black and Veatch 1950; Griggs 1955).

Test well TW-3 monitors the water in the main aquifer beneath the alluvial aquifer in Los Alamos Canyon (Fig. XVII-D). Test well TW-4 (Fig. XVII-E) is located to monitor the water in the main aquifer in the vicinity of the old waste treatment plant at TA-21 (which has been removed) (Black and Veatch 1950; Griggs 1955).

Test holes TH-5, TH-6, and TH-7 were exploratory holes to determine the geology and determine if water occurred in the rocks underlying the alluvium (Figs. XVII-F through XVII-H) in Pajarito and Ancho Canyons (Griggs 1955).

Test well TW-8 was drilled and completed to test the quality of water of the main aquifer beneath Mortandad Canyon (Fig. XVII-I). Mortandad Canyon receives treated industrial effluents from the waste treatment plant at TA-50 (Baltz et al. 1963).

Test hole $\mathrm{H}-19$ was drilled for geologic and hydrologic information (Fig. XVII-J). The test hole was drilled as part of the water investigation of the
Valles Caldera in 1949. The test hole encountered massive, thick sections of latite and dacite flows of the Tschicoma Formation. The hydrologic properties of the Tschicoma show that it is not capable of being developed as a water supply (Griggs 1955).

Test hole Sigma Mesa was intended as a test of the geothermal potential of the plateau area. The hole was targeted for a depth of $6000 \mathrm{ft}$. The hole was started on July 2, 1979. The hole experienced serious drilling problems with lost drilling fluids, essentially right out of the conductor pipe. The magnitude of the lost circulation problem is summarized in Table XVII-C. During July, 19 zones in the $1264 \mathrm{ft}$ of hole drilled were cemented to shut off the zones that lost circulation. A total of 7280 sacks of cement were used. The last plug set (No. 19) indicates the lack of success of the operations; the cement plug disappeared completely into the formation. The drilling continued until December, when the project ran out of money and luck. The test hole was drilled to a total depth of $2292 \mathrm{ft}$. Most of the hole was drilled with little or no circulation or drill cutting returns. At a depth of about $2292 \mathrm{ft}$ the drill string separated, leaving an unknown number of drill stems, drill collars, and the bit in the hole. The cuttings from the hole were few, while those captured contained much of the lost circulation material and redrilled sections. As a result, the geologic log prepared in 1979 was reviewed and revised using geophysical logs, a comparison of logs of nearby test wells and supply wells, and the R. F. Smith Corp. Geothermal Data Log of the hole (Table XVII-B and Fig. XVII-K).

Layne Western, located in Guaje Canyon, was drilled in 1950 (Tables XVII-A and XVII-B) to supply drilling water for the drilling and construction of the supply wells of the Guaje Field (Griggs 1955).

Four test holes were drilled in 1985 at the ski area on Pajarito Mountain west of the Laboratory. The westernmost hole encountered water and was completed as a well. The other three holes drilled to the east did not encounter water. They were drilled to depths of $400 \mathrm{ft}$ through the volcanic rocks of the Bandelier Tuff and Tschicoma Formation (Tables XVII-A and XVII-B). 


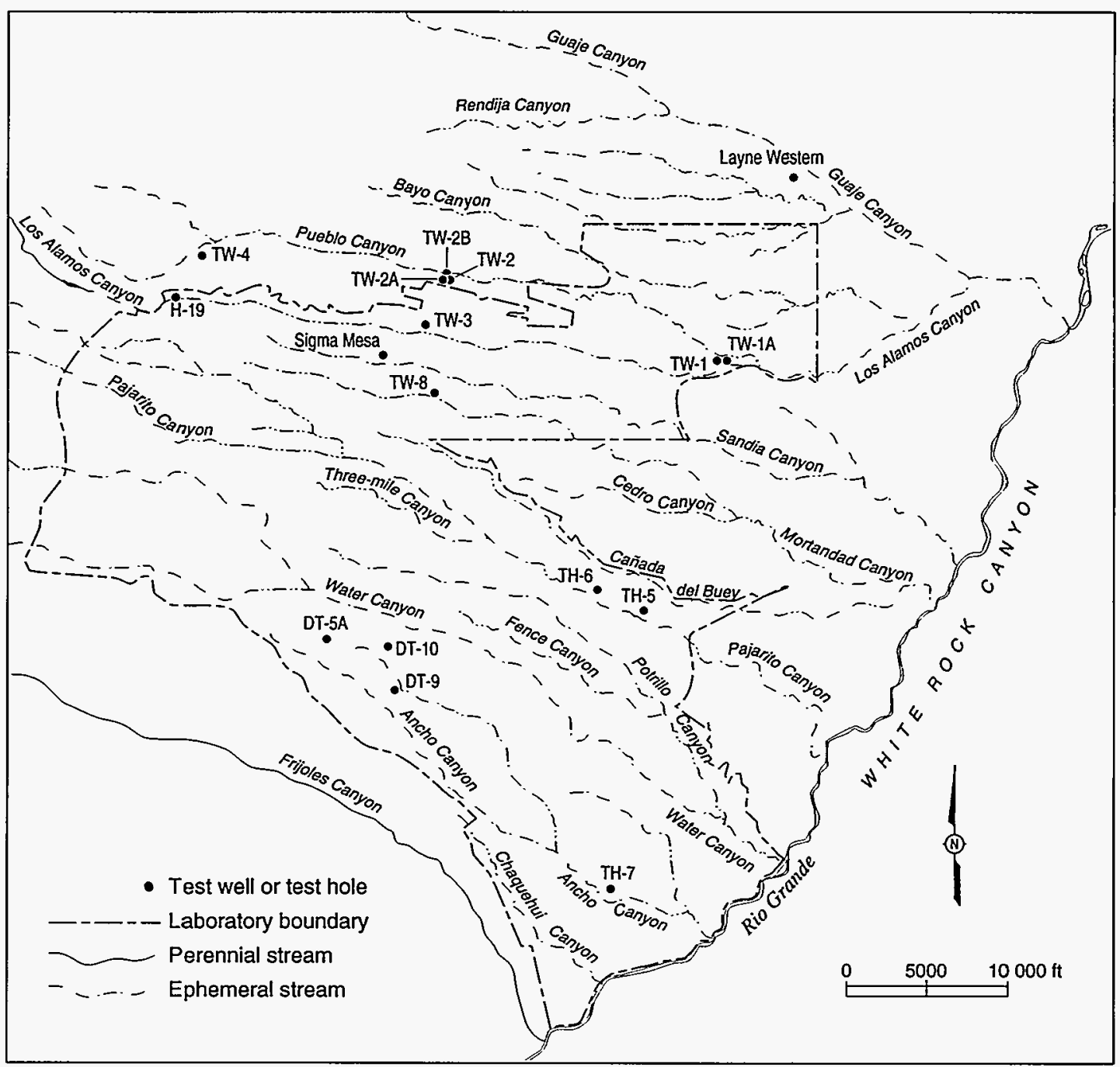

Fig. XVII-A. Test wells and test holes on the Pajarito Plateau.

\section{REFERENCES}

E. H. Baltz, J. H. Abrahams, and W. D. Purtymun, "Preliminary Report on the Geology and Hydrology of Mortandad Canyon, Los Alamos, New Mexico, with Special Reference to Disposal of Liquid LowLevel Radioactive Wastes," U.S. Geological Survey Open-File Report (1963).
Black and Veatch (Consulting Engineers), "GroundWater Observation Wells, Los Alamos, New Mexico," Administrative Report prepared for the U.S. Atomic Energy Commission (1950).

R. L. Griggs, "Geology and Ground-Water Resources of the Los Alamos Area, New Mexico," U.S. Geol. Survey Admin. Report to the U.S. Atomic Energy Commission (1955). 


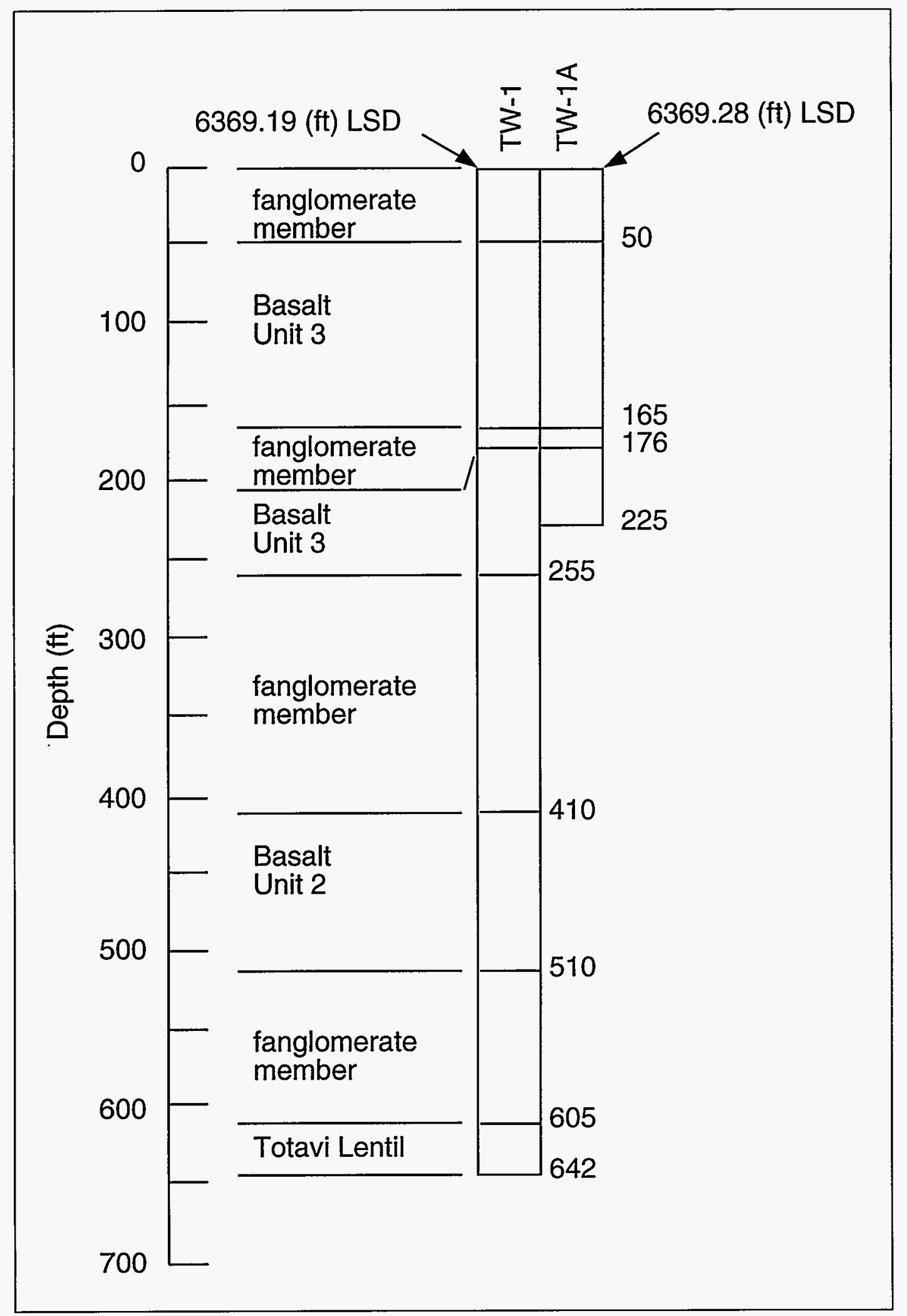

Fig. XVII-B. Geologic logs of test well TW-1, completed January 1950, water level $585 \mathrm{ft}$, and offset test well TW-1A, completed January 1950, water level $188 \mathrm{ft}$ (Griggs 1955). 


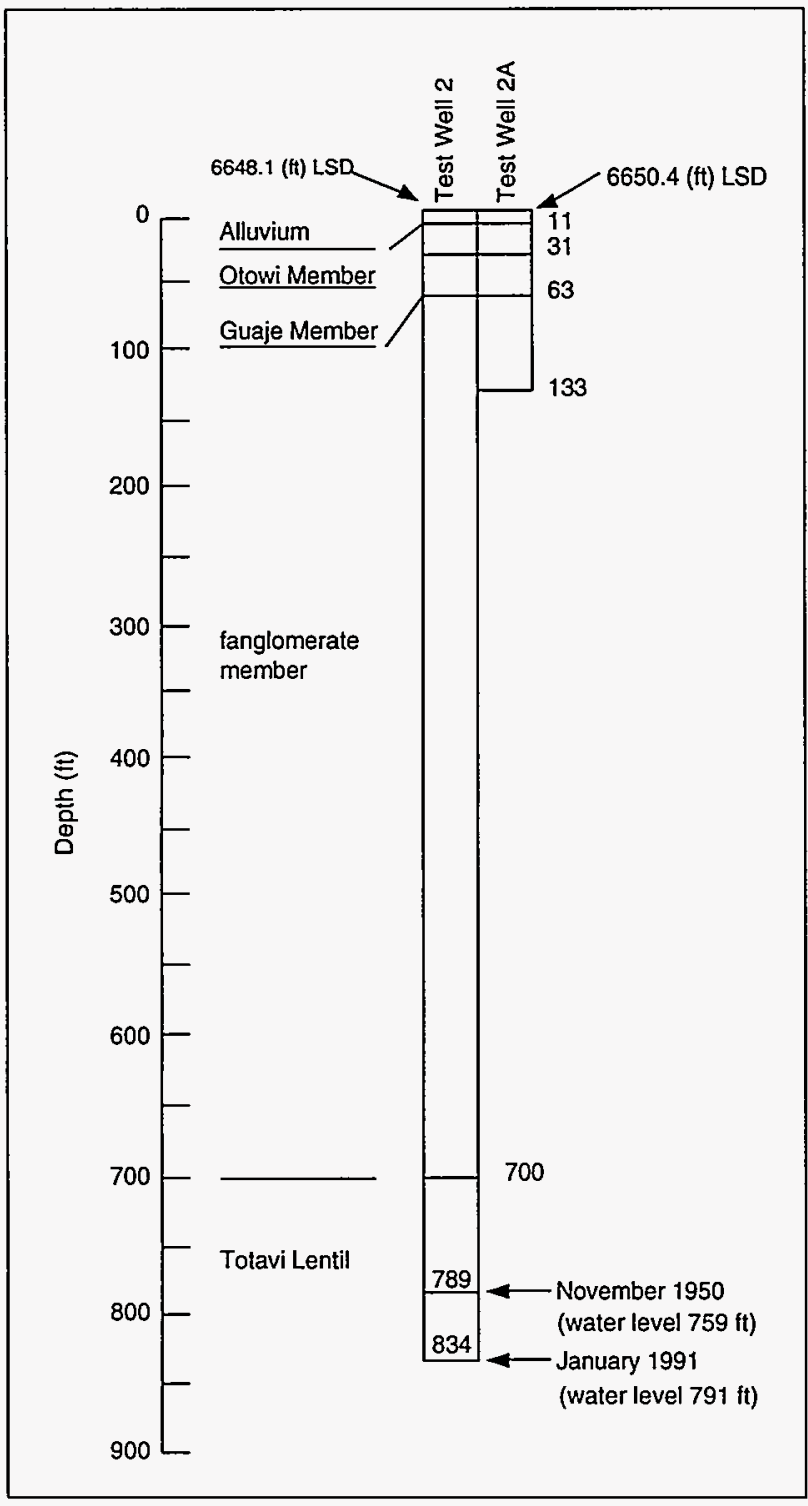

Fig. XVII-C. Geologic logs of test well TW-2, completed November 1949, water level $759 \mathrm{ft}$, and offset test well $\mathrm{TW}-2 \mathrm{~A}$, water level $121 \mathrm{ft}$ (Griggs 1955).

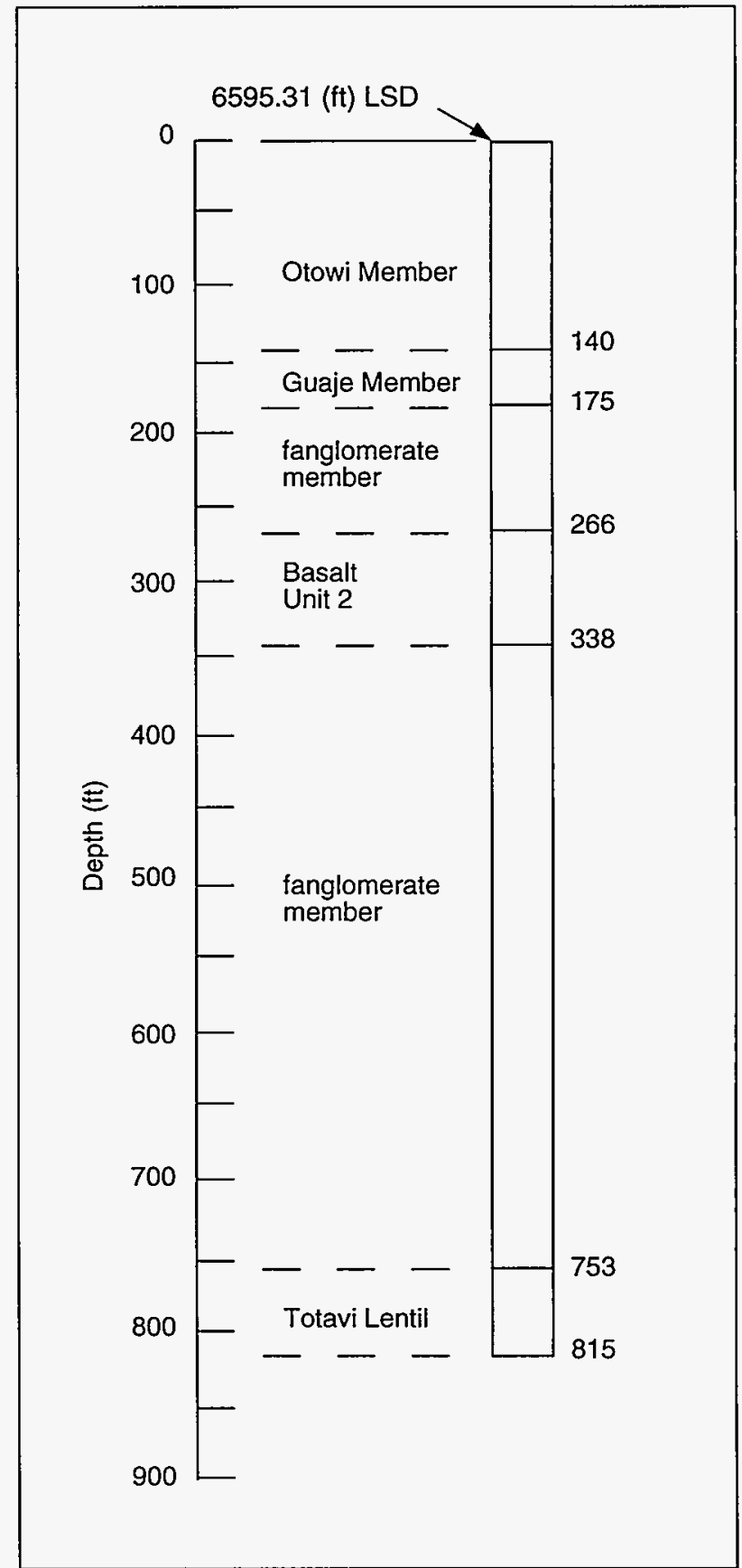

Fig. XVII-D. Geologic log of test well TW-3, completed November 1949, water level $743 \mathrm{ft}$ (Griggs 1955). 


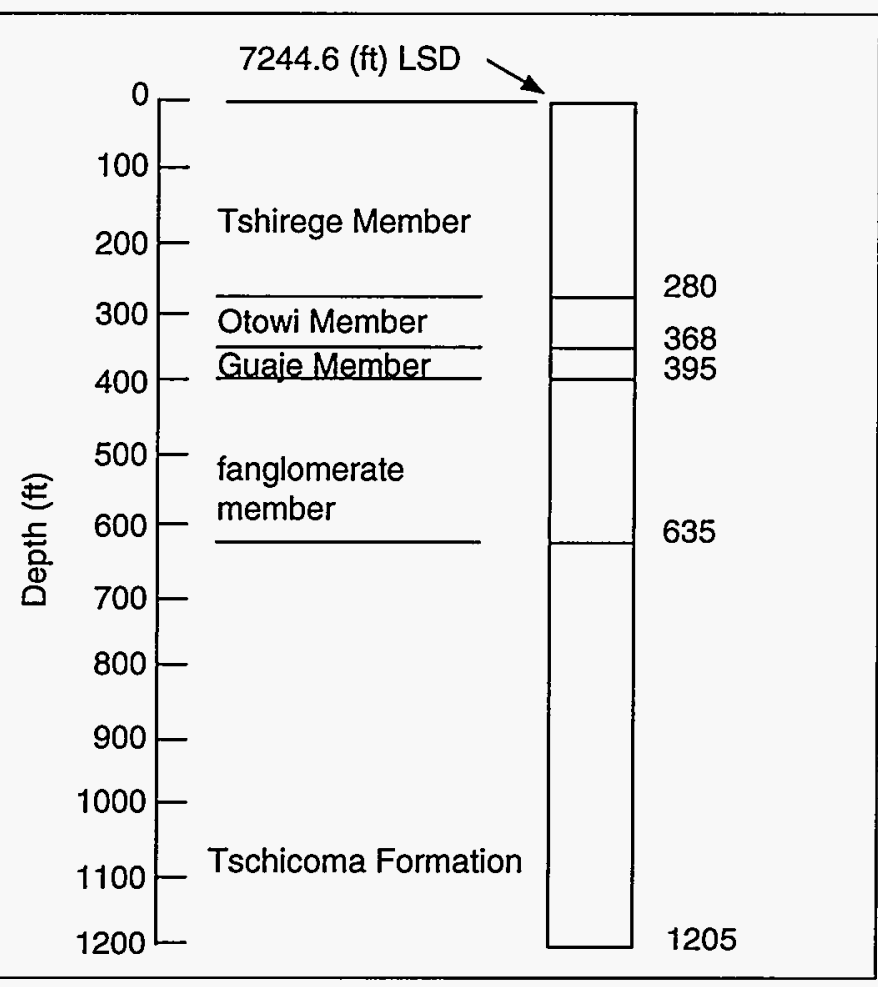

Fig. XVII-E. Geologic log of test well TW-4, completed March 1950, water level $1171 \mathrm{ft}$ (Griggs 1955).

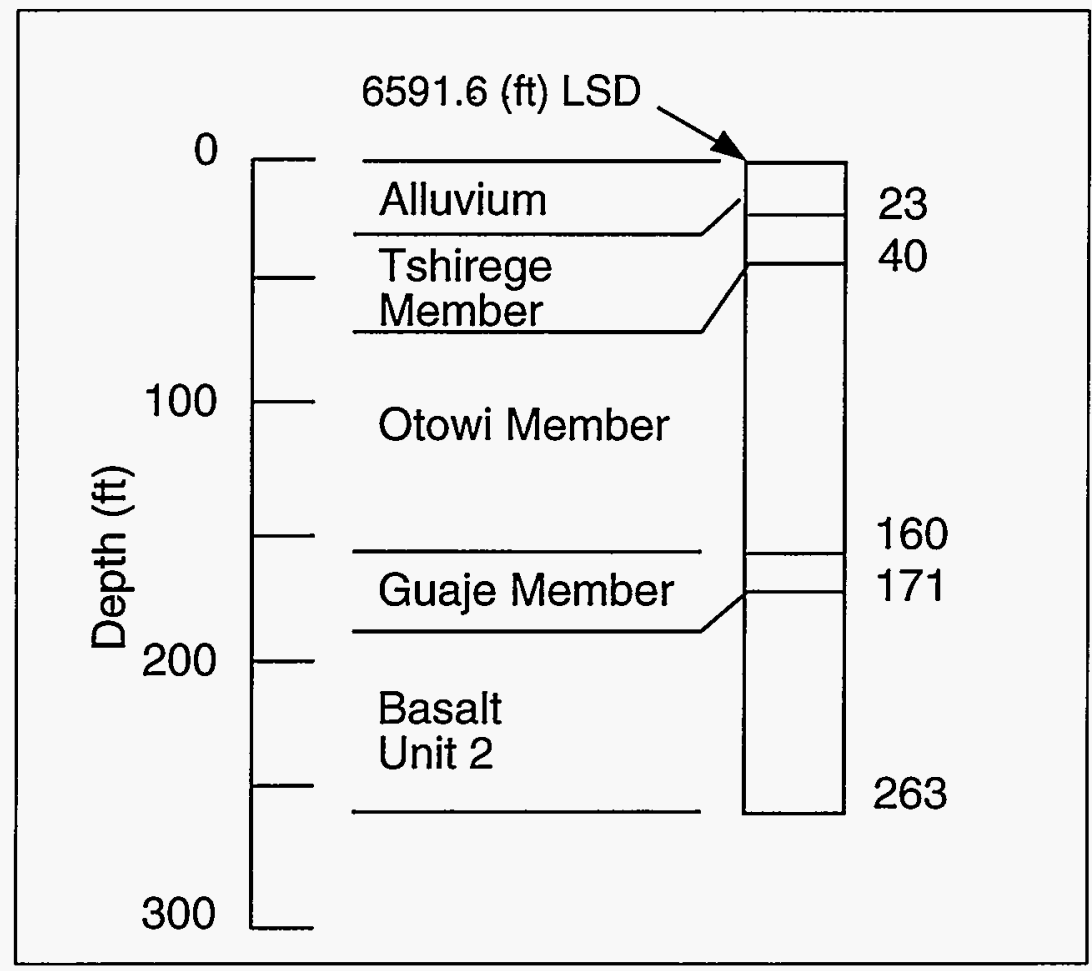

Fig. XVII-F. Geologic log of test hole TH-5, completed March 1950, dry (Griggs 1955). 


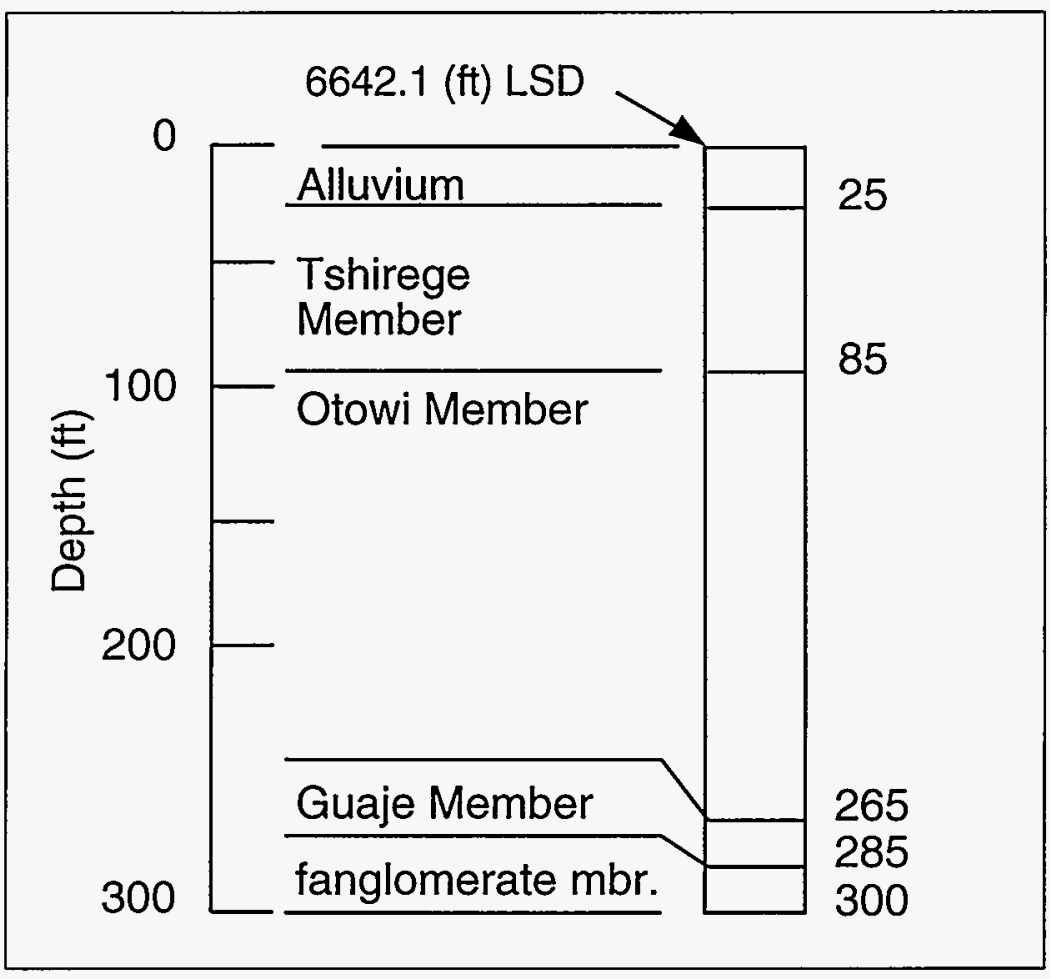

Fig. XVII-G. Geologic log of test hole TH-6, completed March 1950, dry (Griggs 1955).

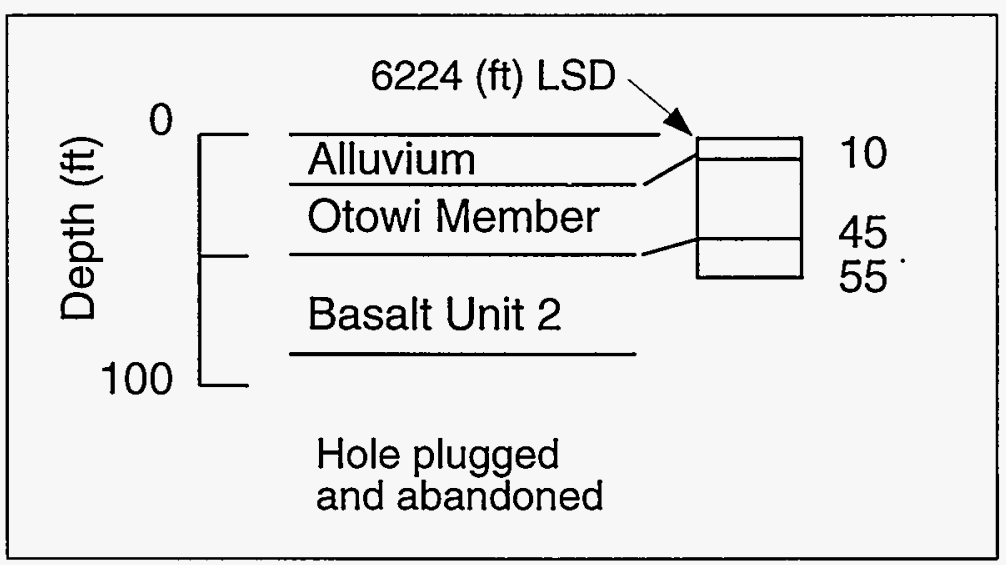

Fig. XVII-H. Geologic log of test hole TH-7, completed April 1950, dry (Griggs 1955). 


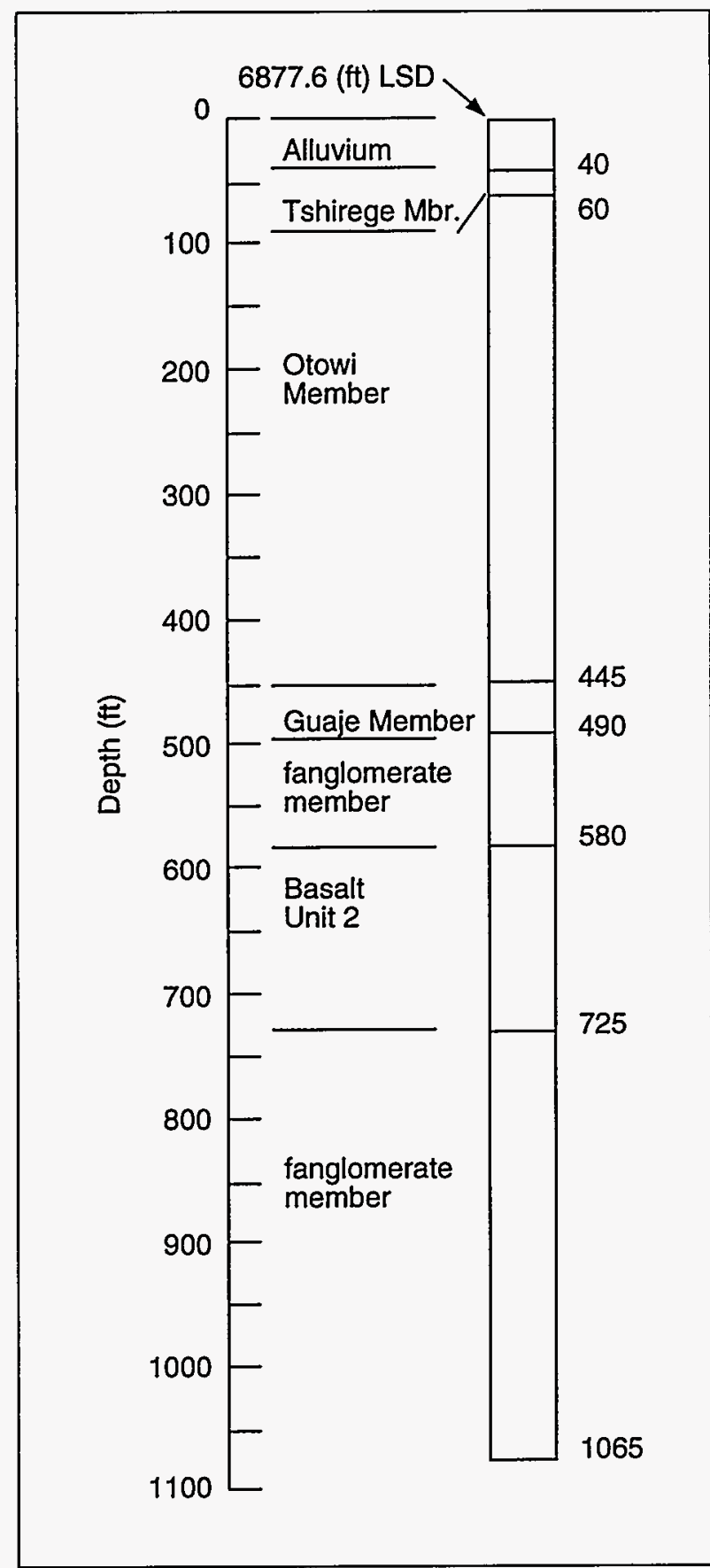

Fig. XVII-I. Geologic log of test well TW-8, completed December 1960, water level $968 \mathrm{ft}$ (Baltz et al. 1963).

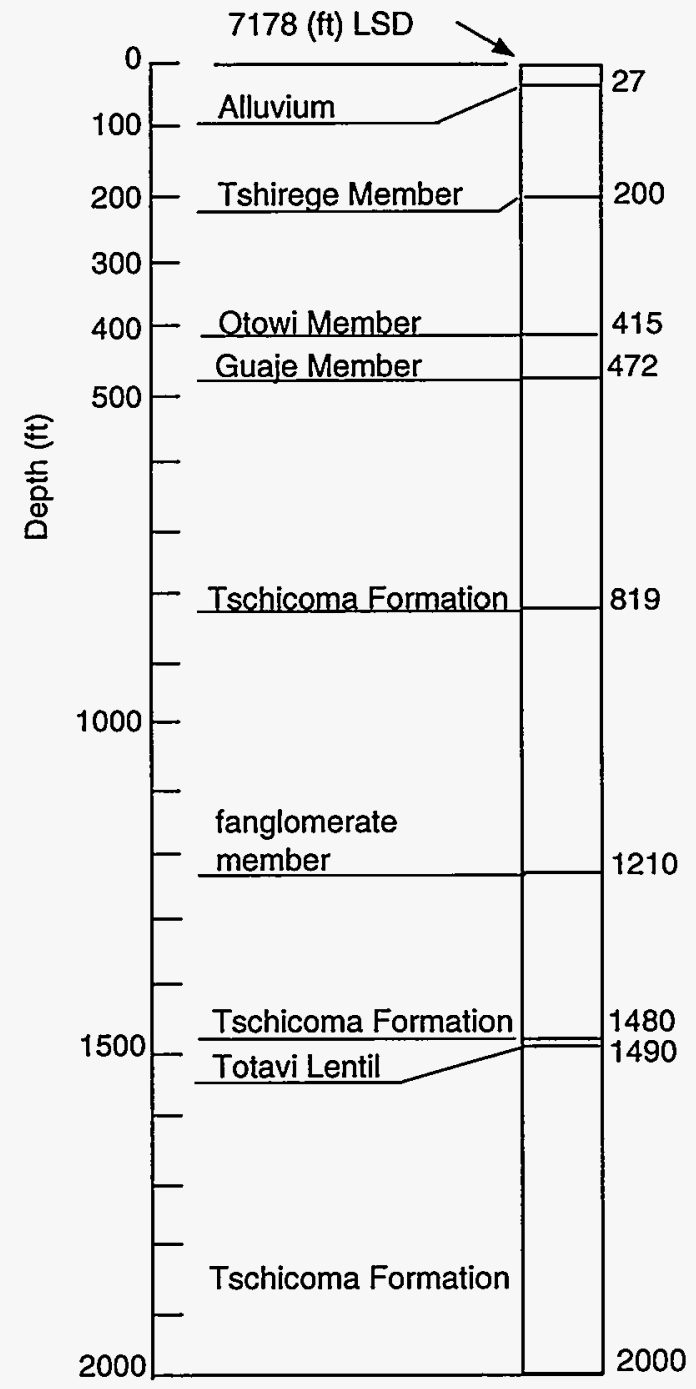

Fig. XVII-J. Geologic log of test hole H-19, completed September 1949, water level $950 \mathrm{ft}$ (Griggs 1955). 


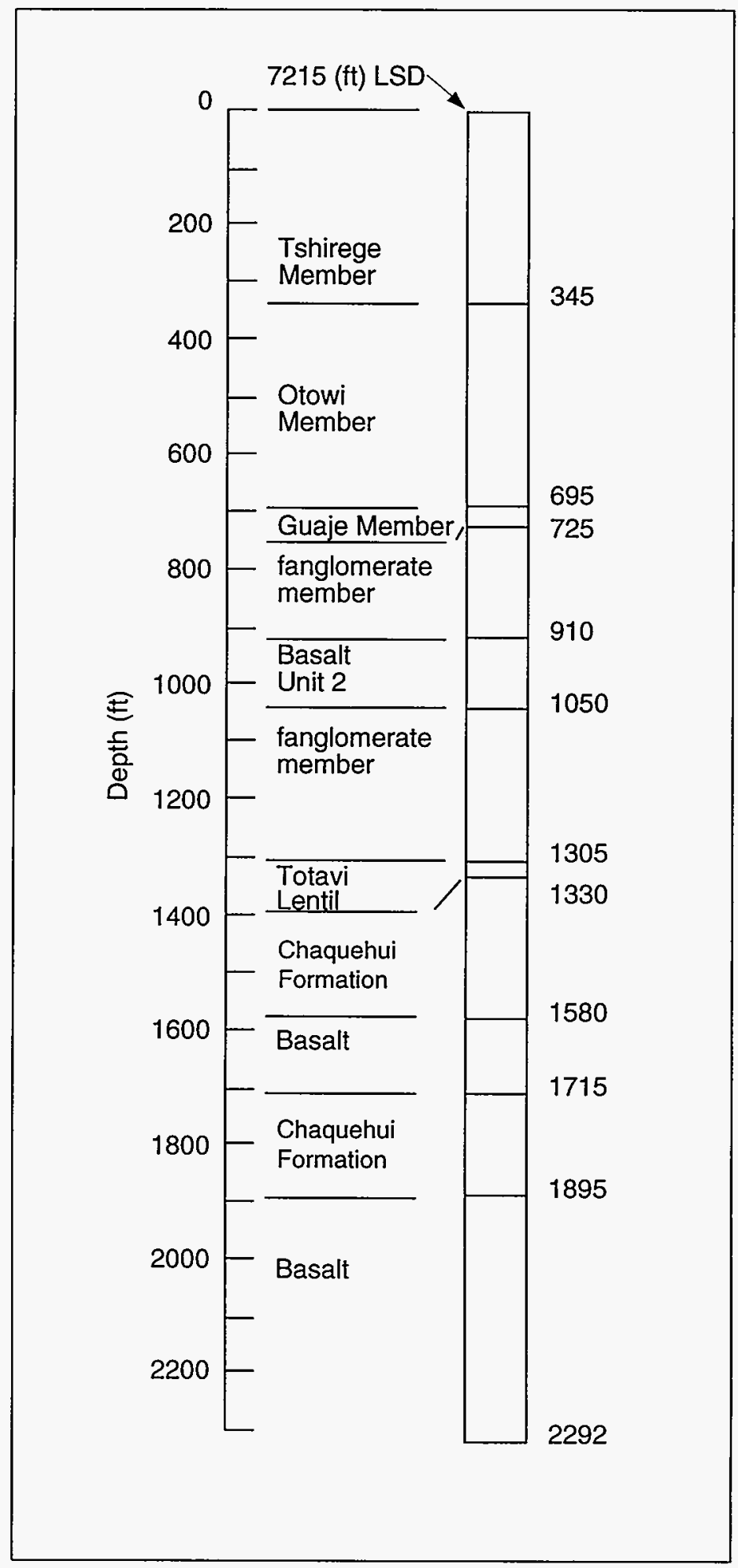

Fig. XVII-K. Geologic log of test hole Sigma Mesa, drilled July-November 1979, water level about 1330 $\mathrm{ft}$ (data from unpublished log by Carolyn Potzich modified by Purtymun; see text and Table XVII-B). 


\begin{tabular}{|c|c|c|c|c|c|c|}
\hline $\begin{array}{l}\text { Test Wells or } \\
\text { Test Holes }\end{array}$ & $\begin{array}{c}\text { Month } \\
\text { Completed }\end{array}$ & $\begin{array}{c}\text { Depth } \\
\text { Drilled } \\
\text { (ft) }\end{array}$ & $\begin{array}{c}\text { Depth } \\
\text { Completed } \\
\text { (ft) }\end{array}$ & $\begin{array}{l}\text { Elevation } \\
\text { (LSD) } \\
\text { (ft) }\end{array}$ & $\begin{array}{c}\text { Water Level } \\
\text { at } \\
\text { Completion } \\
\text { (ft) }\end{array}$ & Remarks \\
\hline Test Well TW-1 & $1 / 50$ & 642 & 642 & 6369.19 & 585 & \\
\hline Test Well TW-1A & $1 / 50$ & 225 & 225 & 6369.28 & 188 & \\
\hline Test Well TW-2 & $11 / 49$ & 789 & 789 & 6648.1 & 759 & \\
\hline Test Well TW-2a & $1 / 91$ & 834 & 834 & 6648.06 & 791 & \\
\hline Test Well TW-2A & $11 / 49$ & 133 & 133 & 6650.40 & 121 & \\
\hline Test Hole TH-2B & $11 / 49$ & 233 & - & 6647 & Dry & \\
\hline Test Well TW-3 & $11 / 49$ & 815 & 815 & 6595.31 & 743 & \\
\hline Test Well TW-4 & $3 / 50$ & 1205 & 1205 & 7244.6 & 1171 & \\
\hline Test Hole TH-5 & $3 / 50$ & 263 & - & 6591.6 & Dry & \\
\hline Test Hole TH- 6 & $3 / 50$ & 300 & 一 & 6642.1 & Dry & \\
\hline Test Hole TH-7 & $4 / 50$ & 55 & 一 & 6224 & Dry & plugged and abandoned \\
\hline Test Well TW-8 & $12 / 60$ & 1065 & 1065 & 6877.62 & 968 & \\
\hline Test Hole H-19 & $9 / 49$ & 2000 & 一 & 7178 & 950 & plugged and abandoned \\
\hline Test Hole Sigma Mesa & $12 / 79$ & 2292 & 1425 & 7215 & 1330 & \\
\hline Layne Western & $3 / 50$ & 157 & 147 & 5971 & 100 & $\begin{array}{l}\text { yielded water to } \\
\text { drill Guaje wells }\end{array}$ \\
\hline Ski Basin Well & $6 / 85$ & 400 & 392 & 9310 & 245 & \\
\hline
\end{tabular}

a Well completed to $789 \mathrm{ft}$ in 1949, drilled and cased to $834 \mathrm{ft}$ in 1991 . 
TABLE XVII-B. Geologic Logs and Construction Data for Test Wells and Test Holes on the Pajarito Plateau (15 Test Wells and Test Holes)

\section{Test Well TW-1}

Elevation (LSD): $6369.19 \mathrm{ft}$

Geologic Log

Puye Conglomerate

Fanglomerate member

Basaltic Rocks of Chino Mesa

Unit 3

Puye Conglomerate

Fanglomerate member

Basaltic Rocks of Chino Mesa

Unit 3

Puye Conglomerate

Fanglomerate member

Basaltic Rocks of Chino Mesa

Unit 2

Puye Conglomerate

Fanglomerate member

Totavi Lentil

Casing Schedule

Inner Diam (in.)

16

12

8

$\begin{array}{cc}\begin{array}{c}\text { Thickness } \\ \text { (ft) }\end{array} & \begin{array}{c}\text { Water Level: } 585 \mathrm{ft}(1950) \\ \text { Depth } \\ (\mathrm{ft})\end{array} \\ 50 & 50 \\ 115 & 165 \\ 11 & 176 \\ 79 & 255 \\ 155 & 410 \\ 100 & 510 \\ 95 & 605 \\ 37 & 642\end{array}$

Depth $(\mathrm{ft})$

$0-52$

$0-241$

$0-627$

622-632

(swaged into bottom of 8-in. casing)

$10 \mathrm{ft}$ of 6-in.-diam screen from 632 to $642 \mathrm{ft}$ swaged into the bottom of the 6-in. casing.

2. Test Well TW-1A

Elevation (LSD): $6369.28 \mathrm{ft}$

Geologic Log

Puye Conglomerate

Fanglomerate member

Basaltic Rocks of Chino Mesa

Unit 3

Puye Conglomerate

Fanglomerate member

Basaltic Rocks of Chino Mesa

Unit 3

$\begin{array}{cc}\begin{array}{c}\text { Water Level: } 188 \mathrm{ft} \\ \begin{array}{c}\text { Thickness } \\ (\mathrm{ft})\end{array}\end{array} & \begin{array}{c}\text { Depth } \\ (\mathrm{ft})\end{array} \\ 50 & 50 \\ 115 & 165 \\ 11 & 176 \\ 49 & 225\end{array}$

Casing Schedule

\begin{tabular}{cc} 
Inner Diam (in.) & Depth (ft) \\
\hline 16 & $0-39$ \\
12 & $0-100$ \\
6 & $0-215$
\end{tabular}

$10 \mathrm{ft}$ of 6-in.-diam screen from 215 to $225 \mathrm{ft}$ swaged into the bottom of the 6-in. casing. 
TABLE XVII-B. Geologic Logs and Construction Data for Test Wells and Test Holes on the Pajarito Plateau (15 Test Wells and Test Holes) (Continued)

3. Test Well TW-2

Elevation (LSD): $6648.1 \mathrm{ft}$

Geologic Log
Alluvium
Bandelier Tuff
Otowi Member
Guaje Member
Puye Conglomerate
Fanglomerate member
Totavi Lentil

\begin{tabular}{|c|c|}
\hline \multicolumn{2}{|c|}{ Water Level: $759 \mathrm{ft}$ (1950) } \\
\hline Thickness & Depth \\
\hline$(\mathrm{ft})$ & $(\mathrm{ft})$ \\
\hline 11 & 11 \\
\hline 20 & 31 \\
\hline 32 & 63 \\
\hline 637 & 700 \\
\hline 134 & 834 \\
\hline
\end{tabular}

Casing Schedule

\begin{tabular}{ccc} 
Inner Diam (in.) & Depth (ft) & \\
\hline 16 & $0-57$ \\
12 & $0-197$ & \\
10 & $0-519$ & \\
8 & $0-779$ \\
6 & $0-834 \quad$ (with slotted section 768 to $824 \mathrm{ft}$ )
\end{tabular}

Note: Well completed to $789 \mathrm{ft}$ in 1949; screen removed 779 to $789 \mathrm{ft}$ and drilled and cased 0 to $834 \mathrm{ft}$ December 1990.

\section{Test Well TW-2A}

Elevation (LSD): $6650.4 \mathrm{ft}$

Geologic Log
Alluvium
Bandelier Tuff
Otowi Member
Guaje Member
Puye Conglomerate

Water Level: $121 \mathrm{ft}(1950)$ Thickness Depth

Fanglomerate member

$\begin{array}{ll}\frac{(\mathrm{ft})}{11} & \frac{(\mathrm{ft})}{11} \\ 20 & 31 \\ 32 & 63 \\ 70 & 133\end{array}$

\section{Casing Schedule}

\begin{tabular}{cc} 
Inner Diam (in.) & Depth (ft) \\
\hline 12 & $0-12$ \\
8 & $0-118$ \\
6 & $0-128$
\end{tabular}

$5 \mathrm{ft}$ of 6-in.-diam screen run from the bottom of the 6-in. casing 128-133 ft.

\section{Test Well TW-2B}

Elevation (LSD): $6647 \mathrm{ft}$

Geologic Log
Alluvium
Bandelier Tuff
Otowi Member
Guaje Member

\begin{tabular}{cc}
\multicolumn{2}{c}{ Water Level: See Note } \\
$\begin{array}{c}\text { Thickness } \\
\text { (ft) }\end{array}$ & $\begin{array}{c}\text { Depth } \\
(\mathrm{ft})\end{array}$ \\
11 & 11 \\
& \\
32 & 31 \\
32 & 63
\end{tabular}


TABLE XVII-B. Geologic Logs and Construction Data for Test Wells and Test Holes on the Pajarito Plateau (15 Test Wells and Test Holes) (Continued)

5. Test Well TW-2B (Continued)

Puye Conglomerate

Fanglomerate member

160

223

Casing Schedule

\begin{tabular}{cc} 
Inner Diam (in.) & Depth (ft) \\
\hline 12 & $0-112$ \\
6 & $0-223$
\end{tabular}

Geophysical Log

Caliper (3-20-69), files available from the ESH-18 Geohydrology section.

Note: Between 12-in. and 6-in. casing: water level $88.1 \mathrm{ft}$; in 6-in. casing, dry at $223 \mathrm{ft}$.

\section{Test Well TW-3}

Elevation (LSD): $6595.31 \mathrm{ft}$

Water Level: $743 \mathrm{ft}$ (1949)

Geologic Log Thickness

Depth

Bandelier Tuff

Otowi Member

Guaje Member

(ft)

(ft)

$140 \quad 140$

$35 \quad 175$

Puye Conglomerate Fanglomerate member

Basaltic Rocks of Chino Mesa

Unit 2

$91 \quad 266$

Puye Conglomerate

Fanglomerate member

72338

Totavi Lentil

$415 \quad 753$

$62 \quad 815$

Casing Schedule

$\begin{array}{cl}\text { Inner Diam (in.) } & \frac{\text { Depth }(\mathrm{ft})}{0-33} \\ 16 & 0-805\end{array}$

$10 \mathrm{ft}$ of 6-in.-diam screen swaged into the bottom of the 10-in. casing from 805 to $815 \mathrm{ft}$.

\section{Test Well TW-4}

Elevation (LSD): $7244.6 \mathrm{ft}$

Geologic Log

Bandelier Tuff

Tshirege Member

Otowi Member

Guaje Member

Puye Conglomerate

Fanglomerate member

Tschicoma Formation

Latite flows and interflow breccias

$\begin{array}{cc}\begin{array}{c}\text { Water Level: } 1171 \mathrm{ft}(1950) \\ \text { Thickness } \\ \text { (ft) }\end{array} & \begin{array}{c}\text { Depth } \\ (\mathrm{ft})\end{array} \\ 280 & 280 \\ 88 & 368 \\ 27 & 395 \\ 240 & 635 \\ 570 & 1205\end{array}$


TABLE XVII-B. Geologic Logs and Construction Data for Test Wells and Test Holes on the Pajarito Plateau (15 Test Wells and Test Holes) (Continued)

\section{Test Well TW-4 (Continued)}

Casing Schedule

\begin{tabular}{|c|c|}
\hline Inner Diam (in.) & Depth (ft) \\
\hline 16 & $0-109$ \\
\hline 12 & $0-288$ \\
\hline 10 & $0-633$ \\
\hline 6 & $0-1195$ \\
\hline
\end{tabular}

$10 \mathrm{ft}$ of 6-in.-diam screen run from the bottom of the 6-in. casing, from 1195 to $1205 \mathrm{ft}$.

Geophysical Log

Gamma-ray (5-7-60), Files ESH-18.

Note: Water level $1168.9 \mathrm{ft}$ (5-7-60); water level $1172 \mathrm{ft} \mathrm{(7-20-92).}$

8. Test Hole TH-5

Elevation (LSD): $6591.6 \mathrm{ft}$

Geologic Log

Alluvium

Bandelier Tuff

Tshirege Member

Otowi Member

Guaje Member

Basaltic Rocks of Chino Mesa

Unit 2

Casing Schedule

$\frac{\text { Outer Diam (in.) }}{24} \quad \frac{\text { Depth (ft) }}{0-24}$

Open Hole 24-163

Note: Water in alluvium cased out of hole.

\section{Test Hole TH-6}

Elevation (LSD): $6642.1 \mathrm{ft}$

\section{Geologic Log \\ Alluvium \\ Bandelier Tuff Tshirege Member Otowi Member Guaje Member \\ Puye Conglomerate Fanglomerate member}

$\begin{array}{cc}\begin{array}{c}\text { Water Level: Dry (1950) } \\ \text { Thickness } \\ (\mathrm{ft}) \\ 23\end{array} & \begin{array}{c}\text { Depth } \\ (\mathrm{ft})\end{array} \\ & 23 \\ 17 & 40 \\ 120 & 160 \\ 11 & 171 \\ 92 & 263\end{array}$

Water Level: Dry (1950) Thickness

$(\mathrm{ft})$

Depth

25

$\frac{(\mathrm{ft})}{25}$

$60 \quad 85$

$180 \quad 265$

$20 \quad 285$

$15 \quad 300$

\section{Casing Schedule Outer Diam (in.) $\quad$ Depth (ft) 8

Note: Water in alluvium cased out of hole. 
TABLE XVII-B. Geologic Logs and Construction Data for Test Wells and Test Holes on the Pajarito Plateau (15 Test Wells and Test Holes) (Continued)

10. Test Hole TH-7

Elevation (LSD): $6224 \mathrm{ft}$

Water Level: Dry (1950)

Geologic Log

Alluvium

Bandelier Tuff

Otowi Member

Basaltic Rocks of Chino Mesa

Unit 2

$\begin{array}{cc}\begin{array}{c}\text { Thickness } \\ \frac{(\mathrm{ft})}{10}\end{array} & \begin{array}{c}\text { Depth } \\ (\mathrm{ft})\end{array} \\ 35 & 10 \\ 10 & 45 \\ & 55\end{array}$

Hole plugged and abandoned.

11. Test Well TW-8

Elevation (LSD): $6877.62 \mathrm{ft}$

Water Level: $968 \mathrm{ft}$ (1960)

Geologic Log

Alluvium Thickness

Depth

Bandelier Tuff

Tshirege Member

40

(ft)

Otowi Member

Guaje Member

Puye Conglomerate

Fanglomerate member

Basalt Unit 2

Fanglomerate member

$20 \quad 60$

$385 \quad 445$

$45 \quad 490$

Casing Schedule

$44 \mathrm{ft}$ of 20 -in. corrugated metal pipe from 0 to $44 \mathrm{ft} ; 64 \mathrm{ft}$ of 14 -in.-outside-diam steel casing 0 to $64 \mathrm{ft}$ cemented in; $1065 \mathrm{ft}$ of 8 -in.-inside-diam steel casing from 0 to $1065 \mathrm{ft}$ with the lower $112 \mathrm{ft}$ slotted.

Geophysical Log

Gamma-ray (11-29-61), files available from the ESH-18 Geohydrology section.

12. Test Hole H-19

Elevation (LSD): $7178 \mathrm{ft}$

Geologic Log

Alluvium

Bandelier Tuff

Tshirege Member

Otowi Member

Guaje Member

Tschicoma Formation

Puye Conglomerate

Fanglomerate member

Tschicoma Formation

Puye Conglomerate

Totavi Lentil

Tschicoma Formation
Water Level: $950 \mathrm{ft}$ (1950) Thickness

(ft)

27

173

215

57

347

391

270

580

725

1065

$\begin{array}{cc}10 & 1490 \\ 510 & 2000\end{array}$


TABLE XVII-B. Geologic Logs and Construction Data for Test Wells and Test Holes on the Pajarito Plateau (15 Test Wells and Test Holes) (Continued)

12. Test Hole H-19 (Continued)

Casing Schedule

$10 \mathrm{ft}$ of 12 -in.-diam surface casing set 0 to $10 \mathrm{ft}$. Exploratory hole drilled by cable tool, casing pulled at end

of tests in 1949. Hole open to $265 \mathrm{ft}(5-7-60)$; to $69 \mathrm{ft}$ (7-20-92).

Geophysical Log

Gamma-ray (5-7-60), files available from the ESH-18 Geohydrology section.

13A. Test Hole Sigma Mesa EGH-LA-1 (1979)

Elevation (LSD): $7215 \mathrm{ft}$ LSD

Geologic Log ${ }^{\mathrm{a}}$

Tshirege Member Bandelier Tuff

Ash flow of Otowi Member

Bandelier Tuff

Guaje Pumice Bed

Puye Conglomerate with interbedded basalt

Aphyric Tschicoma Flow

Hornblende-bearing Tschicoma Flow

Fanglomerate member of Puye

Conglomerate

$\begin{array}{cc}\begin{array}{c}\text { Thickness } \\ (\mathrm{ft})\end{array} & \begin{array}{c}\text { Depth } \\ (\mathrm{ft})\end{array} \\ 270 & 270 \\ 430 & 700 \\ 35 & 735 \\ & \\ 110 & 845 \\ 80 & 925 \\ 45 & 970 \\ & \\ 365 & 1335 \\ & \\ 65 & 1400 \\ & \\ 500 & 1900 \\ 35 & 1935 \\ 60 & 1995 \\ 297 & 2292\end{array}$

Totavi Lentil of the Puye

Formation

Chamita Formation of the

Santa Fe Group

Tschicoma Flow

Chamita Formation of the Santa Fe Group

297

2292

13B. Test Hole Sigma Mesa EGH-LA-1 (1992)

Elevation (LSD): $7215 \mathrm{ft}$ LSD

Geologic Log ${ }^{b}$

Bandelier Tuff

Tshirege Member

Otowi Member

Guaje Member

Water Level: $1330 \mathrm{ft}(1979$, geophysical log)

Thickness Depth

(ft) $\quad$ (ft)

Puye Conglomerate

Fanglomerate member $\quad 185 \quad 910$

Basalt Unit $2 \quad 140 \quad 1050$

Fanglomerate member $\quad 255 \quad 1305$

Totavi Lentil $\quad 25 \quad 1330$

Santa Fe Group

Chaquehui Formation $\quad 250 \quad 1580$

Basalt and basalt breccias $\quad 135 \quad 1715$

Chaquehui Formation $\quad 180 \quad 1895$

Basalt and basalt breccias $\quad 397 \quad 2292$

a Logged by Carolyn Potzich.

${ }^{b}$ Revised log by W. D. Purtymun from geophysical logs, comparision with logs of nearby supply and test wells, and R. F. Smith Corp. Geothermal Data Log. 
TABLE XVII-B. Geologic Logs and Construction Data for Test Wells and Test Holes on the Pajarito Plateau (15 Test Wells and Test Holes) (Continued)

13B. Test Hole Sigma Mesa EGH-LA-1 (1992)(Continued)

Casing Schedule

Hole size: 36 -in. diam to $85 \mathrm{ft}, 26$-in. diam to $2292 \mathrm{ft}$; casing size 30 -in. diam to $85 \mathrm{ft}, 20$-in. diam to $1627 \mathrm{ft}$. Hole plugged with cement at about $1425 \mathrm{ft}$; unknown length of drill stem, drill collars, and bit lost in the bottom of the hole. The hole had a bad history of lost circulation throughout the entire depth drilled; large volumes of water, drilling mud, lost circulation materials, and cement were pumped into the hole. The hole was abandoned in December 1979.

\section{Geophysical Logs}

Temperature, compensated neutron-formation density; dual induction-SFL with linear correlation log; and R.F. Smith Corp. Geothermal Data Log (files available from the ESH-18 Geohydrology section).

14. Layne Western

Elevation (LSD): $5971 \mathrm{ft}$

Geologic Log

Alluvium

Puye Conglomerate

Fanglomerate member

Totavi Lentil

Tesuque Formation

Siltstone and sandstone
Water Level: $100 \mathrm{ft}$ (1950) Thickness

(ft)

12

$13 \quad 25$

$50 \quad 75$

82

157 (ft)

Casing Schedule

$147 \mathrm{ft}$ of 8 -in.-diam casing set from 0 to $147 \mathrm{ft}$, screen from 127 to $147 \mathrm{ft}$.

15. Ski Basin Well

Elevation (LSD): $9310 \mathrm{ft}$

Geologic Log

Tough sandstone (probably Tshirege Member Bandelier Tuff, welded unit)

Lost circulation: same formation throughout, probably Tschicoma

Formation latite and rhyolite

flow, water perched on interflow breccia of pebbly cobbles in a matrix of silt and clay
Water Level: $245 \mathrm{ft}$ (June 1985) Thickness

(ft)

Depth

(ft)

35

35 
TABLE XVII-C. Drilling Progress Report for Sigma Mesa EGH-LA-1

\begin{tabular}{|c|c|c|c|}
\hline $\begin{array}{c}\text { Lost } \\
\text { Circulation }\end{array}$ & Cement & $\begin{array}{l}\text { Number } \\
\text { of Sacks }\end{array}$ & $\begin{array}{l}\text { Top Depth } \\
\text { after Setting }\end{array}$ \\
\hline $\begin{array}{l}\text { Depth } \\
\text { (ft) }\end{array}$ & $\begin{array}{l}\text { Plug } \\
\text { (No.) }\end{array}$ & $\begin{array}{c}\text { of } \\
\text { Cement }\end{array}$ & $\begin{array}{c}\text { Plug } \\
\text { (ft) }\end{array}$ \\
\hline 787 & $1-8$ & 3005 & 75 \\
\hline 240 & 9 & 900 & 62 \\
\hline 461 & 10 & 325 & 437 \\
\hline 749 & 11 & 350 & 681 \\
\hline 733 & 12 & 450 & 539 \\
\hline 760 & 13 & 450 & 683 \\
\hline $773^{a}$ & 14 & 450 & 618 \\
\hline 987 & 15 & 450 & 816 \\
\hline 1133 & 16 & 225 & 1057 \\
\hline \multirow[t]{2}{*}{$1412^{\mathrm{b}}$} & $17-19$ & 675 & 1264 \\
\hline & & 7280 & \\
\hline
\end{tabular}

a Drilled without returns from $773 \mathrm{ft}$ to $818 \mathrm{ft}$ when plug 14 was set.

b Plug 17 was set at $1412 \mathrm{ft}$ and tagged at $1348 \mathrm{ft}$. Lost 500 barrels of mud trying to establish returns. Set plug 18 at $1348 \mathrm{ft}$ and tagged at $1264 \mathrm{ft}$. Still could not establish circulation, attempted to set plug 19. Plug 19 disappeared completely into the formation.

From the technical status report for July 1979.

TABLE XVII-D. Locations and Elevations (NAD 1927)

Test Well TW-1

Test Well TW-1A

Test Well TW-2

Test Well TW-2A

Test Well TW-2B

Test Well TW-3

Test Well TW-4

Test Hole TH-5

Test Hole TH-6

Test Hole TH-7

Test Well TW-8

Test Hole H-19

Sigma Mesa

Layne Western

Ski Basin Well
N 1,772,014.8
N 1,772,003.7
N 1,777,205.8
N $1,777,226.0$
N $1,777,200$
N 1,773,075.9
N 1,777,618.0
N 1,756,514.6
N 1,757,817.7
N $1,740,400$
N 1,769,444.6
N $1,775,400$
N $1,771,800$
N 1,783,200
N $1,780,700$

E $509,797.3$
E $509,812.7$
E $493,986.9$
E $493,940.6$
E 493,900
E $497,483.2$
E $483,783.9$
E $503,312.1$
E $500,272.2$
E 500,500
E $492,329.6$
E 478,200
E 484,100
E 516,000
E 457,700

E $509,797.3$

$6369.2 \mathrm{ft}$

$6369.3 \mathrm{ft}$

$6648.1 \mathrm{ft}$

$6650.4 \mathrm{ft}$

$6647 \mathrm{ft}$

$6595.3 \mathrm{ft}$

$7244.6 \mathrm{ft}$

$6591.6 \mathrm{ft}$

$6642.1 \mathrm{ft}$

$6224 \mathrm{ft}$

$6877.6 \mathrm{ft}$

$7178 \mathrm{ft}$

$7215 \mathrm{ft}$

$5971 \mathrm{ft}$

$9310 \mathrm{ft}$ 


\section{TEST HOLES IN THE VALLE TOLEDO AND VALLE GRANDE (1948)}

Seven test holes ranging in depth from 31 to 361 $\mathrm{ft}$ were drilled in the Valle Toledo and Valle Grande during the spring and summer of 1948 (Fig. XVIII-A, Table XVIII-A). The holes were drilled to determine if a water supply for Los Alamos could be obtained from the Valle Toledo or Valle Grande in Valles Caldera west of Los Alamos (Stearns 1948).

The seven test holes drilled in the caldera encountered water in the alluvium along the stream channels of San Antonio Creek, the East Fork of the Jemez and the older lake clay and sediments (Table XVIII-B). Bailing tests indicated that water was

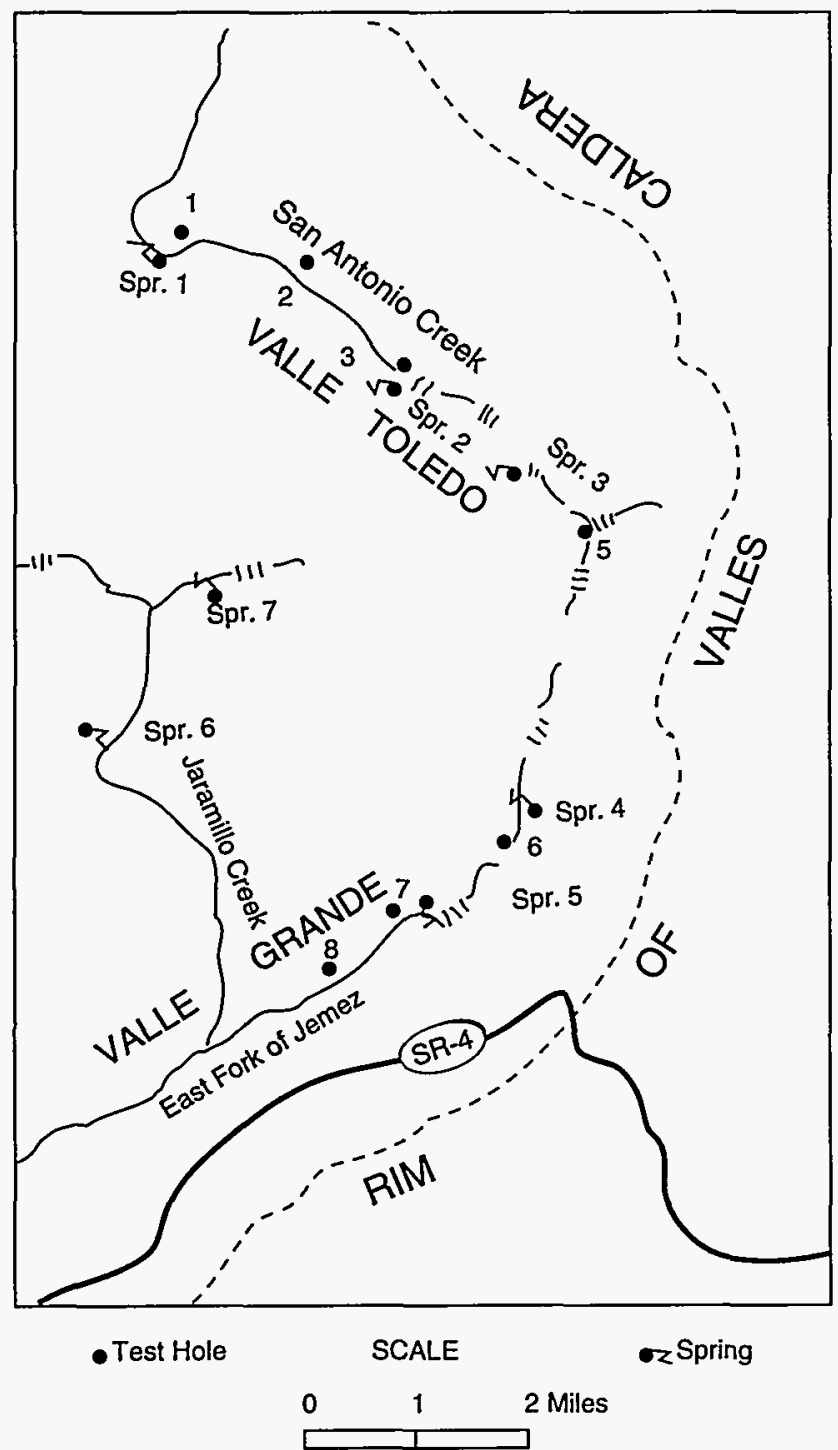

available; however, the amount could not be determined without additional investigation.

An inventory was made of the springs in the two areas (Fig. XVIII-A and Table XVIII-C). The discharge from the three springs in the Valle Toledo and the four springs in the Valle Grande ranged from 15 to $875 \mathrm{gpm}$.

\section{REFERENCE}

H. T. Stearns, "Ground-Water Supplies for Los Alamos," Consulting Report to the U.S. Atomic Energy Commission (1948).
Fig. XVIII-A. Test wells and springs in the Valle Toledo and Valle Grande (Stearns 1948). 


\begin{tabular}{lcccccc}
\hline \multicolumn{7}{c}{ TABLE XVIII-A. Records of the Test Holes in the Valle Toledo and } \\
Valle Grande
\end{tabular}

Source: Stearns 1948. 


\section{Test Hole 1}

Location: Valle Toledo

Depth: $100 \mathrm{ft}$

Depth to water: $10 \mathrm{ft}$ after $15 \mathrm{~min}$ bailing and $10 \mathrm{~min}$ recovery; hole filled up to $73 \mathrm{ft}$ with sand while bailing; abundant water.

\section{$\underline{\log }$}

Silt, sand, and gravel

Sand and gravel alternating with sticky brown clay
Thickness

(ft)

11

89
Depth

(ft)

11

100

\section{Test Hole 2}

Location: Valle Toledo

Depth: $100 \mathrm{ft}$

Depth to water: artesian flow at $73 \mathrm{gpm}$.

\section{$\underline{\log }$}

Silt, sand, and gravel, cobbles

Sand and gravel alternating with sticky clay
Thickness

(ft)

11

89
Depth

(ft)

11

100

\section{Test Hole 3}

Location: Valle Toledo

Depth: $31 \mathrm{ft}$

Depth to water: $4.5 \mathrm{ft}$; hole abandoned due to running sand.

$\underline{\log }$

Thickness

Depth

Loose rock, sand,

(ft)

(ft)

gravel, and clay

31

31

\section{Test Hole 4}

No hole drilled.

\section{Test Hole 5}

Location: Valle Toledo

Depth: $361 \mathrm{ft}$

Depth to water: $128.8 \mathrm{ft}$; there was some flow of water into the hole from the $15 \mathrm{ft}$ level.

Log

Thickness

Depth

Sand and gravel, some angular, volcanic rock

Sand, gravel, with some clay lenses, all volcanic rock, containing much pumice

(ft)

(ft)

11

11

350

361

Note: The whole section or deposit compacted to stand as an open hole, but was not firm enough to core; from 26 to $361 \mathrm{ft}$ lapilli of rhyolitic tuff, weakly consolidated. 
TABLE XVIII-B. Geologic Logs of Test Holes in the Valle Toledo and Valle Grande

(7 Test Holes) (Continued)

6. Test Hole 6

Location: Valle Grande

Depth: $140 \mathrm{ft}$

Depth to water: $10 \mathrm{ft}$; bailed at $30 \mathrm{gpm}$ without lowering water level; hole filled up with sand to $70 \mathrm{ft}$ after bailing.

\section{$\underline{\log }$}

Gravel with some clay

Gravel, clay, volcanic debris and pumice

$\begin{array}{cc}\begin{array}{c}\text { Thickness } \\ (\mathrm{ft})\end{array} & \begin{array}{c}\text { Depth } \\ (\mathrm{ft})\end{array} \\ 130 & 10 \\ & 140\end{array}$

\section{Test Hole 7}

Location: Valle Grande

Depth: $40 \mathrm{ft}$

Depth to water: $5.5 \mathrm{ft}$ (6-29-48); 6.0 (7-1-48)

\section{$\underline{\log }$}

Rhyolite and obsidian gravel

$\begin{array}{cc}\begin{array}{c}\text { Thickness } \\ \frac{(\mathrm{ft})}{40}\end{array} & \begin{array}{c}\text { Depth } \\ (\mathrm{ft})\end{array} \\ 40\end{array}$

Note: Hole abandoned due to broken core barrel.

\section{Test Hole 8}

Location: Valle Grande

Depth: $299 \mathrm{ft}$

Depth to water: $3.5 \mathrm{ft}(6-30-48) ; 2.6$ (7-1-48)

\section{$\underline{\log }$}

Sticky brown lake-bed clay

Thickness

$\underline{(\mathrm{ft})}$

288

11
Depth

$\frac{(\mathrm{ft})}{288}$

$\frac{(f)}{288}$

299 quartz grains

Source: Stearns 1948.

TABLE XVIII-C. Records of Springs in the Valle Toledo and Valle Grande

\begin{tabular}{ccc}
$\begin{array}{c}\text { Elevation } \\
\text { LSD } \\
(\mathrm{ft})\end{array}$ & $\begin{array}{c}\text { Topographic Situation } \\
\text { and }\end{array}$ & $\begin{array}{c}\text { Estimated } \\
\text { Discharge } \\
(\mathrm{gpm})\end{array}$ \\
\hline
\end{tabular}

Valle Toledo

Spring 1

8570

Spring 2

8732

Spring 3

8768

Contact alluvium and rhyolite

875

Contact alluvium and rhyolite

Alluvium

Valle Grande

Spring 4

8600

Spring 5

8524

Spring 6

8640

Alluvium

Spring 7

8700

Fractured rhyolite

Rhyolite

Contact alluvium and rhyolite

Note: Elevations estimated with aneroid barometer; data collected June 1948.

Source: Stearns 1948. 


\section{A. Valle Toledo}

TH-1

TH-2

TH-3

TH-4

TH-5

B. Valle Grande

$$
\begin{gathered}
\text { N } 1,804,000 \\
\text { N } 1,802,000 \\
\text { N } 1,799,000 \\
\text { (hole not drilled) } \\
\text { N } 1,791,000
\end{gathered}
$$

E 431,000

E 437,000

E 441,000

E 451,000

E 447,000

E 441,000

E 439,000

N $1,773,000$

N $1,770,000$

N $1,804,000$

N 1,799,000

N 1,794,000

Spring 2

Spring 3

D. Valle Grande

\section{Spring 4}

Spring 5

Spring 6

Spring 7
N $1,778,000$
N $1,773,000$
N $1,780,800$
N $1,788,000$
E 430,000

E 441,000

E 444,000

E 447,000

E 444,000

E 427,500

E 431,000
$8599 \mathrm{ft}$

$8650 \mathrm{ft}$

$8740 \mathrm{ft}$

$8930 \mathrm{ft}$

$8590 \mathrm{ft}$

$8532 \mathrm{ft}$

$8507 \mathrm{ft}$

$8570 \mathrm{ft}$

$8732 \mathrm{ft}$

$8768 \mathrm{ft}$

$8600 \mathrm{ft}$ $8524 \mathrm{ft}$ $8640 \mathrm{ft}$ $8700 \mathrm{ft}$

Note: Location to the nearest $1000 \mathrm{ft}$; no topographic map existed when work was done (see Fig. XVIII-A).

Source: Stearns 1948. 


\section{TEST HOLES IN THE VALLE TOLEDO, VALLE GRANDE, AND VALLE DE LOS POSOS (1949)}

As a result of the 1948 investigation (see Section XVIII), 17 test holes were drilled in the Valle Toledo, Valle Grande, Valle de los Posos, and adjacent areas (Figs. XIX-A, XIX-B, and XIX-C). Six holes in the Valle Toledo (H-1 through $\mathrm{H}-6$ ) and six holes in the Valle Grande ( $\mathrm{H}-7$ through $\mathrm{H}-12$ ) were laid out for aquifer tests (Fig. XIX-D and Fig. XIX-E). The remaining holes were drilled for additional geologic and hydrologic information in the Valle de los Posos ( $\mathrm{H}-13, \mathrm{H}-17)$, one ( $\mathrm{H}-14)$ on the divide between Valle Toledo and Valle Grande, one ( $\mathrm{H}-15)$ at the upper end of the Valle Grande, and one (H-16) on the east rim of the caldera (Table XIX-A).

The test holes penetrated alluvium, Quaternary fill (gravels washed out from the flanks of the caldera), and caldera fill (lake sediments and gravels). A lake occupied the depression after the formation of the Valles Caldera. Sediments that accumulated in the lake consisted of clayey silt, sand, and gravel derived from the volcanic debris that formed the inner walls and rim of the caldera. Gravel lenses are numerous, interbedded with sand and silt lenses. The lake sediments and caldera fill are porous and permeable.
The wells used in the aquifer tests were completed into the lake sediments or caldera fill as shown by the geologic logs and construction details (Table XIX-B). The results of the aquifer tests indicated that there was water available for a water supply for Los Alamos; however, the testing indicated that the amount of water that would need to be pumped would deplete the stream flow. As water in the stream was already owned by downstream users, additional testing was discontinued. The planned development of a water supply from the Valle Toledo and Valle Grande was terminated (Griggs 1955, Conover et al. 1963).

\section{REFERENCES}

R. L. Griggs, "Geology and Water Resources of the Los Alamos Area, New Mexico," U.S. Geol. Survey Admin. Report to the U.S. Atomic Energy Commission (1955).

C. S. Conover, C. V. Theis, and R. L. Griggs, "Geology and Hydrology of the Valle Grande and Valle Toledo, Sandoval County, New Mexico," U.S. Geol. Survey Water-Supply Paper 1619-Y (1963).

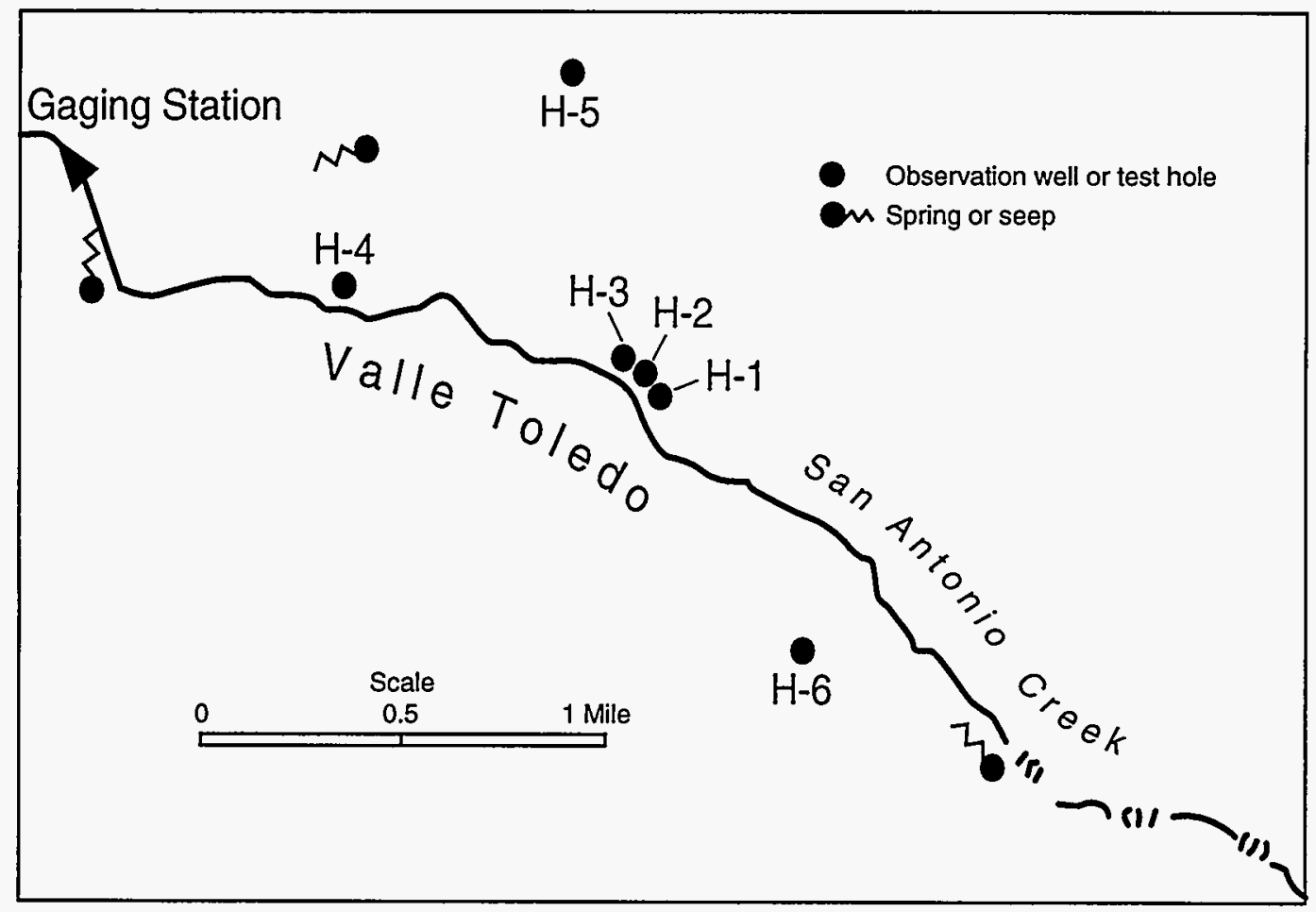

Fig. XIX-A. Locations of test holes in the Valle Toledo (1949). 


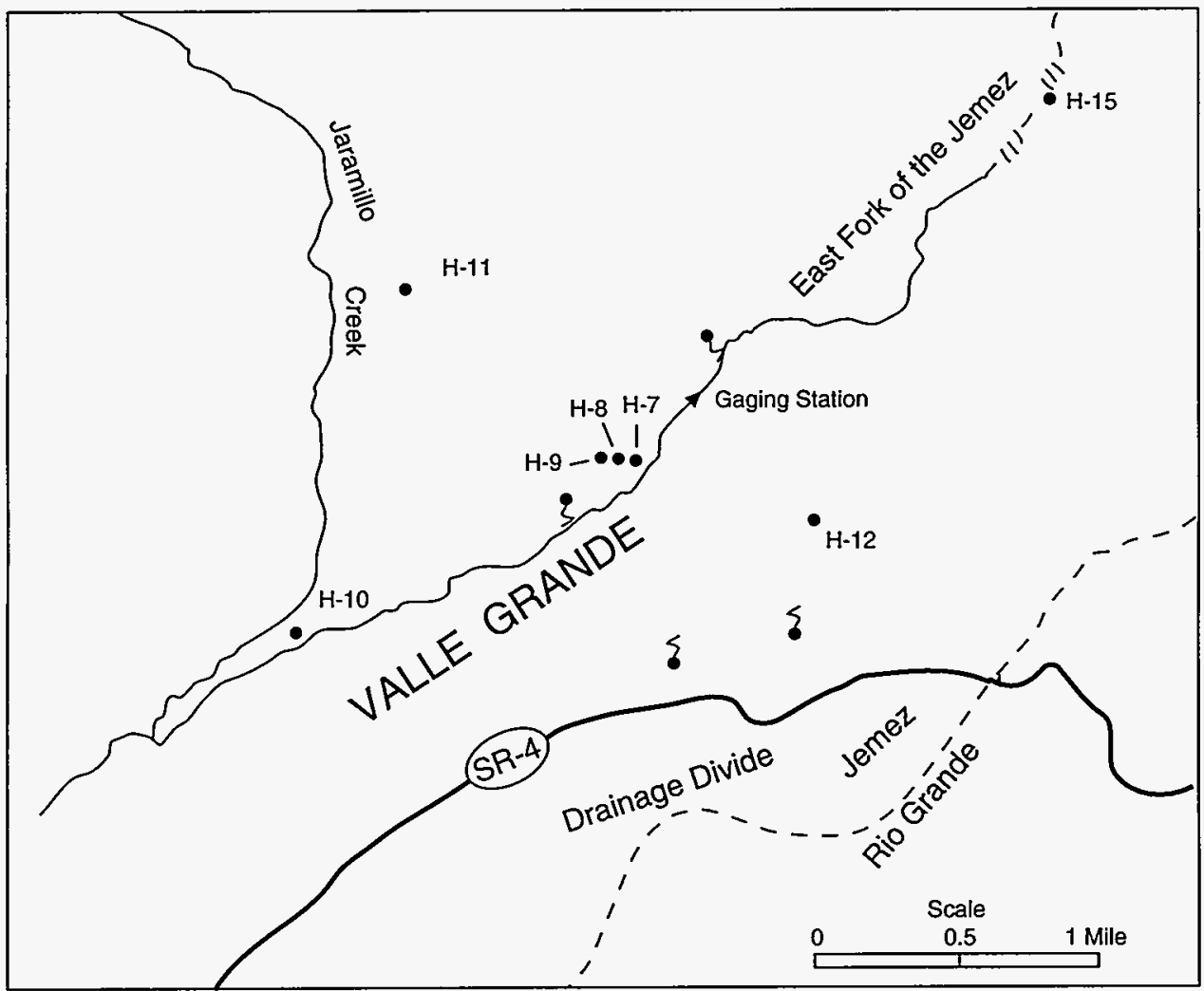

Fig. XIX-B. Generalized location of test holes in the Valle Grande (1949).

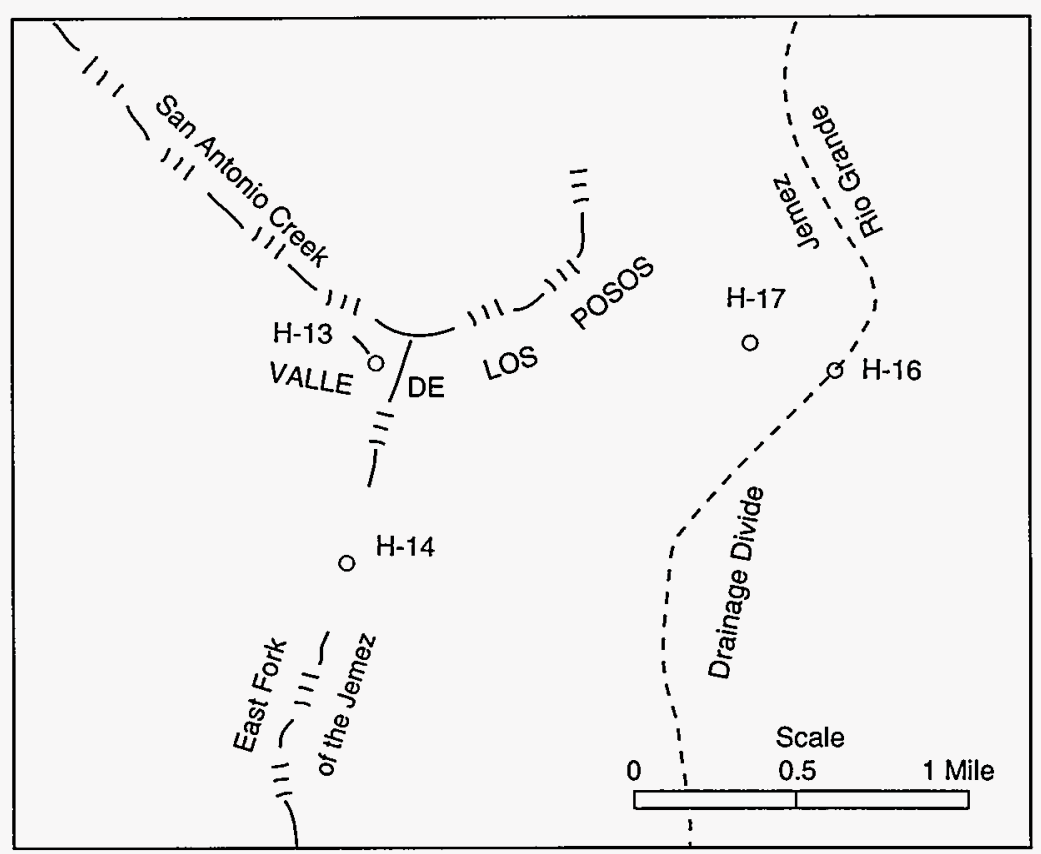

Fig. XIX-C. Locations of test holes in the Valle de los Posos and on the drainage divide. 


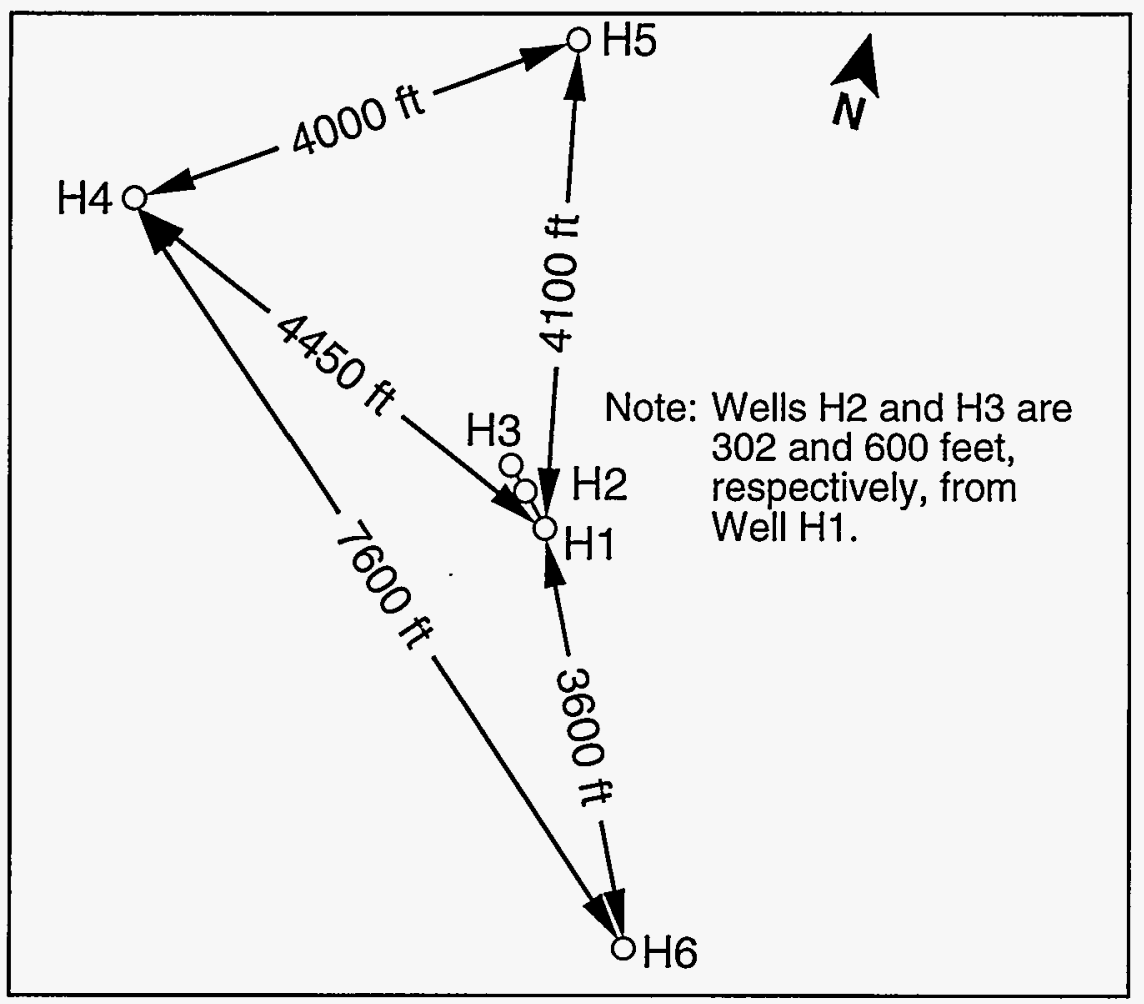

Fig. XIX-D. Locations of test holes used in the aquifer test in the Valle Toledo (Griggs 1955). See also Fig. XIX-A.

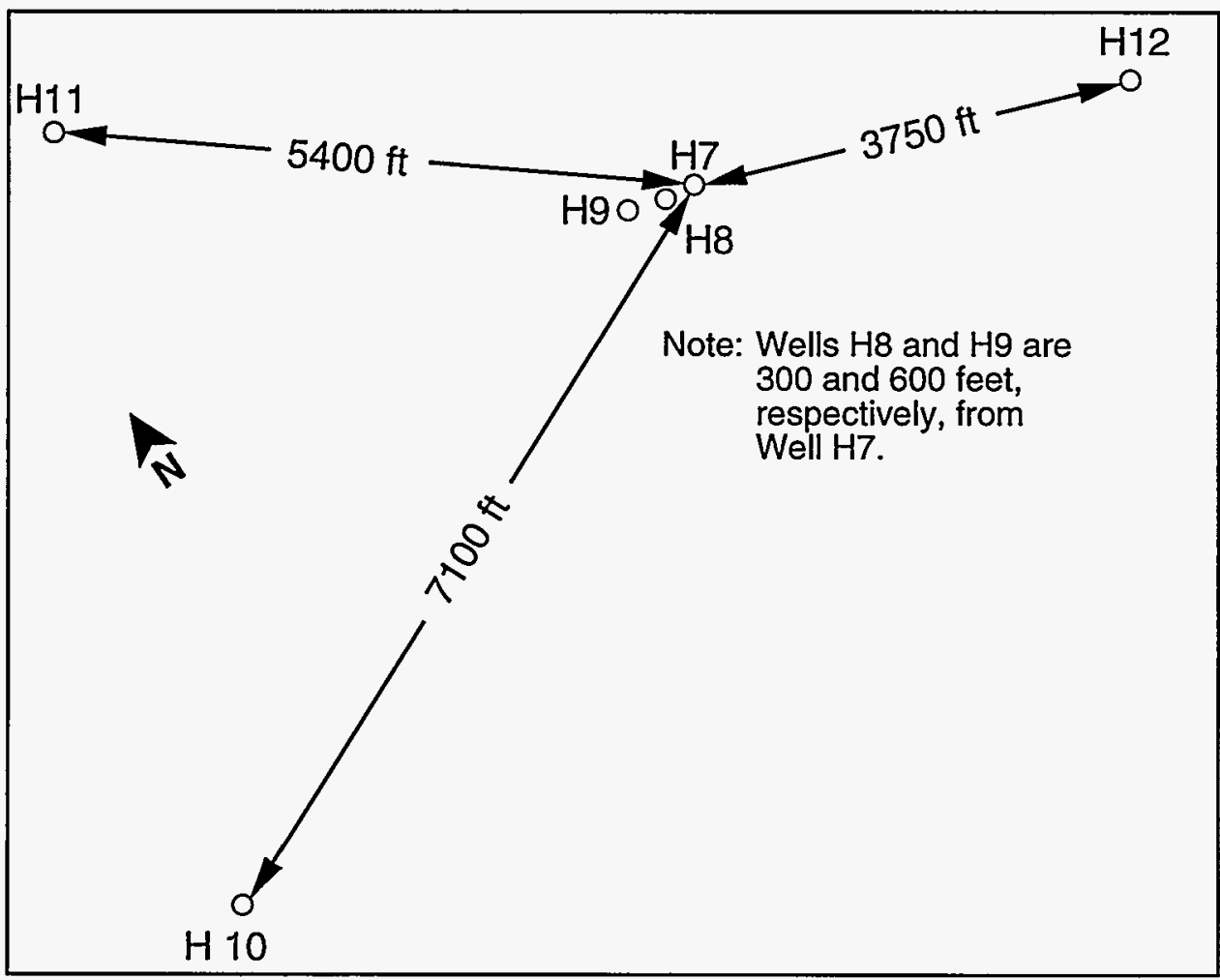

Fig. XIX-E. Locations of test holes used in the aquifer test in the Valle Grande (Griggs 1955). See also Fig. XIX-B. 
TABLE XIX-A. Records of Test Holes in the Valle Toledo, Valle Grande, and Adjacent Areas

\section{Head of}

Pressure When

Completed $(+\mathrm{ft})$

Water Level

$\begin{array}{cccc} & \text { Elevation } & & \text { Water Level } \\ \text { Month } & \text { LSD } & \text { Depth } & \text { below LSD } \\ \text { Completed } & (\mathrm{ft}) & (\mathrm{ft}) & (\mathrm{ft})\end{array}$

Remarks

Valle Toledo

$\begin{array}{lllll}\text { H-1 } & 10 / 49 & 8650 & 652 & +36 \\ & & & & \\ \text { H-2 } & 10 / 49 & 8648 & 410 & +35 \\ \text { H-3 } & 10 / 49 & 8647 & 405 & +38 \\ \text { H-4 } & 10 / 49 & 8603 & 285 & -7.5 \\ \text { H-5 } & 10 / 49 & 8769 & 530 & -71 \\ \text { H-6 } & 10 / 49 & 8684 & 444 & +19\end{array}$

$\underline{\text { Valle Grande }}$

$\begin{array}{lllll}\text { H-7 } & 11 / 49 & 8507 & 1185 & +9.6 \\ & & & & \\ \text { H-8 } & 11 / 49^{\circ} & 8506 & 595 & +11 \\ \text { H-9 } & 11 / 49 & 8506 & 595 & +11 \\ \text { H-10 } & 11 / 49 & 8491 & 589 & +23 \\ \text { H-11 } & 11 / 49 & 8534 & 630 & -16 \\ \text { H-12 } & 11 / 49 & 8545 & 634 & -15\end{array}$

Specific capacity: $10 \mathrm{gpm} / \mathrm{ft}$ of drawdown

Specific capacity: $50 \mathrm{gpm} / \mathrm{ft}$ of drawdown

$+38$

$-7.5$

$+19$

Valle de los Posos
$\mathrm{H}-13^{\mathrm{a}}$
$10 / 49$
8930
800
Log-no mention of water

$\underline{\text { Divide }}$
$\mathrm{H}-14^{\mathrm{a}}$
$10 / 49$
8990
420
Log-no mention of water

Valle Grande

$\begin{array}{llll}\mathrm{H}-15^{\mathrm{a}} & 10 / 49 & 9505 & 1269\end{array}$

Log-several water-bearing zones

East Rim of Caldera
H-16
1949
9505
1269
Log-no mention of water

Valle de los Posos

1949

9237

493

Log_no mention of water

Note: Test holes completed in caldera fill, except for H-16 and H-17 (completed in the Bandelier Tuff and Tschicoma Formation).

aNo casing.

Source: Griggs 1955. 
TABLE XIX-B. Geologic Logs and Casing Schedules of Test Holes in the Valle Toledo, Valle Grande, and Adjacent Areas (17 Test Holes)

1. $\underline{\text { Hole } \mathrm{H}-1}$

Location: Valle Toledo

Depth: $652 \mathrm{ft}$

$\underline{\log }$

Alluvium

Caldera fill

Water: 95 to $140 \mathrm{ft}$

Water: 175 to $345 \mathrm{ft}$

Water: 370 to $410 \mathrm{ft}$

$\begin{array}{cc}\begin{array}{c}\text { Thickness } \\ \frac{(\mathrm{ft})}{12}\end{array} & \begin{array}{c}\text { Depth } \\ (\mathrm{ft})\end{array} \\ 640 & 12 \\ & 652\end{array}$

Casing Record

$70 \mathrm{ft}$ of 16-in.-diam surface casing cemented in 0 to $70 \mathrm{ft} ; 450 \mathrm{ft}$ of 12-in.-diam casing with $40 \mathrm{ft}$ of screen from 383 to $427 \mathrm{ft}$; 12-in.-diam casing perforated from: 80 to $120 \mathrm{ft} ; 125$ to $150 \mathrm{ft} ; 170$ to $240 \mathrm{ft} ; 265$ to 300 $\mathrm{ft}$; and 329 to $340 \mathrm{ft}$.

2. Hole H-2

Location: Valle Toledo

Depth: $410 \mathrm{ft}$

\section{$\underline{\log }$}

Same as Hole $\mathrm{H}-1,300 \mathrm{ft}$ east

Casing Record

$79 \mathrm{ft}$ of 6-in.-diam surface casing cemented in 0 to $79 \mathrm{ft} ; 407 \mathrm{ft}$ of 2-in.-diam tubing with 30-in. sandpoint at lower end, set 0 to $407 \mathrm{ft}$.

\section{Hole H-3}

Location: Valle Toledo

Depth: $405 \mathrm{ft}$

$\underline{\log }$

Same as Hole $\mathrm{H}-1,600 \mathrm{ft}$ east

Casing Record

$64 \mathrm{ft}$ of 6 -in.-diam casing cemented in 0 to $64 \mathrm{ft} ; 405 \mathrm{ft}$ of 2-in.-diam tubing with 30-in. sandpoint at lower end, set 0 to $405 \mathrm{ft}$.

4. Hole H-4

Location: Valle Toledo

Depth: $285 \mathrm{ft}$

$\underline{\log }$

Thickness

Depth

Alluvium

(ft)

Caldera fill

10

275

(ft)

10

Water: 115 to $210 \mathrm{ft}$

285

Casing Record

$49 \mathrm{ft}$ of 6-in.-diam casing cemented in 0 to $49 \mathrm{ft} ; 240 \mathrm{ft}$ of 4 -in.-diam tubing with 30-in. sandpoint at lower end, set 0 to $240 \mathrm{ft}$. 
TABLE XIX-B. Geologic Logs and Casing Schedules of Test Holes in the Valle Toledo, Valle Grande, and Adjacent Areas (17 Test Holes) (Continued)

\section{5. $\underline{\text { Hole H}-5}$}

Location: Valle Toledo

Depth: $530 \mathrm{ft}$

$\underline{\log }$

Terrace material Gravel, sandy to silty, light gray

Caldera fill Water: 320 to $530 \mathrm{ft}$

\section{Thickness}

(ft)

32

498
Depth

$\underline{(\mathrm{ft})}$

32

530

\section{Casing Record}

$99 \mathrm{ft}$ of 6-in.-diam casing cemented in 0 to $99 \mathrm{ft} ; 527 \mathrm{ft}$ of 2-in.-diam tubing with a 30-in. sandpoint on lower end set 0 to $530 \mathrm{ft}$.

6. Hole H-6

Location: Valle Toledo

Depth: $444 \mathrm{ft}$

$\underline{\log }$

Alluvium

Caldera fill

Thickness

Depth

(ft)

5

439

(ft)

5

Water: 110 to $400 \mathrm{ft}$

Casing Record

$99 \mathrm{ft}$ of 6-in.-diam casing cemented in 0 to $99 \mathrm{ft} ; 441 \mathrm{ft}$ of 2-in.-diam tubing with 30 -in. sandpoint on lower end, set 0 to $444 \mathrm{ft}$.

\section{7. $\underline{\text { Hole H-7 }}$}

Location: Valle Grande

Depth: $1185 \mathrm{ft}$

$\underline{\log }$

Alluvium

Caldera fill

Water: 300 to $860 \mathrm{ft}$

$\begin{array}{cc}\begin{array}{c}\text { Thickness } \\ (\mathrm{ft})\end{array} & \begin{array}{c}\text { Depth } \\ (\mathrm{ft})\end{array} \\ 10 & 10 \\ 1175 & 1185\end{array}$

\section{Casing Record}

$66 \mathrm{ft}$ of 16-in.-diam surface casing cemented in 0 to $66 \mathrm{ft}$; $595 \mathrm{ft} 12$-in.-diam casing with five 10 -ft screen sections set up at intervals, 300 to $595 \mathrm{ft}$; the 12-in.-diam casing between the screen sections torch slotted.

8. $\underline{\text { Hole } \mathrm{H}-8}$

Location: Valle Grande

Depth: $595 \mathrm{ft}$

$\underline{\log }$

Same as Hole H-7, $300 \mathrm{ft}$ east

Casing Record

$60 \mathrm{ft}$ of 6-in.-diam casing cemented in 0 to $60 \mathrm{ft}, 592 \mathrm{ft}$ of 2-in.-diam tubing with 30-in. sandpoint at lower end, set 0 to $595 \mathrm{ft}$. 
TABLE XIX-B. Geologic Logs and Casing Schedules of Test Holes in the Valle Toledo, Valle Grande, and Adjacent Areas (17 Test Holes) (Continued)

9. $\underline{\text { Hole H-9 }}$

Location: Valle Grande

Depth: $595 \mathrm{ft}$

$\underline{\log }$

Same as Hole $\mathrm{H}-7,700 \mathrm{ft}$ east

Casing Record

$67 \mathrm{ft}$ of 6-in.-diam casing cemented in 0 to $67 \mathrm{ft} ; 592 \mathrm{ft}$ of 2-in.-diam tubing with 30-in. sandpoint on lower end, set 0 to $595 \mathrm{ft}$.

10. $\underline{\text { Hole H-10 }}$

Location: Valle Grande

Depth: $589 \mathrm{ft}$

Log

Alluvium

Caldera fill

Thickness

Depth

(ft)

15

574

(ft)

15

589

Water: 205 to $589 \mathrm{ft}$

Casing Record

$65 \mathrm{ft}$ of 6 -in.-diam casing cemented in 0 to $65 \mathrm{ft} ; 581 \mathrm{ft}$ of 2 -in.-diam tubing with 30-in. sandpoint at lower end, set 0 to $584 \mathrm{ft}$.

\section{Hole $\mathrm{H}-11$}

Location: Valle Grande

Depth: $630 \mathrm{ft}$

$\underline{\log }$

Thickness Depth

(ft) $\quad(\mathrm{ft})$

Terrace material, Sand and gravel, light gray to light buff

Caldera fill

Water: 275 to $305 \mathrm{ft}$

Water: 310 to $630 \mathrm{ft}$

Casing Record

$88 \mathrm{ft}$ of 6 -in.-diam casing cemented in 0 to $88 \mathrm{ft} ; 622 \mathrm{ft}$ of 2-in.-diam tubing with 30 -in. sandpoint at lower end, set 0 to $625 \mathrm{ft}$.

12. Hole H-12

Location: Valle Grande

Depth: $634 \mathrm{ft}$

Log

$\begin{array}{cc}\begin{array}{c}\text { Thickness } \\ (\mathrm{ft})\end{array} & \begin{array}{c}\text { Depth } \\ (\mathrm{ft})\end{array} \\ 35 & \\ 599 & 35 \\ & 634\end{array}$

$\begin{array}{lcc}\text { Gravel, sandy, light buff } & 35 & 35 \\ \text { Caldera fill } & 599 & 634\end{array}$

Water: 212 to $634 \mathrm{ft}$ 
TABLE XIX-B. Geologic Logs and Casing Schedules of Test Holes in the Valle Toledo, Valle Grande, and Adjacent Areas (17 Test Holes) (Continued)

12. Hole H-12 (Continued)

Casing Record

$71 \mathrm{ft}$ of 6-in.-diam casing cemented in 0 to $77 \mathrm{ft} ; 634 \mathrm{ft}$ of 2 -in.-diam tubing with 30 -in. sandpoint at lower end, set 0 to $634 \mathrm{ft}$.

13. Hole H-13

Location: Valle de los Posos

Depth: $800 \mathrm{ft}$

\section{$\underline{\log }$}

Quaternary fan

Gravel outwash, gray

Caldera fill

(no water)

Thickness

(ft)

30

770
Depth

(ft)

30

800

Casing Schedule

No casing.

14. $\underline{\text { Hole } \mathrm{H}-14}$

Location: Divide between the Valle Grande and the Valle de los Posos

Depth: $420 \mathrm{ft}$

$\underline{\log }$

Quaternary fan

Gravel outwash, gray

Caldera Fill

Valle Rhyolite: rhyolite dome of pumiceous glass, sanidine, quartz, biotite, and hornblende (no water)

Thickness

(ft)

97

311

12
Depth

(ft)

97

408

420

Casing Schedule

No casing.

\section{Hole H-15}

Location: Valle Grande

Depth: $600 \mathrm{ft}$

$\underline{\log }$

Quaternary fan Gravel outwash

Caldera fill

Water: 125 to $400 \mathrm{ft}$

$\begin{array}{cc}\begin{array}{c}\text { Thickness } \\ (\mathrm{ft})\end{array} & \begin{array}{c}\text { Depth } \\ (\mathrm{ft})\end{array} \\ 7 & \\ 593 & 7 \\ & 600\end{array}$

Casing Schedule

No casing. 
TABLE XIX-B. Geologic Logs and Casing Schedules of Test Holes in the Valle Toledo, Valle Grande, and Adjacent Areas (17 Test Holes) (Continued)

16. $\underline{\text { Hole H-16 }}$

Location: East Rim of Caldera

Depth: $1269 \mathrm{ft}$

$\underline{\log }$

Bandelier Tuff

Tshirege Member

Bandelier Tuff

Undifferentiated

Tschicoma Formation

latite and quartz,

latite flows

(no water)

Casing Schedule

No casing.

17. Hole H-17

Location: Valle de los Posos

Depth: $493 \mathrm{ft}$

$\underline{\log }$

Quaternary fan: gravel

Bandelier Tuff

Thickness

Depth

(ft)

(ft)

295

295

332

627

642

1269

Tschicoma Formation

Latite flow

(no water)

Thickness

Depth

(ft)

10

(ft)

413

10

423

70

493

Casing Schedule

No casing.

Source: Griggs 1955. 


$\begin{array}{llll}\text { A. Valle Toledo } & & & \\ \text { H-1 } & \text { N } 1,802,400 & \text { E 437,200 } & 8650 \mathrm{ft} \\ \text { H-2 } & \text { N } 1,802,700 & \text { E 436,900 } & 8648 \mathrm{ft} \\ \text { H-3 } & \text { N } 1,802,900 & \text { E 436,700 } & 8647 \mathrm{ft} \\ \text { H-4 } & \text { N } 1,803,900 & \text { E } 432,900 & 8603 \mathrm{ft} \\ \text { H-5 } & \text { N } 1,806,600 & \text { E 436,000 } & 8769 \mathrm{ft} \\ \text { H-6 } & \text { N } 1,799,600 & \text { E } 438,900 & 8684 \mathrm{ft}\end{array}$

B. Valle Grande

$\begin{array}{llll}\text { H-7 } & \text { N } 1,769,900 & \text { E 439,200 } & 8507 \mathrm{ft} \\ \text { H-8 } & \text { N } 1,769,900 & \text { E 438,900 } & 8506 \mathrm{ft} \\ \text { H-9 } & \text { N } 1,770,000 & \text { E 438,600 } & 8506 \mathrm{ft} \\ \text { H-10 } & \text { N } 1,766,600 & \text { E 432,700 } & 8491 \mathrm{ft} \\ \text { H-11 } & \text { N } 1,773,100 & \text { E 434,800 } & 8534 \mathrm{ft} \\ \text { H-12 } & \text { N } 1,768,700 & \text { E 442,700 } & 8545 \mathrm{ft}\end{array}$

C. Valle de los Posos

$\mathrm{H}-13$

D. Divide

$\mathrm{H}-14$

E. Valle Grande

$\mathrm{H}-15$

F. East Rim of Caldera

H-16

G. Valle de los Posos

$\mathrm{H}-17$

N $1,790,900$

E 450,500

$8930 \mathrm{ft}$

N $1,787,800$

E 449,800

$8990 \mathrm{ft}$

N $1,777,800$

E 447,300

$8595 \mathrm{ft}$

N $1,790,900 \quad E 457,700 \quad 9505 \mathrm{ft}$

Source: Griggs 1955. 
XX. TEST HOLES ALONG THE RIO GRANDE AND LOWER LOS ALAMOS CANYON

Four test holes (the Rio Grande Tests) were drilled north of Otowi on the west side of the Rio Grande (Fig. XX-A). These holes, drilled in 1946, were completed to determine whether a ground water supply could be obtained from the alluvium along the river or from the sediments underlying the alluvium (Table XX-A). The holes ranged in depth from 53 to $497 \mathrm{ft}$. Limited saturation of the alluvium and the low permeability of the claystone, siltstone, and silty sandstone of the Tesuque Formation precluded their use as a water supply.

Five test holes (the Guaje Tests) were drilled west of Otowi in lower Los Alamos Canyon (Fig. XX-A). These holes were drilled in 1946 to determine whether a water supply could be developed from the alluvium or sediments underlying the alluvium (Table XX-A). The depth of these test holes ranged from 50 to $475 \mathrm{ft}$ (Black and Veatch 1946, 1948). The alluvium in the canyon is too thin to provide an entire municipal supply on its own. Water flowed from the deeper test holes when completed. The sediments below the alluvium were considerably more permeable than those at the Rio Grande test holes, and the Los Alamos well field was developed in 1947 with the drilling and completion of wells LA-1, LA-2, and LA-3.

\section{REFERENCES}

Black and Veatch (Consulting Engineers, Kansas City, Mo.), "Report on Additional Water Supply Sources, Los Alamos, New Mexico," report to the U.S. Atomic Energy Commission (two reports: 1946 and 1948).

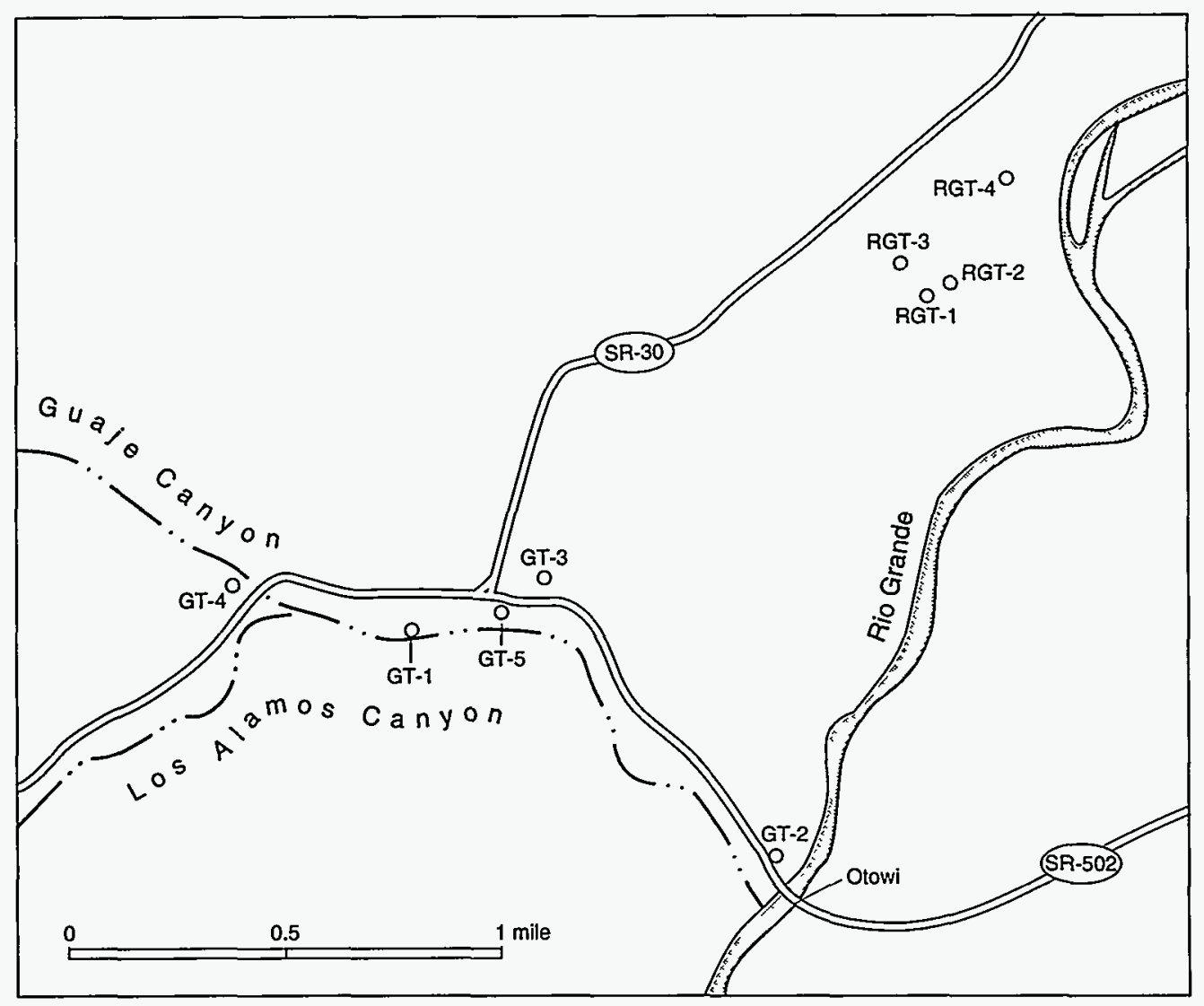

Fig. XX-A. Locations of Rio Grande and Guaje test holes. 
TABLE XX-A. Geologic Logs and Construction Data of Rio Grande and Guaje Test Holes

\begin{tabular}{|c|c|c|c|c|c|c|c|}
\hline & \multirow[b]{2}{*}{$\begin{array}{l}\text { Month } \\
\text { Drilled }\end{array}$} & \multirow[b]{2}{*}{$\begin{array}{l}\text { Elevation } \\
\quad(\mathrm{ft})\end{array}$} & \multirow[b]{2}{*}{$\begin{array}{l}\text { Depth } \\
\text { (ft) }\end{array}$} & \multirow[b]{2}{*}{ Casing } & \multicolumn{2}{|c|}{ Geologic Log } & \multirow[b]{2}{*}{ Remarks } \\
\hline & & & & & $\begin{array}{l}\text { Alluvium } \\
\quad(\mathrm{ft})\end{array}$ & $\begin{array}{l}\text { Tesuque } \\
\text { Formation } \\
\text { (ft) }\end{array}$ & \\
\hline \multicolumn{8}{|c|}{ Rio Grande Tests } \\
\hline RGT-1 & $2 / 46$ & 5530 & 53 & $\mathbf{a}$ & 48 & 5 & \\
\hline RGT-2 & $2 / 46$ & 5525 & 497 & a & 41 & 456 & Water in alluvium \\
\hline RGT-3 & $2 / 46$ & 5545 & 495 & a & 68 & 427 & Water in alluvium \\
\hline RGT-4 & $2 / 46$ & 5537 & 495 & a & 47 & 448 & Water in alluvium \\
\hline \multicolumn{8}{|c|}{ Guaje Tests } \\
\hline GT-1 & $3 / 46$ & 5624 & 400 & b & 78 & 322 & $\begin{array}{l}\text { Artesian (also known as well } \\
\text { LA-1A) }\end{array}$ \\
\hline GT-2 & $3 / 46$ & 5560 & 50 & a & 40 & 10 & \\
\hline GT-3 & $3 / 46$ & 5620 & 475 & a & 31 & 444 & Artesian \\
\hline GT-4 & $3 / 46$ & 5675 & 315 & c & 54 & 261 & $\begin{array}{l}\text { Artesian (also known as well } \\
\text { LA-3A) }\end{array}$ \\
\hline GT-5 & $3 / 46$ & 5609 & 475 & d & 38 & 475 & $\begin{array}{l}\text { Artesian (also known as } \\
\text { Stop Sign well) }\end{array}$ \\
\hline \multicolumn{8}{|c|}{$\begin{array}{l}\text { a Open hole. } \\
\text { b 6-in.-diam steel } 0 \text { to } 76 \mathrm{ft} \text {; } 4 \text {-in.-diam steel } 0 \text { to } 400 \mathrm{ft} \text {. } \\
\text { c } 2 \text {-in.-diam galvanized steel } 0 \text { to } 315 \mathrm{ft} \text {; perforated } 60 \text { to } 315 \mathrm{ft} \text {. } \\
\text { d } 2 \text {-in.-diam galvanized steel } 0 \text { to undetermined depth (sounded } 10 / 65 \text { to } 275 \mathrm{ft} \text { ). }\end{array}$} \\
\hline
\end{tabular}

Source: Black and Veatch 1946, 1948.

TABLE XX-B. Locations and Elevations (NAD 1927)

A. Rio Grande Tests

\begin{tabular}{|c|c|c|c|}
\hline RGT-1 & $\mathrm{N} 1,780,700$ & E 533,800 & $5530 \mathrm{ft}$ \\
\hline RGT-2 & $\mathrm{N} 1,780,900$ & E 534,100 & $5525 \mathrm{ft}$ \\
\hline RGT-3 & $\mathrm{N} 1,781,100$ & E 533,600 & $5545 \mathrm{ft}$ \\
\hline RGT-4 & N $1,782,100$ & E 534,700 & $5537 \mathrm{ft}$ \\
\hline \multicolumn{4}{|c|}{ B. Guaje Tests (Lower Los Alamos Canyon) } \\
\hline GT-1 & $\mathrm{N} 1,776,800$ & E 527,700 & $5624 \mathrm{ft}$ \\
\hline GT-2 & N $1,773,900$ & E 532,100 & $5560 \mathrm{ft}$ \\
\hline GT-3 & N $1,777,300$ & E 529,200 & $5620 \mathrm{ft}$ \\
\hline GT-4 & N $1,777,200$ & E 525,700 & $5675 \mathrm{ft}$ \\
\hline GT-5 & N $1,776,900$ & E 528,800 & $5609 \mathrm{ft}$ \\
\hline
\end{tabular}

Source: Black and Veatch 1946, 1948. 


\section{SUPPLY WELLS}

Municipal and industrial water supply for the Laboratory and the communities of Los Alamos and White Rock is from four well fields: Los Alamos, Guaje, Pajarito, and Otowi (Fig. XXI-A). The wells in the fields range in depth from $870 \mathrm{ft}$ in lower Los Alamos Canyon to $3093 \mathrm{ft}$ on the Pajarito Plateau (Table XXI-A). Water levels at completion ranged from free-flowing in lower Los Alamos Canyon to over $1200 \mathrm{ft}$ near the center of the plateau. The wells were completed in the main aquifer, the only aquifer in the area capable of municipal and industrial water supply.

\section{A. Los Alamos Field}

The Los Alamos Field was composed of seven wells, six completed in 1946-1948, the seventh added in 1960 (Fig. XXI-A). During the spring of 1992, production from the field was terminated. The relocation of State Road 502 crossed the transmission line. Due to the age of the wells, the production from the field had decreased to the point where it was not economically feasible to relocate the line. Pumps were removed from all wells except LA-2, which was used by the road contractor. Some of the wells were plugged and abandoned while others will be used for hydrologic data collection. Well LA- 6 was taken offline in 1977 due to excess amounts of naturally occurring arsenic.

Geologic logs for the seven supply wells are shown in Figs. XXI-B through XXI-H. Logs and construction data are presented in Table XXI-B. No record can be found of the surface casing for the six wells drilled 1946-1948. It could be assumed that surface casing was set through the alluvium into the Tesuque Formation to prevent fluid loss during drilling of the well and to allow gravel pack of the well upon completion of the drilling operation (Black and Veatch 1946, 1948, and 1951; Cushman 1965).

\section{B. Guaje Field}

The Guaje Field is composed of seven wells, six completed in the period 1950 to 1952, the seventh well added in 1964 (Fig. XXI-A and Table XXI-C). Only six wells are operational; however, the yield has declined in several of the wells so that they are not pumped except when there is heavy water demand.
The well casing failed in well G-3, and when water is pumped from it, gravel pack and sand enter the well, reducing its usability.

Geologic logs for the six wells are presented in Figs. XXI-I through XXI-O. No record can be found of the surface casing of the wells drilled 1950 to 1952. Surface casing, as stated in the previous section, is probably set through the alluvium and friable fanglomerate member into the consolidated Tesuque Formation (Black and Veatch 1951; Cushman 1965; Cooper et al. 1965).

\section{Pajarito Field}

The Pajarito Field is composed of five wells, three completed 1964 to 1967 , one added in 1981, and another in 1982 (Fig. XXI-A and Table XXI-A). All wells are operational (Cooper et al. 1965; Purtymun 1967; Purtymun et al. 1983 and 1984).

Geologic logs and construction data are presented in Table XXI-D. Geologic logs are also shown in Figs. XXI-P through XXI-T. All wells have surface casing that extends to or near the top of the main aquifer. This casing is cemented in from the bottom, to prevent surface contamination from reaching the main aquifer.

\section{Otowi Field}

The Otowi Field is composed of two supply wells that were completed in 1990 (Fig. XXI-A and Table XXI-A). These wells are not equipped with pumps, nor are the storage reservoirs and transmission lines complete. Geologic logs and construction data are presented in Table XXI-E. Geologic logs of the two wells are shown in Figs. XXI-U and XXI-V (Stoker et al. 1992). The wells have casing that extends from the land surface to near the top of the main aquifer. The casing is cemented in from the bottom to prevent surface contamination from reaching the main aquifer.

\section{E. Water Supply Reports}

A summary report (1947-1971) and annual reports related to well and well-field characteristics have been published to ensure a continuing historical record and to provide guidance for the management of water resources in long-range planning for the water supply system. 
1947-1971 data: LA-5040-MS, November 1972 1971 data: LA-5039-MS, October 1972 1972 data: LA-5296-MS, December 1973 1973 data: LA-5636-MS, June 1974 1974 data: LA-5998-MS, June 1975 1975 data: LA-6461-PR, September 1976 1976 data: LA-6814-PR, May 1977 1977 data: LA-7436-MS, August 1978 1978 data: LA-8074-PR, October 1979 1979 data: LA-8504-PR, August 1980 1980 data: LA-9007-PR, September 1981 1981 data: LA-9734-PR, May 1983 1982 data: LA-9896-PR, January 1984 1983 data: LA-10327-PR, February 1985 1984 data: LA-10584-PR, January 1986 1985 data: LA-10835-PR, October 1986 1986 data: LA-11046-PR, August 1987 1987 data: LA-1 1478-PR, January 1989 1988 data: LA-11679-PR, October 1989 1989 data: LA-12276-PR, May 1992 1990 data: LA-12471-PR, February 1993 1991 data: LA-12770-PR, June 1994

\section{REFERENCES}

Black and Veatch, "Report on Additional Water Supply Sources, Los Alamos, New Mexico," Consulting Engineers, Kansas City, Mo., report to the U.S. Atomic Energy Commission (three reports: 1946, 1948, and 1951).

R. L. Cushman, "An Evaluation of Aquifer and Well Characteristics of Municipal Well Fields in the Los Alamos and Guaje Canyons Near Los Alamos, New Mexico," U.S. Geol. Survey Water-Supply Paper 1809-D (1965).
J. B. Cooper, W. D. Purtymun, and E. C. John, "Records of Water-Supply Wells Guaje Canyon 6, Pajarito Mesa 1, and Pajarito Mesa 2, Los Alamos, New Mexico, Basic Data Report," U.S. Geol. Survey Open-File Report (1965).

R. L. Griggs, "Geology and Water Resources of the Los Alamos Area, New Mexico," U. S. Geological Survey Admin. Report to the U.S. Atomic Energy Commission (1955).

W. D. Purtymun, "Record of Water-Supply Well PM-3, Los Alamos New Mexico," U.S. Geol. Survey Open-File Report (1967).

W. D. Purtymun, N. M. Becker, and M. Maes, "Water Supply at Los Alamos During 1981," Los Alamos National Laboratory report LA-9734-PR (1983).

W. D. Purtymun, N. M. Becker, and M. Maes, "Water Supply at Los Alamos During 1982," Los Alamos National Laboratory report LA-9896-PR (1984).

W. D. Purtymun, A. Stoker, S. McLin, M. Maes, and G. Hammock, "Water Supply at Los Alamos During 1990," Los Alamos National Laboratory report LA-12471-PR (1993).

A. Stoker, S. McLin, W. D. Purtymun, M. Maes, and G. Hammock, "Water Supply at Los Alamos During 1989," Los Alamos National Laboratory report LA-12276-PR (1992). 


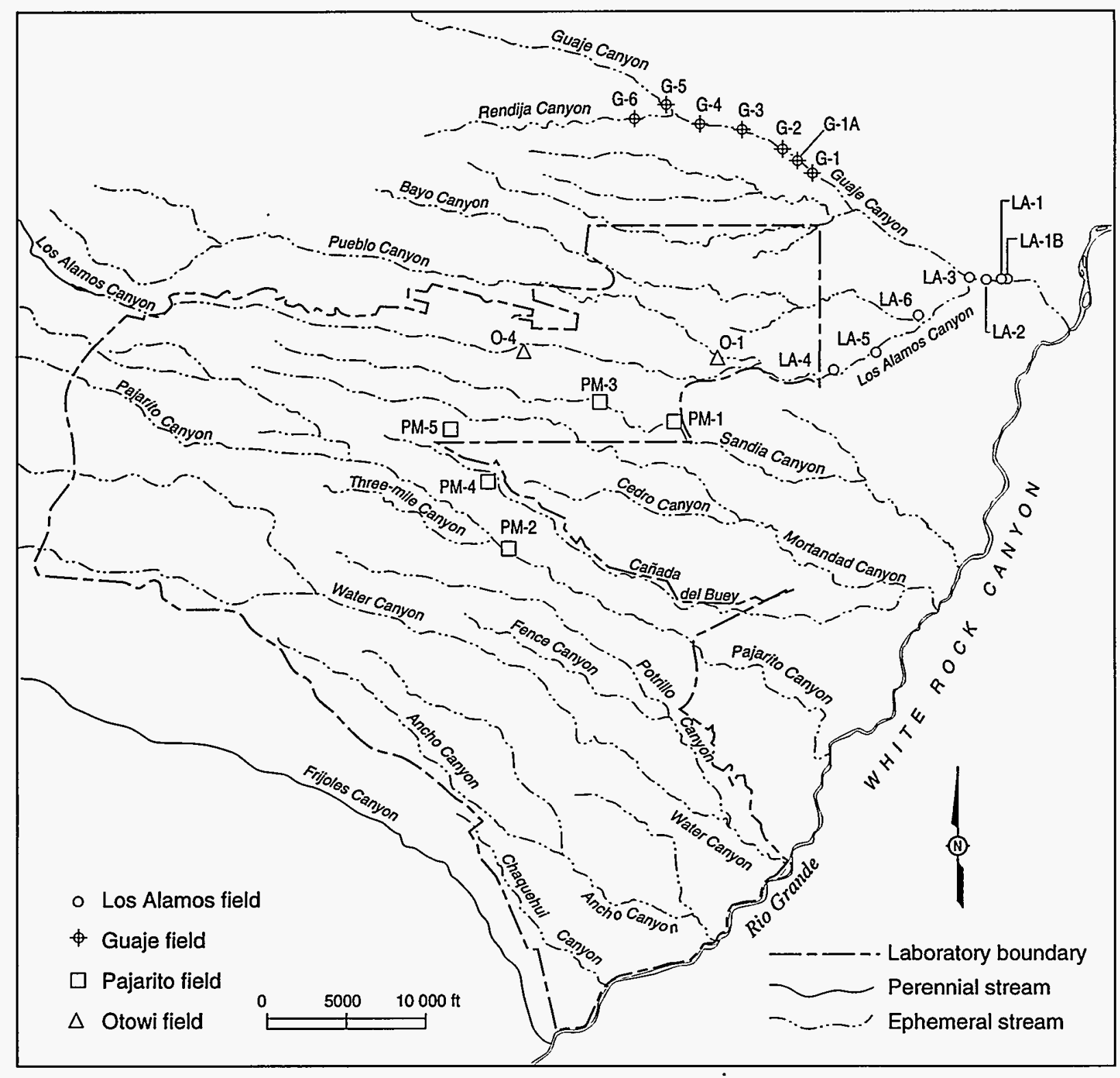

Fig. XXI-A. Locations of supply wells in the Los Alamos, Guaje, Pajarito, and Otowi well fields. 


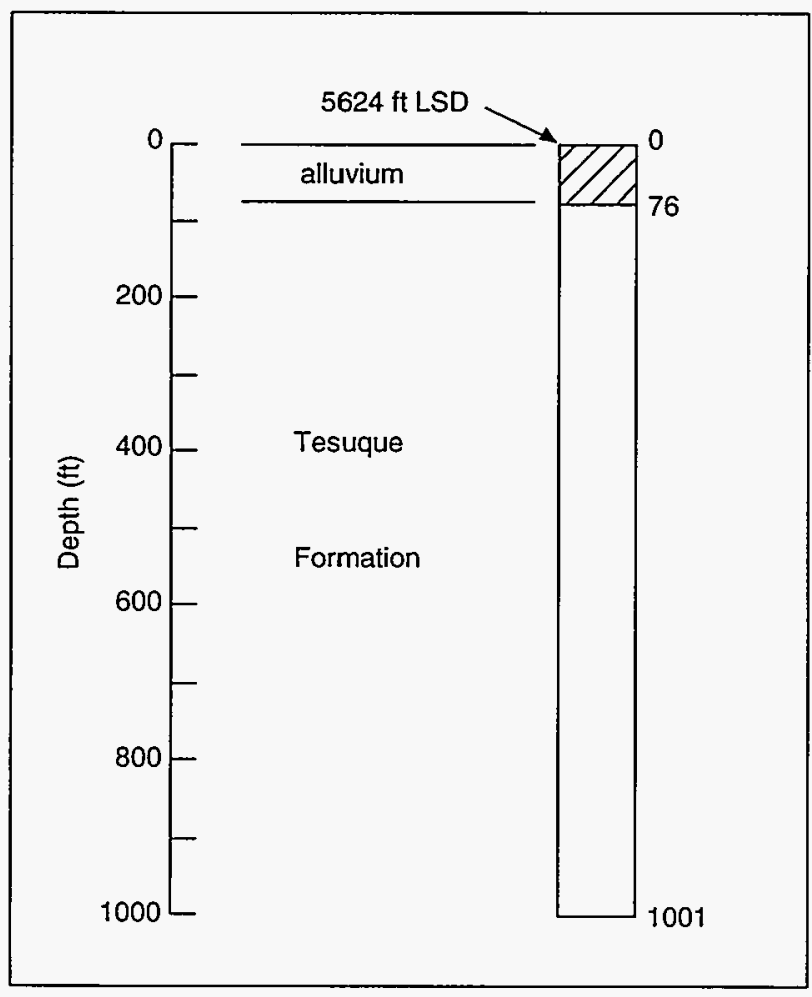

Fig. XXI-B. Geologic log of supply well LA-1, completed November 1946, flowing (Black and Veatch 1948; Cushman 1965).

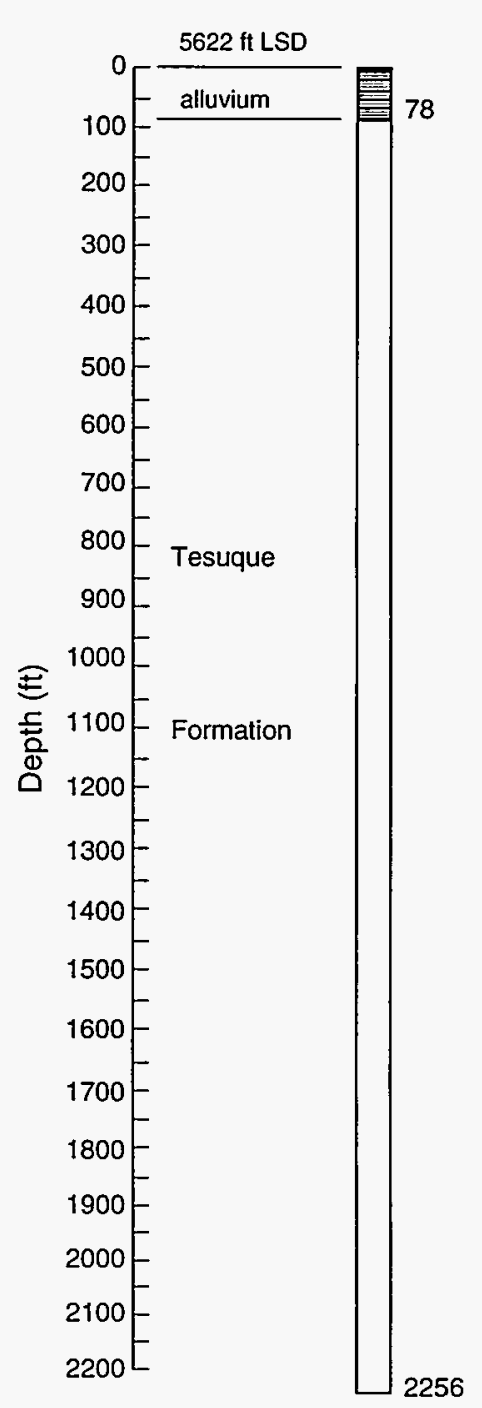

Fig. XXI-C. Geologic log of supply well LA-1B, completed May 1960, flowing (Cushman 1965). 


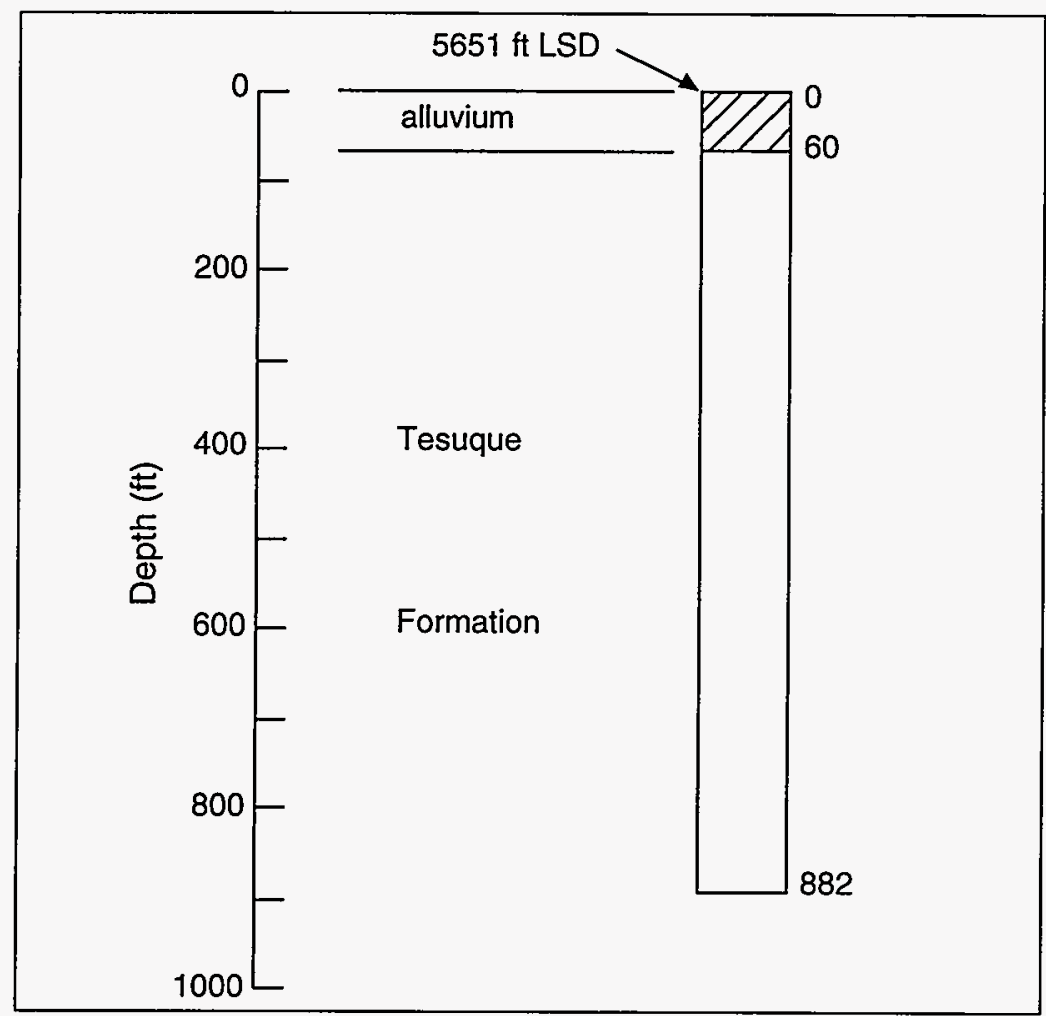

Fig. XXI-D. Geologic log of supply well LA-2, completed December 1946, flowing (Black and Veatch 1948; Cushman 1965).

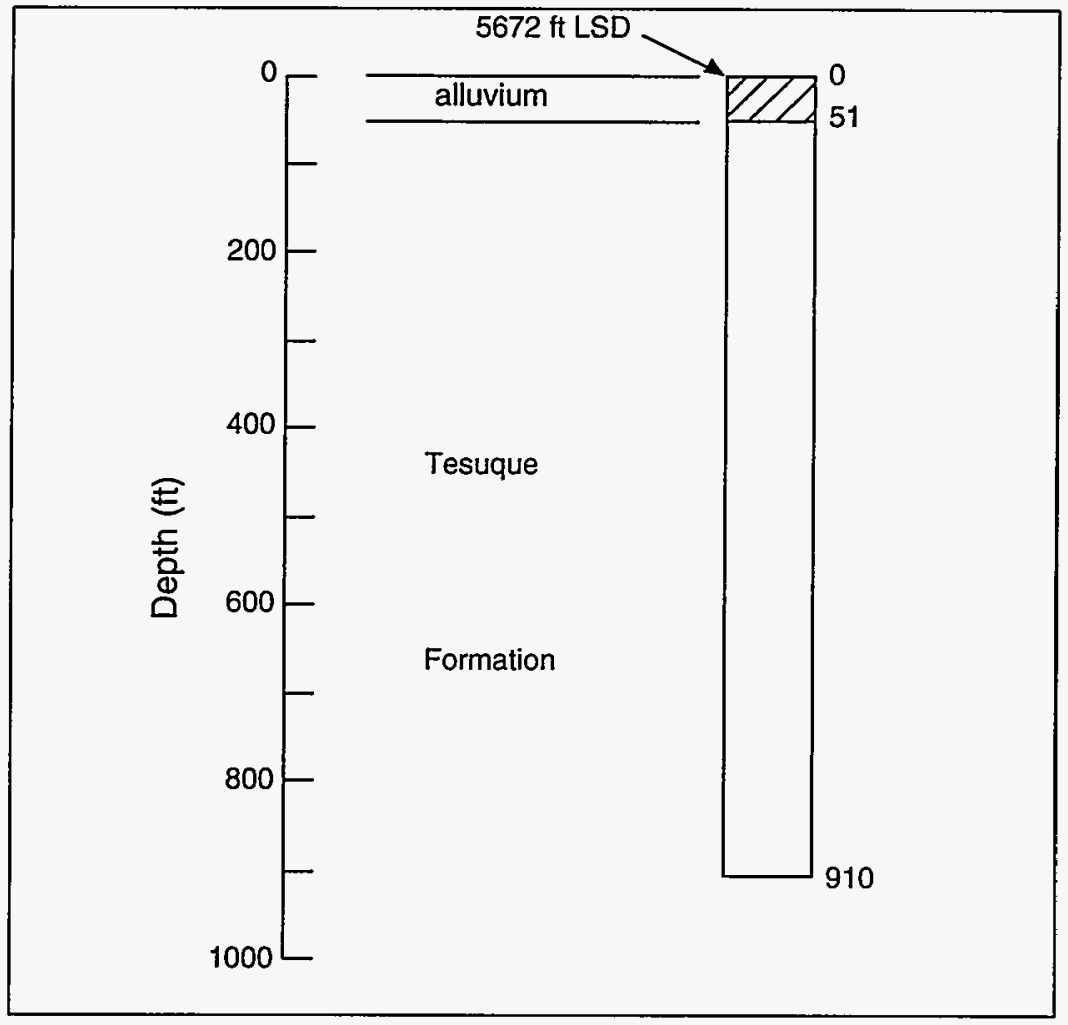

Fig. XXI-E. Geologic log of supply well LA-3, completed May 1947, flowing (Black and Veatch 1948; Cushman 1965). 

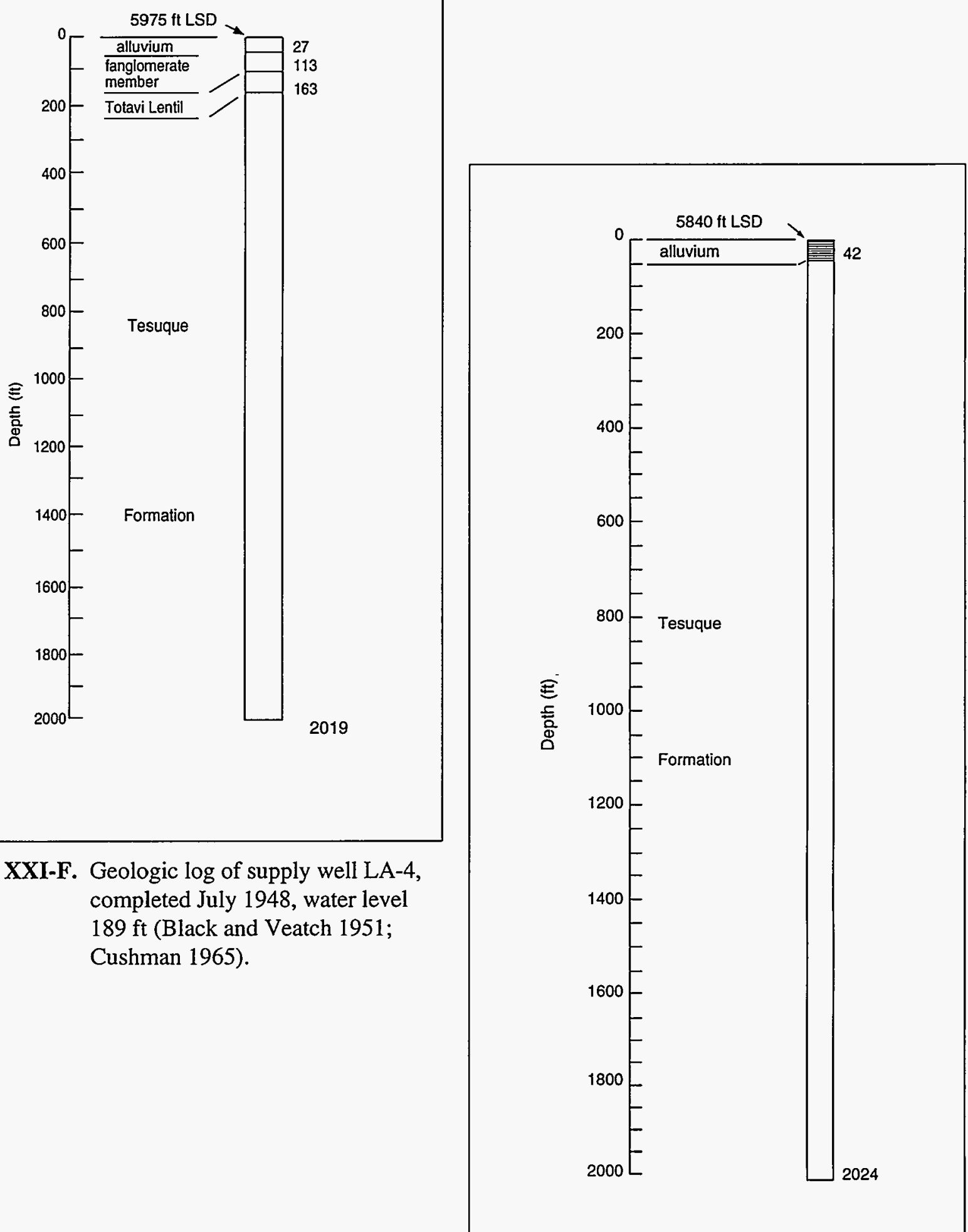

Fig. XXI-G. Geologic log of supply well LA-5, completed September 1948, water level $71 \mathrm{ft}$ (Black and Veatch 1951; Cushman 1965). 


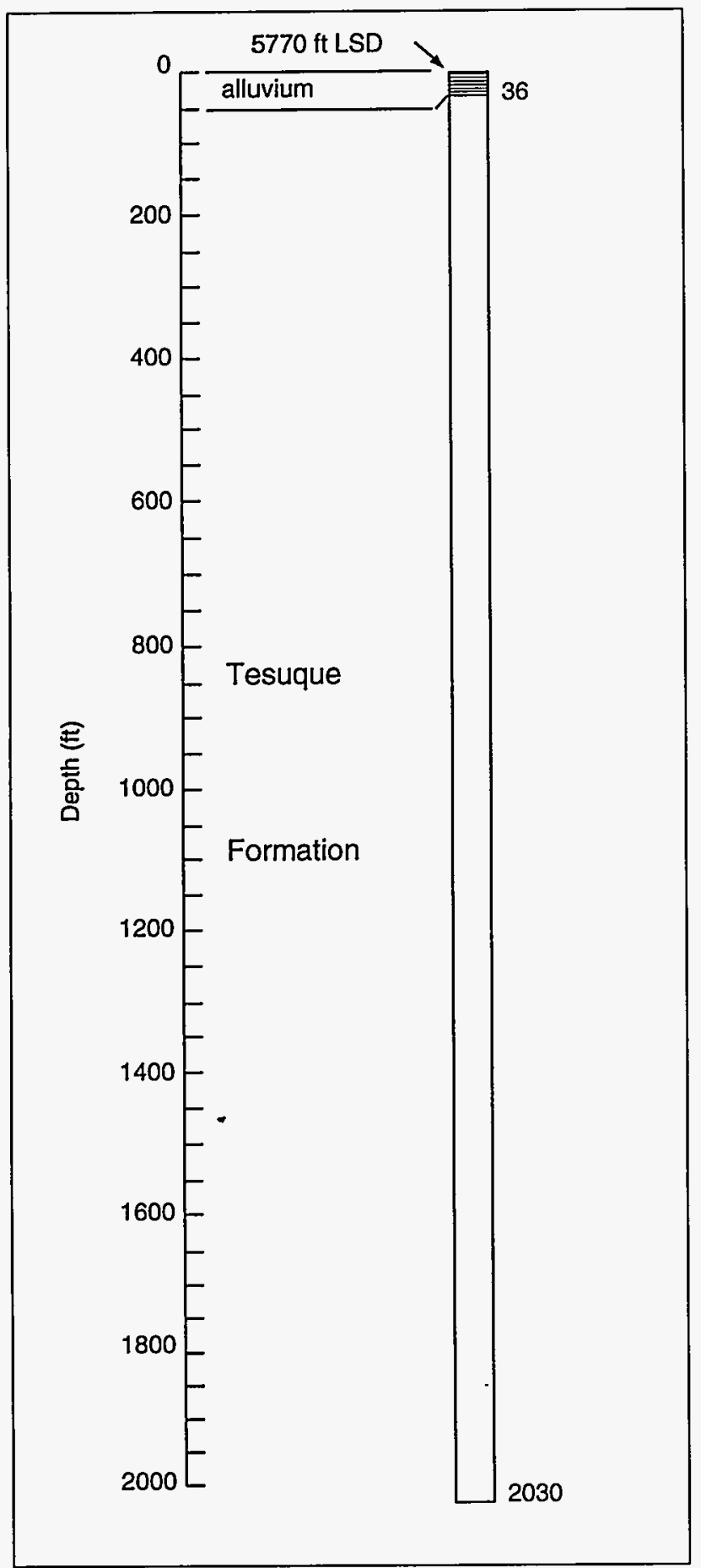

Fig. XXI-H. Geologic log of supply well LA-6, completed December 1948, water level $2 \mathrm{ft}$ (Black and Veatch 1951; Cushman 1965).

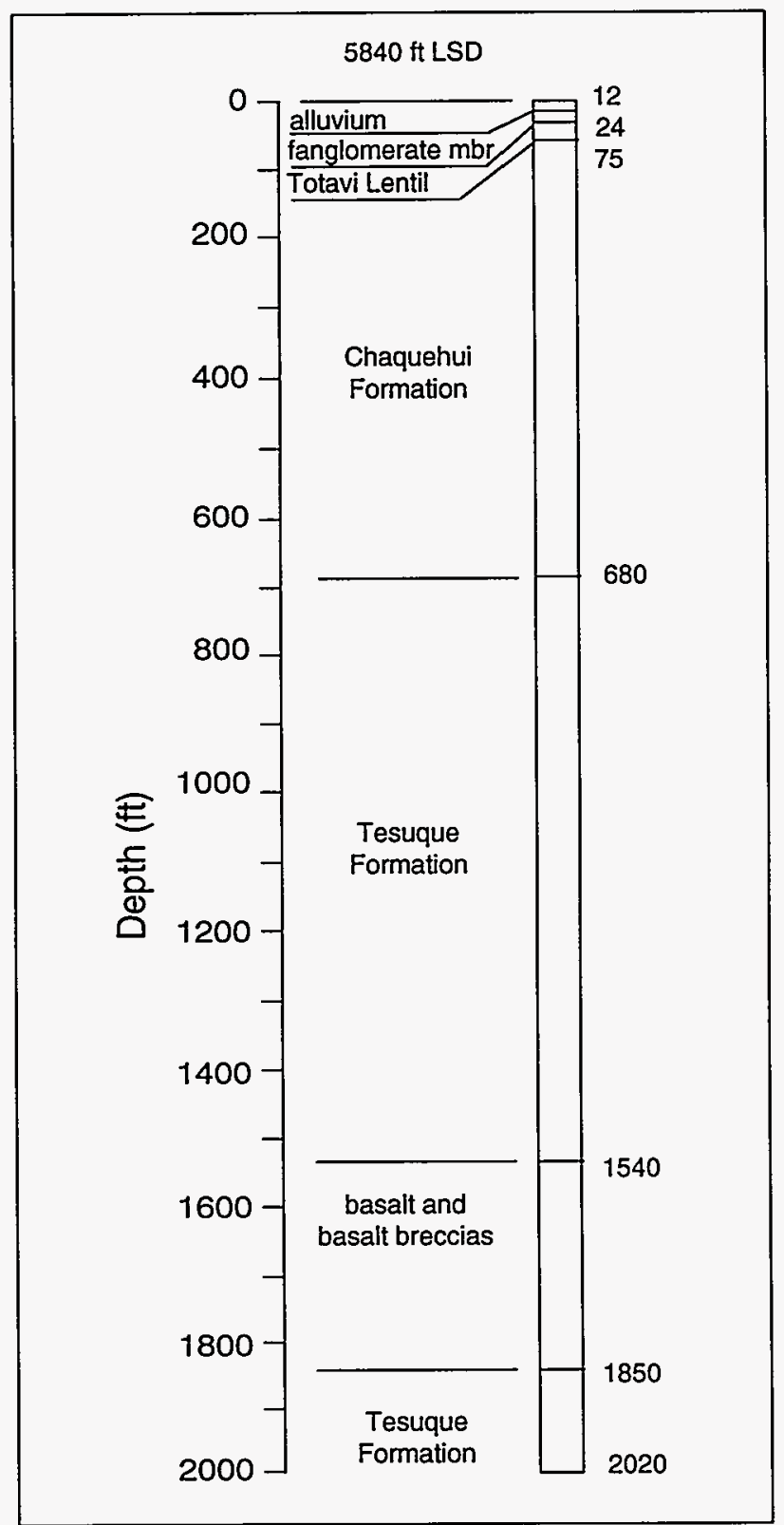

Fig. XXI-I. Geologic log of supply well G-1, completed July 1950, water level $192 \mathrm{ft}$ (Black and Veatch 1951; Griggs 1955; and Cushman 1965: modified by Purtymun for this report). 


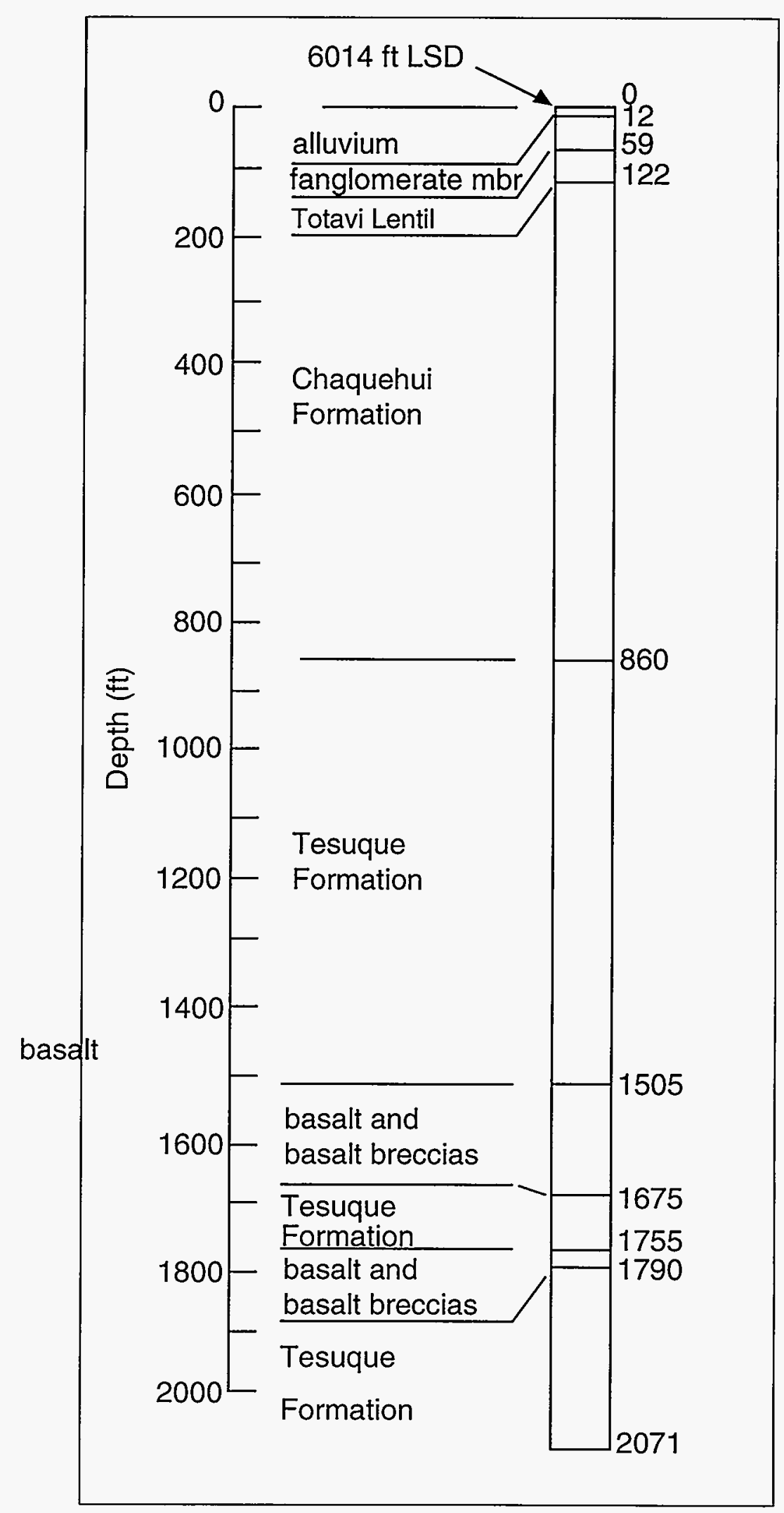

Fig. XXI-J. Geologic log of supply well G-1A, completed October 1954, water level $250 \mathrm{ft}$ (Cushman 1965, modified by Purtymun for this report). 


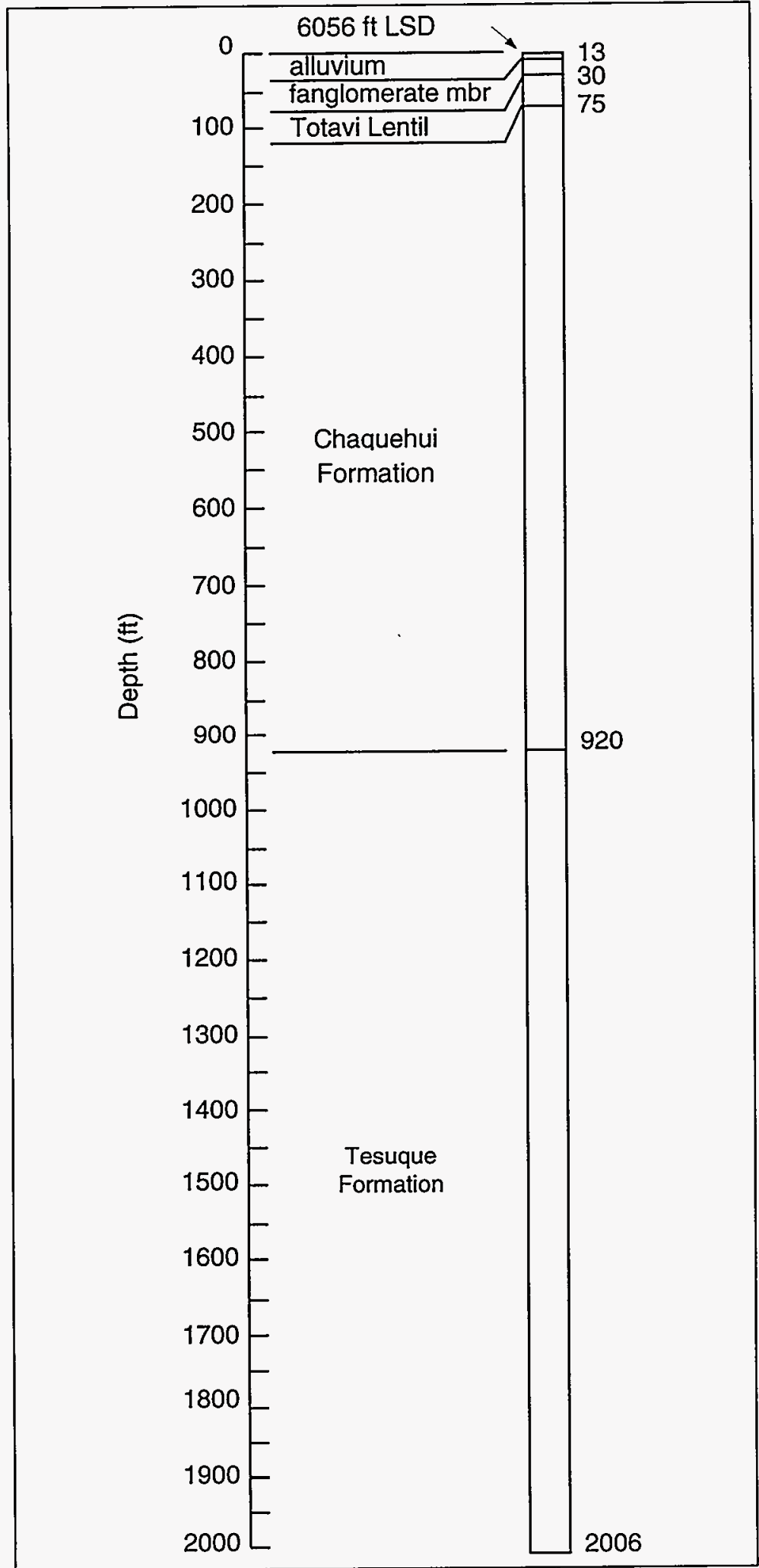

Fig. XXI-K. Geologic log of supply well G-2, completed August 1951, water level $259 \mathrm{ft}$ (Black and Veatch 1951; Griggs 1955; Cushman 1965: modified by Purtymun for this report). 


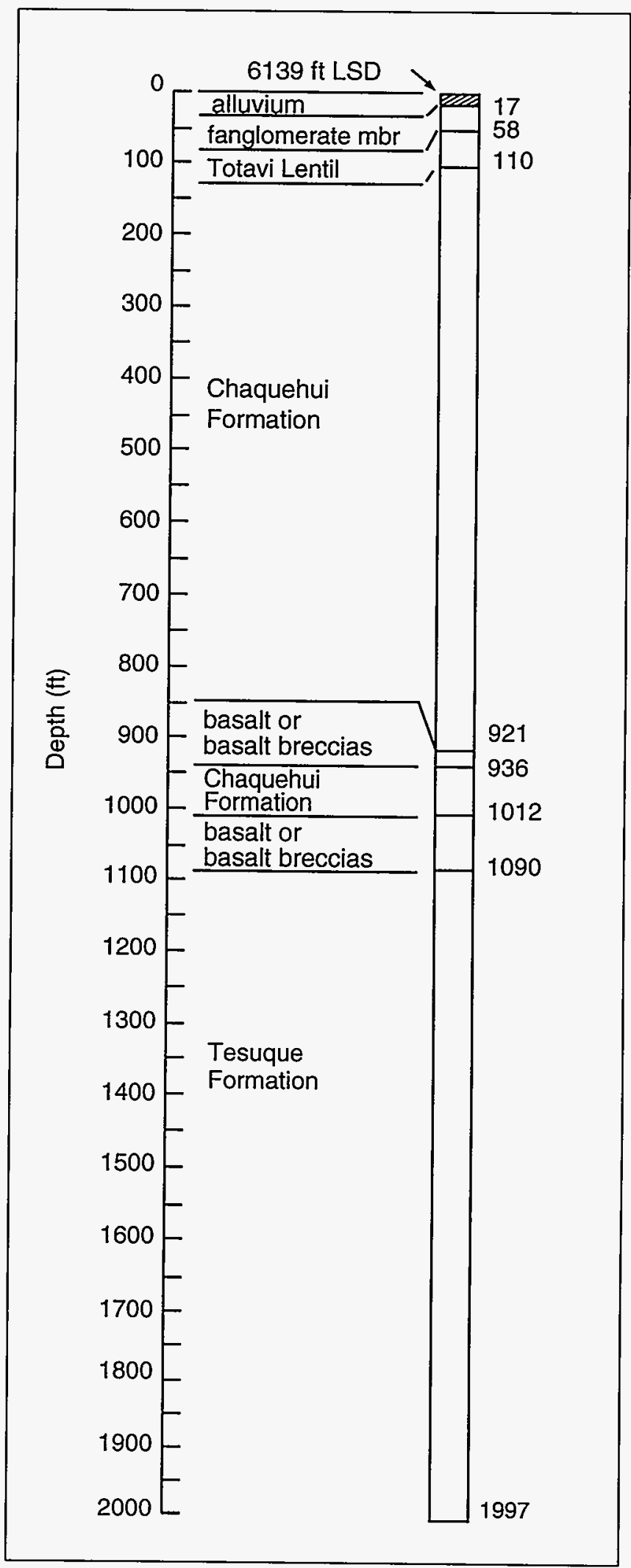

Fig. XXI-L. Geologic log of supply well G-3, completed July 1951, water level $280 \mathrm{ft}$ (Black and Veatch 1951; Griggs 1955; Cushman 1965: modified by Purtymun for this report). 


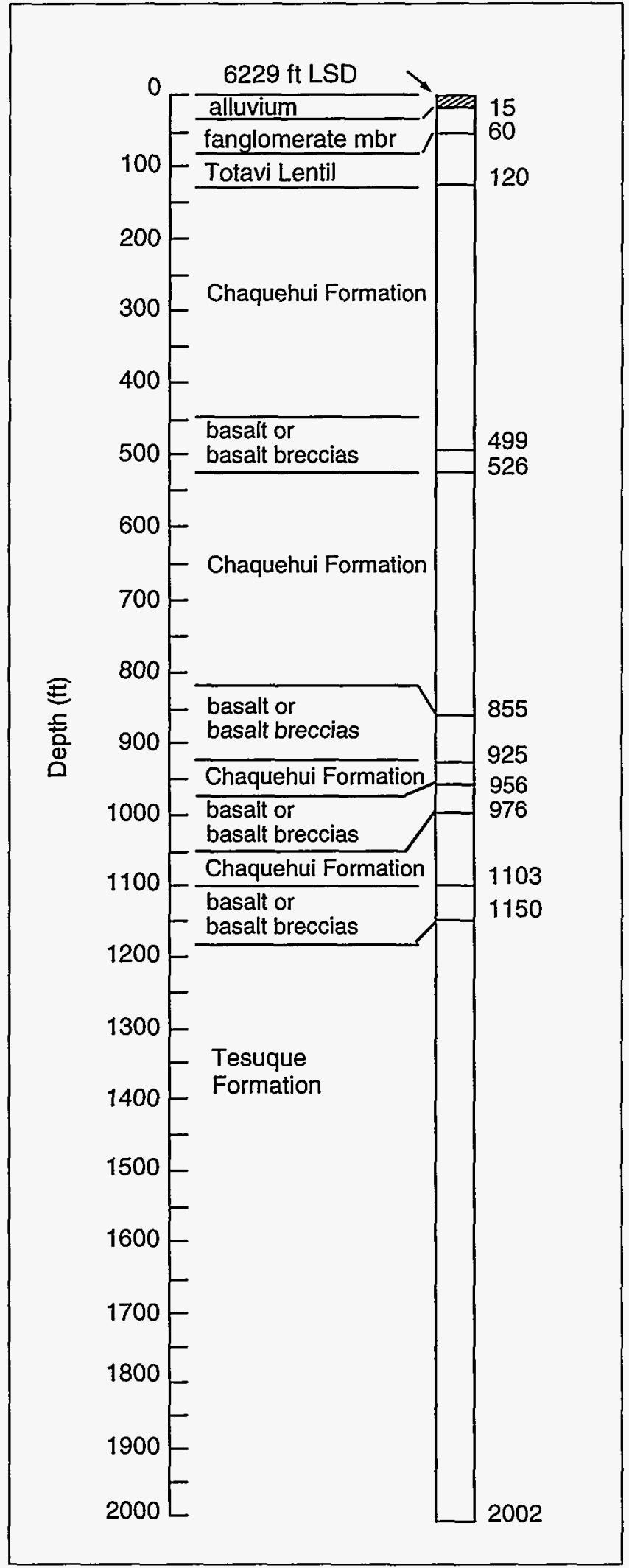

Fig. XXI-M. Geologic log of supply well G-4, completed May 1951, water level $347 \mathrm{ft}$ (Black and Veatch 1951; Griggs 1955; Cushman 1965: modified by Purtymun for this report). 


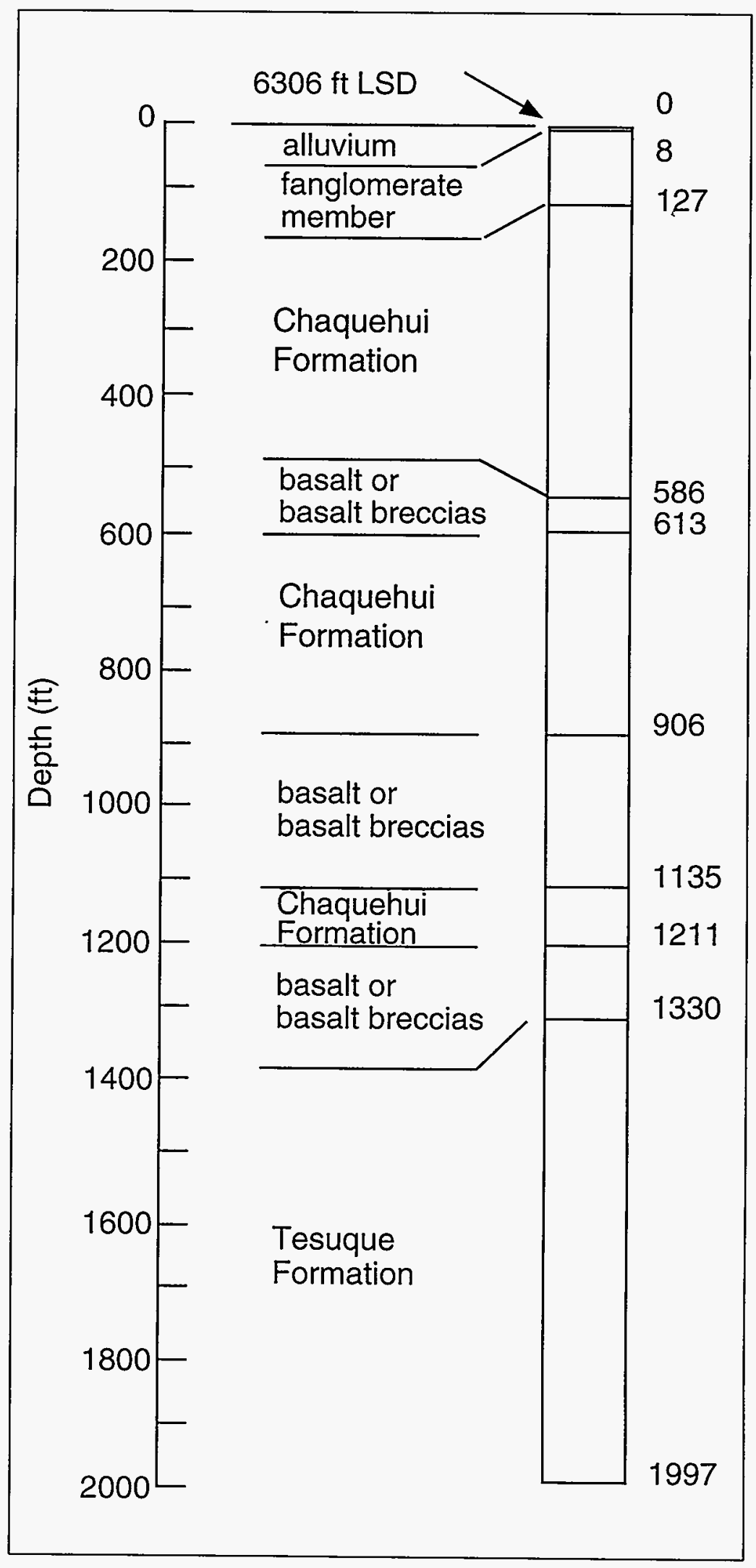

Fig. XXI-N. Geologic log of supply well G-5, completed May 1951, water level $411 \mathrm{ft}$ (Black and Veatch 1951; Griggs 1955; Cushman 1965: modified by Purtymun for this report). 


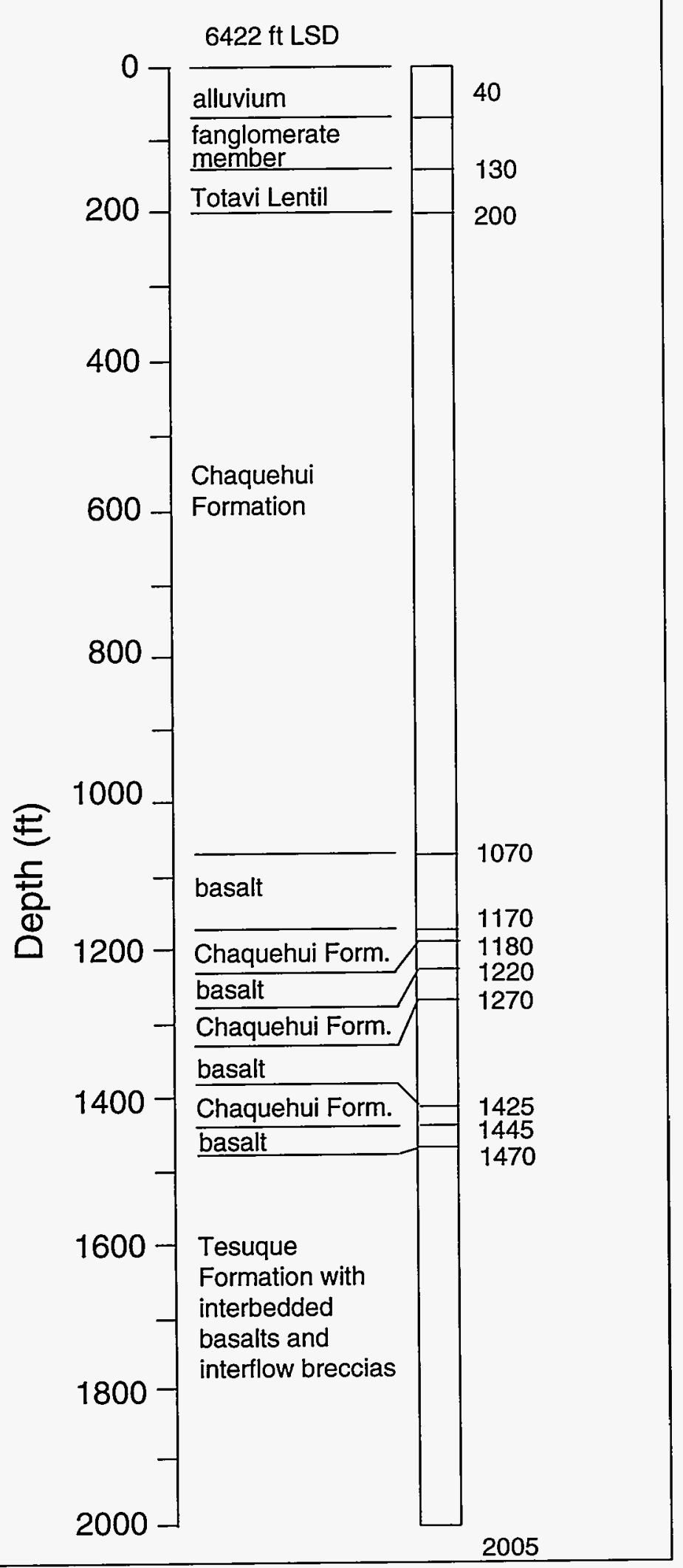

Fig. XXI-O. Geologic log of supply well G-6, completed March 1964, water level $572 \mathrm{ft}$ (Cooper et al. 1965, modified by Purtymun for this report). 


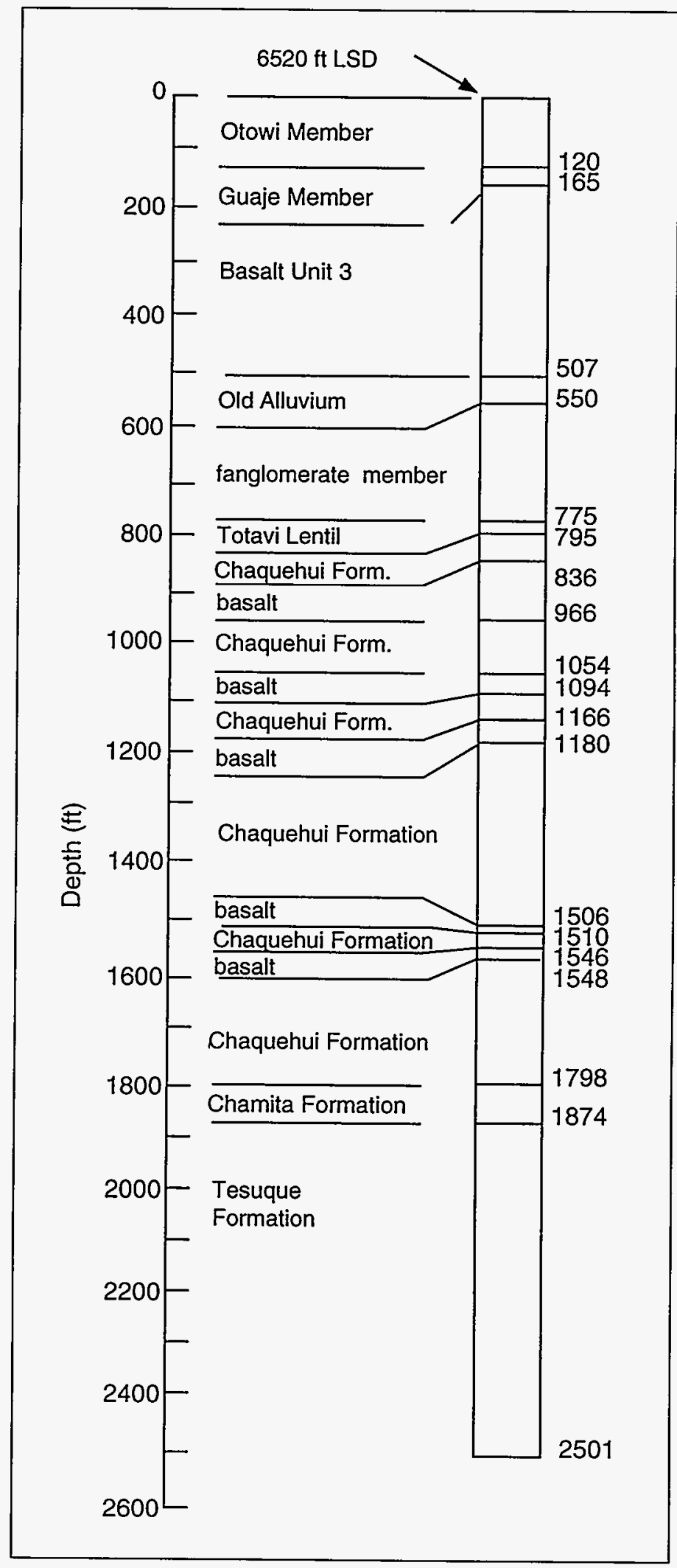

Fig. XXI-P. Geologic log of supply well PM-1, completed February 1965, water level $722 \mathrm{ft}$ (Cooper et al. 1965, modified by Purtymun for this report). 


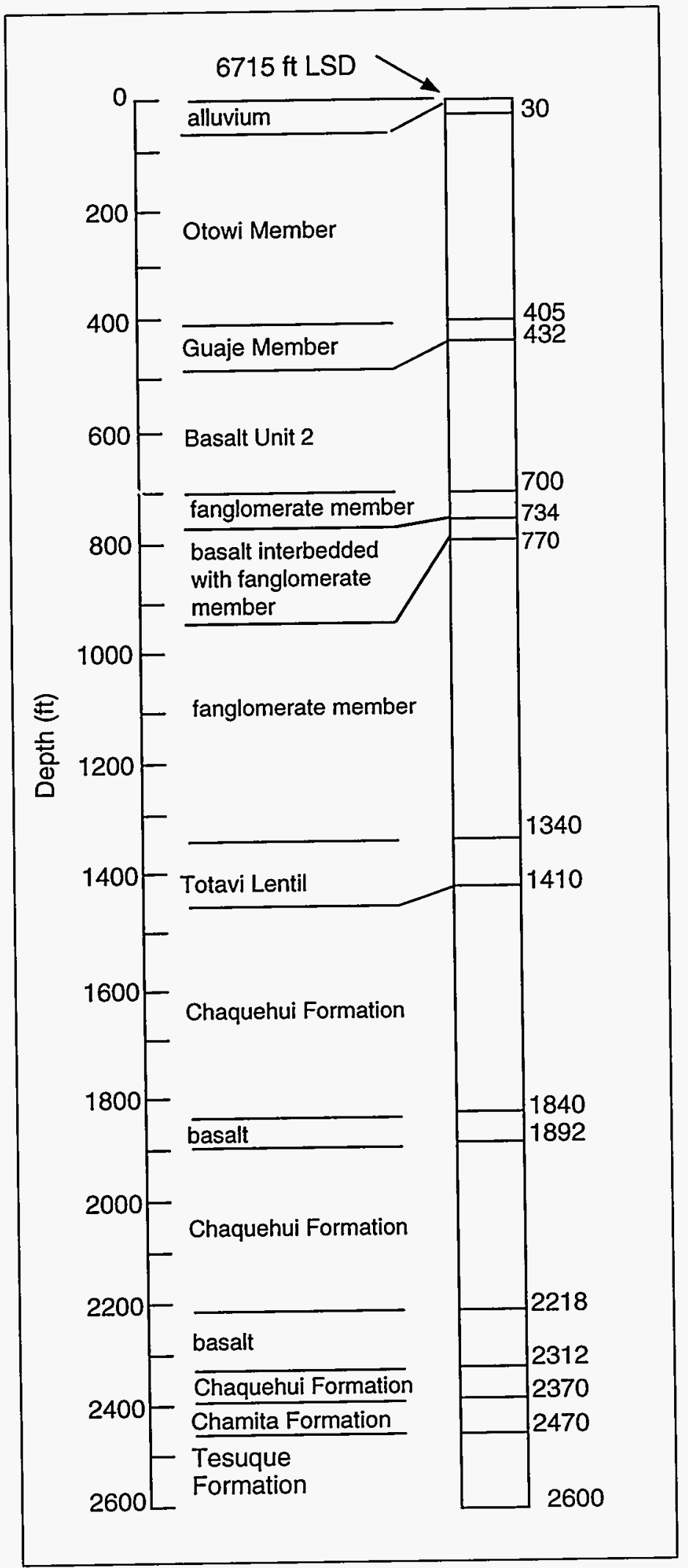

Fig. XXI-Q. Geologic log of supply well PM-2, completed July 1965, water level $823 \mathrm{ft}$ (Cooper et al. 1965, modified by Purtymun for this report). 


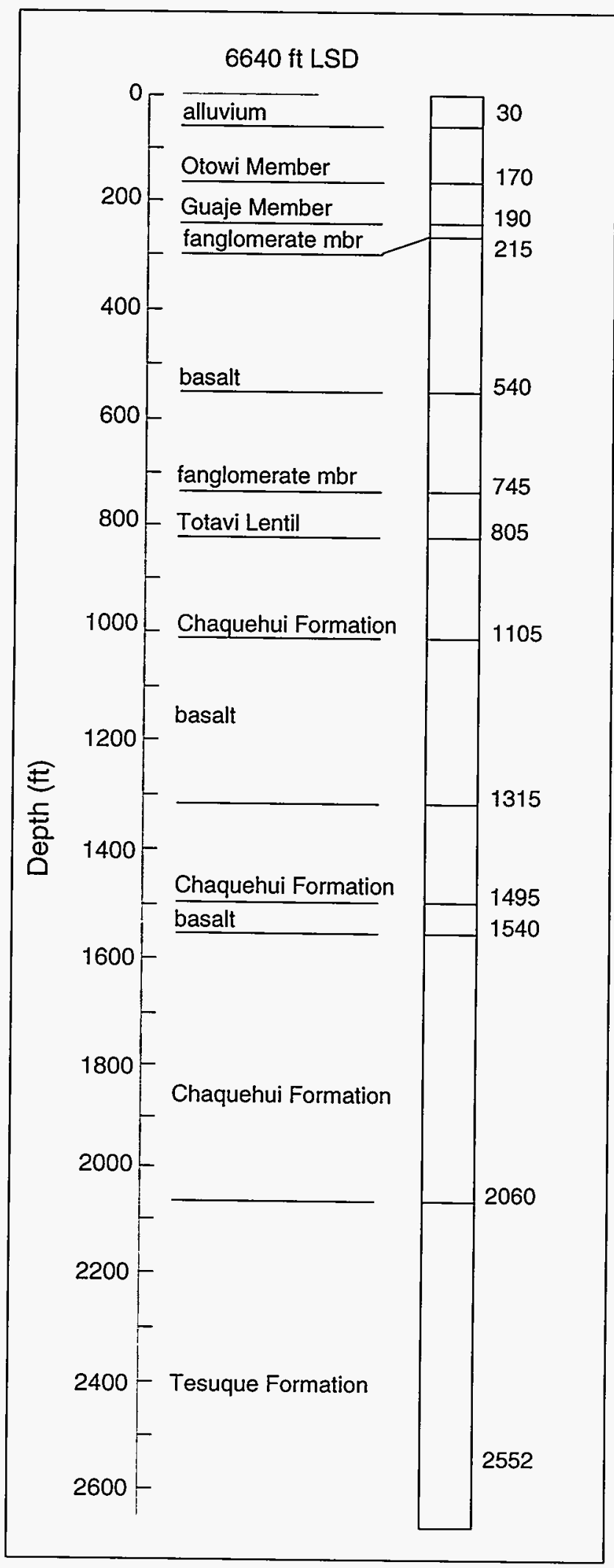

Fig. XXI-R. Geologic log of supply well PM-3, completed November 1966, water level $740 \mathrm{ft}$ (Purtymun 1967, modified by Purtymun for this report). 


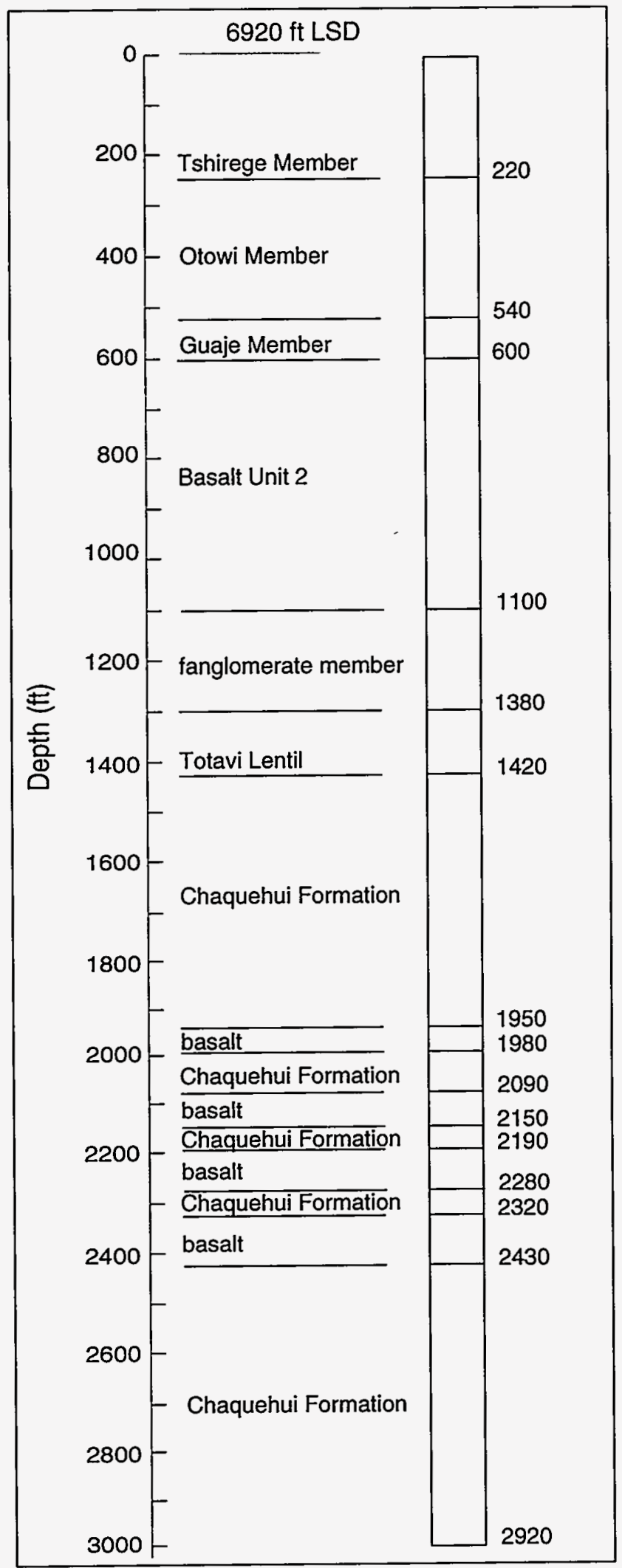

Fig. XXI-S. Geologic log of supply well PM-4, completed August 1981, water level $1060 \mathrm{ft}$ (Purtymun et al. 1983, modified by Purtymun for this report). 


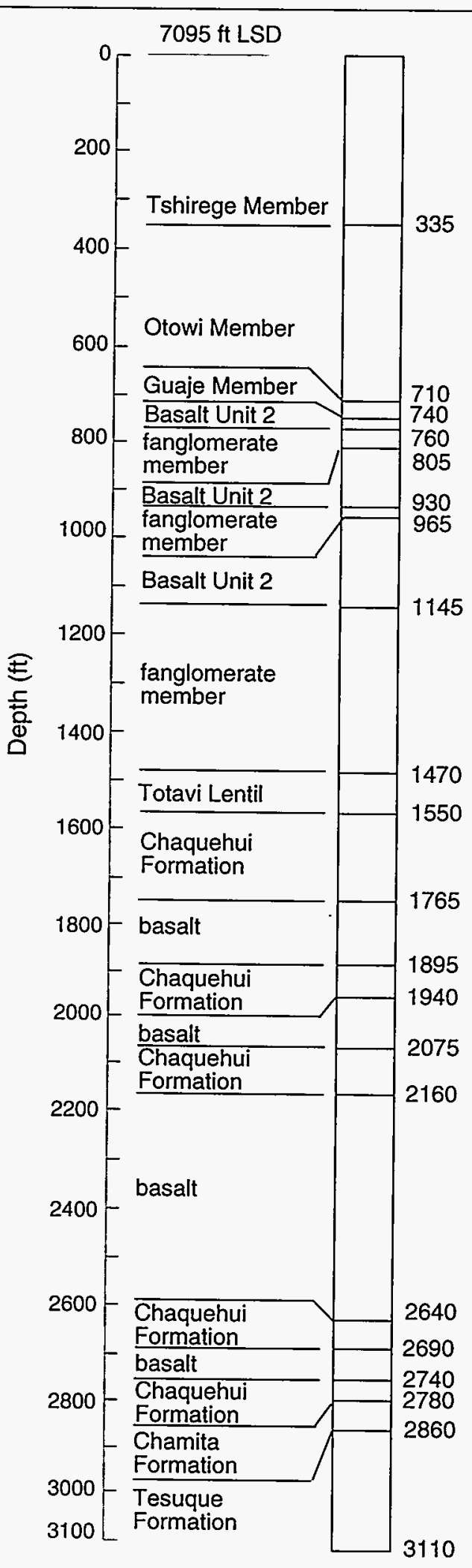

Fig. XXI-T. Geologic log of supply well PM-5, completed September 1982, water level $1208 \mathrm{ft}$ (Purtymun et al. 1984, modified by Purtymun for this report). 


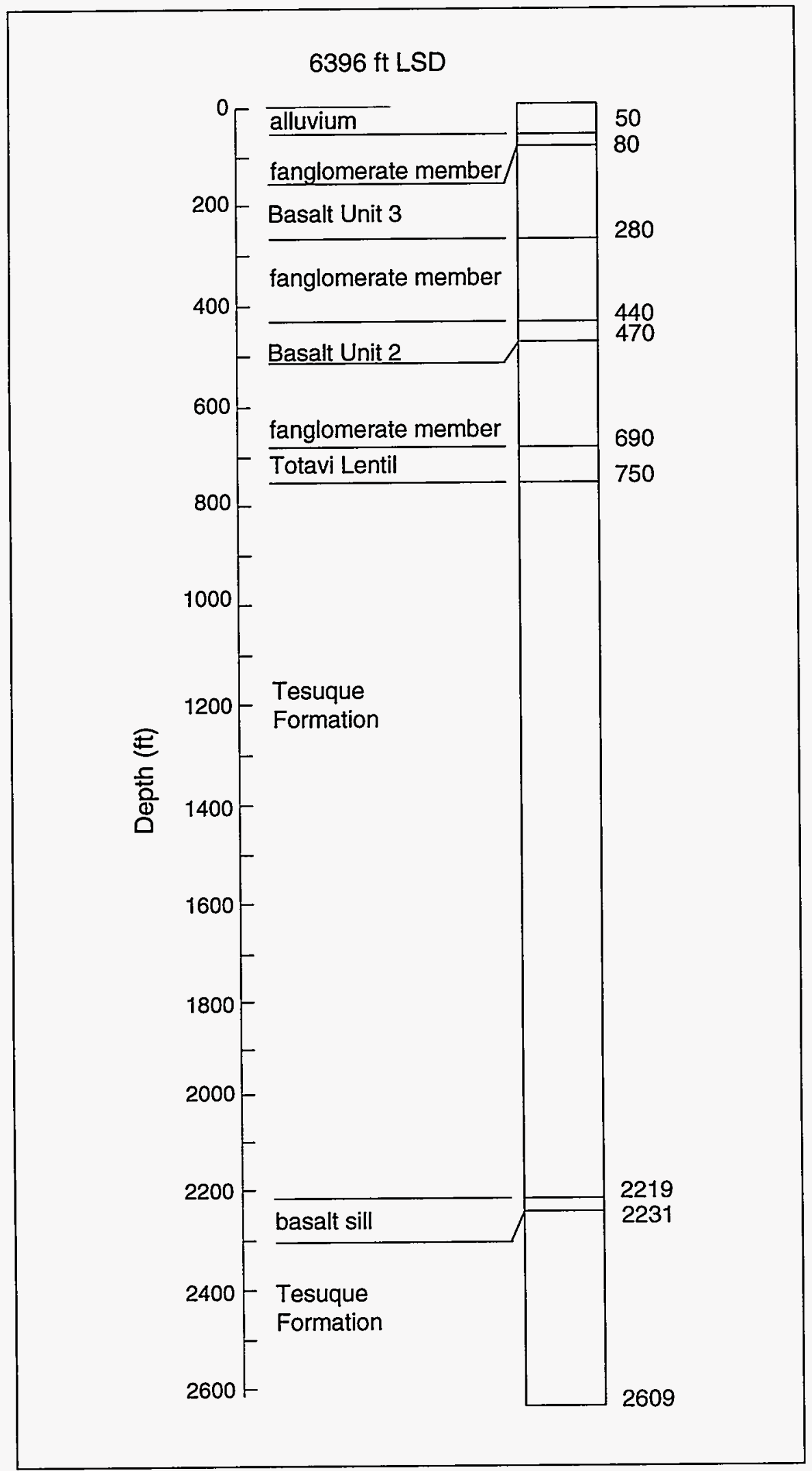

Fig. XXI-U. Geologic log of supply well O-1, completed July 1990, water level $673 \mathrm{ft}$ (Purtymun et al. 1993). 


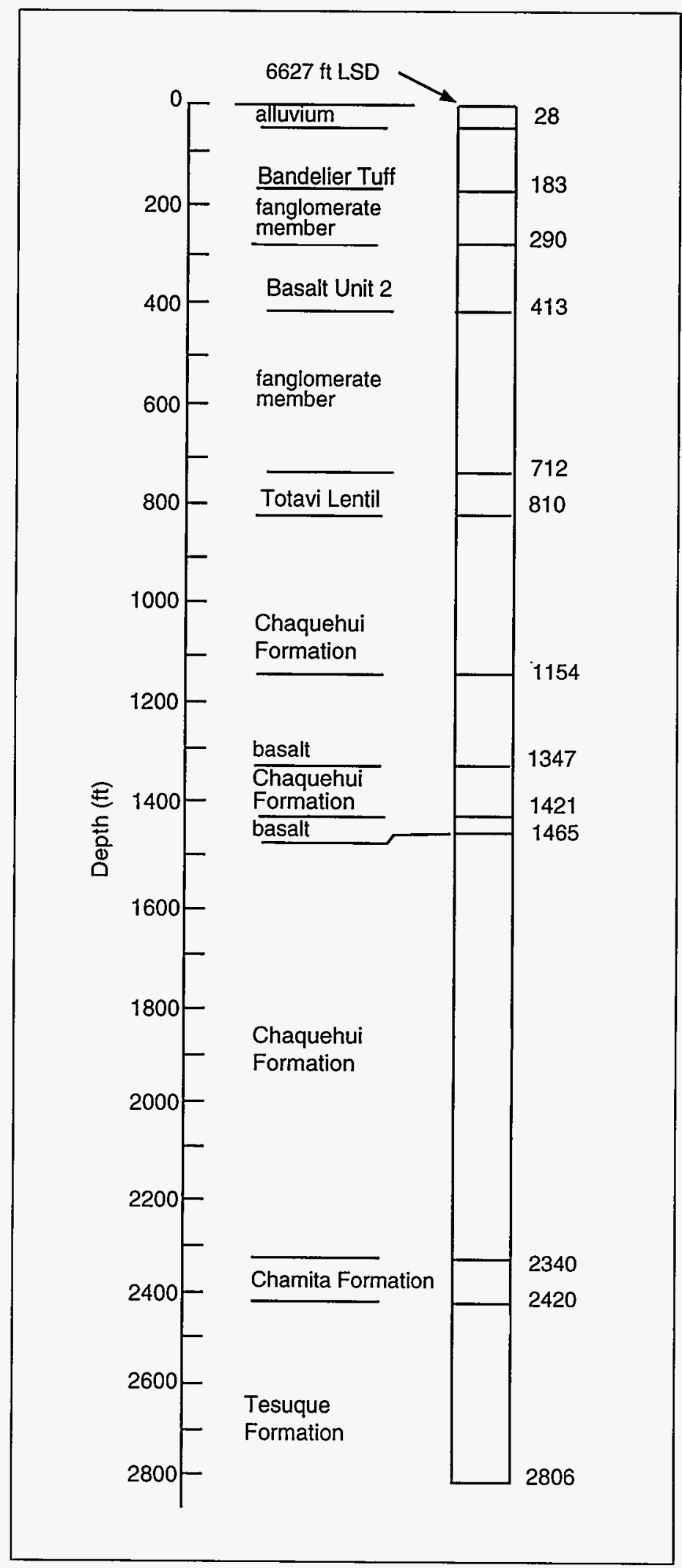

Fig. XXI-V. Geologic log of supply well O-4, completed April 1990, water level $780 \mathrm{ft}$ (Stoker et al. 1992, modified by Purtymun for this report). 
TABLE XXI-A. Construction Data and Hydrologic Characteristics of Supply Wells in the Los Alamos, Guaje, Pajarito, and Otowi Well Fields

\begin{tabular}{|c|c|c|c|c|c|c|c|c|}
\hline \multicolumn{4}{|c|}{ Construction } & \multicolumn{5}{|c|}{ Hydrologic Characteristics } \\
\hline $\begin{array}{cc} & \text { Depth } \\
\text { Year } & \text { Drilled } \\
\text { Completed }(\mathrm{ft})\end{array}$ & $\begin{array}{l}\text { Depth } \\
\text { Cased } \\
(\mathrm{ft})\end{array}$ & $\begin{array}{l}\text { Depth } \\
\text { Open }\end{array}$ & Year & $\begin{array}{c}\text { Head of Pressure } \\
\text { When } \\
\text { Cased }(+\mathrm{ft}) \\
\text { or } \\
\text { Water Level (ft) } \\
\text { below LSD }\end{array}$ & $\begin{array}{c}\text { Current } \\
\text { Water } \\
\text { Level } \\
\text { (ft) }\end{array}$ & $\begin{array}{c}\text { Yield } \\
(\mathrm{gpm})\end{array}$ & $\begin{array}{c}\text { Specific } \\
\text { Capacity } \\
\mathrm{gpm} / \mathrm{ft}\end{array}$ & Remarks \\
\hline
\end{tabular}

Los Alamos Well Field

$\begin{array}{lcccccccccc}\text { Well LA-1 } & 1946 & 1001 & 870 & 598 & 1960 & F(1946) & 84(1990) & 366 & 0.8 & \begin{array}{l}\text { unequipped } \\ (1990)\end{array} \\ \text { Well LA-1B } 1960 & 2256 & 1750 & 1655 & 1983 & +34(1960) & 70(1990) & 561 & 4.4 & \begin{array}{l}\text { unequipped } \\ (1992)\end{array} \\ \text { Well LA-2 } & 1946 & 882 & 870 & 878 & 1962 & F(1946) & 134(1990) & 280 & 1.4 & \\ \text { Well LA-3 } & 1947 & 910 & 870 & 816 & 1983 & F(1947) & 122(1990) & 302 & 1.7 & \begin{array}{l}\text { unequipped } \\ (1992)\end{array} \\ \text { Well LA-4 } & 1948 & 2019 & 1964 & 1907 & 1988 & 189(1948) & 284(1986) & 552 & 5.9 & \begin{array}{l}\text { unequipped } \\ \text { (1990) }\end{array} \\ \text { Well LA-5 } & 1948 & 2024 & 1750 & 1954 & 1962 & 71(1948) & 168(1986) & 419 & 2.9 & \begin{array}{l}\text { unequipped } \\ \text { (1994) } \\ \text { unequipped } \\ \text { (1990) }\end{array} \\ \text { Well LA-6 } & 1948 & 2030 & 1710 & 1200 & 1976 & 2(1948) & 92(1985) & 580 & 10.2\end{array}$

Guaje Well Field

$\begin{array}{lcccccccccc}\text { Well G-1 } & 1950 & 2020 & 2000 & 1750 & 1962 & 192(1951) & 284(1990) & 241 & 1.4 & \\ \text { Well G-1A } & 1954 & 2071 & 1519 & 1500 & 1973 & 250(1954) & 322(1990) & 499 & 12.4 & \\ \text { Well G-2 } & 1951 & 2006 & 1970 & 1707 & 1981 & 259(1951) & 321(1990) & 443 & 11.6 & \\ \text { Well G-3 } & 1951 & 1997 & 1792 & 1238 & 1988 & 280(1951) & 375(1986) & 196 & 1.9 & \text { not on-line } \\ \text { Well G-4 } & 1951 & 2002 & 1930 & 1177 & 1981 & 347(1951) & 381(1990) & 177 & 0.9 & \\ \text { Well G-5 } & 1951 & 1997 & 1840 & 703 & 1986 & 411(1951) & 491(1990) & 390 & 10.0 & \\ \text { Well G-6 } & 1964 & 2005 & 1530 & 1480 & 1979 & 572(1964) & 589(1990) & 272 & 3.3 & \end{array}$

Pajarito Well Field

$\begin{array}{llllllllll}\text { Well PM-1 } & 1965 & 2501 & 2499 & 2479 & 1973 & 722(1965) & 752(1990) & 561 & 31.6 \\ \text { Well PM-2 } & 1965 & 2600 & 2300 & 2286 & 1987 & 823(1965) & 860(1990) & 1319 & 17.6 \\ \text { Well PM-3 } & 1966 & 2552 & 2552 & 2552 & 1966 & 740(1966) & 767(1990) & 1382 & 64.7 \\ \text { Well PM-4 } & 1981 & 2920 & 2875 & 2875 & 1981 & 1060(1981) & 1083(1990) & 1293 & 34.3 \\ \text { Well PM-5 } & 1982 & 3120 & 3092 & 3092 & 1982 & 1208(1982) & 1234(1990) & 1250 & 11.7\end{array}$

Otowi Well Field

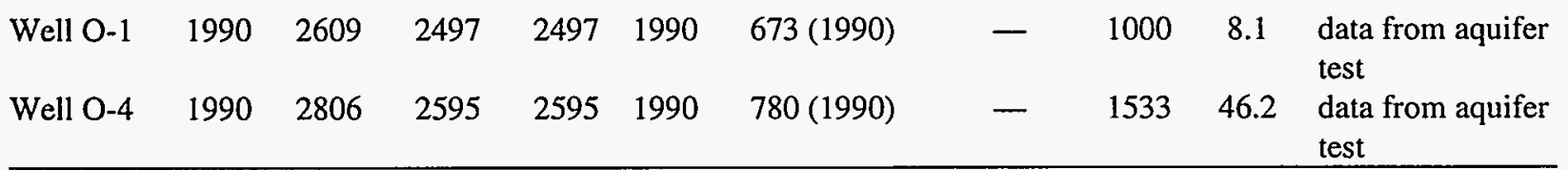
Depth of well to where infiltrating sand has filled it in. 
TABLE XXI-B. Geologic Logs and Casing Schedules for Supply Wells in the Los Alamos Well Field (7 Wells)

1. Well LA-1

Elevation (LSD): $5624 \mathrm{ft}$

Geologic Log

Alluvium

Santa Fe Group

Chamita Formation

Tesuque Formation

$\begin{array}{cc}\begin{array}{c}\text { Thickness } \\ \frac{(\mathrm{ft})}{76}\end{array} & \begin{array}{c}\text { Depth } \\ \frac{(\mathrm{ft})}{76}\end{array} \\ 0 & \\ 925 & 1001\end{array}$

Casing Schedule

$870 \mathrm{ft}$ of 12 -in.-diam casing set from 0 to $870 \mathrm{ft} ; 805 \mathrm{ft}$ of slots between 60 and $865 \mathrm{ft}$; gravel packed.

Geophysical Log

None.

2. Well LA-1B

Elevation (LSD): $5622 \mathrm{ft}$

Geologic Log

Alluvium

Santa Fe Group

Chamita Formation

Tesuque Formation

$\begin{array}{cc}\begin{array}{c}\text { Thickness } \\ \frac{(\mathrm{ft})}{78}\end{array} & \begin{array}{c}\text { Depth } \\ \frac{(\mathrm{ft})}{78}\end{array} \\ 0 & \\ 2178 & 2256\end{array}$

Casing Schedule

$64 \mathrm{ft}$ of 36 -in.-diam corrugated metal pipe set from 0 to $64 \mathrm{ft} ; 104 \mathrm{ft}$ of 26 -in.-diam steel casing set from 0 to $104 \mathrm{ft} ; 650 \mathrm{ft}$ of 12 -in.-diam wrought iron casing set from 0 to $650 \mathrm{ft} ; 1100 \mathrm{ft}$ of 10 -in.-diam wrought iron casing welded to 12 -in.-diam casing set from $650 \mathrm{ft}$ to $1750 \mathrm{ft} ; 591 \mathrm{ft}$ of perforations between $326 \mathrm{ft}$ and $1694 \mathrm{ft}$; gravel packed.

Geophysical Log

Electrical log (Cushman 1965).

3. Well LA-2

Elevation (LSD): $5651 \mathrm{ft}$

Geologic Log

Alluvium

Thickness

Depth

$\frac{(\mathrm{ft})}{60} \quad(\mathrm{ft})$

Santa Fe Group

Chamita Formation

60

60

Tesuque Formation

0

$822 \quad 882$

Casing Schedule

$870 \mathrm{ft}$ of 12 -in.-diam casing set from 0 to $870 \mathrm{ft} ; 760 \mathrm{ft}$ of slotted casing and screen between 105 and $865 \mathrm{ft}$; gravel packed.

Geophysical Logs

None.

4. Well LA-3

Elevation (LSD): $5672 \mathrm{ft}$

Geologic Log

$\begin{array}{cc}\begin{array}{c}\text { Thickness } \\ (\mathrm{ft})\end{array} & \begin{array}{c}\text { Depth } \\ 51\end{array} \\ \frac{(\mathrm{ft})}{51}\end{array}$


TABLE XXI-B. Geologic Logs and Casing Schedules for Supply Wells in the Los Alamos Well Field (7 Wells) (Continued)

4. Well LA-3 (Continued)

Santa Fe Group

Chamita Formation

Tesuque Formation 0 859

910

Casing Schedule

$870 \mathrm{ft}$ of 12 -in.-diam casing set from 0 to $870 \mathrm{ft} ; 760 \mathrm{ft}$ of slotted casing and screen between 105 and $865 \mathrm{ft}$; gravel packed.

Geophysical Logs

None.

\title{
5. Well LA-4
}

Elevation (LSD): $5975 \mathrm{ft}$

Geologic Log

Alluvium Thickness

Depth

(ft)

$\underline{(\mathrm{ft})}$

Puye Conglomerate

27

27

Fanglomerate member

$86 \quad 113$

Totavi Lentil

50

163

Santa Fe Group

Chamita Formation

Tesuque Formation

\section{0}

1856

2019

Casing Schedule

$754 \mathrm{ft}$ of 12 -in.-diam casing set 0 to $754 \mathrm{ft}$; with $1211 \mathrm{ft}$ of 10 -in.-diam casing from 754 to $1965 \mathrm{ft}$;

$350 \mathrm{ft}$ of slotted casing between $754 \mathrm{ft}$ and $1964 \mathrm{ft}$; gravel packed.

Geophysical Log

Electrical (Cushman 1965).

\section{Well LA-5}

Elevation (LSD): $5840 \mathrm{ft}$

\author{
Geologic Log \\ Alluvium \\ Santa Fe Group \\ Chamita Formation \\ Tesuque Formation
}

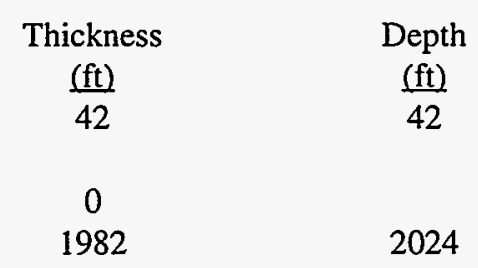

Casing Schedule

$630 \mathrm{ft}$ of 12-in.-diam casing set from 0 to $630 \mathrm{ft} ; 1120 \mathrm{ft}$ of 10 -in.-diam casing from 630 to $1750 \mathrm{ft}$; $350 \mathrm{ft}$ of slotted casing between $440 \mathrm{ft}$ and $1740 \mathrm{ft}$; gravel packed.

Geophysical Log

Electrical (Cushman 1965). 
TABLE XXI-B. Geologic Logs and Casing Schedules for Supply Wells in the Los Alamos Well Field (7 Wells) (Continued)

7. Well LA-6

Elevation (LSD): $5770 \mathrm{ft}$

Geologic Log

Alluvium

Thickness

Depth

Santa Fe Group

Chamita Formation

Tesuque Formation

$\underline{(\mathrm{ft})}$

$\underline{(\mathrm{ft})}$

$36 \quad 36$

0

$1994 \quad 2030$

Casing Schedule

$597 \mathrm{ft}$ of 12 -in.-diam casing set from 0 to $597 \mathrm{ft} ; 1193 \mathrm{ft}$ of 10 -in.-diam casing from 597 to $1790 \mathrm{ft} ; 400 \mathrm{ft}$ of slotted casing between $420 \mathrm{ft}$ and $1778 \mathrm{ft}$; gravel packed.

Geophysical Log

Electrical (Cushman 1965); conductivity, temperature, gamma-ray/neutron (Purtymun 1977). 
TABLE XXI-C. Geologic Logs and Casing Schedules for Supply Wells in the Guaje Well Field (7 Wells)

1. Well G-1

Elevation (LSD): $5973 \mathrm{ft}$

$\begin{array}{lcc}\text { Geologic Log } & \frac{(\mathrm{ft})}{12} & \frac{\mathrm{ft})}{12} \\ \text { Alluvium } & & 25 \\ \text { Puye Conglomerate } & 13 & 75 \\ \quad \text { Fanglomerate member } & 50 & 680 \\ \quad \text { Totavi Lentil } & 605 & \\ \begin{array}{l}\text { Santa Fe Group } \\ \quad \text { Chaquehui Formation }\end{array} & 0 & 2020 \\ \quad \text { Chamita Formation } \\ \quad \begin{array}{l}\text { Tesuque Formation } \\ \quad \text { Basalts or basalt breccias logged } \\ \quad \text { from } 1540 \text { to } 1838 \mathrm{ft}\end{array} \\ \begin{array}{l}\text { Casing Schedule } \\ 490 \mathrm{ft} \text { of } 12 \text {-in.-diam casing set } 0 \text { to } 490 \mathrm{ft} ; 1510 \mathrm{ft} \text { of 10-in.-diam casing from } 490 \text { to } 2000 \mathrm{ft} \text {; }\end{array} \\ 490 \mathrm{ft} \text { of slotted casing between } 282 \text { and } 1980 \mathrm{ft} \text {; gravel packed. }\end{array}$

Geophysical Log

Electrical (Cushman 1965).

\section{Well G-1A}

Elevation (LSD): $6014 \mathrm{ft}$

\section{Geologic Log}

Alluvium

Puye Conglomerate

Fanglomerate member

Totavi Lentil

Santa Fe Group

Chaquehui Formation

Chamita Formation

Tesuque Formation

Basalt or basalt breccias logged

from 1505 to $1675 \mathrm{ft} ; 1755$ to $1790 \mathrm{ft}$

$\begin{array}{cc}\begin{array}{c}\text { Thickness } \\ \frac{\mathrm{ft})}{12}\end{array} & \begin{array}{c}\text { Depth } \\ (\mathrm{ft})\end{array} \\ 47 & 12 \\ 63 & 59 \\ 738 & 122 \\ 0 & 860 \\ & \\ 1211 & 2071\end{array}$

\section{Casing Schedule}

$663 \mathrm{ft}$ of 12 -in.-diam casing set from 0 to $663 \mathrm{ft} ; 856 \mathrm{ft}$ of 10 -in.-diam casing from 663 to $1519 \mathrm{ft}$;

$563 \mathrm{ft}$ of slotted casing between 272 and $1513 \mathrm{ft}$; gravel packed.

Geophysical Log

Electrical (Cushman 1965).

\section{Well G-2}

Elevation (LSD): $6056 \mathrm{ft}$

\section{Geologic Log}

Alluvium

Puye Conglomerate

Fanglomerate member Totavi Lentil

$\begin{array}{cc}\begin{array}{c}\text { Thickness } \\ \frac{(\mathrm{ft})}{13}\end{array} & \begin{array}{c}\text { Depth } \\ (\mathrm{ft})\end{array} \\ & 13 \\ 17 & 30 \\ 45 & 75\end{array}$


TABLE XXI-C. Geologic Logs and Casing Schedules for Supply Wells in the Guaje Well Field (7 Wells) (Continued)

\section{Well G-2 (Continued)}

Santa Fe Group

Chaquehui Formation

Chamita Formation

Tesuque Formation

845

920

(no basalts logged)

1086

2006

Casing Schedule

$600 \mathrm{ft}$ of 12 -in.-diam casing set from 0 to $600 \mathrm{ft} ; 1370 \mathrm{ft}$ of 10 -in.-diam casing from 600 to $1970 \mathrm{ft}$;

$425 \mathrm{ft}$ of slotted casing from 281 to $1960 \mathrm{ft}$; gravel packed.

Geophysical Log

Electrical (Cushman 1965).

\section{Well G-3}

Elevation (LSD): $6139 \mathrm{ft}$

\section{Geologic Log}

Alluvium

$\begin{array}{cc}\begin{array}{c}\text { Thickness } \\ \frac{(\mathrm{ft})}{17}\end{array} & \begin{array}{c}\text { Depth } \\ \frac{(\mathrm{ft})}{17}\end{array} \\ 41 & \\ 52 & 58 \\ & 110\end{array}$

Fanglomerate member

Totavi Lentil

52

110

Santa Fe Group

Chaquehui Formation

Basalt or basalt breccias logged

from 921 to $936 \mathrm{ft} ; 1012$ to $1090 \mathrm{ft}$

Chamita Formation

Tesuque Formation

$\begin{array}{cc}980 & 1090 \\ 0 & \\ 906 & 1997\end{array}$

Casing Schedule

12-in.-diam casing set from 0 to $695 \mathrm{ft} ; 1097 \mathrm{ft}$ of $10 \mathrm{in}$.-diam casing from 695 to $1792 \mathrm{ft}$; $400 \mathrm{ft}$ of slotted casing between 441 and $1785 \mathrm{ft}$; gravel packed.

Geophysical Log

Electrical (Cushman 1965).

5. Well G-4

Elevation (LSD): $6229 \mathrm{ft}$

Geologic Log

Alluvium

Thickness

(ft)

15

45

60

1030

0

852
Depth

(ft)

15

60

120

Santa Fe Group

Chaquehui Formation

Basalt or basalt breccias from

499 to $526 \mathrm{ft} ; 855$ to $925 \mathrm{ft}$;

956 to $976 \mathrm{ft} ; 1103$ to $1150 \mathrm{ft}$

Chamita Formation

1150

Tesuque Formation

2002 
TABLE XXI-C. Geologic Logs and Casing Schedules for Supply Wells in the Guaje Well Field (7 Wells)

(Continued)

\section{Well G-4 (Continued)}

Casing Schedule

$720 \mathrm{ft}$ of 12 -in.-diam casing set 0 to $720 \mathrm{ft} ; 1210 \mathrm{ft}$ of 10 -in.-diam casing from 720 to $1930 \mathrm{ft}$;

$360 \mathrm{ft}$ of slotted casing between 426 and $1925 \mathrm{ft}$; well damage repaired 1977, slotted liner set in well from 1214 to $1750 \mathrm{ft}$; gravel packed.

Geophysical Log

Electrical (Cushman 1965).

\section{Well G-5}

Elevation (LSD): $6306 \mathrm{ft}$

\section{Geologic Log}

Alluvium

$\begin{array}{cc}\begin{array}{c}\text { Thickness } \\ (\mathrm{ft})\end{array} & \begin{array}{c}\text { Depth } \\ \text { (ft) }\end{array} \\ .8 & \frac{8}{8}\end{array}$

Puye Conglomerate

Fanglomerate member

119

127

Totavi Lentil

Santa $\mathrm{Fe}$ Group

Chaquehui Formation

Basalt or basalt breccias from

586 to $613 \mathrm{ft}$; 906 to $1135 \mathrm{ft}$;

$1211 \mathrm{ft}$ to $1330 \mathrm{ft}$

Chamita Formation

Tesuque Formation

1203

0

667
1330

1997

Casing Schedule

$739 \mathrm{ft}$ of 12-in.-diam casing set from 0 to $739 \mathrm{ft} ; 1101 \mathrm{ft}$ of 10-in.-diam casing from 739 to $1840 \mathrm{ft}$; $400 \mathrm{ft}$ of slotted casing between 462 and $1830 \mathrm{ft}$.

Geophysical Log

Electrical (Cushman 1965).

7. Well G-6

Elevation (LSD): $6422 \mathrm{ft}$

\begin{tabular}{lcc} 
Geologic Log & $\frac{(\mathrm{ft})}{40}$ & $\frac{(\mathrm{ft})}{40}$ \\
\hline Alluvium & & 130 \\
Puye Conglomerate & 90 & 200 \\
$\quad$ Fanglomerate member & 70 & \\
$\quad$ Totavi Lentil & & \\
Santa Fe Group & & 1470 \\
$\quad$ Chaquehui Formation & 1270 \\
$\quad$ Basalt from 1070 to $1170 \mathrm{ft}$; & 0 & \\
$\quad 1180$ to $1220 \mathrm{ft} ; 1270$ to $1425 \mathrm{ft} ;$ & & \\
$\quad 1445 \mathrm{ft}$ to $1470 \mathrm{ft}$ & & \\
Chamita Formation & & 2005 \\
Tesuque Formation &
\end{tabular}


TABLE XXI-C. Geologic Logs and Casing Schedules for Supply Wells in the Guaje Well Field (7 Wells) (Continued)

7. Well G-6 (Continued)

Casing Schedule

$206 \mathrm{ft}$ of 24-in.-diam casing cemented in 0 to $206 \mathrm{ft} ; 1530 \mathrm{ft}$ of 12 -in.-diam casing: blank from

0 to $700 \mathrm{ft}$ with louvers from 700 to $1510 \mathrm{ft}$, blank from 1510 to $1530 \mathrm{ft}$.

Geophysical Log

Temperature, gamma-ray/neutron, induction-electric, and microlog with caliper

(Cooper et al. 1965). 
TABLE XXI-D. Geologic Logs and Casing Schedules for Supply Wells in the Pajarito Well Field (5 Wells)

1. Well PM-1

Elevation (LSD): $6520 \mathrm{ft}$

\begin{tabular}{|c|c|c|}
\hline Geologic Log & $(\mathrm{ft})$ & $\underline{(\mathrm{ft})}$ \\
\hline \multicolumn{3}{|l|}{ Bandelier Tuff } \\
\hline Otowi Member & 120 & 120 \\
\hline Guaje Member & 45 & 165 \\
\hline \multicolumn{3}{|l|}{ Basaltic Rocks of Chino Mesa } \\
\hline Unit 3 & 342 & 507 \\
\hline Old Alluvium & 43 & 550 \\
\hline \multicolumn{3}{|l|}{ Puye Conglomerate } \\
\hline Fanglomerate member & 225 & 775 \\
\hline Totavi Lentil & 20 & 795 \\
\hline \multicolumn{3}{|l|}{ Santa Fe Group } \\
\hline \multicolumn{3}{|l|}{ Chaquehui Formation } \\
\hline \multicolumn{3}{|l|}{ Basalt from 836 to $966 \mathrm{ft}$; } \\
\hline \multicolumn{3}{|l|}{1166 to $1180 \mathrm{ft} ; 1506$ to } \\
\hline $1510 \mathrm{ft} ; 1546$ to $1548 \mathrm{ft}$ & 1003 & 1798 \\
\hline Chamita Formation & 76 & 1874 \\
\hline Tesuque Formation & 627 & 2501 \\
\hline Casing Schedule & & \\
\hline
\end{tabular}

Geophysical Logs

Temperature, gamma-ray/neutron, induction-electric, microlog with caliper (Cooper et al. 1965.)

\section{Well PM-2}

Elevation (LSD): $6715 \mathrm{ft}$

$\begin{array}{lcc}\text { Geologic Log } & \begin{array}{c}\frac{(\mathrm{ft})}{30} \\ \text { Alluvium }\end{array} & \begin{array}{c}\text { (ft) } \\ \text { Bandelier Tuff }\end{array} \\ \quad \text { Otowi Member } & 375 & 405 \\ \quad \text { Guaje Member } & 27 & 432 \\ \text { Basaltic Rocks of Chino Mesa } & 268 & 700 \\ \quad \text { Unit 2 } & & \\ \text { Puye Conglomerate } & & \\ \quad \text { Fanglomerate member } & & \\ \quad \text { Basalt Unit 2 from 734 to 738 ft; } & 640 & 1340 \\ \quad 758 \text { to 770 ft } & 70 & \\ \quad \text { Totavi Lentil } & & \\ \text { Santa Fe Group } & & 2370 \\ \quad \text { Chaquehui Formation } & & 2410 \\ \quad \text { Basalt from 1840 to } 1892 \mathrm{ft} ; & 960 & 2600 \\ \quad \text { 2218 to 2312 ft } & 40 & \end{array}$


TABLE XXI-D. Geologic Logs and Casing Schedules for Supply Wells in the Pajarito Well Field (5 Wells) (Continued)

2. Well PM-2 (Continued)

Casing Schedule

$504 \mathrm{ft}$ of 26 -in.-diam casing cemented in 0 to $504 \mathrm{ft} ; 2300 \mathrm{ft}$ of 14 -in.-diam casing: blank from 0 to $1004 \mathrm{ft}$, louvers from 1004 to $2280 \mathrm{ft}$, blank from 2280 to $2300 \mathrm{ft}$.

Geophysical Logs

Temperature, gamma-ray/neutron, induction-electrical, and microlog with caliper (Cooper et al.1965.)

\section{Well PM-3}

Elevation (LSD): $6640 \mathrm{ft}$

\begin{tabular}{|c|c|c|}
\hline Geologic Log & $(\mathrm{ft})$ & $(\mathrm{ft})$ \\
\hline Alluvium & 30 & 30 \\
\hline \multicolumn{3}{|l|}{ Bandelier Tuff } \\
\hline Otowi Member & 140 & 170 \\
\hline Guaje Member & 20 & 190 \\
\hline \multicolumn{3}{|l|}{ Puye Conglomerate } \\
\hline Fanglomerate member & 25 & 215 \\
\hline \multicolumn{3}{|c|}{ Basaltic Rocks of Chino Mesa } \\
\hline Unit 2 & 325 & 540 \\
\hline \multicolumn{3}{|l|}{ Puye Conglomerate } \\
\hline Fanglomerate member & 205 & 745 \\
\hline Totavi Lentil & 60 & 805 \\
\hline \multicolumn{3}{|l|}{ Santa Fe Group } \\
\hline \multicolumn{3}{|l|}{ Chaquehui Formation } \\
\hline \multicolumn{3}{|c|}{ Basalt from 1105 to $1315 \mathrm{ft}$; } \\
\hline Chamita Formation & 0 & \\
\hline Tesuque Formation & 492 & 2552 \\
\hline \multicolumn{3}{|c|}{$\begin{array}{l}\text { Casing Schedule } \\
552 \mathrm{ft} \text { of } 26 \text {-in.-diam casing cemented in } 0 \text { to } 552 \mathrm{ft} ; 2552 \mathrm{ft} \text { of } 14 \text {-in.-diam casing: bla }\end{array}$} \\
\hline \multicolumn{3}{|c|}{$\begin{array}{l}552 \mathrm{ft} \text { of } 26 \text {-in.-diam casing cemented in } 0 \text { to } 552 \mathrm{ft} ; 2552 \mathrm{ft} \text { of } 14 \text {-in.-diam casing: blank from } 0 \text { to } 956 \mathrm{ft} \text {, } \\
\text { louvers from } 956 \mathrm{ft} \text { to } 2532 \mathrm{ft} \text {, blank from } 2532 \text { to } 2552 \mathrm{ft} \text {; gravel packed. }\end{array}$} \\
\hline
\end{tabular}

\section{Well PM-4}

Elevation (LSD): $6920 \mathrm{ft}$

Geologic Log

Bandelier Tuff

$\begin{array}{lll}\text { Tshirege Member } & 220 & 220\end{array}$

Otowi Member - $320 \quad 540$

Guaje Member $\quad 60 \quad 600$

Basaltic Rocks of Chino Mesa $\quad 500$ 
TABLE XXI-D. Geologic Logs and Casing Schedules for Supply Wells in the Pajarito Well Field (5 Wells) (Continued)

4. Well PM-4 (Continued)

Puye Conglomerate

Fanglomerate member

$280 \quad 1380$

Totavi Lentil

$40-1420$

Santa Fe Group

Chaquehui Formation

Basalt 1950 to $1980 \mathrm{ft}$;

2090 to $2150 \mathrm{ft} ; 2190$ to

$2280 ; 2320$ to $2430 \mathrm{ft}$

1500

2920

Casing Schedule

$41 \mathrm{ft}$ of 42 -in.-diam casing cemented in from 0 to $41 \mathrm{ft} ; 923 \mathrm{ft}$ of 28 -in.-diam casing cemented in 0 to $923 \mathrm{ft}$; $2874 \mathrm{ft}$ of 16-in.-diam casing: blank from 0 to $1260 \mathrm{ft}$; louvers from 1260 to $2854 \mathrm{ft}$; blank 2854 to $2874 \mathrm{ft}$; gravel packed.

Geophysical Logs

Dual-induction, microlaterolog-microlog, compensated neutron-formation density, and temperature (files available from ESH-18 Geohydrology section).

\section{Well PM-5}

Elevation (LSD): $7095 \mathrm{ft}$

Geologic Log

Bandelier Tuff

Tshirege Member

Otowi Member

Guaje Member

Basaltic Rocks of Chino Mesa

Unit 2

Puye Conglomerate

Fanglomerate member

Basaltic Rocks of Chino Mesa

Unit 2

Thickness

(ft)

335

375

30

20

45

125

35

180

325

80

Totavi Lentil

Santa Fe Group

Chaquehui Formation

Basalt from 1765 to $1895 \mathrm{ft} ; 1940$ to $2075 \mathrm{ft}$; 2160 to $2640 \mathrm{ft} ; 2690$ to $2740 \mathrm{ft}$

Chamita Formation

Tesuque Formation
1230

2780

80

250

2860

3110
Depth

(ft)

335

710

740

760

805

930

965

1145

1470

1550

Casing Schedule

$40 \mathrm{ft}$ of 42 -in.-diam casing cemented in 0 to $40 \mathrm{ft} ; 1178 \mathrm{ft}$ of 28 -in.-diam blank casing cemented in 0 to

$1178 \mathrm{ft}$; $3092 \mathrm{ft}$ of 16 -in.-diam casing: blank 0 to $1440 \mathrm{ft}$, louvers from 1440 to $3072 \mathrm{ft}$, blank 3072 to $3092 \mathrm{ft}$.

Geophysical Log

Dual-induction, microlaterolog-microlog, compensated neutron-formation density, and temperature (files available from ESH-18 Geohydrology section). 
TABLE XXI-E. Geologic Logs and Casing Schedules for Supply Wells in the Otowi Well Field (2 Wells)

1. Well O-1

Elevation (LSD): $6396 \mathrm{ft}$

Geologic Log

Alluvium

Thickness

Depth

$\frac{(\mathrm{ft})}{50} \quad \frac{(\mathrm{ft})}{50}$

Puye Conglomerate Fanglomerate member

$30 \quad 80$

Basaltic Rocks of Chino Mesa Unit 3

200

280

Puye Conglomerate Fanglomerate member

$160 \quad 440$

Basaltic Rocks of Chino Mesa

Unit 2

$30 \quad 470$

Puye Conglomerate Fanglomerate member $\quad 220$

Totavi Lentil

60

750

Santa Fe Group

Chaquehui Formation

Chamita Formation

Tesuque Formation

Basalt sill from 2219 to $2231 \mathrm{ft}$

0

0

18592609

Casing Schedule

$60 \mathrm{ft}$ of 38-in.-diam blank casing cemented in 0 to $60 \mathrm{ft}$; $662 \mathrm{ft}$ of 28 -in.-diam blank casing cemented in 0 to $662 \mathrm{ft} ; 2498 \mathrm{ft}$ of 16 -in.-diam casing: blank 0 to $1017 \mathrm{ft}$; louvers 1017 to $2477 \mathrm{ft} ; 20 \mathrm{ft}$ blank casing 2477 to $2497 \mathrm{ft}$.

Geophysical Logs

Temperature, microlog, compensated neutron-formation density, and dual induction-SFL (files available from ESH-18 Geohydrology section).

2. Well O-4

Elevation (LSD): $6627 \mathrm{ft}$

Geologic Log

Alluvium

Bandelier Tuff

Puye Conglomerate

Fanglomerate member

Basaltic Rocks of Chino Mesa

Unit 2

$\begin{array}{cc}\begin{array}{c}\text { Thickness } \\ \frac{(\mathrm{ft})}{28}\end{array} & \begin{array}{c}\text { Depth } \\ (\mathrm{ft})\end{array} \\ 155 & 28 \\ & 183 \\ 107 & 290 \\ & \\ 123 & 413 \\ 299 & 712 \\ 98 & 810 \\ & \\ 1530 & 2340 \\ 80 & 2420 \\ 386 & 2806\end{array}$

Puye Conglomerate

Fanglomerate member

Totavi Lentil

Santa Fe Group

Chaquehui Formation

$\begin{array}{lcc}\text { Basalt from } 1154 \text { to } 1347 \mathrm{ft} ; 1421 \text { to } 1465 \mathrm{ft} & 1530 & 2340 \\ \text { Chamita Formation } & 80 & 2420\end{array}$

2806

Casing Schedule

$60 \mathrm{ft}$ of 38-in.-diam blank casing cemented in 0 to $60 \mathrm{ft} ; 723 \mathrm{ft}$ of 28 -in.-diam blank casing cemented in

0 to $723 \mathrm{ft} ; 2617 \mathrm{ft}$ of 16 -in.-diam casing: blank 0 to $1115 \mathrm{ft}$, louvers 1115 to $2596 \mathrm{ft}$ blank 2596 to $2617 \mathrm{ft}$.

Geophysical Logs

Temperature, microlog, compensated neutron-formation density, and dual induction-SFL (files available from ESH-18 Geohydrology section). 
A. Los Alamos Well Field

Well LA-I

Well LA-1B

Well LA-2

Well LA-3

Well LA-4

Well LA-5

Well LA-6

B. Guaje Well Field

$\begin{array}{lll}\text { N } 1,776,865 & \text { E } 527,838 & 5624 \mathrm{ft} \\ \text { N } 1,776,890 & \text { E } 528,004 & 5622 \mathrm{ft} \\ N 1,777,157 & \text { E } 526,681 & 5651 \mathrm{ft} \\ \text { N } 1,777,123 & \text { E } 525,747 & 5672 \mathrm{ft} \\ \text { N } 1,771,171 & \text { E } 517,203 & 5975 \mathrm{ft} \\ \text { N } 1,772,471 & \text { E } 519,582 & 5840 \mathrm{ft} \\ \text { N } 1,774,531 & \text { E } 522,637 & 5770 \mathrm{ft}\end{array}$

N 1,783,547

E 515,946

E 514,997

E 513,966

E 511,432

E 508,705

E 506,705

E 504,580

$5973 \mathrm{ft}$ $6014 \mathrm{ft}$ $6056 \mathrm{ft}$ $6139 \mathrm{ft}$ $6229 \mathrm{ft}$ $6306 \mathrm{ft}$ $6422 \mathrm{ft}$
N $1,787,845$

N $1,786,789$

C. Pajarito Well Field

$\begin{array}{ll}\text { Well PM-1 } & \text { N } 1,768,050 \\ \text { Well PM-2 } & \text { N } 1,760,264 \\ \text { Well PM-3 } & \text { N } 1,769,364 \\ \text { Well PM-4 } & \text { N } 1,764,612 \\ \text { Well PM-5 } & \text { N } 1,767,747\end{array}$

D. Otowi Well Field
E 507,490

E 496,542

E 505,387

E 495,472

E 492,839
$6520 \mathrm{ft}$

$6715 \mathrm{ft}$ $6640 \mathrm{ft}$ $6920 \mathrm{ft}$ $7095 \mathrm{ft}$

Well O-1

N $1,772,169$

N 1,772,933

E 509,152

E 497,093

$6396 \mathrm{ft}$

$6627 \mathrm{ft}$ 


\section{SPRINGS IN THE LOS ALAMOS AREA}

Springs in the Los Alamos area divide into three groups: (1) springs on the flanks of the Sierra de los Valles; (2) springs in lower Los Alamos Canyon; and (3) springs in White Rock Canyon. Springs in DP and Pajarito canyons were discussed in sections IV and VII respectively.

\section{A. Springs on the Flanks of the Mountains}

There are 13 springs located on the flanks of the mountains west of the Pajarito Plateau (Fig. XXII-A). Some discharge from alluvium in the canyon bottoms from seepage from coalluvium on the canyon walls or from perched areas in the Bandelier Tuff (Table XXII-A). A number of these springs furnished the early water supply to the ranch school (prior to 1943) and the Laboratory (thereafter).

The 1948 investigation of the caldera included a study of springs on the flanks of the mountains, with the aim of determining whether they could furnish a water supply to Los Alamos. The study indicated that only a small number of springs were suitable for water supply development, and that the amount of water available fell short of the projected demand (Stearns 1948).

\section{B. Springs in Lower Los Alamos Canyon}

Basalt Spring, in Los Alamos Canyon, discharges from Unit 3 of the Basaltic Rocks of Chino Mesa from a perched aquifer located in Pueblo, Los Alamos and Sandia Canyons to the west (Fig. XXII-B). This same perched aquifer probably recharges Sandia Spring, which discharges from the Totavi Lentil. Los Alamos Spring discharges from Unit 4 of the Basaltic Rocks of Chino Mesa (Table XXII-A). The spring is a seep recharged locally.

Indian and Sacred Springs discharge from a fault zone in the siltstones and silty sandstones of the Tesuque Formation that extends north/south from Los Alamos Canyon to the unnamed canyon to the north.

\section{Springs in White Rock Canyon}

Twenty-seven springs discharge from the main aquifer in and along the Rio Grande in White Rock Canyon (Fig. XXII-B). Twenty-two of the springs are separated into three groups of similar aquifer-related chemical quality (Table XXII-A). The five remaining springs make up a fourth group that varies in quality according to localized conditions in the aquifer.

Group I springs discharge from the Totavi Lentil that is composed of sand, gravel, cobbles, and boulders of quartzite, massive white-to-pink quartz, granite, and other felsic rock debris. The lentil is generally less than $50 \mathrm{ft}$ thick. The water is mainly a calcium-bicarbonate type with average total dissolved solids of $165 \mathrm{mg} / \mathrm{L}$.

Group II springs discharge from the coarsegrained sediments composed of arkosic siltstones and sandstone with a mixture of volcanic sediments. These sediments represent the Chaquehui Formation and associated maar sediments. They are interbedded in some places with some of the older basalt flows. The water is a sodium-bicarbonate type with average total dissolved solids of $185 \mathrm{mg} / \mathrm{L}$.

Group III springs discharge from fine-grained sediments of the Tesuque Formation that consist of arkosic siltstones and silty sandstones, with an occasional lens of siltstone or pebbly conglomerate. The water is mainly a calcium-bicarbonite type, with average total dissolved solids of $215 \mathrm{mg} / \mathrm{L}$.

Group IV springs are five springs located on the east side of the river which discharge from the finegrained sediments of the Tesuque Formation in areas that are associated with faulting or basalt plugs. Chemical constituents are higher in general, with average total dissolved solids of $510 \mathrm{mg} / \mathrm{L}$.

Spring 4A and Ancho Spring discharge from the Totavi Lentil above the river in the lower parts of Pajarito and Ancho Canyons (Fig. XXII-B and Table XXII-A). Stream flow from these springs is of sufficient volume to reach the Rio Grande (Table XXII-B). There are 11 major canyons that enter the Rio Grande in the 12-mile reach of the river from Otowi to the mouth of Frijoles Canyon.

\section{REFERENCES}

R. L. Griggs, "Geology and Water Resources of the Los Alamos Area, New Mexico," U.S. Geol. Survey Admin. Report to the U.S. Atomic Energy Commission (1955).

W. D. Purtymun, "Geology and Hydrology of White Rock Canyon from Otowi to the Confluence of Frijoles Canyon, Los Alamos and Santa Fe Counties, New Mexico," U.S. Geol. Survey Open-File Report (1966).

W. D. Purtymun, R. J. Peters, and J. W. Owens, "Geohydrology of White Rock Canyon of the Rio Grande from Otowi to Frijoles Canyon," Los Alamos Scientific Laboratory report LA-8635-MS (1980).

H. T. Stearns, "Ground-Water Supplies for Los Alamos, New Mexico," Consulting Geologist Report to the U.S. Atomic Energy Commission (1948). 


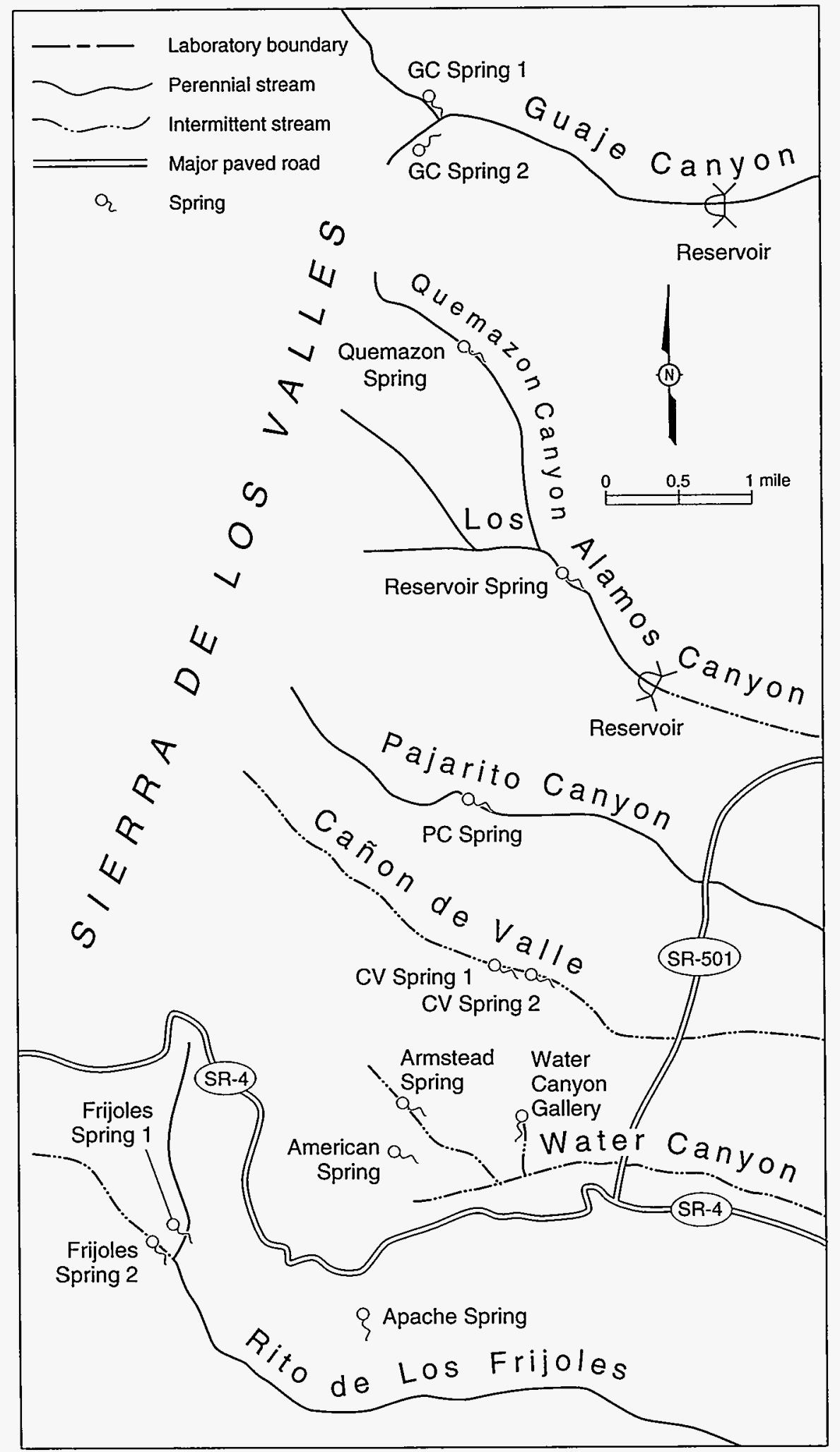

Fig. XXII-A. Locations of springs on the east flank of the Sierra de los Valles. 


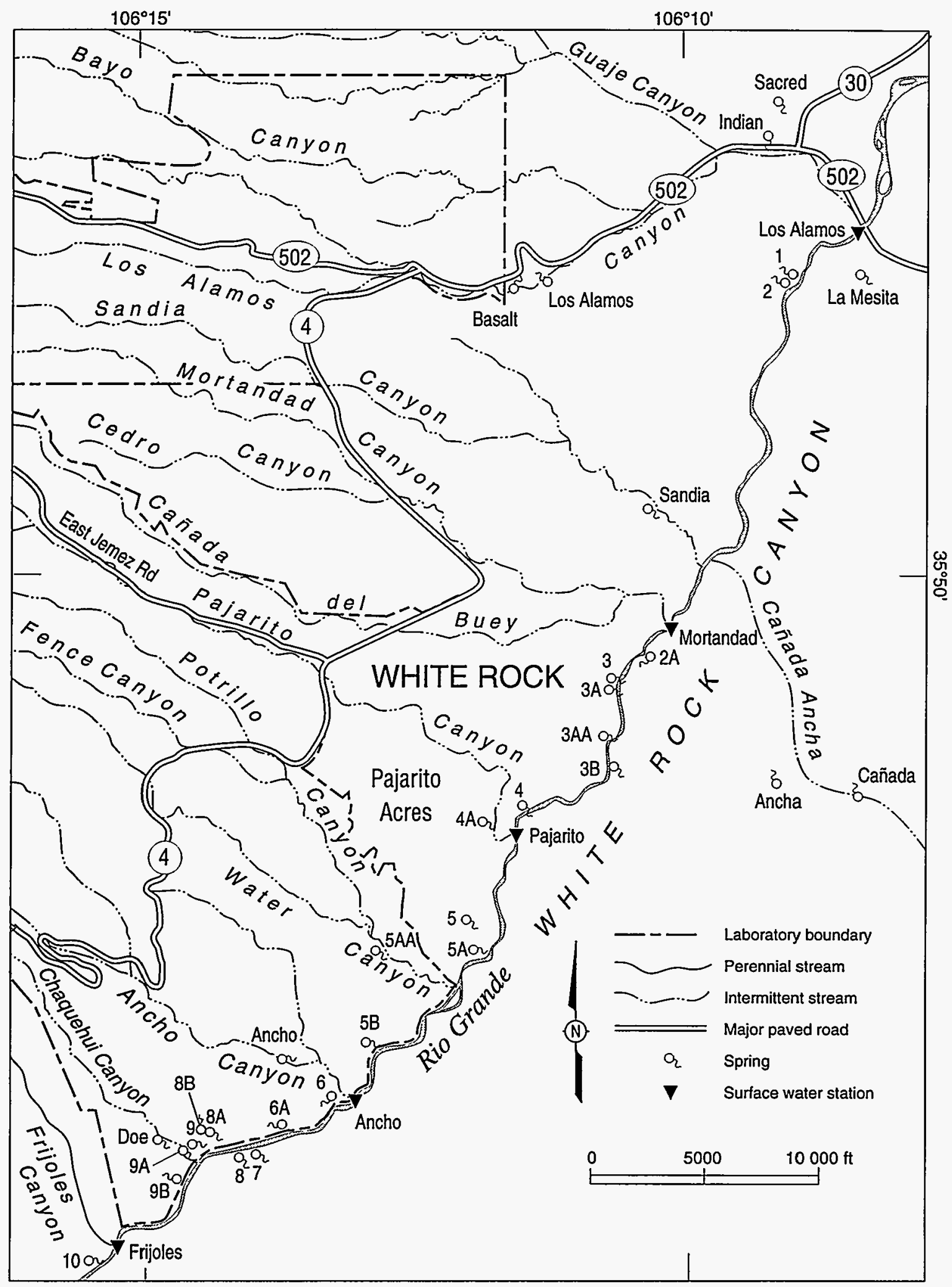

Fig. XXII-B. Locations of springs in lower Los Alamos Canyon and in White Rock Canyon along the Rio Grande. 


\begin{tabular}{|c|c|c|c|c|}
\hline \multicolumn{5}{|c|}{ TABLE XXII-A. Records of Springs in the Los Alamos Area (46 Springs) } \\
\hline $\begin{array}{l}\text { Elevation } \\
\text { LSD } \\
\text { (ft) }\end{array}$ & $\begin{array}{c}\text { Topographic Situation } \\
\text { and } \\
\text { Geologic Formation }\end{array}$ & $\begin{array}{r}\frac{E}{D} \\
\underset{\left({ }^{\circ} \mathrm{F}\right)}{\text { Temp. }}\end{array}$ & $\begin{array}{l}\text { Estimated } \\
\text { Discharge } \\
\text { into } \\
\text { Rio } \\
\text { Grande } \\
\text { (gpm) }\end{array}$ & Remarks \\
\hline
\end{tabular}

\section{Springs on the Eastern Flank of the Sierra de los Valles}

\begin{tabular}{ll} 
GC Spring 1 & 8850 \\
GC Spring 2 & 8840 \\
Quemazon Spring & 8660 \\
Reservoir Spring & 8000 \\
PC Springs & 8660 \\
CV Spring 1 & 8260 \\
CV Spring 2 & 8240 \\
Water Canyon Gallery & 8000 \\
Armstead Spring & 8216 \\
American Spring & 8280 \\
Apache Spring & 8320 \\
Frijoles Spring 1 & 8430 \\
Frijoles Spring 2 & 8430 \\
& \\
prings in the Vicinity of \\
ower Los Alamos Canyon \\
\hline
\end{tabular}

Los Alamos Spring

6000

Indian Spring

5640

Sacred Spring

5640

\section{Springs in White Rock Canyon}

\section{Group I}

$\underline{\text { Totavi Lentil }}$
Sandia Spring

Spring 3

Spring 3A

Spring 3AA

Spring 4

Spring 4A

Spring 5

Spring 5AA

Ancho Spring
5700

5560

5560

5460

5570

5570

5770

5760

5700
Canyon floor $\mathrm{Qb}_{\mathrm{t}}$

Canyon floor $\mathrm{Qb}_{\mathrm{t}}$

Canyon floor $\mathrm{Qal}-\mathrm{Qb}_{\mathbf{t}}$

Canyon floor $\mathrm{Q} a \mathrm{l}-\mathrm{Q} \mathrm{b}_{\mathrm{t}}$

Canyon floor $\mathrm{Qal}-\mathrm{Qb}$,

Canyon floor $\mathrm{Qal}-\mathrm{Qb}_{\mathrm{t}}$

Canyon floor $\mathrm{Qal}-\mathrm{Qb} \mathrm{b}_{\mathrm{t}}$

Cliff end of canyon $\mathrm{Qb}_{\mathrm{t}}$

Canyon floor $\mathrm{Qal}-\mathrm{Qb}_{\mathrm{t}}$

Ridge above canyon $\mathrm{Qb}_{\mathrm{t}}$

Steep slope $\mathrm{Qb}_{\mathrm{t}}$

West wall-

North Fork Frijoles Canyon $\mathrm{Qb}_{\mathrm{t}}$

North wall-

West Fork Frijoles Canyon $\mathrm{Qb}_{\mathrm{t}}$
25 base flow Guaje Stream

40 base flow Guaje Stream

15

20

25

4

4

$\approx 150$ industrial water supply S-Site

2 probably seepage from talus

5

$<1 \quad$ CCC - stock tank

100 base flow Frijoles Stream

110 base flow Frijoles Stream
Talus slope - $\mathrm{QTb}_{3}$

Seepage from basalt - $\mathrm{QTb}_{4}$

Canyon slope - road cut - $T_{t}$

Seep area above stream $-T_{t}$ $\approx 51 \quad 3$

$\approx 51<1$

$\approx 62<1$ discharge from fault zone

$\approx 58<1$ discharge from fault zone
Seep area in and adjacent to channel

Gravel terrace above river

Gravel terrace above river

Gravel terrace above river

Gravel slope above river

Gravel terrace above channel

Gravel on steep slope above river

Seep in channel forms pools

Gravels underlying basalt in channel
72

0 Sandia Canyon

$\begin{array}{ll}72 & 20\end{array}$

7250

$66<1$

$66 \quad 80$

70120 Pajarito Canyon

$\begin{array}{ll}70 & 10\end{array}$

640 Water Canyon

72 
TABLE XXII-A. Records of Springs in the Los Alamos Area (46 Springs) (Continued)

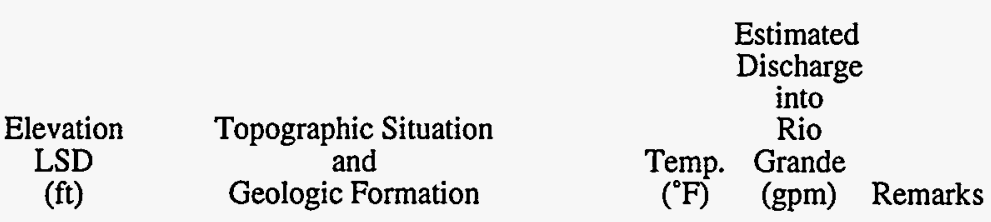

Springs in White Rock Canyon

\section{Group II}

Chaquehui Formation and Associated Basalts and Maar Sediments

$\begin{array}{llllr}\text { Spring 5A } & 5395 & \text { Fractures in basalt at edge of river } & 70 & 25 \\ \text { Spring 5B } & 5390 & \text { Steep slope at edge of river } & 61 & 10 \\ \text { Spring 6 } & 5380 & \text { Fractures in basalt at edge of river } & 73 & 60 \\ \text { Spring 6A } & 5375 & \text { Fractures in basalt at river level } & 72 & 150 \\ \text { Spring 7 } & 5370 & \text { Slope at edge of river } & 70 & 175 \\ \text { Spring 8 } & 5370 & \text { Slope at edge of river } & 72 & 70 \\ \text { Spring 8A } & 5370 & \text { Slope at edge of river } & 72 & 25 \\ \text { Spring 8B } & 5380 & \text { Seep in channel above river } & 68 & 10 \\ \text { Spring 9 } & 5385 & \text { Large seep above river } & 68 & 10 \\ \text { Spring 9A } & 5525 & \text { Seep area on canyon wall } & 66 & 0 \\ \text { Spring 9B } & 5525 & \text { Seep in cave/canyon wall } & 65 & 0 \\ \text { Spring 10 } & 5390 & \text { Edge of alluvium above river } & 66 & <1 \\ \text { Doe Spring } & 5600 & \text { Seep area in channel and } & 70 & <1 \\ & & \text { canyon wall } & & \end{array}$

Chaquehui Canyon west side Rio Grande Frijoles Canyon Chaquehui Canyon

\section{Group III}

Tesuque Formation

Spring 1

Spring 2

\section{Group IV}

Tesuque Formation (fine-grained basalt intrusion or faults)

\begin{tabular}{|c|c|c|c|}
\hline La Mesita Spring & 5580 & Seep area above channel & 65 \\
\hline Ancha Spring & 5775 & \multicolumn{2}{|c|}{ Seep area in channel, basalt sediments } \\
\hline Spring 2A & 5490 & Gravels along edge of river & 72 \\
\hline Spring 3B & 5450 & Terrace on slope above river & 68 \\
\hline Cañada Spring & 5780 & Seep area in channel & 66 \\
\hline Note: & \multicolumn{3}{|c|}{$\begin{array}{l}\text { Qal-recent alluvium } \\
\text { QTb }{ }_{4}-\text { Basaltic Rocks of Chino Mesa Unit } 4 \\
\text { QTb } 3 \text {-Basaltic Rocks of Chino Mesa Unit } 3 \\
\text { Qbt-Bandelier Tuff } \\
\mathrm{T}_{t}-\text { Tesuque Formation }\end{array}$} \\
\hline
\end{tabular}

5615 Seep area on slope above river $65<1$ 5600 Seep area on slope above river $65<1$ 
TABLE XXII-B. Major Canyons and Streams Entering the Rio Grande in White Rock Canyon

\begin{tabular}{lccccl} 
Canyon & $\begin{array}{c}\text { Drainage } \\
\text { Area } \\
\left(\mathrm{mi}^{2}\right)\end{array}$ & $\begin{array}{c}\text { Elevation } \\
\text { at River } \\
(\mathrm{ft})\end{array}$ & $\begin{array}{c}\text { Type } \\
\text { of } \\
\text { Flow }^{\mathrm{a}}\end{array}$ & $\begin{array}{c}\text { Discharge } \\
\text { at River } \\
(\mathrm{gpm})\end{array}$ & Source \\
\hline Los Alamos & 58.7 & 5495 & $\mathrm{I}$ & - & - \\
La Mesita & - & 5490 & $\mathrm{P}$ & $\approx 2$ & La Mesita Spring \\
Sandia & 5.6 & 5465 & $\mathrm{I}$ & - & - \\
Cañada Ancha & - & 5445 & $\mathrm{I}$ & - & - \\
Mortandad & 10.4 & 5435 & $\mathrm{P}$ & 10 to 100 & sanitary effluent \\
Spring 3B & - & 5420 & $\mathrm{P}$ & $\approx 10$ & Spring 3B \\
Pajarito & 13.6 & 5410 & $\mathrm{P}$ & $\approx 450$ & Spring 4A \\
Water & 19.5 & 5395 & $\mathrm{I}$ & - & - \\
Ancho & 7.0 & 5390 & $\mathrm{P}$ & $\approx 30$ & Ancho Spring \\
Chaquehui & 1.5 & 5370 & $\mathrm{I}$ & - & - \\
Frijoles & 18.0 & 5365 & $\mathrm{P}$ & $\approx 20$ & Frijoles Springs 1 and 2
\end{tabular}

Note: La Mesita, Cañada Ancha, and Spring 3B enter the Rio Grande from the east; the others enter the Rio Grande from the west or from the Pajarito Plateau.I

a $=$ intermittent $; \mathrm{P}=$ perennial 
TABLE XXII-C. Locations and Elevations (NAD 1927)

\section{A. Springs on the Flank of the Mountains}

Guaje Spring 1

Guaje Spring 2

Quemazon Spring

Reservoir Spring

PC Spring

Valle Spring 1

Valle Spring 2

Water Canyon Gallery

Armstead Spring

American Spring

Apache Spring

Frijoles Spring 1

Frijoles Spring 2
N $1,797,700$

N $1,796,000$

N $1,788,400$

N $1,778,800$

N $1,773,200$

N 1,766,400

N $1,766,500$

$\mathrm{N} 1,762,500$

$\mathrm{N} 1,762,700$

N $1,760,000$

N $1,753,600$

N 1,759,500

N 1,759,300
E 460,200

E 460,200

E 462,800

E 465,700

E 461,600

E 463,900

E 464,100

E 463,900

E 459,500

E 460,800

E 458,900

E 452,100

E 449,100
$8850 \mathrm{ft}$

$8840 \mathrm{ft}$

$8660 \mathrm{ft}$

$8000 \mathrm{ft}$

$8660 \mathrm{ft}$

$8260 \mathrm{ft}$

$8240 \mathrm{ft}$

$8000 \mathrm{ft}$

$8216 \mathrm{ft}$

$8280 \mathrm{ft}$

$8320 \mathrm{ft}$

$8430 \mathrm{ft}$

$8430 \mathrm{ft}$

\section{B. Springs in Lower Los Alamos Canyon}

N $1,770,700$

N $1,770,900$

N $1,777,200$

N $1,780,300$
E 516,300

E 517,200

E 525,700

E 529,800
$6000 \mathrm{ft}$

$6000 \mathrm{ft}$

$5640 \mathrm{ft}$

$5640 \mathrm{ft}$

\section{Springs in White Rock Canyon}

\section{Group I (Totavi Lentil)}

Sandia Spring
Spring 3
Spring 3A
Spring 3AA
Spring 4
Spring 4A
Spring 5
Spring 5AA
Ancho Spring

Sandia Spring

Spring $3 A$

Spring 3AA

Spring 4

Spring 4A

Spring 5AA

Ancho Spring
N $1,761,500$
N $1,753,611$
N $1,753,345$
N 1,751,492
N $1,748,348$
N $1,747,815$
N 1,742,987
$\mathrm{N} 1,742,500$
N 1,737,900

E 523,000

E 521,071

E 521,100

E 520,883

E 517,189

E 515,904

E 515,240

E 510,900

E 505,400
$5700 \mathrm{ft}$

$5560 \mathrm{ft}$

$5560 \mathrm{ft}$

$5460 \mathrm{ft}$

$5570 \mathrm{ft}$

$5570 \mathrm{ft}$

$5770 \mathrm{ft}$

$5760 \mathrm{ft}$

$5700 \mathrm{ft}$

Group II (Chaquehui Formation and Associated Basalts and Maar Sediments)

Spring 5A
Spring 5B
Spring 6
Spring 6A
Spring 7
Spring 8
Spring 8A
Spring 8B
Spring 9
Spring 9A
Spring 9B
Spring 10
Doe Spring
N $1,741,921$

N $1,738,109$

N $1,735,617$

N $1,734,503$

N 1,733,541

N $1,733,417$

N $1,733,958$

$\mathrm{N} 1,733,491$

N 1,733,676

N $1,733,407$

N $1,732,876$

N $1,728,932$

N $1,733,800$
E 515,500

E 510,836

E 508,947

E 507,146

E 504,763

E 504,168

E 503,173

E 503,040

E 502,687

E 502,408

E 502,193

E 498,467

E 501,800
$5395 \mathrm{ft}$

$5390 \mathrm{ft}$

$5380 \mathrm{ft}$

$5375 \mathrm{ft}$

$5370 \mathrm{ft}$

$5370 \mathrm{ft}$

$5370 \mathrm{ft}$

$5380 \mathrm{ft}$

$5385 \mathrm{ft}$

$5525 \mathrm{ft}$

$5525 \mathrm{ft}$

$5390 \mathrm{ft}$

$5600 \mathrm{ft}$ 
XXII-C. Locations and Elevations (NAD 1927) (Continued)

Group III (Tesuque Formation)

Spring 1

Spring 2
$\mathrm{N} 1,771,547$

N $1,771,084$

E 529,268

E 529,052

Group IV (Tesuque Formation - Basalt Intrusion or Fault)
La Mesita Spring

Ancha Spring

Spring 2A

Spring 3B

Cañada Spring
N $1,771,600$

N $1,749,600$

N $1,754,818$

N $1,749,934$

N $1,748,600$
E 532,100

E 528,900

E 522,427

E 521,345

E 532,500
$5615 \mathrm{ft}$

$5600 \mathrm{ft}$

\section{Streams Entering the Rio Grande in White Rock Canyon}

Los Alamos
La Mesita
Sandia
Cañada Ancha
Mortandad
Spring 3B
Pajarito
Water
Ancho
Chaquehui
Frijoles

Los Alamos

N $1,773,000$

N $1,772,700$

N $1,759,300$

N $1,754,100$

N $1,756,400$

N $1,749,600$

N $1,747,400$

N $1,741,000$

N $1,735,700$

N $1,733,100$

N 1,729,500
E 532,300

E 531,600

E 525,400

E 535,500

E 523,500

E 520,900

E 516,800

E 513,300

E 509,400

E 502,600

E 499,300
$5580 \mathrm{ft}$

$5775 \mathrm{ft}$

$5490 \mathrm{ft}$

$5450 \mathrm{ft}$

$5780 \mathrm{ft}$
$5495 \mathrm{ft}$

$5490 \mathrm{ft}$

$5465 \mathrm{ft}$

$5445 \mathrm{ft}$

$5435 \mathrm{ft}$

$5420 \mathrm{ft}$

$5410 \mathrm{ft}$

$5395 \mathrm{ft}$

$5390 \mathrm{ft}$

$5370 \mathrm{ft}$

$5365 \mathrm{ft}$ 


\section{DOCUMENTED STUDIES RELATED TO GEOLOGY, HYDROLOGY, OR SURVEILLANCE}

Specific studies related to geology, hydrology, or surveillance have been reported in formal and semiformal reports. The purpose of this section is to identify reports that were the results of these studies. The reports resulting from the studies are referenced, and the locations of their subjects are shown on a generalized map of the area (Fig. XXIII-A).

\section{A. Decontamination of TA-1}

Over 140 test holes ranging in depth from $3 \mathrm{ft}$ to over $30 \mathrm{ft}$ were drilled to collect samples for radiochemical analyses in the decontamination of former TA-1. Map location TA-1-A (Fig. XXIII-A).

\section{REFERENCES}

A. J. Ahiquist, A. K. Stoker, and L. K. Trocki, "Radiological Survey and Decontamination of the Former Main Technical Area (TA-1) at Los Alamos, New Mexico," Los Alamos Scientific Laboratory report LA-6887 (1977).

W. D. Purtymun, "Source Document Compilation: Los Alamos Investigations Related to the Environment, Engineering, Geology, and Hydrology, 1961-1990," Los Alamos National Laboratory report LA-12733-MS (1994), chapters 49, 50, 51, 52, 53, and 57.

\section{B. Test Holes in Seepage Beds at TA-21 (1953)}

To determine the retention of plutonium in the soil and tuff under and adjacent to seepage pits used to dispose of radioactive effluents, five test holes were drilled to collect samples from the berm adjacent to the pits (two holes), through the seepage bed (two holes), and under the seepage bed (one angle hole). Holes ranged in depth from $10 \mathrm{ft}$ to $20 \mathrm{ft}$. Map location TA-21-A (Fig. XXIII-A).

\section{REFERENCE}

W. D. Purtymun, "Geohydrology of the Pajarito Plateau with Reference to Quality of Water 1949-1972," Los Alamos Scientific Laboratory, Group H-8 internal document, 1975, pp. 69-71.

\section{Test Holes in Seepage Beds at TA-21 (1985)}

Four holes were cored through the seepage pits that received radioactive effluents from 1943 to 1952 to determine the depth to which contamination was carried beneath the pits. The holes were cored to a depth of 100 ft. Map location TA-21-B (Fig. XXIII-A).

\section{REFERENCE}

J. Nyhan, B. Drennon, W. Abeele, M. Wheeler, W. D. Purtymun, G. Trujillo, W. Herrera, and J. Booth, "Distribution of Plutonium and Americium beneath a 33-Year-Old Liquid Waste Disposal Site," Journal of Environmental Quality 14, no. 4 (Oct-Dec 1985).

\section{Movement of Plutonium through Tuff at TA-21}

A shaft about $6 \mathrm{ft}$ wide, $12 \mathrm{ft}$ long, and $30 \mathrm{ft}$ deep was dug in the berm between two of the seepage pits that received radioactive wastes from 1944 through 1952. Horizontal holes were drilled from the shaft under the pit. The holes were paired at various depths, one hole was used as a moisture-access hole, the other equipped with a vacuum cup system. Water or effluent was added to the seepage pit, moisture measured, and samples of fluids collected by the vacuum system, if possible. Six vertical holes were drilled in the berm around the shaft to depths of about $100 \mathrm{ft}$. These holes were used as moisture-access holes to determine the moisture content of the tuff at depths below the shaft and seepage pit. Map location TA-21-C (Fig. XXIII-A).

\section{REFERENCE}

C. W. Christenson and R. G. Thomas, "Movement of Plutonium through Los Alamos Tuff," in Second Ground Disposal of Radioactive Waste Conference, U.S. Department of Commerce TID-7628 (1962).

\section{E. Movement of Fluids and Plutonium from Shafts at TA-21}

A study was done in two parts: (1) to determine the movement of fluids (water containing treated chemicals) and radioactive contaminates from a shaft filled with waste-cement paste under normal operation conditions, and (2) to determine the movement of fluids and plutonium under test conditions without the radioactive sludge fixed with cement. 
In the first part of the study, a 59-ft-deep, 6-ft-diam shaft was drilled about $2 \mathrm{ft}$ from a previously constructed $100-\mathrm{ft}$ moisture-access hole. The shaft was filled with contaminated-sludge-cement paste. Moisture moving from the paste into the tuff was measured. A second test hole was drilled and samples collected for analysis.

In the second part of the study, a 20-ft-deep, 2-ft-diam shaft was constructed, with four moistureaccess holes ( $40 \mathrm{ft}$ deep) at various distances from the shaft. The shaft was partly filled with contaminated sludge. Moisture moving from the sludge into the tuff was monitored. When moisture in the tuff did not change, three holes were cored to a depth of about $35 \mathrm{ft}$. Samples were collected for analysis in holes at various distances from the shaft and at different depths. Map location TA-21-D (Fig. XXIII-A).

\section{REFERENCE}

W. D. Purtymun, R. Garde, and R. Peters, "Movement of Fluids and Plutonium from Shafts at Los Alamos, New Mexico," Los Àlamos Scientific Laboratory report LA-7379-MS (1978).

\section{F. Exploratory and Foundation Test Holes at TA-3 (1948)}

The report cited describes the core drilling of exploratory and foundation test holes for the new main technical area (TA-3) on South Mesa (south of Los Alamos Canyon), for the bridge crossing Los Alamos Canyon south and west of the present hospital, and for foundation tests at the hospital itself.

There were 63 holes cored during the study. Fortynine of the holes were drilled in the South Mesa area (TA-3), 12 at the bridge crossing, and 2 at the new hospital site. Seven of the holes were $350 \mathrm{ft}$ deep and the remaining holes ranged in depth from $50 \mathrm{ft}$ to $100 \mathrm{ft}$. Load-bearing tests were conducted at the proposed locations for the three heaviest structures: the power plant, the Van de Graaff Building, and the main warehouse. Map location TA-3-A (Fig. XXIII-A).

\section{REFERENCE}

W. C. Kruger \& Associates, "Subsurface Investigation of South Mesa and Vicinity," Kruger and Associates, Architect-Engineers report to the U.S. Atomic Energy
Commission and Engineering Division of Los Alamos Scientific Laboratory (1948).

\section{G. Exploratory and Foundation Test Holes at TA-53 (1966)}

During the preliminary site investigation for the Meson Physics Facility, 28 test holes were cored on the Mesita de los Alamos. In addition to performing detailed geologic mapping, bearing capacities of the tuff and ground vibration characteristics of the mesa were determined. Map location TA-53-A (Fig. XXIII-A).

\section{REFERENCES}

W. D. Purtymun, "Geology and Physical Properties of the Near-Surface Rocks of Mesita de los Alamos, Los Alamos County, New Mexico," U.S. Geol. Survey Open-File Report (1966).

M. D. Keller, "Geologic Studies and Material Property Investigations of Mesita de los Alamos," Los Alamos Scientific Laboratory report LA-3728 (1968).

W. D. Purtymun, "Source Document Compilation: Los Alamos Investigations Related to the Environment, Engineering, Geology, and Hydrology, 1961-1990," Los Alamos National Laboratory report LA-12733-MS (1994), chapters $4,5,6,9,17,18,72,95,96,101,180$, and 193.

\section{H. Preliminary Site Investigation of the Plutonium Processing Facility at TA-55}

A detailed investigation was made of the geology, hydrology, and seismic characteristics of the site. A number of test holes were drilled to determine the physical characteristics of the tuff. The study also included trenching to determine if there was any possibility of extension of the Los Alamos fault into the area from the north. Map location TA-55-A (Fig. XXIII-A).

\section{REFERENCE}

Dames and Moore, "Report of Geologic, Foundation, Hydrologic, and Seismic Investigations for the Plutonium Processing Facility at the Los Alamos Scientific Laboratory," Consulting Engineers report to the U.S. Atomic Energy Commission and the Los Alamos Scientific Laboratory (1972). 


\section{Movement of Tritium through Tuff at TA-54 Area $\mathbf{G}$}

The movement of tritium from wastes disposed of in shafts at TA-54 Area $G$ was investigated by drilling 14 test holes to a depth of $50 \mathrm{ft}$ adjacent to a shaft disposal area that contained tritium wastes. The tuff was not saturated, having a moisture content of less than $8 \%$ by volume. Tritium migrated in the vapor phase a distance of $105 \mathrm{ft}$ in 4 years. Map location TA-54-A (Fig. XXIII-A).

\section{REFERENCES}

W. D. Purtymun, "Underground Movement of Tritium from Solid-Waste Storage Shafts," Los Alamos Scientific Laboratory report LA-5286-MS (1973).

W. D. Purtymun, "Source Document Compilation: Los Alamos Investigations Related to the Environment, Engineering, Geology, and Hydrology, 1961-1990," Los Alamos National Laboratory report LA-12733-MS (1994), chapter 20.

\section{J. Containment of Tritium in Buried Wastes at TA-54, Area G}

Asphalt had been used since 1970 to contain the migration of tritium from disposal shafts. Methods used have not been effective and new techniques are being implemented. During this investigation 18 test holes were drilled, and samples were collected and analyzed for moisture and tritium. The test holes were drilled to a depth of $40 \mathrm{ft}$. Map location TA-54-B (Fig. XXIII-A).

\section{REFERENCE}

M. L. Wheeler and J. L. Warren, "Tritium Containment after Burial of Contaminated Solid Waste," Proceedings of 23rd Conference on Remote Systems Technology, San Francisco, Calif. (1975).

\section{K. Horizontal Core Holes at TA-54 Area G and Other Studies at TA-54 Areas G and L}

Five horizontal holes were cored from a canyon under a waste disposal pit at Area $\mathrm{G}$. The length of the holes ranged from $240 \mathrm{ft}$ to $287 \mathrm{ft}$. They were drilled using air as a cuttings carrier. The holes penetrated both
Units 2A and 2B of the Tshirege Member of the Bandelier Tuff. Total core recovery ranged from $51 \%$ to $75 \%$. A vertical hole was cored from the same drill pad to a depth of $157 \mathrm{ft}$. The hole penetrated the lower units of the Tshirege Member, the Otowi Member, and the Guaje Member, and was completed into the top of Unit 2 of the Basaltic Rocks of Chino Mesa. No core was recovered. The purpose of the holes was to determine if contamination had leached from the pits into the underlying tuff. No apparent contamination was encountered. Map Location TA-54-C (Fig. XXIII-A). Other studies related to storage and disposal of wastes and to the geology of Areas $G$ and $\mathrm{L}$ may be found in Purtymun (1994).

\section{REFERENCES}

Reynolds Electric and Engineering Co., "Horizontal Monitoring Holes, Los Alamos, New Mexico," Completion Report to U.S. Energy Research and Development Agency, Contract E(26-1)-410 (1976).

W. D. Purtymun, M. L. Wheeler, and M. A. Rogers, "Geologic Description of Cores from Holes P-2 MH-1 through P-2 MH-5, Area G, Technical Area 54," Los Alamos Scientific Laboratory report LA-7308-MS (1978).

W. D. Purtymun, M. L. Wheeler, and M. A. Rogers, "Radiochemical Analyses of Samples from Beneath a Solid Radioactive Waste Disposal Pit at Los Alamos, New Mexico," Los Alamos Scientific Laboratory report LA-8422-MS (1980).

W. D. Purtymun, "Source Document Compilation: Los Alamos Investigations Related to the Environment, Engineering, Geology, and Hydrology, 1961-1990," Los Alamos National Laboratory report LA-12733-MS (1994), chapters 7, 8, 20, 25, 32-34, 58, 98, 104, 109 . $110,116,118,119,121-123,125,136,137,139,140$, $143,147,150,155,156,163,168,171,174,185,186$, 196 , and 202.

\section{Test Holes at TA-33}

During an investigation to determine the extent of any possible contamination resulting from underground experiments, six holes were cored with depths ranging from $29 \mathrm{ft}$ to $59 \mathrm{ft}$ at Area D; six holes were cored with depths ranging from $29 \mathrm{ft}$ to $59 \mathrm{ft}$ at Area E; and two holes with depths of $149 \mathrm{ft}$ and $174 \mathrm{ft}$ were cored at the tritium facility at Area T. Map location T-33-A

(Fig. XXIII-A). 


\section{REFERENCES}

Weston, Consulting Engineers, "Weston Data Material from Areas T and E," Volumes 1 and 2, and "Weston Data Material from Area D, TA-33," Basic Data Report in the files of Group CL-1 (1989).

\section{Near-Surface Land Disposal Facilities for Radioactive Wastes (Areas A, B, C, D, E, F, G, and $\mathrm{T}$ )}

A source document concerning the history and environmental setting of eight LASL near-surface land disposal facilities was prepared in two volumes. The report contains a number of references to test holes drilled in the solid disposal area. Map location TA-0-A (Fig. XXIII-A).

A second similar type of report was prepared by the U.S. Geological Survey covering the same sites.

\section{REFERENCES}

M. A. Rodgers, "History and Environmental Setting of LASL Near-Surface Land Disposal Facilities for Radioactive Wastes (A, B, C. D, E, F, G, and T), A Source Document," Los Alamos Scientific Laboratory report LA-6848-MS, Vol. I and II (1977).

T. E. Kelley, "Evaluation of Monitoring of Radioactive Solid-Waste Burial Sites at Los Alamos, New Mexico," U.S. Geol. Survey Open-File Report 75-406 (1975).

\section{N. Pumice Investigation}

One of the first geologic reports prepared for the U.S. Atomic Energy Commission related to the development and mining of pumice from the lower beds of the Bandelier Tuff or Guaje Member. Data related to the thickness and distribution of the pumice. Map location TA-0-B (Fig. XXIII-A).

\section{REFERENCE}

V. C. Kelley, "Geology and Pumice Deposits of the Pajarito Plateau, Sandoval, Santa Fe, and Rio Arriba Counties, New Mexico," Los Alamos Project-Pumice Investigations for the Operations Division, Los Alamos Scientific Laboratory, Contract No. AT-(29-1)-553 (1948).

\section{O. Subsurface Geology of the Pajarito Plateau}

Geologic report integrating data from wells, geophysical surveys, and surface exposures to develop structure contour and paleogeologic maps of the preBandelier Tuff surface beneath the Pajarito Plateau. Map location TA-0-C (Fig. XXIII-A).

\section{REFERENCE}

B. J. Dransfield and J. N. Gardner, "Subsurface Geology of the Pajarito Plateau, Española Basin, New Mexico," Los Alamos National Laboratory report LA-10455-MS (1985).

\section{P. Proposed Borrow Pit in Mortandad Canyon}

Test holes drilled in the eastern part of Mortandad Canyon indicated that in the study area about 170000 cubic yards of uncontaminated fill material is available in the upper 9 yards of the canyon bottom. Map location TA-O-D (Fig. XXIII-A).

\section{REFERENCE}

W. D. Purtymun, "Source Document Compilation: Los Alamos Investigations Related to the Environment, Engineering, Geology, and Hydrology, 1961-1990," Los Alamos National Laboratory report LA-12733-MS (1994), chapter 132.

\section{Q. Construction of Sediment Retention Ponds in Mortandad Canyon}

Prior to the construction of retention ponds, five injection shafts were constructed in the stream bed to retain and store runoff and suspended sediments in lower Mortandad Canyon. Map location TA-O-E (Fig. XXIII-A).

\section{REFERENCE}

W. D. Purtymun, "Source Document Compilation: Los Alamos Investigations Related to the Environment, Engineering, Geology, and Hydrology, 1961-1990," Los Alamos National Laboratory report LA-12733-MS (1994), chapters 40, 41, and 181. 


\section{R. Long-Range Plan for Water Supply (1986)}

A long-range plan concerning the water supply at Los Alamos was prepared for the Department of Energy. This included a short-term management plan for the San Juan-Chama water.

\section{REFERENCE}

U.S. Corps of Engineers, "Los Alamos Water Supply, Los Alamos, New Mexico," Contract No. D.E.-A13283Al22421, U.S. Corps of Engineers, Albuquerque, New Mexico (1986).

\section{S. Buckman Well Field}

The Buckman Well Field, which furnishes a part of the water supply to Santa Fe, lies east of the Rio Grande about a mile south of Otowi. A preliminary report was prepared to define the geologic and hydrologic properties of the aquifer underlying the Buckman Well Field and the effects of pumpage on the aquifer.

\section{REFERENCE}

Black and Veatch (Consulting Engineers), "Preliminary Report to the Public Service Company of New Mexico, Buckman Well Field," Black and Veatch, Project 6607, Denver, Colo. (1976).

\section{T. Ground Water Model of the Buckman Well Field}

A ground water flow model was prepared to evaluate the ground water withdrawal from the Buckman Well Field. A simulated effect of the historic withdrawal 1972 to 1986 was prepared as was the future effect on the aquifer for the period 1987 to 2045.

\section{REFERENCE}

D. P. McAda, "Simulation Effect of Ground-Water Withdrawal from a Well Field Adjacent to the Rio Grande, Santa Fe County, New Mexico," U.S. Geol. Survey Water Resources Investigation Report 89-4184 (1990).

\section{U. Test Holes Drilled on the Cerros del Rio}

Across the Rio Grande from the Pajarito Plateau 106 test holes were drilled into the Cerros del Rio. The holes were drilled and logged as part of a uranium investigation. Geologic logs and some hydrologic data related to the test holes are available from the State Engineer.

\section{REFERENCE}

R. L. Borton, "A Listing of Geohydrologic Data for 106 Exploratory Holes Drilled by Nuclear Dynamics, Inc., in Rio Arriba, Sandoval, and Santa Fe Counties, New Mexico 1970-1972," State Engineer Open-File Report (1974).

\section{Environmental Study of the Pueblo of San Ildefonso}

A cooperative agreement was made between the Pueblo of San Ildefonso, the Bureau of Indian Affairs, and the Department of Energy in order to evaluate the environmental impact of the Laboratory operation on off-site areas. The agreement in 1987 was the beginning of annual investigations made to evaluate the quality of surface and ground water, soil, and sediments in the pueblo.

\section{REFERENCES}

W. D. Purtymun and M. N. Maes, "Environmental Study of the Pueblo of San Ildefonso: Reference to Water, Soil, and Sediments," Los Alamos National Laboratory document LA-UR-88-3646 (1988). Reporting data annually in LA-11628-ENV (1988), LA-12000ENV (1989), and LA-12271-MS (1990).

\section{W. Seismic Hazards Program Core Holes}

Four holes were cored as part of the Laboratory's Seismic Hazards Program for the purpose of determining near-surface seismic velocity at key Laboratory facilities (Fig. XXIII-B). The report does not cover the velocity structure surveys but reports on characteristics of the drilling, geology, and some of the hydrologic aspects of the holes. 


\section{REFERENCE}

J. N. Gardner, T. Kolbe, and S. Chang, "Geology, Drilling, and Some Hydrologic Aspects of Seismic Hazards Program Core Holes, Los Alamos National Laboratory, New Mexico," Los Alamos National Laboratory report LA-12460-MS (1993).

\section{Earthquake and Rockfall Potential at Omega Site}

In August 1970 the U.S. Geological Survey conducted a brief geologic reconnaissance in the vicinity of the Omega West Reactor in order to determine the possibility of damage to the reactor by rockfalls triggered by earthquakes or other factors. Other rockfall investigations were conducted and are reported in Purtymun (1994).

\section{REFERENCES}

T. E. Kelley, "Earthquake and Rockfall Potential near Omega Site, Los Alamos, New Mexico," U.S. Geological Survey informal report, Albuquerque, New Mexico, September 1970.

W. D. Purtymun, "Source Document Compilation: Los Alamos Investigations Related to the Environment, Engineering, Geology, and Hydrology, 1961-1990," Los Alamos National Laboratory report LA-12733-MS (1994), chapters $68,85,100,117,131,145,176,191$, 199, 200, 204, and 205.

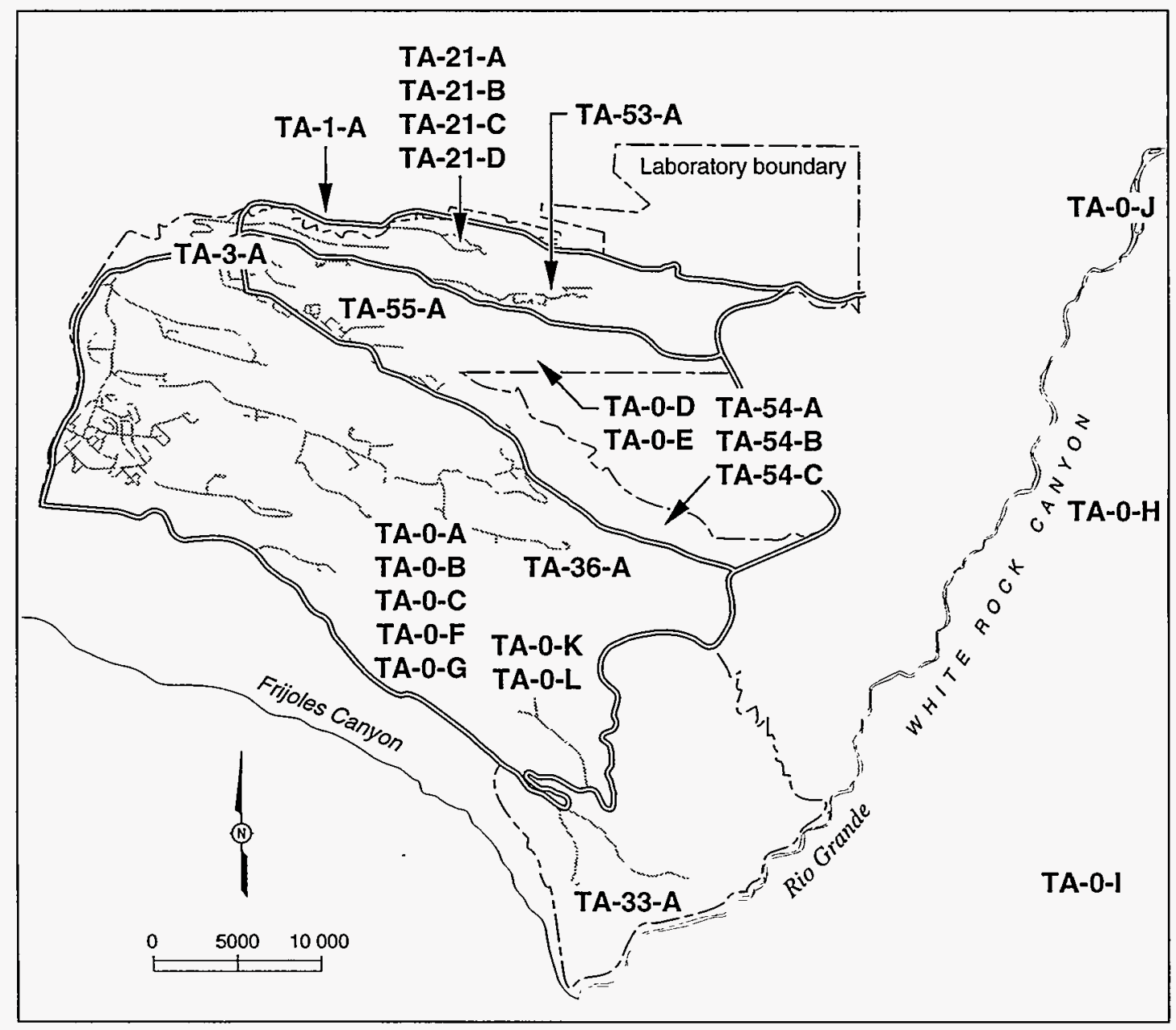

Fig. XXIII-A. Locations of geologic, hydrologic, engineering, and environmental investigations. 


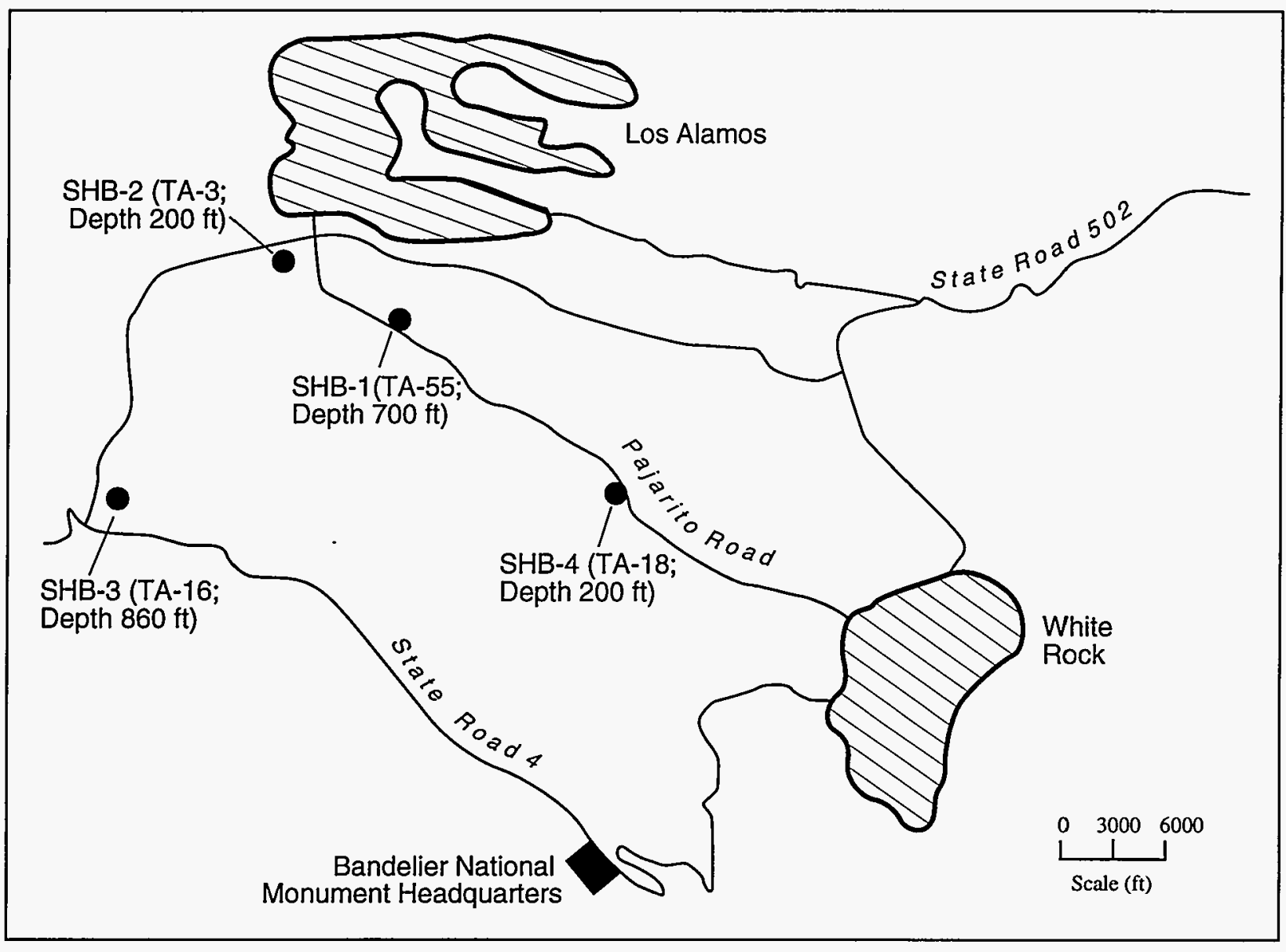

Fig. XXIII-B. Locations of test holes for seismic investigation. 


\section{RACK ASSEMBLY ALIGNMENT FACILITIES}

In order to check the tolerance and alignment of instruments and instrument packages to be run down holes at the Nevada Test Site, towers or bays were constructed over holes. The older RAAC (Rack Assembly Alignment Complex) facilities are at TA-3 near SM-38 (Fig. XXIV-A). These facilities are no longer in use, and the testing is now done at TA-60.

The older RAAC facilities at TA-3 consisted of three test holes. The oldest test hole at SM-245 was about $3 \mathrm{ft}$ in diameter and about $100 \mathrm{ft}$ deep. This hole was plugged and abandoned. The next oldest test hole at TA-3, at SM-447, has a hole drilled to a depth of $96 \mathrm{ft}$. The upper part of the hole is cased to a depth of $20 \mathrm{ft}$ with a 5-ft-4-in.-diam CMP (corrugated metal pipe). The holes were completed in the Tshirege Member of the Bandelier Tuff.
The last RAAC structure is at SM-1483. The hole was drilled to a depth of $120 \mathrm{ft}$. The upper part of the hole is cased with $20 \mathrm{ft}$ of 7.5 -ft-diam CMP.

The new rack facilities are located at TA-60 at SM-19 (Fig. XXIV-A). There are two holes augered to a depth of $100 \mathrm{ft}$. The diameter of the holes is $11 \mathrm{ft}$. The upper part of both holes is cased to a depth of $20 \mathrm{ft}$ with 10 -ft-2-in.-diam CMP.

\section{REFERENCE}

W. D. Purtymun, "Source Document Compilation: Los Alamos Investigations Related to the Environment, Engineering, Geology, and Hydrology, 19611990," Los Alamos National Laboratory report LA12733-MS (1994), chapter 134.
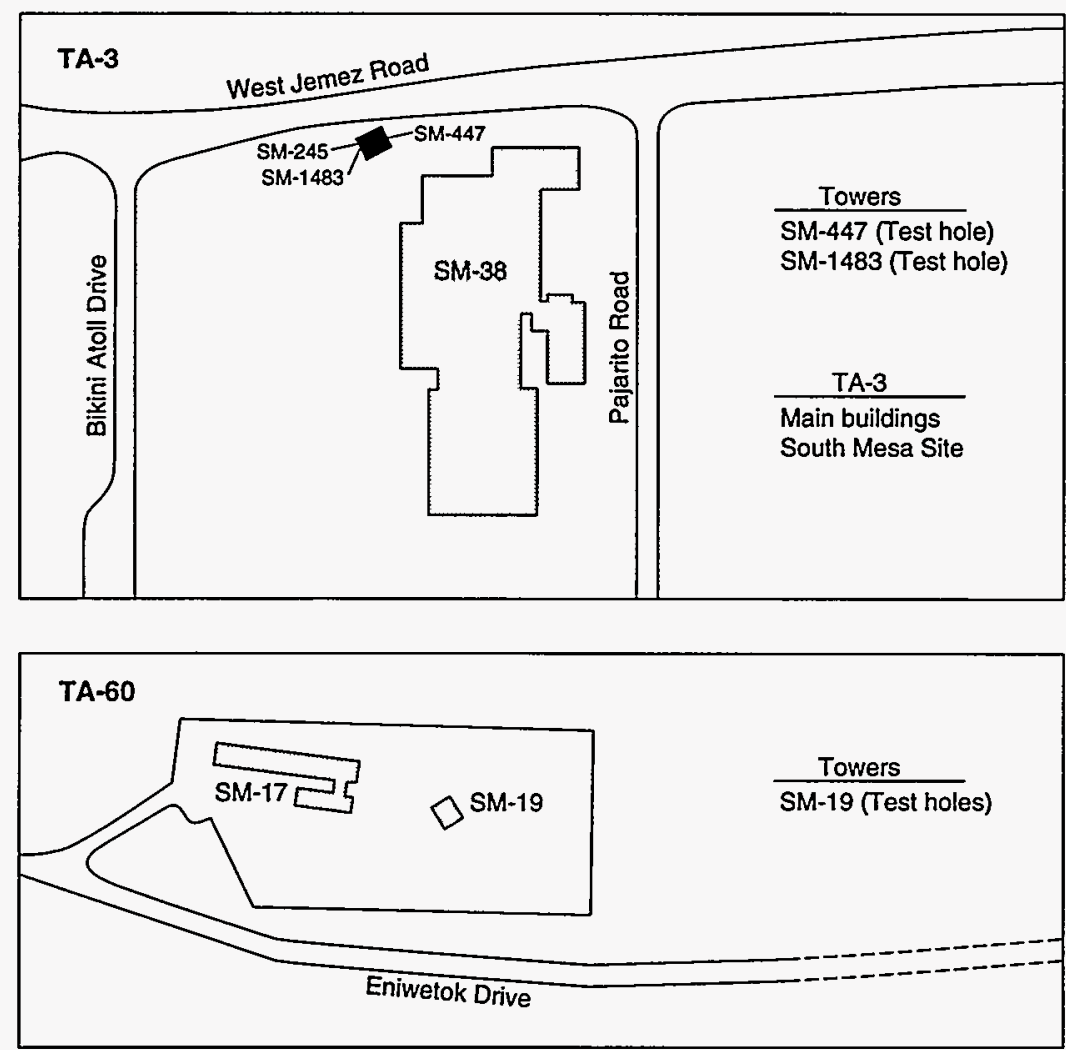

Fig. XXIV-A. Locations of rack alignment holes at TA-3 and TA-60.

TABLE XXIV-A. Locations and Elevations (NAD 1927)
A. TA-3
$\mathrm{N} 1,774,200$
E 477,200
$7440 \mathrm{ft}$
B. TA-60
N 7,771,800
E 483,000
$7330 \mathrm{ft}$ 


\section{TEST HOLES IN UPPER GUAJE CANYON}

Two shallow test holes were drilled in upper Guaje Canyon between the Los Alamos and Guaje Faults in the fall of 1966 (Fig. XXV-A). The holes were drilled to determine the rock type and the depth of saturation between the two faults, and to explore the possibility of developing short-term high-yield wells.

Test hole 1 (elevation $7180 \mathrm{ft}$ ) was drilled to a depth of about $23 \mathrm{ft}$ and was completed in the alluvium. The alluvium was saturated to near the stream level. Test hole 2 (elevation $7060 \mathrm{ft}$ ) was drilled to a depth of $103 \mathrm{ft}$, penetrating $17 \mathrm{ft}$ of alluvium and $86 \mathrm{ft}$ of the gravel of the Puye Conglomerate. The alluvium and gravel were saturated to near the stream level.
Both holes were cased with 2-in.-diam perforated plastic pipe; the depth and the length of the perforations are unknown. The test holes indicated a saturated thickness of the gravels penetrated; however, the saturated thickness is not sufficient to develop a high-yield well. Additional testing would be necessary to determine the total thickness of saturated gravels between the two faults.

\section{REFERENCE}

W. D. Purtymun, "Geohydrology of the Pajarito Plateau with Reference to Quality of Water 19491972," Los Alamos Scientific Laboratory internal document, 1975.

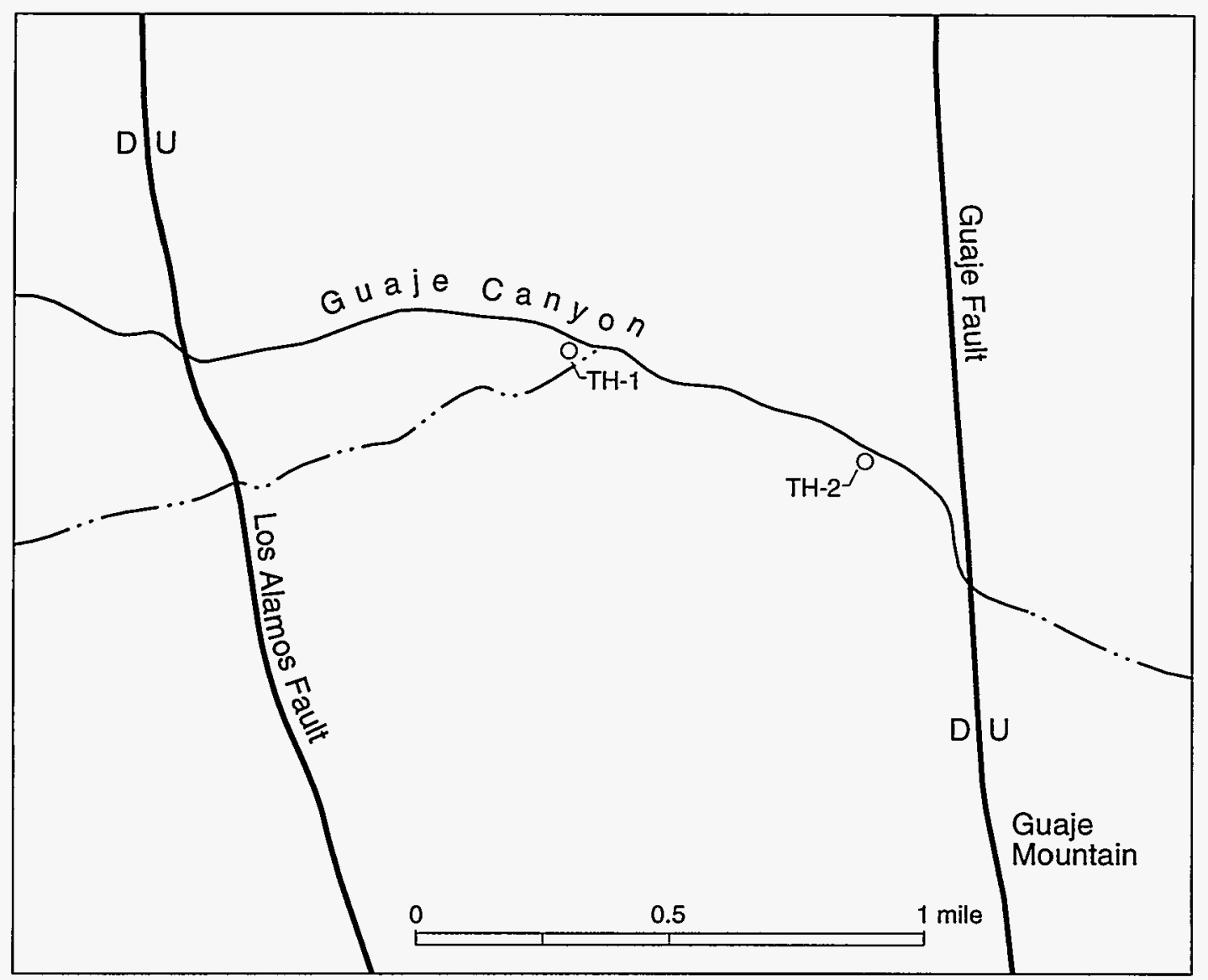

Fig. XXV-A. Location of test holes in upper Guaje Canyon.

TABLE XXV-A. Locations and Elevations (NAD 1927)
A. Test Hole 1
N $1,795,700$
E 484,600
$7180 \mathrm{ft}$
B. Test Hole 2
N $1,794,600$
E 486,600
$7060 \mathrm{ft}$ 


\section{FENTON HILL}

Fenton Hill is located about 35 miles west of Los Alamos on the western flanks of the Valles Caldera. The studies at this site have been based on extracting heat from dry geothermal reservoirs by developing artificial hydrothermal systems. Two systems were developed at the site. The first system was composed of two deep holes drilled into the dry Precambrian rock to a depth of about $10000 \mathrm{ft}$. The holes are connected by a fracture induced by hydrologic pressure. Water is circulated under pressure through this system to recover heat from the fractured area.

The second similar system has been developed at the site to a depth of about $14000 \mathrm{ft}$. Both systems have been tested.

Site selection for the test area began in the winter of 1971-1972. In December 1971, seven shallow heat-flow holes (Sites 1, 2, 3, 4, 5, 6, and 7) were drilled to about $100 \mathrm{ft}$ around the Valles Caldera (Fig. XXVI-A). Three additional holes (Sites 8, 9, and 10) were drilled on the west side of the caldera in February 1972 (Fig. XXVI-A). These holes were less than $80 \mathrm{ft}$ deep and were cased with 2-in.-diam plastic pipe. The heat-flow measurements in the holes indicated that the heat flow was greatest west of the caldera, and other data from the U.S. Geological Survey indicated that the geologic structure there was the least complex and that the depth to the Precambrian rocks was moderate. This was the type of geologic environment necessary for the development of dry geothermal energy.

In the spring of 1972 , test holes TH-A, TH-B, TH-C, and TH-D were drilled around the west rim of the Valles Caldera (Fig. XXVI-B). Cores were taken in 10-ft samples for every $100 \mathrm{ft}$ of depth. The holes ranged from 500 to $750 \mathrm{ft}$ in depth (geologic logs and construction data appear in Table XXVI-A). Surface casing was cemented in the top of the holes and blank casing was set into the lower part to facilitate heatflow logging. The heat-flow measurements indicated that the heat flow was greatest near the rim of the caldera and decreased westward. Upon completion of the core holes and heat-flow logging, a deep test hole GT-1 (depth $2575 \mathrm{ft}$ ) was drilled $470 \mathrm{ft}$ into the top of the Precambrian granite (Fig. XXVI-B, Table XXVI-A). Based on heat-flow measurements and geology, the test site, Fenton Hill TA-57, was located north of La Cueva at the top of Fenton Hill, just off State Road 126 (Fig. XXVI-B).

Two test holes were drilled near Fenton Hill for the placement of geophones for the site seismic operations and to obtain geologic and hydrologic information (Fig. XXVI-B). The holes, PC-1 and PC-2, were drilled through the volcanics and into the sediments. The holes were completed in the sediments just above the Precambrian level (Table XXVI-B).

Within the site, two sets of energy extraction holes were drilled, GT-2 and EE-1 (about $10000 \mathrm{ft}$ deep) and EE-2 and EE-4 (about $14000 \mathrm{ft}$ deep), both completed in the Precambrian rocks (Fig. XXVI-C). A well was drilled and completed in a shallow aquifer to provide a water supply (water level about $360 \mathrm{ft}$, base of aquifer at about $460 \mathrm{ft}$ ). Two additional wells were added (Fig. XXVI-C, Table XXVI-C). Five observation wells, 6 in. in diameter, were drilled to depths of $500 \mathrm{ft}$. They were used to test the aquifer and as a support for applications for water rights. The observation wells were completed through the aquifer, the Abiquiu Tuff, and into the perching formation of silts and clays of the Abo Formation. They were cased with 2-in.-diam galvanized pipe with the lower $50 \mathrm{ft}$ slotted.

A preliminary study of the quality of surface and ground water in the drainage area of the Jemez River and the Rio Guadalupe was made to establish background data, prior to any experiments by the Laboratory. The data include chemical analyses from 17 surface water stations, 15 mineral and thermal springs (Fig. XXVI-D), and 53 ground water stations (Fig. XXVI-E).

Based on the preliminary study of the quality of water in the vicinity of Fenton Hill, a number of surface and ground water stations were established to monitor any effect of the operations of the Fenton Hill site on the environment. The collection of quality-of-water data began in 1974 and has continued to the present (Fig. XXVI-F). The number of stations has remained about the same, with little change: 13 surface water stations (Table XXVI-D) and 20 ground water stations (Table XXVI-E). The chemical quality of the surface and ground water is grouped around common chemical properties and total dissolved solids. The water-quality data and related hydrologic data collected at Fenton Hill have been published in a series of Los Alamos reports: 
1974 data: LA-6093-MS, December 1975

1975 data: LA-6511-MS, September 1976

1976 data: LA-7307-MS, May 1978

1977 data: LA-7468-PR, September 1978

1978 data: LA-8217-PR, January 1980

1979 data: LA-8424-PR, June 1980

1980 data: LA-9007-PR, September 1981

1981-1982 data: LA-9854-PR, September 1983

1983-1984 data: LA-10892-PR, January 1987

1985-1986 data: LA-11210-PR, March 1988

1987-1988 data: LA-12030-PR, March 1991

1989 data: LA-12000-ENV, December 1990

1990 data: LA-12271-MS, March 1992

\section{REFERENCES}

American Ground Water Consultants, Inc., "Hydrology of the Hot Dry Rock Site at Fenton Hill,

Sandoval County, New Mexico," report submitted to the Los Alamos Scientific Laboratory (June 1980).

American Ground Water Consultants, Inc., "Results of Ground Water Model Studies at Fenton Hill, Sandoval County, New Mexico," report submitted to the Los Alamos Scientific Laboratory (July 1980).

N.M. Becker, W. D. Purtymun, and W. C. Ballance, "Aquifer Evaluation at Fenton Hill, October and November 1980," Los Alamos National Laboratory report LA-8964-MS (1981).

W. D. Purtymun, "Geology of the Jemez Plateau West of the Valles Caldera," Los Alamos Scientific Laboratory report LA-5124-MS (1973).
W. D. Purtymun, "Source Document Compilation: Los Alamos Investigations Related to the Environment, Engineering, Geology, and Hydrology, 19611990," Los Alamos National Laboratory report LA12733-MS (1994) chapters 26, 28, 36, 44, 54, 59, 60, $73,79,80,86,87,89,116,154,166$, and 198.

W. D. Purtymun, R. W. Ferenbaugh, A. K. Stoker, W. H. Adams, "Quality of Water in the Vicinity of Fenton Hill, 1979," Los Alamos Scientific Laboratory report LA-8424-PR (1980).

W. D. Purtymun, R. W. Ferenbaugh, N. M. Becker, M. C. Williams, and M. N. Maes, "Water Quality in the Vicinity of Fenton Hill, 1983 and 1984," Los Alamos National Laboratory report LA-10892-PR (1987)

W. D. Purtymun, F. G. West, and W. H. Adams, "Preliminary Study of the Quality of Water in the Drainage Area of the Jemez River and Rio

Guadalupe," Los Alamos Scientific Laboratory report LA-5595-MS (1974)

W. D. Purtymun, F. G. West, and R. A. Pettitt, "Geology of Geothermal Test Hole GT-2, Fenton Hill Site, July 1974," Los Alamos Scientific Laboratory report LA- 5780-MS (1974).

J. W. Tester, "Proceedings of the NATO-CCMS Information Meeting on Dry Hot Rock Geothermal Energy," Los Alamos Scientific Laboratory report LA-5518-C, NATO CCMS report No. 38 (1974).

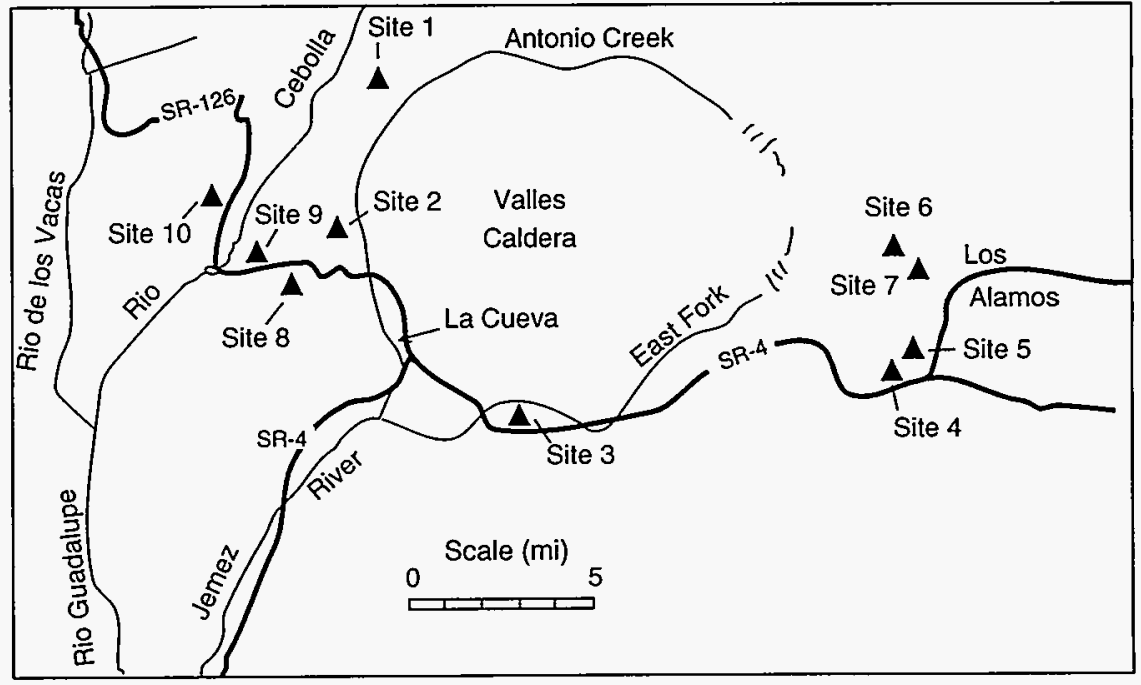

Fig. XXVI-A. Heat-flow sites, December 1971 and February 1972 (Purtymun 1994). 


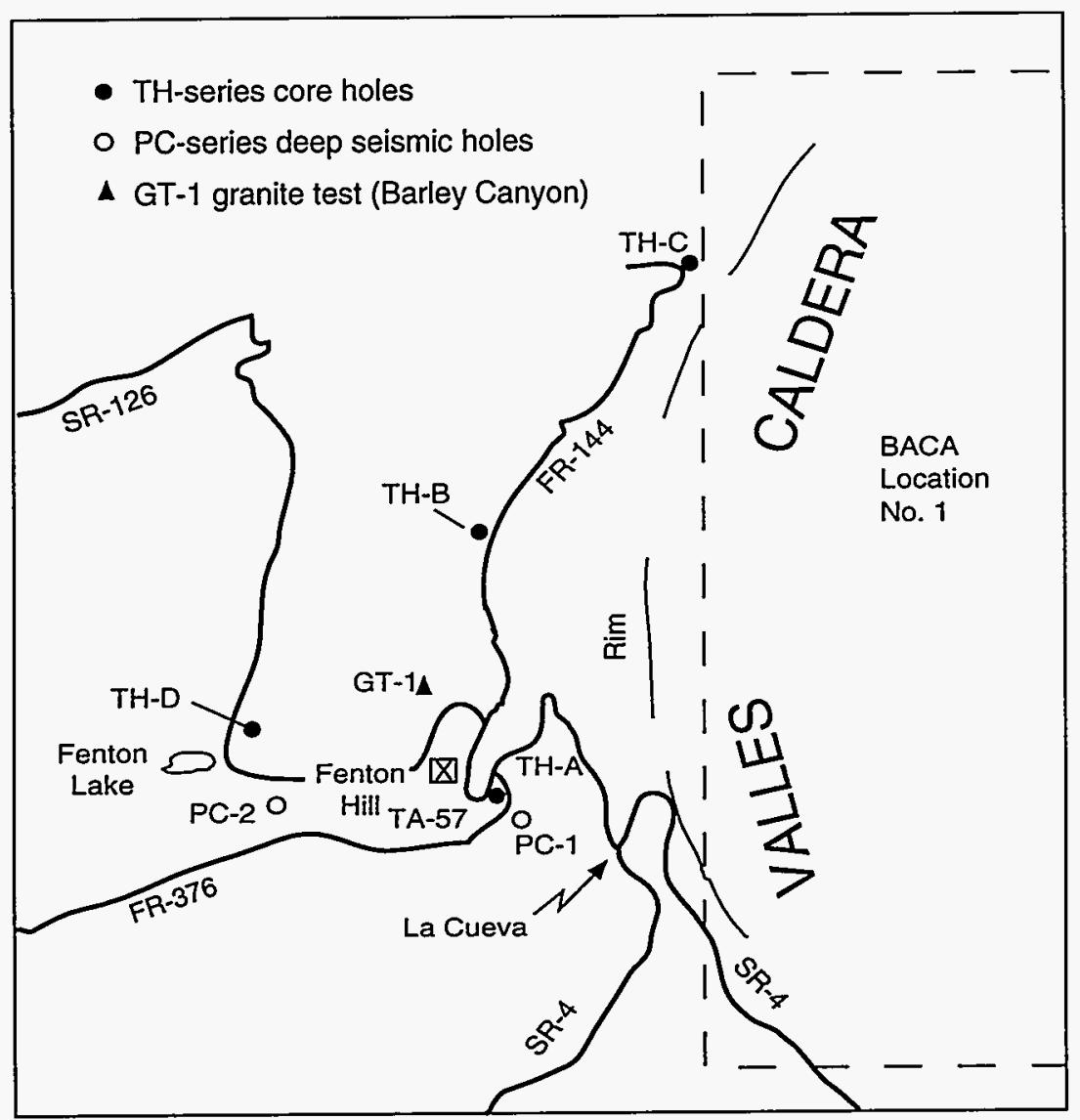

Fig. XXVI-B. Location of test holes (TH-series, PC-series, and GT-1) west of the Valles Caldera (Purtymun et al. 1987).

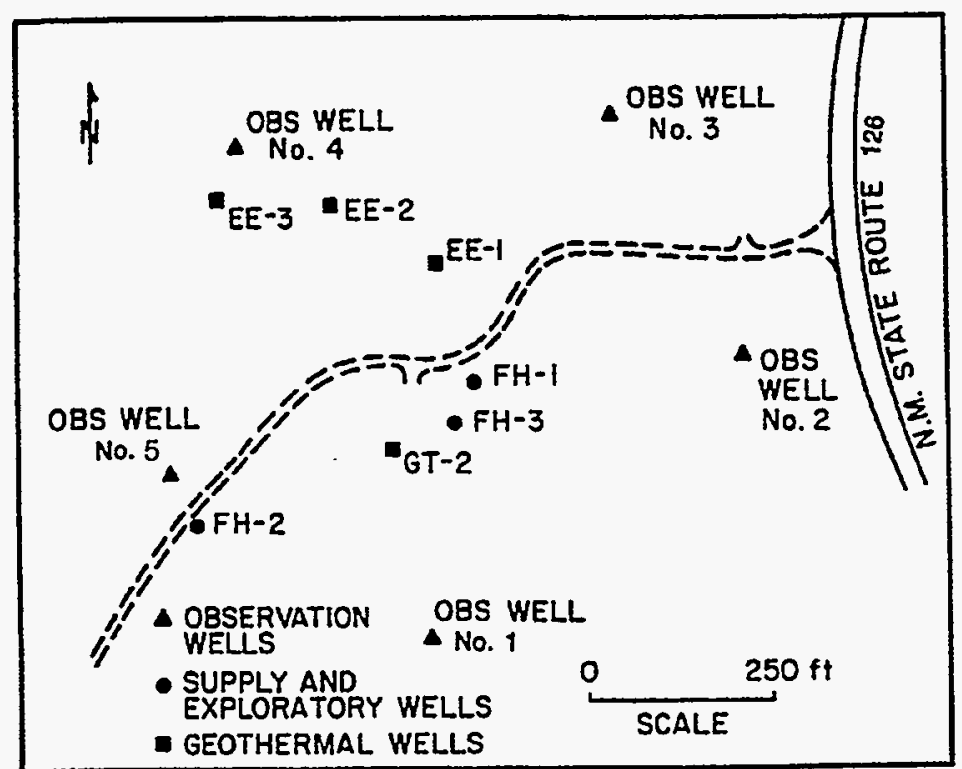

Fig. XXVI-C. Site map of Fenton Hill showing locations of observation, supply, exploratory, and geothermal wells (Becker et al, 1981). 


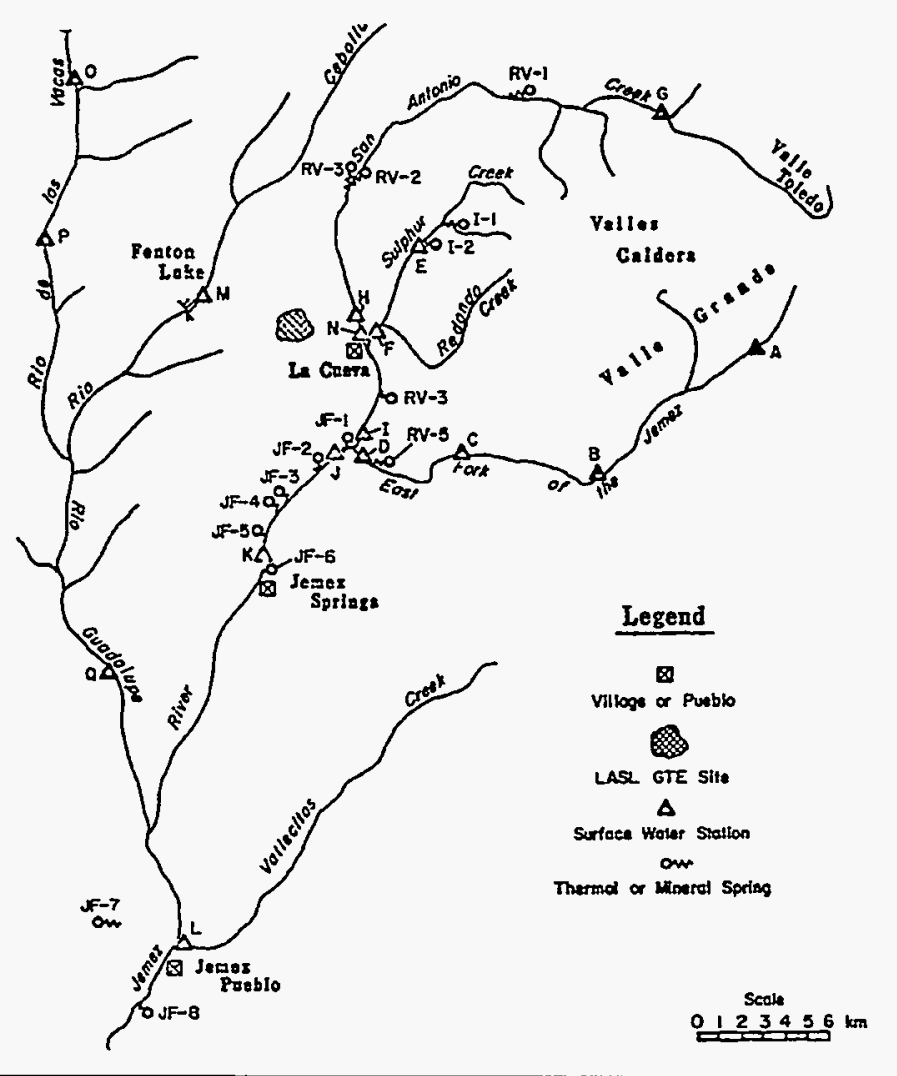

Fig. XXVI-D. Surface water stations, thermal and mineral springs (Purtymun et al. 1974).

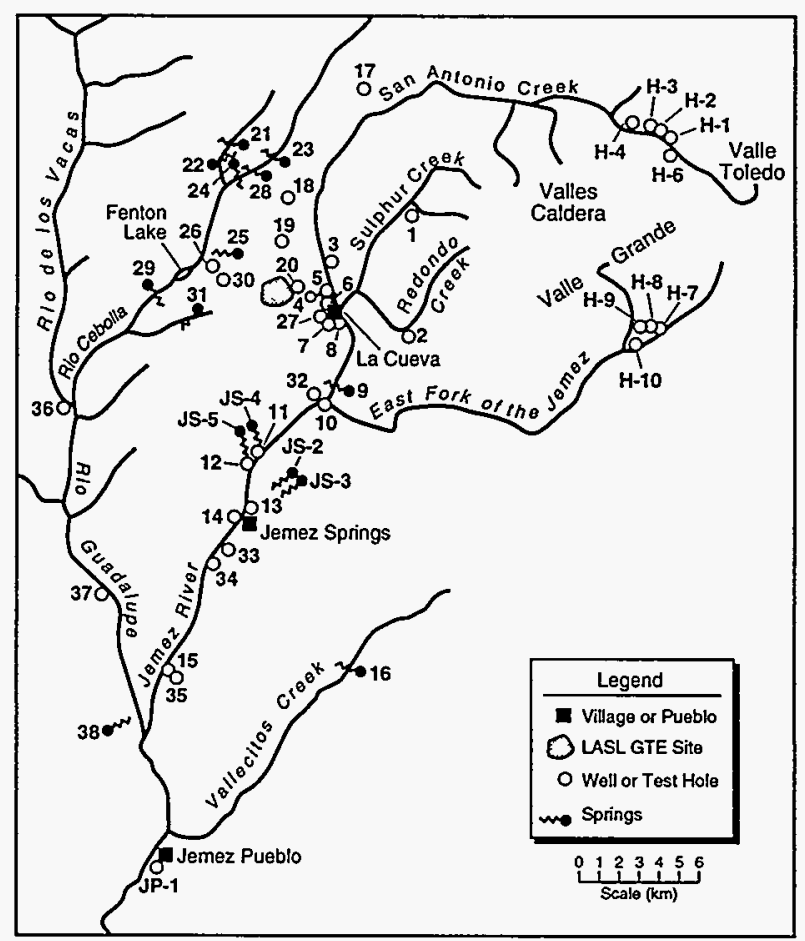

Fig. XXVI-E. Wells, test holes, and springs (Purtymun et al. 1974). 


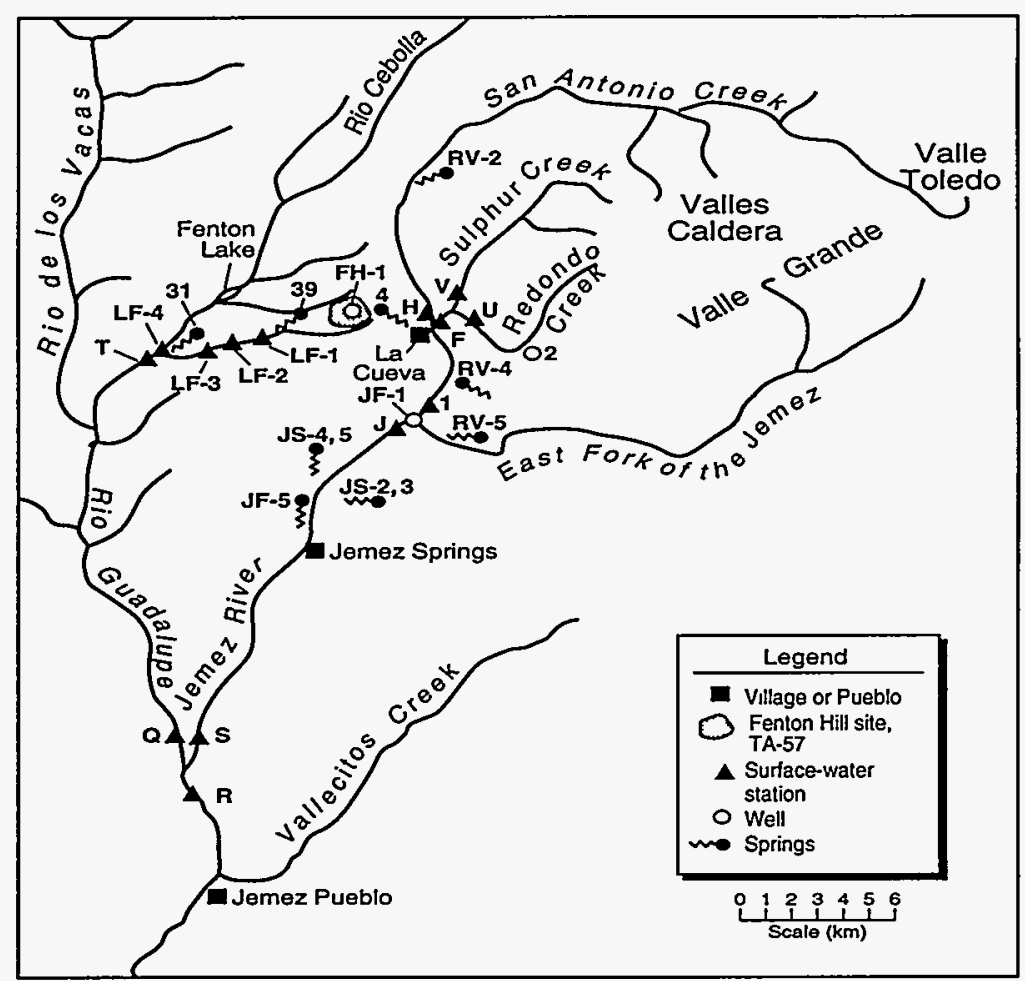

Locations of sampling stations

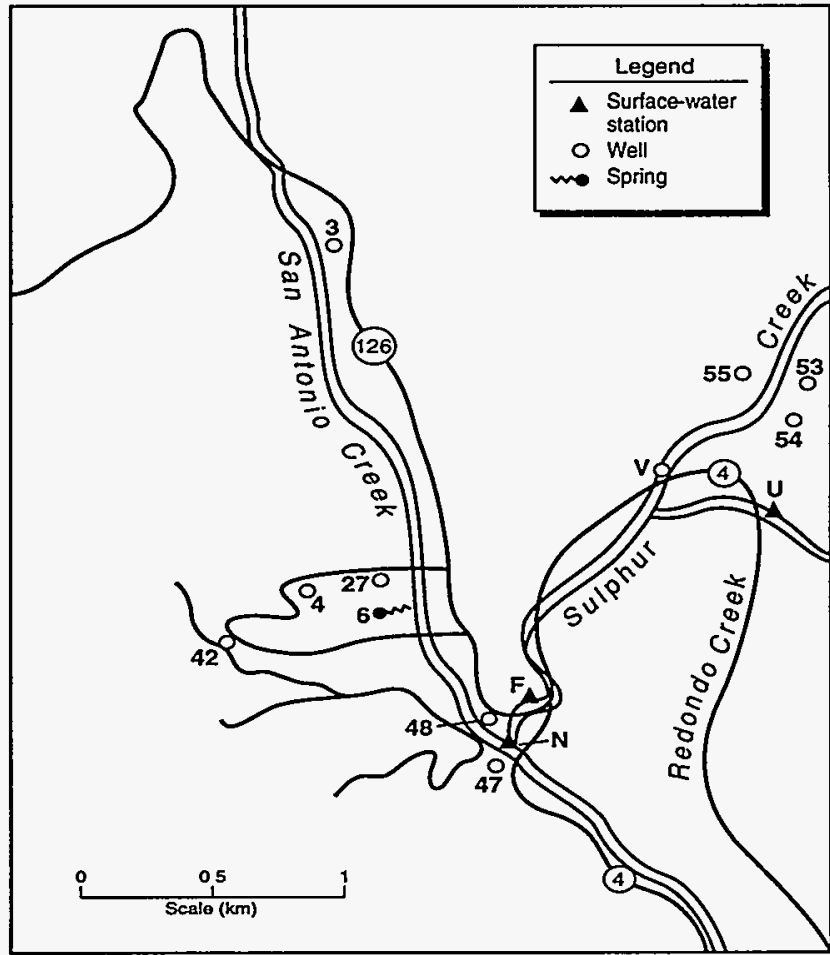

Locations of sampling stations at La Cueva

Fig. XXVI-F. Locations of surface-water stations and wells used in monitoring quality of water after 1974 (Purtymun et al. 1980). 
TABLE XXVI-A. Geologic Logs and Construction Data for Granite Test Hole (GT-1) and Test Holes TH-A, TH-B, TH-C, and TH-D

GT-1

$\underline{\log }$

Bandelier Tuff

Abiquiu Tuff

Abo Formation

Magdalena Group

Upper limestone member

Lower limestone member

Sandia Formation

Upper clastic member

Lower limestone

Precambrian rock

TH-A

Log

Bandelier Tuff

Abiquiu Tuff

Abo Formation

$\underline{\mathrm{TH}-\mathrm{B}}$

$\underline{\log }$

Bandelier Tuff

Abiquiu Tuff

Abo Formation

$\underline{\text { TH-C }}$

$\underline{\log }$

Bandelier Tuff

Abiquiu Tuff

Abo Formation

$\underline{\mathrm{TH}-\mathrm{D}}$

$\underline{\log }$

Bandelier Tuff

Abo Formation
June 1972

$\begin{array}{cc}\begin{array}{c}\text { Thickness } \\ (\mathrm{ft})\end{array} & \begin{array}{c}\text { Depth } \\ (\mathrm{ft})\end{array} \\ 60 & 60 \\ 100 & 160 \\ 910 & 1070 \\ & \\ 590 & 1660 \\ 155 & 1815 \\ & \\ 235 & 2050 \\ 55 & 2105 \\ 470 & 2575\end{array}$

April 1972

Thickness

Depth

$\underline{(\mathrm{ft})}$

$(\mathrm{ft})$

30

30

120

155

435

590

April 1972

Elevation $8625 \mathrm{ft}$

$\begin{array}{cc}\begin{array}{c}\text { Thickness } \\ (\mathrm{ft})\end{array} & \begin{array}{c}\text { Depth } \\ (\mathrm{ft})\end{array} \\ 380 & 380 \\ 60 & 440 \\ 210 & 650\end{array}$

April 1972

Elevation $8700 \mathrm{ft}$

$\begin{array}{cc}\begin{array}{c}\text { Thickness } \\ (\mathrm{ft})\end{array} & \begin{array}{c}\text { Depth } \\ (\mathrm{ft})\end{array} \\ 240 & 240 \\ 340 & 580 \\ 170 & 750\end{array}$

April 1972

Elevation $7900 \mathrm{ft}$

Thickness Depth

(ft) $\quad(\mathrm{ft})$

120

120

$380 \quad 500$ 
TABLE XXVI-A. Geologic Logs and Construction Data for Granite Test Hole (GT-1) and Test Holes TH-A, TH-B, TH-C, and TH-D (Continued)

Construction

GT-1 Depth $2575 \mathrm{ft}$

Hole diam

$33 / 4$ in. to $280 \mathrm{ft}$

$97 / 8$ in. to $1600 \mathrm{ft}$

$63 / 4$ in. to $2410 \mathrm{ft}$

Casing schedule

$41 / 4$ in. to $2575 \mathrm{ft}$

(outside diam)

$103 / 4$ in. to $258 \mathrm{ft}$

$75 / 8$ in. to $1357 \mathrm{ft}$

5 in. to $2400 \mathrm{ft}$

open hole 2400 to $2575 \mathrm{ft}$

Drilled air-mist-rotary to $2410 \mathrm{ft}$, core-water-rotary to 2410 to $2575 \mathrm{ft}$, all strings cemented in.

$\underline{\text { TH-A }}$

Depth $590 \mathrm{ft}$

Hole diam

Casing schedule

(outside diam)

$\underline{\mathrm{TH}-\mathrm{B}}$

Hole diam

Casing schedule

(outside diam)

$\underline{\text { TH-C }}$

Hole diam

Casing schedule

(outside diam)

$\underline{\text { TH-D }}$

Hole diam

Casing schedule

(outside diam)
$95 / 8 \mathrm{in}$. to $100 \mathrm{ft}$

$6 \mathrm{l} / 4 \mathrm{in}$. to $590 \mathrm{ft}$

7 in. to $97 \mathrm{ft}$

$41 / 2$ in. to $578 \mathrm{ft}$

Depth $650 \mathrm{ft}$

$95 / 8 \mathrm{in}$. to $100 \mathrm{ft}$

$61 / 4$ in. to $650 \mathrm{ft}$

7 in. to $97 \mathrm{ft}$

$41 / 4$ in. to $566 \mathrm{ft}$

Depth $750 \mathrm{ft}$

$95 / 8$ in. to $100 \mathrm{ft}$

$61 / 4$ in. to $500 \mathrm{ft}$

7 in. to $97 \mathrm{ft}$

$41 / 4$ in. to $750 \mathrm{ft}$

Depth $500 \mathrm{ft}$

$95 / 8 \mathrm{in}$. to $100 \mathrm{ft}$

$61 / 4$ in. to $750 \mathrm{ft}$

7 in. to $97 \mathrm{ft}$

$41 / 4$ in. to $500 \mathrm{ft}$

Note: TH-A,-B,-C,-D were mud-rotary drilled and cored at intervals; 4-1/4 in.-outside-diam (o.d.) final string for heat-flow measurements: no slots, open end. Only the surface string had a 7-in.-o.d. pipe cemented in.

Source: Purtymun 1973. 
TABLE XXVI-B. Precambrian Test Holes PC-1 and PC-2

$\underline{\mathrm{PC}-1}$

December 1983

Elevation $8400 \mathrm{ft}$

$\underline{\log }$

Overburden

Bandelier Tuff

Abo Formation

Madera Limestone

Thickness

(ft)

12

Depth

181

814

1171

(ft)

12

193

1007

2178

Note: Completed in granite wash above the Precambrian. Hole cased to depth of $2175 \mathrm{ft}$. Drilled by cable tool. No geophysical logs. Geology by Dan Miles in Purtymun et al. 1987.

$\underline{\mathrm{PC}-2}$

December 1983

Elevation $8623 \mathrm{ft}$

$\underline{\log }$

Bandelier Tuff

Abo Formation

Madera Limestone

$\begin{array}{cc}\begin{array}{c}\text { Thickness } \\ (\mathrm{ft})\end{array} & \begin{array}{c}\text { Depth } \\ (\mathrm{ft})\end{array} \\ 394 & 394 \\ 737 & 1131 \\ 694 & 1825\end{array}$

Note: Hole blew out at a depth of $1825 \mathrm{ft}$ when a pocket of gas was encountered; hole cased to a depth of $1819 \mathrm{ft}$. Drilled by cable tool. No geophysical logs. Geology by Dan Miles in Purtymun et al. 1987.

Source: Purtymun et al. 1987. 


\section{TABLE XXVI-C. Geologic Logs and Construction Data for Supply Wells at Fenton Hill}

Supply Wells

$\underline{\mathrm{FH}-1}$

August 1976

Elevation $8690 \mathrm{ft}$

$\underline{\log }$

Bandelier Tuff

Paliza Canyon Formation

Abiquiu Tuff

$\begin{array}{cc}\begin{array}{c}\text { Thickness } \\ (\mathrm{ft})\end{array} & \begin{array}{c}\text { Depth } \\ 50\end{array} \\ 310 & 50 \\ 90 & 360\end{array}$

$\underline{\mathrm{FH}-2}$

December 1980

Elevation $8691 \mathrm{ft}$

Thickness

Depth

$\underline{\log }$

$\begin{array}{rr}\frac{(\mathrm{ft})}{50} & \frac{(\mathrm{ft})}{50} \\ 310 & 360 \\ 73 & 433 \\ 17 & 450\end{array}$

FH-3

March 1980

Elevation $8692 \mathrm{ft}$

Thickness

$\begin{array}{lrr}\text { Bg } & (\mathrm{ft}) & (\mathrm{ft}) \\ \text { Pandelier Tuff } & 50 & 50 \\ \text { Abiqa Canyon Formation } & 310 & 360 \\ \text { Abo Formation } & 95 & 455 \\ & 5 & 460\end{array}$

Well Construction FH-1, FH-2, and FH-3

Diameter of Casing (in.)

Depth Cased (ft)

Depth to Water (ft)

Elevation to Water Surface ( $\mathrm{ft}$ )

Thickness to Aquifer (ft)

Length of Screen or Slots ( $\mathrm{ft}$ )

Specific Capacity $(\mathrm{gpm} / \mathrm{ft})$

$\underline{F H-1} \quad \underline{F H}-2 \quad \underline{F H}-3$

$\begin{array}{ccc}7^{\mathrm{a}} & 16 & 16 \\ 450 & 450 & 460 \\ 372 & 371 & 373 \\ 8318 & 8320 & 8319 \\ 78+ & 63 & 85 \\ 60^{\mathrm{b}} & 59^{\mathrm{c}} & 69^{\mathrm{c}} \\ 100+ & \approx 1 & <1\end{array}$

aSet with screen on liner 5-1/2 in.

bSlotted screen 0.025 -in. slots

cTorch-slotted casing.

Note: Water levels from 1980 measurements.

Source: Becker et al. 1981. 
TABLE XXVI-D. Surface Water Quality at Water Stations in the Jemez Mountains

Sodium Chloride

Redondo Creek (U)

Jemez River (R)

$\underline{\text { Calcium Bicarbonate }}$

San Antonio Creek (N)

Rio Cebolla ( $\mathrm{T}$ )

Rio Guadalupe

Lake Fork 1 (LF-1)

Lake Fork 2 (LF-2)

Lake Fork 3 (LF-3)

Lake Fork 4 (LF-4)

$\underline{\text { Calcium Sulfate }}$

Sulphur Creek (V)

Sulphur Creek (F)

$\underline{\text { Sodium Bicarbonate }}$

Jemez River (J)
Remarks

above confluence with Sulphur Creek

below confluence with Rio Guadalupe

above confluence with Sulphur Creek

below confluence with Lake Fork Canyon

above confluence with Jemez River

at crossing to stock corral

change in channel gradient

bend in road, old beaver dam in channel

below corral on north side of valley

at SR-4 above confluence with Redondo Creek

above confluence with San Antonio Creek

at U.S. Geol. Survey gaging station

Note: Letters or combinations of letters and numbers refer to the sampling locations shown in Fig. XXVI-F.

Sources: Purtymun et al. 1974 and 1991. 
TABLE XXVI-E. Ground Water Quality at Water Stations in the Jemez Mountains

Sodium Chloride

Location JF-1

Location JF-5

Calcium Bicarbonate

FH-1

FH-2

Location 6

Location 27

Location 39

Location 42

Location 48

Location 53

Location 54

Location 55

\section{$\underline{\text { Sodium Bicarbonate }}$}

\section{JS-2,3}

JS-4,5

Location 4

Location 31

RV-2

RV -4

RV-5

Location 47
Remarks

Limestone Spring (mineral) CMP under SR-4

Soda Dam (Hot Spring) west side SR-4

supply well Fenton Hill site

observation well Fenton Hill site

spring overflow (pump house) in valley

artesian well overflow from tank

USFS cattle tank-Lake Fork Canyon

well (Goldstone)

well (La Cueva Lumber Yard)

well (Crane, Sulphur Creek)

well (Hansen, Sulphur Creek)

well (Olsen, Sulphur Creek)

Note: Numbers or combinations of numbers and letters refer to the sampling locations shown in Fig. XXVI-F.

Sources: Purtymun et al. 1974 and 1991. 
TABLE XXVI-F. Locations and Elevations (NAD 1927)

A. Heat-Flow Sites

No locations (generalized in Fig. XXVI-A)

B. Test Holes

$\begin{array}{llll}\text { GT-1 } & \text { N } 1,784,600 & \text { E } 375,600 & 8475 \mathrm{ft} \\ \text { TH-A } & \text { N } 1,775,700 & \text { E } 376,700 & 8450 \mathrm{ft} \\ \text { TH-B } & \text { N } 1,799,600 & \text { E } 380,600 & 8625 \mathrm{ft} \\ \text { TH-C } & \text { N } 1,808,600 & \text { E } 389,300 & 8700 \mathrm{ft} \\ \text { TH-D } & \text { N } 1,779,600 & \text { E } 363,400 & 7900 \mathrm{ft} \\ \text { PC-1 } & \text { N } 1,774,600 & \text { E } 378,000 & 8400 \mathrm{ft} \\ \text { PC-2 } & \text { N } 1,774,400 & \text { E } 371,500 & 8623 \mathrm{ft}\end{array}$

C. Supply Well and Observation Holes

No coordinates or elevations (within TA-57, see Fig. XXVI-C)

$\begin{array}{llll}\text { TA-57 } & \text { N } 1,775,800 & \text { E } 375,000 & 8700 \mathrm{ft}\end{array}$

D. Surface Water Stations

$\begin{array}{llll}\text { Redondo Creek (U) } & \text { N } 1,774,500 & \text { E 388,100 } & 7750 \mathrm{ft} \\ \text { Jemez River (R) } & \text { N } 1,699,300 & \text { E 356,200 } & 5645 \mathrm{ft} \\ \text { Jemez River (S) } & \text { N } 1,699,900 & \text { E 356,100 } & 5650 \mathrm{ft} \\ \text { San Antonio Creek (N) } & \text { N } 1,770,800 & \text { E 384,700 } & 7620 \mathrm{ft} \\ \text { Rio Cebolla (T) } & \text { N } 1,766,200 & \text { E 348,000 } & 7460 \mathrm{ft} \\ \text { Rio Guadalupe (Q) } & \text { N } 1,699,900 & \text { E 355,900 } & 5650 \mathrm{ft} \\ \text { Lake Fork 1 (LF-1) } & \text { N } 1,769,800 & \text { E 360,500 } & 7845 \mathrm{ft} \\ \text { Lake Fork 2 (LF-2) } & \text { N } 1,768,300 & \text { E 357,000 } & 7800 \mathrm{ft} \\ \text { Lake Fork 3 (LF-3) } & \text { N } 1,766,800 & \text { E 352,500 } & 7610 \mathrm{ft} \\ \text { Lake Fork 4 (LF-4) } & \text { N 1,766,900 } & \text { E 350,800 } & 7510 \mathrm{ft} \\ \text { Sulphur Creek (V) } & \text { N } 1,774,700 & \text { E 386,800 } & 7720 \mathrm{ft} \\ \text { Sulphur Creek (F) } & \text { N } 1,770,900 & \text { E 385,000 } & 7620 \mathrm{ft} \\ \text { Jemez River (J) } & \text { N 1,756,500 } & \text { E 381,300 } & 6750 \mathrm{ft}\end{array}$

E. Ground Water Stations

Location JF-1 (Hot Spring) N 1,757,500

Location JF-5 (Hot Spring) N 1,743,600

FH-1 Supply Well N $1,775,800$

FH-2 Observation Well $\quad$ N 1,775,800

Location 6 (Spring) N $1,772,800$

Location 27 (Well) N $1.773,600$

Location 39 (Spring) N $1,770,300$

Location 42 (Well) $\quad$ N 1,772,300

Location 48 (Well) N $1,771,200$

Location 53 (Well) N $1,776,700$

Location 54 (Well) N $1,776,200$

Location 55 (Well) N $1,776,600$

IS-2, 3 (Spring) N $1,735,700$

JS-4, 5 (Spring) N $1,741,100$

Location 4 (Well) N $1,773,000$

Location 31 (Spring) N $1,767,200$

RV-2 (Hot Spring) N $1,796,800$

RV-4 (Hot Spring) N $1,764,700$

RV-5 (Hot Spring) N $1,753,900$

Location 47 (Well) N $1,770,700$

$\begin{array}{ll}\text { E 382,300 } & 6780 \mathrm{ft} \\ \text { E 370,600 } & 6400 \mathrm{ft} \\ \text { E 375,000 } & 8675 \mathrm{ft} \\ \text { E 375,000 } & 8692 \mathrm{ft} \\ \text { E 383,600 } & 7670 \mathrm{ft} \\ \text { E 383,900 } & 7650 \mathrm{ft} \\ \text { E 361,900 } & 7880 \mathrm{ft} \\ \text { E 381,400 } & 7840 \mathrm{ft} \\ \text { E 384,600 } & 7630 \mathrm{ft} \\ \text { E 388,800 } & 7835 \mathrm{ft} \\ \text { E 388,200 } & 7795 \mathrm{ft} \\ \text { E 388,500 } & 7805 \mathrm{ft} \\ \text { E 369,300 } & 6220 \mathrm{ft} \\ \text { E 370,800 } & 6265 \mathrm{ft} \\ \text { E 382,200 } & 7760 \mathrm{ft} \\ \text { E 350,900 } & 7600 \mathrm{ft} \\ \text { E 383,000 } & 8360 \mathrm{ft} \\ \text { E 387,800 } & 7360 \mathrm{ft} \\ \text { E 388,300 } & 7340 \mathrm{ft} \\ \text { E 384,600 } & 7640 \mathrm{ft}\end{array}$




\section{GUAJE AND LOS ALAMOS RESERVOIRS}

Water from Guaje and Los Alamos Reservoirs was used for municipal and industrial use at Los Alamos during the early days of the Manhattan Project (Fig. XXVII-A). Use of the water from the reservoirs was discontinued in 1959 because of intermittent periods of turbidity caused by storm runoff and because of difficulties in maintaining bacteriological levels below the limits allowed for municipal supply.

Both of the reservoirs and adjacent areas are open for recreational use. Water from the reservoirs is available for irrigation of lawns and shrubs in the community and Laboratory. Parts of the water lines are above ground and are subject to freezing; thus, water use from the reservoirs is limited to the period from late spring to early fall.

Guaje Reservoir in upper Guaje Canyon has a capacity of 250000 gallons and has a drainage area of $5.6 \mathrm{sq} \mathrm{mi}$. The reservoir is for diversion rather than storage, as perennial flow is maintained by a spring in the canyon above the reservoir. Water flows by gravity through 6.8 miles of distribution lines to Los Alamos.

Los Alamos Reservoir in upper Los Alamos Canyon has a capacity of about 13000000 gallons and has a drainage area of $6.4 \mathrm{sq} \mathrm{mi}$. Water flows by gravity through 2.6 miles of distribution lines to the townsite.

Since 1958, the water lines from both reservoirs have not been part of, or been connected to, the distribution system for the municipal water supply.

\section{REFERENCES}

Black and Veatch, "Report on Water Supply, Los Alamos Project, New Mexico," Consulting Engineers, Kansas City, Mo. Administrative Report to the U.S. Atomic Energy Commission (1951).

W. D. Purtymun, M. N. Maes, and S. G. McLin, "Water Supply at Los Alamos During 1988," Los Alamos National Laboratory report LA-11679-PR (1989).

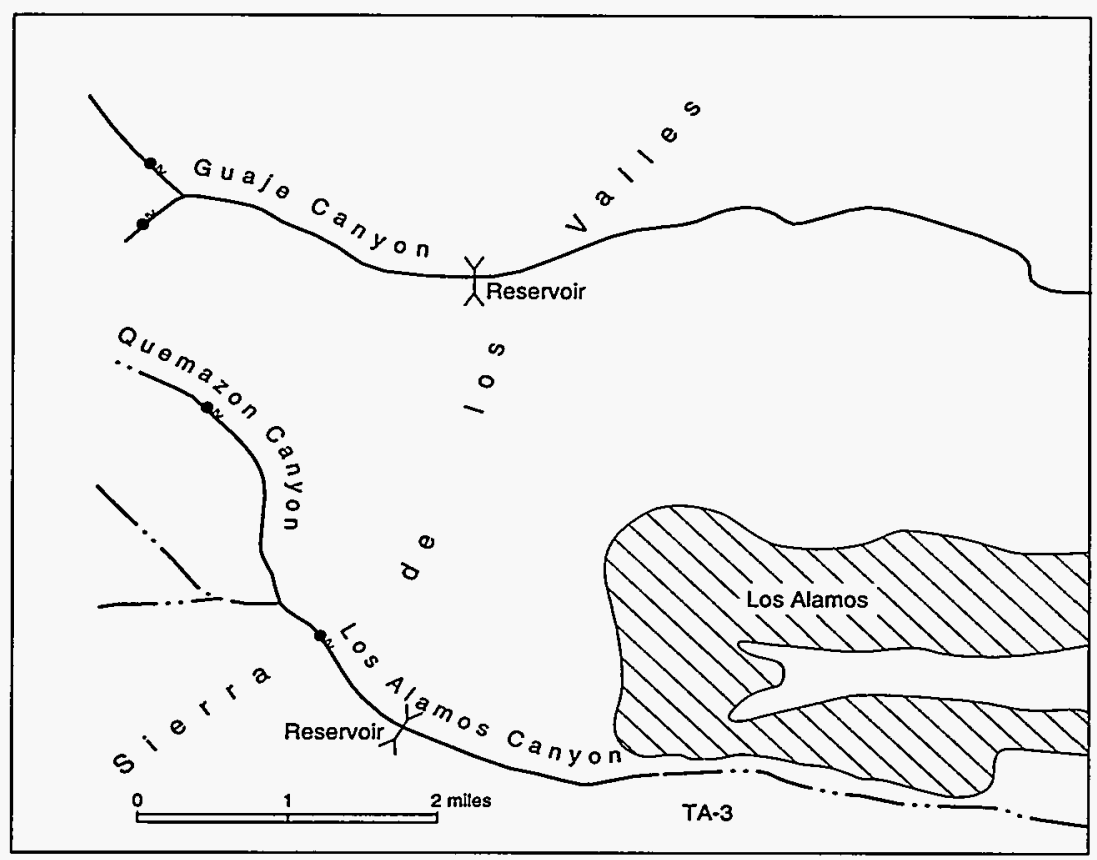

Fig. XXVII-A. Locations of Guaje and Los Alamos reservoirs.

TABLE XXVII-A. Locations and Elevations (NAD 1927)

Guaje Reservoir

Los Alamos Reservoir
N $1,794,000$

N $1,777,200$
E 471,600

E 468,600
$8017 \mathrm{ft}$

$7659 \mathrm{ft}$ 
XXVIII. LOW-FLOW INVESTIGATIONS IN . SANTA CLARA, GUAJE, LOS ALAMOS, AND FRIJOLES CANYONS

Low-flow investigations were made in Santa Clara, Guaje, Los Alamos, and Frijoles Canyons in 1958, 1959, and 1960 (Fig. XXVIII-A). An additional set of measurements were made in Santa Clara Canyon in 1967. The low-flow investigations were made to relate geology or geologic structure to loss or gain in stream flow in evaluating recharge or discharge to stream-connected aquifers or the main aquifer.

Geologic sections were prepared along the stream channels of Santa Clara (Fig. XXVIII-B), Guaje (Fig. XXVIII-C), and Los Alamos Canyons (Fig. XXVIII-D), and the Rito de los Frijoles (Fig. XXVIII-E) using existing geologic maps modified by field investigations. The subsurface correlations were interpreted from outcrops and logs of existing test holes or wells.

The results of the low-flow measurements (cu ft/s) for Santa Clara, Guaje, Los Alamos, and Frijoles Canyons are shown in Tables XXVIII-A through XXVIII-D respectively. The annual runoff (volume of runoff as determined from gaging station records as compared to drainage area) for Santa Clara and Frijoles Canyons is also shown on the tables for those canyons.

\section{REFERENCES}

U.S. Geological Survey, "Surface Water Supply of the United States, Part 8, 1959, Western Gulf of Mexico Basins," U. S. Geol. Survey Water-Supply Paper 1632 (1962).

U.S. Geological Survey, "Surface Water Supply of the United States, Part 8, 1959," U.S. Geol. Survey Water-Supply Paper 1712 (1963).

U.S. Geological Survey, "Quality of Surface Water of the United States, Parts 7 and 8, 1959, Lower Mississippi River Basin and Western Gulf of Mexico Basins," U.S. Geol. Survey Water-Supply Paper 1744 (1961).

U.S. Geological Survey, "Quality of Surface Water of the United States, Parts 7 and 8, 1960, Lower Mississippi River Basins and Western Gulf of Mexico Basins," U.S. Geol. Survey Water-Supply Paper 1814 (1962).

W.D. Purtymun, "Geohydrology of the Pajarito Plateau with Reference to Quality of Water, 19491972," Los Alamos Scientific Laboratory, internal document, 1975. 


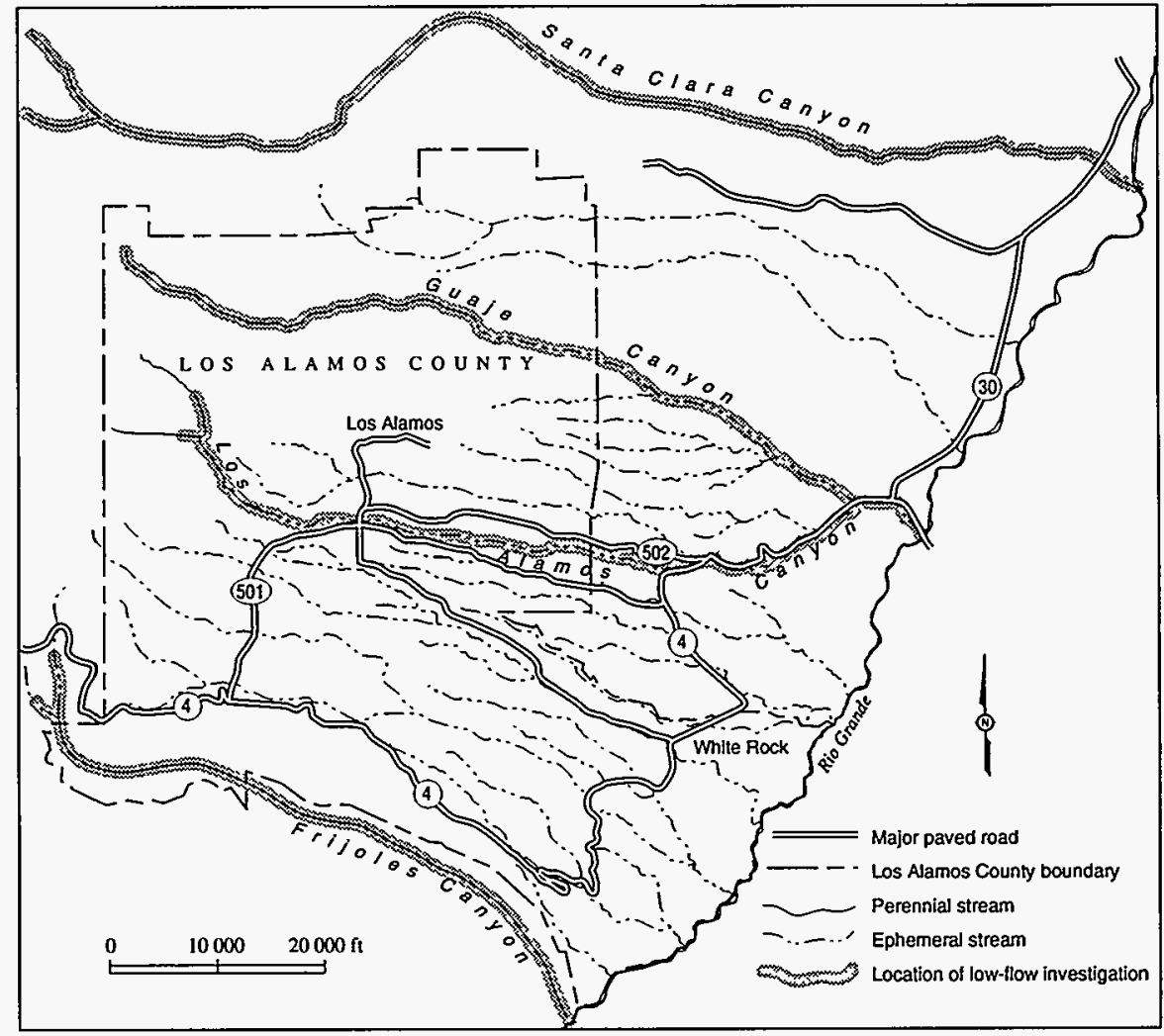

Fig. XXVIII-A. Locations of low-flow investigations in Santa Clara, Guaje, Los Alamos, and Frijoles Canyons.

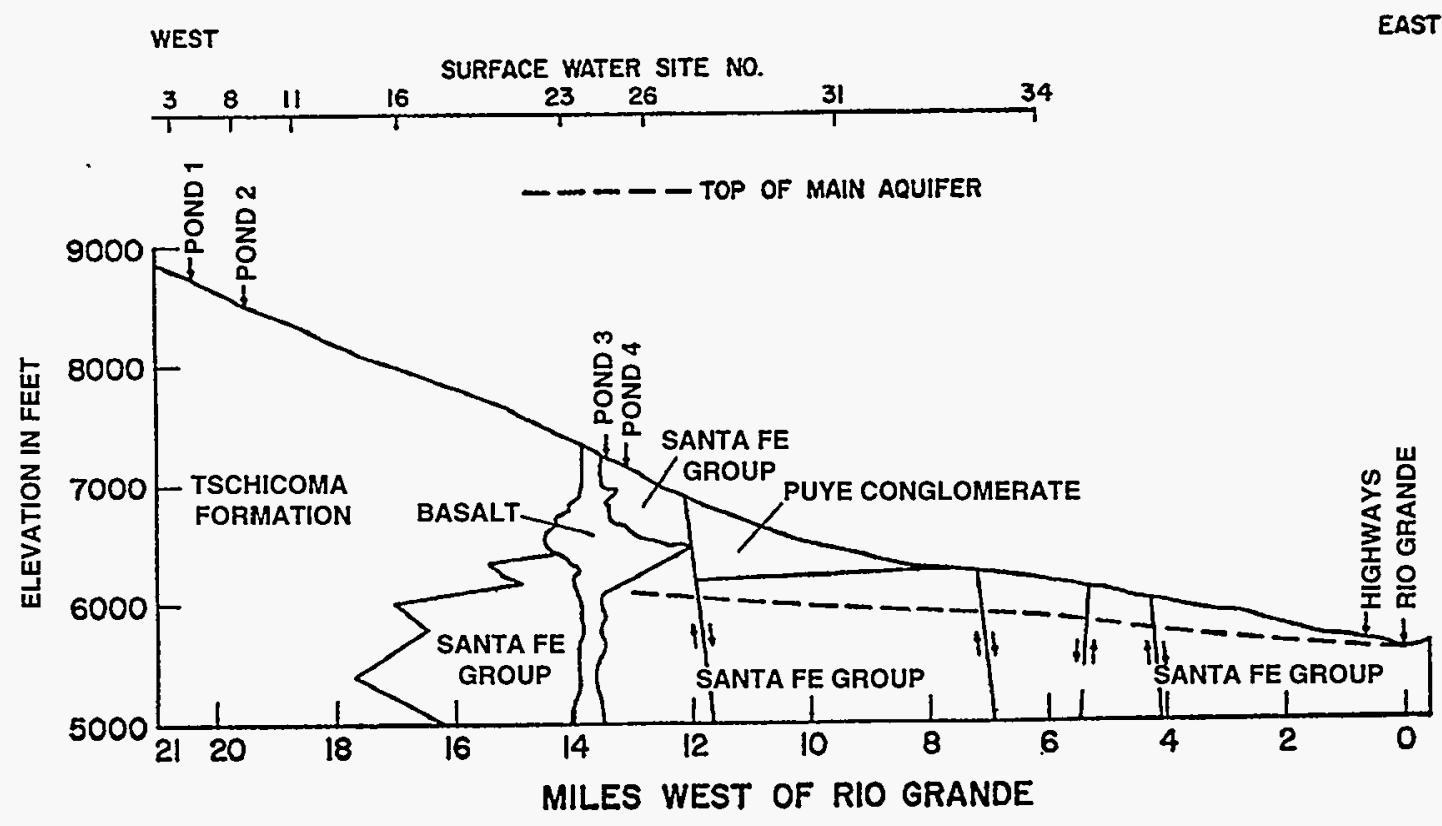

Fig. XXVIII-B. Geologic section of Santa Clara Canyon showing locations of low-flow measurements. 


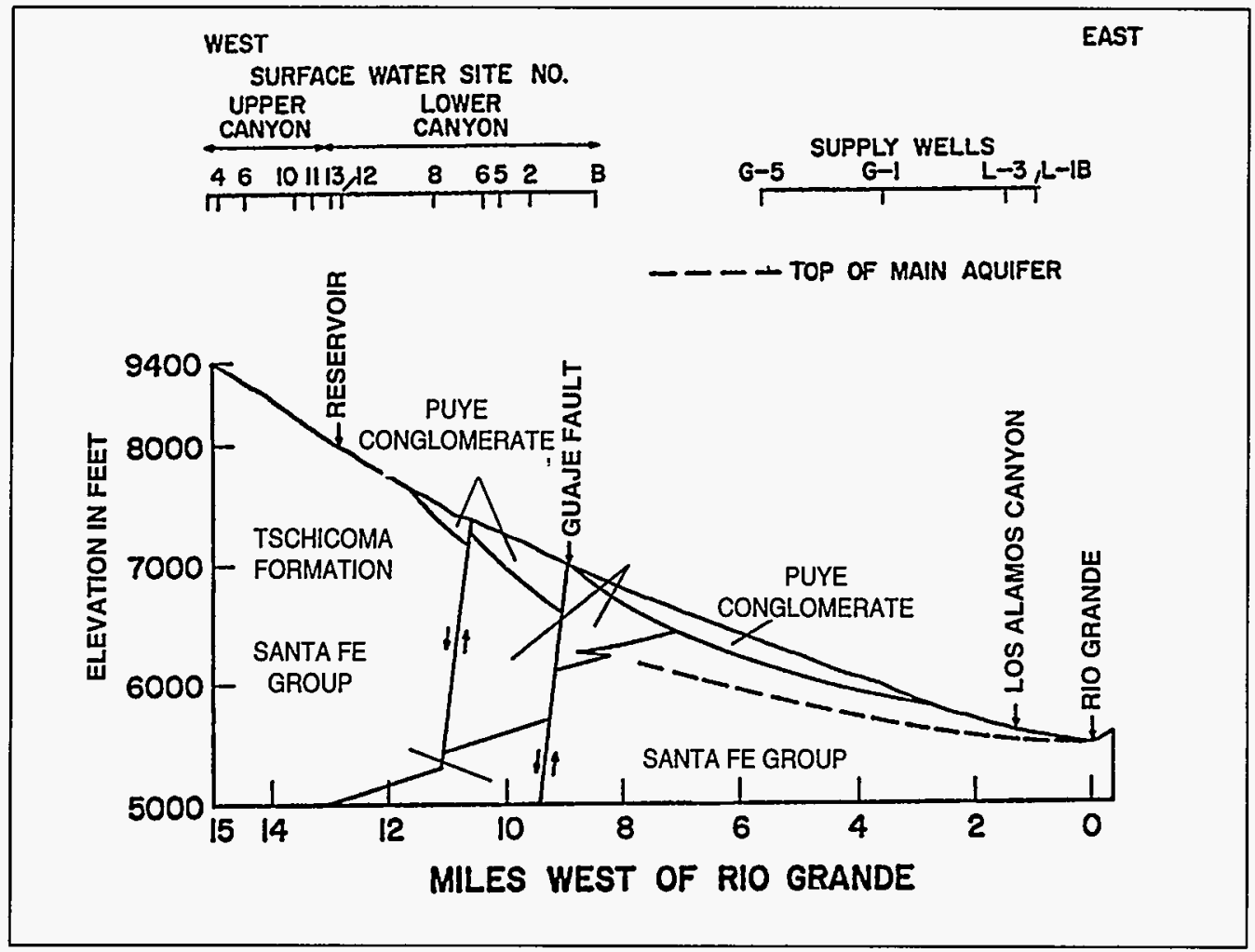

Fig. XXVIII-C. Geologic section of Guaje Canyon showing locations of low-flow measurements.

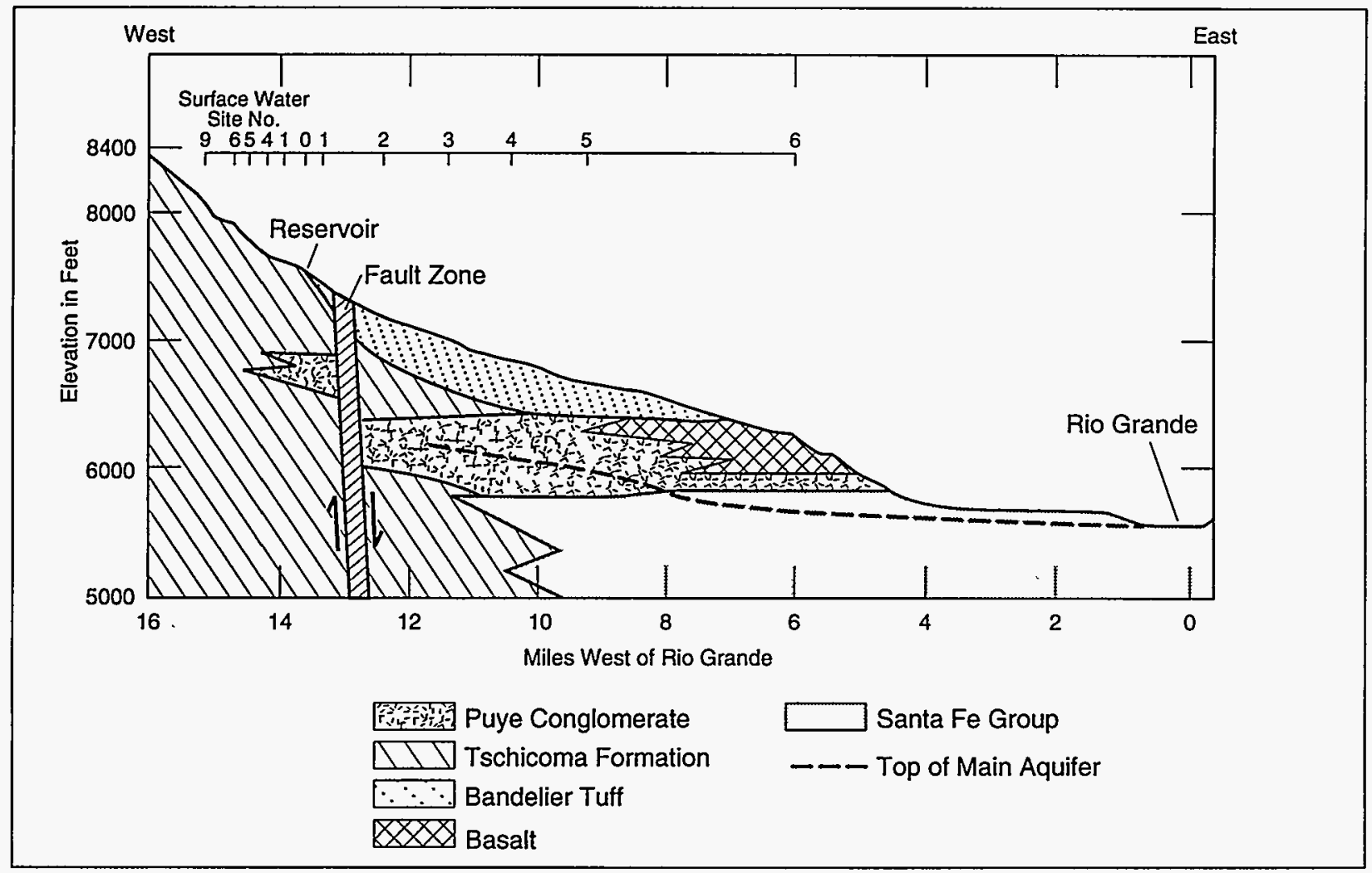

Fig. XXVIII-D. Geologic section of Los Alamos Canyon showing locations of low-flow measurements. 


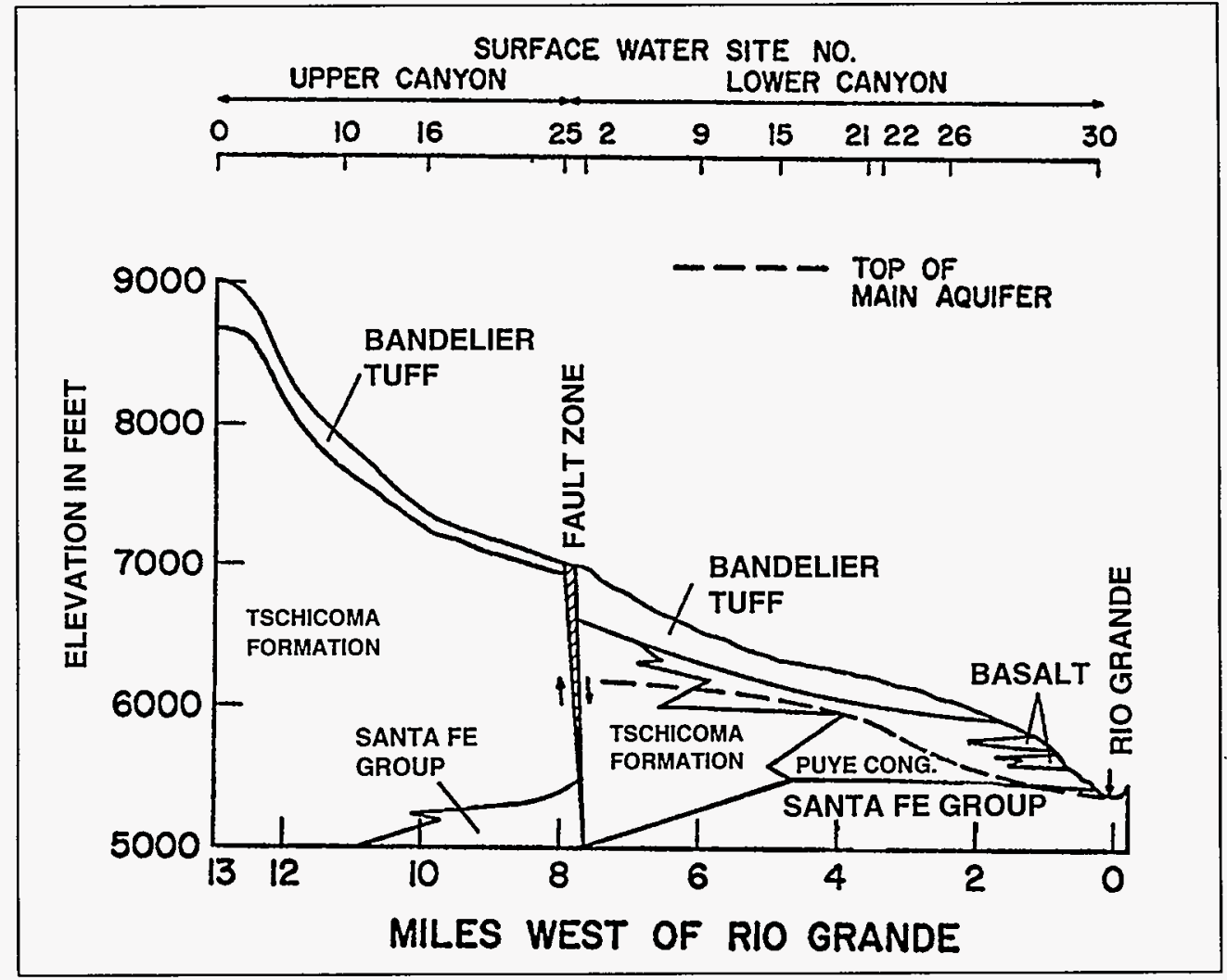

Fig. XXVIII-E. Geologic section of Frijoles Canyon showing locations of low-flow measurements. 
TABLE XXVIII-A. Low-Flow Measurements and Annual Runoff in Santa Clara Canyon

Santa Clara Low-Flow Measurements (cubic feet per second)

\begin{tabular}{|c|c|c|c|c|c|c|c|c|}
\hline & 1958 & \multicolumn{9}{|c|}{1959} & \multicolumn{2}{|c|}{1960} & 1967 \\
\cline { 2 - 9 } Site & Oct. & Apr. & June & Aug. & Oct. & $\begin{array}{c}\text { May } \\
16-17\end{array}$ & $\begin{array}{c}\text { June } \\
20-22\end{array}$ & $\begin{array}{c}\text { June } \\
\text { No. }\end{array}$ \\
\hline $4-15$ & 14 & 2 & 31 & $12-14$ & - \\
\hline 3 & 2.0 & 2.2 & 2.7 & 2.6 & 2.2 & 5.4 & 1.9 & - \\
8 & 4.0 & 4.0 & 4.9 & 4.1 & 3.4 & 7.1 & 2.0 & 3.6 \\
11 & 4.0 & 4.1 & 5.2 & 4.8 & 3.8 & 8.6 & 2.8 & 3.5 \\
16 & 4.6 & 5.4 & 4.9 & 5.6 & 4.5 & 8.6 & 2.8 & 3.4 \\
23 & 4.5 & 5.4 & 5.2 & 6.1 & 4.3 & 7.9 & 3.7 & 3.4 \\
26 & 3.9 & 6.0 & 5.3 & 4.9 & 4.2 & 8.8 & 4.3 & 3.2 \\
31 & 5.5 & 5.0 & 4.6 & 5.3 & 3.4 & 8.3 & 3.6 & 2.7 \\
34 & 3.1 & 3.6 & 3.9 & 4.3 & 3.2 & 7.4 & 2.1 & - \\
\hline
\end{tabular}

Annual Runoff at Gaging Station in Santa Clara Canyon

\begin{tabular}{|l|c|c|}
\hline \multirow{2}{*}{ Water Year } & \multicolumn{2}{|c|}{ Annual Runoff } \\
\cline { 2 - 3 } & Acre Feet & Inches \\
\hline & & \\
1937 & 3368 & 1.8 \\
1938 & 3039 & 1.7 \\
1939 & 2630 & 1.4 \\
1940 & 2825 & 1.5 \\
1941 & 5602 & 3.0 \\
1950 & 2460 & 1.3 \\
\hline
\end{tabular}

Drainage area $34.5 \mathrm{sq}$ mi. 
TABLE XXVIII-B. Low-Flow Measurements in Guaje Canyon

Guaje Canyon Low-Flow Measurements (cubic feet per second)

\begin{tabular}{|c|c|c|c|c|c|c|c|c|c|}
\hline \multicolumn{2}{|c|}{1958} & \multicolumn{4}{|c|}{1959} & \multicolumn{2}{|c|}{1960} & \multicolumn{2}{|c|}{1967} \\
\hline $\begin{array}{l}\text { Site } \\
\text { No. }\end{array}$ & $\begin{array}{c}\text { Oct. } \\
17\end{array}$ & $\begin{array}{c}\text { Apr. } \\
15\end{array}$ & $\begin{array}{c}\text { June } \\
3\end{array}$ & $\begin{array}{l}\text { Sept. } \\
1 \& 4\end{array}$ & $\begin{array}{c}\text { Oct. } \\
12-14\end{array}$ & $\begin{array}{c}\text { May } \\
16-17\end{array}$ & $\begin{array}{c}\text { June } \\
20-22\end{array}$ & $\begin{array}{c}\text { May } \\
3^{\mathrm{a}}\end{array}$ & $\begin{array}{c}\text { June } \\
9^{a} \\
\end{array}$ \\
\hline 4 & 0.2 & 0.2 & 0.3 & 0.5 & 0.2 & 0.4 & $\overline{0.3}$ & & \\
\hline 6 & 0.4 & 0.4 & 0.4 & 1.0 & 0.4 & 1.0 & 0.5 & & \\
\hline 10 & 0.4 & 0.4 & 0.5 & 2.0 & 0.4 & 1.1 & 0.5 & & \\
\hline 11 & 0.5 & 0.5 & 0.5 & 2.0 & 0.4 & 1.0 & 0.6 & & \\
\hline 13 & 0.4 & 0.6 & 0.4 & 2.7 & 0.5 & 1.5 & 0.5 & 0.34 & 0.31 \\
\hline $\operatorname{Dam}^{b}$ & & & & & & & & & \\
\hline 12 & 0.3 & 0.7 & 0 & & 0 & 0.9 & 0 & 0.36 & 0.34 \\
\hline 8 & 0.3 & 0.8 & 0.04 & & 0.01 & 0.8 & 0.04 & 0.29 & 0.26 \\
\hline 6 & 0.2 & 0.5 & 0.02 & & 0 & 1.0 & 0.05 & 0.24 & 0.21 \\
\hline 5 & 0.03 & 0.3 & 0 & & 0 & 1.0 & 0 & 0.17 & 0.15 \\
\hline 2 & 0.05 & 0.4 & 0.04 & & 0.08 & 1.2 & 0.1 & 0.21 & 0.18 \\
\hline B & 0 & - & 0 & & 0 & 0.9 & 0 & 0 & 0 \\
\hline
\end{tabular}

a Measurements with Parshall flume.

b Water diverted to Los Alamos on all runs except April 15, 1959.

TABLE XXVIII-C. Low-Flow Measurements in Los Alamos Canyon

Los Alamos Canyon Low-Flow Measurements (cubic feet per second)

\begin{tabular}{|l|c|c|c|c|c|}
\hline \multirow{3}{*}{$\begin{array}{l}\text { Site } \\
\text { No. }\end{array}$} & 1958 & \multicolumn{5}{|c|}{1959} & 1961 \\
\hline 9 & 23 & Oct. & Apr. & May & Apr \\
6 & - & 30 & 15 & 15 & 27 \\
\hline 5 & - & 0.0 & 0.0 & 0.0 & - \\
4 & - & 0.4 & 0.3 & 0.4 & - \\
1 & - & 0.1 & 0.4 & 0.4 & - \\
Dam & - & 0.1 & 0.4 & 0.4 & - \\
1 & - & 0.1 & 0.5 & 0.5 & - \\
2 & - & - & - & - & $3.2^{\mathrm{a}}$ \\
3 & $9.0^{\mathrm{a}}$ & - & - & - & 3.2 \\
4 & - & - & - & - & 2.9 \\
5 & 6.3 & - & - & - & 3.1 \\
6 & 5.5 & - & - & - & 1.2 \\
& & - & - & - & 0.3 \\
\hline
\end{tabular}

a Runoff over dam. 
TABLE XXVIII-D. Low-Flow Measurements and Annual Runoff in Frijoles Canyon

Frijoles Canyon Low-Flow Measurements (cubic feet per second)

\begin{tabular}{|c|c|c|c|c|c|c|c|c|}
\hline \multirow[b]{2}{*}{$\begin{array}{l}\text { Site } \\
\text { No. }\end{array}$} & 1958 & \multicolumn{5}{|c|}{1959} & \multicolumn{2}{|c|}{1960} \\
\hline & $\begin{array}{c}\text { Oct. } \\
20\end{array}$ & $\begin{array}{c}\text { Apr. } \\
16\end{array}$ & $\begin{array}{c}\text { Apr. } \\
29\end{array}$ & $\begin{array}{c}\text { June } \\
2-3\end{array}$ & $\begin{array}{c}\text { Sept. } \\
2-3\end{array}$ & $\begin{array}{c}\text { Oct. } \\
12-14\end{array}$ & $\begin{array}{c}\text { May } \\
16-17\end{array}$ & $\begin{array}{c}\text { June } \\
20-22\end{array}$ \\
\hline 10 & - & - & 0.9 & 0.5 & 0.3 & 0.1 & 0.9 & 0.5 \\
\hline 16 & - & - & 1.4 & 0.9 & 0.6 & 0.6 & 1.4 & 0.9 \\
\hline 25 & - & - & 2.1 & 1.5 & 1.2 & 1.2 & 1.6 & 1.2 \\
\hline 2 & 1.9 & 2.7 & - & 1.6 & - & 1.4 & 2.1 & 1.2 \\
\hline 9 & 1.2 & 2.6 & - & 1.5 & 1.2 & 1.0 & 1.5 & 0.8 \\
\hline 15 & 1.5 & 2.4 & - & 1.1 & 1.2 & 1.1 & - & 0.9 \\
\hline 21 & 1.2 & 2.2 & - & 1.3 & 1.2 & 1.0 & 1.7 & 1.0 \\
\hline 22 & 1.3 & 2.6 & - & 1.1 & 1.1 & 1.0 & 1.5 & 0.8 \\
\hline 26 & 1.2 & 1.6 & - & 1.1 & 1.2 & 0.8 & 1.4 & 0.8 \\
\hline 30 & - & - & - & - & 0.7 & 0.5 & 1.2 & 0.3 \\
\hline
\end{tabular}

Annual Runoff at Gaging Station in Frijoles Canyon

\begin{tabular}{|c|c|c|}
\hline \multirow{2}{*}{ Water Year } & \multicolumn{2}{|c|}{ Annual Runoff } \\
\cline { 2 - 3 } & Acre Feet & Inches \\
\hline 1960 & 1332 & 2.8 \\
1961 & 1180 & 2.5 \\
1962 & 1240 & 2.6 \\
1963 & - & - \\
1964 & 580 & 0.6 \\
1965 & 830 & 0.8 \\
1966 & 735 & 0.8 \\
1967 & 673 & 0.7 \\
1968 & 1260 & 1.3 \\
1969 & 1040 & 1.1 \\
\hline
\end{tabular}

Gaging station moved in 1963; drainage area 1960-1962, 8.9 sq mi; 1964-1967, 17.5 sq mi.

TABLE XXVIII-E. Locations and Elevations

Locations of low-flow stations in each of the four canyons are shown in Figs. XXVII-B through E. 


\section{SURFACE WATER GAGING STATIONS ON THE RIO CHAMA, RIO GRANDE, JEMEZ RIVER, RIO GUADALUPE, SANTA CLARA CREEK, AND RITO DE LOS FRIJOLES}

Surface water stations that have gaging records on the Rio Chama, Rio Grande, Jemez River, Rio Guadalupe, Santa Clara Creek, and Rito de los Frijoles have been used in monitoring the quality of surface and ground water at or adjacent to Los Alamos or in low-flow investigations in the area (Fig. XXIX-A). The stations have been operated by the U.S. Geological Survey Water Resources Division in Albuquerque, New Mexico. The Laboratory has used these stations upgradient from Los Alamos for the collection of surface water for chemical and radiochemical background, and to evaluate the effect (if any) of the Laboratory's operation on the downgradient stations.

\section{A. Rio Chama}

The Rio Chama at Chamita has a drainage area of about $3144 \mathrm{sq} \mathrm{mi}$ in north-central New Mexico and a small part of southern Colorado. The Rio Chama is tributary to the Rio Grande about $2.5 \mathrm{mi}$ west of the gaging station. The river also receives some transmountain diversion water from the San Juan River. The period of record is from October 1912 to 1990. The range in discharge during the period of record has been from no flow at times to as much as $15000 \mathrm{cfs}$ (cubic ft/sec) on May 22, 1920.

\section{B. Rio Grande}

The three stations on the Rio Grande used for monitoring that have gaging stations are at Embudo, Otowi, and Cochiti. A fourth station that has no gaging station at present but is used for monitoring is on the Rio Grande at Bernalillo (Fig. XXIX-A).

The Rio Grande at Embudo has a drainage area of about $10400 \mathrm{sq}$ mi in north-central New Mexico and southern Colorado. The period of record is from January 1889 to 1990 . The discharge during the period of record has ranged from $130 \mathrm{cfs}$ on June 30 , 1902, to $16200 \mathrm{cfs}$ on June 19, 1903.

The Rio Grande at Otowi has a drainage area of about 14300 sq mi in north-central New Mexico and southern Colorado. The period of record is from February 1895 to 1905 and from June 1909 to 1990. The discharge during the period of record has ranged from 60 cfs July $4-5,1902$, to $24400 \mathrm{cfs}$ May 23, 1920.

The Rio Grande below Cochiti Dam has a drainage area of about $14900 \mathrm{sq}$ mi in north-central New Mexico and southern Colorado. The period of record is from October 1970 to 1990 . The discharge is controlled by Cochiti Reservoir and has ranged from $0.5 \mathrm{cfs}$ August 3-5, 1977, to $10300 \mathrm{cfs}$ on July $26,1971$.

The Rio Grande at Bernalillo (at SR-44) has been used as a monitoring station from the early 1970s. The drainage area above the station is $25400 \mathrm{sq} \mathrm{mi}$ in north-central New Mexico and southern Colorado. A gaging station was operated at the site from May 1941 to September 1969, when it was discontinued. The discharge during the period of record ranged from no flow at times to $25400 \mathrm{cfs}$.

\section{Jemez River}

There are two gaging stations on the Jemez River and one on the Rio Guadalupe, a tributary of the Jemez, that are near or at monitoring stations.

The upper gaging station is on the Jemez River below the East Fork, Jemez Springs, NM. The drainage area above the station is $173 \mathrm{sq} \mathrm{mi}$, mainly from the Valles Caldera. The periods of record are from July 1949 to October 1950, May 1951 to September 1957, March 1958 to September 1976, and July 1981 to September 1990, when the station was discontinued.

The discharge during these periods ranged from $0.9 \mathrm{cfs}$ on January 24,1969 , to $2500 \mathrm{cfs}$ on April 21, 1958.

The second station lies on the Jemez River below the confluence with the Rio Guadalupe, near Jemez, NM. Its drainage area is about $470 \mathrm{sq} \mathrm{mi}$, from the Valles Caldera and the western side of the caldera. The periods of record are from June 1936 to May 1941, August 1949 to October 1950, May 1951 to September 1952, and March 1953 to 1990. The discharge during these periods ranged from $1.2 \mathrm{cfs}$ on July 25, 1981, to 5900 cfs April 21, 1958. 


\section{Rio Guadalupe}

The drainage area above the gaging station on the Rio Guadalupe at Box Canyon, NM is about $235 \mathrm{sq}$ $\mathrm{mi}$, along the western side of the Valles Caldera. The periods of record are from November 1938 to September 1942, August 1949 to September 1950, May 1951 to September 1957, May 1958 to September 1976 , and July 1981 to 1990 . The discharge during these periods ranged from $2.8 \mathrm{cfs}$ on December 9 , 1967, to 3190 cfs on May 13 and 14, 1941.

\section{E. Santa Clara Creek}

Low-flow investigations utilized some of the data from the gaging station on Santa Clara Creek. Santa Clara Creek is on the Santa Clara Pueblo Indian Reservation. The drainage area above the gaging station is $34.5 \mathrm{sq} \mathrm{mi}$, along the eastern flank of the Sierra de los Valles and part of the Pajarito Plateau. The creek discharges into the Rio Grande. The periods of record for the station are from February 1936 to September 1941, August 1949 to September 1961, and April 1984 to 1990 . There is some diversion for irrigation above the gage. The discharge during the periods of record ranged from no flow August 8-13, 1984 and March 9, 1990 (during periods of extreme diversion), to $970 \mathrm{cfs}$ on September 22, 1941.

\section{F. Rito de los Frijoles}

The Rito de los Frijoles heads on the flanks of the Sierra de los Valles and has cut a deep canyon across the Pajarito Plateau to discharge into the Rio Grande. The stream and canyon are in Bandelier National Monument. Gaging stations have been operated on the Rito de los Frijoles at two different locations. In 1959 a station was located about $5.8 \mathrm{mi}$ west of the park headquarters at the upper crossing. The station was operated at the western edge of the Pajarito Plateau (at the Pajarito Fault Zone) to aid in the lowflow investigations. In 1963 the station was moved to the park headquarters, to monitor flow across the plateau.

The drainage area above the gaging station at the upper crossing (on the flanks of the mountains) is $8.9 \mathrm{sq} \mathrm{mi}$. The period of record for the station was from August 1959 to October 1963. The discharge during that period ranged from $0.7 \mathrm{cfs}$ on April 7, 1960, to 13 cfs on June 29, 1960.

When the station was moved to near the park headquarters, the drainage area above the station increased to $18.1 \mathrm{sq} \mathrm{mi}$. The periods of record for the new station were July 1963 to September 1969 and July 1977 to September 1982. The discharge ranged from no flow (due to a freeze-up) on February 6 , 1968, to $3030 \mathrm{cfs}$ on July 21, 1978. Prior to the 1977 forest fire that destroyed $44 \%$ of the vegetation and trees in the drainage area, the largest discharge was $19 \mathrm{cfs}$ on June 18,1965 . The forest fire changed the runoff characteristics of the canyon.

\section{REFERENCES}

W. D. Purtymun, "Geohydrology of Bandelier National Monument, New Mexico," Los Alamos Scientific Laboratory report LA-5716-MS (1980).

Surface Water Records for the above U.S. Geol. Survey Gaging Stations from 1936 to 1961 are found in the annual reports "Surface Water Supply of the United States, Part 8, Western Gulf of Mexico Basins," U.S. Geol. Survey Water-Supply Papers.

Surface Water Records for the above U.S. Geol. Survey Gaging Stations from 1961 through 1990 are found in the annual reports "Water Resources Data For New Mexico," U.S. Geol. Survey, Water Resources Division, Albuquerque, New Mexico. 


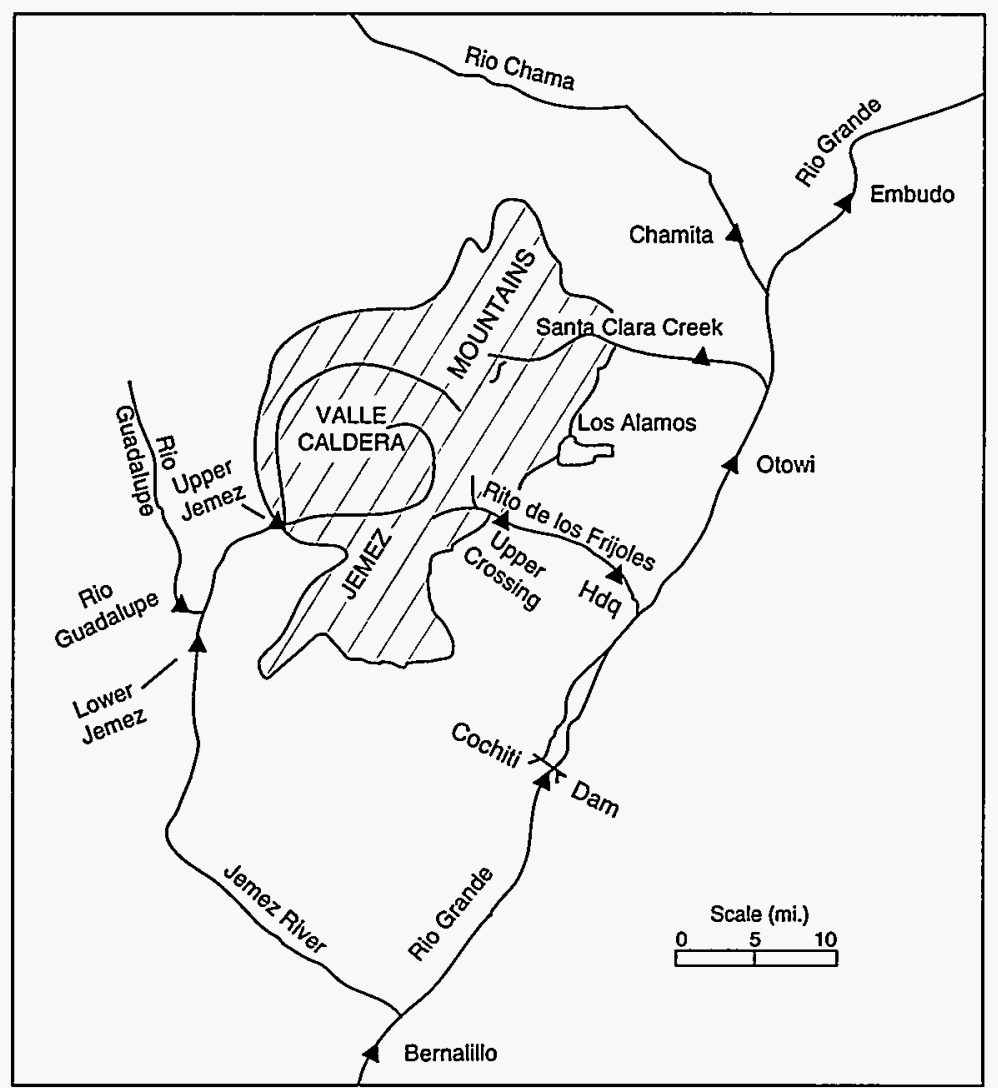

Fig. XXIX-A. Locations of gaging stations on the Rio Chama, Rio Grande, Jemez River, Rio Guadalupe, Santa Clara Creek, and Rito de los Frijoles.

TABLE XXIX-A. Locations and Elevations of Gaging Stations (NAD 1927)

\begin{tabular}{|c|c|c|c|}
\hline $\begin{array}{r}\text { A. Rio Chama } \\
\text { Chamita }\end{array}$ & N 1,846,000 & E 541,200 & $5660 \mathrm{ft}$ \\
\hline \multicolumn{4}{|l|}{ B. Rio Grande } \\
\hline Embudo & $N 1,874,100$ & E 584,400 & $5812 \mathrm{ft}$ \\
\hline Otowi & $N 1,773,600$ & E 533,000 & $5495 \mathrm{ft}$ \\
\hline Cochiti (below dam) & N $1,685,400$ & E 479,500 & $5240 \mathrm{ft}$ \\
\hline Bernalillo & $N 1,552,700$ & E 379,900 & $5054 \mathrm{ft}$ \\
\hline \multicolumn{4}{|l|}{ C. Jemez River } \\
\hline Near Jemez Springs & $N 1,756,200$ & E 381,400 & $6700 \mathrm{ft}$ \\
\hline Near Jemez Pueblo & N 1,699,600 & E 353,500 & $5650 \mathrm{ft}$ \\
\hline \multicolumn{4}{|l|}{ D. Rio Guadalupe } \\
\hline Box Canyon & $\mathrm{N} 1,722,000$ & E 347,900 & $6040 \mathrm{ft}$ \\
\hline \multicolumn{4}{|l|}{ E. Santa Clara Creek } \\
\hline Gaging Station & $N 1,810,300$ & E 525,300 & $6080 \mathrm{ft}$ \\
\hline \multicolumn{4}{|l|}{ F. Rito de los Frijoles } \\
\hline Upper Crossing & $\mathrm{N} 1,751,900$ & E 467,100 & $7015 \mathrm{ft}$ \\
\hline Park Headquarters & $\mathrm{N} 1,738,100$ & E 494,500 & $6040 \mathrm{ft}$ \\
\hline
\end{tabular}




\section{STUDY OF SURFACE IMPOUNDMENT AT TA-53}

The study of the surface impoundment at TA-53 was made to meet certain requirements of the $\mathrm{Re}$ source Conservation and Recovery Act and to support the Part B permit application for surface impoundment. The basic information collected describes the potential for human exposure to contaminants via several pathways. The main pathways referred to in this report are ground water, surface water, and release from the soil. In the course of this investigation, eight test holes were drilled; five were completed as moisture-access holes for future monitoring of the dispersion and movement of moisture from the surface impoundments; one was completed as a pore gas monitoring hole with five sampling ports at various depths; and two open holes were drilled for geologic and hydrologic information.
The moisture-access and pore gas sampling holes and one of the open holes were completed on the surface of the mesa (Fig. XXX-A). The eighth hole was completed in Sandia Canyon just south of the surface impoundment that is on the mesa top. Geologic logs and completion data for the test holes are shown on Table XXX-A. Geologic descriptions used are after Baltz (1963), Keller (1968), and Purtymun (1966); see also sections I-D4 and XXIII-G of this report. The locations and elevations of these holes were not surveyed.

\section{REFERENCE}

S. G. McLin, "Identification of Potential Pathways of Human Exposure to Hazardous Wastes Constituent Releases from the TA-53 Surface Impoundments," Los Alamos National Laboratory, Group EM-8 internal document, Sept. 6, 1991.

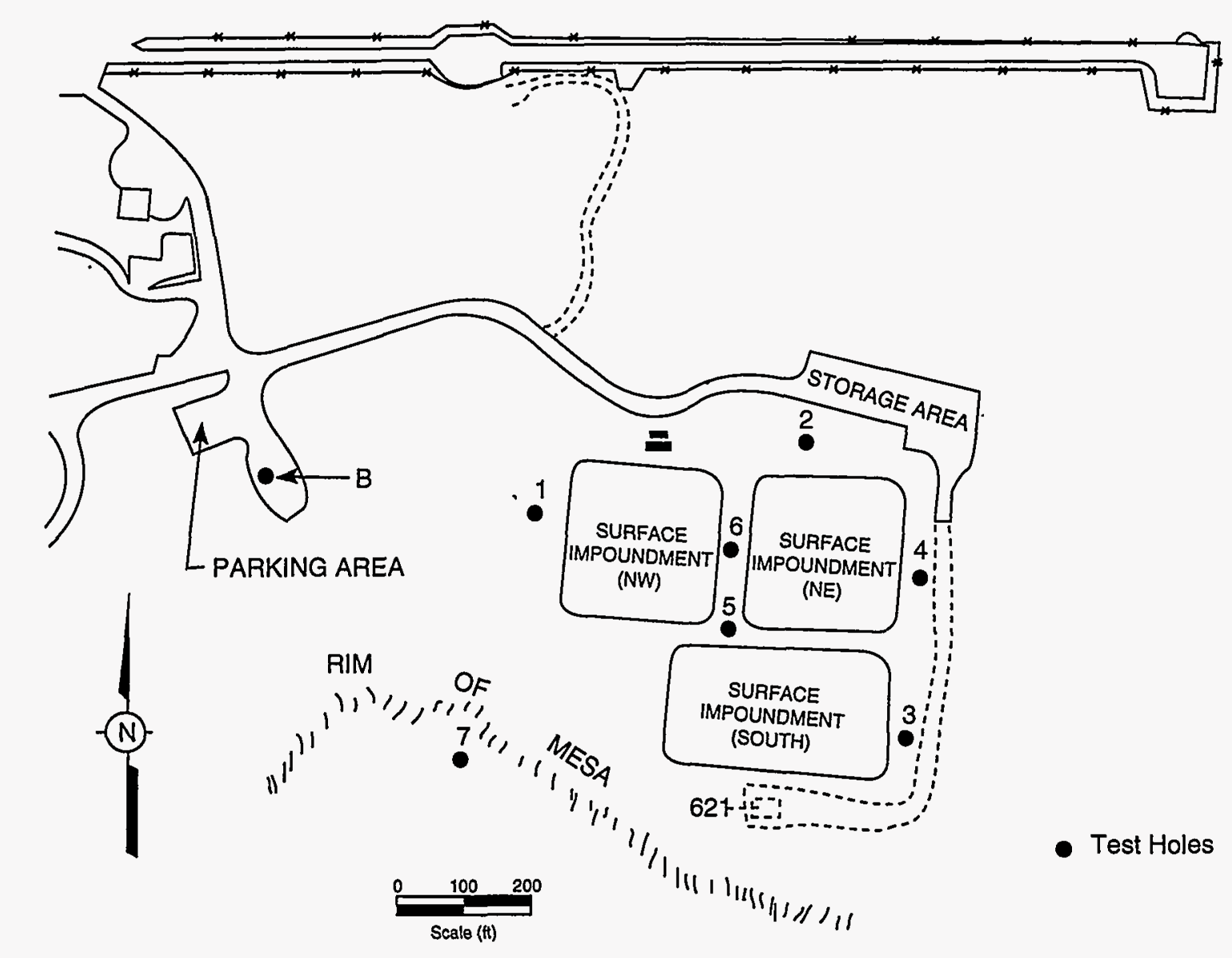

Fig. XXX-A. Locations of test holes near the TA-53 surface impoundment. 


\section{TABLE XXX-A. Geologic Logs and Construction Data for Test Holes at TA-53}

1. Test Hole B-53

Moisture-Access Hole

$\underline{\log }$

Surface fill material

Tuff, Tshirege Member, Unit 2B low moisture content
Hole: Dry

Thickness

(ft)

1

48
Depth

(ft)

1

49

Construction: Hole augered to 4 -in. diam; $45 \mathrm{ft}$ of 2-in.-diam aluminum pipe set 0 to $45 \mathrm{ft}$; steel locking cap.

2. Test Hole 1-53

Moisture-Access Hole

$\underline{\log }$

Surface fill material

Tuff, Tshirege Member, Unit 2B low moisture content
Hole: Dry

Thickness

(ft)

1

48
Depth

1

49

Construction: Hole augered to 4-in. diam; $46 \mathrm{ft}$ of 2-in.-diam aluminum pipe set 0 to $46 \mathrm{ft}$; steel locking cap.

3. Test Hole 2-53

Moisture-Access Hole

$\underline{\log }$

Surface fill material

Tuff, Tshirege Member, Unit 2B low moisture content
Hole: Dry

Thickness

(ft)

1

48
Depth

(ft)

1

49

Construction: Hole augered to 4 -in. diam; $46 \mathrm{ft}$ of 2-in.-diam aluminum pipe set 0 to $46 \mathrm{ft}$; steel locking cap.

4. Test Hole 3-53

Moisture-Access Hole

$\underline{\log }$

Surface fill material

Tuff, Tshirege Member, Unit 2B low moisture content
Hole: Dry

Thickness (ft)

1

48
Depth

(ft)

1

49

Construction: Hole augered to 4-in.-diam; $48 \mathrm{ft}$ of 2-in.-diam aluminum pipe set 0 to $48 \mathrm{ft}$; steel locking cap.

5. Test Hole 4-53

Moisture-Access Hole

$\underline{\log }$

Surface fill material

Tuff, Tshirege Member, Unit 2B low moisture content
Hole: Dry

Thickness

(ft)

1

48
Depth

(ft)

1

49

Construction: Hole augered to 4 -in. diam; $47 \mathrm{ft}$ of 2 -in.-diam aluminum pipe set 0 to $47 \mathrm{ft}$; steel locking cap. 
TABLE XXX-A. Geologic Logs and Construction Data for Test Holes at TA-53 (Continued)

6. Test Hole 5-53

Pore Gas Well

$\underline{\log }$

Surface fill material

Tuff, Tshirege Member, Unit 2B low moisture content

Tuff, Tshirege Member, Unit 2A low moisture content
Hole: Dry

Thickness

(ft)

3

65

68

32

100

Construction: Hole augered to 4 -in. diam; $4 \mathrm{ft}$ of aluminum casing 0 to $4 \mathrm{ft}$; cement 0 to $1 \mathrm{ft}$; bentonite 1 to $4 \mathrm{ft}$; sampling ports at $20 \mathrm{ft}, 40 \mathrm{ft}, 60 \mathrm{ft}, 80 \mathrm{ft}$, and $93.5 \mathrm{ft}$; hole adjacent to sampling tube filled with sand; steel locking cap.

7. Test Hole 6-53

Open Hole

$\underline{\log }$

Surface fill material

Tuff, Tshirege Member, Unit 2B low moisture content

Tuff, Tshirege Member, Unit 2A low moisture content

Tuff, Tshirege Member, Unit 1B

Tuff, Tshirege Member, Unit 1A

Construction: Open hole.

8. Test Hole 7-53

Open Hole

$\underline{\log }$

Alluvium

Tuff, Tshirege Member, Unit 2B low moisture content

Tsankawi Member, low moisture content

Otowi Member, low moisture content
Hole: Dry

Thickness

(ft)

3

65

68

45

113

20

133

17

150

Hole: Dry

Thickness

(ft)

Depth

1

23

24

19

43

37

80

Construction: $77 \mathrm{ft}$ of 2-in.-diam aluminum pipe set in hole 0 to $77 \mathrm{ft}$; bentonite pellets 0 to $0.5 \mathrm{ft}$; silica sand 0.5 to $35 \mathrm{ft}$; bentonite 35 to $37 \mathrm{ft}$; lysimeter port at $37 \mathrm{ft}$ with fine silica from 37 to $39 \mathrm{ft} ; 39 \mathrm{ft}$ to $40 \mathrm{ft}$ silica sand; 40 to $77 \mathrm{ft}$ fine sand; steel locking cap; hole cored to 6.875 -in. diam; hole diam $7.25 \mathrm{in}$. 


\section{TRANSPORT STUDIES OF URANIUM IN POTRILLO CANYON TA-36}

Three shallow moisture-access holes were drilled in Potrillo Canyon in 1989 to investigate the infiltration of surface water into the alluvium. Two deeper holes were cored in 1991. These test holes were completed as wells. One had three zones at various depths separated from each other by bentonite and cement; the second well was constructed with two zones. The zones were packed with sand. The moisture-access holes and wells were completed as part of a study to determine whether there was recharge to the alluvium and underlying tuff and transport of depleted uranium from the intermittent stream in Potrillo Canyon in TA-36. The wells were installed to study the chemistry and radiochemistry of infiltrating water at different depths.
The locations of the three moisture-access holes and two wells are shown in Fig. XXXI-A. The construction and geologic logs for the moistureaccess holes appear in Table XXXI-A, while the logs for the test wells appear in Figs. XXXI-B and XXXI-C.

\section{REFERENCE}

N. M. Becker, "Influence of Hydraulic and Geomorphologic Components of a Semi-Arid Watershed on Depleted Uranium Transport," Los Alamos National Laboratory document LA-UR-93-2165.

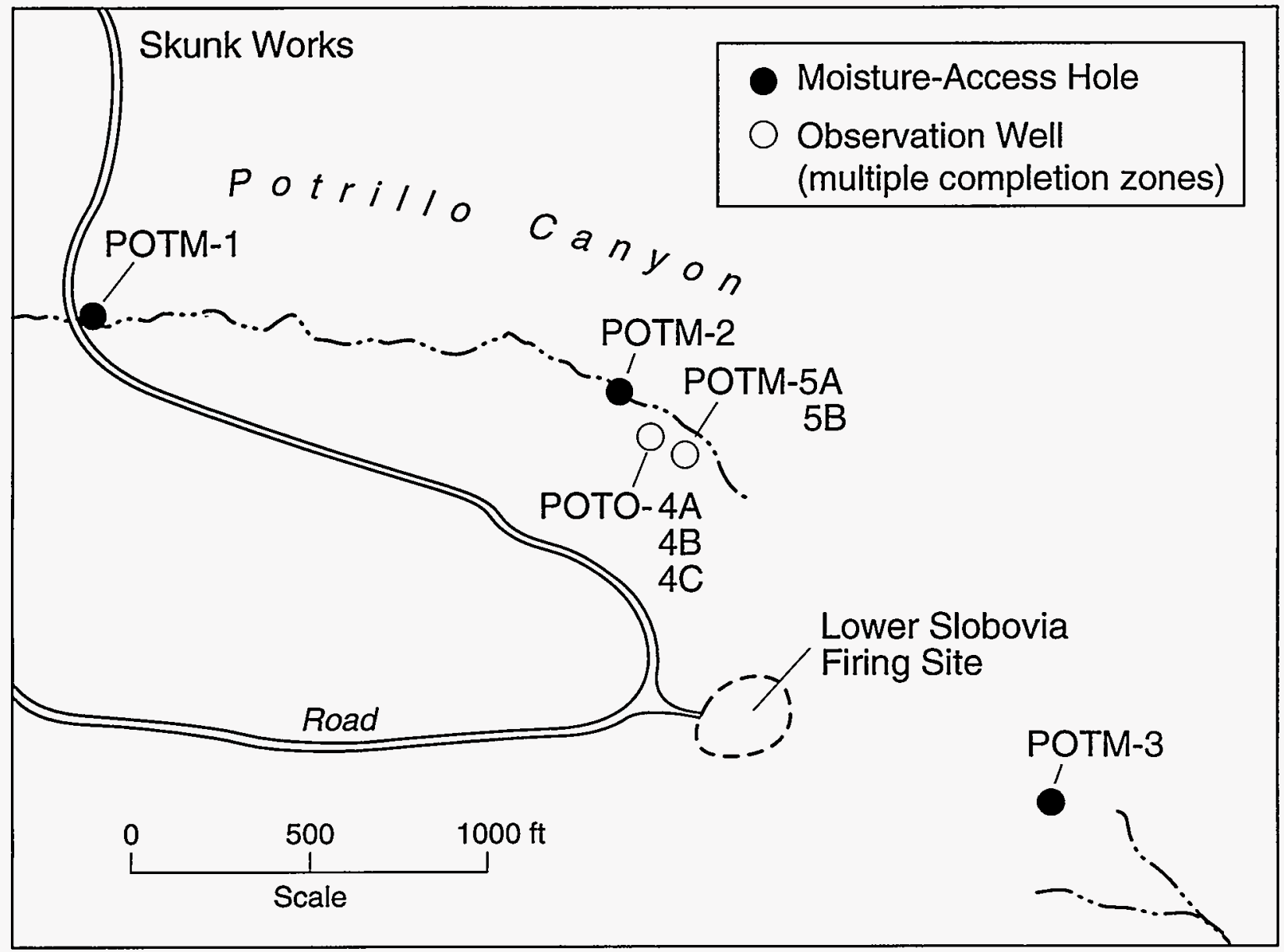

Fig. XXXI-A. Locations of moisture-access holes and observation wells in Potrillo Canyon. 


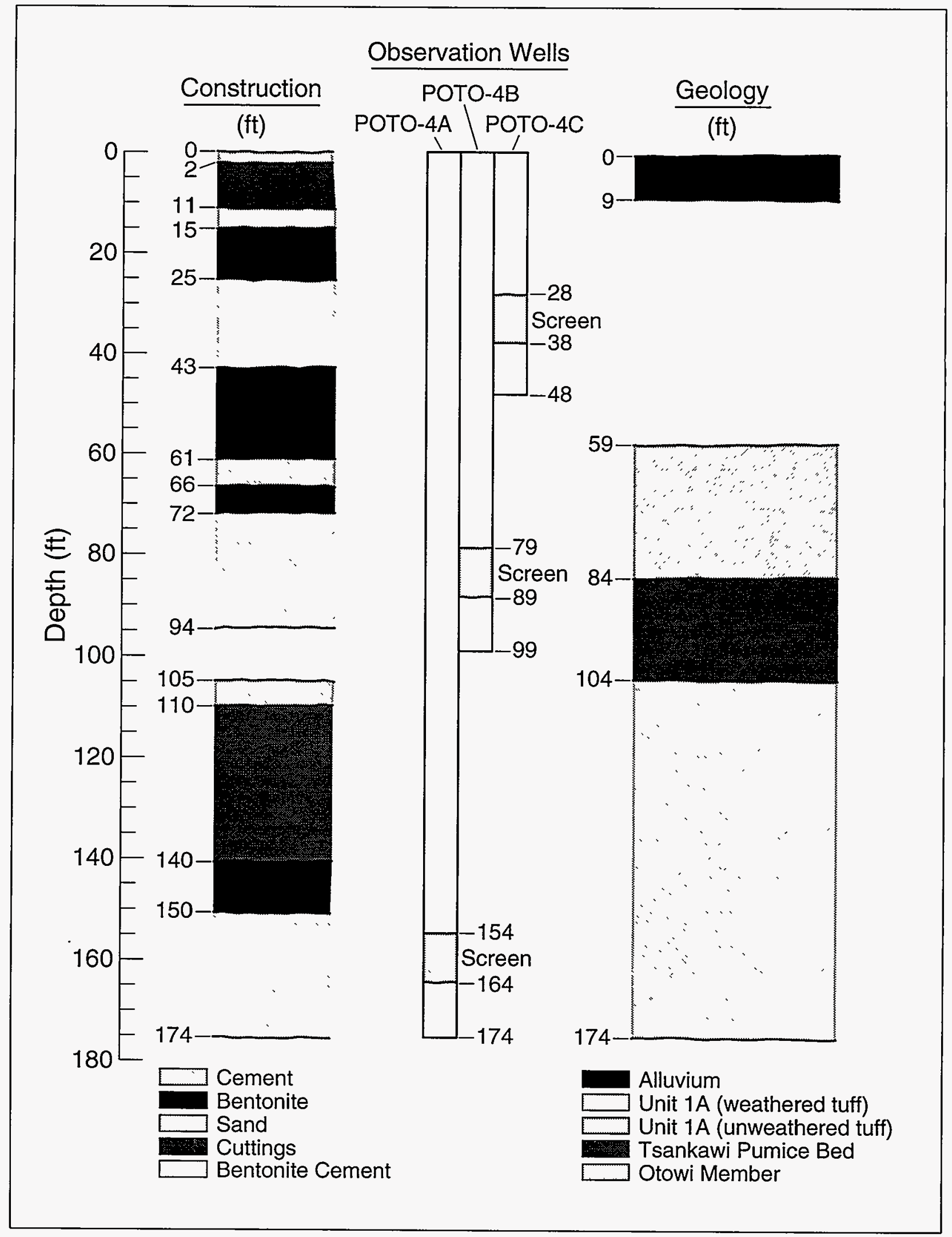

Fig. XXXI-B. Construction and geologic logs of observation wells POTO-4A, POTO-4B, and POTO-4C. 


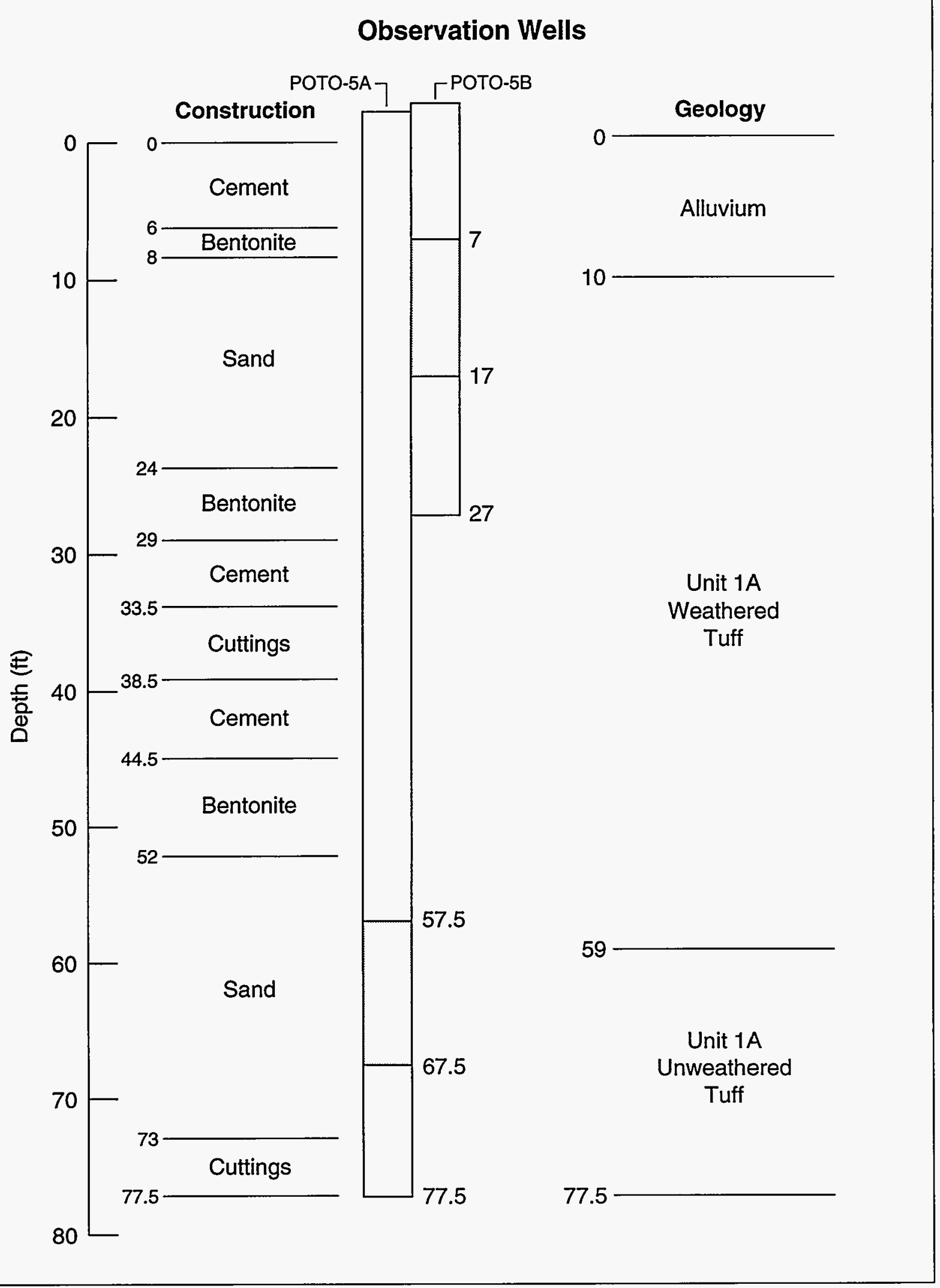

Fig. XXXI-C. Construction and geologic logs of observation wells POTO-5A and POTO-5B. 


\begin{tabular}{|c|c|c|c|}
\hline & POTM-1 & POTM-2 & POTM-3 \\
\hline Alluvium & $0-28$ & $0-11$ & $0-15$ \\
\hline Weathered Tuff $(\mathrm{ft})$ & $28-50$ & $11-56$ & $15-52$ \\
\hline Casing Tuff $(\mathrm{ft})$ & 47 & 54 & 48 \\
\hline \multicolumn{4}{|c|}{$\begin{array}{l}\text { Construction: } 2 \text {-in.-diam aluminum casing with cap welded on bottom, casing cemented in } 5 \text { to } 9 \mathrm{ft} \text {; holes offse } \\
\text { with shallow moisture-access holes } 5 \text { to } 9 \mathrm{ft} \text { to study moisture content of alluvium adjacent to the } \\
\text { cemented sections of deeper moisture-access holes. }\end{array}$} \\
\hline \multicolumn{4}{|c|}{ TABLE XXXI-B. Locations and Elevations (NAD 1927) } \\
\hline POTM-1 & N $1,757,200$ & E 497,600 & $6655 \mathrm{ft}$ \\
\hline POTM-2 & N $1,757,100$ & E 498,300 & $6620 \mathrm{ft}$ \\
\hline POTM-3 & N $1,755,600$ & E 500,000 & $6575 \mathrm{ft}$ \\
\hline POTM-4 ABC & N $1,757,000$ & E 498,400 & $6620 \mathrm{ft}$ \\
\hline POTM-5 AB & N $1,757,000$ & E 498,400 & $6620 \mathrm{ft}$ \\
\hline
\end{tabular}




\section{SPECIAL TEST HOLES AT TA-49 TO MEASURE BAROMETRIC EFFECTS AND DEFORMATION OF THE TUFF}

Two test holes were cored ( 7 1/4-in. diam) near the eastern edge of TA-49 near well DT-10

(Fig. XXXII-A). The holes were completed in the upper units of the Tshirege Member of the Bandelier Tuff (Fig. XXXII-B). Geologic units are those described by Weir and Purtymun (1962).

Test hole TBM-1 was constructed to measure the barometric effect in the tuff caused by atmospheric pressure changes (Fig. XXXII-C). Test hole TBM-2 was equipped with a Geodetic Biaxial Tiltmeter to determine the deformation of the tuff caused by seismic events. The wellheads for both holes have an 8-ft-sq concrete slab about 6 in. thick. Location is

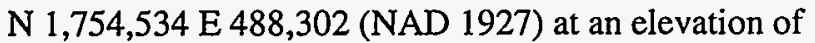
$7038 \mathrm{ft}$.

\section{REFERENCES}

W. D. Purtymun, Los Alamos National Laboratory, unpublished data (EM-8 field notes), 1993.

J. E. Weir and W. D. Purtymun, "Geology and Hydrology of Technical Area 49, Frijoles Mesa, Los Alamos County, New Mexico," U.S. Geol. Survey Admin. Report (1962).

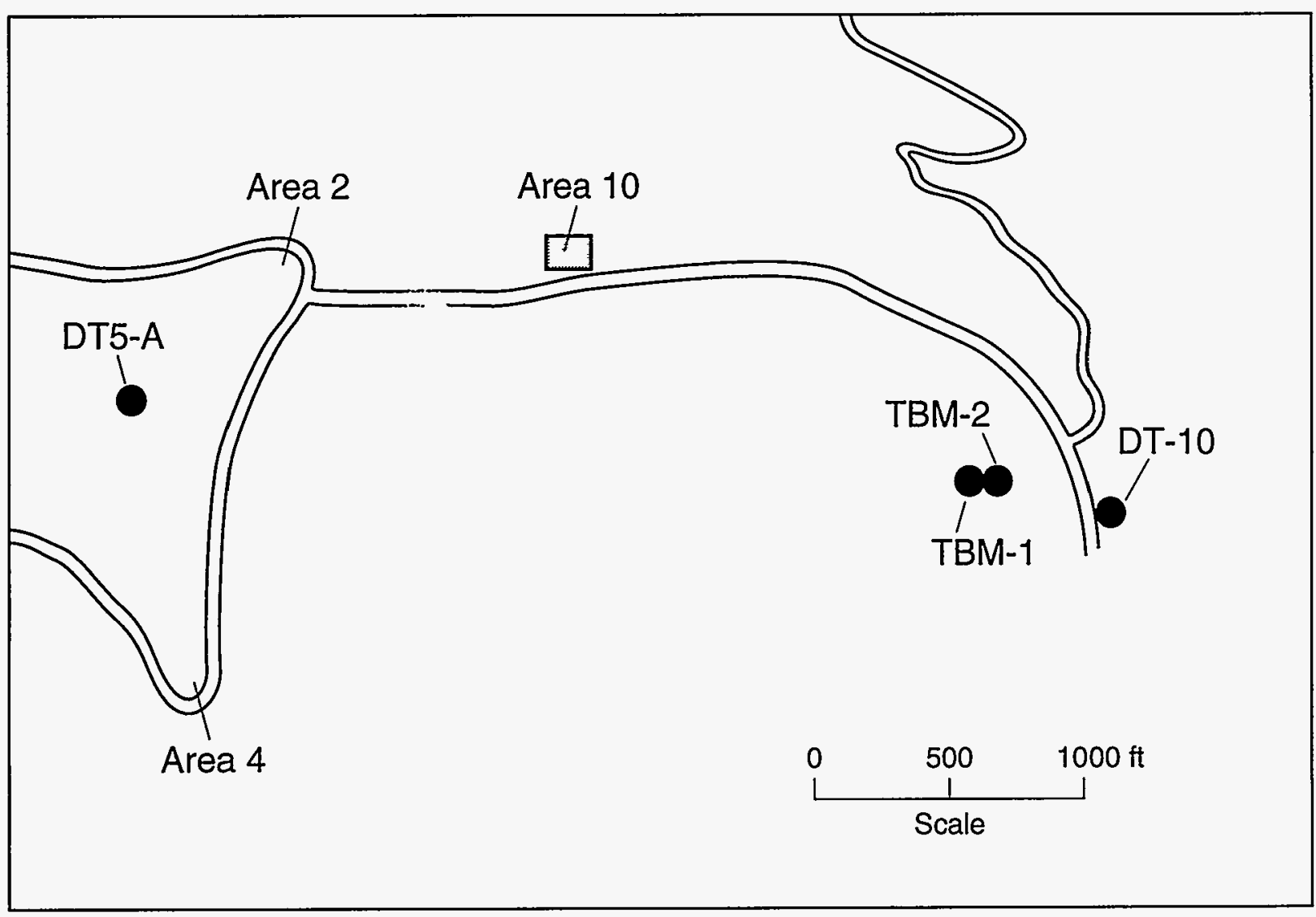

Fig. XXXII-A. Locations of test holes TBM-1 and TBM-2 at TA-49 (Purtymun 1993). 


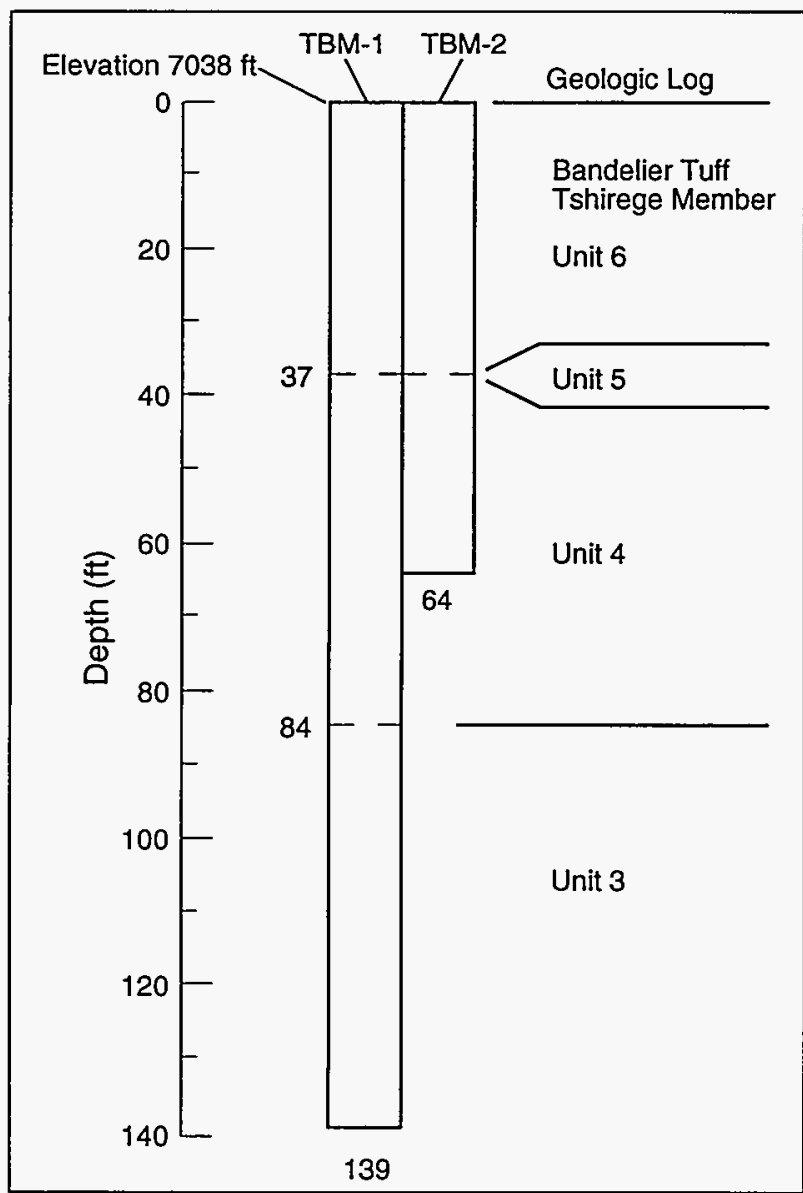

Fig. XXXII-B. Geologic logs of test holes TBM-1 and TBM-2 at TA-49 (Purtymun 1993).

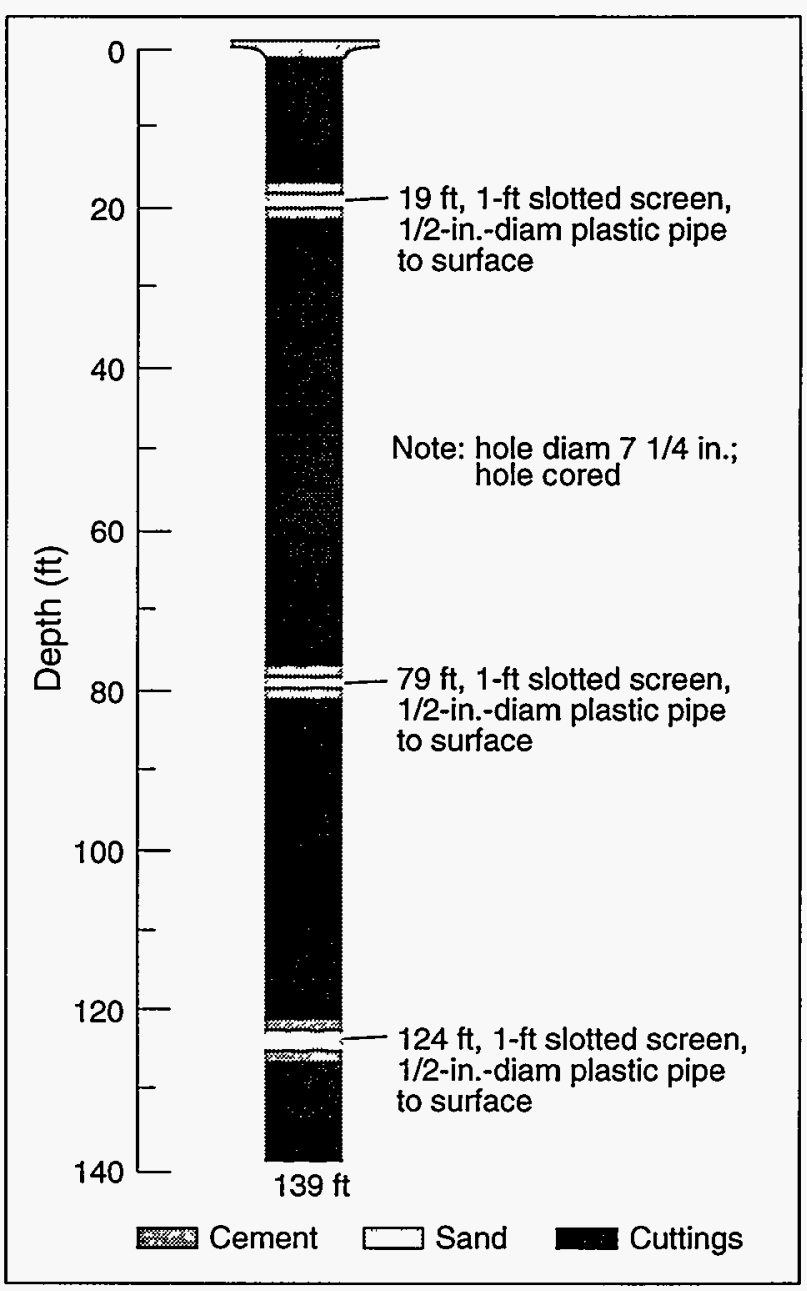

Fig. XXXII-C. Test hole TBM-1 constructed with three zones to measure barometric pressures in the tuff at depths of 19, 79, and $124 \mathrm{ft}$. 


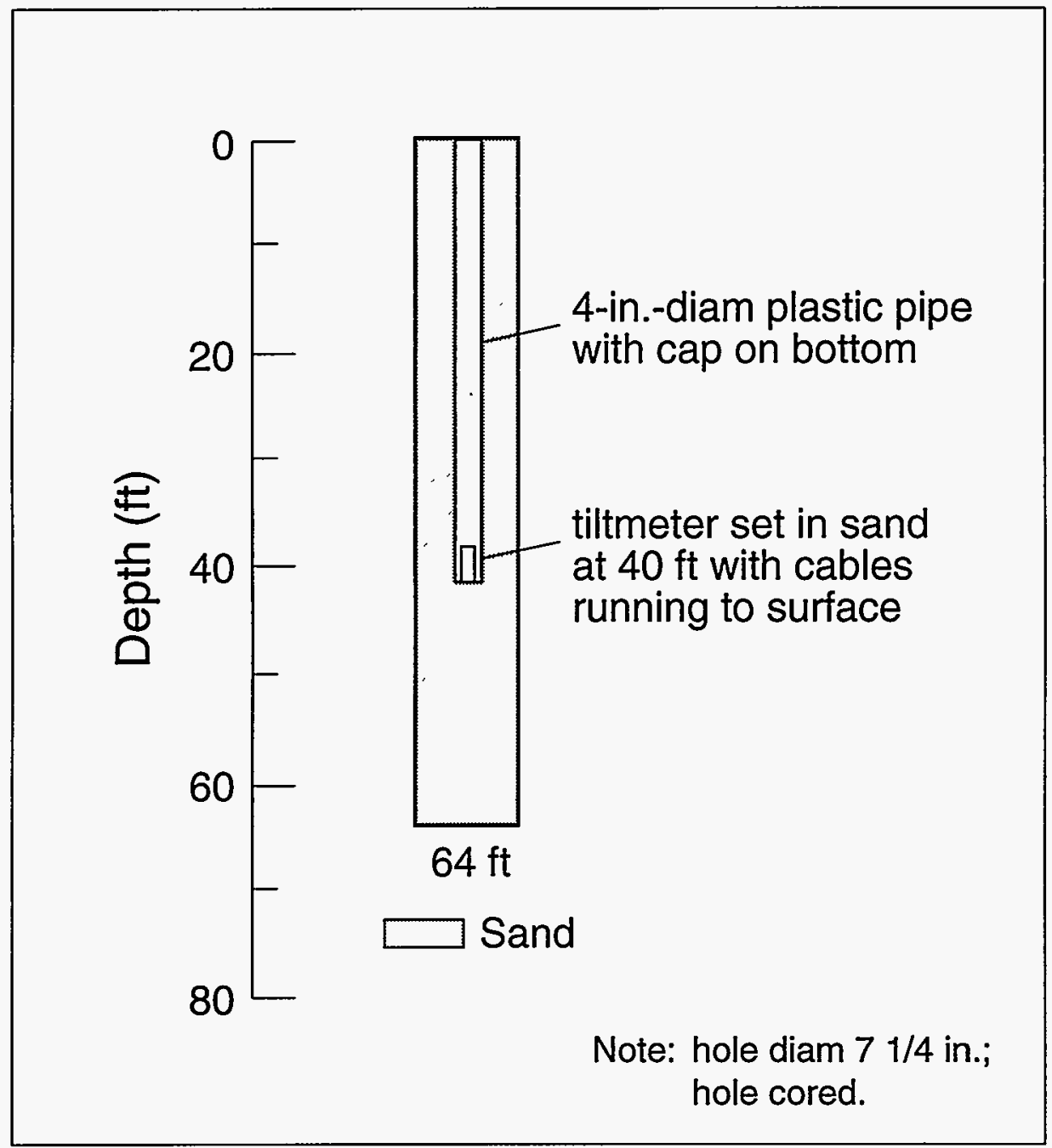

Fig. XXXII-D. Test hole TBM-2 equipped with a biaxial tiltmeter to measure deformation of the tuff at $40 \mathrm{ft}$. 


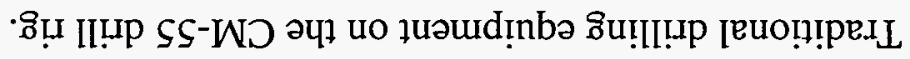

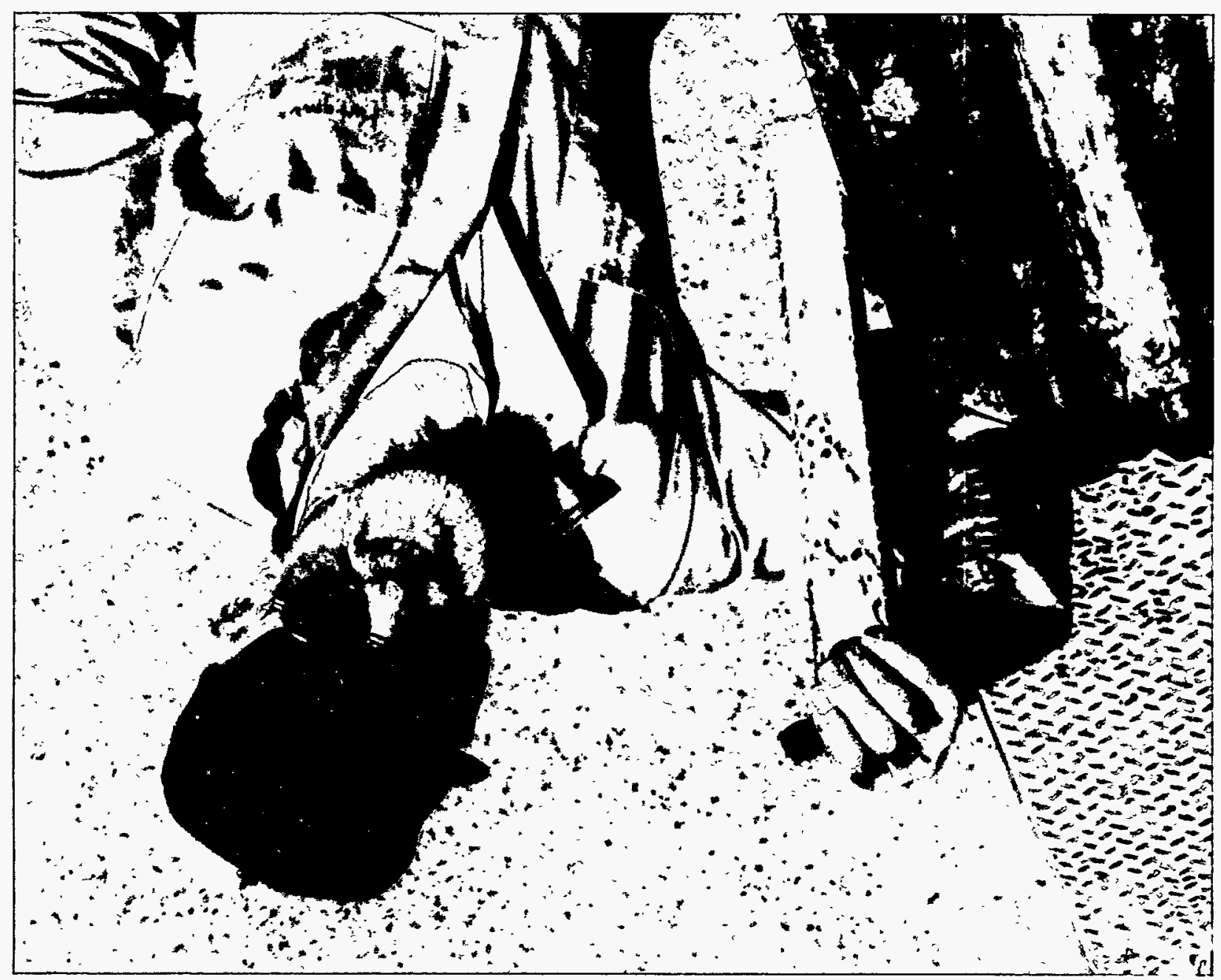




\section{ACKNOWLEDGMENTS}

The data contained in this report cover an almost 50-year span and were collected by many individuals. From the U.S. Geological Survey Water Resources Division, Roy Griggs, Bert Weir, Elmer Baltz, Bob Cushman, Jim Cooper, J. L. Kunkler, and John Abrahams must be acknowledged. Frank Koopman was the greatest; he taught me that the studies that were in progress were not work, but an adventure. Also acknowledged is the work of Roy Bailey and Bob Smith of the Geologic Division of the U.S. Geological Survey.

From the Los Alamos Scientific Laboratory that provided data and support in the early years were Jack Abey, Pablo Romero, Pat Trujillo, and Bill Kennedy, who was Group Leader of the Environmental Group ( $\mathrm{H}-6)$. One must also acknowledge the work and support of Mort Smith (the last of the real gentlemen), Don Brown, Bob Potter, and Daryl Sims of the pre-funded Hot Dry Rock Project. It was with this informal group that geoscience was introduced into the Laboratory itself.

Close ties existed with the AEC and DOE in the development of the water supply for Los Alamos. Those that provided support were Edwin Wingfield, Tom Roehl, Cecil Bingham, and Eloy Nunez. Glenn Hammock, consulting engineer, provided technical support on drilling and well construction over a period of 26 years with the construction of 8 supply wells.

Environmental issues became a front runner in popularity in the early 1980 s, but the AEC and the Laboratory began monitoring water, soil, and sediments in the mid-1940s. The Environmental Studies Group, H-8 (formed in 1971), and the Water Quality and Hydrology Group (ESH-18) have been major players in monitoring the environment. Those in the group that contributed support and collection of data used in this report are Eric Koenig, Steve McLin, Don Van Etten, and Naomi Becker. Naomi's support through countless field studies is especially appreciated. Dick Peters provided radiochemistry support and took part in many of the studies. Max Maes has been my good arm during the period from 1972 to the present. Max has collected tons of water, as well as soil and sediment samples, for analysis as part of the monitoring program. He has been a big help in reducing the hydrologic data from the supply wells into a usable form. The two of us have drilled hundreds of wells and test holes together.

The list of acknowledgments would not be complete without Alan Stoker, my mentor. He provided support, contributed to the data collection, and made suggestions for studies. I also wish to acknowledge Steven Reneau (EES-1), Jake Turin (EES-1), John Schrandt (ESH-18), Bruce Gallaher of ESH-18 (who performed the technical review of this report), and Jered Sneesby and Greg Cole of EES-1, who checked and corrected many of the NAD 1927 locations.

Special thanks are due to the staff of CIC-1 Central. Vai Stewart edited this report, harmonizing and correcting the text, figures, and tables, and coordinating the project. Many compositors (in our group as well as in CIC-1) put together the many papers and reports that make up this report. Deidre' Plumlee composed this report's final version, revising and redrawing many of the figures. Kim Valencia and Joyce Martinez created many of the figures in the report. Patrick McFarlin contributed to the composition and the drawing of figures, as did Chad Kieffer, Karina Berta, and Zena Kolshorn. Eileen Patterson proofread the report when it was near its final form.

Although the data presented here will undoubtedly be expanded and clarified in the future, this represents the amalgamation and distillation of the efforts of three generations of investigators, who have sought to understand our local environment and who have worked hard to protect it. My hope is that this report will contribute to the continuation of that work. 